


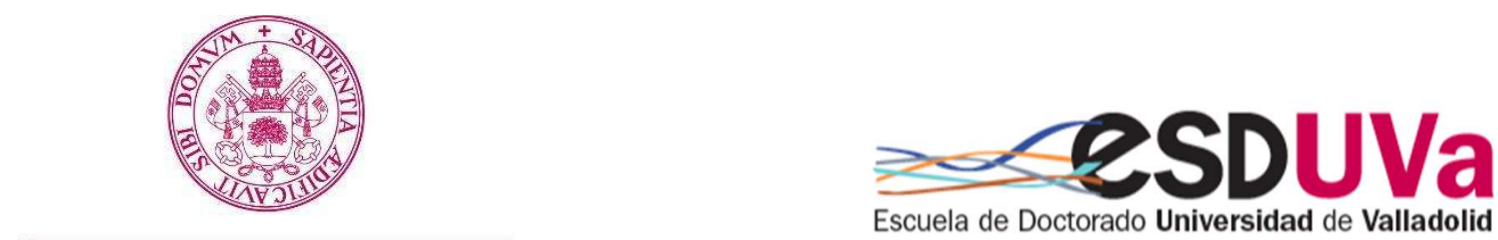

Universidad deValladolid

PROGRAMA DE DOCTORADO EN DERECHO

TESIS DOCTORAL:

\title{
LAS UNIONES DE HECHO: PRESENTE Y FUTURO
}

\author{
Presentada por Antonio Rodríguez González \\ para optar al grado de \\ Doctor por la Universidad de Valladolid
}

Dirigida por:

Dra. Henar Álvarez Álvarez

Dr. Ignacio Díaz de Lezcano Sevillano 

A mi madre, in memoriam 



\section{RESUMEN}

Las uniones de pareja no matrimoniales han representado una forma de relación convivencial en todos los tiempos históricos. En los últimos cuarenta años, en nuestro país, este modo de convivencia more uxorio ha experimentado un crecimiento exponencial. Modificándose, también, la percepción social de la figura, que ha conseguido un reconocimiento social y jurídico, especialmente, de aquellas parejas que se inscriben como tales en los correspondientes registros autonómicos. Ello ha conducido a un importante reconocimiento de derechos en el ámbito del Derecho público, mientras que tal reconocimiento de derechos es menor en el ámbito del Derecho privado. Nuestro estudio sobre Las uniones de hecho: presente y futuro analiza la evolución histórica de las uniones de hecho, así como su realidad actual, tanto en los aspectos personales como patrimoniales de la pareja. A la vez que hemos comprobado la percepción social de estas uniones de hecho, con el fin de intentar interpretar la evolución jurídica que debe experimentar la su regulación de las uniones de hecho para adaptar la figura a la realidad social.

\footnotetext{
ABSTRACT

Non-marital couple unions have represented a relational model of coexistence in all historical times. In the last forty years, in our country, this more uxorio way of coexistence has experienced an exponential growth and also the social perception of the figure has been modified, by achieving social and legal recognition, especially, that of those couples who are registered as such in the corresponding regional registers. This has led to an important recognition of rights in the field of public law, while such recognition has been lesser in private's law field. Our study on De facto unions: present and future analyzes the historical evolution of de facto unions, as well as their current reality, both in the couple's personal and patrimonial aspects, at the same time that we have touched the social perception of these unions, in order to try to interpret the legal evolution that the regulation of de facto unions must undergo to adapt the institution to social reality.
} 



\section{ÍNDICE}

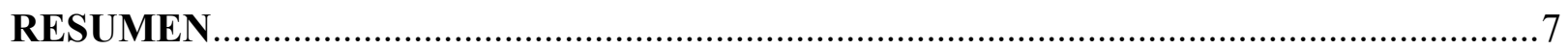

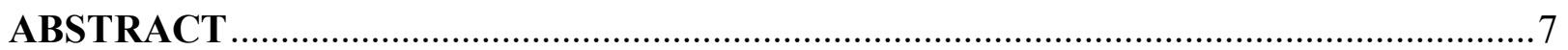

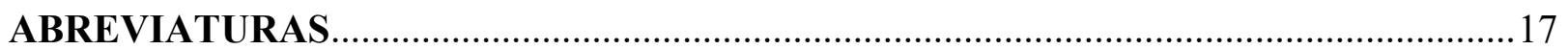

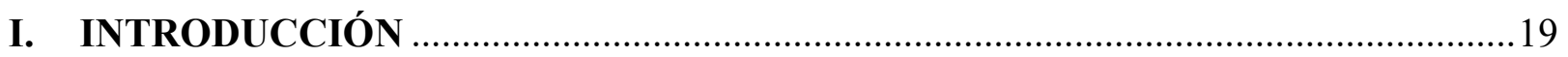

II. ANTECEDENTES HISTÓRICOS DE LAS UNIONES POR VÍA DE HECHO .........23

A) Importancia social del modo de relación de convivencia de la pareja....................................23

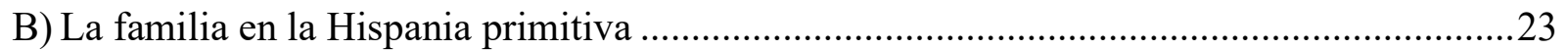

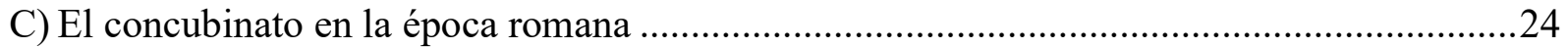

D) Uniones matrimoniales y de concubinato en la época visigótica ...........................................2

E) La situación en el Derecho musulmán y otros derechos vigentes en Al-Andalus.................29

1. El Mut'ah: una práctica matrimonial por período pactado...................................................30

2. El Derecho de Moisés y la interpretación del Talmud en España ..........................................31

F) La Iglesia católica y las uniones no matrimoniales durante la Alta Edad Media ...................31

G) Uniones no matrimoniales en la España cristiana durante el Medievo ..................................33

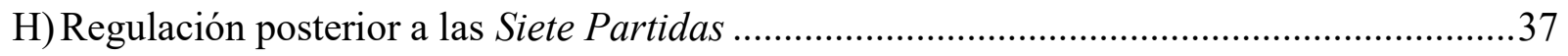

I) La modificación del Concilio de Trento y su repercusión en la legislación secular .............38

J) La persecución del concubinato por el Tribunal de la Inquisición .........................................40

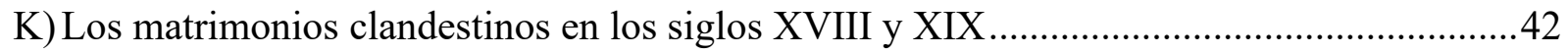

L) El concubinato durante la codificación...............................................................................4

\section{LA DISTINTA NATURALEZA JURÍDICA DEL MATRIMONIO Y LAS UNIONES

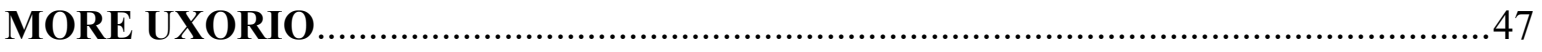

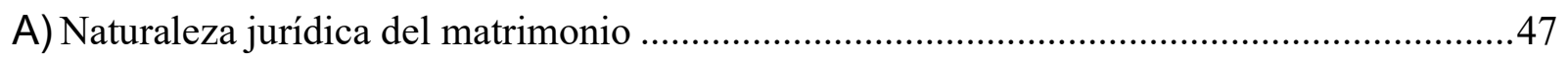

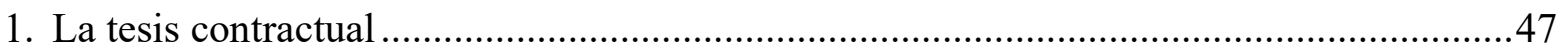

2. El matrimonio como negocio jurídico de Derecho de Familia.............................................49

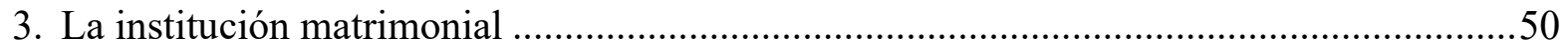


B) La unión de hecho como acuerdo de voluntades .........................................................51

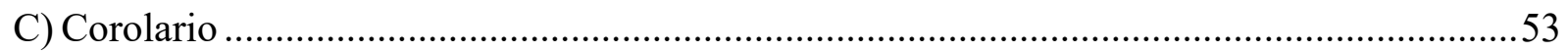

\section{ASPECTOS PERSONALES DE LA PAREJA DE HECHO EN EL ORDENAMIENTO

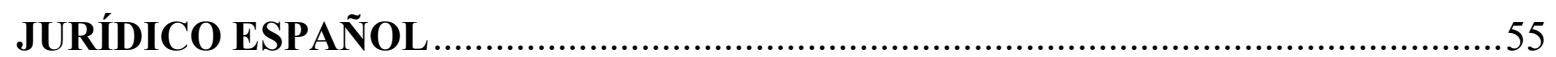

A) Antecedentes próximos de la situación actual ............................................................55

B) Causas que dan lugar a las uniones de hecho ..........................................................60

1. Uniones de Hecho creadas por causas ajenas a la voluntad de la pareja..........................61

2. Uniones de Hecho surgidas por la voluntad de no casarse de los miembros de la pareja..63

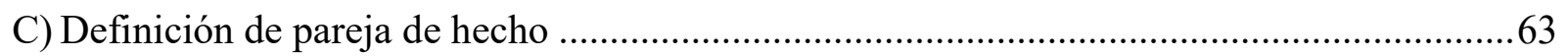

1. Una definición estatal de pareja de hecho ..........................................................67

2. Definiciones autonómicas de las uniones de hecho ..................................................68

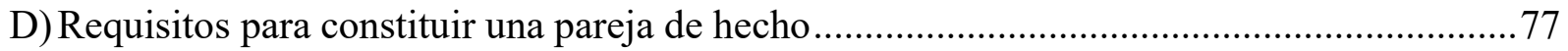

E) Comparativa entre los requisitos para constituir pareja de hecho y los exigidos para la

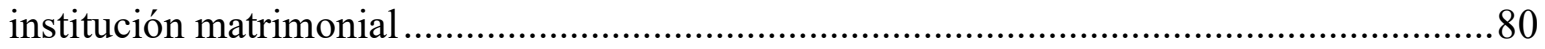

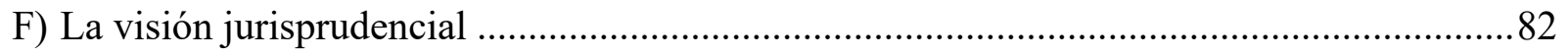

G) De la elaboración del expediente administrativo para acceder a la inscripción como unión de hecho .84

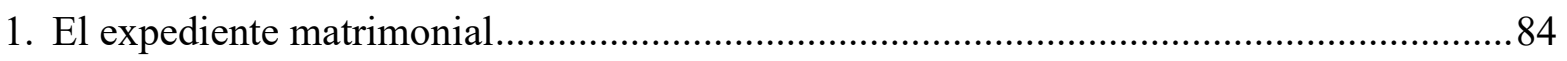

2. De la tramitación del expediente de unión de hecho en las distintas CCAA ....................88

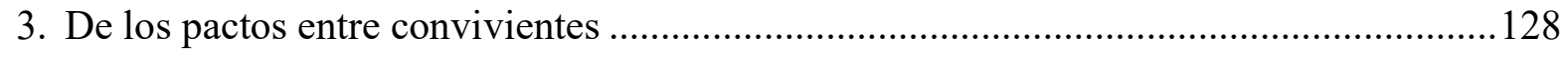

4. La actuación del notario en la formalización de parejas que conviven maritalmente...... 130

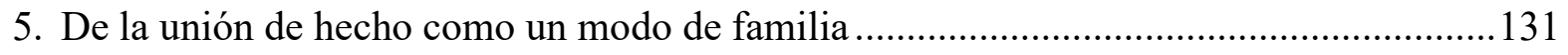

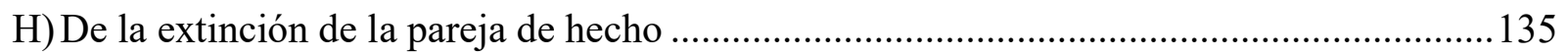

I) El principio del libre desarrollo de la personalidad ................................................. 137

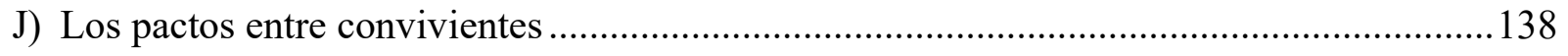

V. LOS ASPECTOS PATRIMONIALES DE LA PAREJA DE HECHO EN EL ORDENAMIENTO JURÍDICO ESPAÑOL 143 
A) Efectos patrimoniales durante la convivencia de la unión de hecho 143

1. La posibilidad de pacto entre convivientes para establecer un régimen económico en la pareja 144

2. La sociedad como régimen económico de las uniones de hecho 147

a) Diferencias con la comunidad de bienes

3. Socorro y ayuda mutua entre los convivientes. La obligación de alimentos. 150

4. Donaciones entre convivientes 152

a) Donaciones válidas 153

a).1. Cuando tiene por objeto satisfacer perjuicios derivados de la relación afectiva ...153

a).2. Donaciones remuneratorias............................................................................................... 154

b) Donaciones declaradas nulas 155

b).1. Las realizadas para remunerar las relaciones extramatrimoniales de carácter amoroso 155

b).2. Las realizadas para poner fin a la relación extramatrimonial .....................................156

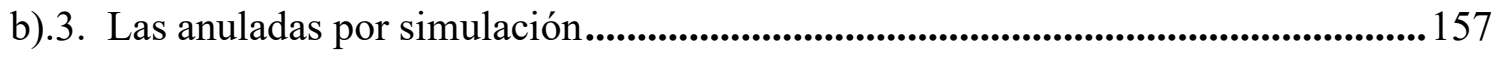

b).4. La anulabilidad de las donaciones realizadas con vicio en el consentimiento ......158

c) La situación actual: la validez de las donaciones entre convivientes .....................159

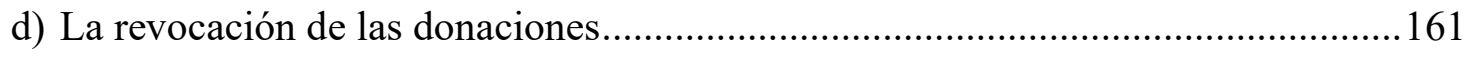

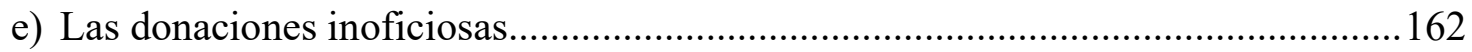

5. La vivienda como hogar familiar de las parejas de hecho.................................................. 165

a) Problemática acerca de la titularidad de la vivienda familiar ..................................166

a).1. Supuestos de cotitularidad .................................................................................................. 168

a).2. Supuestos de titularidad exclusiva .................................................................................. 169

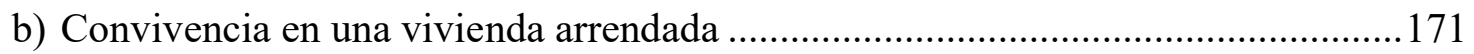

b).1. Desistimiento, no renovación o abandono del conviviente titular del arrendamiento 172

b).2. Realización de obras de adaptación en la vivienda familiar 174 
b).3. La unión extramatrimonial y la resolución del contrato por actividades inmorales o incómodas en la vivienda 175

B) Efectos patrimoniales derivados del fallecimiento de uno de los convivientes...................176

1. La subrogación mortis causa del conviviente en el contrato de arrendamiento ................176

2. La indemnización por causa de muerte y la legitimación activa del conviviente more uxorio 178

3. La unión de hecho y la sucesión por causa de muerte.......................................................181

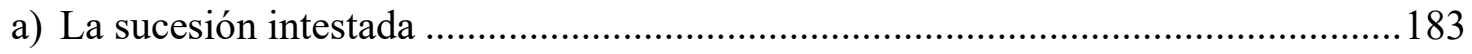

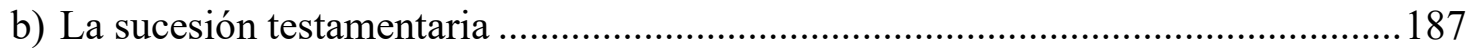

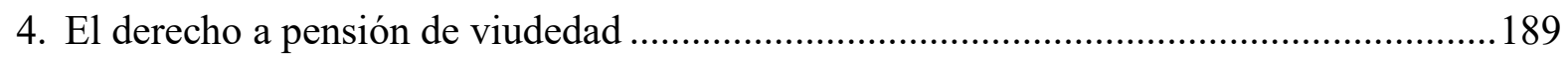

C) Efectos patrimoniales derivados de la ruptura de la pareja de hecho ..................................194

1. Figuras jurídicas aplicables a la liquidación del patrimonio adquirido durante la convivencia

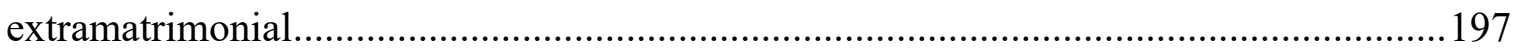

a) La aplicación análoga del régimen de gananciales .................................................198

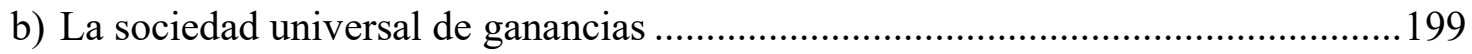

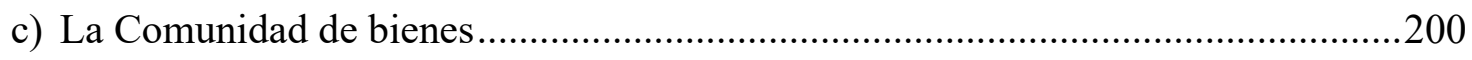

2. Otros efectos derivados del cese de la convivencia extramatrimonial ............................201

3. Atribución del uso de la vivienda familiar en las situaciones de ruptura de pareja de hecho

a) Supuestos de existencia de hijos en la convivencia extramatrimonial....................204

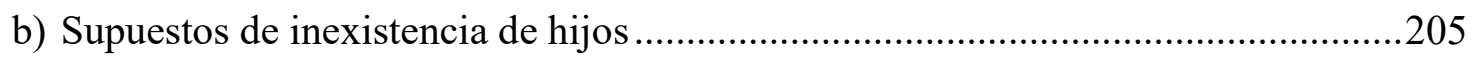

4. Problemática en la aplicación del artículo 96 del CC a las uniones de hecho...................206

5. Reclamaciones económicas entre los convivientes en el momento de la ruptura de la

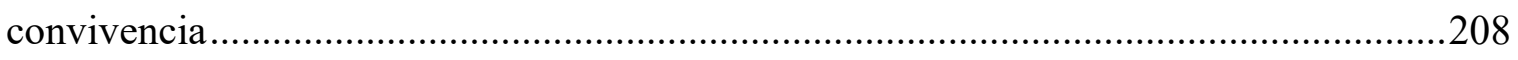

a) El desequilibrio económico como fundamento de la reclamación ..........................209

b) Las soluciones en las CCAA con Derecho Civil propio .........................................211

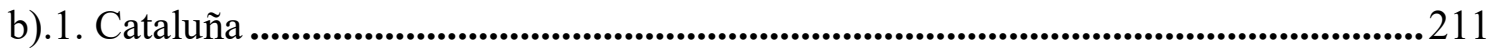

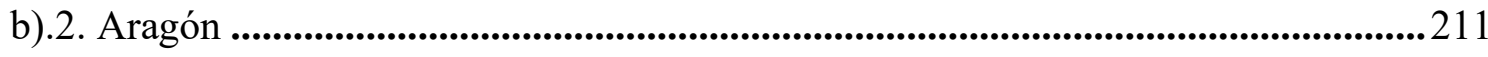




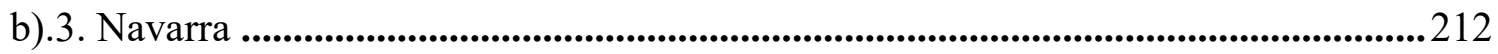

b).4. País Vasco........................................................................................................................2212

b).5. Islas Baleares ...................................................................................................................2213

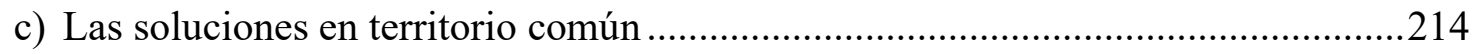

d) El enriquecimiento injusto como criterio de atribución.............................................216

e) Compensación económica por dedicación a la familia...........................................218

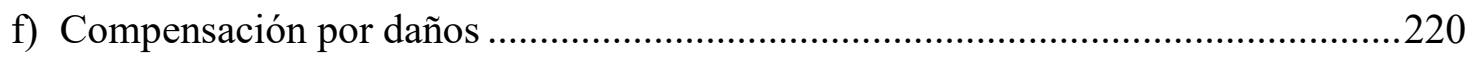

g) El principio de protección al conviviente perjudicado por la ruptura como fundamento

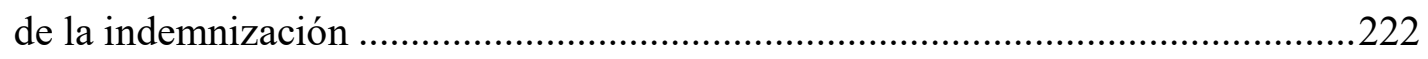

\section{LA REGULACIÓN DE LAS PAREJAS DE HECHO EN NUESTRO ENTORNO .225}

A) Las parejas de hecho en la UE tras la entrada en vigor del Reglamento (UE) 2016/1104, del

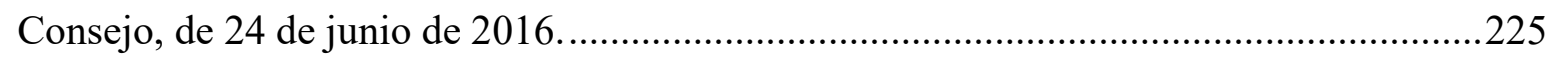

1. Limitaciones en el ámbito regulado por el Reglamento Europeo ……………………......226

2. Características generales del Reglamento UE 2016/1104, del Consejo............................228

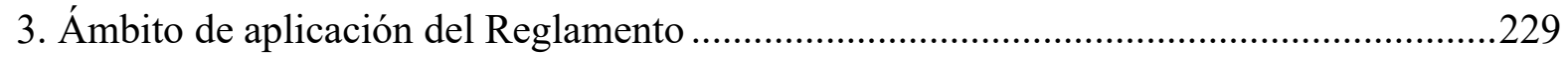

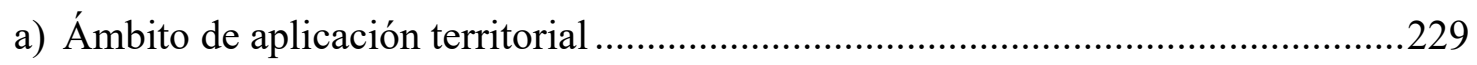

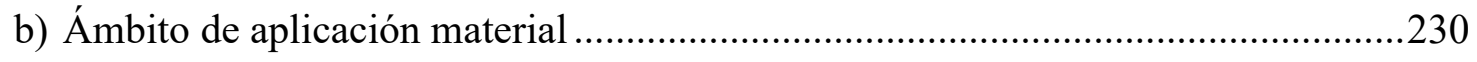

c) Competencia judicial internacional...................................................................231

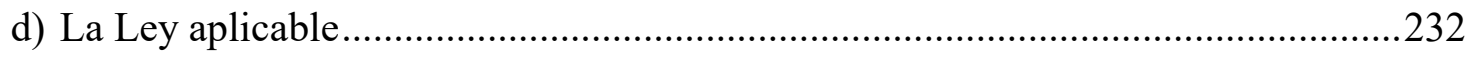

4. Reconocimiento, fuerza ejecutiva y ejecución de las resoluciones, documentos públicos y

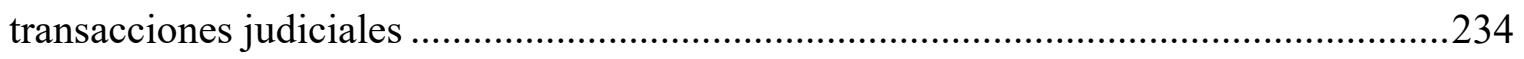

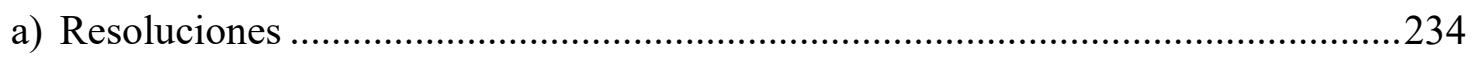

b) Documentos públicos y transacciones judiciales ..................................................234

5. Efectos de la entrada en vigor del nuevo Reglamento europeo en los aspectos patrimoniales

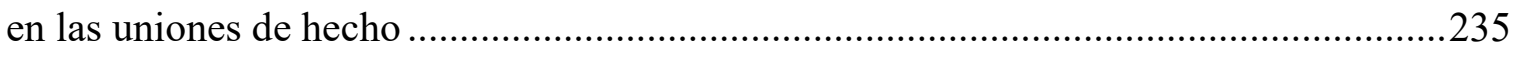

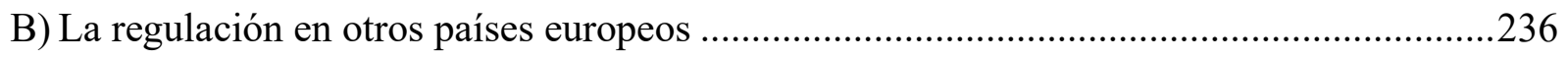

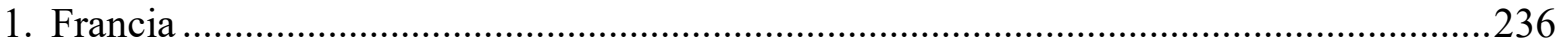

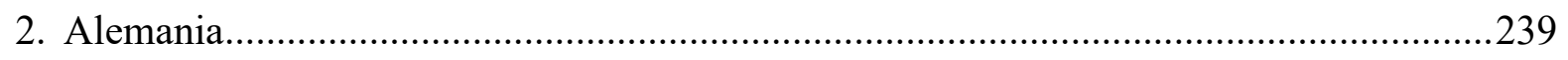




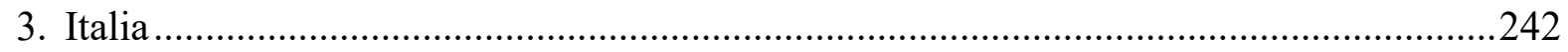

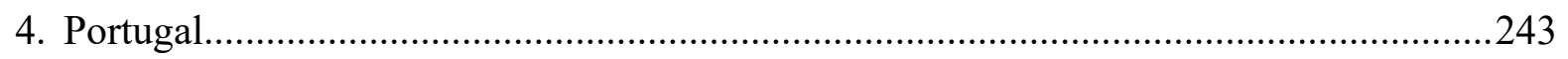

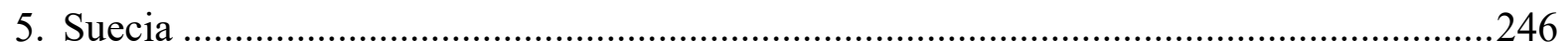

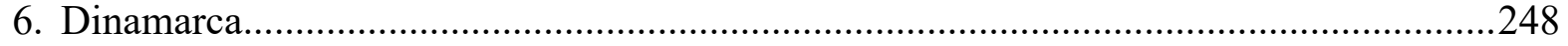

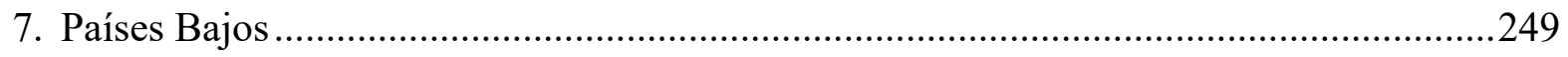

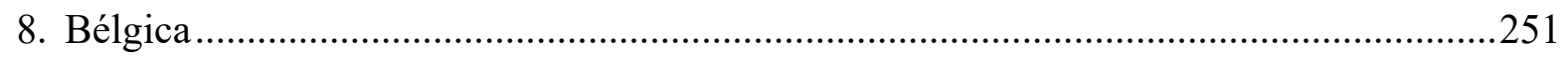

VII. UN ANÁLISIS DEL CONOCIMIENTO SOCIAL SOBRE LAS UNIONES DE HECHO

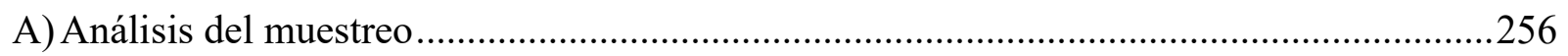

1. Preguntas generales sobre el universo de la muestra.......................................................256

2. Preguntas específicas sobre el conocimiento social de las uniones de hecho ...................256

3. Nivel de conocimiento sobre la existencia de las parejas de hecho ................................258

4. Conocimiento social y definición general de la pareja de hecho .....................................259

5. Conocimiento social de los requisitos para poder formar una pareja de hecho ...............263

6. Valoración social sobre los derechos y obligaciones, de carácter general, entre los miembros

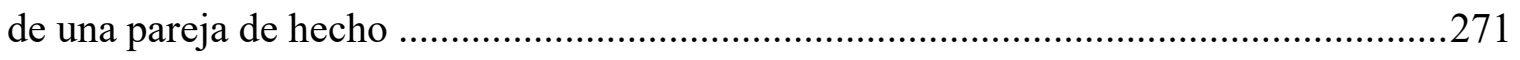

B) Valoración sobre derechos concretos entre los miembros de una pareja de hecho ............279

C) Valoración sobre obligaciones concretas entre los miembros de una pareja de hecho ......282

D) Valoración social sobre las obligaciones patrimoniales, de carácter legal, entre los miembros

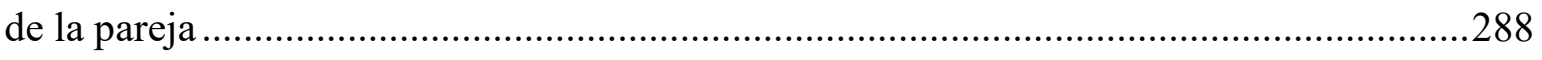

E) Valoración social de los requisitos para el reconocimiento legal de la pareja de hecho ....290

F) Análisis de los resultados obtenidos ...........................................................................292

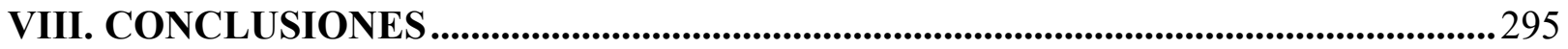

BIBLIOGRAFÍA...............................................................................................................................

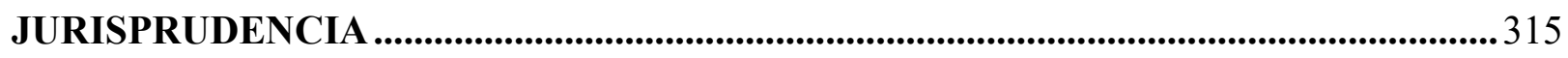

ANEXO. FICHA TÉCNICA DE LA ENCUESTA.............................................................321 


\section{RELACIÓN DE GRÁFICOS}

Gráfico 1. ¿Sabe o conoce lo que es una pareja de hecho? ..................................................259

Gráfico 2. Conocimiento sobre las parejas de hecho, respuesta general ..............................260

Gráfico 3. Conocimiento general sobre las parejas de hecho en la cohorte de 31 a 50 años, por sexo

Gráfico 4. Conocimiento general sobre las parejas de hecho en la cohorte de 51 a 65 años, por sexo 261

Gráfico 5. Requisitos necesarios para formar una pareja de hecho, respuesta general ..........264

Gráfico 6. Requisitos necesarios para formar una pareja de hecho, respuesta por sexo 265

Gráfico 7. Requisitos necesarios para formar una pareja de hecho, respuesta por sexo en la cohorte de 18 a 30 años .266

Gráfico 8. Requisitos necesarios para formar una pareja de hecho, respuesta por sexo en la cohorte de 31 a 50 años.....

Gráfico 9. Requisitos necesarios para formar una pareja de hecho, respuesta por sexo en la cohorte de 51 a 65 años. .268

Gráfico 10. Requisitos necesarios para formar una pareja de hecho, respuesta por sexo y estado civil casado .269

Gráfico 11. Requisitos necesarios para formar una pareja de hecho, respuesta por sexo y estado civil de pareja de hecho no registrada

Gráfico 12. Derechos y obligaciones legales entre los miembros de una pareja de hecho, respuesta general

Gráfico 13. Derechos y obligaciones legales entre los miembros de una pareja de hecho, respuesta por sexo

Gráfico 14. Derechos y obligaciones legales entre los miembros de una pareja de hecho, respuesta por sexo en la cohorte de 18 a 30 años

Gráfico 15. Derechos y obligaciones legales entre los miembros de una pareja de hecho, respuesta por sexo en la cohorte de 31 a 50 años 274 
Gráfico 16. Derechos y obligaciones legales entre los miembros de una pareja de hecho, respuesta por sexo en la cohorte de 51 a 65 años .275

Gráfico 17. Derechos y obligaciones legales entre los miembros de una pareja de hecho, respuesta por sexo y estado civil de casado 276

Gráfico 18. Derechos y obligaciones legales entre los miembros de una pareja de hecho, respuesta por sexo y estado civil de pareja de hecho 277

Gráfico 19. Derechos y obligaciones legales entre los miembros de una pareja de hecho, respuesta por sexo y estado civil de soltería .278

Gráfico 20. Conocimiento de los derechos legales entre los miembros de una pareja de hecho, respuesta general .280

Gráfico 21. Conocimiento de los derechos legales entre los miembros de una pareja de hecho, respuesta por sexo 281

Gráfico 22. Conocimiento de las obligaciones legales entre los miembros de una pareja de hecho, respuesta general 283

Gráfico 23. Conocimiento de las obligaciones legales entre los miembros de una pareja de hecho, respuesta por sexo .284

Gráfico 24. Conocimiento de las obligaciones legales entre los miembros de una pareja de hecho, respuesta de personas solteros según mantengan o no una relación estable 285

Gráfico 25. Conocimiento de las obligaciones legales entre los miembros de una pareja de hecho, respuesta de personas en pareja de hecho según esté o no registrada la relación .286

Gráfico 26. Conocimiento de las obligaciones legales entre los miembros de una pareja de hecho, respuesta por edad 287

Gráfico 27. Régimen económico en las parejas de hecho, respuesta general .288

Gráfico 28. Régimen económico en las parejas de hecho, respuesta por sexo 289

Gráfico 29. Requisitos para el reconocimiento de una pareja de hecho, respuesta general ....291 Gráfico 30. Requisitos para el reconocimiento de una pareja de hecho, respuesta por sexo ..292 


\begin{tabular}{|c|c|}
\hline $\mathrm{AC}$ & Aranzadi Civil \\
\hline $\mathrm{ADC}$ & Anuario de Derecho Civil \\
\hline AP & Audiencia Provincial \\
\hline ATC & Auto del Tribunal Constitucional \\
\hline ATS & Auto del Tribunal Supremo \\
\hline BOCN & Boletín Oficial de la Comunidad de Navarra \\
\hline BOCyL & Boletín Oficial de Castilla y León \\
\hline $\mathrm{BOE}$ & Boletín Oficial del Estado \\
\hline $\mathrm{CC}$ & Código Civil \\
\hline CCAA & Comunidades Autónomas \\
\hline $\mathrm{CE}$ & Constitución Española \\
\hline $\begin{array}{c}\text { DGRN } \\
\text { (actualmente DGSJ y FP) }\end{array}$ & Dirección General de Registros y del Notariado \\
\hline FJ & Fundamento Jurídico \\
\hline INSS & Instituto Nacional de la Seguridad Social \\
\hline $\mathrm{JT}$ & jurisprudencia Tributaria Aranzadi \\
\hline LAU & Ley de Arrendamientos Urbanos \\
\hline LUEP & Ley de Uniones Estables de Pareja \\
\hline PACS & Pacto Civil de Solidaridad \\
\hline RCDI & Revista Crítica de Derecho Inmobiliario \\
\hline $\mathrm{RD}$ & Real Decreto \\
\hline RJ & Repertorio de jurisprudencia Aranzadi \\
\hline
\end{tabular}




$\begin{array}{ll}\text { RPJ } & \text { Revista del Poder Judicial } \\ \text { RJCA } & \text { Repertorio jurisprudencia Contencioso-Administrativa } \\ \text { RTC } & \text { Repertorio del Tribunal Constitucional } \\ \text { SAP } & \text { Sentencia de Audiencia Provincial } \\ \text { STC } & \text { Sentencia del Tribunal Constitucional } \\ \text { STS } & \text { Sentencia del Tribunal Supremo } \\ \text { TC } & \text { Tribunal Constitucional } \\ \text { TS } & \text { Tribunal Supremo } \\ \text { TSJM } & \text { Tribunal Superior de Justicia de Madrid } \\ \text { UE } & \text { Unión Europea }\end{array}$




\section{INTRODUCCIÓN}

El presente trabajo pretende analizar la situación jurídica que, actualmente, plantea el fenómeno de las parejas de hecho, a la vez que trata de vislumbrar la evolución futura de este fenómeno social. Sobre esta temática se ha escrito muchísimo, en especial, durante los últimos treinta y cinco años. Esto ha sido así tanto por la incuestionable importancia de esta realidad social como por la trascendencia jurídica de los efectos derivados de este nuevo modelo de familia.

La importancia cuantitativa de las parejas que optan por este modelo de convivencia que, en nuestro país, es el elegido por algo cada más de una de siete parejas que deciden vivir juntos, obliga a una profunda reflexión sobre la cuestión, así como a plantear soluciones que adecúen el ordenamiento jurídico a esta pujante realidad social.

El concepto de familia ha sufrido una fuerte convulsión en el último siglo. El modelo de familia patriarcal se puede considerar en vías de extinción ante la aparición de nuevos modelos, todos ellos merecedores de la protección de los poderes públicos, por expreso mandato constitucional. Es indudable que, a fecha de hoy, el modelo básico es el de la familia nuclear, constituida por una pareja y sus hijos. Pero dentro de este modelo de familia surgen diversos subgrupos, cuyas diferencias pivotan, fundamentalmente, sobre la pareja origen del grupo familiar. Sin duda, la pareja formada por dos personas casadas, sean del mismo o distinto sexo, sigue siendo el modelo numéricamente mayoritario, aunque dentro del mismo, surgen de inmediato al menos dos subgrupos.

Pero existe también un importante conjunto de parejas que decide constituir su modo de convivencia al margen del matrimonio. Y este modelo de familia, objeto de nuestro estudio, goza de la misma protección jurídica que el formado por personas casadas. Pese a ello, en lo que tiene que ver con el reconocimiento jurídico de la pareja origen de este modelo de familia, el legislador estatal viene mirando hacia otro lado, obviando la imprescindible regulación legal de estas parejas. Regulación que debe hacerse desde el respeto a las ideas de quienes, pudiendo casarse, optan por no hacerlo y, por tanto, no someterse a las normas propias del matrimonio. Ante la mentada falta de actuación del legislador estatal, han sido las CCAA las que han legislado al respecto, lo que nos ha conducido no solo a la existencia de distintas legislaciones, sino a que existan sustanciales diferencias por razón de origen, dado que las CCAA con competencias en materia de Derecho Civil han podido incluir derechos de los convivientes que le son vedados a quienes tienen vecindad civil de territorio común. 
Sin embargo, la respuesta de los poderes públicos ante tal acto de libertad no puede ser la inacción. El legislador no puede obviar que la función del Derecho es regular la vida social y, por tanto, ante la existencia de una realidad social de la importancia reseñada, el legislador estatal debe establecer una regulación que, respetando la voluntad de los convivientes, ofrezca una seguridad jurídica a los miembros de la pareja tanto en sus relaciones internas como en las interacciones de la pareja con terceras personas. Especialmente cuando en lo legislado sobre esta realidad social se viene exigiendo, para el reconocimiento social de la pareja de hecho, la inscripción en determinados registros públicos.

Por ello, el objeto de este estudio será analizar tanto los aspectos personales cuanto los patrimoniales de las uniones de hecho, así como la naturaleza jurídica de este modo de convivencia, completando el análisis con una mirada al pasado y a nuestro entorno actual, tomando el pulso además, a la opinión de la sociedad sobre este fenómeno social. Intentando de este modo tener una idea de conjunto de la realidad jurídica y social, a día de hoy, de este modo de convivencia, comprobando los desajustes normativos que obstaculizan el desarrollo vital de quienes, de forma libre y voluntaria, y con plena consciencia de lo que hacen, optan por mantener este tipo de convivencia libre.

Hoy en día, son importantes las complicaciones a las que se enfrenta el legislador estatal para regular de manera armónica las uniones de hecho en todo el Estado, debido a la proliferación de normas autonómicas que, coincidentes en muchos aspectos, no obstante, difieren de manera sustancial en otros. Ante esta situación el legislador nacional debe establecer unos cauces mínimos que, respetando el carácter voluntario de la unión, permitan a los legisladores autonómicos arbitrar los mecanismos para que, quienes decidan organizar su vida de pareja mediante una relación de convivencia libre, puedan establecer, entre sí, los derechos y deberes que tengan por conveniente, sin limitaciones legislativas discriminatorias en relación con las parejas que optan por casarse.

De modo que, a lo largo de este trabajo, comprobaremos las legislaciones existentes y las limitaciones que de las mismas se derivan en diferentes aspectos del desarrollo de estas parejas. Comprobaremos cómo, en las normas nacionales de Derecho público, sí que existe una importante asimilación al matrimonio de las parejas unidas por una relación de análoga afectividad, mientras que, en lo relativo a los aspectos de Derecho privado, las leyes estatales impiden a los convivientes la transmisión de determinados derechos que, sin embargo, forman parte natural de la transmisión 
en el ámbito del matrimonio. Tales limitaciones afectan, fundamentalmente, a los aspectos patrimoniales de la relación de convivencia.

Veremos, también, cómo han enfrentado la cuestión diferentes países de nuestro entorno, así como la incidencia de nuestra pertenencia a la UE en relación con la norma aplicable, especialmente en las relaciones de pareja transnacionales. Y analizaremos también un aspecto trascendente para determinar las diferencias entre el matrimonio y las uniones libres, como es la distinta naturaleza jurídica de ambas formas de convivencia diferencia sustancial que ha de resultar determinante a la hora de legislar con respeto al libre desarrollo de la personalidad, sin discriminaciones.

Y, por último, aportamos un breve estudio sociológico sobre el modo en el que la sociedad percibe el fenómeno de las uniones de hecho, para comprobar el conocimiento real de la sociedad de cómo están reguladas y lo que se piensa sobre el modo correcto de regulación. Obviamente, el estudio está condicionado por el tamaño de la encuesta que, para obtener conclusiones definitivas, precisaría de un estudio específico de los organismos estatales, en concreto del Centro de Investigaciones Sociológicas, con una encuesta a gran escala y con suficiente amplitud como para establecer las diferencias por rasgos como sexo, edad o situación de relación sentimental, entre otras cuestiones, en función de los distintos ámbitos geográficos. En especial, atendiendo a la existencia de las diferentes legislaciones autonómicas que, indudablemente, han de influir en la opinión de los encuestados. Como decimos, dado el tamaño de la muestra, no ha sido posible establecer diferencias por autonomías, lo que dotaría de mayor relevancia a la encuesta.

Pese a ello, el muestreo es más que suficiente para observar tendencias en la percepción ciudadana. Es cierto que, al no existir un reparto del muestreo proporcional a la población de las diferentes autonomías, se producen sesgos en la encuesta que ha sido preciso valorar a efectos de obtener una mejor aproximación a la percepción a nivel de todo el Estado, que es para el ámbito en que se ha realizado la encuesta. Esta muestra tiene la virtud de indicar tendencias generales sobre la posición de la población española ante el fenómeno de la convivencia more uxorio, destacando, en primer lugar, la normalidad con la que los españoles convivimos con este modelo de relación de pareja, perfectamente integrada en la realidad social de hoy en día. Lo que, por sí mismo, acredita la principal conclusión de este trabajo, que no es otra que la necesidad de normalizar, a nivel legislativo, la realidad social de las uniones de hecho como grupos familiares que deben ser contemplados por el Ordenamiento jurídico. En especial, aquellas parejas que, no 
queriendo casarse, sin embargo reclaman un reconocimiento social a esa relación. Es decir, aquellas parejas que convierten la situación de hecho en una situación jurídica al registrar dicha unión, aunque no lo hagan en el Registro Civil y como matrimonio. 


\section{II.ANTECEDENTES HISTÓRICOS DE LAS UNIONES POR VÍA DE HECHO}

\section{A) IMPORTANCIA SOCIAL DEL MODO DE RELACIÓN DE CONVIVENCIA DE LA PAREJA}

Resulta indiscutible que la familia es el embrión básico sobre el que se fundamenta la sociedad tal como la entendemos. Por ello, al conjunto social siempre le ha importado la determinación de quiénes son los miembros de la familia, lo que se ha manifestado hasta la vigente CE mediante la legitimidad, o no, de los nacidos

Hoy, este es un debate ampliamente superado: los hijos, sean o no matrimoniales, adoptados o recibidos en el seno familiar mediante fórmulas de reproducción asistida serán, en todos los casos, iguales en derechos y obligaciones en el ámbito familiar. Esta consideración es sumamente reciente, ya que lo que ocurría a lo largo de los tiempos era exactamente lo contrario: solamente los hijos legítimos eran sujetos de derechos y obligaciones en el ámbito familiar.

Y es en este aspecto en el que más importante ha sido la existencia de uniones reconocidas legalmente o no. Naturalmente, tampoco esta es una verdad absoluta, ya que las valoraciones sociales también han variado a lo largo del tiempo. Aspectos como el reconocimiento social de la mujer, dependiendo de que se tratase de la esposa o de una unión no matrimonial, o los aspectos vinculados al anatema religioso de las relaciones no santificadas por la Iglesia, han tenido especial importancia a lo largo de los siglos.

Será con la llamada revolución neolítica cuando comiencen a sentarse las bases de las nuevas concepciones del régimen familiar de bienes, herencia, transmisión de la propiedad ${ }^{1}$, y con ello la importancia de las relaciones familiares y la incorporación, o no, de los nacidos al grupo familiar.

\section{B) LA FAMILIA EN LA HiSPANiA PRIMitiva}

Se conoce de manera muy fragmentaria la regulación jurídica de la familia en la Hispania anterior a la conquista latina, aunque es fácil suponer que existiría algún tipo de reconocimiento para las uniones no matrimoniales con las esclavas.

\footnotetext{
${ }^{1}$ ALVARAdO PLANAS, J.; MONTES SALGUERO, J.J.; PÉREZ MARCOS, R.M.a; SÁNCHEZ GONZÁLEZ, M. ${ }^{a}$ D.: Historia del Derecho español, Sanz y Torres, Madrid (2010), pág. 38.
} 
Lo que sí es obvio es la existencia de la familia, entendida en un sentido amplio, como forma de organización social. Las tribus o gens y las gentilitas como organización social eran, en buena medida, una extensión de la familia patriarcal conocida posteriormente.

Dentro de estas formas de inclusión en el grupo familiar hay que reseñar la existencia de costumbres peculiares en el mundo prerromano como la covada, descrita del siguiente modo por Estrabón": "Entre los cántabros... las mujeres cultivan la tierra; apenas han dado a luz ceden el lecho a sus maridos y los cuidan". Esta costumbre implica un reconocimiento de paternidad, es decir, es claramente una manera de legitimación del recién nacido y, con tal legitimación del nacido, también lo es de la relación con la madre, especialmente en una sociedad matrilineal como era la cántabra.

Así pues, del propio texto de Estrabón podemos deducir la existencia de diferentes tipos de relaciones convivenciales, unas con reconocimiento social, que eran aquellas en las que el hombre realizaba las actuaciones públicas propias de la paternidad e implicaba la incorporación al grupo familiar del nacido, y otro tipo de relaciones convivenciales en las que los hijos no eran reconocidos por el varón y, en consecuencia, no pasaba a formar parte del mencionado grupo familiar. De modo que, ya en el propio Derecho ibérico anterior a la conquista romana, encontramos la existencia de relaciones con reconocimiento social y otras que no lo tenían.

\section{C) El CONCUBinato EN LA ÉPOCA ROMANA}

En el Derecho clásico romano se entiende por concubinato la unión estable de un hombre y una mujer sin affectio maritalis, o que teniéndola carecen del derecho de conubium ${ }^{3}$, de modo que sería una unión autorizada, aunque ilegítima. La ausencia de cualquiera de los requisitos señalados diferencia el concubinato del matrimonio en Roma, del mismo modo que la nota de estabilidad lo diferenciaba de la simple relación sexual. En el caso de personas que no tienen el derecho de conubium su unión se consideraba como matrimonio injusto o como concubinato. Son las concepciones y prácticas sociales, y la unión con determinadas personas de clase social inferior, las que distinguen un matrimonio de un concubinato ${ }^{4}$.

\footnotetext{
${ }^{2}$ ALVARADO PLANAS, J.; MONTES SALGUERO, J.J.; PEREZ MARCOS, R.M.a ; y SÁNCHEZ GONZÁLEZ, M. ${ }^{a}$ D.: Textos comentados de historia del Derecho y de las instituciones, ed. Centro de Estudios Ramón Areces, Madrid (2002), pág. 23.

3 PANERO GUTIÉRREZ, R.: Derecho romano, Tirant lo Blanc, Valencia (2008), pág. 311. Entendemos por conubium, o ius conubii, la capacidad jurídica para contraer matrimonio.

${ }^{4}$ GARCÍA GARRIDO, M.J.: Derecho privado romano. Ediciones Académicas, Madrid (2010), pág. 45.
} 
A raíz de que la legislación matrimonial de Augusto restringió el número de mujeres con las que se podía contraer matrimonio, proliferaron las relaciones de concubinato ante la gran cantidad de personas que no podían contraer matrimonio, ya fuera por la existencia de impedimentos de algún tipo o por el incumplimiento de alguno de los requisitos ${ }^{5}$ para contraer iustae nuptiae. La lex Iulia de adulteriis castigaba toda unión sexual fuera del matrimonio como adulterium o como stuprum, y enumeraba toda una serie de mujeres, pertenecientes a clases sociales inferiores, con las cuales era posible mantener relaciones sexuales sin incurrir en las penas previstas para tales delitos 6 .

En los supuestos de concubinato entre personas que tenían el ius conubii —es decir, que podían contraer justo matrimonio pero optaban por no hacerlo- estamos ante la ausencia de affectio maritalis: la ausencia de la intención (ya que affectio es intención) de los concubinos de tenerse mutuamente por marido y mujer (ya que maritalis es marital, conyugal). La citada affectio maritalis, junto al denominado honor matrimonii, ${ }^{7}$ son requisitos indispensables para la existencia del matrimonio romano.

Por lo que los elementos en la concepción romana del matrimonio serán: 1) el elemento subjetivo o intencional (consensus o affectio) y 2) el objetivo y material, la convivencia reflejada en la consideración social de unión estable y permanente (honor matrimonii) ${ }^{8}$. En consecuencia, nos encontraremos ante una situación de concubinato en los supuestos en que exista la unión estable entre dos personas sin affectio maritalis y sin honor matrimonii por parte de la concubina, quien no solo carecería de participación en el rango y la dignidad social del marido, sino a la que no se le guardaría el respeto y la consideración de cónyuge. La falta de estos elementos era lo que diferenciaba al matrimonio romano del concubinato.

Pese a las diferencias existentes en la doctrina sobre el momento en el que el concubinato pasó de ser una situación de hecho a ser una institución jurídica, parece haber bastante coincidencia en reconocer que las leyes de Augusto, que no se refieren a estas uniones como una institución

\footnotetext{
${ }^{5}$ El matrimonio, según la concepción del Derecho Romano clásico, era la unión conyugal de un hombre y una mujer entre los que exista conubium, capacidad natural de contraer matrimonio y un consenso continuado. A tal unión se designaba con los términos iustum matrimonium o iustae nuptiae.

${ }^{6}$ En esta lista estaban: las esclavas, las libertas, meretrices y actrices que hubieran sido condenadas en juicios públicos y las mujeres adúlteras.

${ }^{7}$ El honor matrimonii implica tanto la participación de la mujer en el status del marido como las muestras recíprocas de respeto conyugal.

${ }^{8}$ Ibid., pág. 43.
} 
contemplada por el Derecho, colaboraron en darle a la misma una gran difusión. De manera que el concubinato era una situación de hecho carente de efectos jurídicos, pero que no solo no era ilegal ni reprobada por la sociedad, sino que, al contrario, tuvo una gran difusión en las costumbres sociales.

Ya en Derecho romano postclásico, los emperadores, entonces cristianos, intentaron combatir el concubinato por una doble vía: de una parte, mediante el desprestigio de la concubina y sus hijos, y de otra parte procurando su transformación en matrimonio ${ }^{9}$. Será posteriormente, en época justiniana, cuando el concubinato pasa a configurarse como un matrimonio inferior (inequale coniugium), en el que la única diferencia que existirá ahora con el matrimonio radica en la voluntad de los miembros de la pareja en mantener uno u otro tipo de relación ${ }^{10}$.

De este modo se produce una cierta equiparación entre el matrimonio y el concubinato, quedando fuera de duda el carácter de institución jurídica de este último. Se regulaban los efectos de esta unión con criterios semejantes al matrimonio, y así se aplicaban los requisitos de la unión monogámica y los impedimentos de parentesco y afinidad ${ }^{11}$. La esclava concubina del dueño y sus hijos son libres si el dueño no ha dispuesto lo contrario, y se permiten determinadas liberalidades mortis causa a favor de la concubina y sus hijos, en cuantía diferente según concurran o no con hijos legítimos ${ }^{12}$.

En cuanto a los hijos naturales habidos en un concubinato lícito, conocidos como liberi naturales, podían ser legitimados y, por tanto, equiparados a los nacidos en un matrimonio. Esta legitimación podía conseguirse por una triple vía: por el matrimonio posterior de los padres —

\footnotetext{
${ }^{9}$ El Código Theodosiano establece limitaciones en las donaciones a las concubinas y sus hijos, lo que sería un ejemplo de ese desprestigio pretendido, mientras en las Constituciones imperiales se legitimaba la situación de la concubina y de sus hijos por el ulterior matrimonio.

${ }^{10}$ En el matrimonio romano de la época clásica solamente se exigía para su validez un consentimiento continuo y duradero, de manera que cuando finaliza la intención (la affectio) de ser marido y mujer cesa también el matrimonio. En cambio, en Derecho postclásico tras el consentimiento inicial de los cónyuges, el matrimonio permanece incluso contra la voluntad de estos.

${ }^{11}$ Ibid., pág. 45.

${ }^{12} \mathrm{Si}$ existen padres o hijos legítimos puede dar, por vía testamentaria, a la concubina media onza del patrimonio (1/24) o hasta una onza (1/12) si es a la concubina y a sus hijos naturales. Si no existen hijos legítimos o padres, a la concubina le corresponden hasta 6 onzas (la mitad del patrimonio). En caso de sucesión ab intestato corresponden a la concubina y a los hijos naturales 2 onzas (1/6) y, si hubiera hijos legítimos, la concubina tiene derecho de alimentos.
} 
como señalamos más arriba-, por la inscripción del hijo en la curia ${ }^{13}$ o por concesión del emperador ${ }^{14}$.

Vemos pues cómo en el amplio período histórico del Derecho romano las uniones no matrimoniales pasaron por muy diversas vicisitudes hasta terminar por convertirse en una institución jurídica asimilable al matrimonio, si bien situada en una categoría inferior a aquel, pero en la que se reconocían una serie de derechos a la concubina.

\section{D) UNIONES MATRIMONIALES Y DE CONCUBINATO EN LA ÉPOCA VISIGÓTICA}

La sociedad visigoda estaba formada por una gran mayoría de hispanorromanos y una pequeña parte de población goda. Ambos grupos sociales tenían costumbres, legislación y religión diferentes. Hasta el reinado de Leovigildo se prohibieron los matrimonios mixtos, lo que no impidió la fusión étnica. Alarico propició una política integradora y de fusión que se culmina con Recaredo, que se convirtió al cristianismo ${ }^{15}$.

En la legislación visigótica se mantuvo un supuesto legal de concubinato forzoso: se trata del supuesto de las uniones entre siervos o entre libre y siervo, dada la falta de personalidad jurídica de estos últimos. De modo que la unión estable con cualquier otra mujer, aunque fuese de distinta condición social, sería considerada matrimonio. El Breviario de Alarico afirmaba que el que tiene mujer no puede tener concubina para que el amor de la concubina no lo separe de la mujer, y regula la sucesión de los hijos de la concubina, que necesariamente ha de ser ingenua ${ }^{16}$, con las reglas del código Theodosiano ${ }^{17}$.

Para el Derecho germánico el matrimonio no era indisoluble, aunque sí heterosexual y monógamo, y en el caso del marido podía coexistir con el concubinato, que producía los mismos efectos que el matrimonio formal.

\footnotetext{
${ }^{13}$ Instaurada en el código Theodosiano a principios del siglo V, posteriormente solo era admitida a falta de hijos legítimos.

${ }^{14}$ Instaurada en las Novella de Justiniano para los supuestos en los que no era posible la legitimación por matrimonio. ${ }^{15}$ ALVARADO PLANAS, J.; MONTES SALGUERO, J.J.; PÉREZ MARCO, R.M.a.; SÁNCHEZ GONZÁLEZ, M. ${ }^{a}$ D.: Historia del Derecho español, Op. cit., pág. 162.

${ }^{16}$ En Roma las personas libres podían ser ingenui o libertini. El término ingenui señalaba a los libres que habían nacido libres. De modo que, al seguir los hijos la condición jurídica de la madre, los hijos de madre ingenua serán, igualmente, ingenuos y no esclavos.

${ }^{17}$ FOSAR BENLLOCH, E.: "Las uniones no matrimoniales en el Derecho histórico español. La sucesión mortis causa a favor de los hijos extramatrimoniales en el Derecho civil aragonés”, RCDI n.․ 557, (1983) pág. 140.
} 
En el Derecho germánico inicialmente solo existía el acto formal del matrimonio, con acuerdo bilateral de voluntades y entrega de precio y novia. La evolución de dicho acto fue desembocando en una ceremonia que simulaba un contrato con arras, separándose la declaración de voluntades del régimen jurídico de las obligaciones. La promesa pública de contraer matrimonio o esponsales, en los cuales el novio prometía contraer matrimonio y la familia de la novia (el que tenía el Munt sobre ella), prometía su entrega. Con posterioridad se realizaba el acto formal del matrimonio. A su vez evolucionó desde el aseguramiento del novio mediante la entrega de anillo y monedas en forma de arras, con lo que la otra parte se obligaba a la entrega de la novia, hasta una ceremonia de promesa guiada mediante el intercambio de anillos de un futuro matrimonio que se realizaba en un segundo acto. Este acto de promesa guiada, con intercambio de arras y anillos, se cristianizó en el rito del matrimonio que permanece hasta nuestros días. Los esponsales también precedieron al matrimonio en el Derecho visigótico, y estuvieron influidos por el Derecho canónico que intentó reforzarlos, llegándose en el Liber Iudiciorum a considerar adulterio la infidelidad de la futura esposa, práctica que debía ser anterior por su condición de antiqua. Perfeccionados los esponsales, no podían ser quebrantados unilateralmente, salvo penalización económica, y el matrimonio debía celebrarse en dos años, pudiendo solicitar el aplazamiento por igual período ${ }^{18}$.

La donación por razón de matrimonio se formalizaba mediante la morgengabe (donación de la mañana que, tras la noche de bodas, hacía el recién casado a su mujer en premio a su virginidad). Esta costumbre aparece en el Liber Iudiciorum, pero con terminología romana ${ }^{19}$. De manera que la morgengabe se configura de manera distinta en las denominadas fórmulas visigóticas ${ }^{20}$ y en el texto que aparece en el Liber.

Así pues, el matrimonio podía ser con traslado del Munt sobre la mujer al marido, el cual se podía realizar de dos maneras: por compra que es la señalada, o por rapto con previo consentimiento de la novia ${ }^{21}$, pues de lo contrario se trataría de un delito.

\footnotetext{
${ }^{18}$ MORÁN MARTÍN, R.: El derecho matrimonial en la historia del Derecho español. ed. Universitas, Madrid (2005), pág. 4.

19 ALVARAdO PlANAS, J.; MONTES SALGUERO, J.J.; PÉREZ MARCO, R.M. a.; SÁNCHEZ GONZÁLEZ, M. ${ }^{a}$ D.: Historia del Derecho español, Op. cit., pág. 171.

${ }^{20}$ La Fórmula visigótica n. 20 la configura del siguiente modo: "Tanto me alimentan las dulzuras de tu amor, que hago contrato de inmensas donaciones a favor tuyo, por razón de la belleza de tus formas.... Entrego diez siervos y diez siervas, diez caballos de buena sangre y diez mulos, entre otras cosas y armas, según lo corriente entre los godos según la antigua costumbre llamada morgengabe”.

${ }^{21}$ Este matrimonio se realizaba mediante un acto en el que la novia era entregada por un mediador que la situaba entre su propio Sippen y la del novio, y la novia elegía irse con su futuro marido que iniciaba la "carrera de la novia" (se fingía la huída con ella de unas decenas de metros) y pagaba a la Sippe de la mujer una composición para evitar que
} 
Junto a estas formas de matrimonio coexistía la unión libre, Friedelehe, concertadas por los propios contrayentes sin requisitos de forma. En estas uniones no hay traslado de Munt ni pago de dote. La existencia de este modo de unión ha sido cuestionada por diversos autores, pese a ello señalaremos algunas de las características de este modo de unión libre: al no existir traslado de la Munt, el marido no se convertía en tutor legal de la mujer, pues el matrimonio se basaba en el acuerdo de los contrayentes, por lo que la mujer tenía el mismo derecho que el hombre para solicitar la disolución de la unión. Aunque solía hacerse entre parejas de diferente posición social, ante la inexistencia de requisitos como la monogamia, el Friedelehe facilitó la poliginia: los hijos no estaban solo bajo el control paterno, sino también del de la madre y, al menos inicialmente, tenían plenos derechos hereditarios, si bien la influencia de la Iglesia fue debilitando esta posición. En cuanto al modo de realización, se constituía mediante el traslado público de la novia al domicilio del novio y la consumación en la noche de bodas. Con el tiempo el Friedelehe pudo convertirse en matrimonio con dote o tutela al entregar el marido una dote a la novia en reserva para el supuesto de que la esposa le sobreviviera. El personaje histórico más conocido nacido de una unión de Friedelehe fue Carlomagno (742): sus padres, unidos por un contrato privado, no contrajeron matrimonio hasta el $744^{22}$.

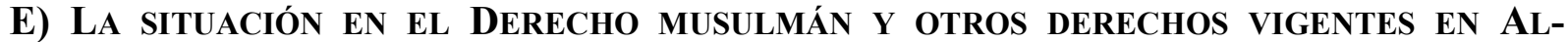
ANDALUS

Tras la conquista de la península por los musulmanes coincidieron distintos ordenamientos jurídicos en el territorio conquistado: el Derecho musulmán, que se aplicaba a los musulmanes que habían conquistado el territorio peninsular y a los que se habían convertido al Islam; el Liber Iudiciorum, que se aplicaba a la población hispanorromana; y el Derecho judío, para los practicantes de esta religión.

En el Derecho musulmán el varón podía contraer matrimonio con cuatro mujeres libres, pero no existían limitaciones en el número de concubinas, que necesariamente eran esclavas, $\mathrm{y}$

\footnotetext{
surgieran enemistades. Para llevar a cabo esta ceremonia era preciso el asentimiento de la Sippe de la mujer, cuando no existía tal asentimiento la relación se equiparaba a la Friedelehe.

${ }^{22}$ El Friedelehe fue declarado ilegítimo en el siglo IX por la Iglesia. Pese a ello, se dice que los vestigios de esta forma de matrimonio han persistido bajo la forma del matrimonio morganático o matrimonio de mano izquierda (se llama así porque en este el marido sostiene la mano derecha de la novia con la suya izquierda, cuando lo normal es hacerlo al revés). Este tipo de matrimonio era conocido en el Derecho germánico, del que pasó a otros pueblos. La Iglesia siempre lo consideró como un matrimonio más.
} 
cuyos hijos habidos de esa relación de concubinato serán legítimos. Cabían pactos entre las familias para que el varón musulmán no pudiese tomar concubinas.

\section{El Mut'ah: una práctica matrimonial por período pactado}

En la comunidad chiita existía la práctica del Mut'ah, la cual ha seguido practicándose por determinadas comunidades chiítas de todo el mundo. Este modo de matrimonio temporal se sigue practicando en el Irán actual, si bien allí es conocido con el nombre persa de sigueh. Entre otros lugares del mundo, en la actualidad esta práctica también se lleva a cabo por la comunidad musulmana de Buenaventura, Cali (Colombia), quienes han llevado una práctica del Corán a esta parte del mundo tan alejada de los territorios en que habitualmente situamos la religión musulmana como predominante ${ }^{23}$. En esta comunidad se configura este modo de relación matrimonial con el siguiente texto:

Colocamos a Dios de testigo y por unas horas, por unos meses, por unas semanas, por un año se casan.

Si tienen hijos, es como un matrimonio completo legalizado con Dios.

Se paga dote, y si queda un hijo, es totalmente reconocido.

\section{Munir Valencia}

La institución de matrimonio temporal aparece registrada en el Corán según la exégesis chiita en la sura 4, aleya 24, cuando se afirma: "En cuanto a aquellas (mujeres) con las cuales hayáis realizado mut'ah, dadles sus dotes como precepto". Así mismo, además de la opinión de los imanes, la tradición chiita cita un dicho del Profeta de Bujari que sustentaría el matrimonio temporal: "Narró Jabir bin Abdullah y Salama bin Al-Akwa: mientras estábamos en un ejército, el Apóstol de Allah, vino a nosotros y dijo: 'os ha sido permitido hacer el (matrimonio) Mut'ah luego hacedlo" $" 24$.

La palabra Mut'ah hace referencia literalmente al placer o deleite. En dicho sentido, el matrimonio temporal es un tipo de pacto o contrato matrimonial cuyo fin principal no es el establecimiento de una unidad familiar o la procreación, sino el placer sexual. Este tipo de

\footnotetext{
${ }^{23}$ GIOVANI CASTELLANOS, D.: "Mut'ah: usos y adaptaciones de una práctica matrimonial islámica en el Pacífico colombiano", Revista de Estudios Colombianos n. ${ }^{\circ} 48$ (2016), pág. 52.

${ }^{24}$ Ibid., pág. 53.
} 
matrimonio tiene como requisitos que la mujer no esté casada (lo cual no se aplica para el hombre), que sea musulmana o monoteísta, así como casta, aunque no necesariamente virgen. Además, se caracteriza porque su duración no es indefinida, como en el matrimonio convencional, sino que es establecida de antemano por los contrayentes. En el contrato verbal o escrito se especifican tanto el tiempo de duración de la unión como el monto de dinero que se entrega. Al parecer, la Mut'ah no suele tener registro legal ni ceremonia de divorcio, y puede durar desde un par de horas hasta noventa y nueve años ${ }^{25}$.

\section{El Derecho de Moisés y la interpretación del Talmud en España}

En la Ley Mosaica, el concubinato es una relación entre un amo y una esclava cuya situación de esclavitud no varía en absoluto por su condición de concubina ${ }^{26}$. Sin embargo, en el Torah se reserva para la concubina un reconocimiento social similar al de una esposa, ya que esta relación se establecía a menudo para conseguir descendencia, lo que era considerado en el judaísmo como una gran bendición. A menudo, cuando no podían tener hijos, eran las propias esposas legítimas las que entregaban sus siervas al esposo para que pudiera tener descendencia. El ejemplo bíblico de Abraham y Sara, quien le entrega su esclava Hagar a su esposo, y el nacimiento de Ismael, hijo de la esclava y Abraham, es absolutamente conocido.

Según el Talmud, la diferencia entre una concubina y una esposa plena era que esta última recibía un contrato de matrimonio y la celebración del matrimonio estaba precedida por unos esponsales en los que se entregaba una dote, de manera que si el marido no entregaba la dote correspondiente se consideraba que no existía matrimonio, sino concubinato. No obstante, y dado que la esclava no perdía su condición de tal, y sus hijos seguían la condición de la madre, los hijos de la esclava se adscribían al ama de esta.

F) LA IGLESia CATÓliCA Y LAS UNIONES NO MATRIMONIALES DURANTE LA ALTA EDAD MEDIA

Aunque los más grandes pensadores de la Iglesia de los primeros tiempos condenaban el concubinato desde una perspectiva moral, que no jurídica, como en el caso de san Agustín, y pese a que era considerado como un pecado grave por otros ilustres pensadores cristianos, como san

\footnotetext{
${ }^{25}$ Ibid., págs 54-56

${ }^{26}$ FOSAR BENLLOCH, E.: Op. cit., pág. 143.
} 
Ambrosio, estos pensamientos no se transformaron en medidas contundentes contra tales prácticas. Debe tenerse en cuenta que no es hasta el Concilio de Trento cuando se exige el requisito ad solemnitatem para la validez del matrimonio, de manera que, en el período al que nos estamos refiriendo, será el mero consensus de los intervinientes lo que resultará decisivo para determinar si la unión es un matrimonio o un concubinato.

Las preocupaciones de la Iglesia en este período se centraban más en evitar que penetrase en los pueblos cristianos la práctica de la poligamia, existente en diversos pueblos con los que estaban en contacto. Por ello, el canon 17 del Primer Concilio de Toledo (año 400) ordena la excomunión del que tuviese a la par esposa y concubina, si bien se le permitía optar entre una u otra, pues prescribió que tan verdadera mujer era para un cristiano la uxo, —es decir, la ingenиa con la que se contraía el iustum matrimonium según el Decreto romano- como la concubina - es decir, la esclava o la libre con la que, de conformidad con ese mismo Derecho, no se podían celebrar las iustae nuptiae ${ }^{27}$ -

En esta misma línea se manifiesta san Isidoro de Sevilla al señalar que al cristiano no le está permitido tener varias mujeres, siendo lícito solamente tener una mujer, por lo que debe elegir entre la esposa legítima o la concubina. En suma, la Iglesia aceptaba cualquier unión estable constituida con intención de permanencia, independientemente de que fuese matrimonial o concubinaria, poniendo en valor la intención de constituir una familia, lo que contraponía a las uniones puramente concupiscentes.

Graciano incluyó en su Concordia discordantium canonum (1140) los textos del Concilio de Toledo y de san Isidoro, que parecen tolerar el concubinato del laico soltero, y si bien incluyó también otros textos que se oponían al concubinato, lo hizo desde una perspectiva puramente moral, proponiendo un ideal de vida cristiana que separaba los preceptos jurídicos del ideal de la moral. Es en ese plano ético de elevación espiritual de la categoría de la unión matrimonial que, posteriormente, sería elevada a sacramento - en el que se encuentra este ideal moral, más que jurídico, de Graciano ${ }^{28}$. Este autor negó el derecho a la sucesión intestada de los hijos naturales. Sin embargo, la doctrina canónica posterior estuvo dominada por autores que no condenaban el concubinato al entender, como Baldo de Ubaldis, que "debemos obedecer a las leyes y no a los

\footnotetext{
${ }^{27}$ MOSTAZA RODRÍGUEZ, A.: "La Iglesia española y el concubinato hasta el siglo X”, en Antología annua, n. 6 (1958), pág. 197.

${ }^{28}$ FOSAR BENLLOCH, E.: Op. cit., pág. 154.
} 
cánones, porque los cánones no permiten el concubinato, porque se comete pecado mortal", idéntica protesta formal de acatar la doctrina de la Iglesia que contienen las Partidas, donde no se dejó de reconocer efectos al concubinato incluso después de la prohibición de Trento ${ }^{29}$.

Como veremos más adelante, la condena de la barraganía por la Iglesia, y el rechazo de esta por la doctrina del ius commune, no fueron obstáculo suficiente para impedir el reconocimiento de la misma por la legislación civil de los reinos medievales.

\section{G) UNIONES NO MATRIMONIALES EN LA ESPAÑA CRISTIANA DURANTE EL MEDIEVo}

Siguiendo una larga tradición que hemos venido señalando, el concubinato continuó estando muy presente en las sociedades medievales. El arraigo de esta práctica concubinaria probablemente derive de su aceptación legal en las épocas romana y visigoda. El contubernium fue una realidad en toda Europa que, al igual que en España, constituyó el modo más habitual de unión y se mantuvo con vigor durante la época altomedieval. En las lenguas romances a este tipo de unión se le denominó barraganía, siendo considerada como una institución definida por la unión de un hombre y una mujer solteros que convivían de manera estable y con vocación de permanencia.

Martínez Marina señala que "según su fuero y costumbre antigua de España, podemos distinguir tres clases de enlace de varón y mujer autorizadas o toleradas por la ley (...), nombrando en primer lugar el matrimonio 'celebrado con todas las solemnidades del Derecho y consagrado por la religión', el denominado matrimonio in facie ecclesiae, y el llamado matrimonio 'a yuras ${ }^{30}$, pasaba a definir la barraganía diciendo que 'la barraganía no era un enlace vago, indeterminado o arbitrario; se fundaba en un contrato de amistad y compañía, cuyas principales condiciones eran la permanencia y fidelidad".

El Fuero de Zamora en su capítulo 38 trata de la Barragana y dice que "Omne que ovier fillo o filla de barragana, los por lengua non heredar, non sean heredados nen nos tragan a derecho. E se fur barragana que coma con él a una escudiela e a una mesa, e casa contovier con ella e non

\footnotetext{
${ }^{29}$ FOSAR BENLLOCH, E.: Op. cit.,, pág. 155.

${ }^{30}$ MARTÍNEZ MARINA, F.: Ensayo crítico sobre la legislación de los reinos de León y Castilla especialmente sobre el Código de las Siete Partidas de Don Alfonso El Sabio, Imprenta de D. E. Aguado, 2a ed., Tomo I, Madrid (1834). El matrimonio "a juras" o "a yuras" era un matrimonio válido al igual que el celebrado in facie ecclesiae, aunque de menor condición social al ser celebrado ante un clérigo pero sin solemnidad. Martínez Marina., indica que "consta del Fuero de Cáceres que el matrimonio a yuras era un contrato juramentado que inducía perpetuidad y las mismas obligaciones que el matrimonio solemne" al ordenar que "Todo home que su mulier de bendiciones o de yuras lexare o ella a él, vaya al obispo o a quien tuviere sus veces, et el obispo mande a los alcaldes que lo aprieten que torne el varón a la mugier y la mugier al marido" (pág. 262).
} 
hovier mulier a beneciçon, e los fillos sean heredados; e en quanto ganaren, en todo aya sua meatade. E esto sea con afronta de V omnes bonos asuso".

Este fuero concede los máximos privilegios a la barragana. Le conceden el mismo trato, o similar, otros fueros locales como los de Cuenca, Teruel, Béjar, etc. Incluso señalando que podían tener barragana tanto los laicos como los clérigos encontramos otros fueros locales como los de Alcalá, Soria, Molina etc. Esta equiparación con la mujer de bendición contenida en dichos fueros es posible que inspirase la llamada "carta de compañería", definida por el Diccionario del español jurídico como "carta o contrato que se hacía para seguridad del contrato de mancebía o concubinato, con el fin de que la manceba o concubina tuviera ciertos derechos, una vez que estos se había perdido con la inserción de principios canónicos en las anteriores uniones de hecho propias del derecho altomedieval, que tenían los mismos efectos que el matrimonio solemne. También se denominaba carta de mancebía"31.

En la Carta de Ávila, que incluye ese contrato con derechos para la concubina, algunos autores no tan antiguos realizan valoraciones que se enfrentan totalmente con los conceptos de la sociedad del siglo XXI, con afirmaciones como que "no hay nada que podamos interpretar como índice de sometimiento de la mujer. Por el contrario, esta recibe una serie de rentas que le garantizan su independencia económica incluso después de la muerte del hombre y un trato respetuoso, reflejado en la afirmación de que comerá con él en la misma mesa"32.

Otro fuero que menciona derechos de la concubina es el de Plasencia "la barragana, si probada fuere fiel a su señor, e buena, herede la meatad que amos en uno ganaren en muebles e en raíz”. En suma, la profusión con la que los fueros hablan de las barraganas, tanto de los clérigos como de los legos, así como de los derechos de las concubinas y de sus hijos, aun cuando la cita sea para negar esos derechos, acreditan la expansión de la costumbre. También se comprueba que en algunos fueros se prohibía a los casados tener barraganas en público, una prohibición que no se

\footnotetext{
${ }^{31}$ En el códice Miscelánea de antigüedades de Ávila se contiene la siguiente carta: "Conoscida cosa sea á cuantos vieren é oyeren la carta de mancebía é compaíña que yo Ñuno Fortunes, filio de Fortun Sancho pongo tal pleito con Doña Elvira González, manceba en cavello, que vos recibo por manceba é compañera á pan é mesa é cuchillo, por todos los días que yo viviere: é vos dono la mitad de la heredad de la torre de Fortun Sánchez, que las tengades después de mis días todo el tiempo que vivieredes, con sus entradas i ejidos i después la herede mi filio Sancho Nuñez: é mas, que hayades las casas que yo tengo en Avila; donde fue facta la carta.- Testes que viderunt et auditerunt.- Diego Nuñet, é Fide Nuñez Velasco, é Roy González, é Domingo Fernandez, é Gonzalo Martín. Facta carta en 27 dias andados de Abril, era 1399.-Nuño Fortunes-Doña Elvira González".

${ }^{32}$ GACTO FERNÁNDEZ, E.: “La filiación no legítima en Derecho histórico español”, en Anales de la Universidad hispalense. Universidad de Sevilla (1969), pág. 263.
} 
extendía a los solteros, pues no resultaba escandaloso o indecente mantener este tipo de relaciones. En cambio, en el caso de los legos, las barraganas eran consideradas como mujeres de segundo orden, pero con cierta asimilación a las esposas legítimas.

Según Gacto Fernández "solían acogerse a esta unión las clases inferiores de la sociedad, poco inclinadas al matrimonio, precisamente por su rigidez, y también los hombres de alguna calidad que deseaban convivir con una mujer de inferior condición social, el matrimonio con la cual hubiera sido objeto de repulsa por sus iguales" 33 .

Este modo de unión, indudablemente ilegítima, que los fueros denominaban como barraganía "producía[n] un estado civil que, si inferior al de los matrimonios solemnes y a yuras, no dejaba de originar derechos importantes, tanto para la barragana como para la prole. El fondo jurídico de la barraganía era un convenio de afecto y compañía para toda la vida de los contrayentes y bajo la ficción de ser como casados; siendo de notar que los fueros permitían sin distinción a todos los solteros, legos o clérigos, y aun en ciertas localidades también a los casados, que tuviesen barragana, la cual había de reunir las condiciones negativas de no ser casada, ni religiosa, ni pariente, ni robada, esto es las mismas que si fuera a ser tomada por mujer de bendición o a yuras. Era la concubina una mujer inferior en categoría a estas dos, pero casi gozaba de iguales derechos, existiendo fueros, como el de Plasencia y Zamora, que le concedían la mitad de los gananciales. La prole procedente de esta clase de uniones era considerada como de la familia y acreditaba respecto del padre una reciprocidad de derechos y deberes igual a los reconocidos en la legítima, en defecto de ésta; pero concurriendo con ella, era postergada, limitándose sus derechos a los señalados para los hijos ilegítimos"34.

Por su parte en las Siete Partidas del Rey Alfonso X tenemos que las tres leyes del Título XIV de la Partida cuarta trata "De las otras mujeres que tienen los hombres que no son de bendiciones" de modo que establecen lo siguiente:

Ley 1: Ingenua mulier es llamada en latín toda mujer que desde el nacimiento fue siempre libre de toda servidumbre y que nunca fue sierva. Y esta puede ser recibida por barragana según las leyes, bien que sea nacida de vil linaje o en vil lugar, o ser mala de su cuerpo o no. Y tomó este nombre de dos palabras, de barra, que de arábigo, que quiere tanto decir como fuera, y

\footnotetext{
${ }^{33}$ GACTO FERNÁNDEZ, E.: "El divorcio en España. Evolución histórica”, en Historia 16, n. ${ }^{\circ} 28$, Madrid (julio de 1978), pág. 33.

${ }^{34}$ SÁNCHEZ ROMÁN, F.: Estudios de Derecho Civil. Introducción e historia general de la legislación española, sucesores de Ribadeneyra, Madrid (1899), pág. 228.
} 
gana que es ladino, que es por ganancia; y estas dos palabras juntadas en uno quieren tanto decir como ganancia que es hecha fuera de mandamiento de la Iglesia, y por ello los que nacen de tales mujeres son llamados hijos de ganancia. Otrosí puede ser recibida por tal mujer también la que fuere liberada como la sierva.

Ley 2. Comunalmente, según las leyes seglares mandan, todo hombre que no fuese impedido por orden o casamiento puede tener barragana sin miedo de pena temporal, solamente que no la tenga virgen ni sea menor de doce años, ni tal viuda que viva honestamente y que sea de buen testimonio. Y tal viuda como esta, queriéndola alguno recibir por barragana u otra mujer que fuese libre desde su nacimiento y no fuese virgen, débelo hacer cuando la recibiese ante hombres buenos, diciendo manifiestamente ante ellos como la recibe por barragana suya; y si de otra manera la recibiese, sospecha cierta sería ante ellos de que era su mujer legítima y no su barragana. Otrosí ningún hombre no puede tener muchas barraganas, pues según las leyes mandan, aquella es llamada barragana que es una sola, y es necesario que sea tal que pueda casar con ella si quiere aquel que la tiene por barragana.

Ley 3: Ilustres personas son llamadas en latín personas honradas y de gran condición, que son puestas en dignidades, así como los reyes y los que descienden de ellos, y los condes, y otrosí los que descienden de ellos, y los otros hombres honrados semejantes de estos; y estos tales comoquiera que según las leyes pueden recibir barraganas, tales mujeres hay que no deben recibir, así como la sierva o hija de sierva, ni otrosí la que fuese liberada ni su hija, ni juglaresa ni su hija, ni tabernera, ni regatera, ni sus hijas, ni alcahueta ni su hija, ni otra ninguna persona de aquellas que son llamadas viles por razón de sí mismas o por razón de aquellos de los que descendieron, pues no sería conveniente cosa que la sangre de los nobles hombres fuese esparcida ni juntada a tan viles mujeres. Y si alguno de los sobredichos hiciese contra esto, si hubiese hijo de tal mujer vil, según las leyes no sería llamado hijo natural, antes sería llamado espurio, que quiere tanto decir como fornecido, y además tal hijo como este no debe tener parte en los bienes de su padre, ni es el padre obligado de criarlo, si no quisiere.

Las Partidas recogen el sistema romano justiniano de sucesión de los hijos naturales en la herencia paterna cuando faltan los legítimos: ab intestato, el hijo puede recibir una sexta parte del patrimonio total, que ha de repartirse con su madre. Se prescinde del requisito romano que hacía depender esta sucesión de la inexistencia no solo de hermanos de matrimonio, sino también de mujer legítima del padre, exclusión que las partidas explican convenientemente -Partida $6^{\mathrm{a}}, 13-$ . Por testamento, siempre sobre la base de la ausencia de otros hijos legítimos, el padre puede instituir al hijo natural como heredero universal, pero debe respetar la legítima de los ascendientes 
- un tercio del caudal hereditario-, en el caso de que sobrevivieran. Este ordenamiento, sin embargo, no reconoce al natural ninguna legítima testamentaria... Pero reconoce el derecho de alimentos del hijo ${ }^{35}$.

La nobleza tenía la necesidad de tener hijos que perpetuasen el linaje familiar, por lo que se utilizaban los medios necesarios para tener una numerosa prole. Es en este marco en el que se desarrollaban las relaciones teniendo los llamados hijos de ganancia: estos hijos permitían potenciar el linaje familiar mediante enlaces matrimoniales con otros linajes importantes. En el caso del Derecho foral Navarro, incluso se admitía la existencia de concubinas y se imponía al marido la obligación de mantenerla en su casa junto a la mujer de bendición.

Las legislaciones medievales de otros reinos peninsulares regularon de modo similar la institución de la barraganía, pues como señala Martínez Marina los fueros medievales "consideraban a las barraganas de los legos como unas mujeres de segundo orden, y les otorgaban casi los mismos favores que a las legítimas" ${ }^{\prime 3}$. Los fueros locales de los distintos reinos regularon con detalle la barraganía, como los de la familia de fueros de Teruel-Cuenca, o algunos fueros locales de Navarra, en los que la barragana aparece en múltiples ocasiones equiparada a la mujer legítima en determinadas condiciones.

\section{H) REgUlaCión POSTERIOR A LAS SIETE PARTIDAS}

Con posterioridad a las Siete Partidas se fueron dictando normas restrictivas en las relaciones de barraganía. En el caso de los clérigos, se prohibió la herencia de los hijos de sus barraganas, así como la obligación de utilizar una indumentaria identificativa de estas ${ }^{37}$.

En este período de la baja edad media, y posteriormente durante la edad moderna, se va consolidando esta situación de disfavor legal hacia la situación de convivencia con barragana entre los laicos, además de establecer fuertes limitaciones a las uniones con barraganas tan arraigadas entre los clérigos. De inicio, los Reyes Católicos dejaron en manos del clero la supresión de la

\footnotetext{
${ }^{35}$ GACTO FERNÁNDEZ, E.: "La filiación no legítima en Derecho histórico español”. Op. cit., págs. 170-171.

${ }^{36}$ MARTÍNEZ MARINA, F.: Op. cit, pág. 264.

${ }^{37}$ MARÍA SERRANO, N.: Diccionario universal de la lengua castellana:ciencias y arte, enciclopedia de los conocimientos humanos, Astort hermanos, Madrid (1876). En las Cortes de Soria de 1380, se recoge en el correspondiente Libro de Órdenes lo siguiente: “Ordenó Juan I, a petición de los procuradores, que los hijos que los clérigos hubiesen en sus barraganas no heredasen los bienes de sus padres ni parientes, ni los pudiesen adquirir a título de manda, donación o venta, porque con esto daban ocasión 'para que otras buenas mujeres, así viudas como vírgenes, sean sus barraganas o hayan de facer pecado'; y a fin de distinguir las mancebas de los clérigos de las mujeres casadas, dispuso que llevasen pública y continuadamente por señal un prendido de paño bermejo encima de las tocas en manera que se paresca" (pág. 230).
} 
barraganía de los clérigos, pues a ello se comprometieron los dirigentes eclesiásticos, incluso promulgaron algunas pragmáticas para restaurar el Derecho canónico y eliminar la barraganía en el clero.

Los mismos reyes, en las Leyes de Toro, incidentalmente rebajaron la importancia de la barraganía entre los laicos. En la medida en que el concepto de hijo natural ya no dependió del nacimiento de mujer barragana, como en las Partidas, sino que según la Ley 11 de "cuando al tiempo que nascieran o fueran concebidos, sus padres se podían casar con sus madres justamente, sin disponsación, con tal que el padre lo reconozca por su fijo, puesto que haya tenido la mujer de quien lo ovo en su casa, ni sea una sola: ca concorriendo en el fijo las calidades susodichas, mandamos que sea fijo natural", se hacía innecesaria la barraganía para atribuir tal calidad. Por otra parte, la prohibición bajo pena de confiscación de bienes y destierro del matrimonio "que la Iglesia tuviere por clandestino", Ley 49 de Toro, muestra un claro disfavor legal a la única barraganía lícita en tal momento: la de los legos ${ }^{38}$.

\section{I) LA MOdificaCión del CONCILIO de TRENTO Y SU REPERCUSión EN LA LEgISLACIÓN}

\section{SECULAR}

Como respuesta a la reforma protestante, en el Concilio de Trento (1545-1563) se prohibirá cualquier tipo de unión que no sea el matrimonio in facie ecclesiae, incluyendo así el requisito de solemnidad como imprescindible para la validez del matrimonio. Del mismo modo se crea el registro de matrimonios para combatir la bigamia.

Así "todo matrimonio no concluido con la forma prescrita era declarado nulo: el matrimonio presunto era abolido y la misma cópula carnal, que anteriormente convertía en verdadero matrimonio los esponsales de futuro, perdía a partir de ahora toda eficacia. El matrimonio de conciencia, al igual que toda cohabitación sexual no acompañada de la celebración del matrimonio, debía considerarse un concubinato. Pero también a este se le cerraba el camino con un canon" 39 . Nunca como ahora la Iglesia católica se había expresado tan claramente contra el concubinato de los laicos. Es natural —aunque de la prohibición del mismo se pudieran encontrar huellas

\footnotetext{
${ }^{38}$ FOSAR BENLLOCH, E. :Op. cit., pág. 152.

39 JIMENO ARANGUREN, R.: Matrimonio y otras uniones afines en el derecho histórico navarro (siglos VIIIXVIII). Dykinson, Madrid (2015), pág. 401.
} 
precedentemente- que el citado canon llegara a ser la fuente a la que después aluden todos tratando de esta materia. No parece, pese a ello, que el concubinato desapareciese ${ }^{40}$.

En el Concilio tridentino se declara la invalidez de los matrimonios clandestinos, exigiendo, bajo pena de nulidad, el requisito de publicidad a través de la presencia del párroco y dos o tres testigos ${ }^{41}$. El mismo Decreto Tametsi estableció importantes penas contra el concubinato ${ }^{42}$.

Los cánones conciliares son trasladados a la legislación civil por la vía de entrada en vigor del Concilio como legislación del Reino, mediante Real Cédula de Felipe II de 12 de julio de 1564 estableciendo la forma canónica de matrimonio y la pena de excomunión a los concubinos, a partir de lo cual vino la persecución del concubinato por la inquisición. No obstante, y pese a sus importantes efectos, la persecución no fue tan intensa como podía esperarse debido al fuerte arraigo de la institución y por la permisibilidad que la doctrina jurídica mantuvo en torno a la institución, que mantuvieron la equiparación entre el matrimonio y la unión estable con ánimo de mantenerse afecto y fidelidad, que construirá la línea de permanencia de la concubina como vice uxor, con más similitud con la Fiedelehe germánica que con el concubinato romano, aunque no fuese llevado a la normativa por influencia de la Iglesia ${ }^{43}$.

Durante al menos cinco siglos la barraganía fue un modo de convivencia aceptado por la sociedad y con efectos jurídicos importantes, pero la Real Cédula de Felipe II —con las importantes penas establecidas y la persecución por el Tribunal de la Inquisición - tuvo indudables efectos sobre la expansión de dicha práctica.

\footnotetext{
${ }^{40}$ FOSAR BENLLOCH, E.: Op. cit., págs. 156-157.

${ }^{41}$ Concilio de Trento, Sesión 24, Capítulo 1, el Decreto Tametsi establece la obligación de la presencia del sacerdote ordinario y la de dos o tres testigos en la firma del contrato matrimonial bajo pena de nulidad del matrimonio.

${ }^{42}$ El capítulo 8 del mencionado Decreto señala que "grave pecado es que los solteros tengan concubinas, pero es mucho más grave, y cometido con notable desprecio de este grande sacramento del matrimonio, que los casados vivan también en este estado de condenación y se atrevan a mantenerlas y conservarlas algunas veces en su misma casa, y aun con sus propias mujeres. Para ocurrir, pues, el santo Concilio con oportunos remedios a tan grave mal, establece que se fulmine excomunión contra semejantes concubinarios, así solteros como casados, de cualquier estado, dignidad o condición que sean, siempre que después de amonestados por el Ordinario aun de oficio, por tres veces, sobre esta culpa, no despidieren a sus concubinas, y no se aparten de su comunicación; sin que puedan ser absueltos de la excomunión, hasta que efectivamente obedezcan a la corrección que se les haya dado. Y si despreciando las censuras permanecieren un año en el concubinato, proceda el ordinario contra ellos severamente, según la calidad del delito. Las mujeres, o casadas o solteras, que vivan públicamente con adúlteros o concubinarios, si amonestadas por tres veces no obedecieren, serán castigadas de oficio por los Ordinarios de los lugares, con pena grave, según su culpa, aunque no haya parte que lo pida; y sean desterradas del lugar o de la diócesis, si así pareciere conveniente a los mismos Ordinarios, invocando, si fuese menester, el brazo secular; quedando en todo su vigor las demás penas fulminadas contra adúlteros y concubinarios".

${ }^{43}$ MORÁN MARTÍN, R.: Op. cit., pág. 14.
} 


\section{J) LA PERSECUCIÓN DEL CONCUBINATO POR EL TRIBUNAL DE LA INQUISICIÓN}

No está claro si se realizaban las admoniciones previstas en el Concilio tridentino contra las prácticas concubinarias con carácter previo a la intervención del Tribunal del Santo Oficio. Incluso existen dudas sobre cuál era el Tribunal que debía actuar frente a los concubinos, ya que en tanto que delito canónico deberían actuar los Tribunales eclesiásticos, dependientes del obispo, pero si se considera un delito contra la fe, el Tribunal que debe actuar es el del Santo Oficio. En todo caso, serían los Tribunales civiles quienes, en cumplimiento del sistema matrimonial adaptado por la Real Cédula al incorporar al sistema civil los cánones tridentinos, deberían ejecutar las penas correspondientes.

Pese a ello, del estudio de las actuaciones de los Tribunales de la Inquisición, algunos autores concluyen que las actuaciones no fueron masivas. Así, por ejemplo, Contreras señala que "si la liberalidad en las relaciones prematrimoniales ocasionales abunda por doquier, en la documentación del Santo Oficio, las formas que denotan la existencia de concubinatos más o menos duraderos, no son tan frecuentes. No falta quien ve en el amancebamiento un estado preferible al del matrimonio. Es la opción temporal de dos personas libres frente al vínculo regularizado e indeleble del matrimonio oficial. Estamos ante uniones duraderas, lo que, recogiendo la voz popular, se podría llamar 'amancebamiento a pan y manteles' (el Fuero de Zamora utiliza términos similares), y tales uniones, para sus autores, no tienen ningún carácter penalizador (...) La defensa del concubinato no supone, aunque pareciere lo contrario, un ataque directo a la institución matrimonial, pero sí es preferible, para algunos procesados (por la inquisición), al matrimonio fracasado" ${ }^{44}$.

Algunos autores sostienen que la barraganía no se extinguió por las razones jurídicas expuestas, sino que su desaparición se debería al cambio en la mentalidad social, de manera que sería esa evolución del pensamiento de la sociedad la que habría terminado desenterrando el concubinato de la sociedad. Sostienen estos autores que la práctica del concubinato fue abandonada de manera espontánea por el conjunto de la sociedad debido al cambio producido en la moralidad pública a partir del Concilio de Trento. Justifican este aserto dichos autores señalando que "prueba de que no fue jurídica la causa de su regresión (del concubinato) es que, incluso en los momentos del más rígido puritanismo, individuos insolidarizados con la mentalidad general han podido

\footnotetext{
${ }^{44}$ CONTRERAS, J.: El Santo Oficio de la Inquisición de Galicia. Poder, Sociedad y Cultura. Akal Editor, Madrid (1982), págs. 641-642.
} 
construir o continuar relaciones de este tipo sin resultar inquietados por el Derecho. El papel que este ha desempeñado en contra del concubinato ha sido en todo caso indirecto, privando a la relación de toda una serie de ventajas y de efectos jurídicos que reconocía, en cambio, al matrimonio como unión perfecta y más completa que ésta" 45 .

Otros autores, en cambio, señalan que una cosa es lo que los franceses denominan le concubinat, es decir una relación jurídica más o menos reglamentada, como nuestra tradicional barraganía, y otra le concubinage, unión de hecho a la que el Derecho no concede efectos jurídicos favorables, y que quienes optaron por este segundo tipo de unión lo hicieron porque la barraganía había sido desprovista de sus efectos, pero que, si se hubiese mantenido, estas personas se habrían aprovechado de tales efectos favorables de la barraganía ${ }^{46}$. Y es que la supresión de la barraganía, como es natural, no implicó la desaparición de las uniones de hecho, si bien desprovistas ahora de cualquier efecto jurídico que pudiera resultarles favorable.

Los efectos del Concilio de Trento se dejaron sentir en los distintos países católicos, en algunos países, como en el caso francés, la persecución del concubinato fue más intensa, pero en el caso español siguieron existiendo situaciones de barraganía "a pan y manteles" o en otras formas menos públicas. Tales uniones parece que no fueron especialmente perseguidas por la Inquisición, en el caso español, siempre que no se cometiesen delitos de opinión, tales como negar la sacralidad del matrimonio u otros, en cuyo caso sí que eran perseguidos, pero no cuando se limitaban a mantener la situación de cohabitación.

De este modo se produjeron durante los siglos siguientes a Trento gran número de nacimientos de hijos ilegítimos ante la imposibilidad de regular la situación de los nacimientos de hijos prematrimoniales o de hijos de mujeres que no podían casarse con los padres por las más diversas razones. No resultó fácil a la mentalidad popular reconocer el matrimonio canónico (de bendición en los siglos anteriores) como el único válido pese a la legislación represora producida a partir del Concilio de Trento tanto por las autoridades seglares como por la propia Iglesia. En los siglos XVII y XVIII la ilegitimidad de los hijos prematrimoniales fue resolviendose por la vía del posterior matrimonio de los progenitores, los denominados "matrimonios forzados" o matrimonios "para reparar la honra".

\footnotetext{
${ }^{45}$ GACTO FERNÁNDEZ, E.: “La filiación no legítima en Derecho histórico español”. Op. cit., pág. 677.

${ }^{46}$ FOSAR BENLLOCH, E.: Op. cit., pág. 159.
} 
En cuanto al amancebamiento ocasional no era habitual que finalizase en los Tribunales, excepto en los supuestos del hombre casado que simultaneara sus amores con varias mujeres ${ }^{47}$. En cambio, las mujeres solteras mancebas de varios hombres eran consideradas "putas"48.

\section{K) LOS MATRIMONIOS CLANDESTINOS EN LOS SIGLOS XVIII Y XIX}

Con la modificación tridentina del Derecho matrimonial se consolida, como único modo válido de unión matrimonial, la realizada en facie ecclesiae, lo que conducía a la realización de los esponsales y, posteriormente, la consumación matrimonial.

La nueva problemática será la de los matrimonios y esponsales "clandestinos", término que se utilizó con varios sentidos, de manera que puede significar: $1^{\circ}$ un matrimonio secreto respecto del cual no existe otra prueba que el testimonio; $2^{\circ}$ un matrimonio hecho en presencia de testigos, pero no in facie ecclesiae; y $3^{\circ}$ tras el Concilio de Letrán de 1215, también siginificaba un matrimonio contraído sin las previas amonestaciones. La razón de este tipo de matrimonios derivaba del convencimiento de que siendo el factor constitutivo del vínculo matrimonial el mutuo consentimiento, sobraban los requisitos externos de la forma y sus solemnidades, así lo entendía y practicaba la gente. Y la Iglesia no puso en duda la validez de estas uniones clandestinas hasta Trento $^{49}$.

Durante los siglos anteriores se había producido la curiosa circunstancia de la prueba de los matrimonios clandestinos por los más diversos medios, así "el cuadro de Jan van Eyck conocido como el matrimonio Arnolfini - Arnolfini Double Portrait (National Gallery, London), de 1434es muy probablemente un documento gráfico de un matrimonio celebrado clandestinamente y encargado como prueba del mismo. De alguna forma simboliza la extensión que adquirieron los matrimonios clandestinos durante el bajo Medievo. Ello también nos indica, creo, la normalidad

\footnotetext{
${ }^{47}$ JIMENO ARANGUREN, R.: Matrimonio y otras uniones afines en el Derecho histórico navarro. Siglos VIII-XVIII., ed. Dykinson, Madrid (2015). En la pág. 405 comenta los casos de Juanes Mikelexa, vecino se Astitz, casado y con hijos, fue acusado en la Corte mayor de estar amancebado con cuatro mujeres, a causa de las cuales "le da mala vida a su mujer y la amenazó que la había de matar" y el de otro mancebo múltiple, un tal Galdeano, de Estella, que vivía "con varias mujeres de algunos años a esta parte, con total abandono de la suia y de la hacienda que está poseyendo", a las mujeres con las que mantenía relaciones ilícitas les hacía tomar "cierta bebida para efecto de abortar o no concebir" y era "hombre tan pernicioso" que afirmaba que no existía el infierno ni el purgatorio.

${ }^{48}$ Ibid., pág. 406, cuenta que María Joániz, conocida como María Zapataria, de Isaba, "es moça de tratos ynlícitos y muy deshonesta y de mala vida, porque sin ser casada a echo dos creaturas, amancebándose con unos y con otros, y ha estado y está en fama y reputación en la dicha villa y fuera della".

${ }^{49}$ RUIZ DE CONDE, J.: El amor y el matrimonio secreto en los libros de caballerías. M. Aguilar Editor, Madrid (1948), pág. 6.
} 
con que se acogía esta forma de celebrar el matrimonio entre los fieles. La Iglesia, por los motivos ya indicados, intentará durante estos siglos imponer una forma pública y religiosa en la celebración de los matrimonios. Intento en el que se verá acompañada de las autoridades seculares, también interesadas en controlar la celebración de los matrimonios. Motivaciones de índole canónica, religiosa y social están en la base de la imposición de la forma pública y religiosa para la celebración de los matrimonios" $"$.

Con el fin de corregir algunos de los problemas personales y familiares que provocaban los esponsales clandestinos, en el último tercio del siglo XVIII las autoridades políticas del Reino de España intentaron paliar la situación existente, primero con la Pragmática de $1776^{51}$, que exigía el consentimiento paterno, y más tarde en la Instrucción Reservada de Floridablanca de $1787^{52}$, en cuyo punto XXI se proponía "limitar o reducir los esponsales obligatorios a los que se celebren con ciertas formalidades" para así conseguir que "los hombres y mujeres fueren más precavidos y morigerados".

No obstante, en la práctica, tales disposiciones no resultarían muy satisfactorias dado el número de disposiciones posteriores complementarias y modificativas, todo lo cual prueba que la Pragmática de Carlos III no habría conseguido plenamente los fines perseguidos.

Todo ello provoca la reforma legislativa culminada con la Pragmática del 28 de abril de 1803, de Carlos IV, titulada Nuevas reglas para la celebración de matrimonios; y formalidades de los esponsales para su validez, título que, por sí solo, prueba la necesidad de renovación de la Normativa precedente. Pues, como señala José María Laina:

Si la pragmática de Carlos III marca una época en relación con el consentimiento paterno para contraer matrimonio, se puede afirmar que la disposición de Carlos IV supone también un cambio respecto al sistema legal anterior. Introduce modificaciones en un doble sentido, pues en lugar de la edad única de veinticinco años establecida en la Pragmática de Carlos III como

\footnotetext{
${ }^{50}$ AZNAR GIL, F.R.: "Penas y sanciones contra los matrimonios clandestinos en la Península ibérica durante la Baja Edad Media”, en Revista de Estudios Histórico-jurídicos n. ${ }^{\circ}$ 25, Valparaíso (2003), pág. 214.

${ }^{51}$ La Pragmática Sanción de 1776 titulada "Pragmática Sanción para evitar el abuso de contraer matrimonios desiguales", fue sancionada por Carlos III, el 23 de marzo de 1776.

${ }^{52}$ Mediante RD de 8 de julio de 1787 se reguló la periodicidad de las reuniones y el funcionamiento de la Junta Suprema de Estado, compuesta por los Secretarios de Estado y de Despacho y creada a instancia de Floridablanca, quien acompañó el decreto con una Instrucción reservada que recogía un detallado programa con los puntos susceptibles de ser tratados en la Junta.
} 
frontera para la necesidad de obtener el permiso paterno, la que ahora estudiamos dispone una pluralidad de edades, que depende de dos variables:

a) Del sexo de la persona que pretendiera casarse, y

b) De quién sea el sujeto que debe prestar su consentimiento para cada matrimonio

Con respecto a esta cuestión del sistema de pluralidad de edades, tanto desde el punto de vista de las personas de los que están sujetos a la necesidad de solicitar el consentimiento de sus padres como con relación a quiénes han de prestarlo, las legislaciones han ofrecido sobre el particular, diversos sistemas con notables divergencias entre unos y otros. ${ }^{53}$

De manera paulatina, la legislación tridentina se impuso, dejando las uniones no matrimoniales en una realidad escasa en cuanto a su número, y el matrimonio canónico quedó como único modo de relación legal de pareja. No es hasta la década de los ochenta del pasado siglo cuando resurge con fuerza el modo de unión more uxorio de las uniones de hecho en los términos que conocemos en la actualidad, como un movimiento que va alcanzando reconocimiento jurídico a una realidad social que se expande.

\section{L) EL CONCUBINATO DURANTE LA CODIFICACIÓN}

No son habituales las menciones legislativas relativas al concubinato durante el siglo XIX, y cuando aparecen es para determinar el castigo por su práctica. Así, durante el primer período del reinado de Fernando VII, y solamente para el caso de ser público, se dispuso que los amancebados fuesen amonestados privadamente por el juez, actuando solamente contra quienes desoyeren dicha amonestación, si bien se establecía que por tales actos solamente cabían penas pecuniarias, la de reclusión en hospicios o casas de corrección o la de aplicación al servicio de armas, según las circunstancias, pero prohibiendo las penas de presidio o cualquier otra infamatoria ${ }^{54}$. Esta legislación quedó derogada con la publicación de los Códigos penales posteriores que castigaban el concubinato solamente cuando configuraba adulterio ${ }^{55}$.

En el período de la Codificación la visión de la cuestión se modifica, al instalar en el centro del debate jurídico la posición de los hijos naturales, debatiéndose sobre qué derechos corresponden

\footnotetext{
${ }^{53}$ LAÍNA GALLEGO, J.M. a: "La Pragmática de Carlos IV y el matrimonio de los hijos de familia", en Revista de Derecho Privado, n. ${ }^{\circ}$ 4, año 87, Madrid (julio, 2003), pág. 512.

${ }^{54}$ Real Orden de 22 de febrero de 1815, complementada por otra Real Orden de 10 de marzo de 1818.

55 Así lo establecían tanto el Código Penal de 1822, como el de 1848.
} 
a estos hijos y cuáles debían serles negados para la defensa del matrimonio y la familia tal como eran concebidos en esa época.

Se llega así a la publicación del CC, el cual contempla solamente el matrimonio como forma de convivencia regulada legalmente, si bien que reconociendo validez tanto a la forma canónica como a la civil establecida en el propio Código. 



\section{LA DISTINTA NATURALEZA JURÍDICA DEL MATRIMONIO Y LAS UNIONES MORE UXORIO}

\section{A) NATURALEZa JURÍdica DEL MATRimonio}

Para la mayoría de las personas legas en Derecho el concepto del matrimonio está claro, con independencia de la aceptación o no del matrimonio entre personas del mismo sexo o la indisolubilidad o no del mismo. Pese a ello, la doctrina científica ha discutido, y sigue haciéndolo, sobre cuál es la naturaleza jurídica del matrimonio, elaborando a lo largo del tiempo diferentes construcciones doctrinales al respecto.

En la idea de matrimonio es necesario un elemento individual de manifestación de la voluntad de constituir la relación conyugal, esto hace nacer el vínculo entre los cónyuges a partir de la concurrencia de dichas manifestaciones de voluntad libremente manifestadas por ambos contrayentes y con el reconocimiento de tal voluntad por la comunidad. A la vez, por ese conocimiento de la comunidad, concurre la circunstancia legal de atribuir a esa unión un estatus dentro de la sociedad. Por todo ello, la unión matrimonial se muestra como una categoría fundamental para la estabilidad de la sociedad y del Estado.

\section{La tesis contractual}

Entre las distintas posturas doctrinales, la más antigua es la de la consideración del matrimonio como un contrato. Esto derivada de la construcción doctrinal elaborada por la Iglesia católica siguiendo la tradición del Imperio romano, afirmando que en Roma el matrimonio constituyó un contrato consensual ${ }^{56}$. Esta posición de considerar el matrimonio romano como un contrato consensual fue seguida por la doctrina durante varios siglos. La otra gran aportación a considerar el matrimonio como contrato procede de la filosofía racionalista ${ }^{57}$, que atribuye a la voluntad ser causa de la realidad social, lo que incluye al Derecho y, por tanto, al matrimonio. Por último, avala esta doctrina el hecho de que la positivización del matrimonio se realiza en sede de contratos desde el propio Código Napoleónico, habiendo sido seguido en esa ubicación sistemática por los códigos subsiguientes.

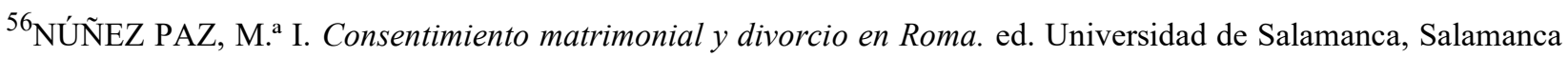
(1988), pág. 55.

${ }^{57} \mathrm{El}$ antecedente más antiguo lo encontraríamos en la escuela de Pitágoras, a principios del siglo VI a.C., y posteriormente es desarrollada por los filósofos racionalistas, en especial por la defensa de esta postura realizada por René Descartes en El discurso del método.
} 
Aun así, afirmar que la naturaleza jurídica del matrimonio es la propia de un contrato, es tanto como afirmar que en el matrimonio se dan todas las características propias del contrato ${ }^{58}$, en el sentido definido por la canonística medieval y recogió en el Code Napoleónico. Pero al analizar el contrato debemos revisar dos aspectos fundamentales definidores del contrato. El primero de ellos afecta a las voluntades generadoras del contrato y su posición sobre los intereses que serán satisfechos para cada una de ellas mediante el acuerdo, teniendo presente que el acuerdo de voluntades en que debe basarse el contrato debe armonizar dos intereses esencialmente contrapuestos, ya que el contrato requiere de la existencia de intereses dispares. El otro aspecto está vinculado con la función socioeconómica del contrato por el necesario contenido patrimonial del mismo ${ }^{59}$. La necesidad de cumplir con ambos aspectos, propios del contrato, condiciona la posibilidad de aceptar, en la actualidad, dicha posición al estar cercenada la posibilidad de pactos por la existencia del estatuto matrimonial sobre el que los contrayentes solamente pueden mostrar su aceptación, sin ningún tipo de reservas, y por carecer el matrimonio de un contenido patrimonial.

Una parte de la doctrina ${ }^{60}$ ha defendido el carácter contractual del matrimonio, si bien indicando que se trataría de un contrato sui generis ${ }^{61}$. De aceptar tal teoría, estaríamos señalando que el matrimonio es un contrato carente de las notas elementales y características estructurales del contrato. Ya que está sustraído a la libre autonomía de la voluntad, pues las partes no pueden regular la relación conyugal, además de carecer de la nota de patrimonialidad, propia del contrato. En suma, la teoría de que la naturaleza jurídica del matrimonio es la de ser un contrato no se sostiene cuando es sometida a un estudio de fondo de sus características ${ }^{62}$.

\footnotetext{
${ }^{58}$ En este sentido se pronuncian, entre otros, PUIG BRUTAU, J.: Fundamentos de Derecho Civil, Familia, Matrimonio, Divorcio, Filiación, patria potestad, Tutela, Tomo IV, $2^{\mathrm{a}}$ ed. Bosch, Barcelona (1985), págs. 13-15; LACRUZ BERDEJO, J.L.; SANCHO REBULLIDA, F.; DELGADO ECHEVERRÍA, J.; LUNA SERRANO, A.; RIVERO FERNÁNDEZ, F.; RAMS ALBESA, J.; Elementos de Derecho Civil. Derecho de Familia, Tomo IV, $3^{\mathrm{a}}$ ed. ed. Dykinson, Madrid (2008), pág. 43. Este último dice del matrimonio que es "un acuerdo cuyas características vienen establecidas de modo inderogable... no le priva de naturaleza contractual...".

${ }^{59}$ En tal sentido lo entiende, DÍEZ-PICAZO, L. en Fundamentos de Derecho Civil Patrimonial, Tomo I, "Introducción. Teoría del Contrato". Thomson-Civitas, Navarra (2007), pág. 137.

${ }^{60}$ Esta posición, desarrollada por la escuela del Derecho natural de los siglos XVII y XVIII, inspiró a los redactores del Código napoleónico, en cuya exposición de motivos se afirma que el matrimonio es un contrato, aunque no puramente civil, porque trae sus principios de la misma naturaleza.

${ }^{61}$ DUALDE GÓMEZ, J.: Concepto de la causa de los contratos (la causa es la causa), Bosch, Barcelona (1949), en la pág. 128 afirma que "el matrimonio solo tiene la cáscara de contrato voluntario y realmente es un contrato imperativo".

${ }^{62}$ LEGAZY LACAMBRA, L.: Filosofía del Derecho, $5^{\text {a }}$ ed. Revisada y aumentada. Bosch, Barcelona (1979). En su pág. 765 afirma que "el matrimonio por su naturaleza no es un contrato... del contrato posee la superestructura: "el acuerdo de voluntades', pero le falta la infraestructura del mismo: aquel cómputo utilitario referido a cosas o prestaciones valorables económicamente que es incompatible con la esencia misma de la institución matrimonial".
} 


\section{El matrimonio como negocio jurídico de Derecho de Familia}

Para los defensores de esta posición doctrinal, el matrimonio es un negocio jurídico con ciertas especialidades, ya que la autonomía de la voluntad está muy limitada y su regulación viene predeterminada por las normas, que tienen carácter de Derecho necesario ${ }^{63}$. De modo que puede calificarse el matrimonio como un negocio jurídico entre un hombre y una mujer, con la finalidad de constituir un consorcio o comunidad de vida, siendo un negocio jurídico, pero con características propias frente al negocio jurídico de Derecho privado, ya que en el matrimonio inciden particularidades afectas al orden público ${ }^{64}$. En este sentido, el matrimonio es un negocio jurídico de entidad personalísima, con una rígida tipicidad y formalidad. Se dice que es de entidad personalísima porque en el matrimonio la persona es el sujeto artífice de la aceptación del conjunto de principios y valores contenidos en la regla normativa. Es esta aceptación lo que conduce a afirmar su evidente tipicidad, entendiendo por típico la totalidad de lo dispuesto en el texto legislativo. Por último, es formal en el sentido de que la misma norma exige que el negocio matrimonial se realice mediante determinadas ritualidades que tienden a demostrar su trascendencia y publicidad ${ }^{65}$.

Mediante tal concepción se logra fijar el matrimonio en alguna categoría conceptual dentro del Sistema del Derecho. También debe considerarse la intervención de la autonomía de la voluntad en la propia constitución del matrimonio, determinando de este modo su pertenencia a los negocios jurídicos del Derecho de familia, al tener su origen en una declaración de voluntad a fin de satisfacer el haz de necesidades y expectativas que el Derecho permite alcanzar mediante un arreglo de intereses entre las partes. Y, en un tercer aspecto, el estado civil, en cuanto objeto del negocio jurídico matrimonial, a la vez que elemento de orden público de ineludible presencia en el matrimonio, que lo transforma en un negocio jurídico con contenido predeterminado que ha de ser

\footnotetext{
${ }^{63}$ En esta línea se posicionan, entre otros muchos, autores como DÍAZ-AMBRONA BARDAJÍ, M. ${ }^{\mathrm{a} D}$., y HERNÁNDEZ GIL, F. Lecciones de Derecho de Familia, $2^{\mathrm{a}}$ ed. Editorial Universitaria Ramón Areces, Madrid (2007), pág. 71; DÍEZ PICAZO, L.: Estudios de Derecho privado. Civitas, Madrid, (1980), pág. 36; CASTÁN TOBEÑAS, J.: Derecho civil español, común y foral, Tomo V, Derecho de Familia, Vol. 1º "Relaciones conyugales", $10^{\mathrm{a}}$ ed. ed. Reus s.a., Madrid (1983), pág. 117 y ss.; O’CALLAGHAN MUÑOZ, X.: "Concepto y calificación jurídica de las uniones de hecho", en Consecuencias jurídicas de las uniones de hecho, Cuadernos de Derecho judicial, número XX. Consejo General del Poder Judicial, Madrid (1997), pág. 18.

${ }^{64}$ PEREDA GÁMEZ, J. y VEGA SALA, F:, Derecho de Familia. Editorial Praxis, Barcelona (1994), págs. 10 y ss.

${ }^{65}$ GUZMÁN GARCÍA, J.J.: La naturaleza jurídica del matrimonio. Universidad de Alcalá de Henares (2002), pág. 328.
} 
aceptado por las partes íntegramente, y sin posibilidad de alteración alguna, para obtener el estado civil de casados.

En definitiva, para los defensores de esta posición doctrinal el matrimonio debe ser entendido como un acto que surge de la autonomía de la voluntad de las personas en las que genera una modificación del estatus que tienen dentro de la sociedad, provocando de este modo los efectos frente a terceros que el ordenamiento jurídico ha considerado adecuados. Tal posicionamiento se centra en el ámbito puramente formal en que se manifiesta el acuerdo de voluntades, al precisar que no hay matrimonio sin el consentimiento matrimonial. Si bien lo definen como un negocio jurídico, sin atender a los aspectos materiales, que es siempre objeto de precisión y valoración por el Derecho positivo ${ }^{66}$.

\section{La institución matrimonial}

Los defensores de que la naturaleza propia del matrimonio es la de una institución jurídica se fundamentan en que el consentimiento prestado es condición necesaria, pero no suficiente, para determinar la verdadera existencia del matrimonio, y ello porque el denominado estatuto matrimonial queda totalmente sustraído a la voluntad de los contrayentes. Este conjunto normativo propio del matrimonio es indisponible por los contrayentes. Por supuesto pueden manifestar su voluntad de acatarlo o no ${ }^{67}$, pero ha de ser en su absoluta integridad, careciendo de cualquier capacidad de autorregulación al respecto. En esta línea se manifiesta gran parte de la doctrina ${ }^{68}$ y muchas sentencias, tanto del TC como del TS, utilizan expresamente el calificativo de institución para el matrimonio. Para los defensores de esta postura, los cónyuges, haciendo uso de su voluntad, deciden constituir el matrimonio, el cual será el origen de la familia. Esto da lugar a la realidad social en que se desarrollará el bien común del grupo familiar, siendo la organización jurídica del mencionado bien común la razón institucional del matrimonio.

\footnotetext{
${ }^{66}$ Lasarte ÁlvareZ, C.: Principios de Derecho Civil VI. Derecho de Familia, $18^{\mathrm{a}}$ ed. Marcial Pons, Madrid (2019), pág. 24.

${ }^{67}$ La STC 198/2012, de 6 de noviembre, en su FJ 10, afirma que: "El derecho a contraer matrimonio, o a no contraerlo, se limita a asegurar la capacidad de elección, a impedir el mandato o la imposibilidad absoluta, pero no a asegurar a quien la ejercita en un determinado sentido los mismos efectos que se atribuyen a quien lo hace en otro", añadiendo que "pese a la identidad de los sujetos titulares de la libertad, el contenido de la libertad positiva y negativa no (tiene) por qué ser homogéneo, y que el legislador ordinario (puede) atribuir ... consecuencias a una y a otra manifestación", de manera "que la primera se constituya en un auténtico derecho subjetivo, mientras que la segunda no sea más que una mera libertad jurídica, integrada en el mismo derecho fundamental, y cuyo contenido se ciñe a la posibilidad de optar o a la existencia de una alternativa de acción".

${ }^{68}$ Los redactores del CC italiano de 1865 consideraban al matrimonio como una "alta institución social", que cae bajo las prescripciones del Estado.
} 
La nota definidora de esta institución vendría fijada por la existencia de un conjunto de normas, conformadoras del denominado estatuto matrimonial que regula los derechos $\mathrm{y}$ obligaciones de los cónyuges. Este estatuto está por encima de la voluntad de los contrayentes, ya que la voluntad de los mismos no es suficiente para alterar o modificar dicho conjunto de normas debido al carácter imperativo de las reglas que rigen el matrimonio.

En definitiva $-\mathrm{y}$ sin entrar a posicionarnos sobre si el matrimonio es un negocio jurídico de derecho familiar o si se trata de una institución-, en lo que ambas posiciones confluyen es en la indisponibilidad de las reglas del matrimonio, el incuestionable carácter imperativo del denominado estatuto matrimonial, el cual solamente puede ser aceptado o rechazado, pero de ningún modo acomodado a la voluntad de los contrayentes.

\section{B) LA UNIÓN DE HECHO COMO ACUERDO DE VOLUNTADES}

Aunque el conjunto normativo que regula el matrimonio es absolutamente indisponible para los cónyuges, no ocurre igual en el caso de las uniones de hecho, las cuales vienen siendo enmarcadas por nuestra jurisprudencia en el ámbito del derecho dispositivo. Es decir, que los convivientes sí pueden pactar libremente los aspectos relativos a su convivencia sin que los mismos vengan prescritos por ningún conjunto normativo.

La mejor concepción de la naturaleza jurídica de las uniones de hecho, a mi entender, nos la proporciona la doctrina que ha ido elaborando el TC, enmarcando la libertad de decisión de los convivientes en el principio del respeto al libre desarrollo de la personalidad, constitucionalmente garantizado. De manera que, en palabras del citado Alto Tribunal" "la unión de hecho puede caracterizarse, en principio, como una relación estable de convivencia more uxorio, cuyo elemento definitorio común queda cifrado en la voluntad libremente configurada de permanecer al margen del Derecho en cuanto a las consecuencias jurídicas inherentes a la institución matrimonial. Por tanto, un elemento esencial de la constitución de la pareja de hecho es, su conformación extramuros de la institución matrimonial por decisión propia de sus integrantes, adoptada en ejercicio de su libertad personal, y que "se vincula con sus convicciones y creencias más íntimas".

Consustancial a esa libertad de decisión —adoptada en el marco de la autonomía privada de los componentes de la pareja- es el poder de gobernarse libremente en la esfera jurídica de ese

\footnotetext{
${ }^{69} \mathrm{La}$ STC 93/2013, de 23 de abril, dedica el FJ 8. ${ }^{\circ}$ a analizar la noción misma de unión de hecho y las notas esenciales que se derivan de la misma.
} 
espacio propio, ordenando por ellos mismos su ámbito privado, el conjunto de derechos, facultades y relaciones que ostenten. Si bien esto es dentro de ciertos límites impuestos por el orden social, ya que la autonomía privada no es una regla absoluta. Así, el art. 1255 del CC plasma el principio de autonomía de la voluntad en las relaciones contractuales privadas, y dispone que los contratantes pueden establecer todos los pactos, cláusulas y condiciones que tengan por conveniente "siempre que no sean contrarios a las leyes, a la moral, ni al orden público”. Este respeto a la autonomía privada de quienes han decidido conformar una unión de hecho se traduce en el reconocimiento de que, en aras a su libertad individual, pueden desarrollar sus relaciones —antes, durante y al extinguirse esa unión - conforme a los pactos que consideren oportunos, sin más límites que los impuestos por la moral y el orden público constitucional. Esta libertad debe ser respetada por el ordenamiento jurídico en todo caso, salvo que su ejercicio concreto pudiera entrar en conflicto con valores constitucionales superiores que justificaran su constricción.

La relación more uxorio se basa precisamente en la decisión libre y, en principio, no jurídicamente formalizada de los convivientes de mantener una relación en común que, también en principio, no produce el nacimiento de ningún derecho u obligación específicos entre ellos ${ }^{70}$. El problema queda, por tanto, cifrado en los límites que la propia esencia de la unión de hecho impone al legislador cuando este decide supeditar su reconocimiento a ciertas condiciones o atribuir determinadas consecuencias jurídicas a tal unión. Obviamente, el límite principal con el que se tropieza es la propia libertad de los integrantes de la pareja y su autonomía privada, por lo que una regulación detallada de los efectos, tanto personales como patrimoniales, que se pretendan atribuir a esa unión puede colisionar con la citada libertad si se impusieran a los integrantes de la pareja unos efectos que, precisamente, los sujetos quisieron excluir en virtud de su decisión libre y constitucionalmente amparada de no contraer matrimonio. Por ello, el régimen jurídico que el legislador puede establecer al efecto deberá ser eminentemente dispositivo y no imperativo, so pena de vulnerar la libertad consagrada en el art. 10.1 de la $C E$. De manera que únicamente podrán considerarse respetuosos de la libertad personal aquellos efectos jurídicos cuya operatividad se condiciona a su previa asunción por ambos miembros de la pareja.

\footnotetext{
${ }^{70}$ La STC 155/1998, de 13 de junio, en su FJ tercero define la absoluta libertad de los convivientes de establecer un modo de relación que, por sí misma, no es generadora de derechos ni obligaciones, sino que serán los propios convivientes quienes, en uso de su libertad, configuren el marco de relación jurídica que tengan por conveniente.
} 
Tal capacidad de disposición le concede a las uniones de hecho un verdadero carácter de convención o acuerdo de voluntades. Es este carácter contractual y esta capacidad de disposición por los convivientes la verdadera diferencia existente con el matrimonio, pues los convivientes sí pueden disponer libremente de cualesquiera aspectos relativos a su convivencia, incluso para el momento de una posible posterior ruptura, en el modo que tengan por conveniente, siempre que se respeten los principios constitucionales (en especial el principio de igualdad entre los convivientes) y lo pactado no vaya contra el Ordenamiento jurídico.

\section{C) Corolario}

Como consecuencia del análisis efectuado, e independientemente de que se pueda considerar que el matrimonio es un negocio jurídico especial de Derecho de familia o que su naturaleza es la propia de una institución jurídica, lo esencial y definidor del matrimonio es que se trata de una manifestación de voluntad por la que los contrayentes deciden de manera libre y voluntaria la aceptación del conjunto de derechos y deberes derivados del estatuto matrimonial sin que frente al mismo planteen ningún tipo de reserva mental. En consecuencia, el matrimonio lleva implícita la aceptación de un conjunto de normas de carácter imperativo y, por ende, absolutamente indisponibles para los cónyuges.

Por su parte, las uniones de hecho son producto del deseo de los convivientes de no someterse al conjunto normativo de ius cogens propio del matrimonio. Dado que se trata de uniones libres, serán los propios convivientes, en uso de su autonomía privada legalmente reconocida, quienes decidan, de modo igualmente libre, cuál será el marco jurídico de su relación. Es decir, en el caso de las uniones de hecho las normas reguladoras no podrán ser de carácter imperativo por ir en contra de la propia naturaleza de la unión de hecho. Precisamente por ese carácter libre de la unión han de poder disponer un marco de relación jurídica que se acomode íntegramente a sus deseos, con los límites derivados de la ley, la moral y el orden público. 



\section{ASPECTOS PERSONALES DE LA PAREJA DE HECHO EN EL ORDENAMIENTO JURÍDICO ESPAÑOL}

\section{A) ANTECEDENTES PRóXimos de LA SITUACIÓN ACTUAL}

En la década de los años ochenta del pasado siglo, como consecuencia de la restauración de la democracia, las parejas de hecho, que habían existido en todo momento, comienzan a constituir una realidad social cada vez más visible. Como consecuencia, paulatinamente, en el ámbito del Derecho público se empiezan a reconocer toda una serie de derechos a los convivientes more uxorio.

Las parejas de hecho de ese período, en las que existía un componente importante de posicionamiento ideológico, solicitaban el reconocimiento de derechos similares al matrimonio. Entre los derechos solicitados de manera más reiterada destacaba el derecho a la pensión de viudedad, teniendo ocasión de pronunciarse el TC en diversas ocasiones al respecto.

En las diversas oportunidades en que el Alto Tribunal llegó a pronunciarse al respecto vino a señalar que "el matrimonio y la convivencia extramatrimonial no son situaciones equivalentes, siendo posible, por ello, que el legislador, dentro de su amplísima libertad de decisión, deduzca razonablemente consecuencias de la diferente situación de partida» (ATC 156/1987). Y, en relación con el concreto derecho a la pensión de viudedad en las situaciones de convivencia more uxorio, fueron reiteradamente inadmitidas por el citado Alto Tribunal al igual que otros derechos prestacionales $^{71}$.

Ya en la STC 184/1990, de 15 de noviembre, señalaba el Tribunal que "la exigencia del vínculo matrimonial como presupuesto para acceder a la pensión de viudedad establecida dentro del sistema de Seguridad Social no pugna con el art. 14 C.E., pues, entre otras consideraciones entonces efectuadas, es preciso recordar, la de que "no serán necesariamente incompatibles con el art. 39.1 C.E., ni tampoco con el principio de igualdad, las medidas de los poderes públicos que otorgan un trato distinto y más favorable a la unión familiar que a otras unidades convivenciales, ni aquellas otras medidas que favorezcan el ejercicio del derecho constitucional a contraer

\footnotetext{
${ }^{71}$ El ATC 788/1987 precisa que la vigente regulación de aquel tiempo del sistema de pensiones de la Seguridad Social no vulneraba el art. 14 CE; en sentido análogo, AATC 1021/1988 y 1022/1988 en relación con el subsidio de desempleo por responsabilidades familiares previsto en el art. 13 de la Ley 31/1984, de 2 de agosto, de protección del desempleo, ni contiene discriminación alguna en función de una "circunstancia social" que trate de excluir socialmente a las parejas que no hayan contraído matrimonio.
} 
matrimonio (art. 32.1 C.E.), siempre, claro es, que con ello no se coarte ni se dificulte irrazonablemente al hombre y la mujer que decidan convivir more uxorio" (FJ $2^{\circ}$ ), concluyéndose, a continuación, que "...siendo el derecho a contraer matrimonio un derecho constitucional, cabe concluir que el legislador puede, en principio, establecer diferencias de tratamiento entre la unión matrimonial y la puramente fáctica y que, en concreto, la diferencia de trato en la pensión de viudedad entre cónyuges y quienes conviven de hecho sin que nada les impida contraer matrimonio no es arbitraria o carente de fundamento" (FJ $3^{\circ}$ ). Doctrina reiterada en multitud de Sentencias posteriores.

En esta situación se llegó a la STC 66/1994, de 28 de febrero ${ }^{72}$, en la que el Constitucional denegó el derecho a la pensión de viudedad a una señora que había convivido más de cincuenta años con su pareja, quien era pensionista de la Seguridad Social, y cuya pensión había sido denegada por el I.N.S.S. ${ }^{73}$ pese a la prolongada convivencia estable citada, así como a pesar del hecho de que habían tenido hijos y concurrían en ella las circunstancias precisas para considerarla como una familia en sentido constitucional, de manera que si no contrajeron matrimonio fue por la ideología anarquista que profesaban ambos y que era contraria a someter su relación al vínculo formal matrimonial. Se planteaba, pues, un nuevo enfoque al reconocimiento de derechos, ya no solo por la posible vulneración del art. $14 \mathrm{CE}$, sino que ahora se centraba, también, en el art. 16.1 CE.

En la referida STC se desestimó el recurso de amparo planteado, pero provocó que se reactivase el debate sobre las parejas de hecho y que muchos municipios de toda España creasen Registros de Uniones de $\mathrm{Hecho}^{74}$, y que en 1998 en Cataluña, y en la misma fecha que se aprobaba el Código de Familia ${ }^{75}$, se aprobara la denominada "Ley de Uniones Estables de Pareja" (en adelante $\mathrm{LUEP}^{76}$ ), primera Ley autonómica sobre la materia, y que regulaba de modo conjunto,

\footnotetext{
${ }^{72} \mathrm{La}$ STC 66/1994, de 28 de febrero, fue publicada en el BOE n. ${ }^{\circ}$ 71, de 24 de marzo de 1994, habiendo sido ponente de la misma el Excmo Sr. D. Luis López Guerra.

${ }^{73}$ INSS, es la abreviatura del Instituto Nacional de la Seguridad Social, se trata de la Entidad gestora, dotada de personalidad jurídica propia, dependiente del Ministerio de Trabajo, Migraciones y Seguridad Social en la actualidad, y que gestiona las prestaciones económicas más importantes del sistema de Seguridad Social en España.

${ }^{74} \mathrm{El}$ primer registro municipal de uniones civiles creado en España fue el de Vitoria-Gasteiz, mediante el Decreto de alcaldía de 28 de febrero de 1994, publicado en el Boletín Ofícial del Territorio Histórico de Álava n. ${ }^{\circ} 3$ de 11 de marzo de 1994.

${ }^{75}$ Ley 9/1998, de 15 de julio, del Código de Familia de Cataluña, publicado en el BOE n. ${ }^{\circ} 198$, de 19 de agosto de 1998, actualmente derogado.

${ }^{76}$ Ley 10/1998, de 15 de julio, de Uniones Estables de Pareja, publicado en el BOE n. ${ }^{\circ}$ 198, de 19 de agosto y actualmente derogada.
} 
pero diferenciado en algunos aspectos, tanto las parejas heterosexuales como las homosexuales. Las primeras podían constituirse tanto por convivencia ininterrumpida durante dos años (o por simple convivencia, si tenían un hijo común) como mediante escritura pública. Las parejas del mismo sexo, en cambio, solo podían constituirse mediante escritura pública. En ninguno de los dos casos era necesario que se inscribieran en ningún tipo de registro público.

La diferencia más notable entre parejas heterosexuales y homosexuales era que, en los supuestos de disolución por muerte, el supérstite de la pareja del mismo sexo tenía más derechos que el de la pareja de sexo opuesto, diferencia que se fundamentaba en que los convivientes homosexuales no tenían la opción de contraer matrimonio. Respecto a las parejas heterosexuales, no se establecía ninguna diferencia de regulación entre parejas formalizadas y no formalizadas y, por ello, gozaban de los mismos derechos tanto si se habían constituido por mera convivencia como mediante documento público.

En cuanto a los derechos y deberes establecidos en la Ley, la mayoría tenían carácter dispositivo y los convivientes podían regular sus relaciones de otro modo sin sujeción a requisito de forma alguno. Sin embargo, algunos tenían carácter imperativo, por lo que no cabía excluirlos por pacto en contrario, ya fuera porque implícitamente estaban considerados de orden público (por ejemplo, la responsabilidad solidaria por gastos comunes [art. 5 LUEP] o el deber recíproco de alimentos [art. 8 LUEP]) o porque la ley establecía expresamente unos derechos mínimos, irrenunciables de antemano (art. 3 LUEP), que estaban destinados a paliar los perjuicios que la convivencia y la subsiguiente ruptura pudieran haber ocasionado al conviviente más vulnerable ${ }^{77}$.

A partir de esta norma catalana fue conformándose un complejo panorama de legislaciones autonómicas de parejas de hecho, tanto en aquellas CCAA que, en aplicación de lo dispuesto en el art. 149.1.8 $\mathrm{CE}$, tienen competencias para la conservación, modificación y desarrollo de los derechos civiles que le son propios y que en aplicación de las citadas competencias conferidas constitucionalmente han desarrollado Normativas civiles especiales ${ }^{78}$, como aquellas otras que, aprovechando el vacío normativo de la legislación estatal y pese a carecer de competencias en

\footnotetext{
${ }^{77}$ MARTÍN-CASALS, M.: "El derecho a la convivencia anómica en pareja ¿un nuevo derecho fundamental? Comentario a la STC de 23.4.2013 (RTC 2013/93)", en InDret, revista para el análisis del Derecho, Barcelona (julio 2013), pág. 5. [Consulta online www.indret.com].

${ }^{78}$ Se encontrarían en ese supuesto las Normas autonómicas sobre uniones de hecho dictadas por las CCAA de Cataluña, Illes Balears, Aragón, Comunidad Foral de Navarra y País Vasco, incluso en cierta interpretación, podría incluirse el supuesto de la Comunidad Valenciana.
} 
materia civil, igualmente han legislado sobre la materia ${ }^{79}$. Incluso en el caso especial de Castilla y León, que no habría legislado sobre la materia, sí creó un registro autonómico de parejas de hecho ${ }^{80}$.

En este desiderátum no faltó la legislación de una comunidad autónoma, en concreto la gallega, que en la primera versión de la Disposición adicional tercera de la Ley 2/2006, de 14 de junio, de Derecho Civil de Galicia, asimilaba las parejas de hecho al matrimonio ${ }^{81}$. Tras su modificación por Ley 10/2007, de 28 de junio, de reforma de la Disposición Adicional Tercera de la legislación originaria de la misma ${ }^{82}$, se atemperaba la homologación original, limitando la asimilación establecida a aquellas uniones de hecho que consten registradas como tales en el Registro de Parejas de Hecho de Galicia.

Esta situación provocó que, por gran parte de la doctrina, se reclamase reiteradamente la armonización desde el Estado de las legislaciones autonómicas surgidas en esos años. Pese a las reiteradas peticiones en ese sentido no se dictó ningún tipo de norma armonizadora de las distintas legislaciones autonómicas.

Fueron, en cambio, diferentes Resoluciones del TC las que han ido señalando el marco de desarrollo de la convivencia more uxorio, resultando especialmente relevante la STC 93/2013, de

\footnotetext{
${ }^{79}$ En este grupo se incluyen, por orden cronológico de publicación de sus leyes sobre la materia, las leyes de las siguientes CCAA: Madrid, Principado de Asturias, Andalucía, Canarias, Extremadura y Cantabria.

${ }^{80}$ Decreto 117/2002, de 24 de octubre, Registro de Uniones de Hecho (BOCyL n. ${ }^{\text { }}$ 212, de 31.10.2002), cuya regulación, no obstante, tiene como objeto principal establecer un registro de parejas de hecho.

${ }^{81}$ En su redacción original, en vigor desde el 2 de julio de 2006 hasta su modificación en 19 de julio de 2007 , esta disposición adicional decía que: "A los efectos de aplicación de la presente ley se equiparan al matrimonio las relaciones maritales mantenidas con intención o vocación de permanencia, con lo cual se extienden, por tanto, a los miembros de la pareja los derechos y obligaciones que esta ley reconoce a los cónyuges. Tendrá la consideración de relación marital análoga al matrimonio la formada por dos personas que lleven conviviendo al menos un año, pudiéndose acreditar tal circunstancia por medio de la inscripción en el registro, manifestación expresa mediante acta de notoriedad o cualquier otro medio admisible en derecho. En caso de tener hijos en común será suficiente con acreditar la convivencia".

${ }^{82}$ En su redacción actual la citada disposición adicional tercera dice lo siguiente:

1. A los efectos de la aplicación de la presente ley, se equiparán al matrimonio las relaciones maritales mantenidas con intención o vocación de permanencia, con lo que se extienden a los miembros de la pareja los derechos y las obligaciones que la presente ley reconoce a los cónyuges.

2. Tendrán la condición de parejas de hecho las uniones de dos personas mayores de edad, capaces, que convivan con la intención o vocación de permanencia en una relación de afectividad análoga a la conyugal y que la inscriban en el Registro de Parejas de Hecho de Galicia, expresando su voluntad de equiparar sus efectos a los del matrimonio. No pueden constituir parejas de hecho:

a) Los familiares en línea recta por consanguinidad o adopción.

b) Los colaterales por consanguinidad o adopción hasta el tercer grado.

c) Los que estén ligados por matrimonio o formen pareja de hecho debidamente formalizada con otra persona.

3. Los miembros de la unión de hecho podrán establecer válidamente en escritura pública los pactos que estimen convenientes para regir sus relaciones económicas durante la convivencia y para liquidarlas tras su extinción, siempre que no sean contrarios a las leyes, limitativos de la igualdad de derechos que corresponden a cada conviviente o gravemente perjudiciales para cada uno de los mismos.

Serán nulos los pactos que contravengan la anterior prohibición.
} 
13 de abril, sobre la Ley Foral Navarra 6/2000, de 3 de julio, para la igualdad jurídica de las parejas estables $^{83}$.

Pese a ello, el Estado ha venido a determinar un cierto marco común, una vez más con una pésima técnica legislativa al hacerlo por medio de una norma que, en principio, no estaría llamada a esta función como es la Ley General de la Seguridad Social ${ }^{84}$ la cual, en el art. $221.2^{85}$, viene a fijar qué se considera una pareja de hecho, a fin de poder tener derecho a la pensión de viudedad. El mencionado artículo señala una serie de requisitos sumamente exigentes para las parejas de hecho, especialmente en lo relativo a la duración de la relación de pareja de hecho; dicha exigencia resulta más llamativa si se compara con la establecida para los supuestos de matrimonio para los que no existe período de existencia del vínculo, salvo que el fallecimiento se deba a enfermedad común ${ }^{86}$ no sobrevenida posteriormente a la celebración, en cuyo caso el período de duración exigido es de un año.

Y, en el segundo párrafo del mencionado apartado del artículo, se establece la obligación de registro o constancia en documento público de la relación de convivencia, al precisar que "La existencia de pareja de hecho se acreditará mediante certificación de la inscripción en alguno de los registros específicos existentes en las CCAA o ayuntamientos del lugar de residencia o mediante documento público en el que conste la constitución de dicha pareja. Tanto la mencionada inscripción como la formalización del correspondiente documento público deberán haberse producido con una antelación mínima de dos años con respecto a la fecha del fallecimiento del

\footnotetext{
${ }^{83}$ La Ley Foral 6/2000, de 3 de julio, para la igualdad jurídica de las parejas estables de la Comunidad Foral de Navarra, fue publicada en el Boletín Oficial de Navarra n. ${ }^{\circ} 82$ de fecha 7 de julio de 2000.

${ }^{84}$ En la versión dada en el RD Legislativo 8/2015, de 30 de octubre, por el que se aprueba el texto refundido de la Ley General de la Seguridad Social, actualmente en vigor.

${ }^{85} \mathrm{El}$ art. 221 de la vigente Ley de la Seguridad Social trata, precisamente, de la pensión de viudedad de las parejas de hecho, y tras señalar en el apartado $10^{\circ}$ el derecho a la pensión de viudedad a quien haya convivido como pareja de hecho, en el apartado 2. ${ }^{\circ}$ establece los requisitos para considerar cuál sea una pareja de hecho a los efectos de la ley en los siguientes términos: " 2 . A efectos de lo establecido en este artículo, se considerará pareja de hecho la constituida, con análoga relación de afectividad a la conyugal, por quienes, no hallándose impedidos para contraer matrimonio, no tengan vínculo matrimonial con otra persona y acrediten, mediante el correspondiente certificado de empadronamiento, una convivencia estable y notoria con carácter inmediato al fallecimiento del causante y con una duración ininterrumpida no inferior a cinco años.

La existencia de pareja de hecho se acreditará mediante certificación de la inscripción en alguno de los registros específicos existentes en las CCAA o ayuntamientos del lugar de residencia o mediante documento público en el que conste la constitución de dicha pareja. Tanto la mencionada inscripción como la formalización del correspondiente documento público deberán haberse producido con una antelación mínima de dos años con respecto a la fecha del fallecimiento del causante".

${ }^{86}$ El RD Legislativo 8/2015, de 30 de octubre, por el que se aprueba el Texto refundido de la Ley General de la Seguridad Social, en su art. 158.2 establece que "se considerarán que constituyen enfermedad común las alteraciones de la salud, que no tenga la condición de accidentes de trabajo ni de enfermedades profesionales".
} 
causante”. Como consecuencia de esta exigencia, las diferentes legislaciones autonómicas han creado, cuando no lo habían hecho con anterioridad, registros específicos de parejas de hecho.

Así pues, las uniones more uxorio han sido una realidad social que ha permanecido a lo largo de la historia con un desarrollo paralelo a la de las uniones de bendición o aprobadas y reconocidas como uniones con todos los derechos. Hemos visto cómo la figura más habitual de esta relación ha sido la del concubinato.

Sin embargo, actualmente, esta realidad social tiene un significado distinto al del período posterior al Concilio de Trento, pasando de una situación de marginalidad y de abandono desde el Ordenamiento jurídico a la realidad del siglo XXI, con una posición de una general aceptación social y con una legislación sobre la materia cada vez más abundante y reguladora de derechos para los convivientes.

De este modo se va configurando la institución de la unión de hecho como una alternativa al matrimonio en el Derecho de familia. Es por ello que se produce la creciente protección legislativa de este modo de uniones. Desde la década de los ochenta del pasado siglo, el fenómeno de las uniones de hecho viene incrementando su presencia como forma de desarrollo de la vida en pareja, de modo que se ha convertido en una especie de alternativa al matrimonio y, en algunos supuestos, en un paso previo para el mismo.

\section{B) Causas Que dan lugar a las uniones de hecho}

La existencia y proliferación de las uniones de hecho es una realidad incuestionable en la sociedad de los últimos años. Los factores que han podido influir en esta expansión de las uniones no matrimoniales responden a distintas razones. Éstas pueden ser debidas a la existencia de impedimentos por los que las parejas no pueden contraer matrimonio; o también, podemos encontrarnos con causas económicas o culturales que hacen más viable la unión sin contraer matrimonio. En la mayoría de los casos, los convivientes han decidido libremente compartir su vida en común sin atender a las formalidades del matrimonio, por el rechazo claro a la solemnidad que este supone ${ }^{87}$.

De modo que podemos establecer dos orígenes diferentes de la existencia de las uniones de hecho: un grupo sería el de aquellas parejas que aunque quisieran casarse no podrían hacerlo por

\footnotetext{
${ }^{87}$ MESA MARRERO, C: Las Uniones de Hecho: análisis de las relaciones económicas y sus efectos, $3^{\mathrm{a}}$ ed., Aranzadi, Pamplona (2006), pág. 24.
} 
diversas causas, es decir, uniones de hecho creadas por razones ajenas a la voluntad de los miembros de la pareja y, por otra parte, estarían las uniones formadas por personas que, pese a no existir nada que impida la unión matrimonial, de manera voluntaria optan por constituirse en unión de hecho.

\section{Uniones de Hecho creadas por causas ajenas a la voluntad de la pareja}

Las razones por las que una pareja de hecho se constituye como tal pueden derivar de impedimentos de diversos tipos, así se producen este tipo de uniones en varios países de América Latina derivado de motivos culturales, de la pobreza y de la marginación ${ }^{88}$. En algunos países de esa zona del mundo la convivencia de hecho constituye una realidad social habitual entre los ciudadanos que se unen sin contraer matrimonio porque este es un modo de convivencia aceptado como otra forma de constituir una familia. ${ }^{89}$

Estas formas de familia son reconocidas mediante normas de Derecho positivo en diversos países, a modo de ejemplo referiremos el caso de la República de México en la que ya desde la Ley de Relaciones familiares de 1917 y el posterior CC de 1928 se fueron introduciendo reformas radicales sobre el tema, al reconocer este modo de convivencia, si bien en principio de manera incipiente y cautelosa, debido a los menguados efectos que se le reconocen ${ }^{90}$. En la exposición de motivos del citado Código se justifica la introducción del concubinato del siguiente modo: "hay entre nosotros, sobre todo, en las clases populares, una manera peculiar de formar una familia: el concubinato. Hasta ahora habían quedado al margen de la ley los que en tal caso vivían; pero el legislador no debe cerrar los ojos para no darse cuenta de un modo de ser muy generalizado en algunas clases sociales y por eso en el proyecto se reconoce que produce efectos jurídicos, ya en bien de los hijos, ya a favor de la concubina, que al mismo tiempo es madre, y que ha vivido mucho tiempo con el jefe de familia. Esos efectos se producen cuando ninguno de los que viven en concubinato es casado, pues se quiso rendir homenaje al matrimonio, que la comisión considera como la forma legal y moral de construir la familia, y si se trata del concubinato es, como se dijo antes, porque se encuentra muy generalizado, hecho que el legislador no debe ignorar”.

\footnotetext{
${ }^{88}$ WÓJCIK, A.: "La unión de hecho y el matrimonio. Diferencia antropológico-jurídica", en ius canonicum n. ${ }^{\circ}$ XLII (2002), pág. 222.

${ }^{89}$ MESA MARRERO, C.: Op. cit. pág. 26.

${ }^{90}$ ARCEO BARANDA, E.: Uniones de Hecho familiares, (tesis doctoral).Universidad de Córdoba (2016), pág. 125.
} 
También, entre determinados grupos sociales, existían impedimentos legales para la celebración del matrimonio, como ocurría con las derogadas leyes ${ }^{91}$ que obligaban a diplomáticos y militares a solicitar licencia de sus superiores para contraer matrimonio. La negativa de la concesión podía llevar a estas personas a mantener la relación convivencial como uniones de hecho.

Más complejo actualmente es el supuesto de la celebración de matrimonios a los que no se les reconocen efectos civiles, se trataría de los matrimonios celebrados con arreglo a ritos o costumbres de determinados grupos sociales, étnicos o religiosos a los que el Ordenamiento jurídico no reconoce efectos civiles, por lo que constituyen uniones de hecho. Se trataría de supuestos como las celebraciones de matrimonios gitanos, zíngaros, o de determinadas sectas religiosas.

Otras causas pueden ser de carácter económico ${ }^{92}$. Así, la decisión de convivir juntos puede deberse a razones tales como que por la condición económica de alguno o de ambos convivientes no puedan afrontar los gastos unidos a la celebración del matrimonio, costumbre social que, a pesar de no resultar necesaria para la validez del mismo, está ineludiblemente unida a la forma de celebración del matrimonio.

También es frecuente que se inicie una convivencia more uxorio en los supuestos en que uno de los convivientes está separado o divorciado porque perdería la pensión compensatoria si contrae nuevo matrimonio ${ }^{93}$.

\footnotetext{
${ }^{91}$ La Ley de 13 de noviembre de 1957, relativa a matrimonios militares, hoy derogada, establecía un sistema de licencia para contraer matrimonio aplicable a Generales, Jefes, Oficiales y Suboficiales; permisos reglamentarios para la clase de tropa y prohibición de contraer matrimonio para los alumnos de las academias militares; algunos autores definían estas limitaciones con el término de "impedimentos impedientes". En el mismo sentido la Ley 29/1961, de 22 de julio, sobre reglamentación del matrimonio de los funcionarios de la carrera diplomática, hoy también derogada, que en su artículo $1 .^{\circ}$ establecía la obligatoriedad del funcionario de la carrera diplomática que pretendía contraer matrimonio de solicitar licencia al Ministerio de Asuntos Exteriores.

${ }^{92} \mathrm{Se}$ dan supuestos de personas que no contraen matrimonio ni constituyen unión de hecho registrada para no perder la pensión de viudedad, ya que el art. 223.2 del RD Legislativo 8/2015, que aprueba el texto refundido de la Ley General de la Seguridad Social establece que "El derecho a pensión de viudedad se extinguirá, en todos los supuestos, cuando el beneficiario contraiga matrimonio o constituya una pareja de hecho en los términos regulados en el artículo $221(\ldots)$ ".

${ }^{93} \mathrm{Y}$ ello a pesar de que el art. 101 del vigente CC precisa que "El derecho a la pensión se extingue por el cese de la causa que lo motivó, por contraer el acreedor nuevo matrimonio o por vivir maritalmente con otra persona", asimilando así, en este aspecto, el matrimonio y la convivencia como unión de hecho.
} 


\section{Uniones de Hecho surgidas por la voluntad de no casarse de los miembros de la pareja}

Igualmente, existen diversas razones por las que una pareja decide no casarse. Podemos poner como un primer grupo el de aquellas personas cuya voluntad de rechazo lo es frente a la forma del matrimonio por el rechazo de los miembros de la pareja a la intervención tanto de la Iglesia como de la autoridad civil en el establecimiento de la relación matrimonial, y ello pese a aceptar todos los derechos y deberes propios del estatuto matrimonial ${ }^{94}$.

Existe otro grupo de personas cuya voluntad de rechazo es por no querer el vínculo, es decir por no aceptar los deberes y derechos derivados del estatuto matrimonial, pero haciendo coincidir esto con la existencia de la convivencia como pareja de hecho. Obviamente para ser considerada esta unión como pareja de hecho precisa de la nota de estabilidad, convirtiendo la unión de hecho como un fin en sí misma para los convivientes, por lo que no se incluyen en ellas aquellas relaciones meramente ocasionales.

En suma, se trataría de personas que, pudiendo casarse, rechazan el matrimonio como expresión de los derechos y obligaciones jurídicamente debidos y derivados del vínculo matrimonial. La presencia en la sociedad actual de uniones no matrimoniales, como otro tipo de vida familiar, es una realidad social importante por el número de personas que optan por esta forma de convivencia. Y, en general, las personas que forman la unión de hecho son ciudadanos integrados totalmente en la sociedad en la que viven, que participan de todo aquello que afecta a su entorno, y que únicamente se deciden a vivir al margen del matrimonio porque sencillamente no están de acuerdo con someter su relación a una formalidad o solemnidad que rechazan, no a causa de ideologías extremistas (como han señalado algunos autores), ya sean de tipo religioso o político $^{95}$.

\section{C) DEFINICIÓN DE PAREJa DE HECHO}

Analizar el fenómeno requiere, por tanto, confrontarlo con la institución matrimonial, de modo que, una primera aproximación al concepto, nos llevaría a definirlo como la unión de dos personas, del mismo o distinto sexo, que conviven maritalmente sin estar casados.

\footnotetext{
${ }^{94}$ WÓJCIK, A.: Op. cit., pág. 222.

${ }^{95}$ MESA MARRERO, C.: Op. cit., pág. 27.
} 
Así, algunos de los rasgos característicos propios de las uniones de hecho, que nos irán acercando a una definición de la institución, serían: unión de dos personas del mismo o distinto sexo, monogamia, convivencia y la ausencia de vínculo matrimonial entre los convivientes. Contempladas de este modo incluimos en el concepto las parejas de personas homosexuales, pero no se incluirían determinadas situaciones poligámicas o poliándricas que empiezan a aparecer en la sociedad y que, entendemos, configuran un fenómeno social con características propias y diferenciadas del de las uniones de hecho, tal como las venimos conociendo.

No existe una definición terminada del concepto, por cuanto las uniones de hecho responden a motivaciones sumamente distintas, ya que en ocasiones se opta por ese modo convivencial porque las personas integrantes de la unión no pueden, por diversos motivos, contraer matrimonio, mientras que, en otras ocasiones, sencillamente los convivientes no quieren contraer matrimonio.

Pese a ello, se puede concluir que existe un cierto consenso en admitir que las parejas de hecho consisten en la convivencia marital, estable, entre dos personas, realizada con vocación de permanencia y sin que exista entre ellas un vínculo matrimonial.

Tal vez por ello el Preámbulo de Ley 25/2010, de 29 de julio, del libro segundo del CC de Cataluña, relativo a la persona y la familia, al referirse a la realidad actual, indica que "(...) Ciertamente, el inicio de un proyecto de vida en común no se hace hoy únicamente por medio del matrimonio (...) y estudios recientes constatan que en parejas jóvenes (la convivencia no matrimonial) se presenta como un fenómeno bastante diferente al matrimonio, a partir de indicadores como la duración, la estabilidad, la fecundidad o el grado de compromiso recíproco manifestado en actos como la puesta en común de bienes o cosas similares. Predomina la modalidad que la concibe como un matrimonio a prueba, bien porque la pareja se rompe o bien porque se transforma en matrimonio". Ciertamente, esta apreciación parece referirse a la situación en Cataluña, ya que la drástica reducción del número de matrimonios que se celebran en el conjunto de España ${ }^{96}$ indicaría que las relaciones de convivencia se plantean, cada vez más, como un fín en sí mismas.

\footnotetext{
${ }^{96}$ Según el INE el número de matrimonios en el conjunto de España ha pasado de 216.451 matrimonios celebrados en el año 2000, a los 162.743 celebrados en el año 2018 (último dato publicado a la fecha de escribir estas líneas).
} 
Casi la totalidad de las CCAA han optado por regular el fenómeno de las parejas de hecho, de modo que, en la actualidad, existen las siguientes regulaciones de las uniones de hecho en España:

- La Ley Foral 6/2000, de 3 de julio, para la igualdad jurídica de las parejas estables de la Comunidad Foral de Navarra, la cual ha resultada profundamente modificada por la Ley Foral 21/2019, de 4 de abril, de modificación y actualización de la compilación del Derecho Civil de navarra o Fuero Nuevo.

- Ley 11/2001, de 19 de diciembre, de Uniones de Hecho de la Comunidad de Madrid.

- Ley 18/2001, de 19 de diciembre, de Parejas Estables de Illes Balears.

- Ley 4/2002, de 23 de mayo, de Parejas Estables del Principado de Asturias.

- Ley 5/2002, de 16 de diciembre, de Parejas de Hecho de Andalucía.

- Ley 5/2003, de 6 de marzo, para la regulación de las Parejas de Hecho en la Comunidad Autónoma de Canarias.

- Ley 5/2003, de 20 de marzo, de Parejas de Hecho de la Comunidad Autónoma de Extremadura.

- Ley 2/2003, de 7 de mayo, reguladora de las Parejas de Hecho de la Comunidad Autónoma del País Vasco, Modificada por la disposición adicional segunda de la Ley 5/2015, de 25 de junio, de Derecho Civil Vasco.

- Ley 1/2005, de 16 de mayo, de Parejas de Hecho de la Comunidad Autónoma de Cantabria, modificada por la Ley 6/2015, de 28 de diciembre, de Medidas Fiscales y Administrativas.

- Ley 5/2012, de 15 de octubre, de Uniones de Hecho Formalizadas de la Comunitat Valenciana.

- Disposición Adicional $3^{a}$ redactada por el artículo único de la Ley 10/2007, de 28 de junio de reforma de la Disposición Adicional 3 ${ }^{a}$ de la Ley 2/2006, de 24 de junio, de Derecho Civil de Galicia.

- Ley 25/2010, de 29 de julio, del Libro Segundo del CC de Cataluña, relativo a la persona y la familia y Decreto-Ley 3/2015, de 6 de octubre, de modificación de la Ley 25/2010, de 29 de julio, del Libro Segundo del CC de Cataluña.

- Decreto Legislativo 1/2011, de 22 de marzo, del Gobierno de Aragón, por el que se aprueba, con el título de "Código del Derecho Foral de Aragón”, el Texto Refundido de 
las Leyes Civiles Aragonesas, dedicando el Título VI del Libro II a "Las parejas Estables No Casadas".

- Ley 7/2018, de 3 de julio, de Parejas de Hecho de la Comunidad Autónoma de la Región de Murcia.

No obstante, en todas las CCAA, tanto las que han legislado sobre la situación de las uniones de hecho (con sus diferentes nombres en las distintas legislaciones) como en las que no lo han hecho (en este momento Castilla y León, Castilla-La Mancha y La Rioja), se han regulado Registros de Uniones de Hecho.

- En Castilla-La Mancha, el Registro de Uniones de Hecho se regula, actualmente, mediante el Decreto 43/2018, de 19 de junio, por el que se modifica el Decreto 124/2000, de 11 de julio, por el que se regula la creación y el régimen de Funcionamiento del Registro de Parejas de Hecho de la Comunidad Autónoma de Castilla-La Mancha.

- En Castilla y León, el Registro de Uniones de Hecho está regulado en el Decreto 117/2002, de 24 de octubre, por el que se crea el registro de uniones de Hecho de Castilla y León y se regula su funcionamiento.

- En La Rioja, se crea el Registro de Parejas de Hecho por el Decreto 30/2010, de 14 de mayo.

Mientras, el Ordenamiento jurídico estatal ha permanecido absolutamente ajeno, durante mucho tiempo, a la existencia de las uniones de hecho, dejando en manos del legislador autonómico el desarrollo normativo que regulase la situación de estas uniones. Durante mucho tiempo se levantaron voces reclamando una norma armonizadora de un modo convivencial que iba ganando importancia numérica en el conjunto del Estado, sin que el legislativo nacional reaccionase en modo alguno. Pese a ello, se han ido introduciendo reformas concretas en diversas normas nacionales dando una respuesta a este fenómeno cada vez más creciente. Sin embargo, tales modificaciones se reducen a normas dispersas en diversas leyes, pero que van teniendo un cierto efecto armonizador de la normativa autonómica. El ejemplo paradigmático de ello es la Disposición Adicional Tercera de la Ley 40/2007, de 4 de diciembre, de medidas en materia de Seguridad Social, que modificó el art. 174 de la entonces vigente Ley General de la Seguridad Social, que venía a reconocer el derecho a la pensión de viudedad en los supuestos de parejas de hecho que, 
cumpliendo los requisitos exigidos en los casos de matrimonio, acreditasen una convivencia estable de seis años, así como la dependencia económica del miembro sobreviviente de la pareja ${ }^{97}$.

\section{Una definición estatal de pareja de hecho}

Aunque el legislador estatal ha rehuido legislar sobre las uniones de hecho, la realidad social lo ha obligado a manifestar su posición en determinados aspectos relativos a estas uniones de convivencia. Un aspecto sobre el que el TC se ha pronunciado en varias oportunidades es el del derecho a pensión de viudedad de las personas que han convivido como pareja de hecho.

De modo que las diversas Resoluciones del Constitucional, y la realidad social han llevado a determinar qué considera la Seguridad Social una pareja de hecho, señalando que "se considerará pareja de hecho la constituida, con análoga relación de afectividad a la conyugal, por quienes, no hallándose impedidos para contraer matrimonio, no tengan vínculo matrimonial con otra persona y acrediten, mediante el correspondiente certificado de empadronamiento, una convivencia estable y notoria con carácter inmediato al fallecimiento del causante y con una duración ininterrumpida no inferior a cinco años" $" 98$.

Estamos, al fin, ante una definición del Estado sobre qué considera que es una unión de hecho, precisando que se considerará como tal la constituida por quienes conviven con otra persona, en una relación de afectividad análoga a la conyugal, aunque exigiendo que concurra en ambos miembros de la pareja la libertad para contraer matrimonio, lo que recalca especialmente la norma, al precisar, de manera un tanto redundante, que los miembros de la pareja no han de incurrir en impedimento alguno para contraer matrimonio, entre los que se encontraría la libertad

\footnotetext{
${ }^{97}$ La Disposición adicional tercera de la Ley 40/2007, de 4 de diciembre, de medidas en materia de Seguridad Social, vino a reconocer el derecho a la pensión de viudedad en supuestos especiales. Con carácter excepcional, reconocía el derecho a la pensión de viudedad cuando, habiéndose producido el hecho causante con anterioridad a la entrada en vigor de la citada Ley, concurriesen las siguientes circunstancias:

a) Que a la muerte del causante, reuniendo este los requisitos de alta y cotización a que se refería el apartado 1 del artículo 174 del texto refundido de la Ley General de la Seguridad Social vigente en el momento [en la actualidad, artículo 219.1 LGSS 2015], no se hubiera podido causar derecho a pensión de viudedad.

b) Que el beneficiario hubiera mantenido convivencia ininterrumpida, como pareja de hecho en los términos establecidos en el primer inciso, párrafo $4 .^{\circ}$, artículo 174.3 de la Ley General de la Seguridad Social, [actualmente, artículo 221 LGSS 2015], con el causante, durante, al menos, los seis años anteriores al fallecimiento de este.

c) Que el causante y el beneficiario hubieran tenido hijos comunes.

d) Que el beneficiario no tuviese reconocido derecho a pensión contributiva de la Seguridad Social.

e) Se concedía un plazo para presentar la correspondiente solicitud de doce meses desde la entrada en vigor de esta Ley. Y se reconocían efectos económicos a la pensión desde el día1de 2007.

${ }^{98}$ Art. 221.2 del RD Legislativo 8/2015, de 30 de octubre, por el que se aprueba el Texto Refundido de la Ley General de la Seguridad Social.
} 
matrimonial, y exigir, además, que no tengan vínculo matrimonial con otra persona. Vínculo que, por sí mismo, sería un impedimento para contraer matrimonio, de ahí que señalemos la redundancia en esta exigencia, que parecería preocupar de modo especial al legislador estatal.

De modo que, también en la legislación estatal, los impedimentos para entender constituida una unión de hecho serían los de edad, parentesco y la libertad matrimonial, en línea con los exigidos por la legislación autonómica.

Se exige, también, que la convivencia debe ser estable y notoria, inmediata al fallecimiento del otro miembro de la pareja, y exigiendo que tal relación tenga una duración, ininterrumpida, de cinco años. Es decir, con una exigencia de estabilidad mucho mayor que al de cualquiera de las legislaciones autonómicas.

Es en el tiempo de duración de la convivencia marital extramatrimonial donde son más radicales las exigencias del legislador estatal, tal vez porque el reconocimiento de la unión de hecho conlleva el pago de prestaciones públicas, aunque no por ello nos parecerá menos riguroso.

Llama especialmente la atención la exigencia de un período tan largo de convivencia al compararlo con el supuesto del matrimonio, pues en tal caso, no se exige período alguno de duración del mismo para generar el derecho a la prestación ${ }^{99}$, y solamente en los supuestos en que el cónyuge fallezca a causa de una enfermedad común, preexistente a la celebración del matrimonio, se establece la exigencia de la celebración del matrimonio con un año de antelación al fallecimiento, o la existencia de hijos comunes, en cuyo caso tampoco se tiene en cuenta período alguno de convivencia.

En tales circunstancias, parece absolutamente desproporcionado el período de convivencia que se exige a las uniones de hecho.

\section{Definiciones autonómicas de las uniones de hecho}

Las diferentes leyes autonómicas incluyen, de forma más o menos expresa, diversas definiciones de las uniones de hecho. Siguiendo el orden cronológico de las diferentes leyes

\footnotetext{
${ }^{99}$ El art. 219 del RD Legislativo 8/2015, de 30 de octubre, por el que se aprueba el Texto refundido de la Ley General de la Seguridad Social establece una excepción para el supuesto de fallecimiento por enfermedad común, al señalar que "En los supuestos excepcionales en que el fallecimiento del causante derivara de enfermedad común, no sobrevenida tras el vínculo conyugal, se requerirá, además, que el matrimonio se hubiera celebrado con un año de antelación como mínimo a la fecha del fallecimiento o, alternativamente, la existencia de hijos comunes. No se exigirá dicha duración del vínculo matrimonial cuando en la fecha de celebración del mismo se acreditará un período de convivencia con el causante, en los términos establecidos en el artículo 221.2, que, sumado al de duración del matrimonio, hubiera superado los dos años".
} 
autonómicas, la Legislación Navarra definía el concepto de pareja estable en su artículo segundo, el cual ha sido derogado por la Disposición Derogatoria Tercera de la Ley Foral 21/2019, de 4 de abril, de modificación y actualización de la Compilación del Derecho Civil de Navarra o Fuero de Navarra ${ }^{100}$; no obstante, la mencionada Ley definía el concepto como:

la unión libre y pública, en una relación de afectividad análoga a la conyugal, con independencia de su orientación sexual, de dos personas mayores de edad o menores emancipadas sin vínculo de parentesco por consanguinidad o adopción en línea recta o colateral hasta el segundo grado, siempre que ninguna de ellas esté unida por un vínculo matrimonial o forme pareja estable con otra persona.

2. Se entenderá que la unión es estable cuando los miembros de la pareja hayan convivido maritalmente, como mínimo, un período ininterrumpido de un año, salvo que tuvieran descendencia común, en cuyo caso bastará la mera convivencia, o salvo que hayan expresado su voluntad de constituir una pareja estable en documento público.

El inciso "hayan convivido maritalmente, como mínimo, un período ininterrumpido de un año, salvo que tuvieran descendencia común, en cuyo caso bastará la mera convivencia, o salvo que", del párrafo 2. ${ }^{\circ}$ del artículo fue declarado inconstitucional y nulo por la STC 93/2013, de 23 de abril ${ }^{101}$. Así lo que se exige es la unión libre y pública, en una relación de afectividad análoga a la marital, de dos personas del mismo o distinto sexo, mayores de edad, y que no estén unidas en otra pareja more uxorio. La norma autonómica establece la posibilidad de creación del registro de estas uniones estables.

Por su parte, la legislación vigente de la Comunidad Autónoma de Madrid define las parejas de hecho del siguiente modo: "personas que convivan en pareja, de forma libre, pública y notoria, vinculadas de forma estable, al menos durante un período ininterrumpido de doce meses, existiendo una relación de afectividad, siempre que voluntariamente decidan someterse a la misma mediante la inscripción de la unión en el Registro de Uniones de Hecho de la Comunidad de Madrid"102.

\footnotetext{
${ }^{100}$ La Ley Foral 21/2019, de 4 de abril, de modificación y actualización de la Compilación del Derecho Civil Foral de Navarra o Fuero Nuevo, fue publicada en el BOE n. ${ }^{\circ} 137$, de 8 de junio de 2019.

${ }^{101}$ La STC n. ${ }^{\circ}$ 93/2013, de 23 de abril de 2013, fue publicada en el BOE n. ${ }^{\circ} 123$, de 23 de mayo de 2013.

${ }^{102}$ Art. 1 de la Ley 11/2001, de 19 de diciembre, de Uniones de Hecho de la Comunidad de Madrid.
} 
De modo que en la Comunidad de Madrid se entendería como pareja de hecho la formada por los convivientes en pareja, de forma libre, pública y notoria, de manera estable, con una relación de afectividad, durante al menos un año, y siempre que consten inscritos en el correspondiente registro de la Comunidad Autónoma. Contempla como impedimentos para constituir la unión de hecho la minoría de edad (admite la constitución como unión de hecho de los menores emancipados), las deficiencias psíquicas que impidan prestar un consentimiento válido, el parentesco en línea recta o colateral por consanguinidad o adopción, las personas casadas y no separadas judicialmente o las que mantienen una unión de hecho.

La Ley de Illes Balears entiende como tales:

Las uniones de dos personas que convivan de forma libre, pública y notoria, en una relación de afectividad análoga a la conyugal.

2. Para que les sea de aplicación esta Ley, los miembros de la pareja tendrán que cumplir los requisitos y las formalidades que se prevén, no estar bajo ningún impedimento que afecte a algunos de ellos o a su relación, e inscribirse voluntariamente en el Registro de Parejas Estables de las Illes Balears. La inscripción en este registro tiene carácter constitutivo ${ }^{103}$.

Una vez más se entiende como pareja de hecho la unión de dos personas que conviven de forma libre, pública y notoria, con una relación de afectividad análoga a la del matrimonio; se exige no estar incurso en causa de impedimento alguna, siendo impedimentos para la constitución de pareja estable la menoría de edad (aunque se permite para el caso de los menores emancipados), el impedimento de parentesco en línea recta o colateral por consanguinidad o adopción, así como estar unido por vínculo matrimonial o como pareja estable inscrita con tercera persona; y se exige, también, la inscripción en el registro de parejas estables, inscripción a la que se le confieren efectos constitutivos. De modo que, pese al carácter voluntario de la inscripción, de no producirse ésta, la pareja se entenderá como no constituida a los efectos legales en dicha Comunidad autónoma.

En la Normativa vigente en el Principado de Asturias,

Se considera pareja estable la unión libre y pública, en una relación de afectividad análoga a la conyugal, con independencia de su sexo, de dos personas mayores de edad o menores emancipadas sin vínculo de parentesco por consanguinidad o adopción en línea recta o colateral

${ }^{103}$ Art. 1 de la Ley 18/2001, de 19 de diciembre, de Parejas Estables de la Comunidad de Illes Balears. 
hasta el segundo grado, siempre que ninguna de ellas esté unida por un vínculo matrimonial o forme pareja estable con otra persona.

2. Se entenderá que la unión es estable cuando los miembros de la pareja hayan convivido maritalmente, como mínimo un período ininterrumpido de un año, salvo que tuvieran descendencia común, en cuyo caso bastará la mera convivencia, o salvo que hayan expresado su voluntad de constituir una pareja estable en documento público, o se hayan inscrito en el Registro de Uniones de Hecho del Principado de Asturias.

3. La existencia de pareja estable o el transcurso del año de convivencia podrán acreditarse a través de cualquier medio de prueba admitido en Derecho ${ }^{104}$.

De nuevo se entiende por unión de hecho la formada por dos personas, del mismo o distinto sexo, unidas de manera estable en una relación de afectividad análoga al matrimonio de manera libre y pública, sobre la que no existan impedimentos, ya sean de edad, pues han de ser mayores de edad o menores emancipados, o de parentesco en línea recta o colateral por consanguinidad o adopción, o derivados de una relación marital o convivencial. En el caso, se confieren efectos declarativos a la inscripción en el correspondiente registro, aceptando para su acreditación cualquier otro medio de prueba válido en Derecho.

Llama la atención como la Ley asturiana contiene un párrafo casi idéntico al declarado inconstitucional en la Ley Foral Navarra pero que, al no haber sido recurrida su inconstitucionalidad, esta norma la mantiene. Nos referimos al inciso relativo a la convivencia marital, durante un período mínimo de un año, salvo que tuvieran descendencia en común, citado en el caso de la Ley Foral.

En la legislación andaluza "se entenderá por pareja de hecho la unión de dos personas, con independencia de su opción sexual, a fin de convivir de forma estable, en una relación de afectividad análoga a la conyugal" "105. Requiere una declaración de voluntad expresa de constituirse como pareja de hecho, así como de no estar incurso en ningún impedimento para la formación de la pareja de hecho, estableciendo como impedimentos para constituirla la menor edad, salvo que estén emancipados, el parentesco por consanguinidad o adopción, sea en línea recta o colateral, así como la coexistencia de vínculo con terceras personas, sea por matrimonio o por pareja de hecho

\footnotetext{
${ }^{104}$ Art. 3 de la Ley 4/2002, de 23 de mayo, de Parejas Estables de la Comunidad Autónoma del principado de Asturias. ${ }^{105}$ Art. 3 de la Ley 5/2002, de 16 de diciembre, de Parejas de Hecho de la Comunidad Autónoma de Andalucía.
} 
anterior inscrita. El registro de parejas de hecho tiene efectos declarativos, pero constar inscrito como tal es necesario para acceder a los beneficios establecidos en la comunidad autónoma.

Por su parte, en la Comunidad Autónoma de Canarias se entiende por pareja de hecho la formada por "personas que convivan en pareja de forma libre, pública y notoria, vinculados de forma estable con independencia de su orientación sexual, al menos durante un periodo ininterrumpido de doce meses, existiendo una relación de afectividad, (...). Bastará la mera convivencia cuando la pareja tuviera descendencia en común"106. Se requiere la convivencia estable de dos personas de forma libre, pública y notoria, durante al menos doce meses y con una relación de afectividad. Los impedimentos son los derivados de la relación de parentesco, de la minoría de edad, o del mantenimiento de otras relaciones de similar afectividad de manera simultánea. Se crea un registro al efecto que tiene carácter declarativo, si bien admite la prueba de la existencia de la pareja con cualquier otro medio de prueba válido en Derecho, señalando el especial valor probatorio del otorgamiento de escritura pública por ambos miembros de la pareja.

En la legislación extremeña tenemos que se entiende por pareja de hecho "la unión estable, libre, pública y notoria, en una relación de afectividad análoga a la conyugal, con independencia de su sexo, de dos personas mayores de edad o menores emancipadas, siempre que voluntariamente decidan someterse a la misma mediante la inscripción de la pareja en el Registro de Parejas de Hecho de la Comunidad Autónoma de Extremadura"107. A la inscripción en el registro de parejas de hecho la norma autonómica de Extremadura le confiere carácter constitutivo; y se entenderá que la unión es estable cuando haya convivido, al menos, durante un año. En cuanto a los impedimentos para constituirse como unión de hecho son los de edad, relación de parentesco o la coexistencia de relaciones de similar afectividad, sean matrimoniales o de otra unión de hecho.

En el caso del País Vasco la vigente legislación considera pareja de hecho "la resultante de la unión libre de dos personas mayores de edad o menores emancipadas, con plena capacidad, que no sean parientes por consanguinidad o adopción en línea recta o por consanguinidad en segundo grado colateral y que se encuentren ligadas por una relación afectivo-sexual, sean del mismo o de distinto género. Asimismo, ambos miembros de la pareja deberán cumplir el requisito de no estar

\footnotetext{
${ }^{106}$ Art. 1 de la Ley 5/2003, de 6 de marzo, para la regulación de las Parejas de Hecho en la Comunidad Autónoma de Canarias.

${ }^{107}$ Art. 2. De la Ley 5/2003, de 20 de marzo, de Parejas de hecho de la Comunidad Autónoma de Extremadura.
} 
unidos a otra persona por vínculo matrimonial o pareja de hecho" "108. Confiere carácter constitutivo a la inscripción en un registro de parejas de hecho, y establece la existencia de impedimentos de edad, al exigir plena capacidad de obrar, así como los de parentesco y el de inexistencia de otra relación, simultánea, de similar afectividad sea por matrimonio o por estar vinculados con otra persona como pareja de hecho. Sorprende en la regulación de la Comunidad Autónoma vasca la no exigencia, de manera expresa, de la nota de estabilidad, aunque la misma pueda inferirse del espíritu de la norma, así como del conjunto de la misma.

En el caso de Cantabria se considera pareja de hecho "a la que resulta de la unión de dos personas de forma estable, libre, pública y notoria, en una relación afectiva análoga a la conyugal, con independencia de su orientación sexual" ${ }^{109}$. Siguiendo un criterio común con otras regulaciones autonómicas considera que se cumple el requisito de estabilidad con la convivencia ininterrumpida durante un año, o con la existencia de descendencia común, sea esta natural o adoptiva. Establece como impedimentos para constituirse como pareja de hecho los de edad, el parentesco en línea recta o colateral por consanguinidad, o bien el estar unido a otra persona por vínculo matrimonial o como pareja de hecho inscrita.

En la norma de la Comunitat Valenciana no se contempla una verdadera definición de pareja de hecho, limitándose a señalar que la norma regula los derechos y deberes de estas uniones "entendiendo por tales las formadas por dos personas que, con independencia de su sexo, convivan en una relación de afectividad análoga a la conyugal, y que cumplan los requisitos de inscripción del artículo 3 de esta ley"110, requiere la declaración de voluntad de los miembros de la pareja, la cual ha de constar, bien por su manifestación ante el encargado o encargada del Registro de Uniones de Hecho, o bien por constar en otro documento público inscrito en el mencionado registro. En cuanto a los impedimentos, sigue la misma línea de establecer el impedimento de edad, de parentesco en línea recta o colateral, así el de existencia de vínculos no extinguidos de relaciones de similar afectividad, sea matrimonial o de pareja de hecho inscrita. Confiere carácter constitutivo a la inscripción en el Registro de Uniones de Hecho Formalizadas de la Comunitat Valenciana.

En cuanto a la legislación foral gallega, tras su reforma, considera pareja de hecho "las uniones de dos personas mayores de edad, capaces, que convivan con la intención o vocación de

\footnotetext{
${ }^{108}$ Art. 2 de la Ley 2/2003, de 7 de mayo, reguladora de las Parejas de Hecho en la Comunidad Autónoma del País Vasco.

${ }^{109}$ Art. 4.2 de la Ley 1/2005, de 16 de mayo, de Parejas de Hecho de la Comunidad Autónoma de Cantabria.

${ }^{110}$ Art. 1.1 de la Ley 5/2012, de 15 de octubre, de Uniones de Hecho Formalizadas de la Comunitat Valenciana.
} 
permanencia en una relación de afectividad análoga a la conyugal y que la inscriban en el Registro de Parejas de Hecho de Galicia, expresando su voluntad de equiparar sus efectos a los del matrimonio" "111. Establece los impedimentos comunes a otras CCAA, de edad (al exigir que se trate de personas mayores de edad), así como los de parentesco en línea recta o colateral por consanguinidad o adopción, así como el de estar unido por relación de similar afectividad, sea ésta matrimonial o como unión de hecho registrada. La norma gallega establece la libertad de pactos económicos entre los convivientes, estipulados en escritura pública, siempre que no sean contrarios a las leyes o al principio de igualdad de derechos entre los miembros de la pareja.

En cuanto a la vigente legislación catalana se pone énfasis en la nota de estabilidad, denominando a estas uniones como uniones estables, que se tendrán por tales en el caso de

Dos personas que conviven en una comunidad de vida análoga a la matrimonial se consideran pareja estable en cualquiera de los siguientes casos:

a) Si la convivencia dura más de dos años ininterrumpidos.

b) Si durante la convivencia, tienen un hijo común.

c) Si formalizan la relación en escritura pública. ${ }^{112}$

Así, pues, se establece cuándo se ha de considerar que una pareja de hecho reúne la nota de estabilidad, la cual será acreditable mediante cualquiera de los medios señalados en la misma. Y, en relación con los impedimentos para constituir pareja estable, se establecen los de edad, parentesco en línea recta o colateral, así como la convivencia con otra persona en situación de similar afectividad, ya sea matrimonial, en cuyo caso será impedimento no estar separado de hecho, o extramatrimonial, en cuyo caso será impedimento para constituir pareja de hecho la convivencia con una tercera persona. La inscripción en el registro de parejas estables tiene efectos declarativos.

En Aragón "Se consideran parejas estables no casadas, a efectos de este Código, las formadas por personas mayores de edad entre las que exista relación de afectividad análoga a la conyugal y que cumplan los requisitos y formalidades que se establecen en este Título." ${ }^{113}$. Para el

\footnotetext{
${ }^{111}$ Disposición Adicional $3^{a} .2$ de la Ley 2/2006, de 24 de junio, de Derecho Civil de Galicia, en su redacción dada por la Ley 10/2007, de 28 de junio, de modificación, precisamente, de la Disposición adicional $3^{\mathrm{a}}$.

${ }^{112}$ Art. 234-1 de la Ley 25/2010, de 29 de julio, del Libro Segundo del CC de Cataluña, relativo a la persona y la familia.

${ }^{113}$ Art. 303 del Decreto Legislativo 1/2011, de 22 de marzo, del Gobierno de Aragón, por el que se aprueba, con el título de "Código del Derecho Foral de Aragón", el Texto refundido de las Leyes civiles aragonesas.
} 
reconocimiento de su existencia deberán constar inscritas en el registro de parejas de hecho, al cual confiere carácter declarativo. Para acreditar la condición de pareja estable se exige la convivencia marital durante dos años, o bien la manifestación de voluntad, en escritura pública, de constituirse como pareja estable. En cuanto a los impedimentos, siguiendo la línea general de las legislaciones autonómicas, se establece el impedimento de edad (se exige que los miembros de la pareja estable sean mayores de edad), así como el de parentesco en línea recta por consanguinidad o adopción, y la inexistencia de vínculos de relación de pareja de similar afectividad, sea por la existencia de vínculo matrimonial, o sea por la existencia de pareja estable con otra persona.

En la Ley de la región de Murcia "se considera pareja de hecho la unión estable, libre, pública y notoria en una relación de afectividad análoga a la conyugal, con independencia de su sexo, de dos personas mayores de edad o menores emancipadas. Si bien se añade el requisito de que "los miembros de la pareja tendrán que haber expresado, de modo fehaciente, su voluntad de constituirse como pareja de hecho"114. De manera que para a la consideración como pareja de hecho se requiere el cumplimiento de los requisitos de que la unión sea libre, estable, pública y notoria, con una relación de afectividad análoga a la matrimonial, y que los miembros de la pareja hayan expresado, de manera fehaciente, su voluntad de constituirse como tal. Para su acreditación deberá constar inscrita en el registro de parejas de hecho, el cual tendrá efectos declarativos, y en relación a los impedimentos para constituir pareja de hecho se establecen los comunes a otras legislaciones autonómicas, es decir, el de edad (si bien en el caso de Murcia, como en algunas otras legislaciones relacionadas, se permite la constitución como pareja de hecho a los menores de edad emancipados), el de parentesco en línea recta o colateral por consanguinidad o adopción, así como las personas unidas mediante vínculo inscrito en una relación matrimonial o de unión de hecho. En el caso murciano, como en alguna otra Comunidad autónoma, se incluye como impedimento el supuesto de estar legalmente incapacitados por sentencia firme.

En el caso de la Comunidad Autónoma de Castilla-La Mancha, tendrán acceso al registro de parejas de hecho "las uniones que formen una pareja no casada y que convivan en relación afectiva análoga a la conyugal, de forma libre"115. Se exige, igualmente, una manifestación de voluntad que deberá formalizarse bien ante el encargado del registro o bien mediante documento

\footnotetext{
${ }^{114}$ Art. 1 de la Ley 7/2018, de 3 de julio, de Parejas de Hecho de la Comunidad Autónoma de la región de Murcia.

${ }^{115}$ Art. 2 del Decreto 124/2000, de 11 de julio, por el que se regula la creación y el régimen de funcionamiento del registro de parejas de Hecho de la Comunidad Autónoma de Castilla-La Mancha, en su redacción dada por el Decreto 43/2018, de 19 de junio, por el que se modifica el mencionado Decreto.
} 
autorizado notarialmente. Se establecen como impedimentos para el acceso al registro de parejas de hecho, la edad (se permite el acceso a los menores emancipados), el impedimento de parentesco en línea recta o colateral por consanguinidad o adopción, así como la existencia de vínculo matrimonial o de pareja de hecho con terceras personas,

En el caso de la Comunidad de Castilla y León se regula el acceso al registro de parejas de hecho de "las uniones que formen una pareja no casada, incluso del mismo sexo, en relación afectiva análoga a la conyugal, de forma libre, cuyos componentes hayan convivido, como mínimo, un período de seis meses y tengan su residencia habitual en la Comunidad de Castilla y León" ${ }^{116}$. El requisito de residencia es común a las diversas legislaciones autonómicas, como es natural. Y la inscripción en el registro de parejas de hecho tiene efectos declarativos. En cuanto a los impedimentos, se contemplan el de edad (se permite la unión de hecho de menores emancipados), el de parentesco en línea recta o colateral por consanguinidad o adopción, así como el de existencia de vínculo matrimonial o formar unión de hecho con otra persona cualquiera de los miembros de la pareja. En el caso castellanoleonés se establece, también, el impedimento de incapacitación judicial.

En el caso de La Rioja tendrán acceso al registro de parejas de hecho, en la redacción dada en el Decreto 10/2013, de 15 de marzo, "las uniones que formen una pareja estable no casada entre dos personas, con independencia de su sexo, que convivan de forma libre, pública y notoria, cuyos componentes hayan convivido como mínimo un periodo ininterrumpido de dos años, existiendo una relación de afectividad análoga a la conyugal, y teniendo ambos la residencia legal y vecindad administrativa en la Comunidad Autónoma de La Rioja”. Exige, pues, para acceder al registro de parejas de hecho, la existencia de una unión estable entre dos personas, y que dicha unión sea pública y notoria, constituida de forma libre, y a fin de acreditar la nota de estabilidad se exige que la convivencia haya durado, al menos, dos años de manera ininterrumpida. En cuanto a los impedimentos, se establecen el de edad (si bien se admite la unión de menores emancipados), el de parentesco en línea recta o colateral, por consanguinidad o adopción, y la inexistencia de vínculo matrimonial o formar pareja de hecho con terceras personas. También en este caso, se añade como impedimento la incapacitación judicial ${ }^{117}$.

\footnotetext{
${ }^{116}$ Art. 2 del Decreto 117/2002, de 24 de octubre, por el que se crea el Registro de Uniones de Hecho en Castilla y León y se regula su funcionamiento.

${ }^{117}$ Arts. 2 y 3 del Decreto 30/2010, de 14 de mayo, por el que se crea el Registro de Parejas de Hecho de La Rioja.
} 


\section{D) REQUISITOS PARA CONSTITUIR UNA PAREJA DE HECHO}

Los requisitos para constituir una pareja de hecho son tanto de carácter objetivo como de tipo subjetivo. Entre los requisitos de carácter objetivo destacan:

\section{a) Convivencia more uxorio}

Lo cual es tanto como decir que la convivencia en pareja pueda identificarse con la vida matrimonial, o sea que el comportamiento de las personas que conviven sea similar al de las personas que han contraído matrimonio legítimo. Este requisito de un modo de convivencia con una relación afectiva similar al matrimonio viene siendo exigido, de manera habitual, por la jurisprudencia $^{118}$.

La convivencia more uxorio significa tanto como el mantenimiento de una comunidad de vida y existencia, como resultado de la exigencia de la similitud a la vida matrimonial. Surgen controversias cuando las parejas por causas ajenas a su voluntad no conviven bajo un mismo techo, llevando como única causa de la unión de hecho la affectio razón última de la unión convivencial.

\section{b) Monogamia y cohabitación}

No parece existir controversia en torno al carácter monógamo de las uniones de hecho, por lo que parece admitirse que las uniones de hecho, al menos tal como las concebimos en la actualidad, son las formadas por dos personas, y solamente dos, del mismo o distinto sexo. Sin embargo, no resulta tan claro si la fidelidad entre los miembros de la pareja es un deber jurídico, como en el matrimonio o, por el contrario, si la inexistencia de vínculo determina que tampoco resulten exigibles jurídicamente las obligaciones derivadas de la relación, más allá del comportamiento de hecho de los miembros de la pareja. Es decir, si la fidelidad es un deber jurídico o simplemente moral entre los miembros de la unión de hecho. Consideramos que resulta indiferente la distinción, por cuanto siendo evidente que en el matrimonio existe el deber jurídico

\footnotetext{
${ }^{118}$ La [STS 18-5-1992 (RJ 1992/4907)], precisa los requisitos que debe cumplir la convivencia more uxorio para su reconocimiento legal, precisando lo siguiente: "la convivencia more uxorio debe desarrollarse en régimen vivencial de coexistencia diaria, estable, con permanencia temporal consolidada a lo largo de los años, practicad de forma externa y pública con acreditadas actuaciones conjuntas de los interesados, creándose así una comunal vida amplia, intereses y fines, en el núcleo de un mismo hogar”.
} 
de fidelidad entre los miembros de la pareja, la inexistencia de cualquier medida de compulsión por el incumplimiento de dicho deber de fidelidad conduce a que, en la práctica, el deber de fidelidad sea un deber moral, mucho más que jurídico. Deber moral que alcanza en similar medida a los miembros de las uniones de hecho.

\section{c) Permanencia o estabilidad}

La comunidad de vida desarrollada por los convivientes debe ser estable. El requisito de la estabilidad se suele valorar exigiendo un período de convivencia. Se considera fundamental el aspecto temporal en la unión, ya que estableciendo un plazo determinado se podrá demostrar la seriedad del compromiso. Las legislaciones que reconocen efectos a las uniones de hecho contemplan la duración de la relación como la mejor forma de juzgar su estabilidad. Sobre el aspecto temporal para medir la estabilidad de una convivencia no matrimonial hay quien opina que no es suficiente el mero transcurso del tiempo, puesto que la determinación del plazo más adecuado sería difícil de precisar. Y, aunque este se concretara, implicaría negar efectos a aquellas uniones estables a las que les faltara uno o varios días para cumplir el plazo legal. En este sentido, bastaría con que la affectio que ha unido a la pareja se traduzca en voluntad real de compartir la vida en común de forma semejante a la conyugal ${ }^{119}$.

El plazo a fijar para determinar que una unión de hecho es una unión estable ha tenido diversas posiciones a lo largo de estos últimos años, así algunos autores como Estrada Alonso fijan que el plazo temporal adecuado sería el de cinco años para que la unión de hecho permita tener efectos jurídicos ${ }^{120}$. Por su parte, otros autores, como Mesa Marrero sostienen que "no sería necesario que transcurriera demasiado tiempo para saber si la pareja se ha unido con propósito de permanencia. Y podría suceder que la unión lleve escaso tiempo, pero que desde su inicio la voluntad de los convivientes ha sido la de fundar una familia estable y duradera ${ }^{121}$.

La tendencia legislativa en España es divergente a la hora de fijar plazos para el reconocimiento de efectos jurídicos a las uniones de hecho. Así, como ya hemos visto

\footnotetext{
${ }^{119}$ MESA MARRERO, C.: Las uniones de hecho. Análisis de las relaciones económicas y sus efectos. ed. Aranzadi, Navarra (2006) págs. 34-35.

${ }^{120}$ ESTRADA ALONSO, E.: Las uniones extramatrimoniales en Derecho Civil español. ed. Civitas, Madrid (1986), pág. 67. En la nota 1 propone que se establezca el mencionado plazo de cinco años. GALLEGO DOMÍNGUEZ, I.: Las uniones de hecho y sus efectos patrimoniales (tesis doctoral), Univ. De Córdoba (1995). En la pág. 65 está de acuerdo con establecer este plazo de cinco años.

${ }^{121}$ MESA MARRERO, C.: Op. cit., pág. 35.
} 
anteriormente, el RD Legislativo 8/2015, de 30 de octubre, por el que se aprueba el texto refundido de la Ley General de la Seguridad Social exige, entre otros requisitos, un plazo de cinco años para tener derecho a una pensión de viudedad ${ }^{122}$.

En cambio, el art. 16.1.b) de la Ley 29/1994, de 24 de noviembre, de Arrendamiento Urbanos, establece un plazo de dos años de convivencia previa al fallecimiento de la pareja para tener derecho a la subrogación en el contrato de arrendamiento urbano, si bien el legislador no establece plazo alguno si "hubieran tenido descendencia en común, en cuyo caso bastará la mera convivencia".

\section{d) Cumplimiento voluntario de los deberes del matrimonio}

El CC regula en los artículos 66 a $71^{123}$ los deberes que han de asumir los cónyuges al contraer matrimonio. Dado que en la pareja de hecho no resulta aplicable analógicamente el régimen establecido en el estatuto matrimonial por la inexistencia del vínculo, que es el elemento generador de tales deberes, resulta obvio que tales obligaciones derivadas de los artículos del CC mencionados no son exigibles en el ámbito de las uniones de hecho

Sin embargo, la mayoría de las parejas que mantienen una relación de hecho estable cumplen voluntariamente estos deberes matrimoniales, es decir, se respetan, viven juntos, se ayudan y se guardan fidelidad, lo que demuestra la seriedad y solidez de la comunidad de vida que desarrollan ${ }^{124}$.

Al efecto cabe destacar que la convivencia de la pareja debe ser exclusiva, es decir, que no sería admisible que uno de los miembros de la pareja que convive mantenga una situación

\footnotetext{
${ }^{122}$ El ya citado art. 221.2 párrafo $1 .^{\circ}$ del RD Legislativo 8/2015 establece una serie de requisitos, como la acreditación de la convivencia estable y notoria, mantenida de manera ininterrumpida durante cinco años y acreditada mediante el correspondiente certificado del registro administrativo, para entender válidamente constituida una pareja de hecho. En torno a este artículo, tanto en su redacción anterior como en la actual, ha tenido ocasión de pronunciarse en repetidas ocasiones el TC.

${ }^{123} \mathrm{El}$ art. 66 del CC establece el principio de igualdad conyugal: "los cónyuges son iguales en derechos y deberes". Mientras que el art. 67 establece la obligación de respeto cualificado, la obligación de ayuda mutua y actuar siempre en interés de la familia: "Los cónyuges deben respetarse y ayudarse mutuamente y actuar en interés de la familia". En el art. 68 se detallan obligaciones propias de la convivencia marital: "Los cónyuges están obligados a vivir juntos, guardarse fidelidad y socorrerse mutuamente. Deberán, además, compartir las responsabilidades domésticas y el cuidado y atención de ascendientes y descendientes y otras personas dependientes a su cargo." Los arts. 69 y 70 están dedicados a la presunción de convivencia y fijación del domicilio, mientras que el 71 se dedica a señalar la inexistencia de representación entre los cónyuges por el hecho del matrimonio, de manera que la representación debe ser expresa. ${ }^{124}$ MESA MARRERO, C.: Op. cit., pág. 38.
} 
matrimonial, simultánea con otra persona, del mismo modo que tampoco cabe admitir la existencia de dos situaciones de convivencia more uxorio al mismo tiempo.

\section{E) COMPARATIVA ENTRE LOS REQUiSitos PARA CONSTITUIR PAREJA DE HECHO Y LOS}

\section{EXIGIDOS PARA LA INSTITUCIÓN MATRIMONIAL}

En esta primera aproximación, veremos que se producen los siguientes rasgos característicos propios del matrimonio para poder confrontarlas, posteriormente, con los requisitos constitutivos de las uniones de hecho. Así, el primero de los requisitos será la unión de dos personas, ya que el matrimonio puede ser homosexual o heterosexual, es decir, será matrimonio la unión de dos personas del mismo o distinto sexo.

El segundo de los requisitos sería el de la monogamia que, admitido el matrimonio entre personas del mismo sexo por la Ley 13/2005, de 1 de julio, por la que se modifica el CC en materia de derecho a contraer matrimonio, obviamente el tradicional requisito de la monogamia arroja para dicho supuesto que el matrimonio debe celebrarse entre dos personas, solo dos, del mismo o distinto sexo ${ }^{125}$, tal como señala Lasarte Álvarez.

Otro requisito será la comunidad de vida y existencia, aunque semejante característica resulte difícil de delimitar o explicar en sentido positivo, pues en definitiva dependerá del carácter y circunstancias de cada pareja, es evidente que resulta necesario subrayarlas, pues no cabe en nuestro Ordenamiento jurídico concebir el matrimonio como la atención de necesidades afectivas o carnales pasajeras o absolutamente momentáneas ${ }^{126}$.

De lo señalado se deriva, igualmente la nota de estabilidad o permanencia inherente a la unión matrimonial. Si bien, en algunos sistemas normativos, la estabilidad se configura como perpetuidad vitalicia, en cuanto su regulación se asienta en el principio de indisolubilidad. No es el caso de la legislación española contemporánea tras la promulgación de la Ley 30/1981 ${ }^{127}$.

El último de los requisitos es el de la solemnidad, y ello porque no cabe duda de que la prestación y manifestación del consentimiento matrimonial es un acto, además de libre y

\footnotetext{
${ }^{125}$ LaSARTe ÁlVAREZ, C.: Principios de Derecho Civil VI. Derecho de Familia. $18^{\mathrm{a}}$ ed., Marcial Pons, Madrid (2019), pág. 17.

${ }^{126}$ LASARTE ÁLVAREZ, C.: Ibid., pág. 18.

${ }^{127} \mathrm{La}$ indisolubilidad del matrimonio quedó derogada en España mediante la publicación de la Ley 30/1981, de 7 de julio, por la que se modifica la regulación del matrimonio en el CC y se determina el procedimiento a seguir en las causas de nulidad, separación y divorcio.
} 
voluntario, solemne, revestido de especiales formalidades que garantizan, precisamente, la concurrencia de todos los presupuestos requeridos legalmente por el Ordenamiento aplicable. De no cumplirse tales requisitos formales, la convivencia que reúna todos los demás requisitos o presupuestos señalados anteriormente deberá considerarse una unión de hecho ${ }^{128}$.

Del análisis realizado resultaría que se exigen los mismos requisitos para constituir matrimonio que para hacerlo como unión de hecho. Se venía señalando, tradicionalmente, que el requisito esencial diferenciador sería el de solemnidad, ya que la pareja de hecho se constituiría mediante un acto puramente privado, sin ningún tipo de formalidades que garantizasen el cumplimiento de los requisitos exigidos para constituirse como tal. Ello conllevaría, como consecuencia natural, la ausencia de reconocimiento social.

Sin embargo, la exigencia de los últimos años para el reconocimiento de ciertos derechos a los convivientes more uxorio, de constar inscritos en un registro público de parejas de hecho, y los trámites previos acreditativos del cumplimiento de los mismos, a la vez de la necesidad de realizar la manifestación de constituirse en unión de hecho ante un empleado público, dota a las uniones de hecho registradas de la característica de la solemnidad.

De manera especial, porque uno de los empleados públicos ante el que se puede manifestar esa libre voluntad de constituirse en pareja de hecho es el notario, el cual está, también, habilitado para que se manifieste ante él la libre voluntad de constituirse en matrimonio. Tal posibilidad practicable en ambos modos de constitución de convivencia en pareja hace que resulte difícil mantener que las uniones de hecho registradas incumplen el requisito de solemnidad, lo que conduce a la inexistencia de vínculo matrimonial. Analizaremos ambas situaciones más adelante, pero queremos dejar constancia desde estas primeras líneas de la paradoja de que una unión de hecho autorizada por un notario sea considerada como de inexistente vínculo por la ausencia de solemnidad, mientras que una unión matrimonial autorizada ante notario se considere que sí está dotada del citado vínculo matrimonial reconociendo el carácter formal y solemne de la escritura pública, y ello cuando los expedientes matrimonial y de unión de hecho para la inscripción registral son similares. Cabría preguntarse al respecto si la actuación notarial es de menor valor en un caso que en el otro.

${ }^{128}$ LASARTE ÁLVAREZ, C.: Ibid., págs. 18 y 19. 


\section{F) LA VISIÓN JURISPRUDENCIAL}

La visión de nuestra jurisprudencia sobre el fenómeno tiene un punto de especial importancia en la STS 611/2005, de 12 de septiembre, sobre la que han corrido ríos de tinta, y en la que el pleno de la Sala de lo Civil del Alto Tribunal fija su postura, que se ha ido manteniendo desde entonces en multitud de sentencias.

Dicha Sentencia, dictada poco después de la entrada en vigor de las leyes 13/2005, de 1 de julio $^{129}$ y $15 / 2005$, de 8 de julio ${ }^{130}$, las cuales habrían llevado a desparecer algunas de las notas que claramente diferenciaban al matrimonio y a las parejas de hecho: por un lado, la disolución del matrimonio ya no está sujeta a la concurrencia y prueba de unas determinadas causas legalmente establecidas, sino que se decretará judicialmente a petición de cualquiera de los cónyuges unilateralmente y sin necesidad de probar y alegar causa alguna, derivado de las modificaciones introducidas en los arts. 86 y 81 del CC, siendo además el plazo de vigencia del matrimonio establecido para poder instar la disolución judicial de solo tres meses; y por otro lado, el matrimonio, que anteriormente estaba vetado a las personas del mismo sexo, les está permitido y produce los mismos efectos jurídicos por la modificación efectuada en el art. 44, párrafo 2. ${ }^{\circ}$ del CC.

En consecuencia, con las modificaciones introducidas por ambas leyes, se ha producido un evidente acercamiento entre matrimonio y pareja de hecho de manera que, tras estas normas, coinciden en buena medida quienes pueden contraer matrimonio con quienes pueden constituir legalmente una pareja de hecho, siendo común en ambos casos la ruptura unilateral y sin causa, aunque en el caso del matrimonio se requiera la formalidad de una sentencia judicial ${ }^{131}$. Es en estas circunstancias en las que la mencionada Sentencia señala que «Hoy por hoy, con la existencia del matrimonio homosexual y del divorcio unilateral, se puede proclamar que la unión de hecho está formada por personas que no quieren, en absoluto, contraer matrimonio con sus consecuencias», posición recogida, posteriormente, en otras Sentencias del Supremo.

De manera que, para el TS, las únicas parejas de hecho son las formadas por aquellas personas que, careciendo de impedimento alguno para contraer matrimonio, es decir, pudiendo

\footnotetext{
${ }^{129}$ La Ley $13 / 2005$, de 1 de julio, por la que se modifica el CC en materia de derecho a contraer matrimonio.

${ }^{130}$ La Ley $15 / 2005$, de 8 de julio, por la que se modifica el CC en materia de separación y divorcio.

${ }^{131}$ GALVEZ CRIADO, A.: "El principio general del libre desarrollo de la personalidad y los pactos entre convivientes tras la STC 93/2013, de 23 de abril”, en RCDI n. ${ }^{\circ} 750$ (julio 2015), pág. 1809.
} 
optar entre casarse o no hacerlo, deciden no hacerlo. Y, tal como señalamos más arriba, ciertamente el grupo más importante de parejas que se conforman en la actualidady, desde luego, todas aquellas uniones de hecho registradas entrarían en el concepto delimitado por el TS.

En línea semejante se manifiesta el TC, en su Sentencia 93/2013, de 23 de abril, a la que nos referiremos más adelante por diversas razones, al disponer que "Bajo el concepto de unión de hecho se agrupa una diversidad de supuestos de parejas estables que, no obstante su heterogeneidad, comparten ciertas notas comunes que permiten conformar una noción general unitaria. En efecto, la unión de hecho puede caracterizarse, en principio, como una relación estable de convivencia more uxorio cuyo elemento definitorio común queda cifrado en la voluntad libremente configurada de permanecer al margen del Derecho en cuanto a las consecuencias jurídicas inherentes a la institución matrimonial a que se refiere el artículo 32 CE (...) Elemento esencial de la constitución de la pareja de hecho es, por tanto, su conformación extramuros de la institución matrimonial por decisión propia de sus integrantes, adoptada en ejercicio de su libertad personal, y que 'se vincula con sus convicciones y creencias más íntimas"”132.

Lo que conduce a que, en la interpretación jurisdiccional, si bien no se establece una definición del concepto de pareja de hecho, sí que se plasmarían una serie de características definitorias de la misma, al señalar como tales características propias de la unión de hecho aspectos como la convivencia, la estabilidad, la exclusividad y la falta de formalidades en la relación que, en la interpretación del citado TC, sería lo buscado por quienes optan por constituirse como pareja de hecho de manera voluntaria.

Tal interpretación es digna de ser compartida en los supuestos en que la unión de hecho, efectivamente, rehúye todo tipo de formalismo y, en consecuencia, queda configurada como una pareja puramente fáctica, sin buscar ningún tipo de reconocimiento jurídico y, en consecuencia, sin aspirar a ser titulares de ningún tipo de derecho derivado de la relación de convivencia elegida. Sin embargo, actualmente, y con la evolución social de la figura de las parejas de hecho, gran parte de estas relaciones de convivencia se inscriben en los Registros de relaciones paramatrimoniales existentes en todas las CCAA, con el evidente objetivo de que los miembros de la pareja sean considerados como titulares de los diversos tipos de derechos conferidos a estas uniones

\footnotetext{
${ }^{132}$ FJ 8 de la STC 93/2013, de 23 de abril. Dictada por el Pleno del Tribunal, ante el Recurso de inconstitucionalidad 5297-2000. Interpuesto por más de cincuenta diputados del grupo parlamentario popular del Congreso de los Diputados en relación con la Ley Foral 6/2000, de 3 de julio, para la igualdad jurídica de parejas estables.
} 
registradas, desde los ligados a la posible percepción de una pensión de viudedad, hasta los permisos laborales o derechos administrativos más diversos.

En suma, en las uniones de hecho registradas, no solo se aceptan determinadas formalidades para su constitución, lo que incluiría la realización del correspondiente expediente, al modo del expediente administrativo, sino que no resulta evidente que, con tales uniones, se pretenda «permanecer al margen del Derecho en cuanto a las consecuencias jurídicas inherentes a la institución matrimonial" ${ }^{133}$, como consta repetidamente acreditado con las peticiones de distintos derechos, esencialmente administrativos y laborales, derivados de la relación de convivencia. A modo de paradigma haremos mención a la múltiple jurisprudencia existente en reclamación de pensiones de viudedad derivadas de la convivencia more uxorio y que han derivado en la modificación legislativa reconociendo ese derecho en determinadas condiciones convivenciales.

\section{G) DE LA ELABORACIÓN DEL EXPEDIENTE ADMINISTRATIVO PARA ACCEDER A LA}

\section{INSCRIPCIÓN COMO UNIÓN DE HECHO}

\section{El expediente matrimonial}

El art. 56 del CC señala que “Quienes deseen contraer matrimonio acreditarán previamente en acta o expediente tramitado conforme a la legislación del Registro Civil, que reúnen los requisitos de capacidad o la inexistencia de impedimentos o su dispensa, de acuerdo con lo previsto en este Código", es decir, que con carácter previo a contraer matrimonio deberá tramitarse el correspondiente expediente.

Como quiera que la entrada en vigor de gran parte de la Ley 20/2011, de 21 de julio, del Registro Civil se dilata una y otra vez ${ }^{134}$, analizaremos brevemente, los trámites exigidos en este

\footnotetext{
${ }^{133}$ Como precisa el FJ 8. ${ }^{\circ}$, párrafo $2 .^{\circ}$, de la STC 93/2013, de 23 de abril, publicada en el BOE n. ${ }^{\circ} 123$, de 23 de mayo de2013.

${ }^{134}$ La Ley 20/2011, de 21 de julio, del Registro Civil, fue publicada en el BOE n. ${ }^{\circ} 175$ de 22 de julio de 2011, y en su disposición final incluía una vacatio legis de tres años, excepto algunas disposiciones adicionales y finales que entraban en vigor al día siguiente de su publicación; pese al largo período dado para su entrada en vigor, el RD-Ley 8/2014, de 4 de julio, de aprobación de medidas urgentes para el crecimiento, la competitividad y la eficiencia, prorrogó la entrada en vigor de la Ley hasta el día 15 de julio de 2015; posteriormente, mediante la disposición final cuarta de la Ley 15/2015, de 2 de julio, de la Jurisdicción voluntaria, se prorroga la entrada en vigor hasta el día 30 de junio de 2017; de nuevo, mediante la modificación dada por la disposición final 4.12 de la Ley 4/2017, de 28 de junio, de modificación de la Ley 15/2015, de 2 de julio, de la Jurisdicción voluntaria, se fija la entrada en vigor de la Ley del Registro Civil para el día 30 de julio de 2018; posteriormente, mediante la disposición final primera de la Ley 5/2018, de 11 de junio, de modificación de la Ley 1/2000, de 7 de enero, de Enjuiciamiento Civil, en relación a la ocupación ilegal de viviendas, se fijó, como nueva fecha de entrada en vigor el día 30 de junio de 2020. A la fecha de escribir estas líneas,
} 
momento para la tramitación del expediente matrimonial y los que se exigirán a partir de la entrada en vigor de la nueva ley del registro civil.

\section{- $\quad$ Tramitación hasta el 30 de abril de $2021^{135}$}

Hasta la mencionada fecha, y de acuerdo al art. 238 del Reglamento del Registro Civil, el funcionario competente para instruir el expediente matrimonial es el Juez encargado del Registro Civil, o el encargado del Registro Civil consular, correspondiente al domicilio de cualquiera de los contrayentes. En cualquier caso, y en relación con el domicilio, es necesario que alguno de los contrayentes tenga su domicilio en España, en la demarcación territorial del instructor del expediente, pues si ninguno de los contrayentes tiene su domicilio en España, nuestro país carece, en principio, de competencia para la instrucción del expediente matrimonial, por lo que el matrimonio no podría celebrarse en España ${ }^{136}$

En cuanto a la forma de tramitación del mencionado expediente, se iniciará mediante la presentación de un escrito ante el Registro Civil, el cual debe contener los siguientes extremos contemplados en el art. 240 del reglamento del Registro Civil:

El expediente se inicia con la presentación de un escrito, que contendrá:

1. ${ }^{\circ}$ Las menciones de identidad, incluso la profesión, de los contrayentes.

2. ${ }^{\circ}$ En su caso, el nombre y apellidos del cónyuge o cónyuges anteriores y fecha de la disolución del matrimonio.

3. ${ }^{\circ}$ La declaración de que no existe impedimento para el matrimonio.

4. ${ }^{\circ}$ El Juez o funcionario elegido, en su caso, para la celebración.

5. ${ }^{\circ}$ Pueblos en que hubiesen residido o estado domiciliados en los dos últimos años.

Este escrito habrá de ir suscrito por los contrayentes, pudiendo ser sustituido por un testigo el contrayente que no pueda hacerlo. Acompañando a este escrito se aportarán las pruebas

no parece probable que esta sea la fecha definitiva de entrada en vigor de la Ley, la cual parece destinada a quedar obsoleta antes de su entrada en vigor.

${ }^{135}$ En el momento de escribir estas líneas, la última prórroga publicada de la vacatio legis de la Ley 20/2011, de 21 de julio, del Registro Civil, es la dispuesta por la disposición final segunda del RD Ley 16/2020, de 28 de abril, de medidas procesales y organizativas para hacer frente al COVID-19 en el ámbito de la Administración de Justicia, que fija la nueva fecha de entrada en vigor el día 30 de abril de 2021.

${ }^{136}$ Así se establece en la Instrucción de la DGRN (actualmente DGSJ y FP) de 29 de julio de 2005, sobre matrimonios civiles entre personas del mismo sexo. En realidad, las exigencias establecidas serían:

$1^{\circ}$ Que al menos uno de los contrayentes ha de ser nacional español;

$2^{\circ} \mathrm{Al}$ menos uno de los contrayentes ha de estar domiciliado en la demarcación consular correspondiente

$3^{\circ} \mathrm{El}$ Estado receptor del Cónsul no debe oponerse a que este celebre matrimonios en su territorio. 
complementarias del mismo, como son la del nacimiento y, en su caso, la prueba de la disolución de los vínculos anteriores, la emancipación o la dispensa.

Tras la subsanación de los defectos que pudieran apreciarse, procederá la ratificación de ambos contrayentes del escrito inicial presentado. Esta ratificación será siempre necesaria sin perjuicio de que, de no estar domiciliado en la demarcación del registro instructor, pueda realizarse por comparecencia ante otro Registro Civil español o por medio de poder especial ${ }^{137}$.

A ello se añade una especial publicidad, mediante la publicación de edictos, a fin de que, quien tuviere noticia de ello, denuncie de la existencia de impedimentos; y en localidades con mayor población se establece un trámite sustitutorio de audiencia "al menos, de un pariente, amigo a allegado de uno u otro contrayente, elegido por el instructor y que deberá manifestar, so pena de falsedad, su convencimiento de que el matrimonio proyectado no incurre en prohibición legal alguna”, según precisa el art. 244 del Reglamento del Registro Civil.

En la tramitación del expediente previo a la celebración del matrimonio civil, existe un trámite esencial del que no debe prescindirse ni cumplirse formulariamente, como es la audiencia personal, reservada y por separado de cada contrayente, que debe efectuar el instructor, asistido del Letrado de la Administración de Justicia, para cerciorarse de la inexistencia de impedimento de ligamen o de cualquier otro obstáculo legal para su celebración ${ }^{138}$.

Esta audiencia debe servir para que el instructor se asegure del verdadero propósito de los comparecientes y de la existencia en ambos de verdadero consentimiento matrimonial ${ }^{139}$. El expediente finaliza mediante Auto que aprueba o deniega la celebración del matrimonio.

Como hemos señalado, de no haber nuevas prórrogas, el 30 de abril de 2021 entrará en vigor la nueva redacción del art. 51 del CC, que amplía a los notarios la competencia para la tramitación del expediente matrimonial ${ }^{140}$. Con la entrada en vigor de la nueva Ley del Registro

\footnotetext{
${ }^{137}$ FAUS, M. y ARIÑO, B.: "Práctico Derecho de Familia", en Vlex (noviembre 2019). [Consulta online https://2019.vlex.com/\#vid/589291118].

${ }^{138}$ FAUS y ARIÑO: Ibid.

${ }^{139}$ La Resolución de la DGRN (actualmente DGSJ y FP) de 31 de mayo de 2006 reconocía la importancia de este trámite ya que, a través de él, puede descubrirse la posible existencia de propósitos fraudulentos, es decir, los famosos matrimonios de conveniencia, para cuyo descubrimiento resulta esencial esta audiencia reservada y por separado con cada contrayente, revelándose durante la misma si el verdadero fin es contraer matrimonio o, por el contrario, lo que se pretende es aprovechar la apariencia matrimonial con fines distintos a los propios de la institución matrimonial.

${ }^{140}$ El párrafo $4 .^{\circ}$ del apartado XI del Preámbulo de la Ley 15/2015, de 2 de julio, de Jurisdicción Voluntaria, dice: "Muy importante es también la nueva regulación que del acta o expediente previo a la celebración del matrimonio recoge el CC, encomendando su tramitación al Secretario judicial, notario, al Encargado del Registro Civil o al Cónsul
} 
Civil, se habilita a los notarios para la tramitación del expediente matrimonial, mientras que cuando sea tramitado por el Letrado de la Administración de Justicia se indica que éstos se encargan de la instrucción del expediente. En la nueva tramitación el expediente finalizará con una resolución del secretario del ayuntamiento en la que se autoriza o deniega la celebración del matrimonio, si bien la denegación deberá ser motivada, expresando la falta de capacidad o el impedimento en el que se fundamenta la denegación. Frente a esta denegación cabe recurso administrativo ante el encargado del Registro Civil, ante cuya resolución se somete al régimen de recursos ante la Dirección General de Seguridad Jurídica y Fe Pública.

\section{- $\quad$ Tramitación posterior al 30 de abril de 2021}

A partir del 30 de abril de 2021, el encargado de tramitar el expediente matrimonial realizará los siguientes trámites:

- Han de ser recibido ambos contrayentes reservadamente y por separado para el instructor cerciorarse de su capacidad y de la inexistencia de cualquier impedimento.

- Podrán solicitar los informes y practicar las diligencias pertinentes, sean o no propuestas por los requirentes, para acreditar el estado, capacidad o domicilio de los contrayentes o cualesquiera otros extremos necesarios para apreciar la validez de su consentimiento y la veracidad del matrimonio.

- Cuando sea necesario, podrá recabar de las administraciones o entidades de iniciativa social de promoción y protección de los derechos de las personas con discapacidad, la provisión de apoyos humanos, técnicos y materiales que faciliten la emisión, interpretación y recepción del consentimiento del o los contrayentes. Solo en el caso excepcional de que alguno de los contrayentes presentare una condición de salud que, de modo evidente, categórico y sustancial, pueda impedirle prestar el consentimiento matrimonial pese a las medidas de apoyo, se recabará dictamen médico sobre su aptitud para prestar el consentimiento.

o funcionario diplomático o consular Encargado del Registro Civil en el extranjero, al tiempo que la celebración del mismo podrá tener lugar ante el Secretario judicial, notario, funcionario diplomático o consular, Juez de Paz y Alcalde o concejal en el que este delegue. Todo ello se enmarca igualmente en el proceso de diversificación de los elementos personales ante los que se lleva a efecto la autorización de determinados actos, que permite la concentración de la Administración de Justicia a la labor fundamental que la Constitución les atribuye de juzgar y ejecutar lo juzgado". 
- De la realización de todas estas actuaciones se dejará constancia en el acta (tramitación por el notario) o expediente (actuación de los otros funcionarios), archivándose junto con los documentos previos a la inscripción de matrimonio. ${ }^{141}$

Finalizado el expediente y aprobada la celebración del matrimonio, este deberá celebrarse en el plazo de un año, pues en otro caso serían necesarias nuevas diligencias y publicaciones. La celebración se realizará ante un Letrado de la Administración de Justicia, Juez de Paz, Alcalde o Concejal en quien este delegue a elección de los contrayentes. Aunque si el expediente hubiese sido tramitado ante notario, el matrimonio se celebrará, a elección de los contrayentes ante ese mismo u otro notario, el Juez de Paz, Alcalde o Concejal en quién este delegue. La diferencia reside en que, si se tramita ante el Letrado de la Administración de Justicia, la celebración será ante este o cualquiera de las otras autoridades señaladas en el CC, pero no el notario, mientras que, si se tramita por el notario, la celebración será ante este u otro notario o cualquiera de las otras autoridades citadas en el Código, pero no ante el letrado de la Administración de Justicia.

La celebración de la ceremonia del matrimonio se hace constar en el oportuno acta o escritura pública, de la que se expide copia para cada uno de los contrayentes, de la citada acta se remite copia al encargado del Registro Civil quien, previa calificación favorable, procede a la inscripción del matrimonio.

\section{De la tramitación del expediente de unión de hecho en las distintas CCAA}

Cumpliendo los requisitos para constituir una pareja de hecho, es posible la inscripción como tal en los registros de parejas de hecho de las distintas CCAA, tal como señalamos más arriba. Para ello será preciso formular la correspondiente solicitud, para lo cual las distintas Comunidades ofrecen mayores o menores facilidades, pero en general se exige la presentación personal de la solicitud suscrita por ambos solicitantes.

La documentación que deberán aportar los solicitantes de la inscripción de la unión de hecho son los acreditativos de cumplir con los requisitos, es decir: que son mayores de edad o menores emancipados; que no están casados ni unidos mediante pareja de hecho vigente; la inexistencia de parentesco en línea recta o colateral, en el grado determinado por la comunidad

\footnotetext{
${ }^{141}$ FAUS y ARIÑO: Ibid.
} 
autónoma correspondiente; que no están incapacitados judicialmente para constituir la unión de hecho.

Como consecuencia de ello, las distintas CCAA exigen la presentación de los documentos acreditativos que corresponden, sin que existan grandes diferencias entre comunidades como veremos.

\section{Andalucía:}

La Ley 5/2002, de 16 de diciembre, de Parejas de Hecho de Andalucía, establece los requisitos para constituir una pareja de hecho, los cuales son desarrollados por el Decreto 35/2005, de 15 de febrero, por el que se constituye y regula el Registro de Parejas de Hecho, y en relación con la documentación acreditativa del cumplimiento de los requisitos exigidos además de la solicitud suscrita por ambos miembros de la pareja, requiere la presentación de la documentación siguiente ${ }^{142}$ :

a) Documentación acreditativa de la identidad de los solicitantes

b) Certificación del estado civil de cada solicitante

c) Certificación acreditativa de la emancipación, si es el caso

d) Certificado de empadronamiento acreditativa de la residencia, de al menos uno de los solicitantes, en la Comunidad Autónoma de Andalucía

e) Declaración responsable de que no existe parentesco en línea recta, ni colateral por consanguinidad en segundo grado

f) Declaración responsable de no estar incapacitado para prestar el consentimiento a fin de constituir una pareja de hecho

g) Certificación negativa de inscripción en el Registro de Parejas de Hecho, así como declaración responsable de que la pareja de hecho, o alguno de sus miembros, no está inscrita en otro Registro como tal o, en su caso, certificación del Registro correspondiente de la cancelación o baja de dicha inscripción

h) Declaración responsable de no formar pareja estable no casada con otra persona

\footnotetext{
${ }^{142}$ El art. 18.1 del Decreto 35/2005, de 15 de febrero, por el que se constituye y regula en Registro de Parejas de Hecho de la Comunidad Autónoma de Andalucía, establece la exigencia de la presentación de la solicitud básica suscrita por ambos miembros de la pareja, que deberá ser presentada bien en las delegaciones provinciales de la Consejería para la Igualdad y Bienestar Social o en el Ayuntamiento de la residencia habitual de los solicitantes.
} 
i) En su caso, escritura pública o medio de prueba acreditativo de la voluntad de constituir una pareja de hecho.

La declaración de voluntad de constituir pareja de hecho manifestando la decisión de mantener una relación de convivencia estable, de conformidad a lo dispuesto en la legislación andaluza, habrá de formalizarse, bien en escritura pública, o bien por comparecencia personal de los interesados ante el encargado del Registro, Alcalde, Concejal o funcionario en quien se delegue. Tal manifestación se realizará en un acto público, salvo petición expresa de los interesados de que se realice de manera reservada ${ }^{143}$. Es decir, habrá de cumplirse con un expediente de carácter administrativo y realizar los convivientes una manifestación de voluntad.

En el apartado 2. ${ }^{\circ}$ del artículo 5 de la ley se recoge que la manifestación de voluntad se formulará ante funcionario público y en un acto que, en general, será igualmente público. Ambos requisitos evidente formales, y que dotan de solemnidad a la unión de hecho registrada en esta comunidad autónoma. Esta visión queda reforzada con lo señalado en el apartado $3 .^{\circ}$ del mismo artículo en el que se dispone que tal manifestación de voluntad puede realizarse mediante escritura pública, es decir, ante notario.

Consideramos especialmente ilustrativa la posibilidad de que una de las formas de acreditación de la manifestación de voluntad de constituirse en pareja de hecho sea la escritura pública ante notario, ya que ante este mismo empleado público se puede formalizar el consentimiento matrimonial, aceptando la vigente legislación en este caso del matrimonio que se cumple con el requisito de solemnidad con la manifestación de voluntad ante notario. La cuestión es ¿por qué entonces se entiende que se incumple con el requisito de solemnidad con una manifestación de voluntad similar formulada ante el mismo empleado público en el caso de las uniones de hecho?

\footnotetext{
${ }^{143} \mathrm{El}$ art, 5 de la Ley 5/2002, de 16 de diciembre, de Parejas de Hecho de Andalucía establece los requisitos que debe cumplir y acreditar una pareja de hecho para tener acceso al Registro de Uniones de Hecho de Andalucía.
} 


\section{Aragón}

El Código del Derecho Foral de Aragón exige la convivencia marital, previa al reconocimiento, de al menos dos años ${ }^{144}$; o bien, la formalización de la misma en escritura pública, manifestando la voluntad de constituir la pareja de hecho ${ }^{145}$.

En cuanto a los requisitos para que proceda la inscripción de una pareja estable en Aragón los establece el Decreto 203/1999, de 2 de noviembre, del Gobierno de Aragón, por el que se regula la creación y régimen de funcionamiento del Registro Administrativo de Parejas Estables no casadas que establece como imprescindible para practicar la inscripción la correspondiente solicitud y documentación acreditativa del cumplimiento de los requisitos. Para ello se exige la presentación de la correspondiente solicitud, conjuntamente por ambos miembros de la pareja, acompañada de la siguiente documentación ${ }^{146}$ :

a) Documentación acreditativa de la identidad de los solicitantes.

b) Certificación del estado civil de los solicitantes.

c) Certificación del padrón municipal acreditativa de la vecindad administrativa de los solicitantes en algún municipio de la Comunidad Autónoma de Aragón.

d) Declaración responsable de no ser miembro de otra pareja estable no casada.

e) Declaración de no tener relación de parentesco por consanguinidad o adopción en línea recta, o en línea colateral en segundo grado.

f) Escritura pública relativa a la constitución de la pareja estable no casada o cualquier otro medio de prueba acreditativo de la convivencia.

En el caso aragonés se da prioridad a la constitución mediante escritura pública, convirtiendo al notario en la clave de bóveda del sistema de reconocimiento de las uniones de hecho. Y ello, porque la única vía que ofrece para constituir la unión de hecho desde el propio momento de la constitución de la misma es, precisamente, la escritura pública.

\footnotetext{
${ }^{144}$ Debe tenerse en cuenta que la STC 93/2013, de 23 de abril, declara inconstitucional un precepto similar de la Ley Foral 6/2000, de 3 de julio, de la Comunidad Foral de Navarra.

${ }^{145}$ El art. 305 del Decreto Legislativo 1/2011, de 22 de marzo, por el que se aprueba el Código del Derecho Foral aragonés establece que:

1. Se considera que hay pareja estable no casada cuando se haya producido la convivencia marital durante un período ininterrumpido de dos años, como mínimo, o se haya manifestado la voluntad de constituirla mediante escritura pública.

2. Podrá acreditarse la existencia de pareja estable no casada y el transcurso de los dos años de referencia, si no existiera escritura pública, mediante cualquiera de los medios de prueba admitidos en derecho, especialmente, a través de acta de notoriedad o documento judicial que acredite la convivencia.

${ }^{146}$ El art. 9 del Decreto 203/1999, de 2 de noviembre, por el que se regula la creación y régimen de funcionamiento del Registro Administrativo de Parejas Estables No Casadas de la Comunidad Autónoma de Aragón, regula la documentación que debe acompañar a la solicitud de inscripción en el Registro.
} 
Pero, incluso, cuando se trata del reconocimiento de parejas de hecho por la vía de la convivencia marital durante dos años, si bien admite cualquier medio de prueba válido en Derecho, precisa como instrumento privilegiado para acreditar la convivencia, el acta notarial, con una nueva remisión a la acreditación mediante la intervención notarial, poniendo este modo de prueba al mismo nivel de la documentación judicial acreditativa de la convivencia.

De nuevo, nos encontramos con que la formalización de la pareja de hecho mediante la manifestación de voluntad ante el notario se establece como modo de acceso al Registro de Uniones de Hecho y, en el caso, aragonés, se añade incluso como medio de prueba especialmente hábil para la prueba de la convivencia marital de la pareja de hecho, durante el plazo exigido de dos años previos, el acta de notoriedad notarial. Dotando de nuevo a estos empleados públicos de la capacidad para dar fe de la voluntad de constituirse en pareja de hecho. Una vez más, empleado público coincidente con una de las autoridades o funcionarios ante los que cabe manifestar la voluntad de contraer matrimonio. En el caso aragonés se añade, como prueba especialmente privilegiada para acreditar la convivencia marital, la documentación judicial acreditativa de tal extremo; de nuevo, la intervención de las mismas autoridades o funcionarios que pueden autorizar la celebración matrimonial.

\section{Asturias}

La Ley 4/2002, de 23 de mayo, de Parejas Estables del Principado de Asturias, resulta de aplicación a las parejas estables cuyos dos miembros estén empadronados en el mismo domicilio y en cualquiera de los Concejos de Asturias. En cuanto a los requisitos que exige la legislación asturiana son:

a) Convivencia mínima e ininterrumpida de un año ${ }^{147}$, salvo el supuesto de que exista descendencia común, en cuyo caso bastará con la mera convivencia.

b) O Escritura pública.

c) O la inscripción en el Registro de Parejas de Hecho de Asturias.

La Norma asturiana admite, igualmente, cualquier otro medio de prueba admitido en Derecho. La legislación asturiana contempla la posibilidad de que los convivientes regulen sus relaciones personales y patrimoniales en uso de la libertad de pacto, lo cual podrán formalizar tanto en documento público como privado, estableciendo los derechos y deberes mutuos, pudiendo

\footnotetext{
${ }^{147} \mathrm{Al}$ igual que ocurría en el caso de Aragón, un precepto similar fue declarado inconstitucional por la STC n. ${ }^{\circ}$ 93/2013, del Pleno del TC sobre la Ley Foral Navarra de parejas estables.
} 
incluir compensaciones económicas para el supuesto de ruptura de la relación de convivencia, naturalmente, todo ello con respeto a la legislación vigente que resulte de aplicación.

En cuanto a la documentación acreditativa del cumplimiento de los requisitos, en Asturias viene regulada en la Resolución de 14 de noviembre de 1994, de la Consejería de Interior y Administraciones Públicas ${ }^{148}$, por la que se aprueban las normas reguladoras del funcionamiento del Registro de Uniones de Hecho del Principado de Asturias, en la que se exige la presentación de la correspondiente solicitud al encargado del registro, mediante comparecencia personal de los solicitantes ante él, que deberá comprobar la personalidad de los solicitantes. A esta solicitud deberán acompañar la siguiente documentación:

a) Documentación acreditativa de la identidad de los solicitantes.

b) Certificación acreditativa de la emancipación, si es el caso.

c) Declaración responsable de no tener relación de parentesco por consanguinidad o adopción en línea recta, o en línea colateral en segundo grado.

d) Declaración responsable de no estar incapacitado para prestar el consentimiento a fin de constituir una pareja de hecho.

e) Certificado del estado civil de los solicitantes.

f) Certificación del padrón municipal acreditativa de que los solicitantes tienen la condición de residentes en algún concejo del Principado de Asturias.

Como en casos anteriores, nos encontramos con que el notario es funcionario habilitado para acreditar la existencia del consentimiento prestado para constituir unión de hecho.

\section{Cantabria}

Los requisitos para constituir pareja de hecho en Cantabria vienen determinados por el art. 4 de la Ley 1/2005, de 16 de mayo, de Parejas de Hecho de la Comunidad Autónoma de Cantabria, en la que se exige que:

a) Que hubieran convivido al menos un año de forma ininterrumpida.

b) Que tengan descendencia común, natural o adoptiva.

c) Que hayan expresado su voluntad de constituir una pareja de hecho en documento público.

\footnotetext{
${ }^{148}$ La Resolución de 14 de noviembre de 1994, de la Consejería de Interior y Administraciones Públicas, por la que se aprueban las normas reguladoras del funcionamiento del Registro de Uniones de Hecho del Principado de Asturias, fue publicada en el Boletín Oficial del Principado de Asturias de 17 de noviembre de 1994.
} 
La documentación acreditativa del cumplimiento de los requisitos para la inscripción de una pareja de hecho se establece en el Decreto 55/2006, de 18 de mayo, por el que se regula la estructura y funcionamiento del Registro de Parejas de Hecho de la Comunidad Autónoma de Cantabria, el cual ha sido modificado por el Decreto 84/2008, de 28 de agosto y el Decreto 44/2016, de 4 de agosto, señalando que será preciso acompañar a la solicitud básica, suscrita por ambos, la siguiente documentación ${ }^{149}$ :

a) Documentación acreditativa de la identidad de los solicitantes.

b) Certificado de empadronamiento de ambos miembros de la pareja, expedido por el Ayuntamiento del municipio de Cantabria correspondiente.

c) Certificado del Registro Civil sobre el estado civil de cada uno de los miembros de la pareja.

d) Declaración responsable de ambos miembros de la pareja haciendo constar los siguientes extremos: convivencia de forma estable, libre, pública y notoria en una relación afectiva análoga a la conyugal; no tener constituida pareja de hecho o de derecho con otra persona; no ser parientes en línea recta por consanguinidad o adopción, o en línea colateral hasta el segundo grado y de no haber sido incapacitados judicialmente para prestar consentimiento válido.

e) Certificado acreditativo de la emancipación, en el caso de menores.

f) Prueba de la estabilidad de la pareja por haber convivido en el mismo domicilio al menos un año de forma ininterrumpida se acreditará mediante alguno de los siguientes medios:

1. Certificados municipales de empadronamiento de los miembros de la pareja.

2. Documento público autorizado con una antelación mínima de un año, con la manifestación de voluntad de la pareja de constituir pareja de hecho.

3. Certificación de un registro de parejas de hecho de otra comunidad autónoma en el que conste la inscripción básica y la cancelación, con sus fechas respectivas.

\footnotetext{
${ }^{149}$ El art. 18.1 del Decreto 55/2006, de 18 de mayo, por el que se regula la estructura y funcionamiento del registro de parejas de hecho de la Comunidad Autónoma de Cantabria, establece los documentos que deben acompañar la solicitud básica de inscripción.
} 
4. Certificado de inscripción de la pareja en un registro similar de una entidad local de Cantabria.

5. Cualquier otro medio de prueba admisible en Derecho, no siendo admisible la mera declaración de los miembros de la pareja.

a) La estabilidad de la pareja por tener descendencia común, natural o adoptiva, podrá acreditarse mediante Libro de Familia, en el que conste la existencia de hijos comunes, o bien mediante el certificado de nacimiento del descendiente común.

b) En el caso de los incapacitados, sentencia de incapacitación que les considere con capacidad para contraer matrimonio.

c) Declaración responsable de ambos miembros de la pareja de no haber inscrito la pareja de hecho en otro registro de parejas de hecho autonómico.

Como en el resto de las CCAA la declaración de voluntad de constituir una pareja de hecho manifestada en documento público, ante notario, se convierte en una de las vías para el reconocimiento de la constitución de la pareja de hecho.

\section{Castilla-La Mancha}

En Castilla-La Mancha no existe ninguna ley reguladora de las parejas de hecho; sin embargo, sí que se ha creado y regulado el Registro autonómico de parejas de hecho mediante el Decreto $124 / 2000$, de 11 de julio ${ }^{150}$, por el que se regula la creación y régimen de funcionamiento del Registro de Parejas de Hecho de la Comunidad Autónoma de Castilla-La Mancha, el cual ha sido modificado por el Decreto 43/2018, de 19 de junio ${ }^{151}$.

No obstante, el Decreto regulador del Registro de Parejas de Hecho de Castilla-La Mancha ya había sido modificado anteriormente por el Decreto 139/2012, de 25 de octubre, en aquella ocasión para exigir a los solicitantes de la inscripción que acreditasen un período de convivencia y empadronamiento en algún municipio de la Comunidad Autónoma durante, al menos, doce meses antes de la solicitud de inscripción como unión de hecho.

\footnotetext{
${ }^{150}$ El Decreto 124/2000, de 11 de julio, por el que se regula la creación y régimen de funcionamiento del Registro de Parejas de Hecho de la Comunidad Autónoma de Castilla la Mancha, fue publicado en el Diario Oficial de Castilla la Mancha de 14 de julio del 2000.

${ }^{151}$ El Decreto 43/2018, de 19 de junio, por el que se modifica el Decreto 124/2000, de 11 de julio, por el que se regula la creación y régimen de funcionamiento del Registro de Parejas de Hecho de Hecho de la Comunidad Autónoma de Castilla la Mancha, fue publicado en el Diario Oficial de Castilla la Mancha de 26 de junio de 2018.
} 
Precisamente la supresión de esta exigencia de un período previo de convivencia para la inscripción de la pareja de hecho es una de las variaciones introducidas en la última modificación de 2018. Y ello, porque la jurisprudencia del TC ha declarado que tal exigencia, redactada de manera imperativa, no se adecúa al Ordenamiento constitucional, dado que el modelo acorde con las características de las uniones de hecho es el régimen dispositivo.

El artículo 3 del mencionado Decreto establece los requisitos que deben concurrir en los miembros de la pareja para constituir una unión de hecho, fijando como el primero de ellos la manifestación de voluntad de constituirse en pareja de hecho, para lo cual se establece que podrá formalizarse de cualquiera de las formas siguientes:

$1^{\circ}$. Comparecencia personal y conjunta de ambos miembros de la pareja ante un funcionario del Registro de Parejas de Hecho o de alguna de las Oficinas de Información y Registro de la Junta de Comunidades de Castilla-La Mancha. Dicho funcionario responsable levantará acta de la comparecencia que quedará incorporada al expediente, previa acreditación de las respectivas identidades mediante la exhibición del documento nacional de identidad o, en su defecto, pasaporte o permiso de conducir, si se trata de ciudadanos españoles, y del pasaporte o, en su defecto, cualquier otro documento que los identifique, si se trata de ciudadanos extranjeros.

$2^{\circ}$. Escritura pública, acta de notoriedad o documento privado con firmas legalizadas notarialmente.

En suma, una manifestación de voluntad manifestada ante empleado público, ya sea el encargado del Registro de Parejas de Hecho o, una vez más, el notario de quien se predica su condición de funcionario habilitado para dar fe pública de la constitución de la unión de hecho, a efectos de Registro.

A la citada manifestación de voluntad se añade la necesidad de presentar documentación acreditativa de los siguientes extremos ${ }^{152}$ :

a) Certificado de emancipación, en el caso de los menores de edad.

b) Declaración responsable de no tener relación de parentesco por consanguinidad o adopción en línea recta, o en línea colateral en segundo grado.

\footnotetext{
${ }^{152} \mathrm{El}$ art. 3 del Decreto 124/2000, de 11 de julio, por el que se regula la creación y régimen de funcionamiento del Registro de Parejas de Hecho de Castilla-La Mancha establece los requisitos que deben probarse documentalmente.
} 
c) Certificado de estado civil y/o Declaración responsable de no ser miembro de otra pareja estable no casada

d) Declaración responsable de no estar incapacitado para prestar el consentimiento a fin de constituir una pareja de hecho

e) Declaración responsable de ambos miembros de la pareja de no haber inscrito la pareja de hecho en otro registro de parejas de hecho autonómico.

f) Certificación del padrón municipal acreditativa de que los solicitantes tienen la condición de residentes en algún municipio de la Comunidad Autónoma de CastillaLa Mancha.

En la comunidad castellano-manchega se establece la necesidad de que la documentación que se aporte haya sido expedida en los tres meses anteriores a la solicitud de inscripción en el Registro.

\section{Castilla y León}

En el caso castellanoleonés tampoco existe ley alguna reguladora de las parejas de hecho; sin embargo, existe el Registro de Parejas de Hecho creado por el Decreto 117/2002, de 24 de octubre $^{153}$, por el que se crea el Registro de Parejas de Hecho de Castilla y León y se regula su funcionamiento. En el citado decreto se establecen los requisitos que debe cumplir la pareja para poder acceder al mencionado Registro.

Así es precisa la presentación de la correspondiente solicitud de los miembros de la unión de hecho, con la acreditación del cumplimiento de los requisitos exigidos para constituir pareja de hecho ${ }^{154}$. La documentación exigida, actualmente, por esta comunidad autónoma es la siguiente:

a) Documentación acreditativa de la identidad y residencia, en el caso de extranjeros no comunitarios se exige pasaporte en vigor.

\footnotetext{
${ }^{153}$ El Decreto 117/2002, de 24 e octubre, por el que se crea el Registro de Uniones de Hecho de Castilla y León y se regula su funcionamiento, fue publicado en el Boletín Oficial de Castilla y León n. ${ }^{\circ}$ 212, de 31 de octubre de 2002.

${ }^{154} \mathrm{El}$ art. 3 del Decreto $117 / 2002$, de 24 de octubre, de Castilla y León exige el cumplimiento de los siguientes requisitos:

1. Ser mayores de edad o emancipados.

2. No tener relación de parentesco en línea recta por consanguinidad o adopción ni colateral hasta el segundo grado.

3. No estar ligados por vínculo matrimonial.

4. No formar unión de hecho con otra persona.

5. No estar incapacitados judicialmente.
} 
b) Documentación acreditativa del estado civil en el caso de no tener la nacionalidad española. Si la nacionalidad es la española, si el estado civil es el divorciado/a documentación acreditativa de este extremo.

c) Copia del certificado acreditativo de la inscripción en otro Registro de Parejas de Hecho, si es el caso.

d) Escritura pública de constitución de la pareja de hecho, cuando este haya sido el modo de constitución.

e) Documentación acreditativa de la convivencia continuada durante seis meses (siempre que la misma no se deduzca de su empadronamiento en el mismo domicilio durante seis meses o del certificado de inscripción en otro registro o de la Escritura de constitución de la unión de hecho).

f) Copia del libro de familia para acreditar la existencia de hijos comunes.

En el caso de existir hijos comunes, no se exige período previo de convivencia. En cuanto a la acreditación de la convivencia, además de los medios de prueba señalados, en esta comunidad autónoma se admiten otros medios probatorios como: contrato de alquiler de una casa a nombre de las dos personas que deseen registrarse como pareja de hecho; recibos de la casa a nombre de los dos; cuentas o libretas de ahorro, etc.

También en el caso de Castilla y León la escritura pública ante notario es un medio para la constitución de la pareja de hecho.

\section{Cataluña}

En Cataluña se dedica el capítulo IV del Título III, Libro segundo del CC catalán, aprobado por la Ley 25/2010, de 29 de julio ${ }^{155}$, a la regulación de la convivencia estable en pareja, considerando que existe pareja estable en cualquiera de los siguientes casos:

a) Si la convivencia dura más de dos años ininterrumpidos.

b) Si durante la convivencia, tienen un hijo común.

c) Si formalizan la relación en escritura pública.

\footnotetext{
${ }^{155}$ La Ley 25/2010, de 29 de julio, del Libro segundo del CC de Cataluña, relativo a la persona y la familia, fue publicado el Diari Oficial de la Generalitat de Catalunya n. ${ }^{\circ}$ 5686, de 5 de agosto de 2010, y en el BOE n. ${ }^{\circ} 203$ de 21 de agosto de 2010.
} 
Una vez más nos encontramos con que es posible constituir la pareja de hecho mediante la formalización en escritura pública, siendo así el notario funcionario habilitado para acreditar que se ha otorgado el consentimiento válido para constituir una pareja estable.

Mediante el Decreto Ley 3/2015, de 6 de octubre ${ }^{156}$, se modificó la mencionada Ley para introducir la creación del Registro de Parejas Estables, siendo desarrollado posteriormente por la Orden JUS/44/2017, de 28 de marzo ${ }^{157}$, por la que se aprueba el Reglamento del Registro de Parejas Estables de Cataluña. Éste señala que, para inscribir una pareja, los convivientes deben presentar una solicitud de inscripción y adjuntar la documentación que acredita la existencia de la pareja estable, así como una declaración responsable, efectuada por los dos convivientes, en la que manifiesten que cumplen todos los requisitos para constituir la pareja estable y que no concurre ninguna de las causas impeditivas para su constitución.

En cuanto a los documentos que debe aportar los convivientes se requieren los siguientes ${ }^{158}$ :

a)Documento de identidad.

b) Certificación literal o completa de nacimiento a los efectos de constatar la emancipación, el divorcio o la separación legal de los convivientes en pareja estable.

c) En caso de que la pareja se haya constituido para la convivencia en una comunidad de vida análoga a la matrimonial dura más de dos años ininterrumpidos, debe adjuntarse el certificado o certificados de empadronamiento municipal.

d) En caso de que la pareja se haya constituido para que durante la convivencia en una comunidad de vida análoga a la matrimonial los convivientes en pareja estable tienen un hijo en común, es necesario aportar el certificado de empadronamiento municipal y el libro de familia o la certificación de nacimiento donde conste la descendencia en común.

Dado que, al momento de crearse este Registro autonómico de parejas estables en Cataluña, ya existían Registros de Uniones de Hecho en muchos ayuntamientos de la comunidad autónoma,

\footnotetext{
${ }^{156}$ El Decreto-Ley 3/2015, de 6 de octubre, de modificación de la Ley 25/2010, de 29 de julio, del Libro segundo del CC de Cataluña, relativa a la creación del Registro de Parejas estables, se publicó en el BOE n. ${ }^{\circ}$ 297, de 12 de diciembre de 2015.

${ }^{157} \mathrm{La}$ Orden JUS/44/2017, de 28 de marzo, por la que se aprueba el Reglamento del Registro de Parejas Estables de Cataluña, fue publicada en el Diari Oficial de la Generalitat de Catalunya n..$^{\circ}$ 7341, de 31 de marzo de 2017.

${ }^{158} \mathrm{La}$ documentación exigida para el caso de inscripción de pareja estable por haber convivido durante al menos dos años de manera ininterrumpida viene descrita en el art. 7 de la Orden de la Consejería de Justicia que aprueba el Reglamento del Registro de parejas estables de Cataluña.
} 
también se recoge este supuesto, al precisar que, en tales casos, los convivientes pueden aportar la certificación emitida por el ayuntamiento correspondiente, quedando eximidos de añadir documentación complementaria ${ }^{159}$.

En el caso de formalización en documento notarial, el notario, a solicitud de los miembros de la pareja, remitirá comunicación telemática de la escritura pública o acta de notoriedad al Colegio de notarios de Cataluña, el cual remitirá también de manera telemática, y semanalmente, para su inscripción la información de todas las comunicaciones recibidas. Estas comunicaciones contendrán el nombre y apellidos de los convivientes, así como documento de identidad y el domicilio de ambos, y el supuesto de constitución de la pareja (convivencia de más de dos años ininterrumpidos, hijo común durante la convivencia o formalización de la relación en escritura pública), el lugar y fecha de la autorización del instrumento público, el número de protocolo correspondiente, los datos del notario autorizante, así como el colegio notarial al que pertenece y la clase de instrumento público acreditativo de la formalización de la pareja estable. Incluso, si así se acordase entre el Registro de parejas estables y el Colegio de notarios de Cataluña, se podrían enviar las comunicaciones directamente al Registro por el notario autorizante.

\section{Extremadura}

La Ley extremeña confiere carácter constitutivo a la inscripción en el registro de parejas de hecho. Previamente, mediante el Decreto 35/1997, de 18 de marzo ${ }^{160}$, se creó el Registro de Uniones de Hecho de la Comunidad Autónoma de Extremadura, el cual fue desarrollado mediante Orden de 14 de mayo de $1997^{161}$ de la Consejería de Bienestar Social.

Para practicar la inscripción de la pareja de hecho se requiere, además de la correspondiente solicitud suscrita por los dos miembros de la pareja, la aportación de la siguiente documentación acreditativa del cumplimiento de los requisitos establecidos:

a) Fotocopia compulsada del Documento Nacional de Identidad de los solicitantes.

\footnotetext{
${ }^{159} \mathrm{El}$ apartado $2^{\circ}$ del art. 6 de la Orden de la Consejería señala que: " 6.2 En el supuesto de parejas estables inscritas en registros municipales, los convivientes pueden aportar, a efectos de constancia, la certificación de inscripción emitida por el ayuntamiento correspondiente." Mientras que en el art. 7 del mismo Cuerpo legal se precisa que "Para acreditar la existencia de una pareja estable, a la solicitud regulada en el apartado $1 .^{\circ}$ del artículo anterior, se debe adjuntar la siguiente documentación: (...)". Es decir, no parece exigirse documentación complementaria en el caso del requisito segundo.

${ }^{160}$ El Decreto 35/1997, de 18 de marzo, de creación del Registro de Uniones de Hecho, fue publicado en el Diario Oficial de Extremadura n. ${ }^{\circ} 36$, de 25 de marzo de 1997.

${ }^{161}$ La Orden de 14 de mayo de 1997, por la que se regula el Registro de Uniones de Hecho de la Comunidad Autónoma de Extremadura, fue publicada en el Diario Oficial de Extremadura n. ${ }^{\circ} 61$ de 27 de mayo de 1997.
} 
b) Certificación del estado civil.

c) Certificación del padrón municipal que acredite que, al menos uno de los solicitantes, tiene la condición de residente en cualquier municipio de la Comunidad Autónoma de Extremadura.

d) Declaración jurada de no tener entre sí relación de parentesco en línea recta o colateral hasta el tercer grado, por consanguinidad o adopción.

e) Declaración jurada de no estar incapacitados a efectos de prestar válidamente su consentimiento a la unión de hecho.

f) Declaración jurada de no formar pareja de hecho con otra persona.

g) Acreditación de la emancipación, en el caso de menores.

h) Acreditación de la convivencia por período ininterrumpido de un año, en caso de tener descendencia común, fotocopia compulsada del libro de familia o, si los convivientes hubieran expresado su voluntad de constituir una pareja estable en documento público, fotocopia compulsada del mismo.

Al igual que el resto de las normas autonómicas que hemos ido viendo, en la legislación extremeña se confiere especial valor a la formalización ante notario de la pareja de hecho, de modo que no resulta preciso el período de convivencia previo de un año ${ }^{162}$ para la constitución de la pareja de hecho y su inscripción en el correspondiente registro.

Como otras legislaciones autonómicas exige la acreditación de convivencia previa de un año (en otras CCAA los períodos van desde seis meses a dos años). En el supuesto de existir descendencia común, no se exige la convivencia previa, aunque habrá de acreditarse tal descendencia, para lo que considera suficiente la aportación del libro de familia.

\section{Galicia}

La disposición adicional tercera de la Ley 2/2006, de 14 de junio ${ }^{163}$, de Derecho Civil de Galicia, que define y reconoce las parejas de hecho, se desarrolla en el Decreto 248/2007, de 20 de

\footnotetext{
${ }^{162}$ El art. 2.2 de la Ley 5/2003, de 20 de marzo, de parejas de hecho de Extremadura establece el mencionado plazo de convivencia previa como requisito para la constitución de la pareja de hecho, si bien exime de dicho período de convivencia en los supuestos de que exista descendencia común o en el caso de constituir la pareja en documento público.

${ }^{163}$ La Ley 2/2006, de 14 de junio, de Derecho Civil de Galicia, se publicó en el Diario Oficial de Galicia n. ${ }^{\circ} 124$, de 29 de junio de 2006, y en el BOE n. ${ }^{\circ} 191$, de 11 de agosto de 2006.
} 
diciembre $^{164}$, por el que se crea y se regula el Registro de Parejas de Hecho de Galicia, el cual ha sido modificado por el Decreto 146/2014, de 13 de noviembre ${ }^{165}$.

Para practicar la inscripción en el caso gallego se exige la formación del correspondiente expediente administrativo, el cual se inicia mediante la correspondiente solicitud, que debe presentarse en el modelo oficial establecido, a la que deben acompañar de la correspondiente documentación, así como una declaración de voluntad de constitución de pareja de hecho mediante comparecencia personal de ambos miembros ante el encargado del registro.

De modo que en la solicitud de inscripción se incluirán las siguientes menciones:

a) Nombre y apellidos de cada uno de los miembros de la pareja.

b) DNI de cada uno de los solicitantes que tengan nacionalidad española o designación del documento equivalente en otro supuesto.

c) Fecha de nacimiento de cada uno.

d) Nacionalidad de cada uno.

e) Estado civil de cada uno.

f) Hijos e hijas de cada uno, comunes o no comunes.

g) Domicilio de la pareja.

h) Lugar y fecha de presentación.

A esta solicitud de inscripción deberán acompañar la siguiente documentación acreditativa del cumplimiento de los requisitos exigidos por la Ley de Derecho Civil de Galicia ${ }^{166}$ :

a) Fotocopia compulsada del DNI de ambos solicitantes.

b) Certificado de empadronamiento de los miembros de la pareja en el mismo domicilio de algún municipio de la Comunidad Autónoma de Galicia.

c) Certificación del Registro Civil sobre el estado civil de ambos miembros de la pareja.

\footnotetext{
${ }^{164}$ El Decreto 248/2007, de 20 de diciembre, por el que se crea y se regula el Registro de Parejas de Hecho de Galicia, se publicó en el Diario Oficial de Galicia n. ${ }^{\circ} 5$ de 8 de enero de 2008.

${ }^{165}$ El Decreto 146/2014, de 13 de noviembre, por el que se modifica el Decreto 248/2007, de 20 de diciembre, por el que se crea y se regula el Registro de Parejas de Hecho de Galicia, fue publicado en el Diario Oficial de Galicia n. $^{\circ}$ 224, de 21 de noviembre de 2014.

${ }^{166}$ Según la redacción dada en el Decreto 146/2014, de 13 de noviembre, al art. 11 del Decreto 248/2007, de 20 de diciembre, por el que se crea y se regula el Registro de Parejas de Hecho de Galicia. En la redacción originaria se requerían, en esencia, los mismos documentos, pero se detallaban diversas declaraciones responsables que, en la modificación se refunden; por lo demás, en la modificación de 2014 se incluye la obligación de la declaración de voluntad por comparecencia ante el encargado del Registro de Parejas de Hecho.
} 
d) Declaración responsable de ambos miembros de la pareja de no tener constituida pareja de hecho con otra persona, de no tener relación de parentesco en línea recta por consanguinidad o adopción ni colateral por consanguinidad o adopción hasta el tercer grado, y de no estar incapacitados a efectos de prestar su consentimiento para constituir una pareja de hecho.

e) En su caso, sentencia judicial firme de divorcio o nulidad o certificado literal de matrimonio en el que conste alguno de estos extremos.

f) Fotocopia compulsada del libro de familia o equivalente en los casos en que hubiera hijos comunes o de cualquiera de los miembros de la pareja.

g) Declaración de voluntad de constituir una pareja de hecho mediante comparecencia personal de ambos miembros ante el encargado o encargada del Registro.

En el caso gallego no se exige convivencia previa para la inscripción como convivientes de la pareja, si bien ambos miembros deben estar empadronados en un mismo domicilio, por lo que, aunque no se establece un período previo de convivencia de manera formal, en la práctica es precisa la convivencia previa, o cuando menos el empadronamiento anterior a la solicitud de inscripción de la pareja en el Registro.

Por otra parte, en el caso de la Comunidad Autónoma de Galicia no se contempla la manifestación de voluntad de constituir la pareja ante el notario como una de las formas de constitución, ya que se exige que tal manifestación de voluntad debe formalizarse, en todos los casos, ante el encargado del Registro de Parejas de Hecho.

\section{Islas Baleares}

La Disposición final primera de la Ley 18/2001, de 19 de diciembre ${ }^{167}$, de parejas estables de Islas Baleares ordenaba la creación y regulación de la organización y gestión del Registro de parejas Estables de las Illes Balears, lo cual fue cumplimentado mediante el Decreto 112/2002, de 30 de agosto ${ }^{168}$, mediante el cual se crea un Registro de Parejas Estables de las Illes Balears y se regula su organización y gestión.

\footnotetext{
${ }^{167}$ La Ley 18/2001, de 19 de diciembre, de Parejas Estables, fue publicado en el Boletín Oficial de las Islas Baleares n. ${ }^{\circ} 156$, de 19 de diciembre de 2001 y en el BOE n. ${ }^{\circ} 14$, de 16 de enero de 2002.

${ }^{168}$ El Decreto 112/2002, de 30 de agosto, mediante el cual se crea un Registro de Parejas Estables de las Illes Balears y se regula su organización y gestión, fue publicado en el Boletín Oficial de las Islas Baleares n. ${ }^{\circ} 108$, de 7 de septiembre de 2002.
} 
Este Decreto establece en el art. 1.2 el carácter constitutivo y voluntario de la inscripción de la Pareja. De suerte que para que a una pareja le resulte aplicable la legislación balear de Parejas Estables es precisa su inscripción en el mencionado registro público.

Para acceder al Registro se exige la correspondiente solicitud de inscripción a la cual se deben acompañar los siguientes documentos ${ }^{169}$ :

a) Original y copia de los documentos de identificación de la pareja.

b) Certificado del Registro Civil o escritura pública de emancipación de los miembros, en su caso.

c) Declaración responsable de ambos miembros de que no hay ninguna relación de parentesco en línea recta por consanguinidad o adopción, ni colateral por consanguinidad o adopción hasta el tercer grado.

d) Declaración responsable de no formar pareja estable con otra persona, inscrita y formalizada debidamente.

e) Certificado acreditativo de la vecindad civil balear de, al menos, uno de los miembros de la pareja.

f) Declaración expresa y por escrito de sometimiento de ambos miembros al régimen que establece la vecindad civil de las Illes Balears.

g) Declaración de voluntad de ambos miembros de constituirse en pareja en una relación de afectividad análoga a la conyugal, sin condiciones y con carácter de permanencia.

Entre la documentación exigida que, en general, será común a la exigida en otras CCAA, llama la atención el establecimiento de una tasa para la tramitación de la inscripción en el Registro de Parejas Estales, dicha tasa que, en la actualidad, está fijada en 21,14 € es una nota singular en relación con el resto de las CCAA en las que la inscripción en el correspondiente Registro administrativo es gratuita.

Otra nota de singularidad de la legislación balear es la exigencia de que ambos miembros de la pareja al régimen jurídico determinado por la vecindad civil balear, sometimiento que deben presentar de manera expresa y por escrito. Este es otro requisito que no se exige en el resto de las

\footnotetext{
${ }^{169}$ Art. 9 del Decreto 112/2002, de 30 de agosto, en su redacción vigente, ya que el mismo ha sido modificado en sucesivas ocasiones desde su publicación originaria.
} 
Comunidades con compilación foral, ya que ninguna otra exige el sometimiento a la vecindad civil foral de la persona que pudiera tener una diferente ${ }^{170}$.

La legislación balear del registro de parejas estables establece también que, una vez comprobada la suficiencia y exactitud de la documentación aportada, ambos miembros de la pareja serán requeridos para que, en el plazo de un mes desde el requerimiento, y ante el responsable del registro, un notario o un alcalde asistido por el secretario, formalicen de forma conjunta y por escrito la voluntad de constituirse en pareja con una relación de afectividad análoga a la conyugal, sin condiciones y con carácter de permanencia ${ }^{171}$.

Al igual que en el resto de las legislaciones autonómicas, también en el caso balear el notario es uno de los funcionarios ante los que es posible formalizar la declaración de voluntad de constituirse en pareja estable con arreglo a la legislación de la citada comunidad autónoma.

\section{Islas Canarias}

El art. 3 de la Ley 5/2003, de 6 de marzo ${ }^{172}$, para la regulación de las parejas de hecho en la Comunidad Autónoma de las Islas Canarias crea el registro de parejas de hecho de esta comunidad, determinando la necesidad de publicar la norma de desarrollo del citado registro en el plazo de un año desde la entrada en vigor de la Ley. Al efecto se dictó el Decreto 60/2004, de 19 de mayo ${ }^{173}$, por el que se aprueba el Reglamento del Registro de Parejas de Hecho en la Comunidad

\footnotetext{
${ }^{170}$ Resulta discutible que este requisito respete el principio de libre desarrollo de la personalidad, desde el momento que "obliga" al miembro de la pareja a someterse al régimen jurídico determinado por la vecindad civil balear. Hemos de entender que, tal exigencia, no hace referencia a la obligación de modificar la vecindad civil del miembro de la pareja no balear, sino que se refiere, exclusivamente, al régimen jurídico que se aplicará a la pareja en cuanto tal.

${ }^{171}$ Art. 10 del Decreto 112/2002, de 30 de agosto, en el cual establece como fecha de la constitución de la pareja estable la de la declaración formalizada del modo descrito; no obstante, la inscripción no mes automática, sino que el encargado del registro elevará la propuesta de constitución e inscripción de la pareja a la persona titular de la Consejería de Presidencia, la cual ha de dictar la correspondiente resolución favorable, la norma prevé silencio administrativo favorable para el supuesto de que no se dictase resolución en el plazo de tres meses desde la formalización de la constitución de la pareja, o desde que tuvo entrada en el registro dicha constitución formal, si la misma fue realizada ante funcionario distinto del encargado del mismo. La inscripción, no obstante, tendrá carácter retroactivo al de la fecha de la declaración formalizada, como hemos indicado. Dado el carácter administrativo del registro, los miembros de la pareja disponen de los recursos administrativos legalmente previstos frente a las resoluciones contrarias a sus intereses.

${ }^{172}$ La Ley 5/2003, de 6 de marzo, para la regulación de las Parejas de Hecho en la Comunidad Autónoma de Canarias se publicó en el BOE n. ${ }^{\circ} 89$, de 14 de abril de 2003.

${ }^{173}$ El Decreto 60/2004, de 19 de mayo, por el que se aprueba el Reglamento del Registro de Parejas de Hecho en la Comunidad Autónoma de Canarias se publicó en el Boletín Oficial de Canarias n. ${ }^{\circ}$ 105, de 22 de junio de 2004.
} 
Autónoma de Canarias, el cual ha sido modificado y actualizado por el Decreto 28/2015, de 19 de $\operatorname{marzo}^{174}$.

Se inscribirán en el Registro de Parejas de Hecho las uniones de dos personas que convivan en pareja de forma libre, pública y notoria, vinculados de forma estable al menos durante un período ininterrumpido de doce meses. Esta exigencia de convivencia previa a la inscripción desaparece en los supuestos de existir descendencia común, en cuyo caso solamente se exige la convivencia al momento de solicitar la inscripción ${ }^{175}$.

Como en algunas otras legislaciones autonómicas se contempla la exigencia de acreditar un período de convivencia previo, en el caso canario de un año; sin embargo, un precepto similar contenido en el art. 2.2 de la Ley 6/2000, de 3 de julio, para la igualdad jurídica de las parejas estables de la Comunidad Foral de Navarra, que en su redacción original decía que "2. Se entenderá que la unión es estable cuando los miembros de la pareja hayan convivido maritalmente, como mínimo, un período ininterrumpido de un año, salvo que tuvieran descendencia común, en cuyo caso bastará la mera convivencia (...)" fue declarado inconstitucional por la STC 93/2013, de 23 de abril ${ }^{176}$.

Para la inscripción de una pareja de hecho en el Registro de Parejas de Hecho de la Comunidad Autónoma de las Islas canarias, además de la correspondiente solicitud deberán acompañarse los siguientes documentos ${ }^{177}$ :

a) Copia simple del documento oficial acreditativo de la identidad de quienes conforman la pareja de hecho.

\footnotetext{
${ }^{174}$ El Decreto 28/2015, de 19 de marzo, por el que se modifica el Reglamento del Registro de Parejas de Hecho en la Comunidad Autónoma de Canarias, aprobado por Decreto 60/2004, de 19 de mayo, se publicó en el Boletín Oficial de Canarias n. ${ }^{\circ} 59$, de 26 de marzo de 2015.

${ }^{175}$ Art. 5 del Decreto 60/2004, de 19 de mayo, que aprueba el reglamento del Registro de Parejas de Hecho en Canarias. Al igual que otras legislaciones de CCAA se mantiene la exigencia de acreditación de convivencia previa de un año.

${ }^{176} \mathrm{E}$ FJ 9. ${ }^{\circ}$ de la citada STC dice que "En consecuencia, hemos de concluir que la regulación discutida responde básicamente a un modelo imperativo, bien alejado del régimen dispositivo que resultaría acorde a las características de las uniones de hecho, y a las exigencias del libre desarrollo de la personalidad recogido en el art. 10.1 CE. El carácter preceptivo implica que el régimen estatuido se impone obligatoriamente a las parejas estables que reúnan las condiciones previstas en los dos primeros supuestos del párrafo $1 .^{\circ}$ del art. 2.2, lo cual debe conducirnos, sin duda, a reiterar aquí la inconstitucionalidad de tales supuestos; asimismo debemos declarar la inconstitucionalidad del párrafo $2{ }^{\circ}$ de dicho art. 2.2, en cuanto que se refiere al cómputo del plazo de un año de convivencia previsto en el párrafo anterior".

${ }^{177}$ El Art. 9 del Decreto 60/2004, de 19 de mayo, regula la documentación complementaria que deben aportar los miembros de la pareja con su solicitud de inscripción en el Registro de Parejas de Hecho de Canarias.
} 
b) Acreditación de la emancipación de los miembros de la pareja mediante certificación del Registro Civil.

c) Certificación del Registro Civil que acredite que no existe ningún vínculo matrimonial con ninguna otra persona.

d) Escritura pública relativa a la constitución de la pareja de hecho, acta de notoriedad, documento judicial o cualquier otro medio de prueba acreditativo de la convivencia de forma estable durante al menos doce meses. o de la mera convivencia, cuando la pareja tuviera descendencia común.

e) Declaración responsable de no estar incapacitado para emitir el consentimiento necesario.

f) Declaración responsable de ambos miembros de que no existe ninguna relación de parentesco en línea recta por consanguinidad o adopción, ni colateral por consanguinidad o adopción hasta el tercer grado.

g) Declaración responsable de ambos miembros de la pareja de no formar pareja estable con otra persona simultáneamente.

h) Certificación de empadronamiento de quienes conforman la pareja en alguno de los Ayuntamientos de la Comunidad Autónoma de Canarias.

En el caso canario la exigencia de prueba de la convivencia previa remite a documentos públicos como referencia. Estos documentos serían la escritura pública o acta de notoriedad, ambos de factura notarial, y existe una remisión genérica a "documento judicial", sin precisar qué tipo de documento judicial resultaría acreditativo de tal convivencia. No se alcanza a entender en qué documento judicial podría estar pensando el legislador autonómico. Igualmente, resulta extraño que no se incluya el empadronamiento de ambos miembros de la pareja en un mismo domicilio de la comunidad autónoma, o la inscripción de la pareja en el registro de otra comunidad autónoma y que se inscriban en el de Canarias por cambio de domicilio; probablemente debamos entender que tales modos de acreditación de la convivencia quedan incluidos en "cualquier otro medio de prueba acreditativo", pero sería de agradecer que el legislador autonómico los hubiese incluido de manera expresa, al menos el del empadronamiento en un mismo domicilio, por su facilidad probatoria y su gratuidad.

De nuevo, en el caso canario, vemos cómo la manifestación de voluntad ante notario es un modo privilegiado de acreditar la constitución de una pareja de hecho. Reiteramos, como en 
todos y cada uno de los casos el notario es funcionario acreditado para dar fe de la manifestación de voluntad de constituir pareja de hecho, al igual que lo es en el caso del matrimonio. Similitud esta que llama poderosamente la atención, pues cuando se exige un expediente para la inscripción con grandes similitudes entre el exigido para el matrimonio y el exigido por las distintas comunidades para la inscripción de la pareja de hecho, y existe al menos un funcionario, como es el notario, ante el que se puede manifestar la voluntad de constituirse en pareja convivencial, resulta extraño que nuestra jurisprudencia venga rechazando de manera reiterada la posibilidad de analogía entre ambos modos de convivencia.

\section{La Rioja}

Pese a que han existido diversas iniciativas legislativas para la promulgación de una ley autonómica sobre las parejas de hecho, la realidad es que, a la fecha en que se escriben estas líneas, no existe norma legislativa con rango de ley en la Comunidad Autónoma de La Rioja ${ }^{178}$; sin embargo, como en alguna otra comunidad, también en La Rioja se afronta el fenómeno de las parejas de hecho mediante el Decreto 30/2010, de 14 de mayo ${ }^{179}$, por el que se crea el Registro de Parejas de Hecho de La Rioja.

$\mathrm{Y}$, siguiendo la tónica general, para la inscripción de la pareja de hecho se exige la correspondiente solicitud de inscripción y la aportación de documentación acreditativa del cumplimiento de los requisitos establecidos. Es decir, se ha de cumplimentar el correspondiente expediente, en este caso administrativo para tener acceso al mencionado Registro de Parejas de Hecho de la Comunidad Autónoma de La Rioja.

Por tanto, para que proceda la inscripción de la pareja de hecho en el Registro de la Comunidad Autónoma de La Rioja será preciso acompañar a la correspondiente solicitud los siguientes documentos acreditativos del cumplimiento de la totalidad de los requisitos exigidos ${ }^{180}$ :

a) Ser mayor de edad o gozar de la condición de menor emancipado. La mayoría de edad se acreditará mediante el documento oficial en el que conste la fecha de nacimiento o mediante una autorización al órgano instructor para que compruebe

\footnotetext{
${ }^{178}$ La última de las propuestas llevadas al Parlamento autonómico fue un proyecto de ley presentado por Podemos en octubre de 2017, que abogaba por la equiparación entre pareja de hecho y matrimonio.

${ }^{179}$ El Decreto 30/2010, de 14 de mayo, por el que se crea el Registro de Parejas de Hecho de La Rioja, se publicó en el Boletín Oficial de La Rioja n. ${ }^{\circ}$ 62, el 21 de mayo de 2010.

${ }^{180}$ El Art. 3 del Decreto 30/2010, de 14 de mayo, de creación del Registro de Parejas de Hecho de La Rioja es el que establece la documentación que debe acompañar a la solicitud para el expediente administrativo para la inscripción de la pareja de hecho.
} 
los datos de identidad personal. La condición de menor emancipado se acreditará mediante resolución judicial o certificación del Registro Civil.

b) Declaración jurada de no tener una relación de parentesco en línea recta por consanguinidad o adopción, ni colateral por consanguinidad o adopción hasta el tercer grado.

c) Tener una convivencia previa que implique una relación de afectividad entre los solicitantes análoga a la conyugal durante al menos dos años ininterrumpidos inmediatamente anterior a la presentación de la solicitud en el mismo domicilio de cualquier municipio de La Rioja. Este requisito se acreditará mediante certificado/s de empadronamiento de cada uno de los solicitantes en los que consten todos los domicilios en los que han estado empadronados durante los dos últimos años y en la fecha de su solicitud.

d) Bastará con la mera convivencia cuando la pareja tuviera descendencia común. En este caso se acreditará mediante la presentación del libro de familia y un certificado de empadronamiento que acredite la residencia de los solicitantes en el mismo domicilio de algún municipio de La Rioja.

e) No estar ligados por vínculo matrimonial. Este requisito se acreditará mediante certificación o fe del estado civil de los mismos.

f) Declaración jurada de no formar pareja de hecho con otra persona.

g) Declaración jurada de no estar incapacitado judicialmente.

h) Ser español o tener la residencia legal en España. Este requisito se acreditará de la siguiente forma:

- Ciudadanos españoles: mediante el DNI, y

- Los ciudadanos extranjeros mediante el NIE y/o pasaporte, ambos en vigor.

Como en otra CCAA, también en La Rioja consta la exigencia de convivencia previa de dos años para acceder a la inscripción en el Registro de Parejas de Hecho, tal vez por ser anterior a la STC 93/2013, de 23 de abril y no haber sido demandada la inconstitucionalidad del precepto.

En el caso de la Comunidad Autónoma de La Rioja no se contempla la manifestación de voluntad mediante escritura pública como forma de acreditación de la constitución de la pareja de hecho lo que, como estamos comprobando, viene a constituir una rareza entre las legislaciones autonómicas. 


\section{Comunidad Autónoma de Madrid}

La Comunidad Autónoma de Madrid ha legislado sobre las parejas de hecho mediante la Ley 11/2001, de 19 de diciembre, de Uniones de Hecho de la Comunidad de Madrid, pero la STC $81 / 2013$, de 11 de abril, declaró la inconstitucionalidad de algunos preceptos de la Ley ${ }^{181}$.

Como desarrollo de la mencionada ley, y mediante el Decreto 134/2002, de 18 de julio ${ }^{182}$, por el que se aprueba el Reglamento del Registro de Uniones de Hecho de la Comunidad de Madrid, se establecen las condiciones de acceso al citado Registro ${ }^{183}$.

En la vigente legislación autonómica se exige la presentación de la solicitud, personal y conjunta de ambos miembros de la pareja, ante el Registro de Uniones de Hecho de la Comunidad de Madrid $^{184}$. Los solicitantes deben acudir acompañados por dos testigos, mayores de edad y en el pleno ejercicio de sus derechos civiles, a fin de acreditar la previa convivencia libre, pública, notoria e ininterrumpida durante, al menos doce meses, en relación de afectividad similar a la conyugal. A esta solicitud de inscripción deben acompañar la siguiente documentación ${ }^{185}$ :

a) DNI, pasaporte o tarjeta de residencia de los solicitantes y testigos.

b) Acreditación de la emancipación, en su caso.

c) Certificación de estado civil.

d) Certificación del padrón municipal que acredite que, al menos, uno de los solicitantes tiene la condición de residente en cualquier municipio de la Comunidad de Madrid.

e) Declaración de no tener entre sí relación de parentesco en línea recta o colateral hasta el tercer grado, por consanguinidad o adopción.

\footnotetext{
${ }^{181}$ La STC 81/2013, de 11 de abril, declaró la inconstitucionalidad de los artículos 4 referido a "la Regulación de la Convivencia" y 5 denominado "Inscripción". Ambos artículos conformaban el Capítulo III de la Norma denominado "De la inscripción de los pactos de convivencia", que termina siendo declarado inconstitucional en su totalidad.

${ }^{182}$ El Decreto 134/2002, de 18 de julio, por el que se aprueba el Reglamento del Registro de Uniones de Hecho de la Comunidad de Madrid, se publicó en el Boletín Oficial de la Comunidad de Madrid de 26 de julio de 2002.

${ }^{183}$ El TSJM declaró en mayo de 2013 la nulidad de pleno derecho, por inconstitucionalidad, del art. 6; la expresión "así como respecto de los pactos reguladores de las relaciones económicas. La validez jurídica y los efectos de los mencionados pactos se producirán al margen de su inscripción en el Registro, y nunca podrán perjudicar a terceros", contenida en el art. 9 y el apartado 2 del art. 10, todos ellos del Decreto 134/2002, de 18 de julio, que aprueba el Reglamento del Registro de Uniones de Hecho de la Comunidad madrileña [STSJM 16-5-2013 (RJCA 2013/923)].

${ }^{184}$ El Registro de Uniones de Hecho de la Comunidad de Madrid se crea y regula por el Decreto 36/1995, de 20 de abril, y la Orden 827/1995, de 25 de abril; mediante la Disposición transitoria segunda de la Ley 11/2001, de 19 de diciembre, de Uniones de Hecho de la Comunidad de Madrid, las inscripciones practicadas en el citado registro se integraban de oficio en el Registro creado por el art. 3 de la mencionada Ley autonómica.

${ }^{185} \mathrm{El}$ art. 10 del Decreto 134/2002, de 18 de julio, regula el modo de presentación de la solicitud y la documentación que debe acompañar a la misma.
} 
f) Declaración de no estar incapacitados a efectos de prestar válidamente su consentimiento a la unión de hecho.

g) Declaración de no formar unión estable con otra persona.

h) Si la unión ya estuviese registrada en otra comunidad autónoma, certificación del

Registro correspondiente de la cancelación de dicha inscripción.

Según declara el propio Decreto de regulación del Registro, las inscripciones tendrán carácter declarativo, pese a ello debe reconocerse a la inscripción un especial valor, más allá de la mera declaración de una situación extrarregistral, toda vez que se exige la inscripción para que la unión de hecho despliegue todos sus efectos jurídicos.

El expediente administrativo iniciado con la solicitud presentada de la forma señalada tiene un plazo máximo, según el Decreto de regulación del Registro de Uniones de Hecho, de dos meses desde la presentación de la solicitud para la notificación de la correspondiente resolución administrativa, pero según el apartado 2.16 del anexo de la Ley $1 / 2001$, de 29 de marzo ${ }^{186}$, por la que se establece la duración máxima y el régimen de silencio administrativo de determinados procedimientos ante la Comunidad de Madrid, en la modificación efectuada por la Ley 8/2009, de 21 de diciembre ${ }^{187}$, se establece un plazo máximo para la resolución de este procedimiento de quince días y se atribuye sentido desestimatorio al silencio administrativo.

La Ley autonómica de uniones de hecho fue objeto de cuestión de constitucionalidad planteada por el TSJM, cuestión que fuera resuelta por le Sentencia del Constitucional 81/2013, de 11 de abril, la cual señalaba en su FJ 4. ${ }^{\circ}$ que "Las consecuencias del examen de esta regulación (artículo 4 y 5 de la Ley 11/2001, de 19 de diciembre) desde la perspectiva del orden constitucional de distribución de competencias son claras, pues ya tenemos declarado que las regulaciones relativas a las relaciones interprivatos constituyen reglas de Derecho privado encuadrables en la materia de legislación civil (STC 28/2012, de 1 de marzo, FJ 5), relaciones interprivatos en las que, indudablemente se integran los pactos de contenido económico y patrimonial a los que se refieren estos preceptos. En dicha materia el Estado ostenta, conforme al primer inciso del art. 149.1.8 CE, la competencia exclusiva sobre "legislación civil; sin perjuicio de la conservación, modificación o

\footnotetext{
${ }^{186}$ La Ley 1/2001, de 29 de marzo, por la que se establece la duración máxima y el régimen de silencio administrativo de determinados procedimientos en la Comunidad de Madrid, fue publicada en el BOE n. ${ }^{\circ} 149$, de 22 de junio de 2001.

${ }^{187}$ La Ley 8/2009, de 21 de diciembre, de Medidas liberalizadoras y de Apoyo a la empresa madrileña, fue publicada en el Boletín Oficial de la Comunidad de Madrid n. ${ }^{\circ} 308$ de 29 de diciembre de 2009 y en el BOE n. 63 de 13 de marzo de 2010, en su art. 8 modifica el anexo de la Ley 1/2001, de 29 de marzo, estableciendo el citado plazo de quince días y efecto desestimatorio para el silencio administrativo del Registro de Uniones de Hecho.
} 
desarrollo por las CCAA de los derechos civiles, forales o especiales, allí donde existan”. Esta última circunstancia, la previa existencia de un Derecho civil foral o especial, no concurre en el caso de la Comunidad de Madrid, cuyo Estatuto de Autonomía no recoge mención alguna a competencias autonómicas en este ámbito". Como consecuencia, declara la inconstitucionalidad de los artículos 4 y 5 de la redacción originaria de la ley autonómica que regulaban los pactos entre los convivientes y la inscripción de los mismos en el Registro de Uniones de Hecho de la Comunidad de Madrid, por regular aspectos sujetos a las circunstancias previstas en el art. 97 del CC (incluso en el art. 4.2 de la original Ley 11/2001, de 19 de diciembre, de Uniones de Hecho de la Comunidad de Madrid, se hacía una remisión expresa al mencionado artículo del CC), generando un régimen normativo con obligaciones económicas derivadas de la situación de hecho, que son propias de las relaciones jurídico-privadas.

\section{Región de Murcia}

La Región de Murcia ha legislado en el año 2018 sobre las parejas de hecho mediante la Ley 7/2018, de 3 de julio ${ }^{188}$, de Parejas de Hecho de la Comunidad Autónoma, en la cual se reconocen como parejas de hecho formalizadas aquellas en que consta su existencia por la declaración de voluntad de sus integrantes ante el funcionario encargado del Registro, plasmada en la correspondiente inscripción. Se admite, igualmente, cualquier otro documento público en que conste la declaración de voluntad de los integrantes de la pareja de hecho, con especial referencia a la escritura pública otorgada, conjuntamente, por ambos miembros de la pareja ${ }^{189}$.

El Registro de Parejas de Hecho, creado en la propia ley citada, tiene carácter administrativo y la inscripción tiene efectos declarativos sobre la constitución, modificación o extinción de las mismas. Y la inscripción en el mismo otorga una presunción iuris tantum de convivencia de los miembros de la misma.

Para que proceda la inscripción los convivientes deberán aportar la siguiente documentación:

a) Solicitud de inscripción de unión de parejas de hecho.

b) Escritura pública otorgada conjuntamente por ambos miembros de la pareja.

\footnotetext{
${ }^{188}$ La Ley 7/2018, de 3 de julio, de Parejas de Hecho de la Comunidad Autónoma de la Región de Murcia, fue publicada en el Boletín Oficial de la Región de Murcia n. ${ }^{\circ}$ 154, de 6 de julio de 208 y en el BOE n. ${ }^{\circ} 183$ de 30 de julio de 2018. ${ }^{189} \mathrm{El}$ art. 4 de la Ley 7/2018, de 3 de julio, de Parejas de Hecho de la Comunidad Autónoma e la región de Murcia, establece el modo de acreditación de la existencia de una pareja de hecho mediante la inscripción en el correspondiente Registro de Parejas de Hecho que crea en el artículo siguiente, así como el modo de inscripción en el mismo.
} 
c) O, si no fuera el caso, la siguiente documentación:

- Acreditación de la identidad de los miembros de la pareja (DNI, NIE, pasaporte, etc.).

- Acreditación, en su caso, de la emancipación, mediante certificado expedido por el Registro Civil o sentencia judicial.

- Acreditación del estado civil de ambos mediante certificaciones del Registro Civil o cualquier otro medio de prueba válido en Derecho, y, en su caso, prueba de la disolución de anteriores vínculos.

- Certificado de empadronamiento de al menos uno de ellos en cualquiera de los municipios de la Región de Murcia.

- Declaración responsable en la que conste: no tener una relación de parentesco por consanguinidad o adopción en línea recta o colateral en tercer grado y no estar inscrito en otro registro de pareas de hecho.

- Haber abonado la tasa correspondiente por inscripción en registros oficiales de la región de Murcia.

Una vez más, se exige la tramitación de un expediente de constitución de pareja de hecho, unida a una declaración de voluntad y formulada con el requisito de publicidad que implica la manifestación ante el encargado del registro de parejas de hecho. También aparece, de nuevo, la posibilidad de realizar esta declaración de voluntad ante el notario, manifestación de voluntad de convivencia que, en el caso de la Región de Murcia como en otros muchos casos, se puede formular de manera válida ante el mismo funcionario que puede autorizar un matrimonio, el notario, y manifestando, igualmente, una voluntad de convivir.

Parecería que, si el requisito de solemnidad exigido en el caso del matrimonio se cumple con la manifestación ante el notario, debería entenderse que la manifestación de voluntad de querer convivir como pareja, emitida ante el mismo notario, debería entenderse que cumple con el mismo requisito de solemnidad. Por lo que, reconociendo la indudable diferencia jurídica entre ambas instituciones, debe reconocerse, igualmente, la existencia de una "identidad de razón" entre ambas instituciones lo que debería conllevar las correspondientes consecuencias jurídicas.

\section{Comunidad Foral de Navarra}

La Ley Foral 6/2000, de 3 de julio, para la igualdad jurídica de las parejas estables, fue declarada inconstitucional en varios de sus artículos por la STC 93/2013, de 23 de mayo de 2013. 
Como consecuencia, la mencionada norma ha sido profundamente modificada, no solo por la mencionada sentencia, sino también por la Ley Foral 21/2019, de 4 de abril, de modificación y actualización de la compilación del Derecho Civil de Navarra o Fuero Nuevo ${ }^{190}$.

El artículo 106 de la compilación del Derecho Civil de Navarra establece que la pareja estable debe inscribirse en un Registro único de parejas estables de Navarra, el cual deberá crearse ya que en el momento de escribir estas líneas dicho Registro no ha sido creado, de manera que la inscripción se realiza en los registros de parejas de hecho creados por los diferentes municipios navarros. No obstante, el mismo artículo exige la manifestación de voluntad, en documento público, de constituirse en una comunidad de vida afectiva análoga a la conyugal.

En cuanto a los requisitos para la inscripción, actualmente vigentes en la Comunidad Navarra, podemos determinar los siguientes:

a) Comparecencia personal y conjunta de ambos miembros de la pareja ante el funcionario encargado del Registro municipal de parejas estables no casadas.

b) Documentación que acredite la identidad de las personas a inscribir (DI, NIE, pasaporte, etc).

c) Declaración jurada de no estar casado ni inscrito en otro registro de parejas estables no casada.

d) Certificación de emancipación en el caso de menores.

e) Declaración jurada de que no existe parentesco por consanguinidad o adopción en línea recta o en línea colateral hasta el segundo grado.

f) En el caso de que alguno de los miembros de la pareja estuviere afectado por deficiencias o anomalías psíquicas, deberá aportase dictamen médico de su aptitud para consentir en la constitución de una unión de convivencia no matrimonial.

g) Pacto de los convivientes relativos a las relaciones personales o patrimoniales entre los miembros de la unión de hecho.

Se reconoce, igualmente, la escritura pública notarial de constitución de la pareja estable. Una vez más, tenemos al notario como funcionario público habilitado para la constitución de pareja

\footnotetext{
${ }^{190}$ La Ley Foral 21/2019, de 4 de abril, de modificación y actualización de la Compilación del Derecho Civil de Navarra o Fuero Nuevo, fue publicada en el BOCN n. ${ }^{\circ} 74$ de 16 de abril de 2019 y en el BOE n. ${ }^{\circ} 137$ de 8 de junio de 2019, y regula en los arts. 106 y siguientes la constitución, registro y régimen jurídico de las parejas estables en la Comunidad Foral.
} 
de hecho, al igual que lo está para la celebración del matrimonio. Es más, tras la declaración de inconstitucionalidad de gran parte de la Ley 6/2000, de 3 de julio, el propio TC dejaba a salvo que se entenderá que la unión es estable "cuando los miembros de la pareja hayan expresado su voluntad de constituir una pareja estable en documento público", reforzando más si cabe la importancia de la figura de este funcionario público en la constitución de la pareja de hecho.

En cuanto al régimen de convivencia, serán los miembros de la pareja estable quienes regularán las relaciones personales y patrimoniales derivadas de su convivencia, para lo cual deberán suscribir un documento, que podrá ser público o privado, en el que se recojan los pactos alcanzados comprensivos de sus respectivos derechos y deberes.

La inconstitucionalidad parcial de la Ley 6/2000, de 3 de julio, para la igualdad jurídica

\section{de las parejas estables}

La meritada Sentencia 93/2013, de 4 de abril, al analizar los aspectos competenciales del recurso de inconstitucionalidad planteado, señalaba la exclusividad competencial del Estado en la regulación del matrimonio, del que afirma es una institución social garantizada por la propia Constitución, a la vez que el derecho a contraerlo es un derecho constitucional, cuyo régimen jurídico corresponde a la Ley por mandato constitucional (art. 32.2 CE), mientras que "nada de ello ocurre en la unión de hecho more uxorio, que ni es una institución jurídicamente garantizada ni hay derecho constitucional expreso a su establecimiento"191.

Destacaremos, la afirmación contenida en la citada sentencia de que, "pese a la posible existencia de paralelismos entre ambas realidades (el matrimonio y las parejas de hecho), su regulación difiere, entre otros aspectos sustanciales, en lo relativo a los requisitos y formalidades que, para la celebración del matrimonio exige la formalización solemne de la prestación de consentimiento al efecto ante funcionario o autoridad (...). Estas evidentes diferencias, que se ponen de relieve desde la esencia misma de una y otra realidades jurídicas impiden su equiparación conceptual, por lo que no se produce invasión alguna de la competencia de la competencia exclusiva estatal sobre las relaciones jurídico-civiles relativas a las formas del matrimonio (...)"192.

Si bien en sede de análisis de las competencias, la STC ya nos empieza a anunciar las razones en que fundamenta su resolución. Al establecer que se trata de situaciones jurídicas

\footnotetext{
${ }^{191}$ FJ cinco, párrafo 5. ${ }^{\circ}$, de STC 93/2013.

${ }^{192} \mathrm{FJ} 5 .^{\circ}$ párrafo $8 .^{\circ}$ de la misma STC.
} 
diferentes, pese a reconocer los paralelismos entre ambas realidades, establece las consecuencias que, posteriormente, recogerá en su resolución ${ }^{193}$.

Resalta la STC como dentro del imprescindible respeto al libre desarrollo de la personalidad $^{194}$ y al derecho a la intimidad ${ }^{195}$ se inscribe la conformación de la relación de convivencia al margen de la regulación de la institución matrimonial, así como la prohibición de interferencia alguna de los poderes públicos en el lícito ejercicio de esa libertad convivencial.

Dentro de esa libertad de decisión, adoptada en el marco de la autonomía privada de los miembros de la pareja, se incluye el poder de autorregulación del conjunto de derechos y obligaciones que habrán de regir la vida de la pareja, pudiendo establecer los pactos, cláusulas y condiciones que tengan por conveniente, dentro de los límites de la autonomía privada. Señalando la citad sentencia que "esta libertad debe ser respetada por el ordenamiento jurídico en todo caso, salvo que su ejercicio pudiera entrar en conflicto con valores constitucionales que justificaran su constricción"196. Es por ello que el propio Tribunal reconoce que el límite principal con que se encuentra el legislador al tratar de regular las uniones de hecho "es la propia libertad de los integrantes de la pareja y su autonomía privada, por lo que una regulación detallada de los efectos, tanto personales como patrimoniales, que se pretendan atribuir a esa unión, puede colisionar con la citada libertad, si se impusieran a los integrantes dela pareja unos efectos que, precisamente, los sujetos quisieron excluir en virtud de su decisión libre y constitucionalmente amparada de no contraer matrimonio. Por ello el régimen jurídico que el legislador puede establecer al efecto deberá ser eminentemente dispositivo y no imperativo, so pena de vulnerar la libertad consagrada en el art. 10.1 CE. De manera que únicamente podrán considerarse respetuosos de la libertad personal

\footnotetext{
${ }^{193}$ Ya en la STC 198/2012, de 6 de noviembre, el Alto Tribunal había señalado que el art. 32 CE deja un amplio margen al legislador no solo para configurar todo lo relativo al matrimonio, sino también para establecer regímenes de convivencia more uxorio paralelos al régimen matrimonial, pero con un reconocimiento jurídico diferenciado, lo que ha venido siendo realizado por el legislador autonómico.

${ }^{194} \mathrm{El}$ art. 10.1 CE establece que "La dignidad de la persona, los derechos inviolables que le son inherentes, el libre desarrollo de la personalidad, el respeto a la ley y a los derechos de los demás son fundamento del orden político y de la paz social", configurando, en consecuencia, el libre desarrollo de la personalidad como fundamento del orden constitucional español.

${ }^{195} \mathrm{El}$ art. 18.1 CE señala que "Se garantiza el derecho al honor, a la intimidad personal y familiar y a la propia imagen", este artículo de la Constitución fue desarrollado por la Ley orgánica 1/1982, de 5 de mayo, de protección civil del derecho al honor, a la intimidad personal y familiar y a la propia imagen, publicada en el BOE n. ${ }^{\circ} 115$ de 14 de mayo de 1982.

${ }^{196} \mathrm{FJ} 4$, párrafo $4 .^{\circ}$ de la citada STC.
} 
aquellos efectos jurídicos cuya operatividad se condiciona a su previa asunción por ambos miembros de la pareja" $" 197$.

Establece así el Constitucional el ámbito concreto de similitud y diferencia entre matrimonio y pareja de hecho, al situar la institución matrimonial en el ámbito de normas imperativas, libremente aceptadas por los cónyuges quienes quedan obligados a todos los extremos del denominado estatuto matrimonial, mientras que la unión de hecho, afectando a una misma realidad social, cual es la convivencia en pareja de dos personas compartiendo la vida y sus distintos avatares, pero en este caso por personas que han optado por hacerlo al margen de la institución matrimonial, entiende el Alto Tribunal, opinión que compartimos, que su regulación debe hacerse en el marco del Derecho dispositivo.

Sin embargo, como bien señala la citada Sentencia, ello no afecta a la adopción de "medidas legales que tutelen derechos fundamentales de los dos o de alguno de los componentes de la pareja de hecho, supuesto en el que se deberán tomar en cuenta los criterios generales sobre la necesidad, adecuación y proporcionalidad de las medidas atendiendo a los intereses en juego (...)”. Parece evidente que, en la relación de pareja sea matrimonial o convivencial, un derecho fundamental a respetar es el de igualdad ${ }^{198}$ de los miembros de la pareja, principio que deberá servirnos como guía en el enfoque de la solución jurídica a la cuestión de la regulación de las parejas de hecho que, libre y voluntariamente, decidan establecer unos pactos de convivencia que regulen los derechos y obligaciones entre los miembros de la pareja.

Precisamente, la razón por la que el TC tacha a la Ley 6/2000 de inconstitucional en diversos preceptos es la imperatividad de la Norma, el carácter preceptivo de diversos artículos lleva al Alto Tribunal a determinar que se conculca el principio de la libertad de decisión, afectando al libre desarrollo de la personalidad constitucionalmente consagrado. Es por ello que la Sentencia declara inconstitucionales todas aquellas partes de la norma autonómica que conllevan derecho y obligaciones que se imponen imperativamente a los miembros de la pareja, reconociendo la constitucionalidad del resto de la Ley en la que, entiende, se respeta la libre aceptación por los miembros de la pareja al requerir la previa y voluntaria solicitud de sus miembros para que resulte de aplicación.

\footnotetext{
${ }^{197}$ FJ 8, párrafo 6. ${ }^{\circ}$, de la STC.

${ }^{198} \mathrm{El}$ art. $14 \mathrm{CE}$ establece que "Los españoles son iguales ante la ley, sin que pueda prevalecer discriminación alguna por razón de nacimiento, raza, sexo, religión, opinión o cualquier otra condición o circunstancia personal o social”.
} 
Como consecuencia de esta línea de pensamiento, se declaró la inconstitucionalidad del art. 2.2, en el inciso "hayan convivido maritalmente, como mínimo, un período ininterrumpido de un año, salvo que tuvieran descendencia común, en cuyo caso bastará la mera convivencia, o salvo que (...)", también declaró la inconstitucionalidad del párrafo $2 .^{\circ}$ del mismo apartado del artículo 2 que precisaba que "En el caso de que un miembro de la pareja o ambos estén ligados por vínculo matrimonial, el tiempo de convivencia transcurrido hasta el momento en que el último de ellos obtenga la disolución o, en su caso, la nulidad, se tendrá en cuenta en el cómputo del período indicado de un año". Igualmente se declaró inconstitucional el inciso del art. 3 que, en relación con los requisitos de acreditación de la existencia de la pareja estable, exigía "y el transcurso del año de convivencia"; se declaraba 1 inconstitucionalidad del apartado 4. ${ }^{\circ}$ del art. 4 al ordenar, de modo imperativo, que "La extinción de la pareja estable implica la revocación de los poderes que cualquiera de los miembros haya otorgado a favor del otro"; del art. 5 se declara la inconstitucional del inciso del apartado 1. ${ }^{\circ}$ que, en los pactos sobre compensaciones económicas en los supuestos de ruptura de la pareja estable, daba libertad de pactos "respetando, en todo caso, los derechos mínimos contemplados en la presente Ley Foral, los cuales son irrenunciables hasta el momento en que son exigibles", inciso entrecomillado que imperativamente impone a los miembros de la pareja una regulación por encima, incluso, de sus propios pactos lo cual resulta claramente contradictorio con el imprescindible carácter dispositivo de las normas reguladoras de las parejas de hecho; igualmente, determinaba la inconstitucionalidad de los apartados 2, 3, 4 y 5 del art. 6 de la norma autonómica relativos a la reclamación de pensión periódica y compensación económica, por su indudable carácter imperativo, del mismo modo que se declaró inconstitucional el art. 7 relativo a la responsabilidad patrimonial, establecida de manera preceptiva como solidaria de los miembros de la pareja, del art. 9 al equiparar a pareja estable al matrimonio en aspecto tales como la tutela, la curatela, la incapacitación, la declaración de ausencia y la declaración de prodigalidad; se declaró inconstitucional, igualmente, el art. 1 al igualar, de manera preceptiva, la pareja estable al matrimonio en materia sucesoria; y la del art. 12.1 al igualar la pareja estable y el matrimonio en cuestiones fiscales. 


\section{País Vasco}

El art. 4 de la Ley 2/2003, de 7 de mayo ${ }^{199}$, reguladora de las parejas de hecho en el País Vasco, creaba el Registro de Parejas de Hecho con carácter administrativo, el cual tiene como objeto la inscripción de la constitución y extinción de las parejas de hecho, así como lo pactos y convenios en las que estas decidan regular sus relaciones económico-patrimoniales.

Al efecto, se promulgó el Decreto 155/2017, de 16 de Mayo $^{200}$, Reglamento regulador del Registro de Parejas de Hecho de la Comunidad Autónoma del País Vasco, que desarrolla la mencionada Norma, la cual regula los diferentes aspectos del citado registro y, en concreto, la tramitación del expediente para la inscripción de la constitución de la pareja de hecho, para lo que establece, en primer lugar, quienes están legitimados para solicitar la inscripción, para lo que se exige, entre otros el requisito de que, al menos uno de los componentes de la pareja, tenga vecindad civil vasca ${ }^{201}$, así como que la solicitud de inscripción como pareja de hecho debe efectuarse conjuntamente por ambos miembros de la pareja.

Todos los solicitantes de inscripción de parejas de hecho deben cumplimentar la solicitud, en documento normalizado, que contenga las siguientes menciones ${ }^{202}$ :
a) Nombre y apellidos de cada miembro de la parea.
b) DN, NIE o pasaporte de cada una de las personas.
c) Fecha de nacimiento de cada persona.
d) Nacionalidad o nacionalidades de cada persona.
e) Estado civil de cada miembro de la pareja.
f) Domicilio de la pareja.
g) Declaración responsable de cada una de las personas que componen la pareja de no estar unidas a otra persona por vínculo matrimonial, o en su caso, no estar constituida como pareja de hecho con otra persona distinta a aquella con la que se

\footnotetext{
${ }^{199}$ La Ley 2/2003, de 7 de mayo, reguladora de las Parejas de Hecho, fue publicada en el Boletín Oficial del País Vasco n. ${ }^{\circ} 100$ de 23 de mayo de 2003 y en el BOE n. 284 de 25 de noviembre de 2003.

${ }^{200}$ El Decreto 155/2017, de 16 de mayo, por el que se aprueba el Reglamento regulador del Registro de Parejas de Hecho de la Comunidad Autónoma del País Vasco fue publicado en el Boletín Oficial del País Vasco n. ${ }^{\circ} 100$ de 29 de mayo de 2017.

${ }^{201}$ En la Norma original se exigía vecindad administrativa vasca, pero fue modificado el art 2 de la Ley $2 / 2003$, de 7 de mayo, mediante la disposición adicional segunda de la Ley 5/2015, de 25 de junio, de Derecho Civil Vasco, pasando a exigir la vecindad civil.

${ }^{202}$ El art. 12 de Reglamento que regula el Registro de Parejas de Hecho de la Comunidad Autónoma del País Vasco establece los requisitos comunes de las solicitudes de inscripción.
} 
pretende la inscripción como pareja de hecho en el registro de parejas de hecho de la Comunidad Autónoma del País Vasco.

h) Declaración responsable de cada una de las personas que componen la pareja informando de los siguientes extremos:

- Que son ciertos y se dan por buenos los datos contenidos en la solicitud y documentación que le acompaña.

- Que son conocedores o conocedoras de los efectos que se derivan de la inscripción de la constitución como pareja de hecho.

i) El lugar y la fecha de presentación de la solicitud, y la firma de ambos miembros de la pareja.

En cuanto a la documentación a aportar junto a la solicitud de inscripción, acreditativa del cumplimiento de los requisitos establecidos en el art. 2 de la Ley se establece que los miembros de la pareja de hecho deben aportar, junto a la solicitud de inscripción, la siguiente documentación ${ }^{203}$ :

a) DNI, NIE o pasaporte de cada persona miembro de la pareja.

b) Acreditación del estado civil de cada una de las personas que componen la pareja, de conformidad con la normativa reguladora del Registro Civil.

c) Acreditación de la vecindad civil vasca en el momento de presentar la solicitud por, al menos, una de las personas integrantes de la pareja de hecho y por alguna de las siguientes formas:

- Personas con nacionalidad española de nacimiento y que residan en la Comunidad Autónoma del País Vasco:

- Acreditación del empadronamiento durante un período superior a 10 años inmediatamente anteriores a la fecha de presentación de la solicitud y certificación literal de nacimiento que acredítela inexistencia de declaración alguna manifestando la voluntad de o adquirir la vecindad civil vasca o, en su caso, la voluntad de mantener la vecindad civil anterior.

\footnotetext{
${ }^{203}$ El art. 13 del Decreto 155/2017, de 16 de mayo, por el que se regula el Reglamento regulador del Registro de Parejas de Hecho de la Comunidad Autónoma del País Vasco establece la documentación a aportar junto a la solicitud de inscripción.
} 
- Con periodo de residencia superior a 2 años inmediatamente anteriores a la fecha de presentación de la solicitud e inferior a 10, certificación literal de nacimiento en la que conste la voluntad de adquirir la vecindad civil vasca.

- Personas con nacionalidad española de nacimiento, y que no residan en la Comunidad Autónoma del País Vasco:

- Certificación literal de nacimiento en la que conste la adquisición de la vecindad civil vasca.

- En su defecto, acreditación del empadronamiento durante un período superior a 10 años inmediatamente anteriores a la fecha de presentación de la solicitud y certificación literal de nacimiento expedida por el Registro Civil.

- Personas extranjeras que hayan adquirido la nacionalidad española:

- Si al adquirir la nacionalidad española optaron por la vecindad civil vasca, certificado de adquisición de la nacionalidad española.

- Si al adquirir la nacionalidad española optó por una vecindad civil distinta a la vasca, se acreditará como la de las personas con nacionalidad española de nacimiento, en función del caso concreto en el que se encuentren.

d) En el caso de que una o las dos personas que componen la pareja sean menores de edad, certificado del Registro Civil acreditativo de la emancipación.

Estas solicitudes podrán, además, acompañarse de un pacto regulador de las relaciones económico-patrimoniales de la pareja, este pacto podrá establecerse en escritura pública o en documento privado, y deberá contar con la firma autógrafa de ambas personas componentes de la pareja.

Con carácter previo la legislación autonómica exige la comparecencia personal de los miembros de la pareja ante el encargado del registro de parejas de hecho de la Comunidad Autónoma del País vasco para que manifiesten su voluntad de inscribirse ${ }^{204}$, así como que reúnen los requisitos exigidos para su constitución como pareja de hecho y que son conocedores de los

\footnotetext{
${ }^{204}$ Esta exigencia vienes establecida por el art.14 del Reglamento regulador el Registro de Parejas de Hecho del País Vaco
} 
efectos que se derivan de la inscripción de la declaración. Se excepcionan de esta exigencia los supuestos de enfermedad grave o el ingreso en establecimiento penitenciario, en cuyo caso cabe el apoderamiento determinando la persona autorizada para actuar en nombre de la persona interesada ante el Registro de Parejas de Hecho y los actos concretos para los que se le faculta, con expresión, si es el caso, del pacto regulador de las relaciones económico-patrimoniales de la pareja por el que hayan optado.

\section{Comunidad Valenciana}

La Ley 5/2012, de 15 de octubre 205 , de uniones de hecho formalizadas de la Comunidad Valenciana fue declara inconstitucional en buena parte de su articulado por la STC 110/2016, de 9 de junio ${ }^{206}$. La mencionada norma ha sido actualizada desde entonces, pero sin entrar a regular los aspectos más importantes declarados inconstitucionales.

La vigente Ley autonómica crea, en su art. 3, el Registro de Uniones de Hecho formalizadas de la Comunidad Valenciana, concediendo carácter constitutivo a la inscripción registral, la cual solamente se producirá mediante resolución expresa del órgano competente para la gestión del mencionado registro administrativo dictada en el plazo de tres meses desde su presentación, ya que el silencio administrativo tiene carácter negativo, lo cual da lugar a los correspondientes recursos administrativos.

Hasta la promulgación de la ley de 2012 en la Comunidad Valenciana había estado vigente la Ley $1 / 2001$, de 6 de abril, de la Generalitat, por la que se regulan las uniones de hecho, que creó el Registro de Uniones de Hecho en la citada comunidad. Por ello, la disposición adicional única adicional contenida en la redacción original concedía un plazo de dos años para que las uniones de hecho inscritas en el mencionado registro pasasen a ser reguladas por la nueva ley, siempre que acreditasen el cumplimiento de los requisitos exigidos en el artículo 2 de la Ley 5/2012. ${ }^{207}$

\footnotetext{
${ }^{205}$ La Ley 5/2012, de 15 de octubre, de Uniones de Hecho Formalizadas de la Comunitat Valenciana se publicó en el Boletín Oficial de la Generalitat Valenciana n. $^{\circ} 6884$ de 18 de octubre de 2012 y en el BOE n. 268 de 7 de noviembre de 2012.

${ }^{206}$ La STC 110/2016, de 9 de junio de 2016, se publicó en el BOE n. ${ }^{\circ} 170$ de 15 de julio de 2016.

${ }^{207} \mathrm{La}$ redacción originaria de la citada disposición adicional única de la Ley 5/2012, de 15 de octubre, establecía diversas exigencias para la inscripción en el nuevo Registro de Uniones de Hecho formalizadas de la Comunitat Valenciana como eran la solicitud de los interesados de tal inscripción, a la vez que se exigía la acreditación del cumplimiento de los requisitos en el plazo de dos años, pero se seguía un procedimiento administrativo que finalizaba con la correspondiente resolución administrativa, en el entendido que el silencio administrativo en el procedimiento tenía efectos negativos, y todo ello sin que se reconociese la existencia de la unión de hecho desde la inscripción n el antiguo registro sino con efectos desde la entrada en vigor de la Ley 5/2012, es decir, desde el 18 de noviembre de 2012.
} 
Con la redacción actual de la mencionada disposición adicional las uniones de hecho inscritas en el antiguo Registro de Uniones de Hecho conforme a la Ley 1/2001 y el decreto 61/2002, de 22 de abril, del Consell, por el que se aprobó el reglamento de desarrollo de la citada Ley, "se integrarán de oficio y de modo automático en el Registro de Uniones de Hecho Formalizadas de la Comunitat Valenciana" contemplado en la Ley 5/2012, de 15 de octubre. ${ }^{208}$

La disposición transitoria única de la vigente Ley 5/2012, establece que, hasta que el Consell apruebe el reglamento del nuevo registro, lo que no ha ocurrido a la fecha de escribir estas líneas, dicha inscripción se realizará en el Registro de Uniones de Hecho de la Comunitat creado por la ley derogada.

El procedimiento que establece el citado decreto para la inscripción de las uniones de hecho ${ }^{209}$ se inicia mediante la correspondiente solicitud formulada por ambos interesados, que debe consignar declaración responsable de no tener otra unión estable con otra persona, de no tener entre sí relación de parentesco en línea recta por consanguinidad o adopción, ni en línea colateral por consanguinidad o adopción dentro del tercer grado, además deberá acompañarse la solicitud con los siguientes documentos:

a) Documentación acreditativa de la identificación de los solicitantes.

b) Acreditación de la emancipación, en su caso.

c) Certificación del estado civil de ambos solicitantes.

d) Certificación del empadronamiento acreditativa que, al menos uno de los solicitantes, tiene la condición de vecino de algún municipio de la Comunitat Valenciana.

e) En su caso, sentencia de incapacitación que les considera con capacidad suficiente para contraer matrimonio.

Una vez presentada la solicitud acompañada de la documentación correspondiente los miembros de la pareja deben comparecer personal y conjuntamente ante el encargado del registro administrativo de uniones de hecho de la Comunitat Valenciana para acreditar su voluntad de

\footnotetext{
${ }^{208}$ Nueva redacción de la disposición adicional dada por el artículo 63 de la Ley 27/018, de 27 de diciembre, de medidas fiscales, de gestión administrativa y financiera y de organización de la Generalitat, con entrada en vigor el $1 .^{\circ}$ de enero de 2019.

${ }^{209} \mathrm{El}$ procedimiento para la inscripción de las uniones de hecho se establece en los arts.13 a 18 del Decreto 61/2002, de 23 de abril, del Consell, por el que se aprueba el Reglamento de desarrollo de la Ley 1/2001, de 6 de abril de la Generalitat Valenciana, por la que se regulan las uniones de hecho.
} 
constituir pareja de hecho. No obstante, será suficiente la comparecencia de uno solo de los miembros de la pareja siempre que se aporte escritura pública en la que conste que ambos miembros manifiestan su voluntad de constituir la unión de hecho, o bien que el otro miembro no compareciente personalmente lo haga mediante apoderado con poder especial.

La norma prohíbe que cualquiera de los miembros de la unión de hecho se atribuya la representación del otro sin que la misma le haya sido expresamente conferida. Y, en cuanto al modo de acreditar la convivencia libre, pública, notoria e ininterrumpida de la relación de afectividad se admite la prueba mediante dos testigos, mayores de edad y en pleno uso de sus derechos civiles.

Una vez más la manifestación de voluntad emitida ante notario sustituye la emisión de voluntad ante el encargado del registro, de modo que se considera suficiente la emisión de voluntad ante el notario, si bien, al igual que en el matrimonio, el acta de la manifestación debe ser aportada al registro correspondiente, en este caso, al Registro de Uniones de Hecho de la Comunitat Valenciana.

Por su parte la STC 110/2016, de 9 de junio, declaró la inconstitucionalidad de una parte importante de la Ley 5/2012, de 15 de octubre, de uniones de hecho formalizadas de la Comunitat Valenciana, por razones de competencia. La sentencia del Alto Tribunal declaró la nulidad de diversos preceptos de la Ley por invadir competencias exclusivas del Estado, al regular derechos y obligaciones de la unión de hecho formalizada, de naturaleza civil,

los siguientes artículos de la Ley: el art. 6, que bajo la rúbrica 'efectos de la extinción de la unión de hecho formalizada' dispone en tal caso la 'revocación automática de los poderes que cualquiera de sus miembros hubiera otorgado a favor del otro'; el artículo 7, que establece la 'libertad de regulación' de las 'relaciones personales y patrimoniales derivadas de la convivencia'; el artículo 8 ('gastos comunes de la unión de hecho formalizada'); el artículo 9, que regula el 'derecho de alimentos' entre los convivientes; el artículo 10 ('disposición de la vivienda habitual de la unión de hecho'); el artículo 11 ('responsabilidad patrimonial'); el artículo 12, que regula el destino del 'ajuar doméstico y uso de la vivienda' tras el fallecimiento de uno de los convivientes; el artículo 13 ('representación legal de la persona conviviente'); y el artículo 14 ('derechos de la persona conviviente supérstite en la sucesión de la persona premuerta'). Todos estos preceptos, al contener normas para las que la Comunidad Valenciana no ostenta competencia, son inconstitucionales y deben ser declarados nulos. 
El artículo 2, que regula el «ámbito de aplicación» de la Ley haciéndolo depender de la «vecindad civil» de «las partes», debe ser igualmente anulado, pues una vez desprovista la Ley de su contenido civil, su ámbito de aplicación debe atenerse al «principio de territorialidad de las competencias» que este Tribunal ha declarado «implícito al propio sistema de autonomías territoriales» [por todas, STC 80/2012, de 18 de abril, FJ 7 b)] y que recoge expresamente el art. 7.2 EAV/2006.

b) En cuanto a los demás preceptos de la Ley, el artículo 1 solamente resulta inconstitucional en el inciso que da soporte a la normativa civil comentada, pero no en su integridad; el resto del precepto puede seguir dando soporte a las normas válidas de la Ley. ${ }^{210}$

A ello hay que añadir la nulidad declarada del inciso "los derechos y deberes de quienes son miembros" del art. 1.1 de la ley, de manera que el fallo de la mencionada sentencia declaraba la inconstitucionalidad y nulidad "de los siguientes artículos de la Ley 5/2012, de 15 de octubre, de uniones de hecho formalizadas de la Comunitat Valenciana: el artículo 1.1, en el inciso «los derechos y deberes de quienes son miembros»; $\operatorname{los}$ artículos 2, 6, 7, 8, 9, 10, 11, 12, 13 y 14.” Todo ello en una norma con quince artículos, una disposición adicional, una disposición transitoria, una disposición derogatoria y tres disposiciones finales, de manera que deja la ley valenciana vacía de contenido, en la práctica.

En la citada sentencia consta el voto particular del magistrado D. Juan Antonio Xiol Ríos, al entender que "la regulación de determinados aspectos de la normativa valenciana sobre uniones de hecho (i) se funda en una competencia reconocida inequívocamente en la reforma del Estatuto de Autonomía de la Comunitat Valenciana; (ii) los derechos históricos en materia de instituciones privadas son reconocidos por el TC cuando se consagran en un estatuto de autonomía; y (iii) aunque no fuera así, dentro de las competencias ordinarias en materia de Derecho civil, la Comunitat Valenciana puede regular esta materia"211.

\footnotetext{
${ }^{210} \mathrm{FJ} 7$ a) y b) de la STC 110/2016, de 9 de junio, fundamento en el que concluye el razonamiento sobre las razones de la falta de competencia de la Comunidad Valenciana para regular derechos y obligaciones de carácter civil.

${ }^{211}$ Esta misma línea argumental había sido desarrollada por el mismo magistrado en su voto particular a la STC 82/2016, de 28 de abril, en que se resolvió el recurso de inconstitucionalidad número 9888-2007 interpuesto contra la Ley 10/2007, de 20 de marzo, de régimen económico matrimonial valenciano, en las que el magistrado se manifestó a favor de la constitucionalidad de las competencias que ostenta la Comunidad Valenciana en materia de derecho civil foral referidas la regulación del matrimonio.
} 
Desde la publicación de la sentencia las modificaciones realizadas en la norma reguladora de las uniones de hecho formalizadas en la Comunitat Valenciana han sido de escasa incidencia, con excepción de la nueva formulación de la disposición adicional única ya comentada.

\section{Ciudad Autónoma de Ceuta}

En la Ciudad Autónoma de Ceuta se creó un Registro de Uniones de Hecho del Ayuntamiento de Ceuta por acuerdo del pleno de la Asamblea de 11 de abril de $1997^{212}$ en el que se aprobaba su reglamento regulador. Para la inscripción de la pareja de hecho es necesaria la presentación de la correspondiente solicitud acompañada de la documentación acreditativa del cumplimiento de los requisitos establecidos en la mencionada Norma.

Los requisitos establecidos en la norma de la ciudad de Ceuta para constituir la unión de hecho son los siguientes ${ }^{213}$ :

a) Otorgar pleno y libre consentimiento para la unión de convivencia no matrimonial.

b) Ser mayor de edad o menores emancipados.

c) No tener entre sí relación de parentesco por consanguinidad o adopción en línea recta o colateral en tercer grado.

d) No encontrarse incapacitado para dar el consentimiento necesario para llevar a efecto el acto o declaración objeto de inscripción.

e) No estar sujeto a vínculo matrimonial.

f) No constar inscrito como integrante de una unión de hecho no matrimonial en ningún otro registro de similares características.

A estos requisitos debe añadirse la exigencia de que ambos miembros de la unión estén empadronados en la ciudad de Ceuta, así como la exigencia de la comparecencia personal y conjunta de ambos miembros de la pareja, ante el negociado correspondiente. La solicitud debe ir suscrita por ambos miembros de la pareja y será acompañada de la siguiente documentación acreditativa del cumplimiento de los requisitos señalados:

a) Copia de los DNI o pasaportes.

b) Acreditación de la emancipación (en caso necesario).

\footnotetext{
${ }^{212}$ El Reglamento sobre Uniones de Hecho de la Ciudad de Ceuta fue publicado en el Boletín Oficial de la Ciudad de Ceuta núm 3.755 de 24 de septiembre de 1998, con el número de publicación 2.670.

${ }^{213}$ Art. 5 del Reglamento Regulador del Registro de Uniones de Hecho de la Ciudad Autónoma de Ceuta.
} 
c) Certificado del estado civil y, en su caso, prueba de la disolución de los anteriores vínculos.

d) Certificado de empadronamiento de ambos miembros de la unión en el municipio de Ceuta.

e) Declaración jurada de no tener una relación de parentesco por consanguinidad o adopción en línea recta o colateral de tercer grado.

f) Declaración jurada de no constar inscrito en otro registro de características similares.

En el mencionado registro se inscriben también los convenios reguladores de las relaciones entre los miembros de la pareja y las declaraciones que afecten de forma relevante a la unión no matrimonial, que no sean susceptibles de inscripción en otro registro público y no sean contrarias al ordenamiento jurídico.

\section{Ciudad Autónoma de Melilla}

La Asamblea de la Ciudad Autónoma de Melilla aprobó, con fecha 28 de enero de $2008^{214}$, el Reglamento Regulador del Registro de Parejas de Hecho de la Ciudad Autónoma de Melilla. El registro tiene carácter administrativo y la inscripción en el mismo es totalmente voluntaria, pudiendo inscribirse las uniones no matrimoniales de convivencia estable de parejas, para lo que se requiere la solicitud conjunta de los miembros que constituyen la unión de hecho, acreditando el cumplimiento de los siguientes requisitos ${ }^{215}$ :

a) Identificación de los miembros de la unión de hecho. Lo que se acreditará con copia del DNI, pasaporte u otra documentación identificativa.

b) Ser mayores de edad o menores emancipados.

c) No tener relación de parentesco por consanguinidad o adopción en línea recta o línea colateral en segundo grado. Lo que se acreditará mediante la correspondiente declaración responsable.

\footnotetext{
${ }^{214}$ El Reglamento Regulador del Registro de Parejas de Hecho de la Ciudad Autónoma de Melilla, de 28 de enero de 2008, se publicó en el Boletín Oficial de Melilla n..$^{\circ}$ 4474, de 1 de febrero de 2008.

${ }^{215}$ Los requisitos para la constitución de las parejas de hecho vienen establecidos en el art. 4.1 del Reglamento de 28 de enero de 2008.
} 
d) No estar incapacitados para contraer matrimonio. Los afectados por deficiencias o anomalías psíquicas deberán aportar certificación médica sobre su capacidad para prestar libre consentimiento.

e) No estar sujetos a vínculo matrimonial. Lo que se acreditará mediante la correspondiente declaración responsable.

f) No figurar inscrito en ningún Registro como miembro de otra unión de hecho no cancelada. Lo que se acreditará mediante declaración responsable.

g) Tener ambos miembros su residencia legal en Melilla y estar debidamente empadronados. Se acreditará mediante los certificados de empadronamiento y documentos acreditativos de la residencia legal.

h) Haber mantenido una convivencia, en relación de afectividad, libre, pública, notoria y estable durante al menos un período continuado de un año. La acreditación de la convivencia ininterrumpida requerirá la personación de los interesados ante el encargado del registro acompañados por dos testigos mayores de edad, que estén en el pleno ejercicio de sus derechos civiles. Asimismo, se podrá presentar documento notarial que acredite el requisito exigido de convivencia en los términos previstos en el presente apartado o acreditación de tener descendencia común.

En su condición de registro administrativo, una vez recibida la solicitud con la documentación acreditativa del cumplimiento de los requisitos, se conceden los plazos administrativos de subsanación de errores $y$, una vez cumplidos la totalidad de los requisitos exigidos se dictará la resolución, frente a la cual caben los recursos administrativos procedentes.

\section{De los pactos entre convivientes}

Pese a que, en una primera época, siguiendo la teoría de la causa ilícita ${ }^{216}$ se reconoció la nulidad e ilicitud de los convenios reguladores de las parejas de hecho, se trata de una etapa bastante lejana en el tiempo ${ }^{217}$.

\footnotetext{
${ }^{216}$ Según esta teoría, y siguiendo lo exigido por el art. 1275 del CC de que será ilícita la causa cuando se opone a las leyes o a la moral, se entendía que en las uniones entre compañeros el contrato es nulo por ilicitud de la causa. Se considera ilícita la causa cuando el contrato pretende el mantenimiento de unas relaciones inmorales; en cambio, se considera válido el contrato cuando la pretensión del mismo es indemnizar a la mujer en cumplimiento de una obligación moral, cual es la atribución patrimonial por razón de la seducción efectuada por el hombre.

${ }^{217}$ MARTÍN MOLINA, A.A.: Efectos de la ruptura de las parejas de hecho (tesis doctoral). Universidad de Granada (2017), pág. 117.
} 
En la actualidad se puede considerar superada la denominada teoría de la causa ${ }^{218}$ ampliamente utilizada en el pasado por nuestra jurisprudencia, al entender que procede una concepción objetiva de la causa, en los términos señalados por el art. 1274 del CC, de modo que, al no identificar la causa del contrato con los motivos de los convivientes para celebrarlo, el negocio jurídico ha de considerarse plenamente eficaz.

Así pues, dado que no existe norma alguna que prohíba contratar a las personas que mantienen una unión de hecho y, exceptuando únicamente aquellos casos en que los convivientes sean incapaces o menores de edad, los convenios celebrados son perfectamente válidos ${ }^{219}$, como nos lo acredita que parte de las normas autonómicas contemplan la libertad de pactos entre los convivientes como modo de regular la vida en pareja. Ahora bien, habrá de tenerse en cuenta que únicamente podrán considerarse respetuosos de la libertad personal aquellos efectos jurídicos cuya operatividad se condiciona a su previa asunción por ambos miembros de la pareja ${ }^{220}$.

Por lo que, siendo los convivientes quienes, en uso de su autonomía de la voluntad consagrado en el artículo $1255 \mathrm{del} \mathrm{CC}^{221}$, pueden determinar, mediante los pactos que tengan por conveniente, el modo de regular su vida en común, dichos pactos deberán ser respetados, tanto en los aspectos que afectan al desarrollo de la vida cotidiana de la pareja como en lo que pudieran haber establecido para el supuesto de ruptura de la pareja.

Habrá de tenerse en cuenta que los deberes propios del matrimonio, tales como la obligación de guardarse fidelidad, el de vivir juntos o el deber de socorro mutuo, entre otros, afectan a los derechos fundamentales de la persona por lo que no podrían ser objeto de pacto, sino que serán cumplidos de manera libre y voluntaria por los miembros de la pareja, pero sin establecer ningún tipo de regulación obligatoria al respecto, pues tales aspectos quedan fuera de la posibilidad de pactos entre las partes.

\footnotetext{
${ }^{218}$ Esta concepción subjetiva de la causa venía a identificar la causa con los motivos que llevaban a los miembros de la pareja a celebrar el contrato, de modo que, al presumir que mediante ese contrato se favorecía una relación ilícita, declaraba nulo el contrato.

${ }^{219}$ MESA MARRERO, C.: Op. cit., pág. 88.

${ }^{220}$ DE AMUNÁTEGUI RODRÍGUEZ, C.: "La situación actual de las parejas no casadas", en InDret: Revista para el análisis del Derecho, Barcelona (julio 2015), págs. 24-25.

${ }^{221}$ En la actualidad el único motivo que podría conducir a limitar esa autonomía de las partes sería que se considerase que la convivencia extramatrimonial es inmoral, algo absolutamente impensable en la sociedad actual. Solamente si en los pactos se atentase contra la libertad, la dignidad o el derecho a la intimidad de cualquiera de los miembros de la pareja el contrato sería nulo, pues el art. 1271 del CC prohíbe la contratación de las cosas que están fuera del comercio de los hombres, como son los derechos fundamentales de la persona.
} 
Por lo tanto, los pactos entre los convivientes más que a regular los aspectos personales de la convivencia se dirigirán a regular los aspectos patrimoniales de la misma, tanto los que regirán durante la vida en común de los mismos, como para el supuesto de ruptura de la relación de convivencia. Más adelante analizaremos los aspectos patrimoniales susceptibles de pacto entre los convivientes.

\section{La actuación del notario en la formalización de parejas que conviven maritalmente}

Entre los distintos modos contemplados en la vigente legislación y, en concreto, desde julio de 2015 con la publicación y entrada en vigor de la Ley de Jurisdicción Voluntaria, los ciudadanos pueden acudir a los notarios españoles para contraer matrimonio, separarse o divorciarse.

Incluso, próximamente, las parejas que deseen contraer matrimonio podrán tramitar el expediente matrimonial en la notaría. Pero ya en este momento los notarios están autorizados para la celebración de todos los matrimonios civiles, matrimonio que celebrarán del mismo modo que cualquier otro oficiante mediante la lectura de los artículos correspondientes del CC, con la presencia de dos testigos y otorgando la correspondiente escritura pública de matrimonio tras el "sí quiero" de los contrayentes. Esta escritura pública será remitida por el notario al Registro Civil correspondiente para su inscripción.

También pueden los notarios intervenir en los procesos de separaciones y divorcios de mutuo acuerdo y sin hijos menores no emancipados o que tengan una discapacidad y dependen de sus padres. Bastará para ello que el matrimonio acuda a la notaría acompañados de abogado y con un convenio regulador redactado. Tras lo cual el notario comprobará y dará fe de que los cónyuges son plenamente conscientes del convenio acordado, que el mismo es equitativo para las partes, y que no conculca el principio de igualdad entre los cónyuges. Tras ello se firmará la escritura de divorcio, que el notario comunicará al Registro Civil.

Pues bien, también puede el notario formalizar una unión de hecho, para lo cual el notario redactará la escritura pública en la que ambos reconocerán convivir de forma marital pudiendo asesorarles sobre las posibilidades para regular la economía interna de la pareja u otras cuestiones jurídicas. En cuanto a los requisitos exigidos por el notario para la constitución de la pareja de hecho serían el de la mayoría de edad o emancipación, no estar casados ni ser pareja de otra persona, estar empadronados al menos uno de los miembros de la pareja en la comunidad autónoma en la que tendrá lugar la declaración formal y manifestar públicamente su compromiso. Con tales 
requisitos el notario estaría habilitado para redactar la escritura pública de formalización de unión de hecho.

En cuanto a la disolución de la pareja de hecho también es posible formalizar la ante notario en escritura pública. En algunas CCAA se exige la asistencia de ambos miembros de la pareja para otorgar la escritura de disolución mientras que en otras comunidades bastará con que uno de ellos acuda a la notaría y notifique fehacientemente al otro su decisión de ruptura.

Como es fácilmente comprobable en ambas formas de unión de parejas, el notario es un mismo funcionario que, en el caso del matrimonio, se considera habilitante para acreditar la solemnidad del compromiso de unión de dos personas, en cambio ese mismo funcionario no parece dotar de solemnidad suficiente al acto de formalización de la unión en los casos de parejas de hecho. La conclusión parece obvia es simplemente una cuestión de opción legislativa el que se siga señalando que la unión de hecho registrada incumple el requisito de solemnidad propio del matrimonio $^{222}$.

\section{De la unión de hecho como un modo de familia}

No existe en nuestro derecho positivo una definición concreta de qué debe entenderse por familia. La idea de familia es tributaria en cada momento histórico de una serie de condicionamientos sociales y se resiste a ser encajonada en una noción concreta que no se plantee con grandes dosis de generalización e imprecisión. Por ello, no existe precepto alguno en la Constitución ni en la legislación ordinaria en la que, de forma precisa, se establezca con carácter general qué es una familia o cómo deben ser las familias ${ }^{223}$. Es decir, la familia constituye un modo de organización social que se configura, en cada momento histórico, en función de las distintas creencias, tradiciones y modelos de comportamiento existentes ${ }^{224}$.

Dejando a un lado las connotaciones sociológicas del término familia que dificultan en gran medida su precisión jurídica, la inclusión de las uniones de hecho dentro del concepto de familia recogido en el artículo $39 \mathrm{CE}$ ha sido una de las cuestiones más discutidas por la doctrina que ha tratado este tema. Actualmente, la mayor parte de la doctrina y de la jurisprudencia considera que

\footnotetext{
${ }^{222}$ Lo señalado en el presente apartado recoge la información facilitada por el Consejo General del Notariado en un folleto informativo a disposición de los usuarios de los servicios de las Notarías, que se incorpora como anexo.

${ }^{223}$ LASATE ÁlVAREZ, C.: Op. cit., pág. 3.

${ }^{224}$ MESA MARRERO, C.: Op. cit., pág. 47.
} 
la familia a la que se refiere el artículo $39 \mathrm{CE}$ no se reduce a la matrimonial, sino que incluye otros tipos de núcleos familiares entre los que se encuentra la convivencia more uxorio ${ }^{225}$.

El artículo 39 de la CE establece la obligación de los poderes públicos de asegurar la protección social económica y jurídica de la familia, pero no señala a ningún modelo de familia en concreto, y si bien la familia tradicional, establecida mediante el matrimonio heterosexual sigue siendo especialmente importante en España, no es menos cierto que, en los últimos tiempos, han surgido otros modelos familiares como las familias monoparentales, tanto paternas como maternas, las familias "reconstituidas" a partir de rupturas anteriores, destacando el importante crecimiento de los segundos matrimonios, así como las unidas por vínculos jurídicos, es decir las familias formadas por parejas no casadas ${ }^{226}$.

Ya la STC de 18 de mayo de 1992 establecía en su FJ 3º lo siguiente "las uniones libres, aunque están carentes de precisa normativa, no por ello son totalmente desconocidas por nuestro ordenamiento jurídico. La Constitución no las prevé, pero tampoco expresamente las interdicta y rechaza y así se desprende de la lectura de su artículo 32 en relación al 39, que se proyecta a la protección de la familia en forma genérica, es decir como núcleo creado tanto por el matrimonio, como por la Unión de hecho; lo que ha llevado al Tribunal de casación de Italia a pronunciar la importante sentencia De dos de febrero de 1977 qué vino a reconocer la familia di fatto. Como grupo social que desempeña una función en la educación y mantenimiento de sus miembros, digno de protección, conforme el artículo 2 de su Constitución. de esta manera si bien no se equiparó estas situaciones a las familias legalmente constituidas, No por eso las margina cuando presentan situaciones de darse una efectiva Comunidad de vida, que la legislación de dicho país Mediterráneo tiene en cuenta cómo 'cohabitación notoria"'227.

En este contexto debemos entender generalmente admitida la protección de la familia en sentido amplio recogida el artículo 39 de la CE. Pese a que no es pacífico en la doctrina, se puede entender cómo muy mayoritaria la interpretación de que no es posible, en la actualidad, identificar a la familia fundada en el matrimonio como la protegida de manera exclusiva por la Constitución;

\footnotetext{
${ }^{225}$ ANDREU MARTÍNEZ, B.: "Unión de hecho y vivienda: soluciones en la jurisprudencia", en Revista jurídica de la Región de Murcia n. ${ }^{\circ} 123$ (1997), págs. 17-18.

${ }^{226}$ RIVAS VALLEJO P. y VILLAGRASA ALCAIDE C.: Revista del Ministerio de Trabajo y Asuntos Sociales n. ${ }^{\circ}$ 57, Madrid (2005), pág. 507.

${ }^{227}$ [STS 18-5-1992 (RJ 1992/4907)].
} 
los defensores de esta interpretación amplia sostienen que la norma constitucional tutela la familia independientemente de si es o no matrimonial.

Los defensores de esta teoría señalan que al utilizar la CE un concepto amplio de familia y dado que no prima a la familia matrimonial, debe afirmarse que la protección dispuesta en el artículo 39 de la CE no puede limitarse a la familia constituida sobre el matrimonio. Asimismo, considerando que no existe un modelo jurídico de familia, sino que, por el contrario, son los hábitos culturales de la sociedad los que van determinando los grupos familiares que, por su importancia en la misma, deben ser protegidos por el derecho, se puede afirmar que sería indiferente el modo de constitución de la familia, ya que cualquiera que fuera este, merece ser protegido por los poderes públicos.

También esgrimen como argumentos en favor de que la protección constitucional de la familia no se refiere exclusivamente a la matrimonial, sino que también abarca a la extramatrimonial el hecho de que, el texto constitucional no prohíbe este modo de convivencia y, además, en ningún precepto se exige que la familia deba constituirse necesariamente sobre el matrimonio, puesto en el artículo 32 solo se establece la igualdad jurídica para contraer matrimonio, pero no una obligación.

En definitiva, parece claro que la redacción del artículo 39 admite una interpretación amplia de la familia que deben proteger los poderes públicos y, por tanto, el amparo constitucional que se dispensa incluye también a la Unión de hecho como otra forma de convivencia estable que se desarrolló en nuestra sociedad y que es tan digno de protección como la familia matrimonial. ${ }^{228}$

El propio TC tras una vacilante jurisprudencia determina en su sentencia 222/1992, de 11 de diciembre, FJ 5." que "Nuestra Constitución no ha identificado la familia a la que manda proteger con la que tiene su origen en el matrimonio, conclusión que se impone no solo por la regulación bien diferenciada de una institución y otra (arts. 32 y 39), sino también, junto a ello, por el mismo sentido amparador o tuitivo con el que la norma fundamental considera siempre a la familia y, en especial, el repetido artículo 39, protección que responde a imperativos ligados al carácter social de nuestro Estado (arts. 1.1 y 9.2) y a la atención, por consiguiente, De la realidad efectiva de los modos de convivencia que en la sociedad se expresen. El sentido de estas normas constitucionales no se concilia, con la constricción del concepto de familia a la de origen matrimonial, relevante que sea nuestra cultura - en los valores y en la realidad de los

\footnotetext{
${ }^{228}$ MESA MARRERO, C.: Op. cit., págs. 54-55.
} 
comportamientos sociales - esa modalidad de vida familiar. Existen otras junto a ella, como corresponde a una sociedad plural, y ello impide interpretar en tales términos restrictivos una norma como la que se contiene en el art. 39.1, Cuyo alcance, por lo demás, ha de ser comprendido también a la luz de lo dispuesto en los apartados 2 y 3 del mismo artículo.

Del propio art. 39.1 no cabe derivar, por lo tanto, una diferenciación necesaria entre familias matrimoniales y no matrimoniales (...)"229.

Esta misma línea doctrinal ha sido seguida por los Tribunales ordinarios que, en los distintos órdenes jurisprudenciales y no solo en el orden civil, han tenido ocasión de pronunciarse y que, han señalado que la protección constitucional de la familia alcanza no solo a la de origen matrimonial $^{230}$.

En suma, en la sociedad actual parece no existir discusión trascendente sobre la realidad como familia de las constituidas en las convivencias more uxorio, así como de que estas familias han de tener el mismo nivel de protección por los poderes públicos que las familias constituidas por vía de matrimonio.

La realidad social de esta forma de convivencia ha conllevado cambios legislativos tanto en el orden civil como en el Derecho público. Esto se pone de manifiesto en múltiples Normas ${ }^{231}$

${ }^{229}$ STC 222/1992, de 11 de diciembre, de la que fuera ponente el Magistrado D. Vicente Gimeno Sendra, y que ya había puesto voto particular en la STC 184/1990, que se había pronunciado en sentido contrario. La jurisprudencia transcrita ha sido seguida, posteriormente, por otras sentencias del TC.

${ }^{230}$ La [STSJM 12-5-2016 (JT 2016/1006)], en su FJ segundo cita la lejana [STS 8-2-2002 (RJ 2002/1928)] en la que ya este Alto Tribunal había dicho "Es verdad que en nuestros días existen situaciones de convivencia more uxorio no prohibidas por la ley e, incluso, en algún aspecto, amparadas por ella, lo cual no es el caso del impuesto de sucesiones. Es cierto, también, que la moderna tendencia social es atribuir la máxima plenitud de efectos a estas situaciones, tendencia a la que no es ajena a esta Sala, pero que para cualquier Tribunal tiene el límite insalvable del sometimiento a la ley".

${ }^{231}$ Algunos ejemplos de lo dicho serían los siguientes: incluyen a la pareja de hecho como presupuesto necesario para la aplicación de la regulación contenida en cada precepto en cuestión, en materia civil, el CC se refiere a las parejas de hecho, en el artículo 101.1, como causa extintiva de la pensión compensatoria, en el artículo 320. 1, como causa que posibilita la emancipación judicial de los mayores de dieciséis años y, en el artículo 831.5, como causa que origina la pérdida de la facultad de mejorar que se otorga al cónyuge; Ley 30/1981, de 7 de julio, por la que se modifica la regulación del matrimonio y se determina el procedimiento a seguir en las causas de nulidad, separación y divorcio, Disposición Adicional Tercera, que le concede el derecho a las prestaciones de la Seguridad Social; así como, a la pensión de viudedad; Ley 21/1987, de 11 de noviembre, por la que se modifican determinados artículos del CC y de la Ley de Enjuiciamiento Civil en materia de adopción, Disposición Adicional $3^{\mathrm{a}}$, que les atribuye la misma capacidad de los cónyuges para adoptar simultáneamente; Ley 29/1994, de 24 de noviembre, de Arrendamientos Urbanos, artículos $12.4,16.1$. b) y 24.1 , que le otorgan la posibilidad de subrogarse inter vivos o mortis causa, así como, la posibilidad de realizar obras en la vivienda por minusvalía; Ley 50/2002, de 26 de diciembre, de Fundaciones, artículo 3 , que establece la prohibición de crear fundaciones cuya finalidad sea destinar sus prestaciones, entre otros, a su cónyuge a la persona ligada con análoga relación de afectividad, y la Ley 22/2003, de 9 de julio, Ley Concursal, artículo 93. 1, que considera como personas especialmente relacionadas con el concursado, entre otras, al cónyuge del concursado o quien hubiera sido dentro de los dos años anteriores a la declaración de concurso, o a las personas que 
y, de manera especial, en el ámbito del Derecho público en el que puede afirmarse que en la actualidad existe una gran asimilación entre las uniones de hecho y el matrimonio.

También se manifiesta esta misma tendencia, aunque de manera menos acusada, en el ámbito propio del Derecho privado ${ }^{232}$, en especial en todos los aspectos de protección de la familia, en los que se ha seguido el mandato constitucional de protección con una tendencial equiparación entre los distintos modos de constitución del grupo familiar. No obstante, subsisten aspectos fundamentales de la relación de convivencia en los que no existe equiparación alguna, de forma señalada en el momento de la extinción de la pareja de hecho.

\section{H) DE LA EXTINCiÓn dE LA PAREJA DE HECHO}

En la totalidad de las regulaciones autonómicas se viene estableciendo las causas de extinción de las parejas de hecho, siendo coincidentes los distintos sistemas autonómicos en configurar como causas de extinción:

convivan con análoga relación de afectividad. En lo que a otras materias, distintas a la civil, se refiere, LO 1/1979, de 26 de septiembre, Ley General de Penitenciaría, artículos 52 y 53, que recogen el régimen de comunicación y visitas de parientes y familiares, entre los que se incluye a la persona íntimamente relacionada con el preso o el detenido; Ley 51/1984, de 26 de marzo, reguladora del derecho de asilo y de la condición de refugiado, artículo 10. 1, modificado por la Ley 9/1994, de 19 de mayo, que, por extensión, concede el asilo a los ascendientes, y descendientes en primer grado y al cónyuge del refugiado, o a la persona con la que se halle ligado por análoga relación de afectividad y convivencia; LO 6/1984, de 24 de mayo, de regulación del procedimiento de Hábeas Corpus, artículo 3. a), que otorga la posibilidad de iniciar este procedimiento, entre otros, al privado de libertad, su cónyuge o persona unida por relación de afectividad; LO 6/1985, de 1 de julio, del Poder Judicial, el artículo 219. 1/ 2, y, 389-397, en los que la situación de hecho asimilable a la matrimonial se recoge como criterio subjetivo que determina la abstención, recusación, incompatibilidad y prohibición de jueces y magistrados; LO 19/1994, de 23 de diciembre, de Protección de Testigos y Peritos en Causas Criminales, artículo 1. 2; LO 10/1995, de 23 de noviembre, del Código Penal, artículos $23,153,424,443,444,454$ y 617.2 , como criterio para atenuar, agravar, eximir o tipificar los delitos que en cada uno de los preceptos citados se señalan; la Ley 35/1995, de 11 de diciembre, de Delitos Violentos y contra la Libertad Sexual, artículo 2, en la que tienen la consideración de víctimas indirectas (por tanto, podrán ser beneficiarios de las ayudas públicas que, en su caso, se estimen), y, por último, el RD Legislativo 8/2015, de 30 de octubre, por el que se aprueba el texto refundido de la Ley General de la Seguridad Social en cuyo artículo 221.1 el derecho a la pensión de viudedad de las parejas de hecho. Si bien estableciendo una serie de condiciones para la consideración de la existencia de la pareja de hecho inscritas en un registro público específico.

232 A modo de ejemplo, en la Ley 21/1987, de 11 de noviembre, por la que se modifican determinados artículos del CC y de la Ley de Enjuiciamiento Civil en materia de adopción en su disposición adicional tercera establece la asimilación entre el matrimonio y las uniones convivenciales de análoga afectividad a la conyugal. En la misma línea, el art. 175.4 de la Ley $26 / 2015$, de 28 de julio, de modificación del sistema de protección a la infancia y a la adolescencia establece que "Nadie podrá ser adoptado por más de una persona, salvo que la adopción se realice conjunta o sucesivamente por ambos cónyuges o por una pareja unida por análoga relación de afectividad a la conyugal. El matrimonio celebrado con posterioridad a la adopción permitirá al cónyuge la adopción de los hijos de su consorte. Esta previsión será también de aplicación a las parejas que se constituyan con posterioridad", asimilando totalmente a la unión de hecho con el matrimonio. Otras leyes que asimilan ambas situaciones serían la Ley 29/1994, de 24 de noviembre de arrendamientos urbanos. También el art. 9.3 de la Ley 14/2006, sobre técnicas de reproducción humana asistida, establece una equiparación al matrimonio en el supuesto de uniones no matrimoniales. 
a) La decisión de mutuo acuerdo de ambos miembros de la pareja.

b) La decisión unilateral de uno de los miembros de la pareja notificada al otro por cualquier medio válido en Derecho.

c) Por fallecimiento de uno de los miembros de la pareja.

d) Por contraer matrimonio uno de los miembros de la pareja.

Algunas de las causas señaladas resultan obvias como causas de extinción por tratarse de causas ajenas a la voluntad de los convivientes, como es el supuesto de la muerte de uno de ellos. En otros supuestos, es la voluntad de las partes lo determinante en orden a la extinción de la relación de convivencia.

En este último caso, vemos como es suficiente la manifestación de voluntad de extinguir la unión de hecho realizada por uno de los miembros de la pareja y su comunicación al Registro correspondiente para que la inscripción registral deje de producir efectos. Curiosamente, no está muy estudiada la actuación de los convivientes en cuanto a la inscripción de la extinción de la unión de hecho, cuando no son extraños los supuestos en que tal inscripción se produce tiempo después de la ruptura de la convivencia, en el momento en que alguno de los antiguamente convivientes trata de inscribir una nueva unión de hecho.

No obstante, al no existir conexión alguna entre el Registro Civil y los Registros de Uniones de Hecho, resulta perfectamente posible la extinción de la unión de hecho por contraer matrimonio uno de los miembros de la pareja, sin que haya sido inscrita la extinción de la misma, por lo que nos encontraríamos con una extinción de la pareja de hecho por "vía de hecho". Lo mismo que sucedería en el caso de que la unión de hecho se convierta en matrimonio, caso en el que la unión de hecho se extingue, por vía de esa transformación, cuando en ocasiones no se notifica al Registro de Uniones de Hecho tal circunstancia modificativa.

Del mismo modo, al no existir comunicación entre los distintos registros autonómicos de uniones de hecho, la posibilidad de constar inscrita una misma persona en más de una unión de hecho, en distintos territorios, es ciertamente muy elevada. Y ello porque mientras que, en relación con la inscripción de las uniones de hecho en los correspondientes registros autonómicos y municipales, existe una amplia percepción social de la conveniencia de inscribirse, no existe la misma en cuanto a la necesidad de inscribir la extinción.

De suerte que se podría concluir que no pocas personas podrían estar formalmente unidos en más de un registro, pese a que, en la realidad, mantengan solamente la relación objeto de la 
última inscripción realizada. Naturalmente, esto solamente ocurre en supuestos de inscripción de la unión de hecho en registros distintos, ya sean de uniones de hecho o de matrimonio. Por tanto, el corolario es evidente, resulta necesaria una coordinación de los registros públicos, al menos entre los diferentes registros autonómicos de uniones de hecho.

\section{I) EL PRINCIPIO DEL LIBRE DESARROLLO DE LA PERSONALIDAD}

El art. 10.1 de la vigente CE establece que "La dignidad de la persona, los derechos inviolables que le son inherentes, el libre desarrollo de la personalidad, el respeto a la ley y a los derechos de los demás son fundamento del orden político y de la paz social". El libre desarrollo de la personalidad, constitucionalmente reconocido, garantiza una amplia esfera de libertad del individuo, que es la que le permite trazar un proyecto vital propio, sin que el Estado interfiera en $e^{233}$.

Ciertamente, el establecimiento de un marco de derechos y obligaciones en las parejas de hecho tiene un problema de difícil solución, y convenimos con Gálvez $\mathrm{Criado}^{234}$ en que el mismo radica en la sorpresa que, para quienes han decidido no casarse, puede suponer la aplicación supletoria de unas normas que, en la mayoría de las ocasiones, son semejantes a las aplicables al matrimonio. No es un problema de eficacia jurídica de la norma (la ignorancia de las leyes no excusa de su cumplimiento, establece el art. $6.1 \mathrm{del} \mathrm{CC}$ ), pero puede ser un problema social sobre la consciencia acerca de la transcendencia jurídica de nuestros actos.

$\mathrm{Y}$ es posible entender que constituye también un problema de relevancia constitucional a la luz de la aplicación que la repetida STC 93/2013 realiza del principio del libre desarrollo de la personalidad respecto a los convivientes (FJ 8):

(...) El problema queda, por tanto, cifrado en los límites que la propia esencia de la unión de hecho impone al legislador cuando este decide supeditar su reconocimiento a ciertas condiciones o atribuir determinadas consecuencias jurídicas a tal unión. Obviamente, el límite principal con el que se tropieza es la propia libertad de los integrantes de la pareja y su autonomía privada, por lo que una regulación detallada de los efectos, tanto personales como patrimoniales, que se pretendan atribuir a esa unión, puede colisionar con la citada libertad, si se impusieran a los integrantes de la pareja unos efectos que, precisamente, los sujetos quisieron excluir en virtud de su decisión

\footnotetext{
${ }^{233}$ MARTÍN-CASALS, M.: Op. cit., pág. 21.

${ }^{234}$ GÁLVEZ CRIADO, A.: "El principio general del libre desarrollo de la personalidad y los pactos entre convivientes tras la STC 93/2013, de 23 de abril”, en RCDI, n. 750 (julio 2015), pág. 1815.
} 
libre y constitucionalmente amparada de no contraer matrimonio. Por ello, el régimen jurídico que el legislador puede establecer al efecto deberá ser eminentemente dispositivo y no imperativo, so pena de vulnerar la libertad consagrada en el art. 10.1 CE. De manera que únicamente podrán considerarse respetuosos de la libertad personal aquellos efectos jurídicos cuya operatividad se condiciona a su previa asunción por ambos miembros de la pareja.

Pero la línea del TC, va más allá de plantear simplemente la exigencia de una regulación de derecho dispositivo, sino que viene a exigir el respeto a una idea que resulta muy asentada en la jurisprudencia del TS cual es que de alguna manera, dos personas que desarrollan una convivencia prolongada en el tiempo ya están realizando una opción tácita o mediante actos concluyentes: la de no casarse y no ser tenidos jurídicamente por cónyuges, sin necesidad de manifestaciones expresas de voluntad en otro sentido ${ }^{235}$.

De manera que el libre desarrollo de la personalidad, en el modo que ha sido interpretado por nuestra jurisprudencia constitucional, implica que la respuesta a los derechos y obligaciones mutuamente conferidos entre los convivientes, solamente serán válidos mediante pacto entre los mismos. Estableciendo el principio al libre desarrollo de la personalidad como límite a la posibilidad del legislador de regular las relaciones entre los convivientes, añadiendo la presunción de que los mismos han optado por no ser tenidos como cónyuges en ningún caso, pues suponemos que esa y no otra ha sido su opción de vida en común.

\section{J) LOS PACTOS ENTRE CONVIVIENTES}

La última jurisprudencia el TC establece, sin lugar a dudas, el carácter dispositivo de las normas que han de regular la convivencia more uxorio. En los términos establecidos por dicha jurisprudencia parece necesario acudir a la vía de la autonomía de la voluntad como fórmula para regular la vida en común de los convivientes, tanto durante el período de convivencia como para supuesto de ruptura de la misma.

Durante años nuestros Tribunales consideraron nulos de pleno derecho estos acuerdos, pues la convivencia extramatrimonial era considerada como una relación contraria a la moral y a las buenas costumbres y, por tanto, ilícita ${ }^{236}$. Los Tribunales estimaban que la existencia de relaciones

${ }^{235}$ GÁLVEZ CRIADO, A.: Op. cit., pág. 1816.

${ }^{236}$ En este sentido, se pronunciaba la STC de 2 de abril de 1941, cuando afirmaba que: "el principio de autonomía de la voluntad (...), no puede menos de estar limitado por adecuadas normas de matiz imperativo, Encargadas de recoger los imperativos éticos y evitar que el derecho contractual sea puesto al servicio de fines Inmorales y antisociales...". 
amorosas fuera del matrimonio provocaba la ilicitud de los contratos que se celebraran entre los convivientes, especialmente cuando con dichos convenios se tratara de iniciar, mantener, restablecer o remunerar dichas relaciones ${ }^{237}$.

En general, la doctrina científica se ha manifestado en contra del concepto de "causa ilícita" manejado por los Tribunales, que seguían una corriente de concepción subjetiva de la causa al identificar causa con motivos, siendo estos motivos los que llevaban a declarar nulo el contrato suscrito entre los convivientes, al considerar que dichos acuerdos se realizaban para facilitar la relación ilícita. Sin embargo, los tratadistas que han estudiado el tema consideran que dicha interpretación se aleja de la concepción objetiva de la causa recogida en el artículo 1274 del CC $^{238}$.

En una segunda época, más cercana en el tiempo y con criterios más actuales, la jurisprudencia ha admitido la validez de los acuerdos reguladores de las uniones extramatrimoniales, en base al principio de la autonomía de la voluntad consagrado en el artículo 1255 del CC, donde se entiende que los convivientes tienen plena libertad y capacidad para decidir aquellas disposiciones o pactos que regulen el ejercicio de su vida diaria del modo que mejor les convenga a ambas partes. A tal conclusión se llega también analizando nuestro derecho histórico y la propia Constitución, que así lo reconoce y garantiza en el marco del respeto al libre desarrollo de la personalidad individual. Por lo que, al establecer los convivientes los pactos que estimen adecuados en la forma de regir su convivencia, deberán ser respetados los mismos, tanto para el desarrollo de la vida cotidiana de pareja como en aquello que establezcan en el caso de ruptura de la pareja ${ }^{239}$.

Así pues, podrán los convivientes en virtud del pacto alcanzado constituir las formas jurídicas que han de regular su convivencia. Tales pactos podrán regular los derechos y obligaciones de toda índole que establezcan los convivientes para regular su relación. De tal manera que se ha de estar, en primer lugar, a lo establecido por la legislación vigente aplicable a la unión de hecho, en segundo lugar, dicha relación se regirá por los pactos alcanzados entre los

\footnotetext{
${ }^{237}$ MESA MARRERO, C.: Op. cit., pág. 84.

${ }^{238}$ En este sentido FOSAR BENLLOCH, E.: "Las uniones no matrimoniales en el Derecho histórico español. La sucesión mortis causa a favor de los hijos extramatrimoniales en el Derecho Civil aragonés", en RCDI n. ${ }^{\circ} 557$, (1983), págs. 36 y ss.; ESTRADA ALONSO, E.: Op. cit., págs. 141 y ss.; MENDIETA JARAMILLO. I.: "Relaciones patrimoniales en la unión familiar de hecho", en $A C$ (1990-91), pág. 197 y ss.

${ }^{239}$ MARTÍN MOLINA, A.A.: Op. cit., pág. 117.
} 
convivientes sin que, en ningún caso, sea posible la aplicación analógica de las normas propias del matrimonio $^{240}$.

Mayor problema suscita la interpretación de posibles pactos tácitos entre los convivientes; pese a ello, el TS en algunas ocasiones los ha admitido, entendiendo que se puede concluir su existencia a partir de los actos y evidencias de dicha relación debidamente probados durante el procedimiento; de tales actos y evidencias se ha entendido que es posible colegir la voluntad de los convivientes en relación al modo de regular su convivencia.

En todo caso, y problemas de prueba aparte, parece evidente que en la actualidad no es posible limitar la capacidad para contratar de los convivientes por el solo hecho de mantener una relación extramatrimonial. Los principales argumentos esgrimidos por la doctrina en defensa de la licitud de los contratos suscritos por los compañeros de una relación no matrimonial se refieren, fundamentalmente, al principio de la autonomía de la voluntad recogido en el artículo 1255 del CC $\mathrm{y}$, de otra parte, al cambio jurídico producido en España durante los últimos años con el sistema de derechos y libertades que la Constitución de 1978 consagra en nuestro ordenamiento jurídico. La licitud de estas convenciones entre convivientes deriva de la admisibilidad de las uniones de hecho en la CE pues, si bien no la reconoce expresamente, es claro que tampoco la rechaza ${ }^{241}$.

Señalado claramente por la STC 93/2013, de 23 de mayo, el imprescindible respeto a la voluntad de los convivientes, en el sentido de que no se puede obligar a aceptar las reglas del matrimonio a quien voluntariamente decidió no aceptarlas; de manera que, excluida por inconstitucional la consideración como pareja estable de aquella basada en la convivencia durante un plazo mínimo marcado por la Ley, y de aquella fundada en la convivencia existiendo descendencia común, parecería lógico pensar que solo cabría conceptuar como pareja estable a aquella que, voluntariamente, decidiese constituirse como tal en documento público, pues solo ella sería respetuosa con el libre desarrollo de la personalidad de sus integrantes ${ }^{242}$.

\footnotetext{
${ }^{240}$ Desde la STC de 12 de septiembre 2005 en la que se dejó rotundamente claro la imposibilidad de aplicar las normas propias el matrimonio a las uniones de hecho, la jurisprudencia de nuestros tribunales ha sido unánime en la no aplicación analógica del Estatuto matrimonial a las uniones extramatrimoniales.

${ }^{241}$ DE LA CÁMARA ÁLVAREZ, M.: La autonomía de la voluntad en el actual Derecho español sobre la familia. Ilustre Colegio Notarial de Granada, 1986, pág. 9, reconoce que el Derecho español especialmente después de las reformas legislativas y, desde luego, de la Constitución de 1978, el margen de actuación de la voluntad dentro del Derecho de familia se ha ensanchado mucho.

${ }^{242}$ NANCLARES VALLE, J.: "Las parejas estables tras la inconstitucionalidad parcial de la Ley Foral 6/2000, de 3 de julio: el retorno a la unión de hecho”, en RCDI n. ${ }^{\circ}$ 750, Madrid (2015), pág. 1879.
} 
Esta interpretación del Constitucional resulta sorprendente, pues hace depender el nacimiento de la unión de hecho no de datos objetivables como la convivencia marital durante un período de tiempo, o las circunstancias concurrentes como la convivencia unida a la existencia de descendencia común; sino de la voluntad de las partes manifestada en documento público.

La interpretación del TC, recogida en la Sentencia sobre la regulación Navarra de las uniones de hecho, conduce a la innecesaridad de leyes reguladoras de la convivencia more uxorio al concluir que la autonomía de la voluntad lo es todo, ya que las normas reguladoras de los aspectos sustantivos de la relación deberán limitarse a garantizar la libertad de pacto entre la pareja, tanto en los aspectos puramente patrimoniales, como en aquellos que delimiten el conjunto de derechos y obligaciones en la relación convivencial. Este carácter de innecesario ${ }^{243}$ de la regulación de los aspectos sustantivos está, igualmente, muy extendido en la doctrina.

Así, pues, la interpretación realizada por nuestro TC parece conducir, de manera inexorable, a la necesidad de que sean los convivientes quienes, mediante el ejercicio del derecho al libre desarrollo de la personalidad establezcan, mediante el correspondiente documento público, el entramado de derechos y obligaciones que han de regir la vida en común de quienes deseando una convivencia estable similar a la del matrimonio, no desean someterse al estatuto matrimonial.

\footnotetext{
${ }^{243}$ El adjetivo calificativo era ya utilizado por ARREGUI GIL, J., en "Sobre la Ley Foral 6/2000, de 3 de julio, para la igualdad de las parejas estables", en Comentarios al Código Civil y Compilaciones Forales, addendum al Tomo XXXVII, vol 2 , Ederesa, Madrid (2001), pág. 1644, precisaba que "toda regulación legal de ese derecho social (...) que exceda de dar el concepto de pareja estable desde el punto de vista jurídico, de determinar la forma y medios de probar su existencia y su acreditación, de establecer las causas de su cese o disolución a efectos legales, así como de regular las consecuencias del cese en relación a los hijos comunes, resulta incuestionablemente innecesaria”.
} 



\section{V.LOS ASPECTOS PATRIMONIALES DE LA PAREJA DE HECHO EN EL ORDENAMIENTO JURÍDICO ESPAÑOL}

\section{A) EFECTOS PATRIMONIALES DURANTE LA CONVIVENCIA DE LA UNIÓN DE HECHO}

De la convivencia more uxorio se deriva para los convivientes, además de efectos personales, otras consecuencias de carácter patrimonial. La legislación autonómica analizada permite a la pareja el establecimiento de los pactos patrimoniales que tengan por conveniente ${ }^{244}$, con respeto siempre a las leyes, las buenas costumbres y a la igualdad de derechos de los convivientes.

Esta posibilidad de pacto entre los convivientes se enmarca en el principio de la autonomía de la voluntad de los miembros de la pareja, quienes, mientras respeten el Ordenamiento jurídico vigente, son plenamente libres para adoptar los acuerdos que tengan por conveniente para regular sus relaciones personales y patrimoniales ${ }^{245}$.

Ha sido muy discutida por la doctrina científica la posibilidad de aplicar de manera análoga las normas económicas previstas para las uniones matrimoniales a las uniones de hecho. Así, un importante sector de la doctrina española rechaza esta posibilidad,' argumentando que en la unión de hecho falta el vínculo jurídico del matrimonio, por lo que la aplicación analógica no es posible. Esta es la línea que ha seguido nuestra jurisprudencia de manera constante, en especial a raíz de la Sentencia del Pleno de la Sala de lo Civil del TS de 12 de septiembre de $2005^{246}$.

\footnotetext{
${ }^{244}$ Así podemos comprobar cómo las distintas Normativas autonómicas lo establecen expresamente, la Ley de la Comunidad de Cantabria (art. 8) la de la Comunidad de Extremadura (art. 6) La de Andalucía (art. 10), la de la Comunitat Valenciana (art. 4), la de Aragón (art. 5), la del País Vasco (art. 5), la de las Islas Canarias (art. 7) la de Illes Balears (art. 4) la de la Comunidad de Madrid (art. 4), la de Cataluña (art. 3) la del Principado de Asturias (art. 5) regulan en unos casos exclusivamente pactos relativos a relaciones patrimoniales entre los convivientes, mientras que en algunas otras CCAA se permite que tales pactos contengan la regulación tanto de aspectos patrimoniales como de ámbito personal.

${ }^{245} \mathrm{La}$ STC 93/2013, de 23 de abril, publicada en el BOE n. ${ }^{\circ} 123$, de 23 de mayo de 2013, precisa en su FJ 8. ${ }^{\circ}$ (párrafo $4^{\circ}$ ) lo siguiente "Consustancial a esa libertad de decisión, adoptada en el marco de la autonomía privada de los componentes de la pareja, es el poder de gobernarse libremente en la esfera jurídica de ese espacio propio, ordenando por sí mismos su ámbito privado, el conjunto de derechos, facultades y relaciones que ostenten, si bien dentro de ciertos límites impuestos por el orden social, ya que la autonomía privada no es una regla absoluta".

${ }^{246}$ La Sentencia de la sala de lo Civil [STS 12-9-2005 (RJ 2005/7148)], de la que fuera ponente el Excmo. Sr. D. Ignacio Sierra Gil de la Cuesta, dejó sentado que no cabe la aplicación análoga de las Normas del matrimonio a las uniones de hecho. En el caso se discutía el posible derecho a una pensión compensatoria derivada de la ruptura de una pareja de hecho, estableciendo el TS que no procedía la aplicación análoga de las Normas de matrimonio, acudiendo a la aplicación de otras Normas del Derecho privado para resolver la posible falta de equidad, como las derivadas de las situaciones de ruptura en el supuesto de disolución de una sociedad civil constituida por tiempo indefinido, o la doctrina del enriquecimiento injusto.
} 
Teniendo todo lo anterior en cuenta, parece altamente improbable que vaya a ser posible la extensión de las Normas económicas del matrimonio a las uniones more uxorio. No obstante, si los convivientes así quisieran, sí que pueden regular sus relaciones patrimoniales de manera similar al matrimonio, suscribiendo los pactos correspondientes para hacerlo posible.

\section{La posibilidad de pacto entre convivientes para establecer un régimen económico en la pareja}

La cuestión que se suscita es si los convivientes pueden determinar, mediante pactos privados, aspectos de sus relaciones económicas tales como el régimen de contribución a los gastos de la pareja, el sistema de adquisición de bienes durante la vida en común o las consecuencias patrimoniales en el supuesto de ruptura, incluyendo aspectos como el sistema de distribución de los bienes comunes, incluso la posibilidad de dejar fijadas pensiones compensatorias.

Una parte de la doctrina sostenía que tales pactos solamente pueden formalizarse mediante la escritura de capitulaciones matrimoniales. Se señala dicha escritura pública como el único instrumento válido para fijar el régimen económico del matrimonio y, dada la imposibilidad de aplicar las Normas del matrimonio a la pareja de hecho, una escritura que contuviese un régimen económico para el supuesto de convivencia more uxorio, devendría nula ${ }^{247}$.

Frente a esta postura, otro sector de la doctrina, actualmente mayoritario, considera que tales acuerdos entre convivientes son perfectamente válidos, en aplicación del principio de libertad de pactos contemplado en el art. $1255 \mathrm{del} \mathrm{CC}^{248}$. La jurisprudencia viene admitiendo la validez de estos pactos, siendo destacable la STS de 18 de mayo de $1992^{249}$, en la que acepta la aplicación del

\footnotetext{
${ }^{247}$ MESA MARRERO, C.: Op. cit., pág. 102, en la nota al pie 11 formula una amplia mención de autores que defienden esta posición, en especial con referencia al régimen de gananciales, citando, entre otros autores, a VIDAL MARTÍNEZ: "Aplicación del régimen de sociedad de gananciales a una relación y convivencia no matrimonial. Convenio económico. Validez", en $R G D$ octubre-noviembre (1986), págs. 4303 y ss.; ESPÍN CÁNOVAS: "Familia no matrimonial", en Congreso Hispanoamericano de Derecho de Familia, Tapia (1987) pág. 13; PEÑA BERNALDO DE QUIRÓS, M.: Derecho de Familia, Facultad de Derecho, Universidad Complutense, Madrid (1989), pág. 399; BAYOD LÓPEZ, C.: "Parejas no casadas, capítulos matrimoniales y normas de régimen económico matrimonial", en $R C D I$, n. $^{\circ} 626$ (1995), pág. 143.

${ }^{248}$ Art. 1255 CC: "Los contratantes pueden establecer los pactos, cláusulas y condiciones que tengan por conveniente, siempre que no sean contrarios a las leyes, a la moral ni al orden público."

${ }^{249}$ La [STS 18-5-1992 (RJ 1992/4907), de la que fuera ponente el Excmo. Sr. D. Alfonso Villagómez Rodil, los antecedentes del caso fueron que, después de una convivencia de más de veinte años, el demandado rompió, de manera violenta, la relación, expulsando de la vivienda a la que había sido su pareja y una hija común, todo ello sin compensación económica alguna. Se interpuso demanda de reclamación de derechos sobre los bienes comunes. La AP estimó parcialmente la demanda, declarando la existencia de una comunidad de bienes sui generis. Interpuesto recurso de casación por el demandado fue desestimado por el TS.
} 
régimen económico acordado entre los convivientes: “...si expresamente se pacta”. A lo que habría que añadir que, a diferencia del matrimonio, en el caso de los convivientes, y problemas de prueba aparte, en aplicación del principio de libertad de forma del art. 1278 del CC, estos pactos no están sujetos a ningún requisito de forma, a diferencia de las capitulaciones matrimoniales que, necesariamente, han de formalizarse mediante escritura pública.

La vía del pacto reviste el máximo interés, al ser el criterio de solución prioritario en atención a múltiple jurisprudencia del TS, así como el cauce de establecimiento de deberes y derechos entre los miembros de la pareja, tal como exige la STC 93/2013, de 23 de abril, para que tales previsiones sean esgrimibles ante los tribunales. Ya no es que sea conveniente, sino que, siguiendo la doctrina del pronunciamiento constitucional se vuelve imprescindible, y así lo evidencia la práctica de los tribunales ordinarios, cada vez más proclives a respetar lo pactado, aunque con el constante recuerdo, por parte de los tribunales, de no blindar la salida de la pareja, lo que sería contrario al libre desarrollo de la personalidad ${ }^{250}$.

Según esta doctrina, podemos entender que los convivientes son libres de pactar el modo de organización económica de la pareja que consideren mejor. Pero solamente mediante el pacto será posible fijar una regulación de la vida económica familiar, los aspectos que no hayan sido previamente pactados no podrán ser resueltos mediante aplicación analógica los regímenes económicos del matrimonio.

Pese a ello, parece obvio que, pactada la remisión a lo dispuesto en el $\mathrm{CC}$, o a la norma autonómica de equivalencia, sería perfectamente viable la aplicación de esas medidas del régimen económico matrimonial a las uniones de hecho con pactos de convivencia en el que definido un régimen regulador de las reglas económicas de su convivencia se remitiesen a las disposiciones previstas en la norma reguladora establecidas para el régimen económico-matrimonial que se pretenda utilizar como referencia. En este caso no estaríamos ante una aplicación análoga de las Normas del matrimonio a las uniones de hecho, sino que se estarían aplicando las reglas pactadas entre los convivientes, y en lo que no estuviese expresamente pactado serían aplicables las Normas reguladoras del régimen pactado, si bien no por aplicación analógica, sino por remisión a las mismas libremente acordado por los convivientes.

${ }^{250}$ DE AMUNÁTEGUI RODRÍGUEZ, C.: "Comentario a la STS de 15 de enero de 2018: Nuevo intento de orden sobre las reclamaciones económicas en el momento de la ruptura de las parejas no casadas", en Comentarios a las Sentencias de unificación de doctrina: civil y mercantil, coord. Mariano Yzquierdo Tolsada, Vol. 10, (2018), pág. 333. 
Desde tal perspectiva, sería perfectamente viable considerar que los convivientes pueden establecer un régimen económico de la pareja en plena libertad y con los mismos efectos que los existentes en la unión matrimonial. La única cuestión es que determinados aspectos, como la posible existencia de una pensión compensatoria, deben ser expresamente previstos en los acuerdos de los convivientes, de lo contrario habría que recurrir a la aplicación analógica de otras instituciones jurídicas, como la de ruptura de sociedades civiles constituidas por tiempo indefinido, o la doctrina del enriquecimiento injusto, como precisa la Sentencia del Pleno del TS 5270/2005, de 12 de septiembre, cuya doctrina ha sido seguida rígidamente por la jurisprudencia desde la publicación de dicha sentencia.

Actualmente sería posible acordar cualquiera de los regímenes económicos matrimoniales, y ello porque el pacto libre, voluntario y consciente de los convivientes ha de ser respetado por el Ordenamiento jurídico. Si bien, hemos de tener en cuenta, que dichos pactos han de referirse a los aspectos patrimoniales entre los miembros de la unión de hecho, sin entrar a regular aspectos de las relaciones personales como las recogidas en los arts. 67 y 68 del CC, ya que al tratarse de cosas extra commercium no son susceptibles de ser objeto del contrato ${ }^{251}$, pues al contravenir lo dispuesto por el art. 1271 del CC se declararían nulos los pactos suscritos que afectan a la persona o a su intimidad, además de vulnerar la CE que proclama, entre los derechos fundamentales de la persona, la dignidad de la misma y el derecho a la intimidad ${ }^{252}$.

Una vez establecido que los convivientes pueden regular sus relaciones patrimoniales de manera convencional, habrá de tener en cuenta que dicha libertad de pacto tiene los límites propios del principio general de la autonomía de la voluntad, es decir, que estos pactos no pueden ser contrarios a las leyes, a la moral o al orden público, tal como prescribe el art. 1255 del CC. Ello conlleva prohibiciones como las señaladas más arriba relativas al objeto del pacto, u otras como la existencia de pactos que fuesen contra normas prohibitivas o que impongan la renuncia a bienes indisponibles o irrenunciables, como la renuncia contraer matrimonio; o estipulaciones que vayan contra la moral, como los pactos patrimoniales que se acuerden bajo la condición de comenzar o

\footnotetext{
${ }^{251} \mathrm{El}$ art. 1271 del CC establece que no pueden ser objeto del contrato las cosas que están fuera del comercio de los hombres. Ciertamente, cuestiones como el respeto, la ayuda o la fidelidad no son evaluables económicamente, por lo que no podrían ser objeto del contrato.

${ }^{252}$ VARGAS ARAVENA, D.: "De los daños civiles en las uniones de hecho", en Daños civiles en el matrimonio. ed. La Ley, Madrid (2009), y publicada en La Ley 7409/2011, pág. 4.
} 
continuar relaciones sexuales; o pactos que vayan contra normas imperativas, como los acuerdos que contravengan el principio de igualdad.

En especial, se debe tener en cuenta que el pacto jamás puede estar destinado a que el conviviente que disuelve la unión tenga que pagar una indemnización al otro por disolverla, ya que sería como estar comprando su libertad pagando un "precio de ruptura". Esto constituiría un obstáculo a la libertad de disolución, facultad irrenunciable emanada del libre derecho de la personalidad y constitucionalmente garantizado, además de adolecer de causa ilícita. Una cosa es que se admita que los convivientes estipulen las consecuencias económicas de la ruptura, en particular "que prevean una indemnización por los perjuicios que la ruptura de la convivencia pueda ocasionar a uno de los convivientes", y otra muy distinta que acuerden el pago de una indemnización para poder dar término a su unión de hecho ${ }^{253}$.

\section{La sociedad como régimen económico de las uniones de hecho}

Una vez establecido el reconocimiento de la libertad de pactos entre los convivientes, y habiendo señalado el TS la figura de la sociedad civil como institución con una similitud suficiente como para aplicar análogamente lo dispuesto para esta en los supuestos de ruptura de la convivencia de las uniones de hecho, parece obvio que debemos detener nuestra mirada en esta figura, a fin de intentar obtener las bases jurídicas suficientes para determinar la validez de los pactos entre convivientes como modo de surgimiento de un régimen económico de las uniones de hecho, libremente decidido por los miembros de la pareja e incardinado en nuestro Ordenamiento jurídico.

Así tenemos que el artículo 1665 del CC define la sociedad civil como un "contrato por el cual dos o más personas se obligan a poner en común dinero, bienes o industria, con ánimo de partir entre sí las ganancias”. En los artículos 1671 y siguientes del CC se establece que las sociedades civiles pueden ser universales o particulares. Las sociedades particulares son aquellas en las que las partes ponen en común la totalidad de los bienes que actualmente les pertenecen, con ánimo de partirlos entre sí, al igual que todas las ganancias que adquieran con ellos (art. 1673), mientras que la sociedad universal de ganancias comprende todo lo que adquieran los socios por su industria o trabajo durante la vida de la sociedad, mientras que los bienes muebles e inmuebles

${ }^{253}$ VARGAS ARAVENA, D.: Ibid., págs. 4 y 5. 
que cada socio posee al tiempo de celebración del contrato continúan siendo de dominio particular, pasando a la sociedad el usufructo.

Habida cuenta de que las sociedades, sean civiles o mercantiles, tienen como fin la obtención de un lucro o ganancia repartible entre los socios, lo que las distingue es la clase de actividad realizada. Así, cuando la sociedad se dedique a la industria o realice actos de comercio, será mercantil y se le aplicarán las reglas del comercio. En cambio, cuando la sociedad realice cualquier otra actividad, será sociedad civil ${ }^{254}$.

Un aspecto importante para la constitución de la sociedad civil es el cumplimiento de lo prescrito en el art. 1665, es decir, la creación de un fondo común, conformado por las aportaciones de los socios para la realización de la actividad societaria con el ánimo de obtener beneficios que se repartirán entre los miembros. Para la constitución de la sociedad no se requiere que las aportaciones sean iguales, ni en su cuantía ni en su objeto. Sin embargo, sí que se requiere que los socios aporten su trabajo o industria, por lo que resulta necesario que los miembros de la pareja aporten patrimonio o su trabajo personal en la actividad desarrollada ${ }^{255}$.

Así pues, ambas partes han de poner en común bien su trabajo o su industria, o ambas cosas, para entender constituida una sociedad civil, la cual además debe tener como objetivo la obtención de ganancias y su reparto entre los miembros de la pareja. Este reparto no necesariamente ha de ser igual para ambos, sino que las partes, de conformidad con lo dispuesto en el art. 1689 del CC pueden pactar libremente la cuantía de la participación de cada uno de los miembros de la sociedad.

Cumplidos los requisitos para la constitución de una sociedad civil, y dentro de los diversos tipos de sociedad contemplados en el Código, entendemos, al igual que algunos autores ${ }^{256}$, que la sociedad universal de ganancias mantiene una fuerte semejanza con el régimen de sociedad de gananciales. Mantienen el carácter privativo de los bienes que pertenecen a cada socio en el momento de la constitución de la sociedad, pero los frutos que dan estos bienes, así como lo

\footnotetext{
${ }^{254}$ MESA MARRERO, C.: Op. cit., pág. 108.

${ }^{255}$ En este sentido la [STS 3-6-1987 (RJ 1987/4025)] afirma que la contribución a los gastos domésticos, tales como la adquisición de muebles, pagos de recibos de energía eléctrica, etc. no suponen la participación cooperativa en los bienes y ganancias que se pretenden dividir.

${ }^{256}$ Especialmente coincidimos plenamente con GALLEGO DOMÍNGUEZ, I.: Las parejas no casadas y sus efectos patrimoniales. Centro de Estudios Registrales, Madrid (1995), pág. 146. Otros autores como LÓPEZ-MUÑIZ GOÑO, M.: "Las uniones paramatrimoniales ante los procesos de familia", en Guía práctica y jurisprudencia, Colex, Madrid (2001), pág. 72; o MENDIETA JARAMILLO, I.: "Relaciones patrimoniales en la unión familiar de hecho", en $A C$ (1990-91), pág. 198, admiten que los convivientes pueden constituir este tipo de sociedad para regular sus relaciones patrimoniales.
} 
obtenido por los socios por su trabajo o industria durante el tiempo en que existe la sociedad, pertenece a la misma.

\section{a) Diferencias con la comunidad de bienes}

Evidentemente, existen muchas similitudes entre la sociedad y la comunidad de bienes, aunque al entrar en un mínimo análisis de las mismas inmediatamente resaltan las diferencias entre ambas. La sociedad es definida como un contrato en el que dos o más personas se obligan a poner en común dinero, bienes o industria, con el ánimo de partir entre sí las ganancias (art. 1665 del CC), mientras que se entiende que hay comunidad de bienes cuando la propiedad de una cosa pertenece pro indiviso a varias personas (art. 392 del CC). De estas definiciones la doctrina deduce la existencia de importantes diferencias entre ambas instituciones. Así se señala que, mientras para constituirse la sociedad será imprescindible el consentimiento de las partes, la comunidad de bienes puede constituirse sin necesidad de tal consentimiento. Otra diferencia importante es que con la sociedad surge, necesariamente, una nueva persona jurídica diferente de cada uno de los socios, lo cual no sucede en el caso de la copropiedad. Una tercera diferencia importante es que la nota esencial de la sociedad es el ánimo de lucro, mientras que en la comunidad de bienes los copartícipes persiguen la simple conservación y aprovechamiento fructífero de la cosa común.

La comunidad puede surgir de dos modos, ya sea de manera incidental, cuando dos o más personas adquieren de manera conjunta un bien o un derecho, o bien de manera convencional, cuando surge por el pacto expreso o acuerdo tácito de dos o más personas. Cualquiera de estos modos de comunidad de bienes es posible en las uniones de hecho. Esta situación nos sitúa ante el escenario en que los convivientes hayan regulado, mediante el correspondiente pacto, los aspectos económicos de la relación de convivencia mediante un régimen de comunidad de bienes ${ }^{257}$.

En ausencia de pacto expreso, de inicio no procede la aplicación de las reglas de la comunidad de bienes a los adquiridos por la pareja durante la convivencia. Si bien es posible que los miembros de la pareja, pese a no existir pacto escrito, hayan manifestado su voluntad de constituir dicha comunidad de forma tácita, por ejemplo, mediante aportaciones comunes

${ }^{257}$ MORENO QUESADA, B.: “La comunidad de bienes surgida en la convivencia de parejas de hecho", en Parejas de hecho. Iltre. Colegio Notarial de Granada, Granada (1996), pág. 72 y ss. 
destinadas a la adquisición de tales bienes, sean estas aportaciones económicas o personales, siempre que la finalidad de dicha adquisición sea, precisamente, la de hacerlos comunes ${ }^{258}$.

La existencia de cuentas bancarias por medio de las cuales se paga un determinado bien, por ejemplo, una vivienda, o las amortizaciones de un préstamo para adquirir dicho bien, sirven a efectos de prueba de la existencia tácita de un régimen de comunidad de bienes, de modo especial si a dicha cuenta se producen contribuciones por parte de ambos convivientes y más aún si dicha cuenta se abre a nombre de ambos. Pero, incluso constando abierta a nombre de uno solo de los miembros de la pareja, si ambos convivientes han aportado fondos a dicha cuenta individual, también se ha considerado la existencia de comunidad ${ }^{259}$.

En definitiva, aunque la mera existencia de la convivencia extramatrimonial no determina por sí misma la constitución de la comunidad de bienes entre los miembros de la pareja, sí es posible su existencia ya sea por pacto expreso o acuerdo tácito de los convivientes, siempre que se acredite la intención de los miembros de la unión de hacer comunes los bienes adquiridos durante la relación de convivencia.

\section{Socorro y ayuda mutua entre los convivientes. La obligación de alimentos}

El socorro y ayuda mutua entre los cónyuges se establece como una exigencia de la propia institución matrimonial ${ }^{260}$. En consecuencia, mientras el matrimonio esté vigente, el sustento familiar es un deber propio del matrimonio como consecuencia de los derechos y deberes, de carácter personal, implícitos en la institución.

\footnotetext{
${ }^{258}$ Así lo expresa múltiple jurisprudencia, valga por todas, la [STS 14-5-2004 (RJ 2004/3477)] que declara lo siguiente: "Ha sido reiterada la jurisprudencia que ha estimado la demanda de la conviviente more uxorio frente al conviviente, que reclama una parte de los bienes adquiridos durante el período de convivencia, que están bajo la titularidad del demandado. Este caso es el inverso: durante el período de convivencia, se adquiere un bien por mitad pro indiviso de los dos — vivienda común - y, tras la ruptura, uno de ellos pretende que se declare su exclusiva propiedad; la sentencia recurrida estima su demanda, por entender que la verdadera voluntad era que fuera el único adquirente, lo cual es absurdo pues en el negocio bilateral ella nunca tuvo esta voluntad, y por estimar la falta de causa porque ella "no aportó en su compra su parte correspondiente" e ignora que una convivencia es no solo una comunidad económica, sino además una comunidad de vida y las aportaciones personales de la convivencia —además de tener un indiscutible valor económico "así, art. 103, medida $3^{\text {a }}$, segundo párrafo - no pueden obviarse al determinar la propiedad de una cosa común".

${ }^{259}$ Es doctrina jurisprudencial consolidada que la propiedad de los fondos y la titularidad de la cuenta bancaria son conceptos jurídicos diferentes, prevaleciendo el primero de ellos. En base a lo cual, la [SAP de Pontevedra 6-4-1998 (AC 1998/4691)], resolvió aplicar el régimen de comunidad de bienes sobre una vivienda, pese a haber sido pagada con cargo a una cuenta individual de uno de los convivientes, y habiendo sido inscrita a nombre solamente del mismo, al considerar acreditado que ambos convivientes contribuyeron con fondos a la mencionada cuenta individual.

${ }^{260} \mathrm{El}$ art. 67 del CC establece que "Los cónyuges deben respetarse y ayudarse mutuamente y actuar en interés de la familia". El art. 68 del mismo Cuerpo legal establece que "los cónyuges están obligados a vivir juntos, guardarse fidelidad y socorrerse mutuamente".
} 
Por otra parte, la obligación de alimentos entre parientes viene establecida en el Título VI del CC, entendiendo por tales los gastos que resulten indispensables para el sustento, habitación, vestido y asistencia médica ${ }^{261}$. Entre los obligados recíprocamente a prestarse alimentos, el art. 143 del CC señala en primer lugar a los cónyuges. Esta obligación resultará exigible en los supuestos de crisis matrimonial, configurándose de este modo en una obligación autónoma ${ }^{262}$.

La cuestión que se suscita es si estos derechos y deberes derivados del matrimonio resultan igualmente de aplicación en las relaciones convivenciales more uxorio. La conclusión es que estos derechos y deberes, propios del matrimonio, no se extienden al supuesto de las uniones de hecho, al menos con carácter general. Esto es debido a la imposibilidad de la aplicación analógica de las Normas del matrimonio a las parejas de hecho, tan reiteradamente sostenida por la jurisprudencia, tanto del TS como del TC 263 .

Otro aspecto a tener en cuenta es que los parientes obligados recíprocamente a prestarse alimentos, relacionados en los arts. 142 y 143 del CC, son siempre cónyuges o personas unidas por una relación de parentesco. Resulta evidente que los convivientes no son ni una cosa ni la otra.

Pese a ello, diversas legislaciones autonómicas contemplan la obligación de alimentos entre los convivientes ${ }^{264}$. En todo caso, parece razonable decir que, durante la convivencia, existe entre los miembros de la pareja una obligación natural de alimentos ${ }^{265}$ derivada de la relación de afectividad que origina la relación de convivencia. Por supuesto, la obligación natural no es exigible jurídicamente, del mismo modo que no cabe la reclamación de lo entregado en cumplimiento de dicha obligación natural, pues de conformidad con lo dispuesto por el art. 1901 del CC no existe la obligación de devolver lo entregado por liberalidad o por otra causa justa.

\footnotetext{
${ }^{261}$ Art. 142 del CC, el cual recoge los aspectos en que se concreta la obligación de alimentos entre parientes.

${ }^{262}$ LACRUZ BERDEJO, J.L.; SANCHO REBULLIDA, F.; LUNA SERRANO, A.; DELGADO ECHEVERRÍA, J.; RIVERO HERNÁNDEZ, F. y RAMS ALBESA, J.: Op. cit., tomo 2, vol. $1^{\circ}, 3^{\text {a }}$ ed. Bosch, Barcelona (1990). Estos autores señalan en la pág. 52 que "El deber conyugal de socorro mutuo se reduce al deber de alimentos cuando se rompe la unidad de vida; durante la preparación y sustanciación del proceso de separación, divorcio o nulidad".

${ }^{263}$ En relación con el deber de ayuda y socorro mutuo, recogidos en los arts. 67 y 68 del CC, la prohibición de la aplicación análoga de las Normas del matrimonio, establecida entre otras muchas, en la STS de 12 de septiembre de 2005, conlleva su inaplicación a las uniones de hecho. Por su parte, la relación de parientes obligados a prestarse alimentos es entendida como un numerus clausus por doctrina y jurisprudencia, y en ella, no se contempla las relaciones de similar afectividad al matrimonio.

${ }^{264}$ En concreto las legislaciones autonómicas de Baleares (art. 6 de la Ley 18/2001, de 19 de diciembre, de parejas estables), Cataluña (art. 234-10 de la Ley 25/2010/, de 29 de julio, del libro segundo del CC de Cataluña) y Aragón (art. 307.3 del Decreto legislativo 1/2011, de 22 de marzo, por el que se aprueba el Código del Derecho Foral de Aragón).

${ }^{265}$ GALLEGO DOMÍNGUEZ, I.: Op. cit., pág. 304.
} 
Obviamente, también es posible el pacto de alimentos recíprocos, suscrito por ambos convivientes, o bien que uno de los miembros de la pareja asuma esa obligación en relación con el otro $^{266}$. Actualmente, no cabe duda de la validez de dichos pactos entre los convivientes, pactos que vienen siendo aceptados tanto por la doctrina, siguiendo lo dispuesto en el art. 153 del $\mathrm{CC}^{267}$, como por la jurisprudencia de las últimas décadas ${ }^{268}$.

Este tipo de pactos no pueden ser considerados contrarios a la Ley, ni a la moral o al orden público en la actualidad, por lo que se ha de reconocer su plena validez, tanto en lo que pudieran pactar los convivientes al respecto para la vigencia de la unión, como lo que, en su caso, pudieran acordar para los supuestos de cese de la convivencia.

\section{Donaciones entre convivientes}

En las relaciones more uxorio no es especialmente extraño que se produzcan donaciones entre los miembros de la pareja. Las razones por las que pueden surgir tales donaciones son de lo más variadas, van desde la pura y simple liberalidad hasta el intento de compensación por los posibles daños y perjuicios causados al otro miembro de la pareja, o la simple remuneración por los cuidados y atenciones recibidas. A priori, los motivos por los que un miembro de la pareja decide realizar la donación resultan intrascendentes. No obstante, debe tenerse en cuenta que la especial complicidad propia de la convivencia more uxorio puede conllevar actuaciones que no pueden ser amparadas por el Derecho.

En un principio, nada impide las donaciones entre los miembros de una pareja de hecho, pues asumiendo la definición del $\mathrm{CC}^{269}$ la donación es un acto de liberalidad realizado por el donante que implica su empobrecimiento y de manera simultánea el enriquecimiento del donatario. Acto que, realizado de manera libre, voluntaria y consciente por el donante y realizado sin perjuicio

\footnotetext{
${ }^{266}$ GARCIA RUBIO, M. ${ }^{\text {a }}$ P.: Alimentos entre cónyuges y entre convivientes de hecho, Civitas, Madrid (1995), pág. 208. Concluye que dicho pacto vinculará a la pareja mientras dure la convivencia, pero que también es posible que pacten el derecho de alimentos de uno de los convivientes en el caso de ruptura de la pareja.

${ }^{267} \mathrm{El}$ art. $153 \mathrm{del} \mathrm{CC}$, en sede de alimentos entre parientes, dispone que "Las disposiciones que preceden son aplicables a los demás casos en que, por este Código, por testamento o por pacto se tenga derecho a alimentos, salvo lo pactado, lo ordenado por el testador o lo dispuesto por la Ley para el caso especial de que se trate".

${ }^{268}$ A modo de ejemplo de dicha jurisprudencia tomaremos la afirmación de la [SAP de Palma de Mallorca 4-2-1993 (AC 1993/599)], en la que dice que "La validez de los pactos que quienes constituyen una unión no matrimonial pudieran celebrar para regular sus relaciones tanto durante la permanencia de su relación como los efectos en caso de producirse el cese, tienen plena validez siempre que su contenido sea patrimonial, dado que, en definitiva, quienes así obran no hacen sino hacer uso de la autonomía de la voluntad que consagra el art. 1255 del CC".

${ }^{269} \mathrm{El}$ art. 618 del CC define la donación como "un acto de liberalidad por el cual una persona dispone gratuitamente de una cosa a favor de otra que lo acepta".
} 
de terceros, ha de tenerse como plenamente válido. Ninguna objeción cabe oponer a la capacidad para disponer o para recibir de los convivientes ${ }^{270}$ y puesto que la relación de convivencia no genera ningún tipo de incapacidad para contratar entre los miembros de la pareja, hemos de concluir con la validez de las donaciones entre ellos.

Pese a lo expuesto, la jurisprudencia ha podido pronunciarse en múltiples ocasiones sobre la validez o nulidad de las donaciones realizadas entre convivientes en la unión de hecho. Y ello porque, durante mucho tiempo, el Derecho español, siguiendo la doctrina del Derecho Civil francesa y basándose en la "inmoralidad" de la relación extramatrimonial ha venido cuestionando la validez de las donaciones en el ámbito de las relaciones more uxorio.

Esta concepción de inmoralidad de la relación extramatrimonial llevó a la jurisprudencia, ya histórica, a declarar la nulidad de las donaciones entre los miembros de la pareja cuando se entendía como pago de una relación sexual entre los mismos ${ }^{271}$. Así pues, conviene analizar en qué supuestos la jurisprudencia ha entendido como válida la donación entre los convivientes y en cuáles la ha considerado nula.

\section{a) Donaciones válidas}

\section{a).1. Cuando tiene por objeto satisfacer perjuicios derivados de la relación afectiva}

Se ha considerado tradicionalmente válida la donación cuando tiene como origen la existencia de una obligación moral derivada de la relación afectiva de la que se deriva un perjuicio moral o patrimonial para uno de los convivientes. En especial se ocasiona por motivo del cese de la convivencia y con la finalidad de contribuir a la subsistencia del conviviente perjudicado con la ruptura, reconociendo de este modo la validez de la obligación natural derivada de una convivencia more uxorio duradera. Si bien, la jurisprudencia no lo reconoció como donación, sino como atribución patrimonial en cumplimiento de una obligación natural reconocida en documento privado $^{272}$. Es decir, no siempre las atribuciones patrimoniales realizadas en el marco del cese de

\footnotetext{
${ }^{270} \mathrm{Al}$ respecto el art. 624 del CC dispone que "Podrán hacer donación todos los que pueden contratar y disponer de sus bienes".

Por su parte, a efectos de la aceptación de la donación, dispone el art. 625 que "podrán aceptar donaciones todos los que no estén especialmente incapacitados por la Ley para ello".

${ }^{271}$ En este sentido se pronuncia diversa jurisprudencia del TS, hoy claramente superada, valgan por todas las sentencias en este sentido [STS 15-11-1968 (RJ 1968/5816)].

${ }^{272}$ Así se manifiesta la STS 179/1914, de 9 de mayo, en la que se debatía la validez de una promesa de pensión vitalicia que el padre y la hermana del fallecido se habían comprometido a abonar a la mujer que había convivido con el finado
} 
la convivencia serán reconocidas como donaciones ${ }^{273}$, solamente cuando dichas atribuciones se realizan con la voluntad de gratificar al otro conviviente, o cuando se realizan por mera liberalidad, nos encontraremos ante una verdadera donación. En cualquier caso, sea como donación o como obligación natural, la atribución patrimonial ha de ser considerada válida.

\section{a).2. Donaciones remuneratorias}

También han de considerarse válidas las donaciones que tienen por objeto gratificar al otro conviviente. Este tipo de donaciones, que tienen su razón de ser en los méritos del donatario o en los servicios prestados por este al donante, se establecen como donación en el art. 619 del CC 274 . De manera que sería un modo de donación en la que se trata de recompensar al donatario por lo recibido del mismo a título gratuito.

Para determinar si nos encontramos ante una donación remuneratoria habrá que tener en cuenta la intención con la que se realiza por el donante, así como las circunstancias concretas del supuesto. Cuando el acto de liberalidad responde a la voluntad del conviviente donante de recompensar las atenciones y cuidados recibidos del otro miembro de la pareja, el carácter remuneratorio de la donación está claro y, en consecuencia, la validez y eficacia de ésta. Para que sea considerada valida, es fundamental que resulte claro que no se trata del pago o remuneración por las relaciones íntimas de la pareja (lo que implicaría la nulidad de la causa), sino que es la

y del concepturi que la misma esperaba al fallecimiento de su pareja. El TS consideró la existencia de una obligación natural derivado del deber de conciencia por la situación en la que había quedado la mujer fruto de la relación extramatrimonial.

${ }^{273}$ Así lo establece la [STS 17-10-1932 (RJ 1932/1235)] que declaró lo siguiente: "Considerando que los amores ilícitos iniciados y mantenidos entre un hombre culto, de edad madura, con pleno sentido de sus responsabilidades conyugales, y una joven huérfana de dieciséis años, que al fin de atender a su subsistencia ejercía un modesto empleo, abandonado luego por ceder al capricho de la seducción, al desplazar a la mujer del ámbito de una vida honesta para situarla en el rango de la concubina, cuya situación irregular se agravó considerablemente al sobrevenir los frutos de la maternidad, es evidente que originaron, desde luego, aparte la pérdida de la estimación social, ciertos deberes morales imputables al varón, el cual consciente de ellos no pudo por menos de traducirlos en auxilios materiales de índole económica, que por el mero hecho de su prestación durante el transcurso de las relaciones íntimas se convirtieron en obligaciones naturales, y después, al romperse aquellas por el desamparo infidente del seductor, y reconocidos por este en la promesa formal la pensión ofrecida, vinieron a transformarse en una obligación civil, perfectamente coercible, a virtud de la cual, el deudor ha de pagar no donandi causa sino solvendi animo, porque el signatario de los documentos en que mediante la promesa quiere cubrir un deber de conciencia no lo hace con intención de gratificar, ni por un movimiento de cordial liberalidad.... Sino acuciado por las reiteradas instancias de la mujer... y estimulado, también, por las propias responsabilidades morales, cuya asunción queda explícita en los términos categóricos de las cartas dirigidas a la amante y ésta aceptó recibir las primeras pensiones mensuales suspendidas radicalmente por el obligado a darlas con manifiesta violación del compromiso contraído".

${ }^{274} \mathrm{El}$ art. 619 del CC señala que "es también donación la que se hace a una persona por sus méritos o por los servicios prestados al donante, siempre que no constituyan deudas exigibles". 
gratificación por las atenciones del otro conviviente, así como por los servicios prestados por el donatario, de manera altruista, durante la convivencia.

\section{b) Donaciones declaradas nulas}

\section{b).1. Las realizadas para remunerar las relaciones extramatrimoniales de carácter}

$\underline{\text { amoroso }}$

Tradicionalmente se han considerado nulas las donaciones que tenían su razón de ser en la remuneración de relaciones sexuales entre los convivientes. Así lo ha venido entendiendo nuestra jurisprudencia $^{275}$ histórica al interpretar la existencia de causa ilícita, por lo que el contrato suscrito sería nulo y, en consecuencia, habría de aplicarse el art. 1303 del CC, que obliga a la devolución de lo recibido como consecuencia de un contrato sin causa o con causa ilícita, como era considerada la del contrato de donación cuando su causa iba contra la moral de la época ${ }^{276}$.

Esta postura mantenida en diversas ocasiones por el Alto Tribunal entiendo que no era correcta, siendo más lógica la aplicación del art. 1306.1 del CC ${ }^{277}$. La argumentación del Tribunal

\footnotetext{
${ }^{275}$ Así lo entendió el TS en un litigio derivado de la entrega de joyas y otros objetos de valor que el hombre había hecho a la mujer. Al romperse la relación sentimental él solicitó la devolución de lo entregado y el Juzgado de Primera Instancia entendió que lo entregado se había hecho a título de donación, siendo la misma ilícita y ordenando a la mujer la devolución de lo recibido. Tramitado el recurso de apelación, la Audiencia entendiendo que existía causa torpe y aplicando el art. 1306 CC concluyó que no existía obligación de devolver lo recibido. Por su parte, el TS, estimó el recurso interpuesto puesto que como dispone el art. $1275 \mathrm{CC}$ los contratos con causa ilícita (y en el caso la causa lo era por ir contra la moral) no producen efecto alguno, por lo que, en aplicación de lo dispuesto en el art. 1303 CC procedía la devolución de lo recibido. La argumentación del Alto Tribunal fue, en lo esencial, la siguiente "La sentencia del Tribunal a quo desestima la demanda por no aparecer probado que la entrega de referencia lo fuera en calidad de devolución de un préstamo comodato, ni en concepto de depósito para guarda y custodia, y sí, en cambio, en el de donación en obsequio a las relaciones ilícitas mantenidas entre los litigantes, a cuyo acto no le es aplicable la revocabilidad por ingratitud..., porque con toda evidencia la entrega de autos tuvo por causa eficiente y final la iniciación y persistencia de las relaciones íntimas fuera de toda regularidad legal, atentatorias a las costumbres patrias, aún entre personas idóneas para contraer entre sí matrimonio, incidiendo, por lo tanto, en la sanción del artículo 1275 del CC, que expresamente declara que los contratos con esta tara de ilicitud no producirán efecto alguno, lo cual lleva implícita... la devolución de las cosas a su titular, según el artículo 1303 del propio Cuerpo legal” [STS 16-10-1959 (RJ 1959/3679)].

${ }^{276}$ En la sentencia de referencia el TS especifica que procede aplicar el art. 1303 que obliga a la devolución de lo recibido, en lugar de aplicar el 1306, puesto que, en palabras del propio Tribunal en la invocada [STS 16-10-1959 (RJ 1959/3679)] "el artículo 1306, número 1 del referido Código, aplicado por la sala de instancia, no es realmente aplicable al caso del litigio, en méritos de que no contempla la hipótesis de contratos con prestaciones recíprocas, y no aquellos otros en los que solo consta la entrega de algo, sin compensación de adverso por una de las partes, según ya declaró este Tribunal en Sentencia de 10 de julio de 1902". En una interpretación que ha sido duramente criticada por la doctrina científica.

277 Art. 1306.1 CC: "Si el hecho en que consiste la causa torpe no constituyere delito ni falta, se observarán las reglas siguientes: $1^{\circ}$ Cuando la culpa esté de parte de ambos contrayentes, ninguno de ellos podrá repetir lo que hubiera dado a virtud del contrato, ni reclamar el cumplimiento de lo que el otro hubiera ofrecido (...)".
} 
de que no procede la aplicación de este artículo cuando no existen obligaciones recíprocas introduce un aspecto no contemplado en el propio artículo, que solamente establece la existencia de la causa torpe en ambos o en uno solo de los contratantes. De modo que, si la causa de la donación era ilícita por razones morales, tal ilicitud afectaba tanto al donante como a la donataria, y puesto que el artículo no exige que exista obligación recíproca, no cabe una interpretación como la que realizaba el TS, "pues tal solución implica la caída de la sanción totalmente sobre la amante, ya que el varón recupera todo lo que había dado después de conseguir lo que había querido. Parece que se estima más culpable al que cobra por pecar que al que paga por ello"278.

\section{b).2. Las realizadas para poner fin a la relación extramatrimonial}

También suelen considerarse nulas las donaciones efectuadas con la finalidad de obtener la ruptura de la relación extramatrimonial. Se declara la nulidad de aquellas donaciones en la que el donante solamente persigue poner fin a la relación y paga por ello al donatario ${ }^{279}$.

Dicho esto, no es sencillo precisar la intención con la que se hace una donación al finalizar una relación more uxorio, resultando extremadamente dificultoso determinar si la donación se ha realizado por pura y simple generosidad, para asegurarse del bienestar del miembro de la pareja que resulte desfavorecido, o si se trata de pagar para conseguir la finalización de una relación en la que ya no se está interesado. Naturalmente, en el primero de los casos la validez de la donación es evidente, pues se trata del cumplimiento de una obligación natural.

Si la prestación se realiza en pago por la ruptura o como precio por el silencio del donatario para evitar los perjuicios que le pudieran ocasionar al donante la publicidad de las relaciones mantenidas, está claro que tales donaciones son nulas por inmoralidad de la causa ${ }^{280}$.

En este supuesto, en realidad nos encontraríamos ante un auténtico chantaje, en lo que se estaría intentando conseguir aceptación de la ruptura de la pareja por parte de uno de los convivientes a cambio de una prestación económica ${ }^{281}$, lo que conlleva una evidente inmoralidad en la causa.

\footnotetext{
${ }^{278}$ TORRALBA SORIANO, V.: “Causa ilícita. Exposición sistemática de la jurisprudencia del TS”, en $A D C$, Tomo XIX (1966), pág. 705.

${ }^{279} \mathrm{La}$ invalidez de tales donaciones deviene de que la libertad individual no puede quedar sometidas a exigencias de carácter económico. En este sentido se manifiesta, entre otros, GALLEGO DOMÍNGUEZ, I.: Op. cit., pág. 259.

${ }^{280}$ MESA MARRERO, C.: Op. cit., pág. 155.

${ }^{281}$ Tal fue el caso resuelto por el TS [STS 2-4-1941 (RJ 1941/493)], cuando dos personas convinieron, en documento privado, que la mujer se comprometía a poner fin a las relaciones amorosas que mantenían desde varios años antes a
} 
En consecuencia, solamente se podrán considerar válidas las donaciones realizadas al término de la convivencia, cuando los motivos para hacerlo sean el afecto entre los miembros de la pareja, o bien cuando se trate con ellos de recompensar los servicios del otro miembro de la pareja, o también cuando con ello se pretenda remediar los perjuicios que la ruptura representa para el conviviente más desfavorecido.

\section{b).3. Las anuladas por simulación}

La jurisprudencia del TS ha declarado la nulidad de las donaciones realizadas entre los convivientes cuando tales liberalidades se han disfrazado bajo otras formas contractuales. Por ejemplo, cuando la pareja ha formalizado una transmisión patrimonial como una compraventa, cuando en realidad se trataba de una liberalidad. Este fue el caso de la STS de 15 de noviembre de $1968^{282}$, que calificó como falsa la causa de la compraventa, declarando nula la escritura pública al considerar probado que nunca se pagó el precio y que la verdadera voluntad del pretendido vendedor era la de donar la finca, defraudando de este modo los legítimos derechos de la esposa. El Alto Tribunal no valoró la situación de separación de hecho de los cónyuges, ni que la esposa estaba conviviendo con un tercero. En este asunto, el Tribunal privilegiaba los intereses de la esposa legítima no conviviente, frente a la mujer con quien, efectivamente, compartía su vida el vendedor. Puede concluirse que la resolución no fue justa en términos de justicia material, por cuanto los legalmente cónyuges solamente lo eran por imperativo legal, ya que cada uno de ellos

cambio de un pago mensual durante dos años, a cambio del cual la mujer se comprometía, además, a no residir en Europa en ese período. Sin embargo, el demandado solamente cumplió su compromiso de pago durante el primer año. Interpuesta la correspondiente demanda solicitando indemnización por los daños y perjuicios, el Juzgado de Primera Instancia desestimó la demanda, la cual fue revocada por la AP estimando la demanda, resolución que fue casada por el Alto Tribunal en la sentencia referida, al estimar el recurso de casación interpuesto por el demandado. La Sala del TS entendió que el citado convenio privado era nulo, puesto que “...resulta indudable que el condicionar la parte actora la ruptura de un estado, no solo anormal, sino contrario a las leyes y a los dictados de la moral menos exigente, a la entrega de una cantidad prevaliéndose de la sugestión e influencia que ejercía sobre la voluntad de la otra parte, equivale a contratar sobre un acto inmoral e ilícito, estipulándose el pago de cantidad determinada a cambio de una obligación de hacer, consistente en dejar a aquella parte en libertad para el cumplimiento de sus deberes legales y morales, lo cual no puede menos de viciar el objeto y la causa del contrato". En definitiva, siendo la finalidad perseguida en el contrato privado la de pagar el precio convenido por la ruptura de la relación extramatrimonial, no podía admitirse la validez de las obligaciones pactadas.

${ }^{282}$ En el caso se enjuiciaba la venta, en escritura pública, realizada por un hombre casado a una mujer con la que mantenía una relación de concubinato, si bien el hombre estaba separado de hecho. A la vez, la esposa también convivía con otro hombre, aunque legalmente seguía vigente el matrimonio (no había divorcio en España, en ese tiempo). Fallecido el esposo, la que era su esposa legal demandó la nulidad de la compraventa realizada entre los concubinos alegando que ella carecía de bienes, y que por tanto la venta había sido una simulación realizada en fraude a la sociedad de gananciales que ella mantenía con su esposo. El TS declaró la nulidad de la escritura de compraventa por ser simulada, y porque la verdadera intención había sido la de donar la finca a la concubina. 
había formado nuevas parejas al existir una separación de hecho mutuamente consentida. Es al fallecimiento del esposo cuando la que era legalmente su esposa contrae nuevas nupcias con el hombre que era su pareja de hecho y reclama a la sociedad de gananciales que mantenía con el difunto la propiedad de la finca que este había adquirido posteriormente a la separación de hecho y que posteriormente "vendió" a la mujer con la que convivía.

Ciertamente, en estos tiempos tal resolución nos puede resultar llamativa y, desde luego, absolutamente injusta desde una perspectiva exclusivamente material, toda vez que el matrimonio era indisoluble en aquel tiempo, pero la misma se ajustaba plenamente a la legalidad vigente en el momento de producirse los hechos y de dictarse la sentencia.

\section{b).4. La anulabilidad de las donaciones realizadas con vicio en el consentimiento}

Dispone el art. 1265 del CC que "será nulo el consentimiento prestado por error, violencia, intimidación o dolo", de manera que cabe dividir los vicios en el consentimiento entre aquellos que afectan al conocimiento de la realidad y aquellos que afectan a la libertad como causa para pedir la nulidad del contrato ${ }^{283}$. Entre los que afectan al conocimiento se incluyen el error y el dolo, pues son supuestos en los que la decisión se adopta sin el conocimiento necesario. Entre los que afectan a la falta de libertad se incluyen la violencia y la intimidación, ya que en estos casos la decisión no se adopta de manera libre.

Pero, para que el contrato sea anulado, es necesario que el vicio del consentimiento sea probado, y que el mismo se haya producido bajo ciertas condiciones ${ }^{284}$. De modo que el miedo a sufrir un mal por uno de los convivientes, o el engaño utilizado por uno de ellos para que se produzca la donación darían lugar a la anulación del contrato en determinadas circunstancias.

\footnotetext{
${ }^{283}$ PUIG BRUTAU, J.: Fundamentos de Derecho civil. Doctrina general del contrato, Tomo II, Vol. 1, $3^{\mathrm{a}}$ ed. Bosch, Barcelona (1988), pág. 73.

${ }^{284} \mathrm{El}$ art. 1266 del CC establece que "Para que el error invalide el consentimiento, deberá recaer sobre la sustancia de la cosa que fuere objeto del contrato, o sobre aquellas condiciones de la misma que principalmente hubiesen dado motivo a celebrarlo". En relación con el dolo como vicio del consentimiento el art. 1269 del CC, dice que "hay dolo cuando, con palabras o maquinaciones insidiosas de parte de uno de los contratantes, es inducido el otro a celebrar un contrato que, sin ellas, no hubiera hecho", añadiendo el art. 1270 del mismo Cuerpo legal que "Para que el dolo produzca la nulidad de los contratos, deberá ser grave y no haber sido empleado por las dos partes contratantes". En cuanto a la violencia y la intimidación señala el art. 1267 del CC que "hay violencia cuando para arrancar el consentimiento se emplea una fuerza irresistible. Hay intimidación cuando se inspira a uno de los contratantes el temor racional y fundado de sufrir un mal inminente y grave en su persona o bienes, o en la persona o bienes de su cónyuge, descendientes o ascendientes. Para calificar la intimidación debe atenderse a la edad y a la condición de la persona.", precisando en el art. 1268 el propio Código que "La violencia o intimidación anularán la obligación, aunque se hayan empleado por un tercero que no intervenga en el contrato".
} 
Así, e cuanto a la intimidación tendría lugar cuando uno de los miembros de la relación extramatrimonial presiona al otro conviviente para formalizar un contrato de donación bajo la amenaza de que va a sufrir un mal, inminente y grave, de modo que la creencia de que esa amenaza será llevada a cabo hace que este preste un consentimiento que, de otro modo, no habría prestado ${ }^{285}$. Para que se pueda declarar la nulidad del contrato es preciso acreditar que la sugestión o la captación sufrida por uno de los contratantes ha sido determinante para la prestación del consentimiento $^{286}$.

Siguiendo las reglas generales, es necesario acreditar que el consentimiento prestado por alguno de los convivientes no cumple con las características exigidas de haberse manifestado de manera libre, voluntaria y consciente, para que proceda la nulidad del contrato de donación.

\section{c) La situación actual: la validez de las donaciones entre convivientes}

Durante mucho tiempo la jurisprudencia, partiendo de la inmoralidad de las relaciones more uxorio, ha venido declarando la nulidad de las donaciones interpretando la ilicitud de la causa al entender que tales relaciones atentaban contra la moral y las buenas costumbres. Tal interpretación hacía uso de una concepción subjetivista de la causa, identificando la causa con los motivos individuales de los convivientes que, teniendo en cuenta la inmoralidad de los motivos subjetivos por los que los convivientes contrataban ${ }^{287}$, declaraba nulo el contrato por ilicitud de su causa ${ }^{288}$.

\footnotetext{
${ }^{285}$ Este tipo de amenazas se producía en el caso resuelto por la STS 1543/1918, de 8 de marzo. Los antecedentes del caso eran que, durante una relación no matrimonial, con múltiples desavenencias entre los convivientes, que incluían denuncias de la mujer al hombre por delito de injurias. En tal estado de cosas, los convivientes suscribieron un documento privado por el que la mujer renunciaba a ejercitar acciones contra el hombre obligándose, además, atenciones y consideraciones de toda clase con el varón. En compensación, el hombre se comprometía a abonarle una pensión vitalicia mensual. En este caso el TS declaró la nulidad del contrato, ya que el mismo había sido suscrito por la presión y amenazas ejercidas por la mujer. También, en otra Resolución de 1941, el miedo al escándalo de un hombre casado, que había mantenido relaciones amorosas con una mujer, le llevó a comprometerse a abonar a su amante una cantidad mensual a cambio de poner fin a las relaciones que venían manteniendo. También en este caso el Alto Tribunal declaró la nulidad del contrato [STS 2-4-1941 (RJ 1941/493)].

${ }^{286}$ Señala GALLEGO DOMÍNGUEZ, I.: Op. cit., pág. 162, que "sobre todo en las primeras etapas de convivencia y en los momentos previos a la extinción de la unión, habrá que extremar el celo en ver si hay captación de consentimiento en los términos de los artículos 1265 a 1270 del CC".

${ }^{287}$ En este sentido, la mencionada sentencia decía "el concepto de causa ilícita permite cobijar no solo las convenciones ilícitas por razón de su objeto o de su motivo, sino también múltiples convenciones que, no encerrando en sí ningún elemento de directa antijuridicidad, son ilícitas por el matiz inmoral que revista la operación en su conjunto" [STS 24-1941 (RJ 1941/493)].

${ }^{288}$ Tal postura de la jurisprudencia ha sido muy criticada por diversos autores, en especial por ESTRADA ALONSO, E.: Op. cit., págs. 295-297. Para quien el criterio subjetivista de la causa empleado por los Tribunales para declarar la nulidad de las donaciones, así como de otras prestaciones entre convivientes, se apartaba de la concepción causal objetiva que establece el artículo 1274 del CC. Sin duda existen otros recursos para conseguir la ineficacia de las donaciones hechas por un conviviente en favor del otro: ilicitud del objeto o vicios del consentimiento.
} 
La jurisprudencia ha variado en la actualidad al haber obtenido las parejas de hecho un importante reconocimiento de efectos jurídicos. Así pues, puede afirmarse que actualmente la validez de las donaciones entre convivientes tiene un planteamiento muy distinto del mantenido en el pasado. No cabe invocar ahora la ilicitud de tal tipo de relaciones para invalidar las donaciones que los convivientes pudiera realizar entre ellos.

Tampoco contiene el CC ninguna prohibición específica que impida a los convivientes more uxorio realizar o percibir donaciones entre sí $^{289}$. Esto deja claro que mantener una relación extramatrimonial no implica causa de incapacidad para realizar donaciones o cualquier otro tipo de contratos, es obvia la licitud de tales donaciones con las limitaciones establecidas para todos los contratos y en particular para las donaciones.

De modo que, admitida la capacidad jurídica de los convivientes para realizarse donaciones entre sí, debemos concluir que, en principio, las donaciones realizadas por los convivientes son perfectamente válidas ya que no existe prohibición alguna que afecte, de manera específica a los convivientes, para la celebración de cualquier tipo de contratos. Ahora bien, si tales liberalidades se realizasen como remuneración por las relaciones íntimas entre donante y donatario, o bien con el propósito de dar inicio a este tipo de relaciones, es evidente la nulidad de tal donación por ilicitud de la causa.

Sin embargo, tratándose de verdaderas uniones familiares de hecho, es altamente improbable que tales donaciones se realicen para remunerar ese tipo de relaciones íntimas. Convendremos en que, en general, estas liberalidades tendrán una motivación diferente, más relacionada con la gratitud, el afecto o el deseo de asegurar el bienestar económico del más desfavorecido, pero no resulta probable que la donación se plantee como la remuneración por el mantenimiento de la relación íntima ${ }^{290}$.

Por tanto, las donaciones que los convivientes realicen entre sí son inicialmente válidas, siempre que en la misma concurran los requisitos legalmente exigidos para la validez de los

\footnotetext{
${ }^{289}$ Tampoco mientras estuvieron prohibidas las donaciones entre cónyuges (artículo 1334 El CC anterior a la reforma de 1981) podía extenderse tal prohibición a los convivientes. En este caso se daba la paradoja de que un hombre casado pudiera, en principio, donar a su concubina lo que no podía donar a su esposa. Vid. GALLEGO DOMÍNGUEZ, I.: Op. cit., págs. 255 y ss.

${ }^{290} \mathrm{Si}$ en algún caso la donación tuviere como razón de ser el pago de un precio por los servicios sexuales prestados por el perceptor de la donación, el objeto del contrato sería ilícito, por la deshonestidad del mismo (art. 1271 del CC).
} 
contratos en general y, en particular, los exigidos por el CC para la realización válida de la donación ${ }^{291}$.

\section{d) La revocación de las donaciones}

De especial interés resulta el examen de las disposiciones del CC relativas a la revocación de las donaciones y cómo afectarían a las hechas entre convivientes. No cabe duda de que las disposiciones sobre revocación de las donaciones contenidas en los artículos 644 y ss. del CC resultan de aplicación a las realizadas entre los miembros de la pareja de hecho. En especial analizaremos si algunas de las vicisitudes propias de la convivencia no matrimonial podrían ser incluidas entre los casos de revocación contemplados por el artículo 648 del CC:

1. Revocación de la donación por infidelidad del donatario: el párrafo $1^{\circ}$ del citado artículo permite al donante revocar la donación "Si el donatario cometiere algún delito contra la persona, el honor o los bienes del donante". En nuestro parecer, no cabe aplicar a los supuestos de infidelidad del donatario esta norma, y ello por dos razones: la primera es que al tratarse de una norma sancionadora su interpretación debe ser restrictiva ${ }^{292}$. En segundo lugar, porque no cabe interpretar como delito la falta de fidelidad entre los miembros de la unión de hecho, de manera que la infidelidad del donatario no puede ser interpretada como un acto de ingratitud hacia el donante que capacite a este para revocar la donación efectuada.

2. Revocación de la donación por negar indebidamente alimentos al donante: el párrafo $3^{\circ}$ del mencionado artículo faculta al donante para revocar la donación si este "le niega indebidamente los alimentos". La cuestión se centra en si este motivo de revocación afecta a las donaciones entre convivientes. Debemos partir de que no es

\footnotetext{
${ }^{291} \mathrm{El}$ artículo 632 del CC dispone que la donación de cosa mueble puede realizarse verbalmente o por escrito. En el primero de los casos, se exige la entrega simultánea de la cosa donada. A falta de este requisito, la donación deberá hacerse por escrito constando de la misma forma la aceptación del donatario. En el artículo 633 del mismo Cuerpo Legal se establece que, si la donación es de bien inmueble se exige el otorgamiento de escritura pública, en la que se expresarán de manera individual los bienes donados, así como el valor de las cargas que, en su caso, deba satisfacer el donatario. También ha de constar en escritura pública tanto la aceptación del donatario como el conocimiento de tal aceptación por el donante.

${ }^{292}$ La jurisprudencia mantiene que, conforme al principio de legalidad que rige en la materia, las causas de ingratitud tipificados en el artículo 648 tienen carácter tasado [STS 13-5-2000 (RJ 2000/3410)]; sin embargo, no es preciso para la aplicación el citado artículo que exista una sentencia penal condenatoria, sino simplemente que la conducta que se impute tenga caracteres delictivos o delictuales (STS 5-12-2006 (RJ 2007/231) y STS 18-12-2012 (RJ 2012/11277)]..
} 
posible aplicar la analogía entre las uniones de hecho y el matrimonio y, puesto que los convivientes no figuran entre los obligados recíprocamente a darse alimentos señalados en el artículo 143 del CC, es evidente que no existe la obligación legal de prestarse alimentos entre los miembros de la pareja. Por lo tanto, debemos considerar que no es posible la revocación de la donación en el supuesto de que el donatario niegue indebidamente alimentos al donante. Sin embargo, algunos autores consideran que el CC impone una obligación de alimentos al donatario derivada del mero hecho de la donación ${ }^{293}$.

Otro aspecto a considerar actualmente es que, de acuerdo con los criterios interpretativos de la realidad social del momento de aplicación de la norma y su propia finalidad, el maltrato de obra o psicológico realizado por el donatario debe quedar reflejado como un hecho integrado en la causa de ingratitud, según el artículo 648 del CC. No cabe duda de que en la actualidad el maltrato de obra o psicológico del donatario, además de ser una conducta socialmente reprobable, reviste o proyecta caracteres delictivos que resultan necesariamente ofensivos para el donante. Por ello su comisión atenta contra los más elementales deberes de consideración y gratitud hacia el donante, dotando de fundamento a la revocación de la donación por ingratitud como sanción impuesta a los donatarios que infringen el deber básico de consideración hacia el donante ${ }^{294}$.

\section{e) Las donaciones inoficiosas}

Finalmente, deberán ser tenidas en cuenta las reducciones de las donaciones inoficiosas realizadas entre los miembros de la pareja, si con ellas se perjudican el derecho a la legítima de los herederos forzosos del donante. El conocimiento de tal inoficiosidad solo será posible al fallecimiento del donante, y una vez realizado el cálculo de la legítima global, habida cuenta de que el haber hereditario incluye tanto del patrimonio relicto cómo de las liberalidades realizadas por el causante, a fin de comprobar si se ha lesionado o no el derecho legitimario de sus herederos

${ }^{293}$ Entre otros DÍEZ-PICAZO, L. y GULLÓN, A.: Sistema de Derecho Civil, Vol. II, Tomo 2, 12 a ed. Madrid (2018), pág.77, para estos autores no hay duda acerca de la obligación de alimentos que el CC impone por razón de la donación. ${ }^{294}$ LASARTE ÁlVAREZ, C.: Principios de Derecho Civil III. Contratos, 21. a ed. Marcial Pons, Madrid (2019), pág. 182. 
forzosos. En definitiva, en la actualidad las donaciones entre miembros de una unión more uxorio tienen un régimen similar al de las existentes dentro de la institución matrimonial.

Dispone el artículo $636 \mathrm{CC}$ que nadie podrá dar ni recibir, por vía de donación, más de lo que pueda dar o recibir por vía de testamento. De modo que será inoficiosa la donación en todo lo que exceda de dicha medida. El CC dedica el capítulo siguiente (artículos 644 a $656 \mathrm{CC}$ ) a la revocación y reducción de las donaciones. En el caso concreto de aquellas donaciones que resulten inoficiosas se recoge lo que es conocido como la reducción de acciones por inoficiosas.

La razón de tal inoficiosidad resulta de la vulneración de la institución de las legítimas, instituto sucesorio, ciertamente complejo y polémico ${ }^{295}$. Ya que, según lo dispuesto en el precepto citado, la donación es inoficiosa únicamente cuando excede en su cuantía de lo que el donante podía dar al donatario por testamento, y tal determinación hay que remitirla al momento de la partición a la que habrá de traerse el valor de los bienes donados al tiempo en que se evalúan los bienes hereditarios (por disponerlo así el artículo 1045 CC) a fin de integrar la masa hereditaria con el relictum más el donatum a efectos de poder calcular las legítimas de los herederos forzosos y comprobar si la donación las ha perjudicado causando su minoración.

Es decir que, dentro de las reglas de la donación, cada uno puede dar lo que quiera o recibir por donación lo que sea, pero siempre respetándose las legítimas. De todas formas, se puede donar cuanto se quiera, pero al morir el donante el mantenimiento posterior de la validez de la donación que antes hizo dependerá de que sea compatible con la cuantía de la legítima que, por no haberla pagado en vida, queda todavía pendiente de pagar a cargo de los bienes relictos. Y este artículo debe ponerse en relación con las consecuencias de la aplicación de los artículos 654 y 655 del mismo cuerpo legal, encuadrados ambos bajo la denominación de revocación y reducción de donaciones. Y así las donaciones inoficiosas deberán ser reducidas en cuanto al exceso, atendiendo al valor líquido de los bienes del donante al tiempo de su muerte, no obstando ello para que tengan efecto durante la vida del donante y para que el donatario haga suyos los frutos, y que solo podrán pedir la reducción de las donaciones aquellos que tengan derecho a legítima o a una parte alícuota de la herencia, y sus herederos y causahabientes. No cabe duda que esa llamada "reducción" no es

\footnotetext{
295 Ello ha llevado a algún sector de la doctrina a señalar la dificultad de encuadrar las legítimas, ya que, en cuanto institución sucesoria se fundamenta en el fallecimiento de una persona, es decir, se manifiesta mediante la sucesión mortis causa, pero también es referido su funcionamiento a actos inter vivos llevado a cabo por el causante, y que encuentra su función y justificación en la tutela de la familia.
} 
más que una "rescisión" parcial que la ley establece para rebajar, en cuanto el exceso, las donaciones que resulten inoficiosas ${ }^{296}$.

Analizada sucintamente la inoficiosidad de la donación, con carácter general, dedicaremos algunas líneas al supuesto de la lesión de la legítima viudal y su reducción. Y ello, porque la lesión cuantitativa de la legítima del cónyuge viudo, tiene connotaciones propias y diferenciadas debido a su configuración legal. Es conocido que tal legítima consiste en una cuota usufructuaria de parte de la masa hereditaria. Cuota que varía en función de los otros legitimarios con quienes concurra en la sucesión. Dado que el derecho legitimario viudal se traduce en obtener el usufructo de un parte del haber hereditario, tal legítima se verá lesionada cuando las liberalidades en pleno dominio otorgadas inter vivos por el causante impidan que el viudo pueda conseguir el usufructo de bienes por el valor de su cuota ${ }^{297}$.

Pese a ello, si los bienes en pleno dominio existentes en el relictum fuesen suficientes para pagar el valor resultante de la capitalización del usufructo viudal, dada la facultad de conmutación conferida a los herederos, estos pueden sustituir la entrega del usufructo de bienes ya sea por una renta vitalicia, los productos de determinados bienes o un capital en efectivo, por disponerlo el artículo 839 CC. De modo que, no siempre podrá el cónyuge viudo impugnar como inoficiosas donaciones que vulneren su cuota viudal usufructuaria.

La misma posición que el cónyuge viudo debería tener el conviviente en unión libre o unión de hecho registrada al que, mediante pacto o por testamento, le hubiese sido otorgada tal posición por el compañero fallecido, pudiendo de tal modo asimilar al conviviente supérstite con el viudo legitimario.

Los términos utilizados de reducción o de rescisión hacen referencia al problema del plazo para el ejercicio de la acción. De manera que, en el capítulo de la revocación y reducción de las donaciones se contemplan los supuestos de rescisión por supervivencia de hijos con un plazo de prescripción de cinco años (artículo $646 \mathrm{CC}$ ); o por causa de ingratitud, por plazo de un año (artículo $652 \mathrm{CC}$ ); mientras que otros dos supuestos, la revocación de la donación por incumplimiento de alguna condición al donatario (artículo 647 CC) y la donación inoficiosa (artículo 654 CC) no tienen plazo definido.

296 [SAP de Alicante 12-7-2007 (JUR 2007/336701)], FJ tercero.

${ }^{297}$ GARCÍA PÉREZ, R.: La acción de reducción de donaciones inoficiosas. Tirant lo Blanch, Valencia (2004), pág. 232. 
En lo que respecta al plazo para el ejercicio de la acción de reducción de las donaciones inoficiosas, aunque no es pacífico en la doctrina, la jurisprudencia del TS, se ha decantado por establecer un plazo de caducidad de cinco años para el ejercicio de la acción ${ }^{298}$, plazo sobre el que parece haber conformidad en que el die a quo será el de la apertura de la sucesión, por ser cuando nace el derecho del legitimario.

\section{La vivienda como hogar familiar de las parejas de hecho}

Resultando indiscutible que, en la actualidad, las uniones de hecho constituyen un modelo de familia al margen del matrimonio, pero con la indudable protección del art. 39.1 de la CE, entendemos que podría definirse la vivienda familiar "por la utilización conjunta, permanente y habitual que los miembros de la familia hacen de aquella y donde priman los intereses de una familia, como entidad propia, frente a los particulares de uno de los cónyuges" 299 . Según esta definición tendríamos que la vivienda familiar no se considera un bien perteneciente a uno de los miembros de la familia, sino que se adscribe al interés general del conjunto familiar, independientemente de la titularidad de la citada vivienda. Tal concepto tendrá trascendencia en aspectos tales como el régimen de disposición de la misma o en la atribución de su uso.

Tampoco parece muy cuestionable que la problemática en torno a la vivienda familiar surge, fundamentalmente, cuando se produce la ruptura de la convivencia de la pareja. Si bien es cierto que durante la convivencia también surgen diversas cuestiones en torno a la vivienda, siendo estas diferentes según sea esta propiedad de uno o ambos convivientes, o se trate de una vivienda arrendada.

$\mathrm{Al}$ analizar el tema de la vivienda en las relaciones de convivencia more uxorio hay que destacar que, en general, no está contemplada en nuestra legislación la situación de las parejas no casadas, puesto que solamente en relación con los arrendamientos urbanos se mencionan estas uniones $^{300}$. La inexistencia de un régimen económico establecido por defecto para las uniones de

\footnotetext{
${ }^{298}$ [ STS 4-5-1999 (RJ 1999/1401)] en cuyo FJ segundo confirma, como ratio decidendi de la Sentencia, lo señalado como meros obiter dicta en otra previa Sentencia de la misma Sala [STS 12-7-1984 (RJ 1984/3944)].

${ }^{299}$ ROBLEDO VILLAR, A.: "La actio communi dividendo ejercitada por el copropietario de una vivienda familiar que está privado de su uso por sentencia judicial", en La Ley, n. ${ }^{\circ} 3905$ (1995), pág. 1.

${ }^{300}$ En la vigente Ley de Arrendamientos Urbanos (LAU) se mencionan las uniones extramatrimoniales en los artículos 12 a efecto del desistimiento o vencimiento del contrato de arrendamiento, en el que será preciso el consentimiento del cónyuge o conviviente, y en el art. 16 en cuanto a la subrogación en el contrato. En ambos supuestos se establece una cierta asimilación de la unión de hecho al matrimonio, si bien en el caso de las parejas no casadas se les exige una convivencia previa de dos años, salvo que tengan descendencia común con el otro conviviente.
} 
hecho que permita resolver las cuestiones relativas a aspectos tales como titularidad, disposición o uso de la vivienda, agrava la falta de previsión legal.

Esta falta de normas legales reguladoras de la vivienda en las uniones de hecho, no impide señalar que la vivienda habitual, aunque extramatrimonial, es la vivienda familiar y por tanto digna de protección. Pero no por ello podemos entender sin más que el régimen aplicable a la vivienda familiar de un matrimonio y a la que constituye el hogar de una unión de hecho sea el mismo. "Digna de protección" no significa la aplicación en bloque de todas aquellas normas contenidas fundamentalmente en nuestro CC y referidas a la vivienda familiar matrimonial, sino que más bien se trata de ver en qué medida son aplicables todos o algunos de esos preceptos, o en qué medida es preciso establecer un régimen propio para la vivienda habitual de las uniones de hecho. Con esto se quiere poner de relieve que admitir que se pueda hablar de vivienda familiar en relación con una unión de hecho no significa, necesariamente, otorgarle la misma protección que a la vivienda de un matrimonio, de igual manera que la inclusión dentro del concepto de familia de la unión extramatrimonial no significa la equiparación entre ambos tipos de familia ${ }^{301}$.

\section{a) Problemática acerca de la titularidad de la vivienda familiar}

En este punto analizaremos la problemática relativa a la titularidad dominical, dejando para más adelante el estudio de la titularidad arrendaticia. En el caso de la titularidad dominical del bien pueden producirse dos situaciones bien distintas: que la vivienda pertenezca en común a ambos convivientes, o que corresponda a uno solo de ellos.

Habitualmente, toda la problemática derivada de las distintas situaciones de titularidad se pone de manifiesto en el momento de la ruptura de la convivencia. El primero de los supuestos es aquel en el que la adquisición de la vivienda se realiza de manera conjunta por ambos convivientes, con aportaciones de ambos, de las cuales surge una situación de copropiedad sobre la vivienda adquirida, resultando de aplicación los artículos 392 y ss. del CC relativos a la comunidad de bienes.

Uno de los problemas que suele surgir se produce cuando la vivienda ha sido adquirida con aportaciones de ambos convivientes, pero en el Registro de la Propiedad figura como titular exclusivo del mismo uno solo de ellos. Es decir, hay supuestos en que la titularidad formal no se

301 ANDREU MARTÍNEZ, B.: "Uniones de Hecho y vivienda: soluciones en la jurisprudencia”, en Revista jurídica de la Región de Murcia, n. 23 (1997), págs. 18-19. 
corresponde con la titularidad real. Se trata, en principio, de un supuesto similar al anterior, puesto que nos encontramos ante una situación de copropiedad proindiviso, perteneciente a ambos convivientes, al margen de los motivos por los que hayan decidido la inscripción registral a nombre de uno solo de ellos. Tal situación puede dar lugar a problemas, por ejemplo, si el titular formal decidiese enajenar por sí solo el bien, sin contar con la voluntad del otro copropietario ${ }^{302}$.

La complicación surge cuando uno de los miembros de la pareja adquiere la vivienda para ambos, o bien cuando la vivienda la adquieren ambos, pero con aportaciones de uno solo de los convivientes. En estos casos, la jurisprudencia ha optado en unos casos por tener en cuenta la procedencia de los fondos utilizados para la adquisición de la vivienda para declarar a ese conviviente como titular exclusivo de la misma, al margen de las manifestaciones realizadas en el momento de la adquisición ${ }^{303} \mathrm{y}$, en otros supuestos, la jurisprudencia de manera mayoritaria ha fijado su atención en la voluntad de las partes, es decir, en los acuerdos de las mismas evidenciados a través de sus actuaciones o manifestaciones de adquirir el bien de manera conjunta y para ambos convivientes $^{304}$.

Cuando se produce este último supuesto, en el que se establece una situación de copropiedad, independientemente de que los fondos usados para adquirir el bien hayan sido aportados por uno solo de los miembros de la pareja ${ }^{305}$, surge una nueva cuestión: la de fijar la cuota de participación en la cotitularidad de cada uno de los convivientes.

En todo caso, y pese a que la jurisprudencia acostumbra a citar la existencia de pactos "expresos" o "tácitos", lo fundamental suele ser lo que las partes acreditan en torno a la existencia

\footnotetext{
${ }^{302}$ Este fue el caso resuelto por la AP de Madrid, en el que, si bien tanto en la escritura pública de adquisición como en el Registro de la Propiedad constaba uno de los convivientes como único titular, fueron ambos los que abonaron parte del precio en el momento de firmar el contrato, y quienes posteriormente siguieron pagando las cantidades restantes. En este caso se tuvieron en cuenta las aportaciones realizadas por cada uno de los miembros de la pareja en orden a determinar la participación de cada uno en la comunidad [SAP de Madrid 20-9-1995 (AC 1995/2518)].

${ }^{303}$ Este es un caso resuelto por la AP de Zaragoza, ambos convivientes aparecen como compradores de una vivienda en el Registro de la Propiedad, constando inscritos como copropietarios, a pesar de que el dinero había sido aportado por uno solo de ellos [SAP de Zaragoza 14-6-1994 (AC 1994/9229)].

${ }^{304}$ En este mismo sentido se manifiesta GALLEGO DOMÍNGUEZ, I.: Op. cit., pág. 211, para quien el hecho de haber manifestado una voluntad de adquirir para ambos sujetos lleva a considerar que se ha adquirido para ambos en comunidad ordinaria, y ello con independencia de que el precio o contraprestación fuese común o privativo del adquirente.

${ }^{305}$ El TS resolvió un caso en el que se había adquirido el bien para la "sociedad conyugal". Si bien no se discutió la cotitularidad, puesto que la vivienda se había adquirido con dinero procedente de un premio de lotería, entrando el Tribunal a determinar el carácter privativo o común de dicho dinero. Para lo cual acudiría a hechos periféricos (el ingreso del importe del premio en una cuenta conjunta, la autorización para disponer a la hija de uno de ellos de este dinero, pero firmada por ambos, etc) de los cuales dedujo el Tribunal la cotitularidad del dinero procedente del premio y, por tanto, de lo adquirido con él [STS 31-10-1996 (RJ 1996/7723)].
} 
del acuerdo de adquirir conjuntamente. Es por ello que, independientemente de que los fondos sean aportados por ambos o por un solo, no resulta determinante a la hora de adjudicar la titularidad.

La cuestión se complica cuando no existe la voluntad de adquirir el bien en copropiedad, o de hacer copartícipe al otro conviviente, o que no pueda deducirse con claridad de las manifestaciones y actuaciones del titular. En estos supuestos vuelven a reproducirse las cuestiones sobre cuál sea la causa de atribución al conviviente no titular, volviendo a analizar las figuras de la obligación natural o de las donaciones en lo que resulten de aplicación al caso concreto, habiendo, en consecuencia, supuestos en que la conclusión sea la cotitularidad y otros en los que deba ser reconocido el carácter exclusivo de la titularidad.

\section{a).1. Supuestos de cotitularidad}

Hemos visto supuestos en los que, bien por la manifestación expresa de voluntad de los convivientes o bien por el modo de adquisición de la vivienda, se podía concluir fácilmente la copropiedad de la misma. Nos referimos ahora a otro tipo de supuestos, aquellos en los que el bien ha sido adquirido por uno solo de los convivientes, figura este como único titular del bien y, además, pertenecen en exclusiva a este conviviente los fondos utilizados para la adquisición del bien. Pese a ello, será posible determinar la voluntad tácita de adquirir para ambos, deducida de los actos periféricos o concluyentes de las partes ${ }^{306}$.

Algunos de los criterios seguidos por la jurisprudencia para concluir la existencia de la voluntad de formar un patrimonio común entre ambos convivientes, se vienen señalando aspectos como la duración de la convivencia, las actividades realizadas en común por los convivientes, la existencia de confusión en gastos, ahorros e inversiones, la colaboración y ayuda de uno en las actividades del otro (trabajo doméstico y/o ayuda en las actividades económicas del otro) como medios para concluir la existencia de un acuerdo tácito entre los convivientes. En muchos de estos casos, y en especial en lo relativo al ajuar doméstico, se suele acudir a las normas relativas a la liquidación de los gananciales para realizar la liquidación de los bienes declarados comunes ${ }^{307}$.

\footnotetext{
${ }^{306}$ El TS declaró probada la voluntad de ambas partes de hacer comunes los bienes adquiridos durante la convivencia, sin que fuera obstáculo para ello el que estos constaran a nombre de uno solo de los convivientes, pues se trataba en realidad de una titularidad dominical fiduciaria. En este caso, la mujer se había dedicado a las tareas del hogar durante los veinte años que duró la relación de convivencia, así como a ayudar a su pareja en las actividades del negocio. Fruto de la relación existían cuentas corrientes comunes. De todo ello se concluyó la existencia de un patrimonio común, a la vez que se entendió creada entre los convivientes una sociedad mercantil irregular [STS 18-5-1992 (RJ 1992/4907)]. ${ }^{307}$ Esta fue la solución dada por la SAP de Oviedo, en un caso en el que ambos miembros recibían ingresos que ponían en común [SAP de Oviedo 10-4-1992 (AC 1992/265)].
} 


\section{a).2. Supuestos de titularidad exclusiva}

Junto a los supuestos ya vistos, existen otros casos en los que se reconoce la titularidad exclusiva de uno de los convivientes, para un mejor entendimiento de la cuestión agruparemos los supuestos posibles en los siguientes tipos:

1. Supuestos derivados de la fecha de adquisición del bien, al igual que en los diversos regímenes económicos matrimoniales, lo bienes adquiridos con anterioridad al inicio de la convivencia pertenecen en exclusiva al conviviente adquiriente del $\operatorname{bien}^{308}$.

2. Un segundo grupo de supuestos es el formado por convivientes que mantienen una separación absoluta de sus bienes, bien por declaración expresa realizada por los convivientes, o bien acreditada mediante los actos de la vida cotidiana, como podría ser el mantenimiento de cuentas corrientes separadas. Estaríamos, pues, en una situación similar a la que se produce en el régimen matrimonial de separación de bienes, manteniendo como propios de cada conviviente los ingresos obtenidos, así como los bienes adquiridos con los fondos privativos, sin perjuicio de la adquisición conjunta de algún determinado bien, al que se aplicarían las reglas de la copropiedad atendiendo a las cuotas de participación de cada uno de ellos ${ }^{309}$.

3. Un tercer grupo estaría formado por aquellas uniones de convivencia en los que, sin que existan datos concluyentes de la voluntad de separación de los bienes, la misma cabe deducirla de otras actuaciones de los convivientes. Esta voluntad puede deducirse tanto de actuaciones como de omisiones del demandado. Por ejemplo, el hecho de que un conviviente adquiera un bien con fondos exclusivamente suyos e inscriba el mismo a su nombre sería indicativo de tal voluntad, pues si su intención

\footnotetext{
${ }^{308}$ Tal fue el caso analizado por la AP de Navarra, en el que el piso había sido adquirido por uno de los convivientes años antes de iniciarse la relación de convivencia, sin que constara que el otro conviviente hubiera realizado pago alguno en relación con la adquisición del citado bien. Como consecuencia, se decretó la titularidad exclusiva de la vivienda [SAP de Navarra 15-9-1994 (AC 1994/1430)].

${ }^{309}$ LACRUZ BERDEJO, J.L.; SANCHO REBULLIDA, F.; DELGADO ECHEVERRÍA, J.; LUNA SERRANO, A.; RIVERO FERNÁNDEZ, F.; RAMS ALBESA, J.; Op. cit., Tomo IV, págs. 292 y 293.
} 
fuese compartir los bienes así adquiridos habría realizado las actuaciones en ese sentido $^{310}$.

En definitiva, los supuestos posibles son muy diversos, si bien podemos concluir que, el hecho de que el bien en discusión sea la vivienda familiar, no resulta especialmente trascendente para determinar la titularidad conjunta. Cuando existe una manifestación de voluntad expresa o tácita de que la adquisición se realiza para la comunidad, no importa cuál sea el bien adquirido. Lo relevante es si los convivientes han declarado su intención de adquirir para ambos o, incluso, si el bien de que se trate ha sido adquirido conjuntamente.

Junto a ello, existen los supuestos en que la voluntad de los convivientes es la de mantener separados sus patrimonios, intención que se deduce bien de las propias manifestaciones de los convivientes, o bien de otras circunstancias del desarrollo de su vida diaria. En tales casos, se determina la titularidad exclusiva del conviviente que adquiere el bien, de nuevo independientemente del tipo de bien adquirido o de la existencia de algún derecho de reintegro al otro conviviente por las aportaciones que haya podido realizar en la adquisición.

Existe un tercer grupo de supuestos que se mueven en una situación ambigua, en los que resulta difícil ver el hecho diferencial, en los que, en función de las circunstancias del caso concreto, se concluye que existe una comunidad de vida (actividad doméstica, ayuda en los negocios del otro conviviente, cuentas bancarias conjuntas, etc.), que tendrá como conclusión que los bienes se han adquirido para la comunidad, en base a la voluntad de los convivientes. La cuestión radica en determinar la existencia o no de la manifestación de voluntad de hacer comunes los bienes adquiridos, por lo que cuando se concluye la inexistencia de esa voluntad procede declarar la titularidad exclusiva del miembro de la pareja que aportó el dinero para adquirir el bien ${ }^{311}$.

\footnotetext{
${ }^{310}$ Véase PAZ CASARES, C.: "Comentarios al artículo 1671 del CC", en Comentarios al CC. Ministerio de Justicia, Madrid (1991), págs. 1385 y ss., donde señala el autor, en relación con la sociedad universal, que la especificidad de ésta se halla, básicamente, en el plano causal, es decir, "en la intención de dotar a la comunidad de vida previamente constituida de una infraestructura patrimonial adecuada", de manera que su hábitat natural sería el ámbito familiar. Sitúa este autor en las relaciones patrimoniales de las parejas no casadas el terreno propicio en el que este tipo de sociedad tiene un cierto papel, sin que esto signifique que "del hecho mismo de la convivencia more uxorio haya de referirse la existencia de una sociedad universal. Para que la sociedad se entienda constituida hace falta un movimiento inequívoco de la voluntad. La voluntad de no contraer matrimonio si de algo es sintomático, es de la voluntad de no estructurar jurídicamente las relaciones personales y patrimoniales entre los convivientes".

${ }^{311}$ La cuestión radica en determinar lo que es común y lo que no lo es. El TS considera que, cuando ambos convivientes contribuyen con su actividad a la obtención de los bienes, estos corresponden a ambos por igual, ya que nos encontraríamos ante un supuesto societario. Así el TS reconoció dicho carácter a una heladería en la que la mujer había aportado su trabajo, pero no otros bienes, adquiridos exclusivamente por el otro miembro de la pareja [STS 18-5-1992 (RJ 1992/4907)]. En otros casos, el mismo Tribunal niega la copropiedad cuando uno de los miembros de la pareja no
} 


\section{b) Convivencia en una vivienda arrendada}

A diferencia de lo visto en el epígrafe anterior, es bastante frecuente que las parejas no casadas tengan su residencia en una vivienda arrendada. Y, de nuevo, nos encontramos con diversas posibilidades, pues la vivienda puede haber sido arrendada conjuntamente por ambos convivientes, por lo que ambos serán cotitulares en el arrendamiento correspondiente. Pero también es bastante común que solamente uno de los convivientes sea el arrendatario de la vivienda, ya sea porque la había arrendado antes de iniciarse la convivencia more uxorio, o porque fuera uno solo de los convivientes el que formalice el contrato.

Naturalmente, la situación arrendaticia de la vivienda habitual resulta generadora de una nueva situación al implicar a un tercero (el arrendador) en la situación convivencia y, en especial en las situaciones de crisis de pareja en las que el arrendador puede verse afectado por las resoluciones de un conflicto en el que no ha participado. Estos aspectos han venido a ser contemplados por la vigente Ley 29/1994, de 24 de noviembre, de Arrendamientos Urbanos (en adelante LAU).

Para llegar a esta situación en la que las uniones de hecho tienen una asimilación al matrimonio en los artículos 12 y 16 de la LAU, previamente la jurisprudencia fue avanzando en el reconocimiento de ciertos derechos en las situaciones de arrendamiento de las uniones extramatrimoniales ${ }^{312}$. Y, si bien algunas sentencias de ciertas Audiencias provinciales ya venían pronunciándose a favor de un derecho a la subrogación en el arrendamiento en supuestos de uniones de hecho, es con la STC 222/1992, de 11 de diciembre, cuando la subrogación en la posición arrendaticia experimentó un cambio radical. La resolución del Tribunal respondía a la

\footnotetext{
haya participado con su patrimonio, o con su actividad (industria o trabajo), en la adquisición de los bienes [STS 182-1993 (RJ 1993/1246)].

${ }^{312}$ Un precedente significativo lo encontramos en la resolución del TS en un caso en que los hechos eran que el arrendatario, casado y separado de su esposa, convivía con otra mujer y una hija de ambos en la vivienda arrendada. El arrendador interpuso una demanda pidiendo que se resolviera el arrendamiento basándose en la inmoralidad de la causa del contrato. El TS casó la sentencia de la Audiencia admitiendo la improcedencia de la causa al señalar que "no puede calificarse de inmoral la actividad del inquilino en el interior de la vivienda desde 1956, contraída a vivir con toda la corrección que imponen las normas de cortesía y de convivencia o vida en comunidad, con su hija y la madre de esta, su familia como realmente lo es, aunque solo lo sea por naturaleza y no por la ley, y menos de inmoral de modo notorio, lo mismo si para emplear este adjetivo se atiende a los efectos, como si se tiene en consideración sus causas, ya que nadie puede conocer la vida íntima de la familia y ésta no se puede estimar que sea contraria a ninguna norma moral aceptada por todos o por una mayoría dominante...". Obviamente, no nos encontramos con una sentencia que declare una asimilación de la unión de hecho al matrimonio, pero sí ante una sentencia que admite ciertos efectos positivos para la unión extramatrimonial, como el que la misma no suponga una causa de desahucio [STS 13-10-1960 (RJ 1960/3168)].
} 
cuestión de constitucionalidad planteada por un juzgado de Fuengirola que, ante la demanda interpuesta por el arrendador a una vivienda en la que solicitaba la resolución del contrato de arrendamiento por fallecimiento del arrendatario, y la oposición de la demandada, compañera del inquilino, que alegaba su derecho a la subrogación, no contemplaba entonces la legislación vigente el derecho a la subrogación mortis causa al miembro supérstite de una pareja no casada ${ }^{313}$, circunstancia que podía entenderse como contraria a los artículos 14 y 39.1 de la Constitución. El TC resolvió la cuestión estableciendo el derecho a la subrogación en las parejas no casadas por diversos motivos: en primer lugar, por la protección a la familia del art. 39.1 de la Constitución, que no distingue entre familias casadas y no casadas, lo que puesto en relación con lo dispuesto por el art. 14 de la Constitución impediría que las diferencias que pudiese adoptar el legislador entre unos y otros tipos de familia fuesen discriminatorias. La sentencia finaliza declarando inconstitucional la exclusión del conviviente del beneficio de subrogación en los contratos de arrendamiento de vivienda.

Para estudiar estas situaciones en la actualidad, analizaremos la legislación vigente, más en concreto, los artículos 12,15 y 16 de la LAU y la problemática derivada que se plantea:

\section{b).1. Desistimiento, no renovación o abandono del conviviente titular del arrendamiento}

Evidentemente, los supuestos más abundantes se producen en los casos en que el arrendamiento se ha contratado por uno solo de los convivientes, lo que da lugar a diferentes supuestos. Se analiza la situación en el art. 12 de la LAU, que lo establece para el supuesto del matrimonio, pero que extiende sus efectos para el supuesto de las uniones de hecho que reúnan determinadas características ${ }^{314}$, en concreto se les exige convivencia previa en los dos años

\footnotetext{
${ }^{313}$ En efecto, la Ley 40/1964, de 11 de junio, de reforma de la LAU, vigente al momento de dictarse la sentencia, establecía en el art. 58.1 el derecho de subrogación de una larga lista de familiares, en la que no se incluían los convivientes no casados, al establecer lo siguiente: "Al fallecimiento del inquilino titular del contrato de arrendamiento, su cónyuge, descendientes, con preferencia los hijos varones menores de edad, las hijas solteras y los mayores impedidos físicamente, hijos adoptivos que hubieran sido adoptados antes de cumplir los dieciocho años, ascendientes y hermanos, con preferencia las hermanas solteras, tanto en el parentesco legítimo como en el natural, que con aquel hubiesen convivido habitualmente en la vivienda con dos años de antelación a la fecha del fallecimiento, podrán subrogarse en los derechos y obligaciones del arrendamiento. No será necesaria la convivencia de los que estuviesen sometidos a la patria potestad del fallecido, y respecto al cónyuge, bastará la mera convivencia, sin exigencia en el plazo de antelación." La cuestión era si tal relación de parientes establece un numerus clausus de beneficiarios de la subrogación o cabe la aplicación análoga para la protección de otros familiares no contemplados, pero con similar relación de afectividad con el fallecido.

${ }^{314}$ En efecto el art. 12.4 extiende a estas uniones los efectos establecidos para el caso de matrimonio al señalar que "4. Lo dispuesto en los apartados anteriores será también de aplicación en favor de la persona que hubiera venido conviviendo con el arrendatario de forma permanente en análoga relación de afectividad a la de cónyuge, con
} 
anteriores, excepto para las uniones de hecho con descendencia común, en cuyo caso el único requisito es el de la convivencia.

Una importante cuestión es la del entendimiento de la existencia de una titularidad común en el arrendamiento, independientemente de que el contrato haya sido suscrito por uno solo de los miembros de la pareja ${ }^{315}$. De este modo, ambos serían titulares del arrendamiento por el mero hecho de estar destinada la vivienda a constituir el hogar familiar, por lo que no existirá cesión alguna entre cónyuges o convivientes en los supuestos de crisis matrimoniales al atribuir el uso de la vivienda familiar a uno de ellos.

El mencionado artículo establece el derecho a continuar en el arrendamiento a ejercitar por el cónyuge o conviviente en análoga relación de afectividad con el arrendatario. Si el arrendatario manifestase su voluntad de no renovar el contrato o de desistir de él o abandonase la vivienda sin manifestación expresa de desistimiento o no renovación, el cónyuge que conviviera con dicho arrendatario podrá continuar en el arrendamiento. También podrá hacerlo la persona que hubiera venido conviviendo con el arrendatario como cónyuge o en análoga relación de afectividad durante, al menos, los dos años anteriores al desistimiento o abandono ${ }^{316}$.

Los supuestos analizados se refieren a actuaciones realizadas de manera unilateral por el cónyuge o conviviente titular del arrendamiento, en perjuicio de su cónyuge o pareja, así como de los hijos que convivan en la vivienda familiar, todo ello sin haber contado con el consentimiento prescrito en el apartado primero del citado artículo 12 de la LAU, el cual establece, para estos supuestos de desistimiento o abandono de la vivienda, el derecho del cónyuge o conviviente a continuar en el arrendamiento de la vivienda familiar asumiendo la condición de arrendatario, para lo cual será preciso que manifieste expresamente al arrendador su voluntad de continuar en dicho arrendamiento.

La norma analizada distingue entre los dos supuestos contemplados. Así, en el primero de ellos, cuando el titular del arrendamiento ha comunicado al arrendador su voluntad de desistir o de no renovar el contrato, el precepto exige al arrendador que se dirija al cónyuge o conviviente con

\footnotetext{
independencia de su orientación sexual, durante, al menos, los dos años anteriores al desistimiento o abandono, salvo que hubieran tenido descendencia en común, en cuyo caso bastará la mera convivencia".

${ }^{315}$ Se trata de una idea con cierto arraigo en el Derecho comparado y que en España ha sido muy difundida, especialmente a partir de la STC 135/1986, de 31 de octubre, que considera común el arrendamiento de vivienda familiar con independencia de quien haya suscrito el contrato de arrendamiento.

${ }^{316}$ DÍAZ DE LEZCANO SEVILLANO, I.: "Parejas no casadas y subrogación en los arrendamientos urbanos", en Boletín de la facultad de Derecho, UNED, Madrid, n. ${ }^{\circ} 8-9$ (1995), pág. 232.
} 
el arrendatario para que manifieste su voluntad de continuar o cesar en el arrendamiento. Si el cónyuge o conviviente no contesta en el plazo de quince días, a contar desde el requerimiento efectuado, se entenderá extinguido el contrato, y si contesta y opta por continuar en el contrato deberá continuar abonando las rentas hasta la extinción del mismo.

En el segundo supuesto, cuando el titular del arrendamiento abandona la vivienda sin realizar manifestación expresa de su voluntad de desistir o de no renovar el contrato, la norma establece la obligación del cónyuge o conviviente de notificar al arrendador, en el plazo de un mes, su voluntad de continuar con el arrendamiento. El incumplimiento de dicha obligación por el cónyuge o conviviente tiene como consecuencia la obligación de pago de la renta de ese mes por el cónyuge o conviviente, así como la extinción del contrato de arrendamiento.

El precepto que estudiamos tiene por objeto la protección de la familia frente a las decisiones que, de manera unilateral, pudiera adoptar el titular del arrendamiento en lo referente a la vivienda familiar. Como hemos señalado, a los efectos de esta norma se entiende por familia tanto la que tiene origen en el matrimonio como la que se origina por la mera voluntad de los convivientes, de conformidad con lo dispuesto en el apartado $4 .^{\circ}$ del citado artículo.

\section{b).2. Realización de obras de adaptación en la vivienda familiar}

El art. 24 LAU autoriza al arrendatario, previa notificación al arrendador, a realizar en la vivienda arrendada las obras de adaptación precisas para que la vivienda pueda ser utilizada acorde a las necesidades de la discapacidad de cualquiera de las personas que residen en la misma de manera permanente ${ }^{317}$.

Este precepto pretende proteger al arrendatario y al resto de los ocupantes de la vivienda en los supuestos de discapacidad o en aquellos casos en que, por razones de edad, sea necesaria la adaptación de la vivienda. Para ello se faculta al arrendatario para llevar a cabo las obras precisas para adecuar la vivienda a las condiciones de la discapacidad concreta, o bien a las que por razones de edad pudieran resultar precisas. La norma establece el procedimiento a seguir, exigiendo la

\footnotetext{
${ }^{317}$ El mencionado art. 24.1 de la LAU 29/1994, de 24 de noviembres, dispone que "1. El arrendatario, previa notificación escrita al arrendador, podrá realizar en el interior de la vivienda aquellas obras o actuaciones necesarias para que pueda ser utilizada de forma adecuada y acorde a la discapacidad o a la edad superior a setenta años, tanto del propio arrendatario como de su cónyuge, de la persona con quien conviva de forma permanente en análoga relación de afectividad, con independencia de su orientación sexual, o de sus familiares que con alguno de ellos convivan de forma permanente, siempre que no afecten a elementos o servicios comunes del edificio ni provoquen una disminución en su estabilidad o seguridad".
} 
notificación por escrito que debe realizar el arrendatario al arrendador sobre su intención de realizar tales obras. No es preciso el consentimiento del arrendador, sino solamente su conocimiento de las obras que se van a realizar. También es importante destacar la obligación que establece el apartado $2{ }^{\circ}$ del mencionado artículo 24 de la LAU de reponer la vivienda al estado anterior, si así lo exigiese el arrendador.

El precepto que estamos analizando establece el derecho a realizar estas obras cuando tal discapacidad la sufre, entre otras personas a las que cita, "la persona con quien conviva (el arrendatario) de forma permanente en análoga relación de afectividad, con independencia de su orientación sexual". Llamamos la atención sobre que, en este caso en particular, no se exige que la convivencia haya durado dos años o el requisito de descendencia común.

\section{b).3. La unión extramatrimonial y la resolución del contrato por actividades inmorales o incómodas en la vivienda}

En el pasado se contemplaba como causa de resolución del contrato de arrendamiento la realización de actividades inmorales o incómodas ${ }^{318}$, dicha disposición se acomodaba, obviamente, al concepto moral de la época, por lo que en no pocas ocasiones fue motivo de rescisión del contrato de arrendamiento del que fuese el hogar familiar de parejas no casadas.

La vigente LAU regula de modo diferente las causas de resolución del contrato, despareciendo los aspectos referidos a la moralidad de las actuaciones realizadas en el interior de la vivienda, así como cualquier mención a la notoriedad de las actuaciones realizadas. La regulación actual establece en el artículo 27.2.e la posibilidad del arrendador de resolver el contrato, entre otras causas, "cuando en la vivienda tengan lugar actividades molestas, insalubres, nocivas, peligrosas o ilícitas". En relación con la inmoralidad de las actuaciones no es tanto que desaparezcan, sino que quedan incluidas en el concepto de "actividades ilícitas", al entenderse que con el mismo no se trata solamente de actividades delictivas, sino que se incluyen todo tipo de actividades que vayan contra el Ordenamiento jurídico.

Cualquier interpretación relativa a la supuesta inmoralidad de la convivencia de parejas no casadas carece de sentido en la actualidad, e incluso vigente la antigua Ley de arrendamientos se

\footnotetext{
${ }^{318} \mathrm{El}$ art. $114.8^{\text {a }}$ de la Ley 40/1964, de 11 de junio, de reforma de la LAU, establecía que procedería de rescisión del contrato, a instancia del arrendador "cuando en el interior de la vivienda o local de negocio tengan lugar actividades que, de modo notorio, resulten inmorales, peligrosas, incómodas o insalubres".
} 
produjeron pronunciamientos jurisprudenciales rechazando tal inmoralidad ${ }^{319}$, como hemos citado más arriba. Cuestión distinta es el que la pareja tenga públicamente una conducta escandalosa, supuesto en el que podría existir motivo para instar la resolución del contrato, pero sería esa actuación escandalosa, pública y continuada, la que podría dar lugar a la rescisión contractual, careciendo de importancia el dato de que tal pareja esté casada o no.

\section{B) EFectos PATRIMoniales DERIVAdos Del FAllecimiento DE UNO DE LOS}

\section{CONVIVIENTES}

El fallecimiento de uno de los miembros de la pareja, al margen de la situación de aflicción derivada del óbito del compañero, conlleva, en los aspectos puramente patrimoniales, la aparición de una situación problemática para el miembro que sobrevive, pues el ordenamiento jurídico lo sitúa en una posición distinta a la del cónyuge supérstite.

Algunos de los aspectos más relevantes de esta situación serían la distinta posición con respecto a la del cónyuge viudo en relación con el derecho a una pensión pública de viudedad del conviviente que sobrevive, o los aspectos relativos al derecho de indemnización en caso de accidente, otro aspecto, que ya hemos tratado, es el de la posibilidad de subrogación en el arrendamiento de vivienda de la que era titular el miembro de la pareja fallecido y, posiblemente el aspecto de mayor diferencia con el matrimonio, la cuestión de los derechos sucesorios de las personas unidas en una relación de convivencia extramatrimonial.

Tales consecuencias derivadas del fallecimiento de uno de los miembros de la pareja serán merecedoras de análisis individualizado, que es a lo que dedicaremos las siguientes líneas.

\section{La subrogación mortis causa del conviviente en el contrato de arrendamiento}

El hecho de que la Ley 40/1964, de Arrendamientos Urbanos, no contemplase la posibilidad de subrogación del conviviente dio lugar, como hemos señalado más arriba, a una evolución jurisprudencial que tuvo su culminación con la ya citada la STC 222/1992, de 11 de diciembre, con

\footnotetext{
${ }^{319}$ A modo de ejemplo, citaremos la SAP de Burgos de 29 de septiembre de 1980 (vigente, por tanto, la LAU de 1964), que dice que "El hecho de que el actor pensara, en el momento de formalizar el contrato, que la persona que vive con el demandado era su legítima esposa y que con posterioridad haya comprobado que no lo es, pudiera ser objeto, en todo caso, de una petición de nulidad contractual por vicio esencial del consentimiento, pero no puede afirmarse que la convivencia irregular de tales personas constituya una actividad que de modo notorio resulte inmoral, peligrosa, incómoda o insalubre y, por ende, que se halle comprendida dentro de la causa resolutoria prevista en el número 8 del artículo 114 de la Ley”.
} 
las fundamentaciones ya $\operatorname{citadas}^{320}$. Esta jurisprudencia del TC fue seguida por otras que fueron conduciendo a la actual redacción del derecho de subrogación en la vigente $\mathrm{LAU}^{321}$.

Tras la mencionada jurisprudencia del TC, anterior a la vigente Ley de arrendamientos Urbanos, la nueva norma no podía sino adaptarse a la interpretación del Alto Tribunal. En consecuencia, el artículo 16 de la LAU vigente establece una serie de personas que pueden subrogarse en el contrato de arrendamiento en el caso de fallecimiento del titular del mismo. Entre las personas que tendrían este derecho de subrogación incluye a "la persona que hubiera venido conviviendo con el arrendatario de forma permanente en análoga relación de afectividad a la de cónyuge, con independencia de su orientación sexual, durante, al menos, los dos años anteriores al tiempo del fallecimiento, salvo que hubieran tenido descendencia en común, en cuyo caso bastará la mera convivencia."

Distingue la LAU, en el mencionado art. 16, entre la convivencia del cónyuge y la del conviviente de hecho, al necesitar distintos requisitos de convivencia en uno y otro caso ${ }^{322}$. De manera que los requisitos exigidos al conviviente supérstite para subrogarse en el contrato son los establecidos en el artículo 12 del mismo Cuerpo legal, por cuanto se sigue exigiendo la convivencia de dos años anteriores al fallecimiento o la existencia de descendencia común. Lo que implica una importante diferencia con el matrimonio ya que a este solamente se le exige la convivencia con el

\footnotetext{
${ }^{320}$ Esta sentencia, de la que fuera ponente el Excmo. Sr. D. Vicente Gimeno Sendra, contó con dos votos particulares. Según el primero de ellos, correspondiente al Excmo. Sr. D. Alvaro Rodríguez Bereijo, el vínculo matrimonial genera una serie de deberes y derechos en los cónyuges, lo cual no sucede en el caso de la convivencia de hecho. Tales diferencias las puede tener en cuenta el legislador ordinario al establecer un determinado régimen jurídico, por lo que podía optar tanto por reconocer el derecho de subrogación de los convivientes como optar por lo contrario. El segundo voto particular, correspondiente al Excmo. Sr. D. José Gabaldón López, se suma a los argumentos del voto particular anterior, recogiendo a grandes rasgos lo siguiente: para que la regulación vigente en ese momento fuese interpretado como contrario al art. 14 de la Constitución por limitar la subrogación en el contrato arrendaticio solo a las parejas casadas, habría de darse una perfecta identidad entre matrimonio y convivencia extramatrimonial more uxorio, pero ambas no son situaciones jurídicamente iguales, ni siquiera son consideradas por ese Tribunal como equivalentes, tal como el mismo había dicho en su Sentencia 184/1990.

${ }^{321}$ No mucho después el mismo TC dictaba la Sentencia 6/1993, de 18 de enero, siendo ponente también D. Vicente Gimeno Sendra, en la que los hechos sometidos a enjuiciamiento consistían en que la arrendadora de una vivienda formuló demanda solicitando la resolución del contrato de arrendamiento contra ignorados familiares de la inquilina fallecida y contra el presunto conviviente de hecho de la fallecida. Habiendo sido estimada la pretensión en la Jurisdicción ordinaria, la arrendadora presentó demanda de amparo al considerar vulnerado en tales Resoluciones judiciales el art. 14 CE. La STC se limitó a reproducir la doctrina de la Sentencia 222/1992, calificando de inconstitucional, por discriminatoria, la diferencia entre el cónyuge supérstite de una unión matrimonial y quien hubiera convivido more uxorio con la persona titular del arrendamiento, al quebrantar el principio de igualdad. No obstante, en la Sentencia no se reconoció el derecho de subrogación como inquilino del demandado al no constar acreditada la convivencia more uxorio con la fallecida y corresponder la apreciación de la prueba a los Tribunales ordinarios. En el mismo sentido se pronunció la Sentencia 47/1993, de 8 de febrero, de la que fuera ponente el Excmo. Sr. D. Julio González Campos.

${ }^{322}$ DÍAZ DE LEZCANO SEVILLANO, I.: Op. cit., pág. 230.
} 
finado, mientras que las exigencias al conviviente, como vemos, van mucho más allá. Se suele considerar que esa convivencia no tiene por qué haberse producido en la misma vivienda arrendada, en la que se pretende continuar.

$\mathrm{Al}$ establecer un orden de prelación en el apartado 1. ${ }^{\circ}$ del artículo en cuanto al derecho de subrogación, se ha producido cierta polémica sobre la posible existencia de situaciones injustas al anteponer al conviviente more uxorio a los hijos del arrendatario fallecido o a los progenitores, si estos tuviesen una edad inferior a los setenta años ${ }^{323}$. No obstante, en la legislación actual, al haber desaparecido las prórrogas forzosas de la Ley de 1964, no parece que vayan a producirse muchas situaciones de subrogaciones sucesivas ${ }^{324}$.

\section{La indemnización por causa de muerte y la legitimación activa del conviviente more uxorio}

En nuestro Derecho la responsabilidad por causa de muerte puede seguir la vía de la Jurisdicción penal, en los casos de muerte dolosa ${ }^{325}$, o la de la Jurisdicción civil en los supuestos en que el hecho merezca ser calificado como un ilícito civil.

La redacción del artículo 1902 del CC establece que "El que por acción u omisión causa daño a otro, interviniendo culpa o negligencia, está obligado a reparar el daño causado”. Incluso en la actual tendencia hacia la objetivación de la responsabilidad, subyace en el precepto la idea de culpa del sujeto causante del daño. Por tanto, en los casos de fallecimiento de la víctima, el causante del daño está obligado a indemnizar todos los perjuicios causados que resulten imputables a su conducta, debiendo resarcir a quienes han resultado damnificados con la muerte, sean o no herederos de la víctima. Con esto lo que se persigue es la reparación del daño causado y no la sanción al autor del daño.

\footnotetext{
${ }^{323}$ CARRASCO PERERA, A. "Comentarios al artículo 16 de la LAU" en "Comentarios a la Ley de Arrendamientos Urbanos, (Coord. RODRIGO BERCOVITZ), Tecnos, Madrid, 1995, págs. 361 y 362, destaca la posible existencia de casos de subrogación a favor del conviviente de un arrendatario (a su vez subrogado en el derecho), cuando existen hijos del matrimonio del primer subrogado, supuesto en el que los propios hijos del conviviente se subrogarán antes que los hijos del inquilino (original) fallecido, que no podrán subrogarse en ningún caso ya que no son hijos del inquilino (subrogado) fallecido. Aunque pone de relieve que el resultado de la Norma seguramente es el perseguido por el legislador y que, de facto, el TC habría venido a consagrar la misma doctrina.

${ }^{324}$ Coincidimos con GALLEGO DOMÍNGUEZ, I.: Op. cit., pág. 385, en que la desaparición de la prórroga forzosa en la vigente LAU, hace disminuir de manera drástica la importancia de las subrogaciones mortis causa, al hacerse complicado que se produzcan muchas subrogaciones en el plazo legal y sus prórrogas de la Norma actual.

${ }^{325}$ Para los supuestos de muerte dolosa producida a causa de un ilícito penal, el art. 113 de la Ley Orgánica 10/1995, de 23 de noviembre, del Código penal, establece que "La indemnización de perjuicios materiales y morales comprenderá no solo a los que se hubieran causado al agraviado, sino también los que se hubieran irrogado a sus familiares o a terceros".
} 
Una cuestión debatida por la doctrina y jurisprudencia es la de qué personas están legitimadas para reclamar la indemnización de daños y perjuicios derivada del hecho dañoso y, más en concreto, si el conviviente more uxorio está legitimado activamente para la reclamación por la responsabilidad extracontractual en el caso de muerte de su compañero.

En los supuestos de fallecimiento por accidente procede acudir a la responsabilidad extracontractual del artículo 1902 del CC, el cual no distingue entre el daño directo causado a la víctima y el daño indirecto que se hubiera producido a las personas relacionadas o dependientes de la víctima ${ }^{326}$. En estos casos, la jurisprudencia entiende que en lo dispuesto por el artículo 1902 del CC se incluyen tanto los daños directos cuanto los indirectos ${ }^{327}$.

Además, debe tomarse en consideración en relación con los daños indirectos los producidos a las personas vinculadas con la víctima. Conforme al Código Penal, están legitimados para reclamar la indemnización por los daños y perjuicios producidos a causa del hecho dañoso, el agraviado y los familiares o terceros relacionados con él ${ }^{328}$. En consecuencia, parece obvio que los familiares y terceros vinculados con el agraviado también estarán legitimados para reclamar este derecho de indemnización de daños y perjuicios en relación con los hechos dañosos producidos en un ilícito civil de los relacionados en el mencionado art. 1902 del CC. La cuestión que se suscita es si el conviviente more uxorio está entre las personas a las que se les reconoce este derecho a la indemnización.

Analizaremos, pues, la legitimación activa del conviviente para reclamar la indemnización de daños y perjuicios en este supuesto. Tradicionalmente nuestra doctrina mayoritaria negaba el derecho del conviviente a reclamar esta indemnización, al entender que se trataba de una unión

\footnotetext{
${ }^{326}$ DE CASTRO Y BRAVO, F., La indemnización por causa de muerte, ADC, Tomo IX, abril-junio de 1956, pág. 449 afirma que "la extensión de la responsabilidad a favor de la familia y del tercero se origina solo por los actos calificados como delictivos o dolosos. Mientras que se deberá responder, conforme el criterio general, es decir, solo a la víctima, por los actos u omisiones en que intervengan simple culpa o negligencia".

${ }^{327}$ Así lo recogen múltiples sentencias, entre muchas otras, [STS 14-2-1980 (RJ 1980/516) y STS 29-9-1986 (RJ 1986/4922).

${ }^{328} \mathrm{El}$ art. 109 del Código Penal establece que "1. La ejecución de un hecho descrito por la ley como delito obliga a reparar, en los términos previstos en las leyes, los daños y perjuicios por él causados. 2. El perjudicado podrá optar, en todo caso, por exigir la responsabilidad civil ante la Jurisdicción Civil." Por su parte, el art. 113 del mismo Cuerpo legal extiende el derecho a la indemnización por daños y perjuicios a los familiares y terceros al señalar que "La indemnización de perjuicios materiales y morales comprenderá no solo los que se hubieren causado al agraviado, sino también los que se hubieren irrogado a sus familiares o a terceros".
} 
contraria al orden público ${ }^{329}$. Otra doctrina consideraba que la existencia del derecho dependería de las circunstancias del caso, y se mostraba partidaria de reconocer la legitimación pasiva en los suspuestos en que existían hijos fruto de la relación de convivencia ${ }^{330}$. Pese a ello, la posición de la jurisprudencia mantuvo un criterio laxo a la hora de conceder la indemnización por daños y perjuicios en caso de accidente a terceras personas que venían manteniendo una especial relación con el finado ${ }^{331}$. En cuanto a los convivientes no casados, el criterio fue el mismo, si bien el número de reclamaciones en este tipo de relaciones era escaso.

En la actualidad, una vez que los argumentos de la pretendida inmoralidad de la relación de convivencia se han superado, la doctrina se pronuncia en el sentido de reconocer al conviviente la legitimación activa para reclamarlos daños y perjuicios derivados del fallecimiento en accidente del compañero ${ }^{332}$.

Por tanto, la persona conviviente en relación de pareja no casada se encuentra legitimada para formular la reclamación de la indemnización de los daños y perjuicios causados en el fallecimiento del compañero en caso de accidente. Esta petición de daños y perjuicios comprenderá tanto los daños morales como patrimoniales producidos y existirá el derecho de reclamación tanto si nos encontramos ante un ilícito penal como si nos encontramos ante un ilícito civil.

En el supuesto de estar ante un ilícito penal, se plantea la cuestión de si la legitimación del conviviente more uxorio deriva de su condición de "familiar" o se trata de un "tercero", en la terminología del artículo 113 del Código Penal. Al respecto entendemos que, estando ampliamente reconocido por doctrina y jurisprudencia, la convivencia more uxorio constituye un modelo de familia digno de la protección del artículo 39.1 de la vigente CE, así como la generalizada aceptación social de este modo de relaciones y la protección jurídica establecida en nuestro Ordenamiento jurídico. Pese a la diferenciación constante y la prohibición de aplicación análoga de las Normas del matrimonio a la relación more uxorio, se reconoce siempre a la unión de parejas

\footnotetext{
${ }^{329}$ A modo de ejemplo, MORENO MONCHOLI, M., El concubinato, ADC, 1941, págs. 54 y ss.; BATLLE VÁZQUEZ, M., La evaluación del daño en las personas, en "Centenario de la Ley del Notariado", Vol. II, Madrid, 1962, págs. 489 y ss.

${ }^{330}$ SANTOS BRIZ, J., La responsabilidad civil, Montecorvo, Madrid, 1991, pág. 351.

${ }^{331}$ Tanto en la Sala de lo Civil como en la de lo Penal del TS se reconoció el derecho a la indemnización de daños y perjuicios, tanto de carácter patrimonial como los de carácter moral, a terceros no familiares del fallecido que habían mantenido una especial relación con la víctima. [STS 26-1-1972 (RJ 1972/120) y STS 31-5-1972 (RJ 1972/2787)].

${ }^{332}$ VATTIER FUENZALIDA, C., Los daños de familiares y terceros por la muerte o lesiones de una persona, en el libro "Centenario del CC", Tomo II, Asociación de profesores de Derecho Civil, ed. Centro de Estudios Ramón Areces, Madrid, 1990, pág. 2081.; GALLEGO DOMÍNGUEZ, I.: Op. cit., págs. 458 y 459.
} 
no casadas como otro modelo de familia. Por ello, no puede entenderse sino que la legitimación para efectuar la reclamación por los daños y perjuicios indirectos del conviviente deriva de su condición de familiar.

Tanto la doctrina ${ }^{333}$ como la jurisprudencia ${ }^{334}$ se han pronunciado en el sentido de que, existiendo una relación de convivencia de pareja no casada, y con independencia de la existencia o no de descendencia común, el fallecimiento en accidente de uno de los miembros de la pareja supone para el conviviente que le sobrevive una serie de perjuicios, morales y patrimoniales, derivados de dicho fallecimiento generadores del derecho a ser indemnizado. De tal modo que la obtención de la correspondiente indemnización por el conviviente dependerá no de si la relación lo legitima para obtenerla, sino del cumplimiento de los requisitos establecidos para determinar la existencia de la responsabilidad extracontractual ex art. 1902 del CC, y de la obligación de reparar el daño establecida en el citado artículo.

Actualmente, esta discusión está superada, siendo admitido unánimemente el derecho del conviviente supérstite a ser indemnizado por la persona responsable del accidente de los daños patrimoniales o morales sufridos ${ }^{335}$

\section{La unión de hecho y la sucesión por causa de muerte}

Una de las causas que provocan la extinción de la relación de convivencia more uxorio es la muerte de uno de los convivientes. Entre las consecuencias derivadas del fallecimiento de uno de los convivientes, nos centraremos en este punto en las expectativas sucesorias del compañero supérstite.

Estando regulada la relación de las parejas de hecho mediante legislación autonómica, veremos cómo en el campo del derecho sucesorio el Estado no hace partícipes del mismo a las

\footnotetext{
${ }^{333}$ GALLEGO DOMÍNGUEZ, I.: Op. cit., pág. 461; ESTRADA ALONSO, E.: Op. cit., pág. 342.

${ }^{334}$ [SAP de Barcelona 8-11-1991 (AC 1991/181105) y SAP de La Rioja 9-3-2005 (AC2005/463)], entre otras muchas.

${ }^{335} \mathrm{Al}$ respecto El art.63 del RD Legislativo 8/2004, de 29 de octubre, por el que se aprueba el texto refundido de la Ley sobre responsabilidad civil y seguro en la circulación de vehículos a motor asimila la pareja de hecho al matrimonio en el derecho indemnizatorio, llegando a precisar en el apartado 2. ${ }^{\circ}$ que " 2 . A los efectos del cómputo establecido en el apartado anterior, si quienes constituyen pareja de hecho estable contraen matrimonio, los años de convivencia se suman a los de matrimonio", lo que confirma, de modo concluyente en el apartado $4 .^{\circ}$ del mismo artículo, en el que la asimilación de matrimonio y unión de hecho es absoluta: "4. En caso de concurrencia de cónyuges o parejas de hecho estables, en los supuestos en que la legislación aplicable lo permita, el importe fijo que establece el apartado 1 se distribuye a partes iguales, y en caso de existir incrementos adicionales, se toma el incremento mayor y se distribuye en proporción a los años adicionales de convivencia, el importe fijo que establece el apartado 1 se distribuye a partes iguales, y en caso de existir incrementos adicionales, se toma el incremento mayor y se distribuye en proporción a los años adicionales de convivencia".
} 
parejas de hecho siendo, una vez más, las CCAA con competencia para ello las que se han encargado de establecer ciertos derechos sucesorios, incluso equiparando en ocasiones al conviviente de hecho supérstite cónyuge viudo ${ }^{336}$. Así lo hace la Ley de Baleares ${ }^{337}$, mientras que la Ley Foral Navarra concede libertad a los convivientes para transmitirse entre ellos los derechos sucesorios que tengan por conveniente ${ }^{338}$. Por su parte la vigente legislación catalana hace una fuerte asimilación entre el conviviente supérstite y el cónyuge viudo ${ }^{339}$. En el caso del País Vasco se asimila la pareja de hecho al matrimonio por vía de remisión ${ }^{340}$; también en el caso de Galicia se produce la asimilación al matrimonio de los derechos del conviviente que sobrevive $\mathrm{e}^{341} \mathrm{y}$, en el caso de Aragón, se conceden igualmente derechos hereditarios al conviviente supérstite ${ }^{342}$.

Esta situación genera una evidente desigualdad por razón del territorio, ya que, dependiendo del territorio en el que se resida, pueden existir o no derechos mortis causa en las relaciones de

${ }^{336}$ AYLLÓN GARCÍA, J.D., Presente y futuro del Derecho sucesorio de las parejas de hecho, en "grandes tratados: la legítima y la capacidad de testar", Aranzadi, 2019, pág. 3.

${ }^{337}$ El artículo 13 de la Ley 18/2001, de 19 de diciembre, de parejas estables de Illes Balears, establece que "Tanto en los supuestos de sucesión testada, como en los de intestada, el conviviente que sobreviviera al miembro de la pareja premuerto tiene los mismos derechos que la Compilación de Derecho Civil balear prevé al cónyuge viudo".

${ }^{338}$ La modificación dada por la Ley Foral 21/2019, de 4 de abril, a la Ley 113 de la Ley 1/1973, de 1 de marzo, por la que se aprueba la Compilación del Derecho Civil Foral de Navarra, lo deja redactado en los siguientes términos: "En caso de extinción de la pareja estable por muerte o declaración de fallecimiento de uno de los convivientes, el sobreviviente solo tendrá los derechos sucesorios que se hubieran otorgado entre sí o por cualquiera de ellos en favor del otro, conjunta o separadamente, por testamento, pacto sucesorio, donación "mortis causa" y demás actos de disposición reconocidos en esta Compilación"

${ }^{339}$ Así lo establece el artículo 234-14 de la Ley 25/2010, de 29 de julio, del Libro segundo del CC de Cataluña, relativo a la persona y la familia, en su actual redacción al señalar que "En caso de extinción de la pareja estable por muerte de uno de los convivientes, el superviviente tiene, además de la compensación por razón de trabajo que eventualmente le corresponda de acuerdo con el artículo 232-5.5, los derechos viduales familiares reconocidos por los artículos 231-30 y 231-31".

${ }^{340}$ La Disposición adicional primera de la Ley 2/2003, de 7 de mayo, reguladora de las parejas de hecho, establece que "Todas las referencias hechas al matrimonio en las normas legales y reglamentarias aprobadas en la Comunidad Autónoma de Euskadi con anterioridad a la entrada en vigor de la presente ley se entenderán hechas también a las parejas de hecho", entre cuyas normas están los derechos del cónyuge viudo reconocidos en la compilación foral del País Vasco.

${ }^{341}$ El apartado 1. ${ }^{\circ}$ de la disposición adicional tercera de la Ley 2/2006, de 24 de junio de Derecho Civil de Galicia, dice al respecto que " 1 . A los efectos de la aplicación de la presente ley, se equiparan al matrimonio las relaciones maritales mantenidas con intención o vocación de permanencia, con lo que se extienden a los miembros de la pareja los derechos y las obligaciones que la presente ley reconoce a los cónyuges".

${ }^{342} \mathrm{El}$ artículo 311 del decreto legislativo 1/2011, de 22 de marzo, por el que se aprueba el Código del Derecho Foral de Aragón señala que "1. En caso de fallecimiento de uno de los miembros de la pareja, el supérstite tendrá derecho, cualquiera que sea el contenido de la escritura de constitución, del testamento o de los pactos sucesorios, al mobiliario, útiles e instrumentos de trabajo que constituyan el ajuar de la vivienda habitual, con exclusión solamente de las joyas u objetos artísticos de valor extraordinario o de los bienes de procedencia familiar. 2. Asimismo, el supérstite podrá, independientemente de los derechos hereditarios que se le atribuyeran, residir gratuitamente en la vivienda habitual durante el plazo de un año". 
convivencia more uxorio. Lo que conlleva, a nuestro entender, una evidente discriminación que podría conculcar el artículo 14 de la $\mathrm{CE}$, cuestión sobre la que volveremos más adelante.

Empezaremos por distinguir las dos formas sucesorias que contempla el CC: la sucesión testamentaria y la sucesión ab intestato o sucesión legal. La sucesión testamentaria tiene lugar cuando el causante nombra en su testamento a la persona o personas llamadas a sucederle. La sucesión legal se produce cuando el finado no ha dispuesto lo que debe ocurrir con su herencia, siendo la ley la encargada de designar a sus sucesores. A ello se debe añadir la llamada sucesión legitimaria que, sin ser un tercer tipo de sucesión, determina que una serie de personas (cónyuge, y parientes en línea recta) tengan derecho a una parte de los bienes del difunto, esa porción es la denominada legítima ${ }^{343}$.

El propio CC establece quiénes son estos herederos forzosos, señalando como tales en primer lugar a los hijos y descendientes y, en defecto de estos, a los ascendientes del fallecido. Pero, coincidiendo con unos u otros herederos forzosos, se señala también como legitimario al cónyuge viudo, cuyos derechos sucesorios serán solamente al usufructo de una porción de la herencia, porción que será diferente según quiénes sean los herederos forzosos con quienes concurra a la herencia. La cuestión que se plantea es si el conviviente extramatrimonial sobreviviente tiene algún tipo de derecho sucesorio.

\section{a) La sucesión intestada}

Como hemos indicado, en el Derecho Civil común, entre los sucesores ab intestato no se encuentra el conviviente supérstite de una relación more uxorio. Por lo que en nuestro Derecho positivo las personas que mantienen una relación de pareja no casada estarían excluidas de la denominada sucesión legal. Solamente mediante una modificación legal sería posible considerar al sobreviviente en una relación extramatrimonial como sucesor ab intestato.

La necesidad de que el conviviente supérstite sea incluido en la relación de herederos legitimarios es reclamada en las últimas décadas por gran parte de la doctrina ${ }^{344}$, posición a la que

\footnotetext{
${ }^{343}$ La legítima la define el art. 806 del CC diciendo que "Legítima es la porción de bienes de que el testador no puede disponer por haberla reservado la ley a determinados herederos, llamados por esto herederos forzosos".

${ }^{344}$ En este sentido PANTALEÓN PRIETO, A. F.: «¿Derechos sucesorios $a b$ intestato del compañero o compañera en la Compilación de Derecho Civil de Cataluña?», en La Reforma de la Compilació. El sistema succesori, Cátedra de Derecho Civil Catalán "Duran i Bas" de la Universidad de Barcelona, Esplugues de Llobregat (1985), donde se muestra partidario de reconocer al conviviente supérstite los mismos derechos que el cónyuge ostenta en la sucesión intestada. A su juicio, la modificación es necesaria, pues la negación de derechos sucesorios ab intestato es incompatible con lo dispuesto en el artículo 14 de la CE. En la misma línea, ROMERO PAREJA, A.: «Los derechos sucesorios de las
} 
nos adherimos. Algunos autores van más allá y llegan a pedir la aplicación de la analogía ante la ausencia de una norma sobre la materia ${ }^{345}$. En este punto examinaremos muy rápidamente algunos artículos en los que el CC menciona al cónyuge para intentar comprobar si permitirían su aplicación al conviviente. No creemos que haya discusión en cuanto a la nulidad de la disposición a favor de la pareja de hecho del o de la notario autorizante del testamento (art. 754) y en que debe ser considerado indigno para suceder el condenado por atentar contra la vida de la pareja de hecho del testador (art. 756.2. ${ }^{\circ}$ ). Se aceptará también, casi con total seguridad, que el testador pueda imponer a su pareja la condición, al instituirla heredera o legataria, de que no contraiga matrimonio (art. 793), incluso, de que no vuelva tener una nueva unión paramatrimonial. Donde tal vez encontraremos mayores obstáculos sea a la hora de reducir la legítima de los ascendientes, caso de concurrir con el conviviente, y dejarla en una tercera parte en lugar de la mitad del haber hereditario (art. 809).

Sin embargo, no creemos que esa sea la vía en la actual situación en la que la jurisprudencia ha dejado clara su posición de la imposibilidad de la aplicación analógica de la institución matrimonial a las uniones de hecho, razón por la que venimos propugnando que se modifique la legislación para permitir al conviviente instituir con los mismos derechos legitimarios al compañero sobreviviente que al cónyuge supérstite, pudiendo determinarlo de ese modo tanto por pacto como por testamento. De manera que sea posible que, en el pacto entre convivientes, se pueda convenir la condición de legitimario al modo conyugal de los convivientes, resolviendo de ese modo la inclusión del conviviente, como legitimario usufructuario, en las sucesiones ab intestato. Y, por vía testamentaria, para que el conviviente pueda incluir a su pareja como usufructuario del tercio de mejora, al margen de lo que desee disponer sobre el tercio libre.

Pero, en todo caso, lo que sí parece claro es que, reconocido el carácter de familia a las uniones de hecho, y en el marco de la protección constitucional, a todo tipo de familias, parece claro que se produce una clara discriminación de los poderes públicos al tratar dos situaciones familiares análogas de manera diferente. Son muchos los supuestos en que se produce una equiparación legal entre la familia matrimonial y la surgida de una relación de hecho. Así, en el

parejas no matrimoniales», en La Ley: Revista jurídica española de doctrina, jurisprudencia y bibliografía n.$^{\circ} 2$, (2003), pág. 1618; también MESA MARRERO, C.: Op. cit., pág. 261.

345 TORRES ESCÁMEZ, S.: Parejas de hecho. Colegio notarial de Granada (1996), pág. 123 y ss., “Así, se trataría de determinar si los preceptos que llaman al cónyuge como heredero abintestato de su consorte podrían ser aplicados al conviviente supérstite, por existir entre ambas situaciones la «identidad de razón» ex art. 4.1 del CC. 
CC encontramos diversas modificaciones tendentes a dicha equiparación, por ejemplo, el artículo 101 que al regular la extinción de la pensión compensatoria en casos de separación o divorcio se refiere a "vivir maritalmente con otra persona"; por su parte el artículo 320 con ocasión de la concesión de la emancipación por decisión judicial incluye la situación de "convivir maritalmente con persona distinta del otro progenitor".

Otras normas civiles siguen esta misma línea, por ejemplo, el art. 10.6 de la ley 41/2003, de 18 de noviembre, de protección patrimonial de las personas con discapacidad y de modificación del CC, de la ley de Enjuiciamiento Civil y de la normativa tributaria, modificando el artículo 831.5 del CC considera causa de extinción de la facultad testamentaria de mejora del cónyuge, el inicio de "una relación de hecho análoga" a la matrimonial. También la Disposición final primera de la Ley 15/2015, de 2 de julio, de Jurisdicción voluntaria, adoptó una nueva forma de referirse a este tipo de uniones en la modificación de los artículos 47 y $48 \mathrm{CC}$, equiparando al cónyuge con la persona "unida al adoptante por análoga relación de afectividad a la conyugal", al regular los impedimentos para contraer matrimonio, idéntica expresión a la utilizada en la nueva redacción del artículo 177.2 CC en cuanto a los requisitos para la adopción, y del artículo 756 CC en relación a los supuestos de indignidad para suceder ${ }^{346}$.

346 Junto al CC se ha venido aprobando otra abundante Normativa en ámbitos específicos que suponen el reconocimiento paulatino de este modo convivencial. Destacaremos las siguientes:

- La Orgánica 1/1979, de 26 de septiembre, General Penitenciaria, que, incidiendo en la intimidad De la relación, reconocía en el artículo 52 el derecho a ser informado del fallecimiento o grave enfermedad a las "Personas íntimamente vinculadas con el recluso, y el 53 el de recibir visitas a los "allegados íntimos ".

- La Orgánica 6/1984, de 24 de mayo, de regulación del procedimiento de Habeas Corpus: el apartado a del artículo 3 confiere la legitimación activa para instar este procedimiento al "privado de libertad, su cónyuge o persona unida por análoga relación de afectividad"

- La Orgánica 6/1985, de 1 de julio, de Poder Judicial: el artículo 219 incluye entre las causas de abstención y recusación de jueces y magistrados "el vínculo matrimonial o situación de hecho asimilable entre aquellos; el artículo 391 señala que no pueden pertenecer a la misma sala los magistrados que "Estuvieran Unidos por vínculo matrimonial o situación de hecho equivalente"

- La Orgánica 19/1994, de 23 de diciembre, de protección a testigos y peritos en causas criminales: el artículo 1.2 equipara al cónyuge la "persona a quien se Halle ligado por análoga relación de afectividad" a efectos de que la autoridad judicial aprecie la existencia de un peligro grave

- la 29/1994, de 24 de noviembre, de Arrendamientos Urbanos Equipara al cónyuge "la persona que hubiera venido conviviendo con el arrendatario de forma permanente en análoga relación de afectividad a la de cónyuge, con independencia de su orientación sexual" tal como hemos visto en epígrafes anteriores.

- La Orgánica 8/1995, de 16 de noviembre, del Tribunal del jurado que modifica la orgánica 5/1995, de 23 de mayo, Qué incluye dentro de las obligaciones para ser jurado a quién mantenga con quien sea parte un vínculo matrimonial o situación de hecho asimilable.

- La 15/1995, de 30 de mayo, sobre límites del dominio sobre inmuebles para facilitar el acceso a las viviendas para eliminar las barreras arquitectónicas que supongan dificultad para los discapacitados en su artículo 2.2 equipara al cónyuge con "la persona que conviva con el titular de forma permanente en análoga relación de afectividad con independencia de su orientación sexual.”. 
En suma, si tanto legal como jurisprudencialmente en las últimas décadas se vienen aplicando las mismas soluciones en diferentes supuestos a las familias matrimoniales y a las familias no casadas, como ocurre en casos como la atribución de la vivienda familiar ${ }^{347}$, o en supuestos de atribución de la pensión de viudedad ${ }^{348}$, por poner algunos ejemplos, entendemos que procede aplicar el mismo régimen sucesorio a ambos tipos de familia, pues en ambos casos el fundamento de la atribución de derechos mortis causa se encuentra en la existencia de una familia

- La 35/1995, de 11 de diciembre, de ayuda y asistencia a las víctimas de delitos violentos y contra la libertad sexual en cuyo artículo 2 apartado 3 a) equipara al cónyuge con la persona con la que hubiera venido "conviviendo con el fallecido de forma permanente con análoga relación de afectividad a la del cónyuge, con independencia de su orientación sexual, durante al menos los dos años anteriores al momento del fallecimiento salvo que hubieran tenido descendencia en común, en cuyo caso bastará la mera convivencia".

- la 50/2002, de 26 de diciembre, reguladora de las fundaciones, equipara en su artículo 3.3 los cónyuges con las parejas de hecho a los efectos de prohibir fundaciones familiares.

- La 22/2003, de 9 de julio, Concursal, no reconoce la situación de pareja de hecho en el momento de solicitud del concurso por el deudor, pero sí para declarar el concurso conjunto siempre que se aprecie la existencia de pactos entre los convivientes para firmar un patrimonio común.

- La 42/2003, de 18 de noviembre, de protección patrimonial de las personas con discapacidad y de modificación del CC, de la de enjuiciamiento civil y de la normativa tributaria, en la modificación del artículo 757.1 de la de Enjuiciamiento civil permitiendo promover la declaración de incapacidad a quién se encuentre en situación de hecho asimilable al matrimonio.

- La Orgánica $1 / 2004$, de 28 de diciembre, de medidas de protección integral contra la violencia de género, viene a definir la existencia de violencia de género como la que tiene lugar "cuando la ofendida, sea o haya sido esposa o mujer de este o haya estado ligada a él por una análoga relación de afectividad aún sin convivencia".

- la 14/2006, de 26 de mayo, sobre técnicas de reproducción humana asistida, se refiere al varón no casado y al varón no unido por vínculo matrimonial.

- La 40/2007, de 4 de diciembre que modifica el artículo 174 del texto refundido de la general de la Seguridad Social, aprobado por RD Legislativo 1/1994, de 20 de junio, concede derecho a pensión de viudedad a quién se encuentre Unido al causante en un momento de su fallecimiento formando una pareja de hecho.

- La 12/2009, de 30 de octubre, del derecho de asilo en cuyo artículo 40.b) extiende este derecho "al cónyuge o la persona ligada por análoga relación de afectividad y convivencia “

- La 20/2011, de 21 de julio, del Registro Civil que establece en su artículo 84 que se presume que ostenta interés legítimo para el acceso a los asientos que contienen información especialmente protegida "el cónyuge del fallecido, pareja de hecho (...)"

- la 29/2011, de 22 de septiembre, de reconocimiento y protección integral a las víctimas del terrorismo, equipada al cónyuge del fallecido la persona ligada con la por análoga relación de afectividad a efectos honoríficos de respeto coma dignidad y defensa pública de estos valores así como a efectos del reconocimiento y de movilidad geográfica de los funcionarios y personal laboral al servicio de las administraciones públicas.

- El RD- 27/2012, de 15 de noviembre, de medidas urgentes para reforzar la protección a los deudores hipotecarios en el artículo 1.4.b) incluye dentro de las unidades familiares "la compuesta por el deudor, su cónyuge no separado legalmente o pareja de hecho inscrita..."

- la Orgánica $1 / 2015$, de 30 de marzo, Código Penal, mantiene la equiparación entre el matrimonio y las análogas relaciones de afectividad excepto para los casos de responsabilidad civil derivada de delitos patrimoniales.

347 Así, el TS ha atribuido el uso de la vivienda en la que había residido la pareja durante la convivencia a favor de aquel que no era su titular [STS 16-12-1996 (RJ 1996/9020)].

348 Confirma esta doctrina, entre otras muchas, la STC 184/1990, de 15 de noviembre, en un supuesto de reclamación de pensión de viudedad por una mujer que no había contraído matrimonio con el difunto. Además, en parecidos términos se pronuncian las SSTC 222/1992, de 11 de diciembre, y 116/1999, de 17 de junio. 
caracterizada por la presencia de la affectio maritalis y no en la existencia del vínculo matrimonial, procediendo la extensión del reconocimiento de los derechos sucesorios a las uniones de hecho entendidas como un modelo de familia constitucionalmente protegida ${ }^{349}$

Y ello, porque si nos encontramos ante dos modelos de convivencia con una similar comunidad de vida, con unos vínculos internos basados en la mutua responsabilidad y cuidado, reconocidos ambos como modelos de familia por la jurisprudencia del TC, emanación ambos modos de convivencia del libre desarrollo de la personalidad individual, protegida en el artículo 10.1 de la Constitución. Y, estando reconocido el derecho a la igualdad, sin que pueda prevalecer discriminación alguna por "cualquier condición o circunstancia personal o social", representa una grave discriminación la promovida por el Estado al poner trabas a un modo de convivencia libremente elegido, como forma de desarrollo de la personalidad, al optar por vivir en pareja sin contraer matrimonio.

Pero, además, es que el Estado estaría incumpliendo su obligación de "promover las condiciones para que la libertad y la igualdad del individuo y de los grupos en que se integra sean reales y efectivas", obviamente, el Estado en el aspecto que estudiamos no solo no cumple con su obligación de promover la igualdad de los grupos y personas, sino que evidentemente mantiene diferencias discriminatorias para el grupo que opta por no casarse, todo lo cual evidencia un choque frontal con el debido respeto al libre desarrollo de la personalidad, sin sufrir por ello discriminación.

En conclusión, parece necesario y, tras el tiempo transcurrido sin acometerlo, diríamos que urgente, promover el cambio legislativo que extienda los derechos legitimarios al conviviente de la unión familiar, tras los parientes en línea recta del difunto, sea tal convivencia matrimonial o no.

\section{b) La sucesión testamentaria}

Mediante el testamento el causante manifiesta su voluntad sobre lo que ha de suceder con su herencia cuando él fallezca. En nuestro Ordenamiento jurídico, esta manifestación de la voluntad del finado prevalece sobre la sucesión legal. En lo que nos ocupa, debemos ver la admisibilidad de las disposiciones testamentarias a favor del conviviente extramatrimonial supérstite. La conclusión no puede ser otra que la inexistencia en nuestro Derecho de prohibición alguna para que el

349 AYLLÓN GARCÍA, J.D.: Op. cit., pág. 4. 
conviviente en una relación extramatrimonial pueda dejar o recibir bienes por testamento ${ }^{350}$. Así pues, es válida la institución de heredero o de legatario a favor del conviviente more uxorio, con el límite general de las legítimas.

Claro está que, existiendo herederos forzosos, la libertad de testar queda limitada por la existencia de los derechos legitimarios de estas personas ${ }^{351}$. Señalando el artículo 807 del CC que tales herederos forzosos serán, en primer lugar, los hijos y descendientes en relación con sus padres y ascendientes, a falta de estos, los padres y ascendientes en relación con los hijos y descendientes, y el viudo o viuda en la forma determinada por el propio Código ${ }^{352}$. Si no existiesen estos parientes, el conviviente puede disponer libremente de toda su herencia

Tal como indicamos más arriba, entendemos que dentro del concepto de legitimario debe incluirse al conviviente mediante la correspondiente reforma legislativa, ya que, en caso contrario, las posibilidades del testador de beneficiar a su compañero, con quien no se ha casado, pero sí ha constituido una familia reconocida socialmente, se ven considerablemente disminuidas.

Otro aspecto que precisa revisión es la consideración del conviviente more uxorio como familia a efectos fiscales, pues en la actualidad la transmisión mortis causa entre los convivientes no casados se encuentra gravada con un tipo impositivo mucho más alto que el establecido para los cónyuges, en una muestra más de la discriminación estatal a las parejas no casadas.

En definitiva, entendemos que deben ser reconocidos derechos sucesorios a favor del conviviente more uxorio supérstite en régimen de igualdad con los del cónyuge viudo. Derechos que no solo han de reflejarse en el testamento, sino también en la legítima, para lo que se hace imprescindible una modificación legal que extienda los derechos del cónyuge viudo al conviviente more uxorio sobreviviente.

\footnotetext{
${ }^{350} \mathrm{La}$ capacidad para suceder se regula en los arts. 744 y ss. del CC. En relación con ello el TS se ha manifestado entendiendo como plenamente válidas los actos dispositivos, realizados a título gratuito y con ánimo de liberalidad, realizados por un conviviente a favor del otro, ya sea como donación o a través de testamento, como precisa, entre otras [STS 18-11-1994 (RJ 1994/8777)].

${ }^{351} \mathrm{El} \mathrm{CC}$ en su art. 806 establece que la "Legítima es la porción de bienes de que el testador no puede disponer por haberla reservado la ley a determinados herederos, llamados por esto herederos forzosos".

${ }^{352} \mathrm{El}$ cónyuge es legitimario en todo caso, es decir, tanto si concurre a la herencia con descendientes como si lo hace con ascendientes, o incluso si no existiese ninguno de estos parientes. Si bien al cónyuge viudo lo que le corresponde es es una cuota usufructuaria, que varía en función de las personas con las que concurre a la herencia (arts. 8344 a 838 del CC). El derecho legitimario del cónyuge viudo está condicionado a la existencia de vínculo matrimonial con el finado.
} 


\section{El derecho a pensión de viudedad}

Probablemente la reclamación de la prestación de la Seguridad Social en materia de viudedad haya sido uno de los aspectos en los que con más insistencia se ha buscado el pronunciamiento de la jurisprudencia a favor de la equiparación de las uniones de hecho con las parejas casadas. El éxito ha sido relativo, ya que hasta la publicación de la Ley 40/2007, de 4 de diciembre, de medidas en materia de Seguridad Social, las pensiones de viudedad eran rechazadas en la mayoría de las ocasiones ${ }^{353}$. Sin embargo, el acceso de las parejas de hecho a la pensión de viudedad, incorporado en la mencionada Norma, no ha significado en modo alguno la equiparación entre el matrimonio y la convivencia more uxorio. Continúa siendo patente cierta desconfianza del legislador hacia las uniones de hecho y su posible creación fraudulenta para beneficiarse de la pensión ${ }^{354}$.

Con la modificación que mencionamos se regulaba, por primera vez en nuestro Ordenamiento, una pensión de viudedad a las parejas de hecho bajo una serie de condiciones contempladas en el párrafo $3 .^{\circ}$ de dicha Norma ${ }^{355}$. El actual artículo 221 del texto refundido de la Ley General de la Seguridad Social, aprobado por el RD legislativo 8/2015, de 30 de octubre, es una transcripción del anterior artículo 174.3 introducido en la entonces vigente Ley General de la Seguridad Social por la Ley 40/2007, de 4 de diciembre, de medidas en materia de Seguridad Social.

Pero el citado artículo de la Ley de 2007 iba más allá, pues incluía por primera vez en una norma de rango estatal los requisitos exigidos para considerar a una unión de hecho como tal, estableciendo, además, los mecanismos para poder acreditar la existencia de dicha unión de hecho, disponiendo en el último párrafo de dicho artículo lo siguiente: "A efectos de lo establecido en este apartado, se considerará pareja de hecho la constituida, con análoga relación de afectividad a la conyugal, por quienes, no hallándose impedidos para contraer matrimonio, no tengan vínculo matrimonial con otra persona y acrediten, mediante el correspondiente certificado de

\footnotetext{
${ }^{353}$ Diversas Resoluciones del TC tuvieron ocasión de pronunciarse sobre la materia. Entre otros pronunciamientos señalaremos la afirmación contenida en su Sentencia 156/1987, de 11 de febrero, en la que señalaba que "el matrimonio y la convivencia en una relación extramatrimonial no son situaciones equivalentes y que por ello es constitucionalmente legítimo que el legislador, en uso de su amplísima libertad de decisión, deduzca razonablemente consecuencias diversas de la diferente situación de hecho tomada como punto de partida".

${ }^{354}$ MANEIRO VELAZQUEZ, Y., La acreditación del vínculo y de la convivencia more uxorio en las parejas de hecho: una aproximación jurisprudencial, Actualidad Laboral, n. ${ }^{\circ}$ 5/2013, págs. 3 y 4.

${ }^{355}$ CASTRO MEJUTO, L.F., A propósito de la pensión de viudedad para las parejas de hecho, Anuario da facultade de Dereito da universidade da Coruña, 2008, pág. 243.
} 
empadronamiento, una convivencia estable y notoria con carácter inmediato al fallecimiento del causante y con una duración ininterrumpida no inferior a cinco años. La existencia de pareja de hecho se acreditará mediante certificación de la inscripción en alguno de los registros específicos existentes en las CCAA o ayuntamientos del lugar de residencia o mediante documento público en el que conste la constitución de dicha pareja. Tanto la mencionada inscripción como la formalización del correspondiente documento público deberán haberse producido con una antelación mínima de dos años con respecto a la fecha del fallecimiento del causante".

Por lo tanto, en esta norma estatal se establecen los siguientes requisitos para reconocer la existencia de una unión de hecho:

a) No estar impedidos para contraer matrimonio y que, además, no tengan vínculo matrimonial con tercera persona.

b) Existencia de convivencia estable y notoria al tiempo del fallecimiento.

c) Duración ininterrumpida de esa convivencia durante al menos cinco años.

d) Acreditación de la convivencia mediante certificado de empadronamiento.

El texto parece incurrir en cierta reiteración cuando, además de exigir el empadronamiento común de los convivientes durante los cinco años anteriores, establece otras formas de acreditar esa convivencia. Llamamos la atención sobre la reiteración que supone en el primer inciso señalar la exigencia de que "acrediten, mediante el correspondiente certificado de empadronamiento" la convivencia estable y notoria con carácter inmediato al fallecimiento y con una duración de al menos cinco años, y continuación se establezcan exigencias para acreditar esa convivencia que, supuestamente, ha quedado acreditada con el certificado de empadronamiento. Los medios para acreditar la existencia, aparentemente a mayores del certificado de empadronamiento, serían la inscripción de la unión de hecho en alguno de los registros establecidos al efecto, o bien mediante documento público de constitución de la citada pareja, inscripción o documento que deberá haber sido realizado, al menos, dos años antes del fallecimiento del conviviente.

$\mathrm{Al}$ respecto, la jurisprudencia ${ }^{356}$ diferencia entre la acreditación del requisito material de la convivencia, lo cual se cumplirá mediante el certificado de empadronamiento al que se refiere la norma o cualquier otro medio de prueba válido en Derecho, y el requisito ad solmenitatem para la

${ }^{356}$ Valgan por todas [STS 30-3-2016 (RJ 2016/1606) y STS 8-11-2016 (RJ 2016/5881)]. 
constitución de la unión de hecho, para lo que necesariamente habrá de acudirse a la inscripción registral o hacerlo mediante documento público ${ }^{357}$.

Es en esta situación que el actual artículo 221 del texto refundido de la Ley General de la Seguridad Social, específicamente establecido para las parejas de hecho, añade para las parejas no casadas un requisito adicional a los exigidos que ya tienen uniones matrimoniales para el reconocimiento a la prestación de viudedad, este requisito es el de que el conviviente beneficiario de la pensión de viudedad dependiese económicamente del fallecido. El apartado 1. ${ }^{\circ}$ del citado artículo señala que:

1. Cumplidos los requisitos de alta y cotización establecidos en el artículo 219, tendrá asimismo derecho a la pensión de viudedad quien se encontrase unido al causante en el momento de su fallecimiento, formando una pareja de hecho, y acreditara que sus ingresos durante el año natural anterior no alcanzaron el 50 por ciento de la suma de los propios y de los del causante habidos en el mismo período. Dicho porcentaje será del 25 por ciento en el caso de inexistencia de hijos comunes con derecho a pensión de orfandad.

No obstante, también se reconocerá derecho a pensión de viudedad cuando los ingresos del sobreviviente resulten inferiores a 1,5 veces el importe del salario mínimo interprofesional vigente en el momento del hecho causante, requisito que deberá concurrir tanto en el momento del hecho causante de la prestación, como durante el período de su

\footnotetext{
${ }^{357}$ En relación con la pensión de viudedad y el tipo de documento público válido para constituir la pareja de hecho, resulta interesante el caso resuelto por el TS [STS 9-5-2019 (RJ 2019/2311)], los hechos son los siguientes: la actora solicitó la pensión de viudedad derivada del fallecimiento de su pareja de hecho en febrero del año 2015. La Sentencia de instancia declara probado que la actora y el causante no habían contraído matrimonio, aun cuando habían convivido desde noviembre de 2007 y no existía impedimento legal alguno. La pareja había tenido dos hijos en común y no se había inscrito como pareja de hecho. La demandante invocaba como documento público constitutivo de la pareja de hecho y acreditativa de la común convivencia un Acta de Manifestaciones, realizada por ambos miembros de la pareja durante su convivencia, en la que manifestaban estas circunstancias.

El Juzgado de Primera Instancia desestimó la demanda de solicitud de pensión de viudedad al negar la eficacia como documento público para constituir una unión de hecho el Acta de Manifestaciones, precisando que tal instrumento se limita a reflejar una situación referida por los propios interesados, de lo que el notario se limita a reflejar en el acta. La Sentencia de suplicación ante el TSJ de Andalucía se pronunció en sentido favorable a las pretensiones de la demandante basándose en dos circunstancias: que las manifestaciones contenidas en el acta son de los interesados y no de terceros, y por la condición de documento público del acta de manifestaciones, que es el requisito alternativo a la inscripción en el registro exigido para la válida constitución de la pareja de hecho. Finalmente, el TS desestimó el recurso de casación, ratificando la STSJ andaluz. En su Resolución el TS abordó la validez de los documentos notariales en relación al cumplimiento de los requisitos exigidos por la Ley General de la Seguridad Social, para el reconocimiento de la pensión de viudedad a las parejas de hecho. Las diferencias entre los documentos analizados (acta de manifestaciones y acta de notoriedad notariales) radican en el tipo de documento notarial. Al señalar el indudable carácter de documento público del acta de manifestaciones no debería ser impedimento para ser vehículo válido de la declaración de voluntad constitutiva de pareja de hecho. Resulta sencillo deducir de las manifestaciones del acta notarial la voluntad de los declarantes de constituirse en pareja de hecho, y no existiendo un documento público específico previsto para este fin, cabe entender que se cumple el requisito legal de documento público.
} 
percepción. El límite indicado se incrementará en 0,5 veces la cuantía del salario mínimo interprofesional vigente, por cada hijo común con derecho a la pensión de orfandad que conviva con el sobreviviente".

El apartado 2. ${ }^{\circ}$ del artículo reproduce el texto del artículo 174.3 de la Ley anterior, transcrito más arriba.

Por tanto, y pese a que en principio la finalidad de la pensión de viudedad no sea la protección de los estados de necesidad ${ }^{358}$ con carácter general, sino compensar el daño sufrido y no en la cobertura de una situación de necesidad o de dependencia económica, asegurando un mínimo de rentas al cónyuge viudo ${ }^{359}$. Esta línea de pensamiento quiebra en el caso de las parejas de hecho, a las que se les exige prueba fehaciente de la ausencia de rentas para poder acceder a dicha prestación, situación que algún sector doctrinal considera discriminatoria ${ }^{360}$.

Analizaremos en primer lugar si la vigente regulación de la pensión de viudedad para los convivientes en pareja de hecho es discriminatoria. Empezaremos por comprobar como, para que las parejas de hecho puedan acceder a la pensión de viudedad, se les exige la comprobación de unas condiciones que no se demandan a las uniones matrimoniales: una convivencia mutua, estable y notoria durante un período amplio, cinco años, además de la existencia de una dependencia económica con respecto al compañero fallecido. En nuestro derecho, la primera de las condiciones exigidas conlleva la transformación de la naturaleza inicial de la unión de hecho, consistente en un dato fáctico, real y constatable en otra naturaleza completamente diferente, al convertirla en una relación de naturaleza jurídica, ya que se produce la exigencia de acreditar su condición de unión more uxorio mediante la correspondiente certificación del registro de parejas de hecho o mediante el documento público en el que conste la constitución de la pareja ${ }^{361}$. Dicho de otro modo, la actual

\footnotetext{
${ }^{358}$ Así lo indican las STC 77/1991, de 11 de abril y la del mismo Alto Tribunal 29/1992, de 9 de marzo.

${ }^{359}$ STC $184 / 1990$, de 15 de noviembre.

${ }^{360}$ BALLESTER PASTOR, I., La cuantía de la prestación de viudedad tras la Ley 40/2007, de 4 de diciembre; cambios puntuales y entrada en juego de las uniones de hecho, Tribuna social n. ${ }^{\circ}$ 209/2008, pág. 70.

${ }^{361} \mathrm{El}$ apartado $2 .^{\circ}$ del mencionado artículo 221 del RD legislativo 8/2015, de 30 de octubre, por el que se aprueba el texto refundido de la Ley General de la Seguridad Social establece que "2. A efectos de lo establecido en este artículo, se considerará pareja de hecho la constituida, con análoga relación de afectividad a la conyugal, por quienes, no hallándose impedidos para contraer matrimonio, no tengan vínculo matrimonial con otra persona y acrediten, mediante el correspondiente certificado de empadronamiento, una convivencia estable y notoria con carácter inmediato al fallecimiento del causante y con una duración ininterrumpida no inferior a cinco años. La existencia de pareja de hecho se acreditará mediante certificación de la inscripción en alguno de los registros específicos existentes en las CCAA o ayuntamientos del lugar de residencia o mediante documento público en el que conste la constitución de dicha pareja. Tanto la mencionada inscripción como la formalización del correspondiente documento público deberán haberse producido con una antelación mínima de dos años con respecto a la fecha del fallecimiento del causante".
} 
regulación viene a señalar que, de todas maneras y para poder ejercer el derecho a una pensión de viudedad, habrá que casarse $\mathrm{o}$, cuando menos, habrá que acudir a un registro o ante un notario, dando publicidad a la relación por medio de un documento, de manera que se desvirtúa tanto el carácter como el origen de las uniones de hecho extramatrimoniales.

La segunda de las condiciones que se exigen a estas uniones de convivencia es la señalada más arriba: ha de existir dependencia económica del conviviente supérstite con respecto al causante, para lo cual se acude a dos tipos de criterios, uno de carácter subjetivo, consistente en la averiguación de las aportaciones que venían realizando cada uno de los convivientes durante el año natural anterior al fallecimiento. Y un segundo criterio, este de carácter objetivo, vinculando el reconocimiento del derecho a la pensión de viudedad al hecho de que los ingresos del sobreviviente sean inferiores a 1,5 veces el salario mínimo interprofesional vigente en el momento del fallecimiento del causante.

Señalamos que solo se exige esta dependencia económica en el caso de las uniones de hecho, no así en el caso de las uniones matrimoniales, y ello pese a que no concurre ninguna razón de protección social que justifique la exigencia de distintos o mayores requisitos a las parejas de hecho que a los matrimonios, ya que, una vez equiparadas las situaciones, sus condiciones deberán ser idénticas para obtener la protección de supervivencia, cualquiera que sea el supuesto o modo de convivencia personal o familiar que cada cual haya elegido previamente. Es lo cierto que, desde el punto de vista de la jurisprudencia, no puede afirmarse que exista discriminación alguna por regular con distintos parámetros las parejas de hecho y los matrimonios ${ }^{362}$. Y ello porque la jurisprudencia del TC ha venido señalando que la negación total de la prestación no vulnera ningún derecho fundamental, a la vez que la exigencia del matrimonio para que se genere el derecho a la prestación no es inconstitucional ${ }^{363}$.

Tal posición resultaba entendible antes de la actual regulación, pero cuando se ha regulado el derecho a la prestación de las uniones de hecho, reconociéndolas como un modelo familiar diferente, resulta sumamente cuestionable que, entre opciones legítimas, se puedan conferir derechos disminuidos a un modelo de familia respecto del otro.

\footnotetext{
${ }^{362}$ CASTRO MEJUTO, L.F., obra citada, págs. 243 y 244.

${ }^{363}$ En este sentido, entre otras, Sentencias del TC números 184/1990, de 15 de noviembre; 29/1991, de 14 de febrero; 77/1991, de 11 de abril; 28/1992, de 9 de marzo; y 66/1994, de 28 de febrero.
} 


\section{C) EFECTOS PATRimoniales deRivados de LA RUPTURA DE LA PAREJA DE HECHO}

Como hemos comentado, durante la convivencia de la pareja de hecho los convivientes deben hacer frente a las necesidades de la familia (alimentación y vestido de los miembros del conjunto familiar, gastos de educación de hijos, si los hay, adquisición de ciertos bienes necesarios, etc.), al igual que sucede en las uniones matrimoniales. Es decir, durante la convivencia se produce, de manera inevitable, una mezcla de los patrimonios de los miembros de la pareja de hecho que complica la diferenciación de los mismos posteriormente.

En estas situaciones de ruptura de las uniones de hecho, y para poder determinar sus consecuencias económicas, será preciso comprobar si existen o no pactos entre los miembros de la pareja que regulen las medidas para el supuesto de ruptura. De este modo, la autonomía de la voluntad de los miembros de la unión de hecho queda configurada como la vía fundamental para la regulación, mediante pactos expresos, tanto de los aspectos personales como de los patrimoniales en las uniones de hecho.

Como hemos señalado, actualmente la validez y eficacia de los pactos entre los convivientes son aceptadas unánimemente por doctrina y jurisprudencia. Esta conclusión se basa en la licitud de la convivencia more uxorio, que ya no contravienen los criterios morales socialmente dominantes, y que han sido reconocidas por el legislador y merecido un juicio favorable por el $\mathrm{TS}^{364}$.

Obviamente, en la ruptura de la pareja de hecho las diversas necesidades aludidas existentes durante la convivencia deben ser mantenidas, en especial en el supuesto de concurrencia de hijos menores o dependientes. A ello se añade la complicación que representa la atribución de los bienes adquiridos en común durante la convivencia.

En estas situaciones de crisis los conflictos de carácter patrimonial más habituales son los referidos a la liquidación y atribución de los bienes adquiridos durante el período de convivencia, ya hayan sido adquiridos de manera conjunta por ambos convivientes o por uno solo. Otro de los aspectos controvertidos es el relativo al reparto de las ganancias obtenidas por uno solo de los convivientes. Estos conflictos se manifiestan de manera más habitual y contundente cuando los convivientes no han pactado un régimen jurídico regulador de las relaciones económicas, tanto durante el período de convivencia como para el momento de una posible ruptura. De ahí que vengamos sosteniendo la conveniencia de acordar, al inicio de la relación de pareja, un régimen

\footnotetext{
${ }^{364}$ MARTÍN MOLINA, A.A.: Op. cit., pág. 156.
} 
económico que regule los más amplios supuestos, siendo aconsejable la remisión a alguno de los regímenes previstos en el CC u otras Normas civiles, no por analogía, sino por remisión al mismo pactada por los propios convenientes, dentro del uso de la autonomía de la libertad que les corresponde.

Otros aspectos que suscitan conflicto en el momento de la ruptura de la pareja de hecho son, de una parte, las posibles reclamaciones cuando uno de los convivientes entiende tener derecho a una compensación económica por el tiempo de convivencia, o cuando entiende que le corresponde esa compensación al haberse producido, a su costa, un enriquecimiento de su compañero $^{365}$. Y, de otra parte, otra gran cuestión que surge en las rupturas de pareja es la relativa a la posible atribución del uso de la vivienda familiar al conviviente no propietario. En esta cuestión será decisiva la existencia de hijos comunes, cuya custodia haya sido conferida en exclusiva al progenitor no titular de la vivienda, puesto que tal atribución viene derivada de lo dispuesto por el artículo 39 de la Constitución, al representar un modo de garantizar esa protección integral proclamada en la citada norma constitucional.

Entendemos, al igual que gran parte de la doctrina ${ }^{366}$, que, a fin de determinar las consecuencias económicas de la ruptura de la convivencia de hecho, lo primero que debe ser tenido en cuenta es la posible existencia de pactos entre los convivientes en uso de su libertad para contratar $^{367}$. Es más, en nuestra opinión, sería necesaria una modificación legislativa mediante la que, por una parte, se dé libertad a los convivientes para pactar libremente cualquier concesión a su compañero, indudablemente respetando el principio de igualdad entre ambos y mientras tales acuerdos no contravengan las leyes, a la moral ni al orden público, sin que, en ningún caso, lo pactado pueda conceder al compañero más derechos de los que tendría si hubiesen contraído

\footnotetext{
${ }^{365}$ Resulta obligado, en este punto, volver a citar la jurisprudencia de referencia [STS 12-9-2005 (RJ 2005/7148)] sentencia del pleno del TS dictada para unificación de doctrina, seguida por múltiple jurisprudencia del mismo Alto Tribunal, en la que, a la vez que entiende que no procede la aplicación análoga de las Normas reguladoras del matrimonio a las parejas de hecho, sí que precisa que pueden resultar de aplicación, para corregir la injusticia patrimonial, en determinados casos, derivada de la ruptura de la pareja de otras instituciones jurídicas, citando expresamente la situación creada en la ruptura de una sociedad civil constituida por tiempo indefinido, o por la aplicación de la doctrina del enriquecimiento injusto, si es lo que procede, en el caso concreto de que se trate.

${ }^{366}$ Por citar a algunos, PINTO ANDRADE, C. Efectos patrimoniales tras la ruptura de la pareja de hecho, Bosch, 2009, págs. 45 y ss.; MARTIN MOLINA, A.A., obra citada, págs. 156 y ss.; LÓPEZ AZCONA, A., La ruptura de las parejas de hecho, Aranzadi, Pamplona, 2002, págs. 67 y ss.

${ }^{367} \mathrm{El}$ artículo 1255 del CC proclama la autonomía de la voluntad como principio fundamental en el derecho contractual al señalar que "Los contratantes pueden establecer los pactos, cláusulas y condiciones que tengan por conveniente, siempre que no sean contrarios a las leyes, a la moral ni al orden público" La validez de tales pactos ha sido ratificado por la jurisprudencia del TS.
} 
matrimonio. Y, por otra parte, una norma armonizadora de las distintas legislaciones autonómicas para establecer la obligatoriedad de que en el expediente de constitución de una pareja de hecho se incluyan un cuestionario a los convivientes en el que se dejen fijadas las concesiones mutuas que esa pareja en concreto desea realizar, con respeto a los mismos principios señalados en el caso anterior.

Hay supuestos en los que los convivientes han optado por no transmitirse ningún tipo de derecho patrimonial entre sí. En el momento de la ruptura no cabe recurrir a ningún régimen económico matrimonial de manera análoga, sino que deberá acudirse a otras instituciones jurídicas más próximas, en el supuesto de las modificaciones que proponemos, como son las ya apuntadas por el TS de la doctrina del enriquecimiento injusto, la aplicación del artículo 1902 del CC o la aplicación análoga de los supuestos de ruptura de una sociedad civil constituida por tiempo indefinido.

Como es natural, es en las situaciones de ruptura de la pareja cuando con más claridad se pone de manifiesto la problemática derivada de la ausencia de una regulación legal de este tipo de uniones. La decisión de los miembros de la pareja de actuar al margen de la regulación del estatuto matrimonial no es razón suficiente para desatender los importantes efectos derivados de la unión de hecho, en especial los de su extinción. El problema radica en que la legislación autonómica, en especial la de aquellas comunidades sin Derecho Civil propio, tiene vedado regular sobre distintos aspectos que, competencialmente, corresponden al Estado, pero este ha hecho dejación de su obligación de legislar sobre la materia. Lo más parecido a un intento armonizador por el Estado fue la redacción del artículo 174.3 de la Ley General de la Seguridad Social dada por la Ley 40/2007, ya comentada y mantenida en lo esencial en la redacción del vigente Texto refundido de la Ley General de la Seguridad Social. Pero ésta se limita a una suerte de definición, sumamente restrictiva y discriminatoria para este tipo de uniones.

Así pues, ante la inexistencia de regulación legal, y para los supuestos de ausencia de pacto entre los convivientes, analizaremos las distintas figuras jurídicas aplicables, dependiendo del supuesto ante el que nos encontremos, que puedan dar respuesta a la reclamación planteada por uno de los convivientes que reivindica participación en las ganancias obtenidas por su compañero vigente la unión de convivencia. 


\section{Figuras jurídicas aplicables a la liquidación del patrimonio adquirido durante la convivencia extramatrimonial}

La jurisprudencia del TC ha venido admitiendo que las CCAA con competencias en Derecho Civil tienen también competencia para regular determinados efectos jurídicos en las relaciones more uxorio, al regular una realidad jurídicamente diferente a la del matrimonio ${ }^{368}$

Las CCAA con competencia para regular los efectos jurídicos a las uniones de hecho, como es sabido, son las de Galicia, Euskadi, Comunidad Foral de Navarra, Aragón, Cataluña e Islas Baleares. Otras Comunidades, que no tienen reconocidas competencias en materia de Derecho Civil, han visto como se declaraban nulas total o parcialmente las leyes autonómicas de uniones de hecho por regular aspectos de derechos y obligaciones entre los convivientes sin tener competencia para ello ${ }^{369}$.

Como venimos señalando, en el territorio común la nota esencial es la ausencia de una regulación legal. Pero la ausencia de Ley no supone ausencia de regulación jurídica, ya que existen otras fuentes del Derecho. Así nos recuerda el TS que «la convivencia more uxorio, entendida como una relación a semejanza de la matrimonial, sin haber recibido sanción legal, no está regulada legalmente, ni tampoco prohibida por el Derecho: es ajurídica, pero no antijurídica; carece de normativa legal, pero produce o puede producir una serie de efectos que tienen trascendencia jurídica y deben ser resueltos con arreglo al sistema de fuentes del Derecho". Así pues, a falta de Ley, los efectos jurídico-patrimoniales que existan derivados de la ruptura de la pareja de hecho, en vida de estos, hay que extraerlos de la doctrina que ha establecido y sigue nuestro TS, teniendo en cuenta también la doctrina constitucional sobre las parejas de hecho en aplicación de otras fuentes. Este régimen será aplicable a los conflictos derivados de parejas no

\footnotetext{
${ }^{368}$ Expresamente lo señala así la STC 93/2013, de 23 de abril, en cuyo FJ 5. ${ }^{\circ}$, penúltimo párrafo, concluye que "Resulta indudable, por consiguiente, que la valoración de conjunto de la Ley permite rechazar la impugnación global que los Diputados recurrentes dirigen contra la misma por vulneración de la competencia del art. 149.1.8 CE, pues resulta claro que el legislador foral no está creando una forma de matrimonio distinta de las previstas por el legislador estatal. $\mathrm{Y}$, por otra parte, aquel puede regular determinados efectos jurídicos derivados de la relación entre los que conviven de hecho, en el ejercicio de las competencias de que dispone, atendiendo a las previsiones de la LORAFNA, en materia de derecho civil (art. 48), función pública [49.1 b)] o régimen tributario (art. 45.3).

${ }^{369}$ Es el caso de la Ley de la Comunitat Valenciana, declarada parcialmente inconstitucional en la STC 110/2016, de 9 de junio, por invadir la Norma autonómica competencias del Estado. Lo mismo sucedió en el caso de la STC 81/2013, de 11 de abril, en relación con determinados preceptos de la Ley de la Comunidad de Madrid.
} 
sometidas (por imposibilidad legal o por voluntad propia) a alguna de las leyes autonómicas que regulan efectos civiles de la convivencia o como consecuencia de su ruptura allí donde existan.

\section{a) La aplicación análoga del régimen de gananciales}

Hemos analizado la posibilidad de pacto entre los convivientes que regulen sus relaciones económicas mediante el sometimiento a la normativa de la sociedad de gananciales, remitiéndose, de forma expresa, a las reglas previstas en el CC para el matrimonio en los supuestos en que no conste estipulación concreta.

En este planteamiento sosteníamos la validez del acuerdo, en virtud de la capacidad autorreguladora de la pareja, resultando de aplicación las normas de la sociedad de gananciales, no por analogía, sino por la remisión expresa realizada por los convivientes a esta normativa. De manera que, si durante su convivencia, los miembros de la pareja de hecho asumieron de manera voluntaria y expresa las reglas del régimen económico matrimonial de la sociedad de gananciales, esas mismas normas resultarán de aplicación en el momento de la ruptura de la convivencia de hecho $^{370}$.

Existiendo pacto expreso al respecto en este sentido, las reglas de la comunidad de gananciales pueden regular la pareja more uxorio por expresa remisión a dicha normativa existente en el pacto entre los convivientes, ya que según reiterada jurisprudencia no cabe la aplicación analógica de la sociedad de gananciales a las parejas de hecho ${ }^{371}$.

En definitiva, nuestra jurisprudencia viene planteando que, puesto que la unión de hecho se entiende como una situación diferente a la de matrimonio, ya que quienes pudiendo casarse deciden no hacerlo. Entiende la jurisprudencia que, en uso de su libertad, estas personas no desean verse sometidos a tales reglas, por lo que tales uniones no son equivalentes al matrimonio. Pese a ello, esa misma jurisprudencia entiende también que los convivientes son plenamente libres de adoptar acuerdos para someter sus relaciones patrimoniales a las reglas propias de cualquiera de los regímenes económicos legalmente previstos para el matrimonio, resultando tales pactos

\footnotetext{
${ }^{370}$ En este sentido se pronuncian MESA MARRERO, C.: Op. cit., págs. 169-170; PANTALEÓN PRIETO, A. F.: «La autorregulación de la unión libre», en RPJ n. 4 (1986), pág. 122; MERINO GUTIÉRREZ, A.: «Las uniones libres y su perspectiva actual», en La Ley (1988-1991), págs. 1109-1111.

${ }^{371}$ Este ha sido el sentido de múltiples sentencias del TS, entre otras muchas citaremos [STS 18-5-1992 (RJ 1992/4907), STS 22-7-1993 (RJ 1993/6247) y STS 4-3-1997 (RJ 1997/1640)], que precedieron a la famosa Sentencia del Pleno del Tribunal de 12 de septiembre de 2005, que fijó la doctrina que se viene siguiendo de manera unánime desde entonces, en la que dice que no cabe la aplicación análoga de las reglas del matrimonio a la pareja de hecho por su distinta naturaleza jurídica.
} 
perfectamente válidos, siempre que incluyan la remisión expresa a las reglas del régimen económico acordado.

\section{b) La sociedad universal de ganancias}

Hemos visto que la pareja de hecho puede pactar de manera expresa la creación de una sociedad universal de ganancias, con las características propias de la sociedad constituida. Pero, como es natural, si se produce la ruptura de la unión de hecho, ello conlleva la extinción de la sociedad constituida entre los convivientes, por lo que procederá realizar el reparto de las ganancias obtenidas del modo en que se hubiera pactado. Si no se hubiera pactado nada al respecto, procede la aplicación de lo dispuesto por el artículo 1689 del CC, es decir, que el reparto será proporcional a lo que hubiera aportado cada uno de los socios.

Cuando los convivientes no han pactado de forma expresa constituir una sociedad universal de ganancias, se plantea la cuestión de si es posible entender que se ha constituido tal modelo de sociedad durante la convivencia de una forma tácita. De inicio, y al amparo de lo dispuesto por el artículo 1667 del $\mathrm{CC}^{372}$, existe libertad de forma para la constitución de la sociedad. Pero, para entender creada la sociedad universal de ganancias de manera tácita, será necesario que se pueda deducir la voluntad tácita de constituir la sociedad de la existencia de hechos concluyentes acreditativos de tal propósito, concurriendo los requisitos esenciales del contrato de sociedad ${ }^{373}$. Sin embargo, la mera convivencia more uxorio por sí misma no permite concluir la existencia de la sociedad universal de ganancias, puesto que para su existencia es imprescindible que concurran todos los elementos exigibles para la validez del contrato de sociedad.

La jurisprudencia ${ }^{374}$ ha ido creando una doctrina respecto a la posibilidad de aplicar las reglas de la sociedad universal de ganancias en los procedimientos de liquidación de los bienes adquiridos durante el período de convivencia de la unión de hecho:

\footnotetext{
${ }^{372}$ El artículo 1667 del CC establece que "La sociedad civil se podrá constituir en cualquier forma, salvo que se aportaren a ella bienes inmuebles o derechos reales, en cuyo caso será necesaria la escritura pública”.

${ }^{373}$ Tales requisitos se deducen del dictado del artículo 1665 del CC "La sociedad es un contrato por el cual dos o más personas se obligan a poner en común dinero, bienes o industria, con ánimo de partir entre sí las ganancias.”, por lo que los requisitos imprescindibles serán: la aportación de ambos socios al fondo común, el ánimo de repartir las ganancias entre los convivientes y, de manera especial, la voluntad de crear la sociedad, obligándose a cumplir los requisitos necesarios para su existencia.

${ }^{374}$ El TS viene pronunciándose al respecto desde hace décadas, a modo de ejemplo [STS 11-12-1992 (RJ 1992/9733), STS 18-2-1993 (RJ 1993/1246) y STS 18-3-1995 (RJ 1995/1962)].
} 
a) Por el mero hecho de haberse producido confusión de bienes durante la existencia de la convivencia extramatrimonial, y a falta de pacto expreso, no puede concluirse de la sola convivencia la existencia de una sociedad. Para que se entienda constituida la sociedad será imprescindible la comprobación de la voluntad de los convivientes, ya sea mediante pacto expreso o tácito, de hacer comunes, en todo o en parte, los bienes adquiridos durante ese período.

b) El consentimiento de los convivientes, manifestado con absoluta claridad, ya sea mediante pacto expreso o de manera tácita, es elemento imprescindible para entender constituida la sociedad. A ello se debe añadir que ambos convivientes deben haber puesto en común dinero, bienes o industria, al objeto de constituir la sociedad. De no existir pacto expreso, tal voluntad de constitución de la sociedad ha de poder deducirse, de manera inequívoca, de los actos continuados realizados por ambos convivientes.

\section{c) La Comunidad de bienes}

No es extraño que al finalizar la unión extramatrimonial exista cierta confusión sobre la titularidad de determinados bienes adquiridos durante el período de convivencia. Dicha confusión puede deberse tanto al hecho de que la titularidad de esos bienes figure a nombre de uno solo de los convivientes, o porque exista la confusión sobre la titularidad misma de los bienes, en especial de aquellos que no precisan constar en ningún registro público.

Cuando la pareja ha constituido una comunidad de bienes mediante pacto, ya sea sobre la totalidad de los bienes adquiridos o sobre bienes determinados, lo habitual es que, finalizada la relación de convivencia, se ponga fin a la situación de condominio, bien mediante acuerdo o por cualquiera de los distintos medios establecidos en los artículos 400 y siguientes del CC sobre la división de la cosa común.

Más problemáticos son los supuestos de adquisición de bienes durante la convivencia cuando no existe pacto al respecto. En tales supuestos, cuando la titularidad del bien adquirido figura a nombre de uno solo de los miembros de la pareja o no está clara la titularidad, los 
Tribunales ${ }^{375}$ deberán entrar a juzgar el modo de adquisición de los mismos, si se adquirieron con fondos pertenecientes solamente al conviviente a cuyo nombre figuran, o si las aportaciones fueron realizadas por ambos y con la intención de hacerlos comunes.

De especial interés resulta la necesaria protección de los terceros afectados por la liquidación de la comunidad de bienes. Por eso, el artículo 405 del CC deja establecido que "la división de una cosa común no perjudicará a tercero", manteniendo este sus derechos en relación con la cosa, todo lo cual se complementa con lo dispuesto por el artículo 403 del mismo cuerpo legal al precisar que "los acreedores o cesionarios de los partícipes podrán concurrir a la división de la cosa común y oponerse a que se la verifique sin su concurso", con lo que se les reconoce el derecho a intervenir en la disolución del condominio, si bien no se especifican cuáles serán las facultades que se atribuyen al tercero en el proceso de disolución.

De lo señalado, la jurisprudencia llega a las siguientes conclusiones: la mera existencia de la unión de hecho no genera, por sí misma, la existencia de una comunidad de bienes. En el caso de que los convivientes hayan pactado someter sus relaciones patrimoniales al régimen de copropiedad, la disolución del condominio será conforme a los acuerdos previstos por las partes. A falta de pacto, la existencia de la comunidad de bienes se hace depender de la prueba de que existía la voluntad de los convivientes de hacer comunes los bienes adquiridos durante la convivencia, aunque la titularidad de los mismos aparezca a nombre de solo uno de ellos, se aplicarán las normas previstas legalmente para la liquidación del condominio.

\section{Otros efectos derivados del cese de la convivencia extramatrimonial}

La cuestión que se nos plantea, en el caso de las parejas extramatrimoniales, es que no son pocas las ocasiones en las que la ruptura de la convivencia acarrea más desventajas para uno de los convivientes, especialmente cuando este se ha dedicado de manera exclusiva al cuidado de la familia, careciendo de medios económicos para hacer frente a la nueva realidad. Ante este tipo de situaciones, y a efecto de corregir los graves desequilibrios fruto de la ruptura, se cuestiona la posible obligación de mantenimiento e indemnización entre los convivientes.

Otras cuestiones que se derivan de la situación de crisis de la pareja extramatrimonial son las relativas a la posible adopción de medidas relativas a la atribución del uso de la vivienda

\footnotetext{
${ }^{375} \mathrm{El} \mathrm{TS}$ ha tenido ocasión de pronunciarse en distintos supuestos en que se discutía en torno a la titularidad de varios bienes, adquiridos durante el período de convivencia, y en los que figuraba exclusivamente la titularidad de uno solo de los convivientes [STS 11-10-1994 (RJ 1994/7476) y STS 7-7-2010 (RJ 2010/3904)].
} 
familiar, o las posibles compensaciones entre los miembros de la pareja a causa del desequilibrio económico en contra de alguno de los convivientes, aplicando mecanismos que consigan un resultado similar al producido en los casos de crisis matrimonial ${ }^{376}$.

\section{Atribución del uso de la vivienda familiar en las situaciones de ruptura de pareja de hecho}

Al finalizar la convivencia se plantea un problema en torno a la atribución del uso de la que, hasta ese momento, ha sido la vivienda familiar. A falta de una definición legal del concepto de vivienda familiar, la jurisprudencia ${ }^{377}$ ha venido realizando un ejercicio de delimitación del mismo.

Así, la STS, de 16 de diciembre de 1996, la define como

el reducto donde se asienta y desarrolla la persona física, como refugio elemental que sirve a la satisfacción de sus necesidades primarias (descanso, aseo, alimentación, vestido, etc.) y protección de su intimidad (privacidad), al tiempo que cuando existen hijos es también auxilio indispensable para el amparo y educación de estos. De ahí que, las normas que sobre el uso de la vivienda familiar contiene el CC en relación con el matrimonio y su crisis se proyectan más allá de su estricto ámbito a situaciones como la convivencia prolongada de un hombre y una mujer como pareja, ya que las razones que abonan y justifican aquella valen también en este último caso".

De inicio, los cónyuges (o los convivientes) pueden disponer libremente y de común acuerdo de la atribución del uso de la vivienda familiar. En los supuestos de discrepancia al respecto, será el Juez quien deba resolver la controversia sobre la atribución de la vivienda, debiendo diferenciar el supuesto de la existencia de hijos de la pareja o cuando no los hay.

En el supuesto de existencia de hijos, a falta de acuerdo entre los progenitores sobre la atribución del uso, con independencia de quien sea el titular de la vivienda, el Juez viene obligado a atribuir el uso de la misma al progenitor que tenga encomendada la guarda y custodia de los hijos,

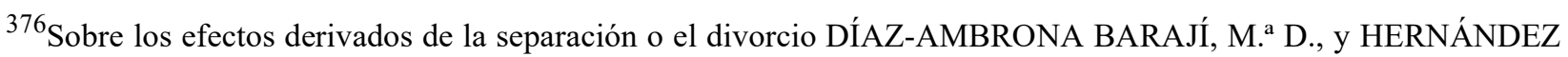
GIL, F., Lecciones de Derecho de familia, $2^{\mathrm{a}}$ ed., Editorial universitaria Ramón Areces, Madrid, 2007, págs. 216-232; LASARTE ÁLVAREZ, C.: obra citada, págs. 114 y ss.

${ }^{377}$ En Sentencias de las Audiencias provinciales se redunda en un similar concepto jurídico de la vivienda familiar, así [SAP de Ciudad Real 30-12-1995 (AC 1995/2306)], la vivienda familiar se define "por la utilización conjunta, permanente y habitual que los miembros de una familia hacen de aquella y donde priman los intereses de la familia, como entidad propia, frente a los particulares de uno de los cónyuges", entre tanto, otra Audiencia provincial [SAP de Las Palmas 28-9-2007 (JUR 2007/353384)], dice que "la vivienda familiar se corresponde con el espacio físico, generalmente cerrado, que es ocupado por los componentes de una pareja, $\mathrm{y}$, en su caso, de sus descendientes más próximos (hijos), y que a su vez constituye el núcleo básico de la convivencia, es decir, el lugar donde se desarrollan habitualmente los quehaceres cotidianos más íntimos”.
} 
por mandato expreso del artículo 96 del CC que establece en su párrafo $1 .^{\circ}$ que "en defecto de acuerdo de los cónyuges aprobado por el Juez, el uso de la vivienda familiar y de los objetos de uso ordinario en ella corresponde a los hijos y al cónyuge en cuya compañía queden" "378. De modo que se establece un cierto automatismo entre la decisión judicial sobre la guarda y custodia y la atribución del uso de la vivienda familiar.

De mayor margen de discrecionalidad dispone el Juez en los supuestos en que algunos de los hijos quedan en compañía de uno de los progenitores y los restantes al cuidado del otro, en este caso el Juez deberá resolver lo que proceda, siempre atendiendo al interés más necesitado de protección.

La misma norma prevé también la posibilidad de que, no existiendo hijos menores o dependientes, pueda ser atribuido el uso de la vivienda familiar al cónyuge no titular del inmueble, siempre que las circunstancias lo aconsejen por ser el interés más necesitado de protección y limitando dicha atribución temporalmente.

Surge la cuestión de si resulta aplicable el régimen de atribución del uso de la vivienda familiar contenido en el CC a los conflictos relativos a la atribución del uso del que fuera el hogar familiar en los casos de convivencia more uxorio. Parece claro que en los supuestos en que exista un pacto entre los convivientes al respecto no se plantean mayores problemas, pudiendo el conviviente titular atribuir el uso al miembro de la pareja no titular utilizando distintos medios jurídicos para su efectividad: puede hacerlo mediante una cesión en precario o mediante diversos tipos de contratos, como puede ser el comodato o incluso el arrendamiento. También puede constituirse un derecho real, como el de uso y habitación, o el de usufructo por tiempo determinado ${ }^{379}$.

\footnotetext{
${ }^{378} \mathrm{Tal}$ es el caso en el que se asigna el uso de la vivienda a un menor por ser el interés más digno de protección y no el de uno u otro cónyuge o conviviente. Y ello porque lo que se protege no es la propiedad de los bienes, sino los derechos del menor en una situación de crisis de pareja [STS 16-6-2014 (RJ 2014/3073)].

${ }^{379}$ GALLEGO DOMÍNGUEZ, I.: Op. cit., pág. 288.
} 


\section{a) Supuestos de existencia de hijos en la convivencia extramatrimonial}

En estos supuestos, tanto la doctrina ${ }^{380}$ como la jurisprudencia ${ }^{381}$ están de acuerdo en atribuir el uso de la vivienda familiar a los hijos menores y al miembro de la pareja al que se atribuya la custodia. La razón que se esgrime para ello es que el artículo 96 del CC es un precepto dirigido a la protección de los hijos, independientemente de su filiación matrimonial o extramatrimonial, por prescripción del artículo 39.2 de la Constitución, por lo que lo dispuesto en el artículo 96.1 del CC resultará de aplicación a las uniones extramatrimoniales con hijos, exactamente igual que si de un matrimonio se tratase.

Esta atribución del uso de la vivienda familiar a los hijos comunes menores o necesitados de protección, es un modo de contribución al mantenimiento de los hijos comunes por parte del progenitor que se ve privado del uso de la vivienda ${ }^{382}$. Atribución de uso que se suele acompañar del establecimiento de una pensión de alimentos que también deberá abonar el progenitor que no convive con los hijos dependientes.

Cuestión distinta es si el criterio será el mismo en el supuesto de hijos no comunes. La doctrina parece posicionarse en contra de extender la aplicación del artículo 96.1 del CC a los supuestos de existencia de hijos no comunes de la pareja, pues parece excesivo, como elemento único determinante de tal decisión, atribuir el uso de la vivienda familiar y la asignación de su cuidado, siendo los hijos solamente de uno de los miembros de la pareja, si bien, si el interés de esos hijos fuere el más necesitado de protección, sí que cabría tal atribución ${ }^{383}$.

\footnotetext{
${ }^{380}$ En este sentido se posicionan, entre otros, ZARRALUQUI SÁNCHEZ-EZNARRIAGA, L.: “La unión paramatrimonial y la vida familiar", en $R G D$, n. 48 (mayo 1993), pág. 4296 y GALLEGO DOMÍNGUEZ, I.: Op. cit., pág. 290.

${ }^{381}$ Son muchas las Sentencias que acogen desde hace varias décadas esta línea de pensamiento, entre otras [SAP de Alicante 18-9-1995 (AC 1995/2141)], o SAP de Salamanca 29-6-1995 (AC 1995/1200)], en todos los casos se acude al principio de favor filii para argumentar la aplicación analógica del artículo 96.1 del CC.

${ }^{382} \mathrm{Tal}$ planteamiento es defendido, para el caso de la ruptura matrimonial, entre otros por ROCA TRÍAS, E.: "Comentarios al artículo 96 CC", en Comentarios a la Reforma del Derecho de Familia, Vol. I. Tecnos, Madrid (1984), pág. 608. En esta línea se ha posicionado múltiple jurisprudencia, precisando en los últimos tiempos que "la vivienda forma parte integrante del concepto de alimentos", si bien en esta Sentencia añade, además, que "obligación (de pago de alimentos) que recae sobre ambos progenitores, y no solamente sobre el progenitor no custodio" [STS 19-1-2017 (RJ 2017/924)].

${ }^{383}$ En este sentido, se pronuncian, entre otros, RAMS ALBESA, J.: Uso, habitación y vivienda familiar. Tecnos, Madrid (1987), pág. 116. ELORRIAGA DE BONIS, F.: Régimen jurídico de la vivienda familiar, Aranzadi, Pamplona (1995), pág. 482; y ANDREU MARTÍNEZ, B.: "Unión de hecho y vivienda: soluciones en la jurisprudencia", en Revista jurídica de la Región de Murcia, n. ${ }^{\circ} 3$ (1997), pág. 47.
} 


\section{b) Supuestos de inexistencia de hijos}

En caso de no existir hijos de la pareja de hecho las soluciones son diversas, puesto que se debe prestar atención a las circunstancias del caso concreto. La doctrina científica niega la aplicación del artículo 96 del CC a estos supuestos ${ }^{384}$ al entender que por la ausencia de hijos se carece de elementos para la aplicación analogica del mencionado artículo.

Por su parte, la jurisprudencia ha determinado en ocasiones la atribución de la vivienda familiar al conviviente no titular. Partiendo de una postura jurisprudencial que entendía la no procedencia de la aplicación analógica del artículo 96 del CC, siguiendo la tradicional doctrina de que matrimonio y uniones de hecho no son situaciones equivalentes al no existir identidad de razón entre ambas figuras ${ }^{385}$. Sin embargo, de manera coetánea incluso, no falta otra jurisprudencia que determinó la atribución de la vivienda familiar al conviviente no titular, aunque no por las razones contempladas en el artículo 96 del Código, sino amparándose en otros posibles derechos que pudieran corresponderle, como pudiera ser el resarcimiento de un enriquecimiento injusto del conviviente titular de la vivienda, o incluso con base en otros preceptos en que sí resulte aplicable la analogía, como es el caso de la disolución de las sociedades civiles constituidas por tiempo indefinido ${ }^{386}$.

Especialmente interesante resulta la STS de 2 de diciembre de 1996, al tratarse de la primera ocasión en que el Alto Tribunal admitió la aplicación análoga del párrafo 96.3 del CC a las uniones more uxorio $^{387}$. Para entender esta postura habrá que atender, en primer lugar, a la evolución de la sociedad en el reconocimiento de la figura de las uniones extramatrimoniales, así como la general admisión de las mismas como uno de los modelos de familia protegidos constitucionalmente. También que las normas relativas a la vivienda familiar vienen establecidas tanto en sede del régimen económico matrimonial como para las situaciones de crisis matrimoniales, y que la Ley

\footnotetext{
${ }^{384}$ En este sentido se pronuncian, entre otros GALLEGO DOMÍNGUEZ, I.: Op. cit., pág. 292; REINA, V. y MARTINELL, J. M.: Las uniones matrimoniales de hecho. Marcial Pons, Madrid (1996), pág. 72.

${ }^{385}$ En este sentido se pronuncian Sentencias que hoy podemos considerar antiguas [STS 20-10-1994 (RJ 1994/7492), o STS 30-12-1994 (RJ 1994/10391)].

${ }^{386}$ En este sentido [STS 22-7-1993 (RJ 1993/6274)].

${ }^{387}$ El caso trataba de una convivencia extramatrimonial, que incluía tres hijos de la mujer, en el que, además, había existido una promesa de matrimonio, la cual fue tratada de manera diferenciada en la Sentencia. El fundamento utilizado fue considerar aplicables determinadas normas previstas para el matrimonio a las uniones de hecho, siempre investigando la identidad de razón. Pone de relieve el Supremo que la atribución del uso de la vivienda familiar a uno de los cónyuges no se basa tanto en la previa existencia del vínculo matrimonial, sino más bien en proteger a la parte más perjudicada por la ruptura, independientemente de que la unión entre ambas personas sea por matrimonio o por convivencia extramatrimonial. Esta Sentencia se vería ratificada más tarde [STS 10-3-1998 (RJ 1998/1272)].
} 
de Arrendamiento Urbanos de 1994 admitía, de manera expresa, el derecho de subrogación en el contrato de arrendamiento por el conviviente de hecho no titular en diversos casos, como hemos visto.

Todo ello conduciría a pensar que las normas sobre vivienda familiar recogidas en el CC no se han establecido únicamente para el caso del matrimonio, sino que tales normas se proyectan también a los supuestos de convivencia extramatrimonial, al entender que las razones que las justifican en el matrimonio son igualmente válidas para la convivencia more uxorio $^{388}$.

Sin embargo, tal postura no encuentra acomodo actualmente ni en la doctrina, que niega la posibilidad de aplicación análoga del artículo 96 del CC a las parejas de hecho ${ }^{389}$, ni en la actual doctrina del TS, la cual empieza a considerar al conviviente no titular en no pocas ocasiones como precarista $^{390}$.

\section{Problemática en la aplicación del artículo 96 del CC a las uniones de hecho}

En las uniones de hecho en situación de crisis, la solución en cuanto a la atribución de la que ha sido la vivienda familiar tendrá indudables diferencias según haya o no descendencia común. Y ello porque, en el primero de los casos, la atribución del que fuera domicilio familiar a los hijos comunes y al miembro de la pareja con el que convivan es un lugar común, que encuentra su amparo, de manera evidente, en la necesaria protección de la familia y en el interés del menor, puesto que reconocida la igualdad de los hijos con independencia de su filiación, la atribución del uso del domicilio a los hijos comunes dependientes encuentra plena justificación en el primer párrafo del artículo 96.

Más complicado resulta el supuesto en que no existen hijos comunes, puesto que la mera convivencia more uxorio no es título jurídico habilitante, por sí mismo, para determinar la atribución del uso del que fuera hogar común. Tal atribución del uso dependerá de otro tipo de cuestiones, como la existencia o no de un pacto al respecto, ya sea expreso o tácito.

\footnotetext{
${ }^{388}$ ANDREU MARTÍNEZ, B. obra citada, pág. 51.

${ }^{389}$ En este sentido GALLEGO DOMÍNGUEZ, I.: Op. cit., pág. 293, o CERDEIRA BRAVO DE MANSILLA, G.: "Atribución de la vivienda familiar en las parejas de hecho tras su ruptura: ¿siempre en precario? ¿siempre sin aplicar el art. 96 CC?", en Revista de Derecho Patrimonial n. ${ }^{\circ}$ 28/2012, Pamplona (2012), págs. 10-14.

${ }^{390}$ Así se pronuncia [STS 27-3-2008 (RJ 2008/4062)], en cuyo FJ $3^{\circ}$, dice que la propia jurisprudencia anterior, la que admitió en ocasiones la aplicación análoga del artículo 96.3 del CC, precisaba que "debe rechazarse la aplicación analógica de los regímenes económicos matrimoniales, puesto que la libertad que se auto conceden los convivientes al margen de las formalidades matrimoniales, no puede paradójica y contradictoriamente tener parigual con vinculaciones societarias de carácter económico". En el mismo sentido se pronunciaban posteriormente otra múltiple jurisprudencia, valga por todas [STS 6-10-2011 (RJ 2011/6708)].
} 
Una de las posibles situaciones, que se produce en no pocas ocasiones, es la de propiedad común del inmueble por ambos convivientes, ya sea en cuotas iguales o distintas en la copropiedad. En estas situaciones, y en caso de ruptura de la pareja, ambos titulares tendrán derecho de goce del inmueble en proporción a sus respectivas cuotas, por lo que podrían acordar el uso del mismo modo que en cualquier otra comunidad. Para el supuesto de inexistencia de acuerdo, podrán acudir a cualquiera de los medios que el Derecho ofrece para poner fin a la situación de copropiedad ${ }^{391}$. Semejante solución sería la aplicable para supuestos en que sobre la vivienda se hubiese establecido algún derecho de naturaleza personal compartido por ambos convivientes, como podría ser la situación de alquiler conjunto del domicilio, en cuyo caso, una vez más, habría que remitirse a lo pactado y, en su defecto, resultaría de aplicación el régimen de Derecho común correspondiente, sin que procediera la aplicación del citado artículo 96 en ninguno de los casos.

No obstante, el mayor problema, como hemos venido señalando, se produce cuando la titularidad de la vivienda que ha venido siendo el hogar común corresponde en exclusiva a uno solo de los convivientes. En tal caso, para el supuesto de existencia de hijos comunes dependientes de la pareja, resultará de aplicación lo dispuesto por el artículo 96. Pero, ante la inexistencia de hijos comunes, la atribución del uso dependerá del posible acuerdo entre los convivientes, más en concreto dependerá de la voluntad del miembro de la pareja titular de la vivienda. Esto no quita que, ante un posible litigio al respecto, el Juez pueda aplicar el artículo 96.3 del CC. Ante el posible perjuicio para el conviviente no titular habrá que acudir a otro tipo de remedios, como la indemnización por daño del artículo 1902 del Código, o la aplicación de la doctrina del enriquecimiento injusto, $\mathrm{u}$ otros que pudieran representar una solución ante la necesidad de proteger el interés del conviviente no titular ${ }^{392}$.

De modo tal que el conviviente no titular sería considerado como precarista en el inmueble, tanto durante el período de convivencia como, especialmente, tras la ruptura de la pareja ${ }^{393}$. Esta

\footnotetext{
${ }^{391}$ En efecto, ante tal eventualidad, cualquiera de los comuneros podría acudir a actuaciones tales como la venta de su cuota de participación, con el derecho de retracto de comuneros ejercitable por el otro ex conviviente, o incluso acudir a la actio communi dividendo del artículo 400 y ss. del CC.

${ }^{392}$ Tal sería la postura mantenida en [STS 6-10-2011 (RJ 2011/6708)], en cuyo FJ tercero dice que "Al descartarse la aplicación por analogía de las normas sobre disolución del matrimonio, únicamente si la concreta ley aplicable a la relación lo prevé, o bien ha habido un pacto entre los convivientes, se aplicara la correspondiente solución que se haya acordado. En el CC no existen normas reguladoras de esta situación por lo que es excluible aplicar por analogía lo establecido en el art. $96 \mathrm{CC}$, que exige el matrimonio, porque está regulando la atribución del domicilio tras el divorcio. En consecuencia, no puede alegar la recurrente que tiene un derecho a ocupar la vivienda, puesto que su situación es diversa, de acuerdo con la jurisprudencia".

${ }^{393}$ CERDEIRA BRAVO DE MANSILLA, G., obra citada, pág. 12.
} 
es la situación en la que se encuentra el conviviente no titular cuando el inmueble en que habitan pertenece en exclusiva al otro miembro de la pareja, ya que su permanencia en la vivienda no se fundamenta en título alguno, pues no cabe invocar la mera convivencia more uxorio como tal, por lo que su estancia en el inmueble se debe a la mera tolerancia del titular del mismo. Tampoco constituiría título habilitante el pago de algún gasto inherente al inmueble que, en todo caso, podría generar el derecho a pedir el reintegro de lo abonado. A la misma conclusión se llega en el caso de que se considere que la situación del conviviente no titular se recondujese al comodato durante el período de convivencia pues, en tal caso, al momento de la ruptura de la convivencia cesaría el derecho en que se fundaba la residencia del conviviente no titular ${ }^{394}$.

En los supuestos en que el domicilio familiar fuese una vivienda arrendada se produce una absoluta asimilación al matrimonio de las parejas de hecho en el artículo 12.4 de la vigente Ley de Arrendamiento Urbanos, de manera similar a lo expresado más arriba para el caso de fallecimiento del cónyuge o el conviviente. De modo tal que, en materia de desistimiento del contrato o abandono de la vivienda por parte del arrendatario, el citado artículo 12 de la Ley 29/1994, de 24 de noviembre, de Arrendamientos Urbanos, establece que si el arrendatario manifestase su voluntad de no renovar el contrato o de desistir de él o abandonare la vivienda sin manifestación expresa de desistimiento o de no renovación, entonces podrá continuar en el arrendamiento el cónyuge que conviviera con el arrendatario. También podrá hacerlo la persona que hubiera venido conviviendo con el arrendatario como cónyuge o en análoga relación de afectividad durante, al menos, los dos años anteriores al desistimiento o abandono, salvo que hubieran tenido descendencia en común, en cuyo caso bastará la mera convivencia. ${ }^{395}$

\section{Reclamaciones económicas entre los convivientes en el momento de la ruptura de la convivencia}

Cuando se produce la ruptura de una relación de convivencia surgen con frecuencia conflictos derivados de la liquidación de los bienes y derechos adquiridos durante la convivencia. En algunas ocasiones, la ruptura de la convivencia extramatrimonial conlleva importantes

\footnotetext{
${ }^{394}$ En tal interpretación, el conviviente no titular, comodatario, vendría obligado a satisfacer los gastos ordinarios en la proporción que se determine. Pero, al entenderse constituido el comodato por tiempo indeterminado, aunque vinculado a la relación de convivencia extramatrimonial, finalizada ésta, según señala el artículo 1749 del CC, el comodatario, conviviente no titular, vendría obligado a poner el bien, en el caso la vivienda, a disposición del titular de la misma. Es decir, que como resultado práctico se llegaría a soluciones similares a la del precario.

${ }^{395}$ DIAZ DE LEZCANO SEVILLANO, I.: Op. cit., pág. 232.
} 
perjuicios para uno de los convivientes, en especial cuando la relación ha sido prolongada en el tiempo y uno de los miembros era el que aportaba los medios económicos para el sostenimiento de la familia pues, en estos casos, el otro miembro de la pareja queda en una peor situación económica.

Pese a ello, no nacerá una obligación de indemnizar al conviviente perjudicado, al menos no por el solo hecho de la convivencia extramatrimonial, ya que los convivientes decidieron crear una unión de convivencia al margen de las reglas del matrimonio, de modo que no procedería aplicar sin más tales reglas a una unión que libremente decidieron constituir al margen de las mismas.

Cuestión distinta será que los convivientes hayan previsto, mediante los oportunos pactos, la determinación de algún tipo de derechos indemnizatorios o alimenticios a favor de cualquiera de ellos en supuesto de ruptura de la pareja. Tales pactos, realizados al amparo de la autonomía de la voluntad, consagrada en el artículo 1255 del CC serán válidos y el conviviente interesado podrá exigir el cumplimiento de lo pactado ${ }^{396}$.

La ausencia de una normativa estatal que regule los efectos derivados de la ruptura de la pareja de hecho conlleva la formulación ante los Tribunales de demandas en las que se pide una compensación económica, por parte de uno de los miembros de la pareja, por los perjuicios derivados del cese de la convivencia. Pese a lo indicado acerca de que el cese de la convivencia no está sometido a las reglas del matrimonio, existen determinadas circunstancias en las que el perjudicado puede obtener algún tipo de indemnización o compensación económica.

\section{a) El desequilibrio económico como fundamento de la reclamación}

En los supuestos de separación o divorcio, nuestro Código fundamenta el establecimiento de una compensación, precisamente, en el desequilibrio económico producido a uno de los cónyuges por la situación de crisis matrimonial ${ }^{397}$. Tal es el mandato del artículo 97 del CC por el que, en defecto de acuerdo, el juez deberá valorar si se produce un desequilibrio económico

\footnotetext{
${ }^{396}$ Estos acuerdos están sometidos a las limitaciones a la autonomía de la libertad que establece el propio Código, es decir, que no podrán incluir cláusulas contrarias a la Ley, la moral o el orden público. Lo que incluye la prohibición de que tal pacto se establezca como condición para el inicio o mantenimiento de las relaciones.

${ }^{397}$ En este sentido, entre otros, LASARTE ÁLVAREZ, C. y VALPUESTA FERNÁNDEZ, M. ${ }^{a}$ R.: "Consideraciones sobre la pensión dimanante de la separación o el divorcio en la Reforma del Derecho de Familia: matrimonio, separación, régimen económico matrimonial, filiación y patria potestad", en Jornadas Hispalenses sobre la reforma del Derecho de Familia. Imprenta sevillana, Sevilla (1982), pág. 75.
} 
derivado de la separación o el divorcio, así como, tras la ponderación de las circunstancias personales de los cónyuges, detalladas en el mencionado artículo, la cuantía de la misma.

Ahora bien, el citado artículo 97 establece la solución para resolver las situaciones de desequilibrio que produce a uno de los "cónyuges" la situación de ruptura matrimonial. Es decir, que tal derecho a la compensación deriva de la preexistencia del matrimonio. De modo que tal derecho no nace entre los miembros de la pareja more uxorio, al no existir el vínculo matrimonial.

Es precisamente esta ausencia de vínculo matrimonial lo que determina la inaplicabilidad de las normas previstas para las situaciones de crisis matrimonial a las uniones extramatrimoniales con carácter general ${ }^{398}$. Y ello porque habiendo renunciado los convivientes a que se apliquen las reglas del matrimonio a su relación durante la vigencia de la misma, no parece lógico reclamar la aplicación de esas reglas al momento de la ruptura de la relación. Es decir, que del mismo modo que la pareja comenzó la convivencia libremente también la ruptura debe ser libre ${ }^{399}$.

Pese a ello, las importantes consecuencias que se pueden producir en determinados supuestos de ruptura de la unión extramatrimonial no deben quedar desatendidas. La relevancia de la cuestión se ha dejado sentir en la actuación de los Tribunales. También ha incidido en el campo legislativo, muy puntualmente en lo que hace referencia a la legislación estatal, y con mayor intensidad, aunque condicionada por sus respectivas posibilidades legislativas, en la legislación autonómica, que ha realizado un destacado esfuerzo por acomodar el ordenamiento jurídico a la realidad social. Algunas CCAA acuden a la normativa del Estado para enfrentar este problema, mientras que otras comunidades con Derecho foral propio establecen la posible compensación que pudiera tener que abonar uno de los convivientes al otro a causa del desequilibrio económico producido por la ruptura de la convivencia.

\footnotetext{
${ }^{398}$ Y ello, porque, como hemos visto, en lo relativo a los hijos habidos en la relación more uxorio sí que resultan de aplicación las normas que regulan las situaciones de crisis matrimonial por aplicación del principio constitucional de la igualdad de los hijos con independencia de su filiación.

${ }^{399}$ La jurisprudencia del TS sobre el tema se sintetiza en que las uniones more uxorio, cuando reúnen determinados requisitos, como la constitución voluntaria, estabilidad, permanencia en el tiempo y con una apariencia pública de comunidad de vida similar a la matrimonial, han merecido el reconocimiento como una modalidad de familia, aunque sin equivalencia con el matrimonio, no siendo posible trasponer a esta uniones el régimen jurídico matrimonial, salvo en algunos aspectos muy concretos. Pero la conciencia de los miembros de la unión de operar fuera del régimen jurídico del matrimonio no es razón suficiente para que se desatiendan las importantes consecuencias que se pueden producir en determinados supuestos, entre los que se encuentra el de la extinción de la convivencia [STS 17-6-2003 (RJ 2003/4605)].
} 


\section{b) Las soluciones en las CCAA con Derecho Civil propio}

Veamos algunas de las leyes autonómicas que regulan, con mayor o menor amplitud, una pensión compensatoria en las uniones de hecho. Como venimos diciendo, las comunidades con Derecho civil propio cuentan con un mayor margen de libertad al respecto.

\section{b).1. Cataluña}

El Capítulo IV de la Ley 25/2010, de 29 de julio, del libro segundo del CC de Cataluña, relativo a la persona y la familia, regula "La convivencia estable en pareja". En el mencionado Capítulo se enmarca el artículo 234-9 titulado "compensación económica por razón de trabajo" por el que si un conviviente ha trabajado para la casa sustancialmente más que el otro, o ha trabajado para el otro sin retribución o con una retribución insuficiente, tiene derecho a una compensación económica por esta dedicación, siempre y cuando en el momento del cese de la convivencia el otro haya obtenido un incremento patrimonial superior. Ello a falta de pacto expreso previo que regule los efectos del cese de la pareja. De este modo, en Cataluña, la pareja de hecho, en cuanto a la pensión compensatoria, se iguala al matrimonio ${ }^{400}$.

\section{b).2. Aragón}

En los supuestos de ruptura de la pareja de hecho, cuando la convivencia haya supuesto una situación de desigualdad patrimonial entre los convivientes que implique un enriquecimiento injusto de uno de ellos, se puede exigir una compensación económica en los casos en que el conviviente perjudicado ha contribuido, ya sea económicamente o con su trabajo, a la conservación o mejora de los bienes comunes o privativos del otro miembro de la pareja, y también cuando el conviviente perjudicado económicamente se ha dedicado al hogar o a los hijos comunes o del otro conviviente. En tales casos, el conviviente perjudicado puede exigir del otro una pensión compensatoria, tanto si fuera necesaria para su sustento como cuando el cuidado de los hijos comunes le impida o dificulte la realización de actividades laborales. En este último caso, la pensión se extinguirá cuando finalice, por cualquier causa, el cuidado de los hijos menores o bien estos alcancen la mayoría de edad o se emancipan.

\footnotetext{
${ }^{400}$ DE LA ROSA YANES, P. M. ; y TRUJILLO GIL, D. A.: "Pensión compensatoria, pensión de viudedad y vivienda, en las uniones de hecho", en La Ley Derecho de Familia, n. 19 (tercer trimestre 2018), pág. 3.
} 


\section{b).3. Navarra}

La derogada Ley Foral 6/2000, de 3 de julio, de igualdad jurídica de las parejas de hecho, declarada inconstitucional por la STC 93/2013, de 23 de abril, regulaba el derecho a una pensión periódica y compensación económica en el artículo 6, declarado nulo en la mencionada sentencia del Constitucional.

En la vigente regulación, contenida en la Ley Foral 21/2019, de 4 de abril, de Modificación y Actualización de la Compilación del Derecho Civil Foral de Navarra o Fuero Nuevo, se establece la necesidad de que los convivientes manifiesten su voluntad de constituirse en pareja estable mediante documento público, pudiendo formular pactos en previsión del cese en la escritura pública de constitución, siendo en todo caso susceptibles de compensación tanto el trabajo realizado para la familia como el desarrollado por uno de los convivientes en las actividades empresariales o profesionales del otro miembro de la pareja ${ }^{401}$.

\section{b).4. País Vasco}

El apartado 2..$^{\circ}$ del artículo 6 de la Ley 2/2003, de 7 de mayo, reguladora de las parejas de hecho en el País Vasco ${ }^{402}$ señala que, en defecto de pacto expreso, los miembros de la pareja pueden

\footnotetext{
${ }^{401}$ Así lo establece la Ley 112 de la Ley Foral 19/2019, de 4 de abril, de Modificación y Actualización de la Compilación del Derecho Civil Foral de Navarra, que se remite a lo dispuesto para el caso de separación matrimonial con régimen de separación de bienes, estableciendo en la Ley 101 que "5. Cuando el trabajo realizado para la familia por un cónyuge de forma personal y no retribuida determine un exceso en la contribución a los gastos del matrimonio que proporcionalmente le corresponda en relación con lo aportado económica y personalmente por el otro, deberá ser compensado en el momento de la extinción del régimen. Para determinar la cuantía de la compensación se tendrá en cuenta, dentro del nivel económico y circunstancias de la familia, los años de matrimonio, la duración e intensidad de la dedicación y la atención personal a los hijos y a otros miembros de la familia que convivan con los cónyuges. 6 . Además, cuando uno de los cónyuges hubiera realizado trabajo en las actividades empresariales o profesionales del otro, tendrá derecho a una compensación proporcional al trabajo realizado, cuando el mismo no haya sido objeto de retribución o lo haya sido con retribución insuficiente, y ello, con independencia de los reembolsos debidos por excesos en el deber de contribución a las cargas del matrimonio".

${ }^{402} \mathrm{El}$ artículo 6.2 de la citada Ley, en relación con las denominadas cláusulas generales, señala que:

2. Los efectos del cese, señalándose: Una pensión periódica para el miembro de la pareja que la necesitara para atender adecuadamente su sustento en uno de los siguientes casos:

1. Si la unión hubiera supuesto disminución en la capacidad del solicitante de obtener ingresos.

2. Si el cuidado de los hijos e hijas comunes a su cargo le impidieran la realización de actividades laborales o las dificultara seriamente.

b) Una compensación económica a favor del miembro de la pareja que, sin retribución o con retribución insuficiente, haya trabajado para el hogar común o para el otro miembro, en el caso de que se haya generado por este motivo una situación de desigualdad entre el patrimonio de ambos que implique un enriquecimiento injusto.
} 
adherirse a las cláusulas establecidas con carácter general, las cuales establecen el derecho a una pensión periódica para el miembro de la pareja que quede en situación de necesitarla para su sustento cuando la convivencia le hubiera supuesto una disminución en sus posibilidades de obtener sus propios ingresos, o si el cuidado de los hijos comunes le ha impedido o difícultado la realización de actividades laborales. También establece el derecho a una compensación económica para el miembro de la pareja que haya trabajado sin retribución, o con una retribución insuficiente, para el hogar común o para el otro miembro de la pareja, si ello ha conllevado una situación de desigualdad patrimonial.

La adhesión a estos pactos tiene carácter voluntario, al precisar la norma que los miembros de la pareja "podrán adherirse". Esto deberá interpretarse a la luz de lo dispuesto por la Disposición adicional primera de la Ley que establece que todas las referencias hechas al matrimonio en las Normas legales y reglamentarias aprobadas en la Comunidad de Euskadi con anterioridad a la entrada en vigor de la Ley $2 / 2003$, se entenderán realizadas también a las parejas de hecho. Por lo que debe entenderse que lo referido a la pensión compensatoria resulta aplicable a las uniones de hecho.

\section{b).5. Islas Baleares}

La Ley 18/2001, de 19 de diciembre, de parejas estables de las Islas Baleares, en su artículo $9^{403}$ regula también una pensión compensatoria en las uniones de hecho acogidas a dicha Norma. La regulación balear sigue la misma línea de las regulaciones anteriores, al establecer la posibilidad de solicitar dicha pensión periódica siempre que la necesite para su sustento y en los supuestos de que la convivencia le haya representado una disminución de su capacidad para obtener ingresos, o que el cuidado de los hijos comunes le impida o dificulte la realización de actividades laborales.

\footnotetext{
403 1. Cuando la convivencia cese, cualquiera de los miembros puede reclamar al otro el pago de una pensión periódica, siempre que la necesite para atender adecuadamente su sustento y se encuentre en uno de los casos siguientes:

a) Que la convivencia haya disminuido la capacidad del solicitante para obtener ingresos.

b) Que el cuidado de los hijos comunes a su cargo impida o dificulte seriamente la realización de actividades laborales.

2. El conviviente perjudicado puede reclamar una compensación económica cuando la convivencia haya supuesto una situación de desigualdad patrimonial entre ambos miembros de la pareja que implique un enriquecimiento injusto y se haya dado uno de los siguientes supuestos:

a) Que el conviviente haya contribuido económicamente o con su trabajo a la adquisición, conservación o mejora de cualquiera de los bienes comunes o privativos del otro miembro de la pareja. familia.

b) Que el conviviente se haya dedicado con exclusividad o de forma principal a la realización de trabajo para la
} 
También se regula en las Islas Baleares la posibilidad de que el perjudicado pueda reclamar una compensación económica cuando la convivencia haya conducido a una desigualdad patrimonial, que implique un enriquecimiento injusto para el otro miembro de la pareja, en los casos en que el conviviente ha contribuido, ya sea económicamente o con su trabajo, a la adquisición o mejora de los bienes comunes o de los privativos del otro miembro de la pareja, o bien cuando el conviviente perjudicado se haya dedicado de modo exclusivo, o principalmente, al trabajo para la familia.

El conviviente perjudicado dispone de un año desde la extinción de la pareja para reclamar estos derechos. En relación con la "pensión periódica", concedida en supuestos de disminución de ingresos, se extingue el derecho en un plazo de tres años desde el primer pago de la pensión, la cual también podrá extinguirse por las causas generales de extinción del derecho de alimentos.

\section{c) Las soluciones en territorio común}

En el territorio común, y ante la falta de respuesta legislativa, el TS ha tenido que entrar a resolver distintos casos en los que se solicitaba una compensación por uno de los miembros de la pareja ante la inexistencia de acuerdos entre los convivientes sobre las consecuencias de la ruptura. A fin de dar respuesta a estas situaciones, el Alto Tribunal, ante la inexistencia de una ley que regule las situaciones producidas tras la ruptura de una convivencia more uxorio, en aplicación del principio iura novit curia, ha acudido a diversas fórmulas de integración acudiendo bien a la analogía o bien a los principios generales del Derecho, en especial a la doctrina del enriquecimiento injusto.

Será preciso el análisis de cada caso concreto para concluir si es posible o no conceder una pensión compensatoria a una de las partes. Parece claro que muchos de los problemas que surgen a este respecto se solucionarían si los miembros de la pareja, al amparo de la libertad de pactos del artículo 1255 del CC, establecieran acuerdos que rigieran su convivencia y las consecuencias de la extinción de esta ${ }^{404}$.

No obstante, y ante la inexistencia de pactos de convivencia que den respuesta a las situaciones derivadas de la ruptura de la convivencia, bien por decisión de ambos convivientes o por decisión exclusiva de uno de ellos, deberá atenderse al siguiente sistema de fuentes:

a) A la legislación de la comunidad autónoma.

\footnotetext{
${ }^{404}$ MARTÍNEZ GALLEGO, E. M.a: "Compensación patrimonial en caso de ruptura de parejas de hecho”, en Práctica de Derecho de daños: Revista de responsabilidad civil y seguros, n. 89 (2011), pág. 4.
} 
b) A los principios generales del Derecho u otras fórmulas de integración.

Teniendo en cuenta que el mero hecho de la ruptura, por sí mismo, no genera obligación de indemnizar. A sensu contrario, si la mera ruptura generase un deber de indemnización nos situaríamos ante una suerte de indisolubilidad de la unión de hecho, o más concretamente, ante una disolubilidad por precio. Tampoco será causa para que nazca el derecho a compensación el posible daño moral a uno de los convivientes derivado del hecho mismo de la ruptura, independientemente de los efectos de ansiedad o similares que tal ruptura le pudiera generar.

Otro aspecto que hemos venido remarcando es la imposibilidad de aplicar las reglas del matrimonio a unas uniones que, por definición, han decidido excluir la aplicación de las mismas al constituir su modo de convivencia. Pese a todo ello, no puede excluirse que, en los supuestos en que se produzca un desequilibrio patrimonial al momento de disolución de una unión de hecho, proceda la aplicación del derecho resarcitorio, es decir, que en determinadas circunstancias la ruptura de la convivencia de hecho puede derivar en una indemnización o en una compensación.

Dentro del ámbito del derecho resarcitorio y dada la ausencia de norma concreta que regule la cuestión actualmente, habrá que recurrir a la técnica de la analogía iuris, o sea, no partir para la aplicación análoga de una sola norma, ni proceder de lo particular a lo particular, sino que, partiendo de una serie o conjunto de normas, tratar de deducir de ellas un principio general del Derecho. En conclusión, que hay que entender la analogía iuris como un mecanismo de obtención y de aplicación de los principios generales del Derecho.

Todo ello lleva ineludiblemente a la aplicación, para resolver el problema fundamentado en la disolución de una unión de hecho, de los principios generales del Derecho, y a la figura del enriquecimiento injusto recogida en el art. 10.9 del CC, que siempre servirá como cláusula de cierre para resolver la cuestión ${ }^{405}$.

En esta necesidad de buscar medios para dar respuesta a estas situaciones de desequilibrio económico, y ante la inexistencia de pacto expreso o tácito de los convivientes, la jurisprudencia ha acudido a diversas medidas. Analizaremos las que han tenido mayor incidencia, en especial a partir de la fundamental STS de 12 de septiembre de 2005, que fijó la doctrina que viene siendo seguida en la materia desde entonces, si bien con base en algunas de las legislaciones autonómicas se han aplicado igualmente otras soluciones.

${ }^{405}$ MARTÍNEZ GALLEGO, E.M. ${ }^{\text {a: }}$ Ibid., pág. 8. 


\section{d) El enriquecimiento injusto como criterio de atribución}

Esta doctrina quedó consagrada en la citada STS de 12 de septiembre de 2005, seguida después por otras muchas ${ }^{406}$, de las cuales se pueden extraer algunas reglas sobre el modo de resolver estas situaciones. En concreto, señala la Sentencia referida que, la ausencia de una ley a nivel estatal, obliga a los jueces, en los supuestos de inexistencia de pacto entre los integrantes de la pareja, a tener que acudir a las soluciones de cierre del sistema ${ }^{407}$ y excluida la analogía con la institución del matrimonio, ello conduce a la aplicación de la figura del enriquecimiento injusto como modo final para resolver la cuestión, si bien se descarta su aplicación generalizada.

El recurso a la doctrina de prohibición del enriquecimiento injusto ha servido de base al TS tanto para fijar una pensión o una indemnización económica a favor de uno de los convivientes con cargo al otro, como para admitir la existencia de una comunidad de bienes, en relación con bienes adquiridos solo por uno de ellos ${ }^{408}$. Dado el carácter privado de los derechos que se ejercitan, y que no estamos ante una materia en que el Estado ejerza una función tuitiva sobre alguna de las partes, habrá que esperar a la concreta acción que ejercite la parte que se crea con derecho a ello y los tribunales, sujetos por el principio de congruencia ${ }^{409}$, se ajustan a las peticiones que las partes hayan ejercitado.

Los requisitos que viene exigiendo la jurisprudencia ${ }^{410}$ para aplicar la doctrina del enriquecimiento injusto son:

\footnotetext{
${ }^{406}$ Señalaremos, a modo de ejemplo del seguimiento de la doctrina fijada en la mencionada Sentencia, las sucesivas [STS 6-10-2006 (RJ 2006/6650) y STS 30-10-2008 (RJ 2009/404)] y, en especial, la dictada por el pleno de la Sala [STS 15-1-2018 (RJ 2018/76)].

${ }^{407}$ DE AMUNÁTEGUI RODRÍGUEZ, C.: Op. cit., (2018), pág. 49.

${ }^{408}$ LÓPEZ JARA, M.: "Efectos patrimoniales derivados de la ruptura de la pareja de hecho", en La Ley, Derecho de Familia, n. ${ }^{\circ} 19$ (tercer trimestre 2018), pág. 6.

${ }^{409}$ El principio de congruencia de la sentencia con la petición de las partes viene exigido por el artículo 218 de la Ley de Enjuiciamiento Civil: "1. Las sentencias deben ser claras, precisas y congruentes con las demandas y con las demás pretensiones de las partes, deducidas oportunamente en el pleito".

${ }^{410}$ Tales requisitos fueron establecidos del modo en que han venido siendo aplicados desde entonces en una ya lejana jurisprudencia que concretaba la existencia de enriquecimiento injusto: "cuando se ha producido un resultado por virtud del cual una persona se enriquece a expensas de otra que, correlativamente, se empobrece careciendo de justificación o de causa (base) que lo legitime, de tal manera que surge una obligación cuya prestación tiende a eliminar el beneficio del enriquecimiento indebido (...) se produce, no solo cuando hay un aumento del patrimonio, o la recepción de un desplazamiento patrimonial, sino también por una no disminución del patrimonio (...). El empobrecimiento no tiene porqué consistir siempre en el desprendimiento de valores patrimoniales, pues lo puede constituir la pérdida de expectativas y el abandono de la actividad en beneficio propio por la dedicación en beneficio de otro. La correlación entre ambos es la medida en que uno determina el otro, y la falta de causa no es otra cosa que la carencia de razón jurídica que fundamente la situación” [STS 17-6-2003 (RJ 2003/4605)].
} 
a) La existencia de un enriquecimiento por uno de los convivientes.

b) Un correlativo empobrecimiento del otro conviviente.

c) La existencia de una conexión causal entre el enriquecimiento de uno y el empobrecimiento del otro.

d) La ausencia de justificación del enriquecimiento.

De manera tal que la existencia de enriquecimiento injusto tiene lugar tanto por el aumento del patrimonio como por la disminución del mismo. En cuanto a la disminución patrimonial se produce no solamente por la pérdida de bienes patrimoniales, sino también por la denominada "pérdida de oportunidad", es decir, por la pérdida de expectativas o el abandono de la propia actividad por la dedicación al cuidado de la familia, o incluso a la empresa o trabajo del otro conviviente.

Esta es la postura que parece imponerse, como última solución, en los casos en que se produce un desequilibrio grave entre los miembros de la pareja al momento de la ruptura, cuando no existe pacto entre los exconvivientes. Algún autor ha criticado, con razón, que se acuda a esta doctrina para evitar la aplicación de la analogía con la pensión compensatoria entre cónyuges; y ello, porque la pensión compensatoria está pensada para el mañana, teniendo en cuenta una serie de circunstancias pasadas, presentes y previsibles de futuro que puedan determinar un desequilibrio próximo que habrá que paliar de alguna manera; mientras que la doctrina del enriquecimiento injusto mira siempre hacia el pasado intentando compensar desplazamientos patrimoniales injustificables que han tenido lugar por determinada situación o realidad, en este caso la convivencia de pareja ${ }^{411}$.

Por lo demás, no procederá la aplicación de la doctrina del enriquecimiento injusto en todos los casos, sino que habrá que entrar a valorar el comportamiento del conviviente que reclama tal compensación, de manera que se podría considerar que no procede su aplicación cuando la razón única en que se fundamente sea la dedicación en exclusiva a la atención de los hijos o el hogar, por cuanto esto no comporta empobrecimiento ni enriquecimiento, toda vez que se trata de comportamientos voluntarios, libremente asumidos por los integrantes de la pareja. Si bien, cuando esta situación conlleva dificultades para el acceso a un empleo a consecuencia de la dedicación a la casa, la conclusión podría ser otra. Es decir, que la dedicación al hogar no es, por sí misma, causa

${ }^{411}$ DE AMUNÁTEGUI RODRÍGUEZ, C.: Op. cit., (2018), pág. 61. 
bastante para apreciar el enriquecimiento injusto, pero si tal dedicación impide o dificulta de manera importante el acceso al trabajo remunerado, entonces podría ser justificativa de un enriquecimiento injustificado del otro miembro de la pareja.

En cambio, resulta más probable la aplicación de esta doctrina en aquellos supuestos en que se produce una pérdida de expectativas laborales o el abandono de una actividad propia en beneficio del demandado. También en supuestos de desatención del propio patrimonio, como podría ser dedicar ingresos propios a mejoras en los bienes del otro.

En definitiva, resulta complejo valorar la existencia de comportamientos voluntarios y enteramente libres en los que las parejas asumen un proceder que, en ocasiones, podría calificarse de excesivamente generoso, mientras que en otros casos podría calificarse de cercano a la mínima diligencia. Todo ello dificulta la valoración de las actuaciones de los miembros de la pareja, a la vez que también resulta extraordinariamente complejo cuantificar las reclamaciones, las cuales requieren de valoraciones económicas concretas y probadas 412

\section{e) Compensación económica por dedicación a la familia}

La dedicación a la familia ha sido utilizada en distintas ocasiones como base para justificar el derecho a una compensación por razón de trabajo. Supuesto este que es recogido, como hemos señalado, en algunas de las Normas autonómicas, y en ese sentido se ha pronunciado también alguna $\mathrm{AP}^{413}$ que considera procedente fijar una compensación cuando, al cesar la convivencia, la posibilidad de obtención de ingresos por uno de los convivientes queda disminuida a causa de su dedicación a la casa y a la familia ${ }^{414}$.

De manera que, si se acredita que el conviviente solicitante no trabajaba con anterioridad a la convivencia extramatrimonial, se concluirá que no ha sufrido disminución alguna en su capacidad para generar ingresos, de modo que no procederá, en tales supuestos, ningún tipo de

\footnotetext{
412 DE AMUNÁTEGUI RODRÍGUEZ, C.: Op. cit., (2018), págs. 331-332.

${ }^{413}$ Citaremos en este sentido la SAP de Tarragona, en un procedimiento en el que la actora solicitaba una compensación económica por haberse dedicado a las labores del hogar durante el período de convivencia, sin haber obtenido retribución alguna, y habiendo renunciado a su trabajo a la vez que habría perdido la posibilidad de promoción laboral, habiendo sido estimada la pretensión [SAP Tarragona 23-1-2009 (JUR 2009/174028)].

${ }^{414}$ En este sentido se pronuncia, por ejemplo, la Sentencia del Tribunal Superior de Justicia de Cataluña [STSJC 4-102004 (RJ 2005/288)].
} 
compensación por el cese de la convivencia de la pareja ${ }^{415}$. Sin embargo, se ha considerado que la dedicación al cuidado y atención de la familia, contribuyendo con ello de manera notoria a mejorar la calidad de vida del otro conviviente y del hijo de este, constituye una contribución al levantamiento de las cargas de la familia que formaban, lo que dará lugar a la fijación de una compensación por razón de trabajo, al entenderse que la consecuencia de dicho trabajo y dedicación tiene como consecuencia un enriquecimiento injusto del otro conviviente ${ }^{416}$, lo que debe conllevar una compensación económica para el conviviente que ha sacrificado su desarrollo personal para el bienestar del conjunto familiar.

En los casos de las CCAA que han legislado al respecto se establecen como requisitos para que nazca el derecho a una compensación por razón de trabajo los siguientes: 1) la realización de un trabajo para el hogar familiar más intenso y relevante por parte de uno de los miembros de la pareja, o el trabajo para el otro con nula o escasa retribución; y $2^{\circ}$ ) que al momento de la extinción de la convivencia se hayan producido un incremento patrimonial para el otro. Debiendo concurrir $\operatorname{ambos}^{417}$.

Esto es porque la compensación económica por el trabajo surge para "equilibrar las desigualdades patrimoniales que pudieran resultar al final de la convivencia matrimonial o de la pareja estable, activándose siempre que uno de los convivientes se hubiere dedicado, aunque no fuere de manera exclusiva, al cuidado de la familia y del hogar o, en su caso, a colaborar desinteresadamente, sin remuneración o con una remuneración insuficiente, en el negocio lucrativo del otro, de manera que solo este hubiera podido obtener un patrimonio exclusivamente privativo por el juego del régimen económico matrimonial de la separación de bienes (...) o, en el caso de las uniones de pareja, por el propio de la titularidad privativa de los bienes de que se trate (...), ya que, habiendo contribuido ambos al levantamiento de las cargas del matrimonio o de la pareja

\footnotetext{
${ }^{415}$ En este sentido [SAP de Barcelona 6-2-2009 (AC 2009/1192)].

${ }^{416}$ En este sentido se manifiestan diversas Audiencias [SAP de Illes Baleares 1-6-2007 (JUR 2007/17661), o SAP de A Coruña 26-9-2008 (JUR 2009/40170)], esta última en un caso en el que, además, el demandado había impedido a su compañera el desarrollo de ciertos trabajos durante el período de convivencia, lo que llevó a la Audiencia a concluir que todo ello "supone una pérdida de oportunidades de continuar en el mercado laboral, con las consiguientes repercusiones. Ahora se ve obligada a reincorporarse, cuando ya tiene 49 años; y además ha perdido la posibilidad de obtener cotizaciones a la Seguridad Social, con lo afectación en cuanto a los futuros derechos pasivos, subsidios de desempleo, etcétera. (Por todo ello), sí se ha producido un enriquecimiento injusto que justifica la indemnización solicitada".

${ }^{417} \mathrm{Se}$ fundamenta tal exigencia en que el desequilibrio producido en las economías de los miembros de la pareja deriva de que uno de los convivientes desarrolla tareas que no generan excedentes y el otro realiza tareas que sí los generan [STSJC 23-1-2017 (RJ 2017/2079)].
} 
según sus posibilidades (...), nada justificaba que uno se hubiere enriquecido y el otro, empobrecido" $" 418$.

En el caso de Cataluña, cuya legislación contempla esta compensación económica acreditado el aumento patrimonial por parte de uno de los convivientes, para determinar la cuantía de la compensación económica se tendrá en cuenta la duración e intensidad de la dedicación, en particular los años de convivencia y si el reclamante se ha ocupado del cuidado y educación de los hijos o de la atención a otros miembros de la familia que conviviesen con la pareja. Existiendo un límite fijado legalmente en una cuarta parte de la diferencia entre los incrementos de los patrimonios de los convivientes. No obstante, esta cuantía puede aumentarse por el juez a petición del acreedor si demuestra que su contribución ha sido notablemente superior y puede reclamarse si concurren determinadas circunstancias, incluso si la pareja se extingue por causa de muerte del que obtuvo el incremento patrimonial ${ }^{419}$.

\section{f) Compensación por daños}

Las normas de la responsabilidad civil extracontractual del artículo 1902 del CC se han convertido en una de las alternativas posibles para reclamar una indemnización por los perjuicios causados, ya sea durante la convivencia o derivados de la situación de abandono derivada del cese de la convivencia, en especial cuando tal cese viene impuesto de manera unilateral por uno de los miembros de la pareja.

En ciertos casos, tanto la doctrina ${ }^{420}$ como la jurisprudencia han aceptado la aplicación del artículo 1902 y ss. del CC siempre que se pruebe el comportamiento doloso o culpable de uno de los miembros de la pareja. En ningún caso puede considerarse como suficiente el mero hecho de la decisión unilateral del cese de la convivencia. Ello porque la convivencia extramatrimonial tiene como base la libertad individual de los miembros de la pareja que, de manera libre, voluntaria y consciente optan por ese modo de relación para constituir una familia, ajena a la regulación de derechos y obligaciones establecidas por el legislador estatal. Y es precisamente esa libertad de constitución de la pareja lo que permitirá a los convivientes su disolución, sin necesidad de expresar causas o respetar formas para determinar el cese da esa convivencia. En consecuencia, la adopción

\footnotetext{
${ }^{418}$ Entre otras muchas, [STSJC 11-4-2016 (RJ 2016/3646)].

${ }^{419}$ LÓPEZ JARA, M.: Op. cit., págs. 10-11.

${ }^{420}$ MESA MARRERO, C.: Op. cit., pág. 221; ESTRADA ALONSO, E.: Op. cit., pág. 237; entre otros.
} 
libre de tal decisión no puede ser considerada, por sí misma, como un comportamiento doloso o culposo generador de una obligación indemnizatoria, lo que descarta la aplicación generalizada de los artículos relativos a la responsabilidad civil extracontractual a los supuestos de ruptura de la unión de hecho.

Los casos en que la jurisprudencia ha entendido que se genera una responsabilidad civil en los supuestos de ruptura de uniones de hecho son, exclusivamente, aquellos en los que se ha probado la concurrencia de una conducta culpable o dolosa por parte de uno de los convivientes.

Siendo, pues, la conducta dolosa o culpable de uno de los convivientes el requisito fundamental para que la reclamación de la indemnización prospere, no será, sin embargo, suficiente que el conviviente sea responsable del hecho ilícito, sino que además será necesario que tal ilícito sea determinante del inicio de la convivencia, sin cuya concurrencia nunca se hubiese iniciado la convivencia more uxorio, se trataría de supuestos en los que ha mediado engaño, promesa de matrimonio, seducción, intimidación, abuso de autoridad u otras causas similares ${ }^{421}$.

Cabe preguntarse si para el ejercicio de la acción de indemnización es imprescindible que se haya producido el cese de la convivencia, o si solamente es necesario que el perjudicado conozca el acto ilícito que motivó la convivencia. Pese a la opinión de algún autor que sostiene que nada impide que pueda exigirse la responsabilidad con anterioridad a la ruptura de la relación ${ }^{422}$, también se ha considerado la imposibilidad de la convivencia presentando una reclamación de estas características $^{423}$. Nosotros entendemos que, desde una perspectiva práctica, es evidente que resultará harto complicado presentar una reclamación imputando un ilícito, incluso penal a la pareja, y mantener la relación de convivencia. Pero, desde una perspectiva puramente jurídica, entendemos que nada impediría tal eventualidad, pese a lo dificultoso de la situación. No obstante, en situaciones de violencia sobre la mujer, no resultan tan extrañas como en principio pudieran parecer. Situaciones en que se presenta la solicitud de una indemnización y se mantiene la relación de convivencia. Si bien en tales supuestos la continuación de la convivencia acostumbra a ir acompañada de un desistimiento de la demanda.

\footnotetext{
${ }^{421}$ MESA MARRERO, C.: Op. cit., pág. 217 y ss.

${ }^{422}$ RODRÍGUEZ GUITIÁN, A. M. a: "Función de la responsabilidad civil en determinadas relaciones de convivencia", en Revista Aranzadi de Derecho patrimonial, nº10 (2003), pág. 86.

${ }^{423}$ VARGAS ARAVENA, D.: Op. cit., págs. 13-21.
} 


\section{g) El principio de protección al conviviente periudicado por la ruptura como}

\section{fundamento de la indemnización}

Entre las distintas soluciones a las que ha recurrido la jurisprudencia ${ }^{424}$ ante la ausencia de una normativa que regule las consecuencias patrimoniales en los casos de ruptura de las uniones de hecho, merece destacarse el llamado "principio de protección al conviviente perjudicado" 425 . Reconociendo que, aunque no cabe la aplicación de las normas del matrimonio a las uniones de hecho, ello no implica que el Derecho pueda permanecer ajeno a un fenómeno social de evidente repercusión. Así se elabora este principio general del Derecho, que deriva de normas constitucionales tales como el derecho al libre desarrollo de la personalidad, el derecho a la dignidad de la persona ${ }^{426}$, el principio de igualdad ante la $\operatorname{Ley}^{427}$ y el principio de protección a la familia ${ }^{428}$. Deriva, igualmente, este principio de protección al conviviente perjudicado, de normas de Derecho privado como el artículo 96 del CC $^{429}$, o de otras normas como la Ley 29/1994, de 24 de noviembre, de Arrendamiento Urbanos, cuyos artículos 12 y 16 reconocen expresamente la protección al conviviente more uxorio, como hemos visto. También se fundamenta este principio general del derecho en la jurisprudencia del TC y del TS, pues en todas sus sentencias al respecto han reconocido derechos al conviviente perjudicado.

\footnotetext{
${ }^{424}$ Entre otras soluciones aplicadas tendríamos el principio de la buena fe y la sanción del abuso del derecho [STS 136-1986 (RJ 1986/3549)]. Se ha recurrido también a la aplicación análoga de la pensión compensatoria [STS 5-7-2001 (RJ 2001/4993) y STS 16-7-2002 RJ 2002/6246)]; además de principios ya citados, como la indemnización de daños y perjuicios, [STS 16-12-1996 (RJ 1996/9020)]; y, de manera reiterada ,la entronizada doctrina del enriquecimiento injusto [STS 12-9-2005 (RJ 2005/7148)], la cual ya había sido ampliamente invocada anteriormente [STS 11-12-1992 (RJ 1992/9733), STS 17-6-2003 (RJ 2003/4605) y STS 23-11-2004 (RJ 2004/7385)].

${ }^{425}$ Este principio fue aplicado por primera vez en un litigio en que se planteaba la atribución del uso de la vivienda familiar tras el cese de la convivencia. Para llegar a esta conclusión el Alto Tribunal recurre a la analogía iuris, de modo que partiendo de un conjunto de normas obtiene un principio general del derecho para aplicarlo a un supuesto no regulado legalmente [STS 10-3-1998 (RJ 1998/1272)].

${ }^{426}$ Tanto el derecho a la dignidad de la persona como el libre desarrollo de la personalidad son recogidos en el artículo 10 de la CE.

${ }^{427}$ La igualdad ante la Ley es recogida en el artículo 14 de la CE.

${ }^{428} \mathrm{El}$ artículo 39 de la CE ordena a los poderes públicos la protección social, económica y jurídica de la familia.

${ }^{429} \mathrm{El}$ artículo $96 \mathrm{del} \mathrm{CC}$, como hemos visto, establece los criterios de atribución del uso de la vivienda familiar en los casos de crisis matrimonial que, en el caso de existencia de hijos menores o dependientes, extiende sus efectos a las familias de convivencia extramatrimonial.
} 
A este principio de protección al conviviente perjudicado por la ruptura han aludido diversas sentencias del TS como la de 27 de marzo de $2001^{430}$, y la de 17 de enero de $2003^{431}$, en las que ha resuelto el Alto Tribunal que, tras una larga convivencia, no puede quedar una de las partes en situación absolutamente desfavorable respecto de la otra. Entendiendo que, aunque los bienes hayan sido adquiridos formalmente por uno solo de ellos, el otro ha colaborado en su adquisición con su atención personal y colaboración en el trabajo fuera o dentro de la casa. En suma, no se trata de imponer una normativa a una situación de hecho, sino de evitar el perjuicio injusto a la parte más débil de una relación.

Esta jurisprudencia del TS lo que viene a poner de relieve es que la inexistencia de una normativa específica en relación con las uniones de hecho no significa una desprotección para el conviviente que resulta perjudicado por una larga convivencia, a la que ha dedicado trabajo y esfuerzo y que finaliza en una ruptura unilateral.

En definitiva, se trata de un principio que protege al conviviente perjudicado en una relación de convivencia, normalmente prolongada, en la que habitualmente ha contribuido con su esfuerzo, trabajo y colaboración y que, a su finalización, queda en una situación de desamparo o claramente peor que la del otro conviviente.

\footnotetext{
${ }^{430}$ En este caso se solicitaba, entre otros pronunciamientos, que el Tribunal fijase una indemnización por los perjuicios derivados de la larga convivencia, la dedicación de la demandante a la familia durante un largo período y por el desequilibrio económico provocado por la ruptura entre los miembros de la pareja. Tras el paso por las instancias inferiores, el TS condenó al demandado a indemnizar a su pareja por la ruptura de la convivencia extramatrimonial.

${ }^{431}$ En el caso se solicitaba la declaración de la existencia de una comunidad de bienes durante la convivencia more uxorio, añadiendo una cadena de peticiones subsidiarias, tales como que, en defecto de la anterior, se declarase la existencia de un régimen de participación de ganancias; $\mathrm{y}$, en defecto de los anteriores, que se declarase que existía una sociedad civil universal de ganancias; $y$, de modo igualmente subsidiario, que había existido una sociedad de gananciales. El TS condenó al demandado a abonar a su compañera un tercio del valor de los bienes obtenidos durante la convivencia.
} 



\section{LA REGULACIÓN DE LAS PAREJAS DE HECHO EN NUESTRO ENTORNO}

\section{A) LAS PAREJAS DE HECHO EN LA UE TRAS LA ENTRADA EN VIGOR DEL REGLAMENTO (UE)}

\section{6/1104, DEL CONSEJO, DE 24 DE JUNIO DE 2016.}

Entre los nuevos modelos de familia surgidos en la segunda mitad del siglo pasado destaca el de convivencia en pareja more uxorio la cual, fruto de su expansión, ha finalizado por encontrar un reconocimiento normativo en buen número de países de la UE. Al efecto, en estos países se han abierto diferentes modelos de registro público, reconociendo distintos derechos a los miembros de la pareja de convivientes.

Dentro del espacio de la UE no es extraña la existencia de parejas de hecho cuyos componentes tienen distinta nacionalidad y que, fruto de la mencionada convivencia more uxorio, adquieren bienes en el lugar en que residen o en cualquier otro de los estados miembros de la UE.

No solo la diferente nacionalidad de los miembros de la pareja, sino otros aspectos tales como la posesión de bienes en distintos estados miembros de la UE vienen a determinar el carácter internacional de la situación creada en supuestos como la disolución de la pareja, ya sea por ruptura de la convivencia decidida por uno o ambos miembros, o bien sea por el fallecimiento de cualquiera de sus componentes en un Estado distinto al de su nacionalidad. Tales situaciones conllevan la producción de una serie de efectos jurídicos, tanto de carácter personal como patrimonial, para los miembros de esa unidad familiar.

Ante tal situación, y dada la inexistencia de normas de Derecho Internacional Privado para este nuevo tipo de familias, durante algún tiempo se trató de dar solución por vía de la aplicación analógica de las Normas que regulan el matrimonio; no obstante, tal solución no resulta de aplicación a la luz de la reiterada doctrina del TC que establece, con absoluta rotundidad, que no es posible la aplicación analógica de las Normas del matrimonio a las parejas de hecho ${ }^{432}$. Pese a ello, la gestión cotidiana de estos bienes plantea problemas específicos.

Con la ingente movilidad actual de los ciudadanos europeos, este tipo de uniones se ha incrementado de manera importante, de donde surge la necesidad de una regulación europea en relación a sus efectos personales y, sobre todo, patrimoniales. De tal manera que "la armonización

\footnotetext{
${ }^{432} \mathrm{El} \mathrm{TC}$ viene desarrollando esta doctrina desde los años noventa del pasado siglo, a título de ejemplo citaremos la Sentencia del citado TC número 194/2014, de 1 de diciembre de 2014, publicada en el BOE n. ${ }^{\circ} 11$ de 13 de enero de 2015 .
} 
y la codificación del Derecho internacional privado en la UE deben contemplarse en el marco de una política tendente a la creación de un auténtico espacio de justicia. La sustitución del Derecho internacional privado nacional por los instrumentos de la UE ya se está manifestando en las temáticas cubiertas por numerosos Reglamentos de la UE. Hasta hace poco en el área del Derecho de familia la 'sustitución' del Derecho internacional privado nacional por una reglamentación procedentes de la UE no era muy importante»" ${ }^{\prime 33}$. Tal situación comenzó a revertirse con la entrada en vigor del Tratado de Ámsterdam de 2 de octubre de 1997, a partir de la cual comenzaron a dictarse distintos reglamentos en el ámbito de las relaciones familiares de carácter transnacional ${ }^{434}$; sin embargo, la UE no se había pronunciado de manera clara respecto a las parejas de hecho hasta la publicación del Reglamento (UE) 216/1104, del Consejo, de 24 de junio de 2016.

Pese a las expectativas sobre la posibilidad de que la norma europea estableciese una cierta unificación en la legislación sobre la materia, la realidad ha sido que dicho Reglamento se ha limitado a aportar soluciones homogéneas en materia de conflictos de leyes y de jurisdicciones.

\section{Limitaciones en el ámbito regulado por el Reglamento Europeo}

Lo cierto es que la situación previa era muy dispar según los diferentes países que componen la Unión, lo cual complicaba cualquier intento de establecer una norma básica común en todos los Estados miembros. Como precisa el propio Reglamento se trata de garantizar la seguridad jurídica de las parejas no casadas en lo que respecta en lo que respecta a su patrimonio ${ }^{435}$, si bien teniendo en cuenta que dicha regulación afectará, solamente, a las uniones registradas, sin que dicho reconocimiento se extienda a los supuestos de las parejas convivenciales por vía de hecho, pero cuya unión no consta inscrita en ningún registro público.

El citado reglamento no regula aspectos del Derecho Civil distintos de los efectos patrimoniales de las uniones registradas. De manera que el Reglamento europeo no resultará

\footnotetext{
${ }^{433}$ FERNÁNDEZ ROZAS, J. C.: "Un hito más en la construcción del Derecho internacional privado de la UE: regímenes económicos matrimoniales y efectos patrimoniales de las uniones registradas", en Revista Iberoamericana de Derecho Internacional y de la Integración, $\mathrm{n}^{\circ} 5$ (noviembre 2016), pág. 1.

${ }^{434}$ En el Tratado de Ámsterdam se modifican el Tratado de la UE, los Tratados constitutivos de las Comunidades europeas y determinados actos conexos, fue firmado el 2 de octubre de 1997, siendo publicado en el Diario Oficial n. ${ }^{\circ}$ 340, de 10 de noviembre de 1997 y entró en vigor el día 1 de enero de 1999, el objetivo del Tratado era dotar a la UE de las capacidades necesarias para afrontar retos tales como la globalización u otros.

${ }^{435}$ Considerando 15 del Reglamento (UE) 2016/1104, del Consejo, de 24 de junio de 2016 que, entre las razones que llevan a la adopción del Reglamento está la de que "Considerando que para garantizar la seguridad jurídica de las parejas no casadas en lo que respecta a su patrimonio y ofrecerles cierta previsibilidad, es conveniente reunir en un único instrumento el conjunto de normas aplicables a los efectos patrimoniales de las uniones registradas".
} 
aplicable a aspectos de indudable importancia en el Derecho Civil como son cuestiones referentes a la capacidad jurídica de los miembros de la unión registrada ${ }^{436}$, o a cuestiones preliminares y que competen a los Derechos internos de los Estados miembros de la Unión, tales como son la propia existencia, validez o reconocimiento de la unión registrada. Otros aspectos del Derecho Civil que tampoco están comprendidos en el ámbito del mencionado Reglamento son los relativos a las obligaciones de alimentos entre los miembros de la unión registrada, por cuanto dicha obligación es objeto de una norma europea específica ${ }^{437}$, igual sucede con lo relativo a las cuestiones sucesorias, las cuales, también, tienen su propia regulación en el ámbito de la $\mathrm{UE}^{438}$. Otro aspecto excluido del ámbito de aplicación del Reglamento, es el relativo a la transmisión de los derechos de pensión de jubilación o invalidez, por tratarse de materia reservada a los Estados miembros; si bien, esta exclusión, debe ser interpretada de forma estricta, reservándose a la regulación comunitaria determinados aspectos concretos relativos a las pensiones, en especial cuando la misma ha sido suscrita con bienes comunes de ambos miembros de la unión registrada.

Pese a ello, el Reglamento europeo debe ser considerado un hito en materia de Derecho de familia, en especial al surgir en medio de regulaciones nacionales absolutamente dispares, por lo que, pese a las críticas por la brevedad de algunas de las soluciones ofrecidas, debe considerarse como un indudable avance hacia una armonización de los derechos de las parejas en los distintos Estados miembros. Aun así, a esta norma se le augura “... un futuro incierto, por varias razones. En primer lugar, la figura de las parejas registradas no es reconocida en todos los Estados miembros de la UE. En segundo lugar, en aquellos países en los que sí lo está, la regulación no es homogénea. $\mathrm{Y}$, en tercer lugar, por las dificultades para delimitar si su verdadera calificación es contractual o patrimonial o puramente matrimonial" ${ }^{\prime 39}$.

\footnotetext{
${ }^{436}$ Sin embargo, el considerando 20 del mismo, establece que sí que es de aplicación el Reglamento (UE) 2016/1104, del Consejo, de 24 de junio de 2016, en relación con las facultades y los derechos específicos de uno o de ambos miembros de la unión registrada con respecto a su patrimonio, bien entre sí, bien por lo que respecta a terceros.

${ }^{437}$ En concreto, el Reglamento (CE) 4/2009 del Consejo, de 18 de diciembre de 2008, relativo a la competencia, la ley aplicable, el reconocimiento y la ejecución de las resoluciones y la cooperación en materia de obligaciones de alimentos.

${ }^{438}$ Reglamento (UE) n ${ }^{\circ} 650 / 2012$ del Parlamento Europeo y del Consejo, de 4 de julio de 2012, relativo a la competencia, la ley aplicable, el reconocimiento y la ejecución de las resoluciones, a la aceptación y la ejecución de los documentos públicos en materia de sucesiones mortis causa y a la creación de un certificado sucesorio europeo.

${ }^{439}$ SOTO MOYA, M.: "El reglamento (UE) 2016/1104 sobre el régimen patrimonial de las parejas registradas: algunas cuestiones controvertidas de su puesta en funcionamiento en el sistema español de Derecho internacional privado", en Revista electrónica de Estudios internacionales, 2018[consulta online www.reei.org, fecha consulta 20/07/2020].
} 


\section{Características generales del Reglamento UE 2016/1104, del Consejo}

Reconocida la necesidad de armonizar el Derecho de familia europeo por la falta de uniformidad, se debe atender a la teoría de la separación entre la tutela interna y la tutela externa desarrollada por la doctrina italiana y tendente a la protección de este modelo de familia. Si la tutela externa consiste en la salvaguarda a los convivientes para garantizarles, constitucionalmente, un trato igualitario ${ }^{440}$, será la tutela interna la que “...hace referencia a las relaciones entre los componentes de la pareja, tanto en su aspecto personal como patrimonial. Parece que en este caso el legislador debe abstenerse de intervenir respetando la decisión de los sujetos de constituir una unión fuera del ordenamiento. En este ámbito no se impone la equiparación y deberán ser los sujetos quienes regulen sus propias relaciones atendiendo a la autonomía de la voluntad. Los principales problemas a resolver serán el sostenimiento de las cargas, la calificación de las atribuciones patrimoniales entre convivientes, la valoración de las prestaciones de trabajo entre los miembros de la pareja, etc." ${ }^{441}$.

Ante esta situación compleja y dispar existente en los ordenamientos de los países de la UE, se hace necesaria una regulación de los efectos patrimoniales de las parejas registradas para aportar mayor seguridad a los ciudadanos europeos. A lograr esta finalidad coadyuva el Reglamento 2016/1104, que regula la competencia, la ley aplicable, el reconocimiento y la ejecución de resoluciones en dicha materia. Se trata de que, por lo menos, las normas de Derecho internacional privado estén unificadas, lo que debe contribuir a evitar las actuaciones fraudulentas de los convivientes que, en caso de conflictos sobre los efectos patrimoniales derivados de su unión, acudan al tribunal cuya ley aplicable más les pueda beneficiar. Al haberse adoptado esta norma de derecho derivado, todos los Estados miembros que forman parte de la misma tendrán idénticas soluciones para resolver los conflictos de leyes y de jurisdicción, aunque siga existiendo un fraccionamiento jurídico en el Derecho material o sustantivo. Por lo tanto, conocer el adecuado funcionamiento de esta nueva regulación, se convierte en imprescindible para los operadores jurídicos que resuelvan controversias en el ámbito del Derecho de familia con repercusión transnacional ${ }^{442}$.

\footnotetext{
${ }^{440}$ ALBA FERRÉ, E. y MORENO BLESA, L.: "El Reglamento (UE) 2016/1104 en materia de efectos patrimoniales de las uniones registradas y su contribución a la armonización del Derecho de familia europeo", en La Ley Derecho de Familia, n. ${ }^{\circ} 19$ (tercer trimestre de 2018), pág. 5.

${ }^{441}$ DE AMUNÁTEGUI RODRÍGUEZ, C.: Uniones de Hecho. Una nueva visión después de la publicación de las leyes sobre parejas estables. Tirant lo Blanch, Valencia (2002), pág. 139.

${ }^{442}$ ALBA FERRÉ, E.; y MORENO BLESA, L.: Op. cit., pág. 6.
} 
Con tal objetivo se dictó el Reglamento europeo, estructurado con las siguientes características generales:

a) Es un texto atinente a aspectos de procedimiento, en concreto atiende a la competencia judicial entendida en sentido amplio, la ley aplicable, y el reconocimiento y ejecución de resoluciones en esta materia. En este sentido se podría encajar en la categoría de las normas de conflicto en derecho internacional privado, que en los últimos tiempos y en el ámbito de la UE van siendo cada vez más abundantes este tipo de reglamentos que desplazan a las normas internas de los Estados.

b) Es un texto con una extensión geográfica limitada, ya que solamente 18 países de los miembros de la UE se han adherido, por el momento, al citado Reglamento no resultando de aplicación en los Estados que todavía no se han adherido.

El propio Reglamento prevé los supuestos, como el español, en que no existe una única norma reguladora de las uniones de hecho para todo el Estado, sino que existen diferentes regulaciones internas en los distintos territorios. Es más, dada la inexistencia de una norma nacional reguladora de las uniones de hecho, no se han regulado, a nivel nacional, los supuestos de conflicto de leyes $^{443}$. En esta situación parece que la norma europea debe resultar inspiradora de la necesidad de dictar una norma a nivel estatal armonizadora de las distintas regulaciones autonómicas y resolviendo las situaciones de conflicto de leyes que pudieran producirse a nivel interno.

\section{3. Ámbito de aplicación del Reglamento}

\section{a) Ámbito de aplicación territorial}

Según señala el propio Reglamento en sus considerandos, entre diciembre de 2015 y febrero de 2016 una serie de Estados miembros de la UE, en concreto, Bélgica, Bulgaria, la República Checa, Grecia, Alemania, España, Francia, Croacia, Italia, Luxemburgo, Malta, los Países Bajos, Austria, Portugal, Eslovenia, Finlandia y Suecia se dirigieron a la Comisión expresando su deseo de establecer una cooperación reforzada entre sí en el ámbito de los regímenes económicos de las

\footnotetext{
${ }^{443}$ En España los supuestos de conflictos de leyes derivados de la existencia de distintas legislaciones civiles en el territorio nacionales se resuelven mediante la aplicación de Normas de Derecho Internacional Privado, por remisión del art. 16 del CC.
} 
parejas internacionales y, concretamente, de la competencia, la ley aplicable, el reconocimiento y la ejecución de resoluciones en materia de regímenes económicos matrimoniales, así como de la competencia, la ley aplicable, el reconocimiento y la ejecución de resoluciones en materia de efectos patrimoniales de las uniones registradas, y solicitaron a la Comisión que presentase una propuesta al Consejo a tal fin. Posteriormente, en marzo de 2016, Chipre manifestó su deseo de incorporarse al establecimiento de cooperación reforzada ${ }^{444}$. De manera que, actualmente, quedan fuera de este instrumento de colaboración seis Estados miembros que no quedan vinculados por este Reglamento: Eslovaquia, Hungría, Letonia, Lituania, Polonia y Rumanía.

\section{b) Ámbito de aplicación material}

El artículo 1 del Reglamento establece su ámbito material de aplicación al precisar que se aplicará, exclusivamente, a los efectos patrimoniales de las uniones registradas. Así, pues, restringe de modo definitivo desde el inicio el ámbito material a los efectos patrimoniales, y exigiendo el registro de las uniones convivenciales dejando, en consecuencia, fuera de la aplicación del Reglamento las uniones de hecho puramente fácticas, aplicando así la famosa máxima napoleónica de que "los concubinos ignoran la Ley, la Ley los ignora".

También, en el mismo artículo se establecen las exclusiones en la aplicación del Reglamento, dejando fuera del ámbito material de aplicación las cuestiones fiscales, aduaneras y administrativas.

Y, asimismo, quedan excluidas: a) la capacidad jurídica (debería decir capacidad de obrar) de los miembros de la pareja; b) la existencia, validez y reconocimiento de la unión registrada, pues es una materia de Derecho sustantivo, no internacional; c) las obligaciones de alimentos, que conflictualmente- se rigen por el Reglamento 4/2009, de 18 de diciembre de 2008, relativo a las obligaciones de alimentos; d) la sucesión hereditaria de uno de los miembros de la pareja, que queda sometida, desde el punto de vista conflictual, al Reglamento de Sucesiones Europeo $^{445}$; e) la Seguridad Social; f) el derecho de transmisión o ajuste entre la pareja, en caso de disolución de la misma, de las pensiones de jubilación o de invalidez devengadas durante la vigencia de la unión registrada que no hayan dado lugar a ingresos mientras haya existido; g) la naturaleza de los

\footnotetext{
${ }^{444}$ Así lo recoge el considerando 11 del Reglamento (UE) 2016/1104, del Consejo.

445 Reglamento UE n. ${ }^{\circ}$ 650/2012 del Parlamento Europeo y del Consejo, de 4 de julio de 2012, relativo a la competencia, la ley aplicable, el reconocimiento y la ejecución de las resoluciones, a la aceptación y la ejecución de los documentos públicos en materia de sucesiones mortis causa y a la creación de un certificado sucesorio europeo.
} 
derechos reales sobre un bien, y h) cualquier inscripción en un registro de derechos sobre bienes muebles o inmuebles, así como sus efectos (si un inmueble radica en España, cualquiera que sea la ley aplicable y la procedencia de la resolución, el derecho inmobiliario registral pertinente serán la ley y reglamento hipotecarios) $)^{446}$.

\section{c) Competencia judicial internacional}

El Reglamento establece, en sus artículos 4 y 5, los principios para determinar la competencia judicial en las situaciones de disolución de la unión registrada, sea mortis causa, regulada en el primero de los artículos mencionados confiriendo la competencia al Tribunal del Estado miembro que conoce de la sucesión del miembro de la pareja fallecido para que conozca, también, de los efectos patrimoniales de la unión registrada. En el artículo 5 se confiere la competencia para conocer de los aspectos patrimoniales de la pareja de hecho a los órganos jurisdiccionales del Estado miembro que conozca de la situación de crisis de la pareja.

En los artículos siguientes el Reglamento establece otras Normas competenciales, cuando no resulten de aplicación los criterios señalados en los artículos anteriores, incluyendo la posibilidad de que las partes opten, de común acuerdo, por el foro que determinen entre los que pudieran tener competencia por cualquiera de las diversas razones contempladas en el artículo 6 del Reglamento.

Se contemplan, igualmente otros supuestos, como la situación de competencias alternativas (artículo 9) o subsidiarias (artículo 10). Y, en el artículo 11 se prevé el denominado forum necessitatis, a fin de evitar supuestos de indefensión, por no existir órgano competente con arreglo a las normas de determinación de la competencia señaladas, en cuyo caso se determina que serán competentes, en casos excepcionales, los órganos jurisdiccionales de un Estado miembro para resolver sobre los efectos patrimoniales de una unión registrada.

Igualmente, se establecen una serie de Normas complementarias relativas a las reconvenciones (artículo 12), la limitación del procedimiento en los supuestos en que la herencia del causante incluya bienes situados en un tercer Estado (artículo 13), la determinación de la sustanciación de un asunto por un órgano jurisdiccional (artículo 14), la verificación de la

${ }^{446}$ GÓMEZ TABOADA, J.: “El nuevo Reglamento europeo de uniones registradas”, en Revista de La Notaría (marzo 2017), pág. 85. 
competencia (artículo 15) o de la admisibilidad (artículo 16), así como los supuestos de litispendencia (artículo 17) y de demandas conexas (artículo 18).

\section{d) La Lev aplicable}

El Reglamento no hace mención a la ley personal de los miembros de la pareja, o al domicilio de los mismos, sino que establece el principio de aplicación universal en el artículo 20, al establecer que "La Ley que se determine aplicable en virtud del presente Reglamento se aplicará aunque no sea la de un estado miembro", abriendo así la puerta a la aplicación de Normas de terceros Estados si son las que resultan de aplicación en atención a las reglas de competencia determinadas en el capítulo II del Reglamento.

Entre los criterios para determinar la Ley aplicable, el primero es el del respeto a la autonomía de la voluntad de los miembros de la pareja quienes pueden determinar cuál sea la norma de aplicación entre las de aquellos estados con los que los miembros de la pareja registrada, o la propia unión registrada, mantengan alguna conexión (artículo 22). Y siempre que la Ley elegida atribuya efectos patrimoniales a la institución de la unión registrada ${ }^{447}$. En cuanto a la validez se exigen requisitos de carácter formal y de carácter material a la prestación del consentimiento para someterse, de manera voluntaria, a una determinada Ley.

Para el supuesto de que no se haya alcanzado acuerdo sobre la Ley aplicable (artículo 26), la opción del Reglamento es por la Ley del lugar de creación de la unión registrada. Si bien, excepcionalmente, y a petición de parte, el juez podrá decidir que la norma aplicable sea la de otro Estado siempre que exista una vinculación con dicho estado por haber mantenido la pareja su última residencia habitual en el mismo, o bien, si los miembros de la pareja han basado sus relaciones patrimoniales en la Ley de dicho estado.

El artículo 27 del Reglamento establece los efectos patrimoniales que regulará la Ley aplicable, señalando entre otros, los siguientes:

a) La clasificación de los bienes de uno o ambos miembros de la unión registrada en diferentes categorías durante la vigencia de la unión registrada y después de la misma.

\footnotetext{
${ }^{447}$ En el caso español no resultará de aplicación el CC al desconocer la existencia de las parejas de hecho, por lo que remite a Normas de derecho material en el ámbito del Derecho internacional privado.
} 
b) La clasificación de bienes de una categoría a otra.

c) La responsabilidad de uno de los miembros de la unión registrada por las obligaciones y deudas de otro.

d) Los poderes, derechos y obligaciones de cualquiera de los miembros de la unión registrada o de ambos con respecto al patrimonio.

e) El reparto, la distribución o la liquidación del patrimonio en caso de disolución de la unión registrada.

f) Los efectos patrimoniales de la unión registrada sobre la relación jurídica entre uno de los miembros y un tercero.

g) La validez de las capitulaciones de la unión registrada.

Sin embargo, debe tenerse en cuenta la protección de los terceros, pues el fuero de la unión registrada tiene limitaciones, ya que “...la ley aplicable a los efectos patrimoniales de la unión registrada entre sus miembros no podrá invocarse frente a un tercero en un litigio entre el tercero y cualquiera de los miembros de la unión registrada o ambos, salvo que el tercero conociera o, actuando con la debida diligencia, debiera haber tenido conocimiento de dicha ley" 448 .

En relación con los derechos reales, se recoge en el artículo 29 una fórmula habitual en los Reglamentos europeos por la que cuando sea invocado un derecho real del que sea titular en virtud de la ley aplicable a los efectos patrimoniales de la unión registrada y la ley del estado miembro en el que se invoque el derecho no conozca el derecho real en cuestión, ese derecho deberá, en caso necesario y en la medida de lo posible, adaptarse al derecho equivalente más cercano del Derecho de ese estado, teniendo en cuenta los objetivos y los intereses que persiga el derecho real específico y los efectos asociados al mismo.

La aplicación de la ley rectora de los efectos patrimoniales de la unión registrada tiene como límites las leyes de policía y la excepción de orden público. En este sentido, el artículo 30 es el que se dedica a las leyes de policía de la ley del foro y destaca que las mismas que no se verán restringidas por las disposiciones de este Reglamento. El considerando 52 establece que el concepto de leyes de policía “...debe abarcar las normas de carácter imperativo, como las normas de protección del hogar familiar”. Estas disposiciones serán importantes en caso de que sea necesaria la protección de la vivienda habitual de las parejas registradas. Respecto a la excepción de orden

${ }^{448}$ Artículo 28.1 del Reglamento (UE) 2016/1104, del Consejo. 
público, el artículo 31 del Reglamento establece que "La aplicación de una disposición de la ley de cualquier Estado determinada por el presente Reglamento solo podrá ser rehusada si dicha aplicación es manifiestamente incompatible con el orden público (ordre public) del foro" ${ }^{449}$.

Para los supuestos como el español, con diferentes regímenes jurídicos, el artículo 34 establece que cualquier referencia a la Ley de ese Estado se entenderá como una referencia al régimen jurídico o al conjunto de normas determinado por las normas vigentes en tal Estado. Ahora bien, para los supuestos en que el conflicto de leyes se plantee, exclusivamente, entre las Normas de distintas unidades territoriales de un mismo Estado, no resultará de aplicación el Reglamento europeo.

\section{Reconocimiento, fuerza ejecutiva y ejecución de las resoluciones, documentos públicos y transacciones judiciales}

\section{a) Resoluciones}

El artículo 36 del Reglamento establece el reconocimiento de las Resoluciones dictadas en un Estado miembro, en el resto de los Estados miembros sin necesidad de procedimiento alguno, tal reconocimiento se basa en el principio de confianza mutua derivada de la integración de los Estados miembros en la UE.

Como consecuencia, el artículo 42 del Reglamento confiere fuerza ejecutiva a tales Resoluciones al establecer que "Las resoluciones dictadas en un Estado miembro y que sean ejecutorias en dicho Estado se ejecutarán en otro Estado miembro cuando, a instancia de cualquier parte interesada, se haya declarado que poseen allí fuerza ejecutiva de conformidad con el procedimiento previsto en los artículos 44 a 57’.

\section{b) Documentos públicos y transacciones judiciales}

En relación a los documentos públicos y a las transacciones judiciales, es el capítulo $\mathrm{V}$ el que resalta la importancia de la aceptación de dichos documentos (artículo 58) a efectos de su libre circulación, así como la fuerza ejecutiva de los mismos (artículo 59) o de las transacciones judiciales (artículo 60). La aceptación de los documentos públicos significa que los expedidos en

\footnotetext{
${ }^{449}$ ALBA FERRÉ, E., y MORENO BLESA, L.: Op. cit., págs. 14 y 15.
} 
un Estado miembro tendrán en otro distinto el mismo valor probatorio que en el de origen o el efecto más parecido posible, así como la misma presunción de autenticidad y fuerza ejecutiva ${ }^{450}$.

\section{Efectos de la entrada en vigor del nuevo Reglamento europeo en los aspectos}

\section{patrimoniales en las uniones de hecho}

Indudablemente, el Reglamento (UE) 2016/1104, del Consejo, de 24 de junio de 2016, por el que se establece una cooperación reforzada en el ámbito de la competencia, la ley aplicable, el reconocimiento y la ejecución de resoluciones en materia de efectos patrimoniales de las uniones registradas, con su entrada en vigor el 29 de enero de 2019, ha supuesto un indudable avance en el reconocimiento de este modelo de familia a nivel europeo, resolviendo cuestiones trascendentes en relación con la ley aplicable y en el ámbito del reconocimiento de las resoluciones y documentos públicos en los distintos Estados miembro en que resulta de aplicación.

En el haber del Reglamento debe incluirse, indudablemente, la homogeneización de las Normas aplicables en los casos de conflicto de leyes, así como en la determinación de la competencia de los órganos jurisdiccionales o, como hemos señalado, en el reconocimiento de las Resoluciones y la aceptación de los documentos públicos en los distintos Estados miembros.

Otro aspecto de indudable importancia es el respeto a la autonomía de la voluntad recogida en el Reglamento, bien que referida al ámbito de elección de la Ley aplicable y de la determinación de la competencia. Pero con ello incide en un aspecto básico, como es la de la diferenciación de las uniones registradas con el matrimonio, al establecer que las uniones registradas tendrían naturaleza claramente contractual, correspondiendo, por tanto, a los convivientes determinar todas y cada una de las estipulaciones que han de regir su relación, tanto en los aspectos personales como patrimoniales, sin más limitación que la que proviene del respeto a la ley y al orden público, con especial atención al respeto escrupuloso al principio de igualdad entre los miembros de la pareja. Aspecto este que lo diferencia del matrimonio y su naturaleza institucional, en la que el respeto a los postulados del estatuto matrimonial es indisponible por los cónyuges.

Sin embargo, pese al indudable avance que supone, deja aspectos importantes sin resolver, probablemente, por la enorme diferencia en el tratamiento de la cuestión en los distintos países firmantes. Pero, aspectos como la falta de definición del carácter de la inscripción, la ausencia de una concreción de lo que se considera como "unión registrada" a nivel europeo y, sobre todo, la

${ }^{450}$ ALBA FERRÉ, E., y MORENO BLESA, L.: Op. cit., pág.16. 
total ausencia de una regulación sustantiva de la figura de las uniones registradas, válida para todos los Estados miembros, sigue dejando en el ámbito estatal la regulación de este modelo familiar con plena autonomía.

Aun así, entendemos que, a nivel español, debe servir como ejemplo y toque de atención para que, de una vez por todas, sea acometida la regulación de las uniones registradas a nivel de Estado, con una norma armonizadora de los aspectos básicos comunes de las uniones de hecho registradas, sometidas a Normas de carácter dispositivo y, con una coordinación de los registros de las CCAA que sirva para mejorar la seguridad jurídica de estas uniones extramatrimoniales.

Analizada pues, la normativa comunitaria procede ver la regulación en distintos países de la UE pues, pese a que en algunos casos, como Polonia o Eslovenia, no existe regulación alguna sobre este tipo de uniones more uxorio, en la mayoría de los Estados europeos existe algún tipo de legislación sobre la materia, aunque ciertamente dispar. En este estudio veremos la regulación en varios de los Estados europeos más próximos a nosotros

\section{B) LA REGULACIÓN EN OTROS PAÍSES EUROPEOS}

\section{Francia}

En el CC francés encontramos una estructura que tiene cierta afinidad con el concepto de unión de hecho que tenemos en España. De una parte, estaría el llamado Pacte civil de solidarité (Pacto civil de solidaridad), regulado en los artículos 515-21 a 515-7 del CC francés; y, de otra parte, estaría el Concubinage (concubinato), regulado en el artículo 515-8 del mismo cuerpo legal.

Atendiendo a la regulación del CC francés, tendremos que la figura jurídica que se asemeja más a las parejas de hecho no inscrita es la del concubinage ${ }^{451}$, pues el artículo que lo regula establece que se trata de "una unión de hecho, caracterizada por una vida en común presentando un carácter de estabilidad y continuidad, entre dos personas, de sexo diferente o del mismo sexo, que viven en pareja”. Definido de este modo comprobamos que el concubinage es para Francia, lo que las parejas de hecho son para España. Debemos precisar que, si bien tradicionalmente las convivencias extramatrimoniales se han denominado concubinage en Francia, en los últimos

${ }^{451}$ AYLLÓN GARCÍA, J.D.: "Las parejas de hecho en el Ordenamiento jurídico español y francés", en Diario La Ley, n. ${ }^{\circ}$ 9415, (15 de mayo de 2019). 
tiempos tal denominación ha venido siendo sustituida por la de unión libre, formulación que incide en el elemento intencional de una unión sin exigencias formales y sin vínculo ${ }^{452}$.

La denominada unión libre no exige ningún tipo de formalidad. Sin embargo, para acreditar su existencia, es imprescindible la dimensión sexual de la relación que se establece como condición imprescindible para determinar su existencia ${ }^{453}$. El concubinato se puede acreditar por diversos medios, ya sea mediante un certificado de concubinato emitido por la municipalidad o, en su defecto, mediante una declaración de honor, suscrita por ambos miembros de la pareja acompañada de todo tipo de pruebas, tales como pasajes de avión, cuentas bancarias comunes, acreditación de convivencia con los datos del buzón, fotos, testigos, etc.

Ninguna de las obligaciones del matrimonio resulta aplicable a las uniones libres, ni en el aspecto personal, ni en el patrimonial, pues cada uno de los concubinos administra sus bienes de manera individual. También, cualquiera de los concubinos puede poner fin a la situación de convivencia sin necesidad de invocar causa alguna. Sin embargo, el concubinato sí genera algunos derechos, como los que resultan de la asimilación al matrimonio en relación con la aplicación de las técnicas de reproducción asistida. También en relación con los contratos de alquiler, incluyendo el derecho del concubino a la subrogación en el contrato en determinados supuestos como los casos de abandono o muerte del concubino titular del contrato. O, en relación con la Seguridad Social, pues uno de los concubinos podrá resultar beneficiario de las prestaciones del otro derechohabiente cuando se encuentre totalmente a su cargo efectiva y permanentemente.

Por su parte, el denominado Pacto Civil de Solidaridad (en adelante, PACS) es un contrato con una evidente dimensión social, definido por el artículo 515-1 del CC como un "contrato entre dos personas físicas mayores, de sexo diferente o del mismo sexo, destinado a organizar su vida en común”. Como consecuencia de tal definición, solamente los mayores de edad pueden celebrar este contrato, y se prohíbe, también, a las personas unidas a otro ya sea por matrimonio o por otro pacto civil de solidaridad. Se establece, igualmente, un impedimento por parentesco, en cualquier grado en línea recta y hasta parientes de tercer grado en línea colateral, para suscribir este pacto civil de solidaridad. En algunos aspectos se aplican las reglas del matrimonio y en otros las de los contratos.

\footnotetext{
${ }^{452}$ Pese a ello, el término "unión libre" no está recogido en el CC francés, que utiliza el término concubinage. En todo caso, los efectos son los mismos, una vez constatada la existencia de dicha situación de hecho.

${ }^{453}$ Durante años los Tribunales franceses se negaron a reconocer como concubinos a las parejas del mismo sexo, al entender que las nociones de "unión libre" o "vida marital" solamente se referían a las parejas heterosexuales. Tal interpretación restrictiva llevó al legislador francés a la aprobación de la figura del Pacto Civil de Solidaridad.
} 
Así, por ejemplo, se utilizan las reglas del matrimonio en materia de simulación o fraude, pero respecto de los vicios del consentimiento se aplican las reglas de los contratos ${ }^{454}$.

El Pacto Civil de Solidaridad es un contrato formal que puede ser realizada mediante escritura pública o mediante una declaración conjunta de los convivientes ante el secretario del Tribunal de instancia ${ }^{455}$ en la jurisdicción en la que tengan su residencia común y que, en todo caso, deberá acompañarse de documentación acreditativa de la inexistencia de impedimentos, incluyendo la inexistencia de que ninguno de los convivientes está unido por otro PACS previo. Cumplidos los trámites el notario ${ }^{456}$ o el secretario inscribe el PACS que, se anota, también, en los registros del Tribunal correspondiente a lugar de nacimiento de cada uno de los convivientes ${ }^{457}$. A este contrato le resultan de aplicación las normas del Derecho común en materia de contratos.

En cuanto a los derechos y obligaciones de los cohabitantes en un pacto civil de solidaridad serán establecidos en el mencionado pacto por los propios convivientes de manera libre, voluntaria y consciente. La ley francesa, se limita a precisar que los convivientes se comprometen a aportarse ayuda mutua y material, la obligación de ayuda material es contemplada como una exigencia de orden público, por lo que cualquier pacto en contrario será nulo de pleno derecho.

En relación con los efectos patrimoniales, entre los miembros del PACS el régimen legal es del de la separación de bienes pero, salvo pacto en contrario, los bienes muebles adquiridos durante la convivencia se presumen adquiridos por mitad por ambos miembros de la pareja. Igualmente, se reconocen a los miembros del PACS algunos de los derechos y obligaciones propios del matrimonio en materia fiscal, patrimonial y de política social ${ }^{458}$. También se establece una solidaridad en las cargas de la pareja durante el período de convivencia, por ejemplo, en los contratos de arrendamiento, ambos miembros son deudores solidarios del alquiler.

\footnotetext{
${ }^{454}$ BORILLO, D.: "Uniones libres, convivenciales y conyugales en el Derecho francés", en Revista de Derecho privado y comunitario (2014), pág. 529.

${ }^{455}$ Los tribunales de instancia, pese a estar integrados en la estructura judicial, tienen competencias en asuntos contenciosos menores y algunas administrativas, como el registro de los PACS.

${ }^{456}$ Cuando la tramitación se realiza por el notario, este procede a la inscripción del PACS en el registro de las convenciones notariales del pacto civil de solidaridad

${ }^{457}$ Pese a ello, el PACS está concebido como un acto público de carácter limitado puesto que, a diferencia del matrimonio, no se realizan proclamas, ni se publican edictos.

${ }^{458}$ Algunos de estos derechos son: que los convivientes, a partir del tercer año, pueden hacer de manera conjunta la declaración de la renta; o la aplicación de las reglas del matrimonio en materia de subrogación en los arrendamientos urbanos; también, se aplica a los PACS el régimen establecido para los funcionarios casados; si uno de los convivientes no tiene cobertura de la Seguridad Social puede beneficiarse del seguro del otro; etc. Sin embargo, mortis causa no se transmite derecho alguno en la sucesión ab intestato al conviviente supérstite.
} 
En cuanto a su disolución, el PACS podrá disolverse:

a) Por defunción de uno de los convivientes.

b) De común acuerdo, mediante una declaración conjunta dirigida al Tribunal de Instancia.

c) De manera unilateral, mediante notificación escrita de dicha decisión al otro miembro de la pareja, con copia a la secretaría del Tribunal de Instancia en el que se inscribió inicialmente el Pacto Civil de Solidaridad.

d) Por matrimonio de uno de los miembros de la pareja. En este caso, el conviviente que contrae matrimonio comunica por escrito el hecho del matrimonio al otro miembro de la pareja, enviando copia al Tribunal que inscribió el acto inicial, junto a la partida de nacimiento en la que viene inscrito su matrimonio.

\section{Alemania}

El artículo 6 de la Ley Fundamental de Bonn atribuye al Estado la especial protección del matrimonio y la familia. Se justifica así, por mandato constitucional, un tratamiento diferenciado del matrimonio respecto a las uniones de hecho ${ }^{459}$. Hasta septiembre del año 2018, en Alemania solamente se podían inscribir parejas de hecho del mismo sexo. A partir del 30 de septiembre de ese año, con la aprobación del matrimonio entre personas del mismo sexo, la Ley de Sociedades de Vida $^{460}$ restringe su aplicación a solamente dos supuestos:

a) Las sociedades civiles constituidas con anterioridad al 1 de octubre de 2017, y que no hayan decidido constituirse en matrimonio.

b) Las sociedades civiles constituidas en el extranjero, en la medida que le resulte aplicable la legislación alemana.

Analizaremos, pues, estas sociedades civiles que siguen existiendo, solamente para los casos señalados, y que forman parte de las soluciones que el legislador alemán se ve obligado a adoptar ante la evolución del concepto tradicional de la familia. En cuanto al modo de constitución de la sociedad civil, se realiza de manera similar al matrimonio, por dos convivientes del mismo

\footnotetext{
${ }^{459}$ NAVA RODRÍGUEZ, J.: "Legislación estatal de los países miembros de la UE sobre las uniones de hecho: estudio de su dimensión de justicia", en Cuadernos doctorales, derecho canónico, derecho eclesiástico del Estado, Universidad de Navarra, n. ${ }^{\circ} 22$ (2007-2008), pág. 64.

${ }^{460}$ La Ley de Sociedades de Vida fue publicada el 16 de febrero de 2001 (Gaceta de Leyes federales, p. 266), habiendo sido modificada el 18 de diciembre de 2018 (Gaceta de leyes federales, p. 2639).
} 
sexo, mayores de edad que, no incurriendo en ninguno de los impedimentos establecidos ${ }^{461}$ manifiesten su deseo de establecer la asociación de vida permanente, sin condición ni término, ante el encargado del registro y en presencia de al menos dos testigos. Siendo imprescindible que ambos miembros acuerden, de manera individual y expresa, establecer en la sociedad de vida los derechos y deberes contenidos en la Ley.

Esta Norma, creada para las personas del mismo sexo que, queriendo casarse no podían, por la exigencia de heterosexualidad del matrimonio hasta la reciente reforma del BGB del año 2018, se limita a indicar qué artículos del Código le resultan aplicables, al entender que en Alemania cualquier regulación constitucional de la familia debe fundarse en estos tres criterios: no puede colocarse en una situación más favorable que la del matrimonio, porque este sí tiene cobertura constitucional, a diferencia de la pareja de hecho que no la tiene; la garantía constitucional establecida en el artículo 6 de la Constitución alemana permite situar al matrimonio en una posición más favorable que a la pareja de hecho; y la regulación que se establezca no puede coaccionar la celebración del matrimonio ${ }^{462}$.

En relación a los derechos y deberes se establece la obligación de apoyo y cuidado mutuo, así como configurar una vida en común, siendo responsables el uno del otro. Lo que viene a decir, que los socios de vida, por la obligación de ayuda mutua, vienen obligados a poner la misma diligencia que la que llevan en sus propios asuntos. También, los convivientes están obligados a prestarse alimentos, resultando de aplicación, al respecto, lo dispuesto en el BGB para el matrimonio.

Resulta, igualmente, de aplicación subsidiaria el BGB en su regulación del matrimonio, en aspectos tales como el régimen económico de la sociedad, sobre el que pueden optar, antes de la constitución de la unión de hecho, entre el régimen de participación o establecer su propio régimen económico. También pueden los convivientes elegir un nombre común ${ }^{463}$ para la pareja, declaración que deben formular al momento de establecerse la sociedad de vida pues, si tal

\footnotetext{
${ }^{461}$ Las prohibiciones establecidas para constituir una sociedad de vida son la de edad, así como la inexistencia de matrimonio u otra sociedad de vida, así como la de parentesco en línea recta.

${ }^{462}$ ROCA TRÍAS, E.: "Propuestas de regulación en el Derecho de familia", en VV.AA.: El Derecho europeo ante las parejas de hecho: la experiencia sueca y las tendencias legislativas de nuestro entorno. ed. Cedecs, Barcelona (1996), pág. 94.

${ }^{463}$ El artículo 3 de la Ley de Sociedad de Vida precisa que los socios vitalicios pueden determinar un nombre común, de modo que, para su razón social, los socios pueden determinar, por ejemplo, el apellido de soltera o el nombre de uno de los socios. El socio de vida conserva el nombre de la sociedad incluso después de que la sociedad ha terminado, según su voluntad manifestada en la oficina del registro.
} 
declaración se realiza más tarde debe ser certificada públicamente. Mediante esta declaración los convivientes pueden designar un apellido común, sea el de nacimiento de uno de ellos o el de cualquiera de los dos en el momento de la declaración.

En cuanto a los derechos sucesorios, una vez más, existe gran similitud con el matrimonio. La sucesión mortis causa se regula de acuerdo a las siguientes reglas: El socio de vida hereda conjuntamente con los parientes en línea recta; también existe la posibilidad de otorgar testamento común por los convivientes; y, se aplica a los socios de vida buena parte del derecho sucesorio contemplado para el matrimonio. La Ley de Sociedad de Vida considera a cada conviviente como perteneciente a la familia de su pareja, lo que genera relaciones por afinidad con la familia del otro. También contempla la mencionada norma jurídica la situación de los socios de vida que viven separados, regulando aspectos tales como la pensión alimenticia, la atribución del domicilio común o la distribución del mobiliario.

En relación a la disolución de la sociedad de vida, ésta se produce por decisión judicial, tras la petición de uno o ambos convivientes. Esta necesidad de intervención judicial determina el carácter de "forma de convivencia", similar al matrimonio, que la Ley quiere dar a las uniones entre personas del mismo sexo ${ }^{464}$. Se establecen, además, una serie de requisitos, fundamentalmente plazos legales, para fomentar la continuidad de las sociedades civiles.

Para que proceda la intervención judicial decretando la nulidad de la sociedad de vida inscrita, será necesario que uno o ambos convivientes manifiesten en documento público su voluntad de poner fin a la relación, manifestación de voluntad que no puede estar sometida a condición ni a término. Realizada dicha manifestación de voluntad se producirá la resolución judicial si es solicitada por ambos socios de común acuerdo si llevan un año separados; si tal declaración de nulidad es pedida unilateralmente por uno solo de los socios deberán haber transcurrido tres años desde la notificación al otro conviviente de la manifestación de voluntad realizada en documento público; por último, también será posible la nulidad unilateral, sin requisitos de separación previa, si la continuación de la sociedad resulta difícil para uno de los socios, en atención a la persona de su compañero.

Anulada la pareja de hecho inscrita, y mientras uno de los socios lo precise, continúa vigente el derecho/deber de prestación de alimentos, en los mismos términos que durante la vigencia de la relación. En relación con el mobiliario doméstico y la vivienda común, a falta de acuerdo entre las

${ }^{464}$ NAVA RODRÍGUEZ, J.: Op. cit., pág. 68. 
partes, será el juez quien decida, a instancia de cualquiera de los socios, en lo que es otra equiparación a la situación de ruptura matrimonial.

\section{Italia}

También en el caso italiano la regulación de las uniones de hecho afecta, exclusivamente, a las personas del mismo sexo, reguladas mediante una Ley de Uniones Civiles, conocido también como matrimonio igualitario ${ }^{465}$. En esta unión, a diferencia del matrimonio tradicional, no existen publicaciones ni proclamas. Viniendo definida por la legislación italiana como una relación en igualdad de derechos y deberes entre los convivientes, con la obligación de convivencia y asistencia y ayuda mutua, ayuda que será tanto moral como material, debiendo contribuir al sostenimiento familiar, en atención a las posibilidades de cada uno de los convivientes.

Los requisitos establecidos para este tipo de uniones civiles es que se trate de parejas del mismo sexo (art. 2 de la Ley) no casadas o unidas en pareja de hecho. Se establece el impedimento de parentesco hasta el tercer grado en línea colateral y prohibición total en línea recta. Otros impedimentos para constituir pareja de hecho son la situación de incapacidad y no haber sido condenados por el homicidio del cónyuge o pareja de hecho del otro conviviente (se establecen los impedimentos en el art. 4 de la Ley italiana).

La constitución de esta unión civil o matrimonio igualitario se formula mediante la declaración de voluntad $^{466}$ de constituirla ante el registrador, en presencia de dos testigos. Formulada la declaración, el registrador emite un documento que acredita la constitución, en este documento se incluyen los datos personales del contrayente, la residencia de los mismos y los datos personales de los testigos, así como el régimen patrimonial elegido. También existe la posibilidad de establecer el apellido de uno de los miembros de la unión como apellido común, pudiendo el otro anteponer o posponer el suyo.

El régimen económico de la unión civil es decidido, libremente y de mutuo acuerdo, por los convivientes. No obstante, el art. 13 de la ley italiana contiene una cláusula de cierre para el supuesto de que los miembros de la unión no alcancen acuerdo al respecto, en cuyo caso el régimen económico de la pareja será el de comunidad patrimonial.

\footnotetext{
${ }^{465}$ Relaciones reguladas en la Ley de 20 de mayo de 2016 de Regulación de las uniones civiles entre personas del mismo sexo y disciplina de la convivencia.

${ }^{466}$ Será causa de nulidad de la declaración de voluntad la existencia de vicios en el consentimiento prestado, sea por error en la persona o cualidades de la misma, o la violencia, intimidación o miedo insuperable.
} 
Los socios de la unión civil, además de poder regular las cuestiones patrimoniales de su vida en común mediante un contrato de convivencia, incluyendo reglas específicas para los supuestos de disolución, gozan de los mismos derechos que los cónyuges en supuestos de enfermedad, hospitalización o muerte. Así, el conviviente podrá visitar al otro si está hospitalizado, o emitir poder al otro conviviente para el supuesto de enfermedad que lo incapacite o, en supuesto de fallecimiento, para cuestiones tales como la donación de órganos, tratamiento del cuerpo y funeral. Tienen, también, los mismos derechos que el cónyuge en relación con el sistema penitenciario.

Para el supuesto de fallecimiento de uno de los convivientes, el sobreviviente tendrá derecho a percibir una pensión, y derecho a la herencia en los mismos porcentajes que el cónyuge en el matrimonio tradicional. En relación con el domicilio, en caso de fallecimiento del propietario del domicilio común, se le permite al otro continuar viviendo en el mismo durante un período mínimo de dos años, que puede llegar a cinco en función del tiempo de convivencia. Este derecho finaliza por nuevo matrimonio o pareja de hecho del sobreviviente. Existe, también, un derecho de sucesión en el arrendamiento para el caso de fallecimiento del conviviente titular del contrato.

Además del fallecimiento de uno de los convivientes, la unión civil se disuelve por la manifestación de la voluntad de disolver la unión civil formulada por cualquiera de los convivientes ante la oficina del registro civil. Transcurridos tres meses desde la citada comunicación se puede solicitar el divorcio, tanto por vía judicial, como mediante convenio firmado ante un oficial del registro civil. Para el caso de divorcio, la Ley prevé que la parte más desfavorecida pueda tener derecho a una pensión de alimentos (art. 65 de la Ley) y a la atribución del uso del domicilio familiar.

\section{Portugal}

En Portugal la vigente regulación de las uniones de hecho contenida en la Ley 71/2018, de 31 de diciembre ${ }^{467}$, contempla la posibilidad del registro de las parejas que optan por este modo de

\footnotetext{
${ }^{467}$ La Norma que regula las uniones de hecho es la Ley 7/2001, de medidas de protección de las uniones de hecho, publicada en el Diario de la República n. $^{\circ}$ 109/2001, de 11 de mayo de 2001; esta Ley ha sido modificada posteriormente por diversas leyes posteriores, la última de ellas mediante la Ley 71/2018, de 31 de diciembre. Pero, en ninguna de estas modificaciones se ha incluido la existencia de un Registro de Uniones de Hecho en Portugal.
} 
convivencia ${ }^{468}$. Siendo definida la unión de hecho, en la norma reguladora, como "la unión jurídica de dos personas que, independientemente del sexo, viven en condiciones análogas a las de los cónyuges durante un período superior a dos años"469.

En la medida en que, en Portugal, la unión de hecho no está sujeta a ninguna formalidad (no está sujeta a inscripción en un registro propio, ni es un acto susceptible de inscripción en el registro civil), resulta particularmente importante la cuestión de la prueba de la existencia de una situación de hecho análoga a la de los cónyuges ${ }^{470}$. Admitiendo la norma actualmente vigente cualquier forma de prueba válida en Derecho. Una de las formas de acreditar la unión de hecho, prevista en la propia Ley, es por medio de una declaración emitida por el órgano municipal competente, en cuyo caso, debe acompañarse de una declaración jurada de ambos miembros de la pareja de que viven en unión de hecho desde hace más de dos años, con copia del certificado de nacimiento de ambos convivientes.

En cuanto a los requisitos para constituir una pareja de hecho, se establecen los siguientes:

a) Ser ambos mayores de edad a la fecha de reconocimiento de la unión de hecho.

b) No estar casado ninguno de ellos, salvo que se haya declarado la separación legal.

c) No pueden ser pariente en línea directa, ni consanguíneos ni por afinidad, o colateral por consanguineidad hasta el segundo grado.

\footnotetext{
${ }^{468}$ La doctrina portuguesa no unánime sobre la necesidad o conveniencia de la existencia de un Registro de Uniones de Hecho, fuera este obligatorio o voluntaria. Así, a favor de la existencia de un registro voluntario de uniones de hecho, PITAO, F.: Uniones de Hecho y economía común, $3^{a}$ ed. Ediçoes Almedina, Coimbra (2011), pág. 77. TAVARES COELHO, J.P.: "La familia: perspectiva evolutiva del concepto tradicional", en Revista del Ministerio Público, n. ${ }^{\circ} 54$ (1993), pág. 121. Aquí defiende que, si bien el registro no puede ser obligatorio, debería existir una solución intermedia, permitiendo el registro voluntario de las uniones de hecho, en los supuestos en que los convivientes deseasen alcanzar un "estatuto específico", atribuyéndoles un conjunto de derechos y deberes similares a los del matrimonio. Otros autores como DE SALTER CID, N.: La comunidad de vida al margen del matrimonio: entre el hecho y el Derecho. Ediçoes Almedina, Coimbra (2005), págs. 50-52, señalan que este tipo de soluciones corresponden, en el fondo, a la creación de otra categoría al margen del matrimonio que, reconocidas legalmente, y objeto de un tratamiento jurídico particular, más o menos próximo al establecido para la relación jurídica matrimonial, se transforman en uniones de Derecho. Por fin, autores como LEOPOLDO FERNANDES, A.C.: La disolución de la unión de hecho: efectos patrimoniales. Univ. Coimbra (2017), pág. 30, afirma que la existencia de cualquier registro, independientemente de que fuera voluntario u obligatorio, aproximaría en exceso la unión de hecho al régimen del matrimonio, y que, basándose las uniones de hecho en el régimen de libertad de las partes, no resultaría justa la propia existencia del registro.

469 Este modelo de relación de hecho fue definido por el Superior Tribunal de Justicia de Portugal, en un Acuerdo de 9 de julio de 2014, precisando que, en realidad, estamos ante una "comunión de lecho, mesa y habitación, a la que tradicionalmente se recurre para caracterizar la relación entre los cónyuges".

${ }^{470}$ PASSINHAS, S.: "La unión de hecho en Portugal", en Actualidad Jurídica Iberoamericana, n. 11 (agosto 2019), pág. 113.
} 
d) No tiene efectos la pareja de hecho cuando uno de sus miembros no se encontrase capacitado para presta consentimiento en el momento del inicio de la unión de hecho.

e) Que ninguno de ellos haya sido condenado por homicidio intencional, como autor o cómplice, contra el cónyuge del otro, aunque no se consume el delito.

Esta unión de hecho se diferencia, en la doctrina portuguesa, de la tradicional relación de concubinato, al precisar que cuando se habla de concubinato duradero no estamos ante unas condiciones análogas a las conyugales, esto es, ante una comunidad de lecho, mesa y habitación, existiendo en el concubinato, solamente, una relación sexual estable. Incluso, una parte de la doctrina $^{471}$ entiende que la propia expresión "concubinato" podría dar a entender que una de las partes está unida por matrimonio con otra persona, habida cuenta de que en el concubinato duradero los concubinos no son tratados como matrimonio por su entorno, de manera contraria a lo que ocurre con las uniones de hecho ${ }^{472}$.

En cuanto a los efectos de la unión de hecho, se debe partir de que los miembros de la unión no están unidos por un vínculo como el conyugal, por lo que tal unión no producirá los mismos efectos que el matrimonio. Así, los unidos no están vinculados por los deberes conyugales, ni establecen relaciones de afinidad con los parientes del otro, ni pueden adoptar el apellido del otro conviviente. Sin embargo, las uniones de hecho sí que garantizan una serie de efectos, como la extensión a las mismas del régimen jurídico aplicable a los cónyuges en diversos derechos laborales, como vacaciones, permisos, preferencia de destino en los trabajadores de las Administraciones públicas, entre otros. También en materia de impuestos le resulta aplicable a los unidos, en su declaración de la renta, el régimen tributario de los cónyuges. Igualmente, los unidos son beneficiarios del sistema de protección social en caso de fallecimiento, resultando de aplicación los regímenes generales o especiales en materia de Seguridad Social, así como las prestaciones por fallecimiento por accidente de trabajo o enfermedad profesional. También dispone del derecho a pedir alimentos con cargo a la herencia del difunto, gozando también de derechos en la transmisión del derecho de arrendamiento y en relación con la vivienda común, al conceder al conviviente un derecho real de habitación en la vivienda común, titularidad del conviviente fallecido, y un derecho

\footnotetext{
${ }^{471}$ DIAS, C.: El régimen de responsabilidad por deudas de los cónyuges: problemas, críticas y sugerencias. Coimbra editora, Coimbra (2009), pág. 976.

${ }^{472}$ LEOPOLDO FERNANDES, A. C.: Op. cit., pág. 32.
} 
de uso de los bienes del hogar durante cinco años, a la vez que dispone de un derecho de adquisición preferente en caso de enajenación de la vivienda. Y, pese a no ser heredero legal, pude ser nombrado heredero testamentario ${ }^{473}$.

En cuanto a la extinción de la unión de hecho se producirá, además de por el fallecimiento de uno de los unidos, por la voluntad conjunta de ambos o de uno solo de ellos y por el matrimonio de uno de los miembros de la unión. Para el caso de ruptura inter vivos, se produce una especial protección de la vivienda común, como ocurría en el caso de fallecimiento, ya analizado. Así, para el caso de tratarse de una vivienda arrendada, el destino de la misma será decidido por acuerdo de los unidos y, a falta de acuerdo, serán los Tribunales los que decidan teniendo en cuenta las necesidades de cada uno de ellos, los intereses de los hijos y otros factores relevantes. En el supuesto de tratarse de vivienda común o propia de uno de los unidos, a falta de acuerdo, podrá el Tribunal cederla en arrendamiento a cualquiera de los convivientes, en atención a los intereses y necesidades en juego. Inicialmente, este arrendamiento queda sujeto a las reglas establecidas para los arrendamientos urbanos, si bien puede el Tribunal definir las condiciones del contrato ${ }^{474}$. Otorgando el mismo tratamiento para la protección del hogar familiar que el dispensado en el caso de las parejas unidas en matrimonio.

\section{Suecia}

En el Ordenamiento jurídico sueco rige el denominado principio de neutralidad, consistente en el no intervencionismo del Estado en la vida privada de los ciudadanos, al tiempo que protege la seguridad individual ${ }^{475}$. En la actualidad, al igual que en el caso alemán, la Ley sobre uniones registradas fue derogada con ocasión de la aprobación del matrimonio entre personas del mismo sexo $^{476}$, pese a ello esta norma sigue vigente para regular la relación de las parejas que celebraron su unión antes de la derogación de la Ley y no han convertido su unión en matrimonio. Estas parejas estables registradas tienen como régimen económico el de la sociedad de gananciales. Por lo demás, las parejas estables registradas tienen los mismos derechos y obligaciones que el matrimonio, a

\footnotetext{
${ }^{473}$ DIAS, C.: "Uniones de Hecho: la posición sucesoria del conviviente supérstite en Portugal", en Anuario da Facultade de Dereito da Universidade de Coruña (2014), págs. 70-72.

${ }^{474}$ PASSINHAS, S.: Op. cit., págs. 125-126.

${ }^{475}$ LÁZARO GONZÁLEZ, I.: "Las Uniones de Hecho en el Derecho internacional privado español: balance de un siglo", en Icade: revista de la facultad de Derecho, n. ${ }^{\circ} 46$ (1999), pág. 97.

${ }^{476}$ La Ley 1994/1117 sobre Uniones Registradas (La Ley de Uniones) fue derogada a finales de abril de 2009, al haber sido aprobado el acceso al matrimonio de las parejas del mismo sexo.
} 
excepción de lo relativo a las disposiciones legales por razón de sexo de uno de ellos y a las instituciones internacionales relativas al matrimonio, adopción y la tutela. También para su disolución se acomodan a lo establecido para el matrimonio.

Junto al matrimonio y a las parejas estables (reconocidas para las relaciones entre personas del mismo sexo, es decir, personas que queriendo casarse no podían hacerlo por disposición legal), existe una legislación aplicable a dos personas no casadas, del mismo o distinto sexo, que viven permanentemente juntos, en una relación de afectividad análoga a la conyugal y que comparten la misma casa. No existe registro alguno para este tipo de convivencia, y la norma que la regula ${ }^{477}$ pretende la protección de la parte más débil de la relación.

La Ley se aplica a dos personas no casadas y que convivan en condiciones análogas al matrimonio, por lo que se suele entender que quedan excluidos del ámbito de la Ley aquellas personas entre las que exista algún impedimento para contraer matrimonio. También se exige cierta estabilidad en la relación, la existencia de relaciones sexuales y una economía y hogar común. No se requiere ninguna inscripción, ni ninguna formalidad para su constitución ${ }^{478}$. El objetivo del legislador es regular distintas cuestiones de carácter patrimonial que faciliten la resolución de problemas que se puedan plantear en la cohabitación. Por otra parte, las parejas de hecho no casadas pueden pactar su régimen económico, pudiendo llegar a convenir que no se les apliquen las normas para la disolución y liquidación previstas en la Ley.

A la finalización de la convivencia cualquiera de los cohabitantes puede pedir la disolución y liquidación judicial del régimen económico pactado, en el plazo de un año desde que haya terminado aquella. Las reglas contempladas en la Ley de parejas de hecho para la división de los bienes se basan en las existentes para el matrimonio, pero afectando a muchos menos bienes, ya que solamente alcanzará al hogar común y enseres domésticos y otros bienes adquiridos para uso conjunto. Para ejecutar la partición de los bienes se divide el valor neto de los mismos y el conviviente propietario de la mayor parte de los bienes de la pareja de hecho podrá elegir si la compensación se realiza mediante el pago de una suma a tanto alzado mediante la transferencia de activos de valor equivalente. Al miembro de la pareja que tenga mayor necesidad del hogar se le puede conceder el derecho a hacerse cargo de la vivienda, una vez finalizada la convivencia, incluso

\footnotetext{
${ }^{477}$ La Ley 2003/376, de Parejas de Hecho, o Ley de Cohabitación, publicada el 12 de junio de 2003.

${ }^{478}$ NAVA RODRÍGUEZ, J.: Op. cit., pág. 42.
} 
en el caso de que la titularidad de la misma pertenezca en exclusiva al otro cohabitante, si bien la tenencia del bien se hará en régimen de alquiler.

\section{Dinamarca}

Dinamarca fue el primer país del mundo en regular las parejas de hecho entre personas del mismo sexo $^{479}$. Esta norma equiparaba en gran medida las parejas de hecho registradas al matrimonio, tanto en aspectos de Derecho público (Derecho tributario, pensiones, Seguridad Social, etc.) como en el ámbito del Derecho privado, reconociendo a la unión registrada los mimos efectos jurídicos que al matrimonio, incluidos los sucesorios, así como en los trámites de su constitución y disolución ${ }^{480}$.

Desde algunos años antes se venía debatiendo en Dinamarca sobre la necesidad de regular la realidad social que representaba la convivencia more uxorio entre personas del mismo sexo. Finalmente, se optó por crear un modelo de convivencia inscrita para estos grupos familiares que les otorgara una situación jurídica asimilada a la de los cónyuges. El reconocimiento legal formulado en estos términos instauró el denominado "modelo nórdico", seguido, en sus rasgos básicos, por otros países de su entorno, como Noruega, Islandia y, como ya hemos visto, Suecia y Alemania.

Esta ley de convivencia danesa, en esencia, se limita a una remisión a la legislación matrimonial, y se estructura con una primera parte en la que se regula el Registro, una segunda dedicada a los efectos legales que produce y una tercera dedicada a las formas de disolución de la pareja registrada.

En cuanto a su aplicación se dirige a la unión de dos personas del mismo sexo, que podrán registrar su convivencia siempre que al menos uno de ellos tenga nacionalidad danesa o bien que ambas partes hayan residido en Dinamarca durante, al menos, dos años. También se establece el impedimento de inscribir la relación si alguno de los miembros de la pareja está vinculado por matrimonio o forma parte de una pareja registrada.

\footnotetext{
${ }^{479}$ Se trata de la Ley de convivencia inscrita de 7 de junio de 1989, modificada parcialmente, años más tarde, por la Ley 360, de 2 de junio de 1999, en relación con los requisitos personales para la aplicación de la Ley, así como en relación con aspectos relacionados con la adopción.

${ }^{480}$ GARCÍA HERVÁS, D.: "Panorámica legislativa sobre uniones de hecho", en ius canonicum, n. ${ }^{\circ} 81$ (2001), pág. 325.
} 
Dado que, en la actualidad, es legal el matrimonio entre personas del mismo sexo ${ }^{481}$ en Dinamarca, las diferencias entre matrimonio y parejas civiles se ha diluido en gran medida ${ }^{482}$. Con la entrada en vigor de la Ley que autoriza el matrimonio entre personas del mismo sexo se permite que las uniones civiles registradas puedan convertirse en matrimonio, a la vez que determina que no pueden realizarse nuevas uniones civiles. Se mantiene, sin embargo, una diferencia entre ambas figuras jurídicas, como es que, mientras que en el matrimonio, sea entre personas del mismo o distinto sexo, y sea civil o religioso, es posible solicitar la mediación de un religioso para la reconciliación de las partes, tal solicitud no es posible en el caso de las parejas registradas.

\section{Países Bajos}

El legislador neerlandés contempla la existencia de varias formas de familia, entre las que se encuentra la de las parejas registradas ${ }^{483}$. Estas parejas pueden establecer contratos de convivencia, también llamados acuerdos de cohabitación, que se regirán por las estipulaciones determinadas por los convivientes, sin que exista regulación legal alguna de tales acuerdos, los cuales vinculan a las partes, pero carece de efectos frente a terceros.

La denominada Ley de convivencia inscrita viene a establecer una fuerte equiparación entre matrimonio y pareja de convivencia inscrita ${ }^{484}$. Y, a diferencia de lo que ocurre en los países nórdicos, esta Ley resulta aplicable tanto a las parejas entre personas del mismo como de distinto sexo, y resulta de aplicación tanto a los holandeses como a los ciudadanos europeos con permiso de residencia en los Países Bajos ${ }^{485}$.

En cuanto a los requisitos, se exige que sea una unión monógama, es decir, de solamente dos personas del mismo o diferente sexo, por lo que no será inscribible si alguno de los convivientes

\footnotetext{
${ }^{481}$ El matrimonio entre personas del mismo sexo es legal en Dinamarca desde el 15 de junio de 2012. Este matrimonio podrá ser celebrado tanto de forma civil como religiosa celebrado por la Iglesia evangélica luterana danesa, mayoritaria en Dinamarca, si bien los sacerdotes pueden negarse a celebrar este tipo de matrimonio. También otras confesiones religiosas pueden celebrar este tipo de matrimonio, pero no están obligadas a hacerlo.

${ }^{482} \mathrm{La}$ otra gran diferencia existente radicaba en la diferencia en las formas de adopción entre el matrimonio y las uniones civiles; sin embargo, el 1 de julio de 2010 entró en vigor una reforma legislativa que autorizaba a los miembros de las uniones civiles a adoptar de forma conjunta.

${ }^{483}$ Regulado en la Ley de parejas registradas de 5 de julio de 1997, y Leyes de 21 de diciembre de 2000 de modificación del Libro I del CC: Ley de apertura del matrimonio a personas del mismo género, y Ley en relación con la adopción por personas del mismo género.

${ }^{484}$ Resulta sumamente interesante la técnica legislativa holandesa consistente en que, en cada uno de los artículos de la legislación dedicada al matrimonio, se indican cuáles son los efectos de esa norma aplicables a las parejas registradas.

${ }^{485}$ GARCÍA HERVÁS, D.: Op. cit., pág. 327.
} 
está formando parte de otra pareja inscrita o está casado. Los restantes requisitos son los mismos que los del matrimonio, tanto el de edad, como de parentesco o de capacidad. También son similares al matrimonio los requisitos de forma, pues también tiene lugar la tramitación del correspondiente expediente y la manifestación de la voluntad de constituir la pareja registrada se formaliza en acto público ante un funcionario municipal en el Ayuntamiento y en presencia de testigos.

En cuanto a los efectos de este tipo de uniones son básicamente los mismos que en el matrimonio. Pues los convivientes se deben socorro y ayuda mutua, tienen obligación de convivencia, fidelidad y contribuir ambos al mantenimiento del hogar. En cuanto al régimen económico aplicable es el mismo que el del matrimonio, el de comunidad de bienes; si bien, pueden excluirlo y adoptar otro mediante un acuerdo prenupcial formalizado en escritura pública. También existe asimilación al matrimonio en otros múltiples aspectos como los derechos sociales o tributarios, o en aspectos tales como derechos hereditarios o en arrendamientos y pensiones.

En cuanto a las causas de extinción de la pareja registrada, una vez más, se encuentra regulada de modo similar al matrimonio, estableciéndose como causas de disolución de la unión registrada: el fallecimiento de alguno de los convivientes; la declaración de fallecimiento y posterior matrimonio o constitución de nueva pareja inscrita por el otro conviviente; la declaración de voluntad de ambos convivientes, suscrito también por uno o dos abogados o notarios, que incluya, además, el reparto de los bienes comunes y la fecha de finalización del acuerdo de convivencia; y por declaración judicial a instancia de una de las partes.

En suma, existe una gran equiparación entre la pareja registrada y el matrimonio. No obstante, se mantienen algunas diferencias entre ambas, tales como las existentes en relación con la adopción conjunta posible en el matrimonio, pero no en las parejas registradas, o en relación con la presunción de paternidad existente en el matrimonio, pero no en las parejas registradas. Siendo a mi entender la más importante que, mientras en el matrimonio los derechos y deberes vienen estipulados por la Ley, en la pareja registrada los convivientes pueden adquirir los mismos derechos y deberes del matrimonio u otros distintos. 


\section{Bélgica}

Las parejas de hecho registradas son contempladas en el caso belga por su $\mathrm{CC}^{486}$, a las que dedica su título 5bis, del Libro tercero, reconociéndolas como situaciones diferenciadas a las uniones registradas en relación con las parejas de hecho no inscritas, así como respecto al matrimonio. Resulta llamativa la ubicación del citado Título en el Código, situado a continuación del destinado a los regímenes económicos matrimoniales. Las normas contenidas en este Título no tienen carácter obligatorio, de modo que los convivientes pueden optar entre el régimen patrimonial establecido por la Ley, constituyendo de ese modo una pareja registrada, o bien optar por el marco común aplicable a las parejas no registradas. Por lo demás, tanto las parejas registradas como las parejas de hecho pueden regular su relación mediante pacto ${ }^{487}$ formalizado en escritura pública ante notario.

La pareja de hecho inscrita se formaliza por escrito ante el registrador del estado civil de la residencia común de los convivientes. En dicho escrito se ha de hacer constar la fecha de la declaración de cohabitación, la filiación completa de ambos cohabitantes, así como lugar y fecha de nacimiento de cada uno de ellos. El escrito, que debe ser firmado por ambos convivientes, debe incluir la residencia común, así como una mención a la voluntad de las partes de cohabitar legalmente y expresar que ambos conocen el contenido de los artículos del CC para la cohabitación legal.

En cuanto a los requisitos que deben cumplir las partes para formar una pareja registrada son los de no estar casados ni formar parte de otra unión de hecho, así como tener capacidad para hacer la declaración de convivencia legal, en el supuesto de las personas con capacidad judicialmente modificada se podrá solicitar una autorización judicial para formular la declaración de cohabitación. También se exige que el consentimiento manifestado para la declaración de convivencia sea libre, voluntario y consciente ${ }^{488} \mathrm{y}$, en su caso, citar la existencia de pactos sobre la cohabitación debidamente formalizados. Una vez comprobado el cumplimiento de los requisitos

\footnotetext{
${ }^{486}$ Las parejas registradas pasan a ser reconocidas en el Derecho belga por medio de la denominada como Ley de cohabitación legal de 23 de noviembre de 1998.

${ }^{487} \mathrm{El}$ artículo 1478 del CC Belga prevé que los cohabitantes pueden regular el modo de cohabitación mediante los acuerdos que tengan por conveniente, siempre que dichos pactos no vayan contra las buenas costumbres el orden público o contravengan las reglas relativas a la autoridad paterna, a la tutela y a las reglas que determinan el orden legal sucesorio.

${ }^{488}$ El CC belga dedica los artículos 1476 bis, 1476 ter, 1476 quater y 1476 quinquies a desarrollar posibles vicios del consentimiento y la consecuencia de nulidad a la que se llega en tal supuesto.
} 
por las partes se inscribe la pareja en el registro de la población correspondiente a la residencia común.

Así pues, se entiende por cohabitación legal la situación de vida en común de dos personas que hagan tal declaración de acuerdo a lo establecido en el artículo 1476 del CC. La cohabitación legal existe, pues, al margen de que entre ellas haya una relación de afectividad análoga a la conyugal. Es decir, no se exige que, entre los miembros de la pareja registrada, exista una relación sexual o afectiva, pudiendo ser cohabitantes un ascendiente con un descendiente, o miembros de una misma familia tales como hermanos, etc. La declaración de cohabitación legal, el escrito presentado en el registro civil del domicilio común carece de requisitos formales, así como de las solemnidades del matrimonio.

El régimen legal de cohabitación no regula aspectos personales de la convivencia de los miembros de la pareja. Y, en relación con los aspectos patrimoniales, la regulación codificada establece, para los cohabitantes, un régimen de separación de bienes, que se combina con la situación de indivisión de los bienes cuya propiedad no puede ser acreditada por ninguno de los convivientes.

El carácter común de los bienes, propios de la situación de convivencia, se le adjudica a aquellos cuya finalidad sea la protección de la vivienda común, o la contribución a las cargas de la convivencia, o que estén destinados a responder de las deudas contraídas por ser necesarias para la vida en común. Como hemos señalado, se considerarán bienes propios de cada conviviente aquellos que pueda probar que le pertenecen, así como los frutos de los mismos o del trabajo de cada uno de ellos. Puesto que los cohabitantes pueden regular mediante pactos sus relaciones patrimoniales pueden, también, determinar el carácter de algunos de los bienes del modo que tengan por conveniente, al margen de las disposiciones contenidas en el Código.

El artículo 1477 del Código regula, también, los derechos y obligaciones de cada cohabitante. Tales derechos y obligaciones se generan por el mero hecho de la cohabitación legal y constituyen el mínimo exigible, con carácter imperativo, a cada cohabitante ${ }^{489}$, estableciéndose un régimen básico durante la vigencia de la cohabitación que afecta a los siguientes aspectos convivenciales:

a) En relación con el levantamiento de las cargas, cada cohabitante contribuye de manera proporcional a sus recursos.

${ }^{489}$ NAVA RODRÍGUEZ, J.: Op. cit., pág. 59. 
b) En cuanto a la protección del hogar familiar se aplican, de manera analógica, las reglas del matrimonio. De modo que cualquier acto dispositivo sobre la vivienda requiere el acuerdo expreso de ambos cohabitantes. De lo contrario, el perjudicado podrá pedir la nulidad del acto.

c) Se establece la solidaridad en las deudas contraídas por uno de los cohabitantes para las necesidades de vida en común o de los hijos excepto cuando sean excesivas para los recursos de ambos. A estos efectos entenderemos por hijos todos los menores o dependientes que convivan con la pareja registrada, independientemente de la existencia o no de vínculo de parentesco entre el cohabitante y el menor.

d) Se establece, también un usufructo viudal en caso de fallecimiento de uno de los cohabitantes, vigente la pareja registrada, mediante el cual la persona superviviente recibe el usufructo del inmueble que constituye la residencia habitual, incluyendo el ajuar doméstico ${ }^{490}$.

En cuanto a la extinción de la pareja registrada se produce por las siguientes causas:

a) Por matrimonio de uno de los cohabitantes, sea con el otro cohabitante o con un tercero.

b) Por fallecimiento de uno de los cohabitantes.

c) Por común acuerdo de las partes, o unilateralmente, en ambos mediante declaración escrita presentada ante el registro civil.

Los dos primeros supuestos implican la disolución automática de la pareja registrada, y el Código no establece regulación alguna al respecto. En el tercer supuesto, es requisito imprescindible la presentación de la declaración escrita ante el registro civil, que debe incluir los mismos datos de la declaración para su inscripción, así como la mención expresa de la voluntad de poner fin a la cohabitación legal y será suscrita por el que la promueve o, en su caso, por ambos cohabitantes.

${ }^{490}$ HERRERA DE LAS HERAS, R.; MARTÍNEZ RUANO, P.; y PAÑOS PÉREZ, A.: "Los derechos sucesorios en la pareja de hecho. Especial referencia a la STC 93/2013, de 23 de abril", en RCDI, n. ${ }^{\circ}$ 749, pág. 1194. 



\section{UN ANÁLISIS DEL CONOCIMIENTO SOCIAL SOBRE LAS UNIONES DE HECHO}

Durante la segunda mitad del pasado siglo hemos ido pasando de la existencia de un reducido número de relaciones concubinarias en España a una importante implantación de las parejas de hecho. Este modo de relación está hoy muy presente en la sociedad española, pese a que, como se comprobará en el cuadro adjunto, las parejas casadas siguen siendo muy mayoritarias en España. Concretamente un $84,30 \%$ de las uniones de pareja en nuestro país lo forman parejas casadas, mientras que las parejas de hecho representan un significativo $15,70 \%$, según el estudio del Instituto Nacional de Estadística.

\begin{tabular}{|c|c|c|c|c|c|}
\hline \multicolumn{6}{|c|}{ Encuesta Continua de Hogares (ECH) } \\
\hline \multirow{2}{*}{\multicolumn{6}{|c|}{ Número de parejas según tipo de unión }} \\
\hline & & & & & \\
\hline & $\begin{array}{c}\text { Total } \\
\text { (Parejas) }\end{array}$ & & $\begin{array}{c}\text { Total } \\
\text { (Parejas) }\end{array}$ & & $\begin{array}{c}\text { Total } \\
\text { (Parejas) }\end{array}$ \\
\hline 2019 & & 2019 & & 2019 & \\
\hline $\begin{array}{c}\text { Total } \\
\text { (Parejas) }\end{array}$ & $11.344,60$ & $\begin{array}{l}\text { Parejas } \\
\text { cas adas }\end{array}$ & $9.563,10$ & $\begin{array}{c}\text { Parejas de } \\
\text { hecho }\end{array}$ & $1.781,50$ \\
\hline Notas: & DISTRIBUCIÓN & $100,00 \%$ & & $100,00 \%$ & \\
\hline Fuente: & Instituto Nacion & & & & \\
\hline
\end{tabular}

A fin de poder afinar el estudio sobre las uniones de hecho, hemos querido conocer la opinión de la sociedad sobre las mismas, en tanto que fenómeno social, y desde la perspectiva jurídica. Para ello, hemos realizado una encuesta de amplio espectro y realizada a través de redes sociales y contestada de forma totalmente anónima.

La pretensión era tomar el pulso del conocimiento social de las uniones de hecho formulando distintas preguntas para comprobar diferentes aspectos relacionados con este tipo de uniones afectivas. La primera parte formada por una serie de preguntas de carácter general, a fin de determinar las características de los encuestados y, a continuación, otra serie de preguntas específicas sobre aspectos concretos de las uniones de hecho. 


\section{A) AnÁlisis del MUeStreo}

\section{Preguntas generales sobre el universo de la muestra}

En las preguntas formuladas vamos viendo cómo, en el universo consultado, es mayor el número de mujeres que el de hombres que han respondido la encuesta; igualmente, se comprueba que el espectro de edad con mayor índice de respuestas es el comprendido entre 31 y 50 años que representan el 44,6 \% de las respuestas obtenidas, mientras que el siguiente sería el de personas entre 51 y 65 años representando el 28,6 \% de las citadas respuestas, por su parte el tramo de los más jóvenes, entre 18 y 30 años, representa solamente el $19 \%$, y los mayores de 65 años tan solo el $7,7 \%$.

También ha de reflejarse que el mayor porcentaje de los encuestados que han respondido estaban casados, en un 41,8 \%, mientras que situaciones tales como soltero/a con relación estable, o soltero/a sin relación, representan respectivamente un 19,7 \% cada una de estas categorías. Los porcentajes de parejas de hecho registradas que han contestado es solamente del 4,5\%, y de parejas de hecho no registradas $8,5 \%$ de las respuestas obtenidas.

\section{Preguntas específicas sobre el conocimiento social de las uniones de hecho}

Dentro de las preguntas específicas, empezábamos preguntando por el concepto de pareja de hecho; se trataba de conocer la opinión social sobre qué consiste una pareja de hecho. Al respecto se ofrecían tres posibles respuestas, además de la opción de que el encuestado ofreciese su propia definición. Las respuestas ofertadas definían la pareja de hecho como una unión estable de convivencia, o bien como una convivencia entre dos personas; la tercera de las opciones era la de que la pareja de hecho es una unión igual al matrimonio.

En la pregunta 7 requerimos sobre los requisitos necesarios para formar una pareja de hecho, ofreciendo distintas opciones, de las cuales el encuestado podía elegir hasta un máximo de dos. Para ello las respuestas posibles no se limitaban a las propuestas, sino que se ofrecía la posibilidad de que el encuestado, que considerase que los requisitos necesarios no se encontraban entre los propuestos, pudiera añadir los que considerase que corresponden. Dado que las respuestas podían ser más de una, la suma de las respuestas no será equivalente a cien. Entre las posibilidades planteadas como requisitos para formar la pareja de hecho se señalaba el no estar casado ni unido como pareja de hecho inscrita; otro de los requisitos planteados era la necesidad de acreditar una convivencia previa, también se señalaba como requisito la existencia de un proyecto de vida 
familiar en común, otro de los requisitos propuestos era acreditar una relación pública y notoria, o la existencia de intereses comunes. También se planteaba la posibilidad de responder que no existe ningún tipo de requisito para formar una pareja de hecho.

Preguntado sobre los derechos y obligaciones legales entre los miembros de una pareja de hecho, se formulaba con carácter general y de respuesta única. Las respuestas planteadas se referencian con relación a los derechos y obligaciones establecidos en el estatuto matrimonial; así, se les planteaban las opciones de elegir si tales derechos y obligaciones eran los mismo que en un matrimonio, o bien si existían derechos y obligaciones, pero menos que en el matrimonio y, una tercera opción, indicando que no existen derechos y obligaciones entre los miembros de la pareja.

La pregunta 9 se centraba en concretar los derechos que existen entre miembros de una pareja de hecho, para lo cual los encuestados podían seleccionar tantas opciones como entendiesen que procedía señalar. En esta ocasión no cabía la posibilidad de incorporar nuevos derechos entre los miembros de la unión convivencial. Las respuestas ofrecidas eran: el derecho a una pensión compensatoria en caso de ruptura de la pareja, también se planteaba la existencia de derechos hereditarios entre los miembros de la pareja, otra de las opciones era el derecho a una pensión de viudedad en caso de fallecimiento del otro miembro de la pareja; se planteaba también el derecho a la adopción conjunta de hijos, o el derecho a días de permiso en el trabajo en caso de enfermedad de uno de los miembros de la pareja, también se señalaba el posible derecho a la mitad de los bienes adquiridos por el otro miembro de la pareja durante el tiempo de convivencia. La última de las opciones era la inexistencia de derechos entre los miembros de la pareja. En la pregunta siguiente nos referíamos a la concreción de obligaciones mutuas entre los miembros de la pareja, pudiendo seleccionar tantas respuestas como se consideren correctas y, al igual que en la pregunta anterior, no se ofrecía la posibilidad de incorporar otras posibles obligaciones entre los convivientes. Como posibles obligaciones se señalaban la de convivir juntos, también se planteaba la obligación de ayudarse mutuamente, tanto personal como económicamente, en caso de necesitarlo el otro miembro de la pareja; otra de las obligaciones propuestas era la de guardarse fidelidad, también se planteaba la obligación de repartirse las responsabilidades en la casa y en el cuidado y atención a las personas que dependen de cualquiera de los miembros de la pareja, también entre las obligaciones propuestas se indicaba la de respeto a las decisiones personales del otro miembro de la pareja; por último, se señalaba la de actuar siempre en interés de la familia que forma con su 
pareja. Finalmente, se daba la opción de señalar la inexistencia de obligaciones entre los miembros de la pareja.

En relación con la pregunta 11, relativa al ámbito económico, se trataba de conocer la valoración social de las obligaciones económicas entre los miembros de la pareja. Las respuestas ofrecidas eran la de que lo percibido por su trabajo por los miembros de la pareja lo ponen en común y pertenece a ambos por igual, al modo de la sociedad de gananciales en el matrimonio. Otra de las respuestas posibles era la de que cada miembro de la pareja debe aportar la mitad de los gastos comunes, como dos personas sin relación afectiva que conviven en un mismo hogar. La tercera de las opciones era la de que cada miembro de la pareja debe aportar a los gastos comunes de manera proporcional a sus ingresos, al modo del régimen económico de separación de bienes en los matrimonios. Y, la última de las alternativas ofrecidas era la de que ninguna de las anteriores era correcta.

En la última pregunta se interroga sobre qué debe de hacer una pareja de hecho para ser reconocida como tal, es decir, qué es preciso para que una unión de hecho sea sujeto de derechos y obligaciones, y ser reconocida como tal por el conjunto social. Al respecto, se señalaban diversas

opciones, la primera señalaba la necesidad de inscribirla en un registro público, en la siguiente opción se indicaba que una pareja de hecho no necesita inscribirse en ningún sitio para ser reconocida como tal. La tercera respuesta indicaba que podía ser reconocida por medio de testigos, otra posible respuesta era el reconocimiento por medio de contratos privados, y también se señalaba la opción de conseguir el reconocimiento mediante el otorgamiento de capitulaciones paramatrimoniales. Finalmente, se dejaba la opción de que el propio encuestado precisase el modo de conseguir el reconocimiento de la pareja de hecho.

\section{Nivel de conocimiento sobre la existencia de las parejas de hecho}

Una de las preguntas formuladas con carácter general buscaba determinar el nivel de conocimiento sobre las parejas de hecho, lo que se planteaba de manera absolutamente directa. La encuesta se programó de modo que las personas que declararon no conocer qué era una pareja de hecho, no contestaban las preguntas específicas formuladas a continuación.

Como resultaba esperable, es muy mayoritario el conocimiento de las parejas de hecho, no solo de su existencia que, sin duda es aún mayor que el resultado reflejado en la encuesta, sino de en qué consiste este modo de relación afectiva. 
En efecto, en las respuestas dadas se obtiene que conocen, en mayor o menor medida, en qué consiste este modo de relación el 95,1 \% de los encuestados (un $70 \%$ declaraba sin ambages conocer las uniones de hecho, mientras que otro $25,1 \%$ decía conocerlas "un poco"), de manera que solo un 4,9\% dijo desconocer en qué consistía este modo de unión afectiva; e, insistimos, creemos que las personas que dijeron no conocer la pareja de hecho, no se referían tanto a desconocer su existencia, sino a que, lo desconocido, es el modo en que dicha relación afectiva se organiza y funciona; no obstante, tal conclusión es fruto de nuestra intuición, careciendo de cualquier dato empírico que lo avale.

\section{Gráfico 1. ¿Sabe o conoce lo que es una pareja de hecho?}

¿Sabe o conoce lo que es una pareja de hecho?

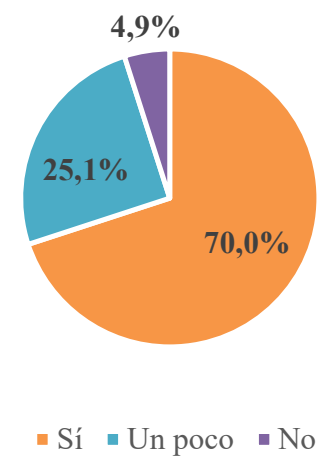

\section{Conocimiento social y definición general de la pareja de hecho}

Entrando en el conjunto de preguntas específicas, la primera de ellas trataba de determinar en una corta definición qué se entiende por una pareja de hecho. Como señalamos más arriba, la respuesta resultaba sumamente indicativa de la opinión. 


\section{Gráfico 2. Conocimiento sobre las parejas de hecho, respuesta general}

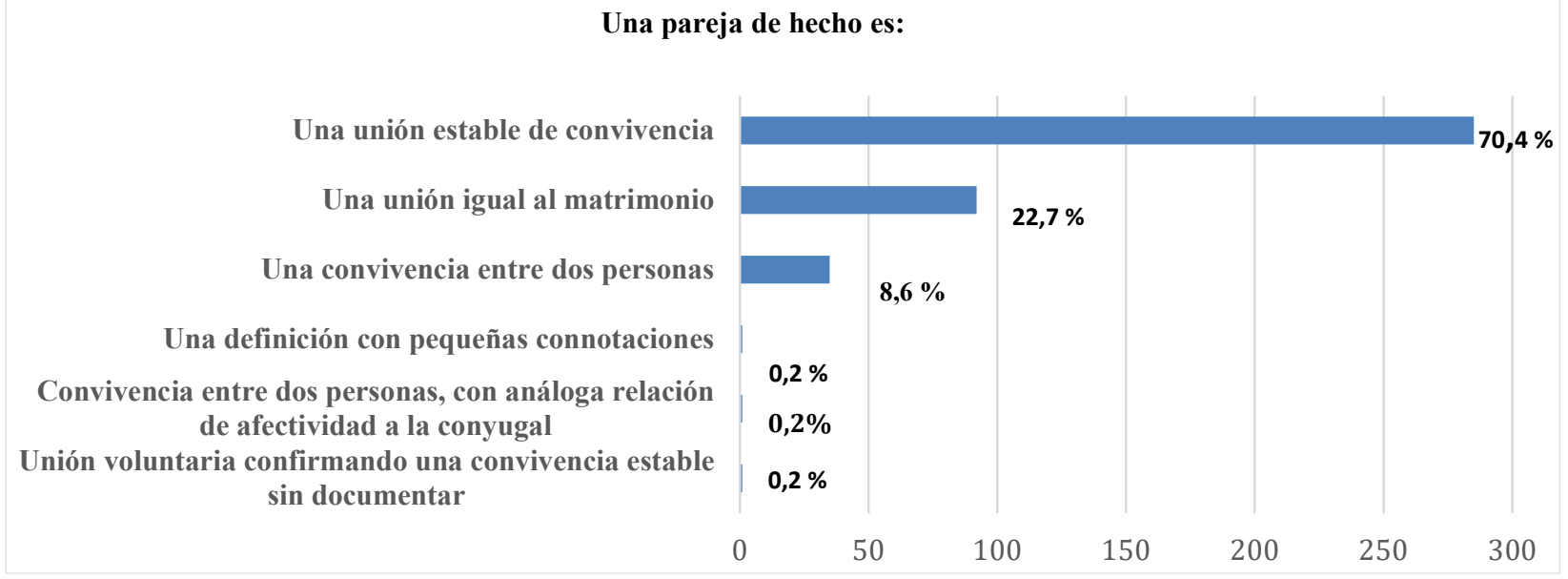

Del total de respuestas recibidas se concluye que la generalidad de la población (el 70,4 \%) considera que la pareja de hecho es una unión estable de convivencia, mientras que un significativo $22,7 \%$ la ve como una unión igual al matrimonio. Naturalmente, en tales concepciones existen matices, así varios de los encuestados han aportado definiciones más complejas que, en definitiva, conducen a la visión de la pareja de hecho como una convivencia estable de dos personas. Resulta sumamente significativo, sin embargo, que uno de cada cinco encuestados considere que es una unión igual al matrimonio.

Prácticamente no existen diferencias entre hombres y mujeres en las respuestas ofrecidas. Sin embargo, se produce una modificación importante al introducir el criterio de la edad, de manera que, mientras entre los hombres entre 31 y 50 años el porcentaje de los que consideran que es una unión igual al matrimonio aumenta hasta un significativo 33,9\%, entre las mujeres de la misma edad el porcentaje se reduce hasta el $17,4 \%$. 
Gráfico 3. Conocimiento general sobre las parejas de hecho en la cohorte de 31 a 50 años, por sexo
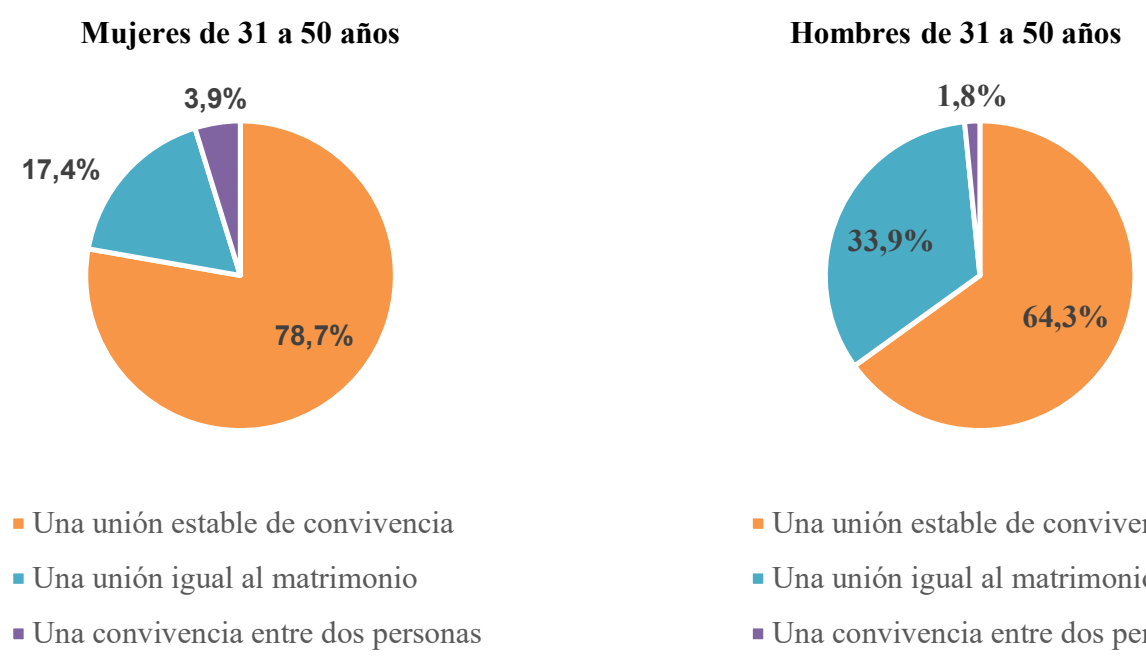

- Una unión estable de convivencia
- Una unión igual al matrimonio
- Una convivencia entre dos personas

En cambio, en el rango de edad de entre 51 y 65 años los resultados sufren una variación sustancial ya que, mientras que los hombres que piensan que es una unión igual al matrimonio se reduce hasta el 11,4\%, entre las mujeres aumenta hasta el 30,6 \%.

\section{Gráfico 4. Conocimiento general sobre las parejas de hecho en la cohorte de 51 a 65 años, por sexo}

Mujeres de 51 a 65 años

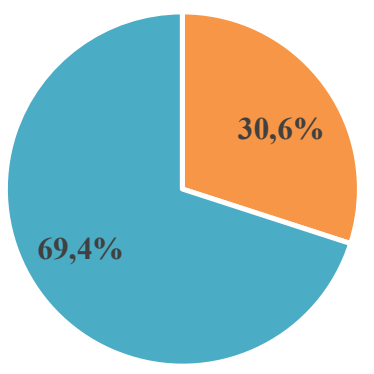

- Una unión igual al matrimonio

- Una relación estable de convivencia
Hombres de 51 a 65 años

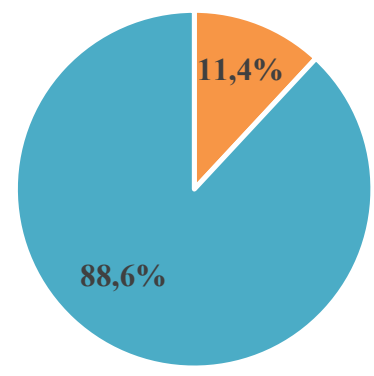

- Una unión igual al matrimonio

- Una relación estable de convivencia

La desviación encontrada, que da variaciones absolutamente contradictorias entre hombres y mujeres al incrementar la edad podría ser un sesgo erróneo de la muestra, o bien indicarnos 
posiciones previas diferentes ante la situación de convivencia more uxorio en los distintos sexos. No olvidemos que, en el total por sexos, las respuestas eran significativamente iguales pero, cuando lo analizamos en función de la edad de los encuestados, se producen bruscas modificaciones en función de la edad y en sentido totalmente divergente entre ambos sexos.

De nuevo cuando se analiza en función del sexo y la situación de pareja, observamos que los hombres casados parecen tener muy claro que una unión de hecho es una unión estable de convivencia, que no es igual al matrimonio, con un abrumador 90,7\% mientras que, entre las mujeres casadas, este porcentaje baja hasta el 69,2\%, considerando un significativo $26,9 \%$ que se trata de una unión igual al matrimonio.

Llama también la atención que en la variable edad, puesta en relación con el sexo, el tramo de hasta 30 años, se produce una gran diferencia en función del sexo de los encuestados, lo que puede hacer pensar que el conocimiento y la utilización de este modo de convivencia pude estar relacionado con la experiencia vivida y/o la formación sociocultural del total de la población encuestada.

También se observan importantes diferencias entre los hombres y mujeres, en el caso de los hombres solteros o unidos en pareja de hecho los porcentajes que consideran que se trata de una relación igual al matrimonio se aproxima a la mitad de los encuestados, mientras que, entre las mujeres con el mismo tipo de relación, es decir, solteras o unidas en pareja de hecho (registrada o no), los porcentajes bajan ostensiblemente, por debajo del $20 \%$ en todos los casos.

Al unir ambos criterios, es decir, edad y situación de pareja de manera simultánea, estas tendencias se acentúan. De manera que se podría concluir que los hombres no casados parecen considerar, en altos porcentajes, que la unión en pareja de hecho es una unión igual al matrimonio, mientras que las mujeres no casadas lo consideran, muy mayoritariamente, una unión estable diferente al matrimonio, si bien se producen diferencias significativas según la edad y situación de relación afectiva. 


\section{Conocimiento social de los requisitos para poder formar una pareja de hecho}

En esta pregunta se pedía a los encuestados que indicasen qué requisitos se exigen para formar una unión de hecho. Obviamente, pese a no indicarlo, se daba por supuesto que para formar una pareja de hecho no registrada no existe más requisito que la voluntad de las personas que así lo desean; de manera que los encuestados respondieron indicando los requisitos exigidos para constituir una pareja de hecho registrada. Que ello ha sido respondido así por los encuestados nos lo indica el que un muy escaso 6,9\% señaló que no hay ningún requisito, lo cual es cierto en el caso de constituirse en pareja de hecho al margen del Derecho. Por tanto, una amplísima mayoría de los encuestados dirigió su respuesta hacia la existencia de una unión de hecho, pero reconocida legalmente, siendo a estos requisitos a los que se dirigía la pregunta, tal como fue interpretado por la inmensa mayoría de los encuestados.

En la encuesta se daba la oportunidad de señalar hasta dos requisitos, de manera que la suma de respuestas no será igual al número de encuestados, ni nos encontraremos ante unos porcentajes de suma cien, sino que los porcentajes de cada una de las respuestas será en relación con el número de encuestados.

Descartada la contestación de que no se exige ningún requisito para la constitución de una pareja de hecho, vemos como entre las posibles respuestas planteadas, elegidas entre las más comunes exigencias de las diferentes legislaciones autonómicas, las contestaciones dadas por el conjunto total de la muestra se dividieron del siguiente modo: El requisito de que exista un proyecto de vida en común era considerado por el $24,2 \%$ de los encuestados como uno los necesarios para constituir una pareja de hecho, la existencia de una relación pública y notoria lo considera un $15,1 \%$ de los encuestados, mientras que un importante $48,1 \%$ piensa que se requiere no estar casado ni unido como pareja de hecho inscrita con terceras personas como requisito para constituir una pareja de hecho; también es importante el número de los que piensan que es necesario que la pareja pueda acreditar una convivencia previa de, al menos seis meses, pues así lo manifiesta un $41 \%$ de los encuestados. Otro requisito señuelo colocado en la encuesta como el de que tengan intereses comunes fue considerado por un exiguo 5,2\%, aunque algunos de los encuestados mencionaron respuestas concretas de las exigidas en determinadas legislaciones autonómicas. 


\section{Gráfico 5. Requisitos necesarios para formar una pareja de hecho, respuesta general}

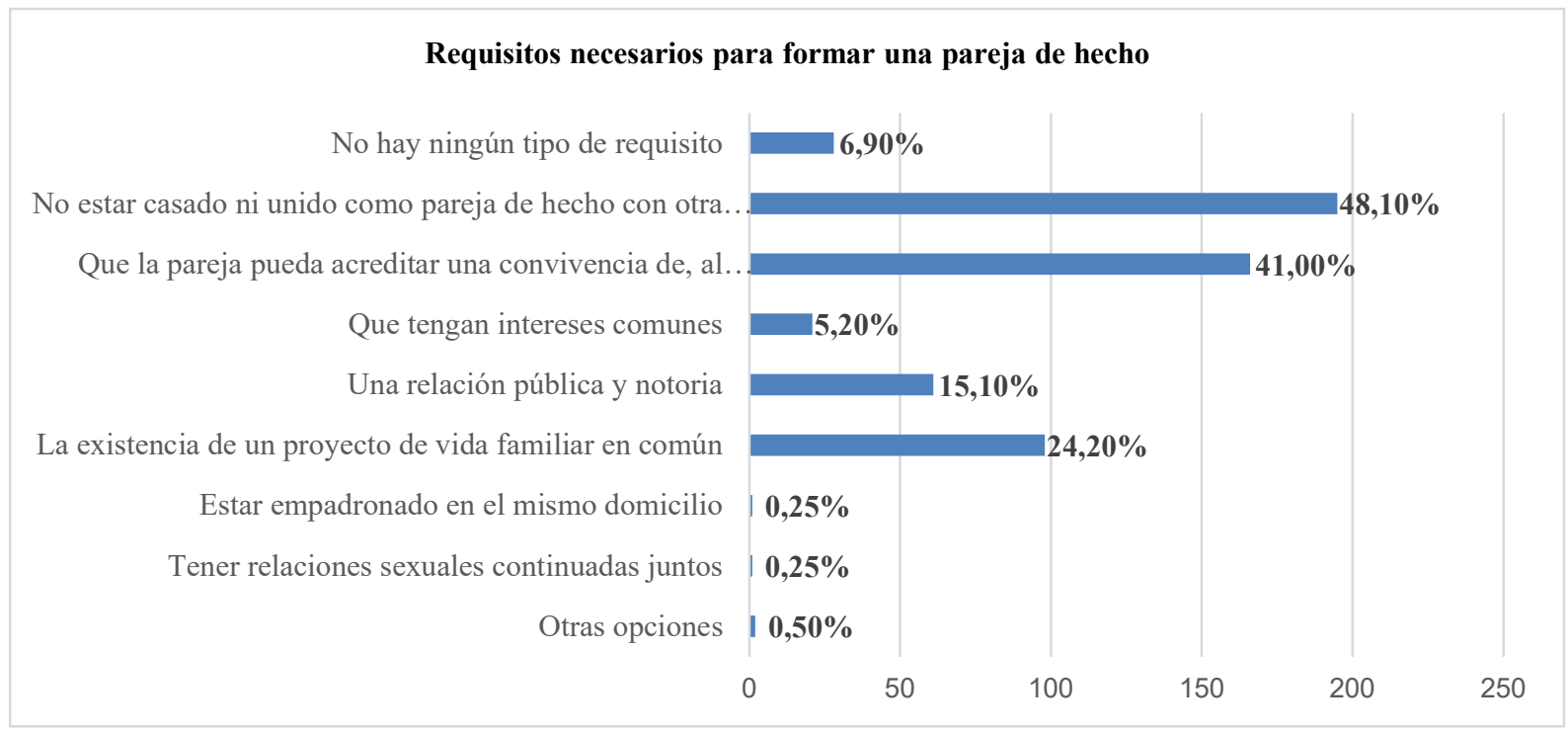

En la segregación por sexos de tales respuestas se mantiene la tónica de los requisitos de no estar unido en otra relación legal y la acreditación de la convivencia como los requisitos exigidos y contemplados de manera mayoritaria en ambos sexos, si bien con algunas diferencias. Que la pareja pueda acreditar un período previo de convivencia es señalado en porcentajes similares en ambos sexos; en cambio, la exigencia de liberad para unirse en una relación de pareja, es decir, no estar unido por matrimonio o como pareja de hecho inscrita con otra persona es considerado como un requisito por un 50,94\% de las mujeres y solamente un 37,58 \% de los hombres.

Entre tanto, una exigencia no legal, como el que exista un proyecto de vida en común es considerado como un requisito imprescindible por un 26,75\% de los hombres frente a un 20,97\% de las mujeres que lo consideran como tal. Esta diferencia se establece, también, en la exigencia de una relación pública y notoria, que es considerada requisito para la constitución de una pareja de hecho por un $12,73 \%$ de las mujeres mientras que dicho porcentaje crece hasta un 17,20\% entre los hombres. 


\section{Gráfico 6. Requisitos necesarios para formar una pareja de hecho, respuesta por sexo}

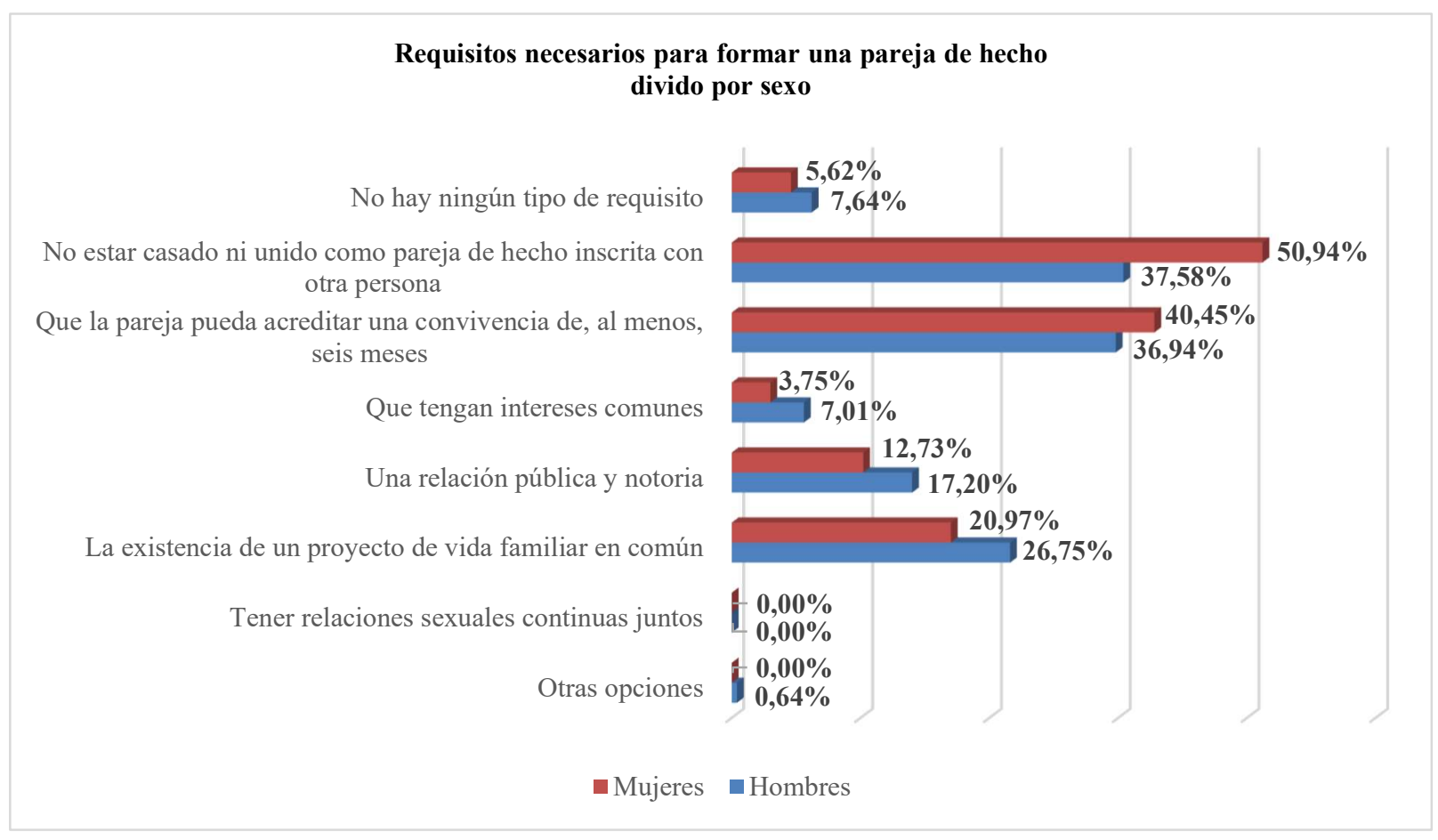

Parece, en cambio, que la edad sí que tiene importancia a la hora de determinar los requisitos necesarios para constituir una pareja de hecho. Así, mientras que las dos respuestas mayoritarias siguen siendo las mismas, independientemente de la edad y el sexo, tenemos que, entre los hombres con una edad entre 18 y 30 años los que sostienen el requisito de la inexistencia de otra relación legal se mantiene en un porcentaje del 48,28 \% en las mujeres de esa misma edad ese porcentaje es del 51,16 \%; pero, en relación con la necesidad de acreditar la convivencia, entre los más jóvenes se establecen diferencias entre los que acompañan el anterior requisito, de libertad para unirse legalmente, con la exigencia de una relación pública y notoria, que es señalada por un importante $31,03 \%$ entre los hombres más jóvenes y un 23,26\% entre las mujeres y los que señalan la exigencia de acreditar dicha convivencia durante un período previo, que es señalada por el 34,48 \% entre los hombres, aumentando dicho porcentaje hasta un 48,84\% entre las mujeres.

Destaca, también cómo entre los hombres se establecen con importantes porcentajes requisitos no legales, como son el de la existencia de un proyecto de vida familiar en común que es considerado por un $34,48 \%$ de los hombres más jóvenes, mientras que solamente es valorado de ese modo por un 18,60 \% de las mujeres de esa misma edad. Algo similar ocurre con la exigencia del requisito de tener intereses comunes, considerado como requisito esencial por un $13,79 \%$ de 
los hombres de 18 a 30 años, mientras que solo es considerado de ese modo por un 6,98\% de las mujeres de esa misma edad.

\section{Gráfico 7. Requisitos necesarios para formar una pareja de hecho, respuesta por sexo en la cohorte de 18 a 30 años}

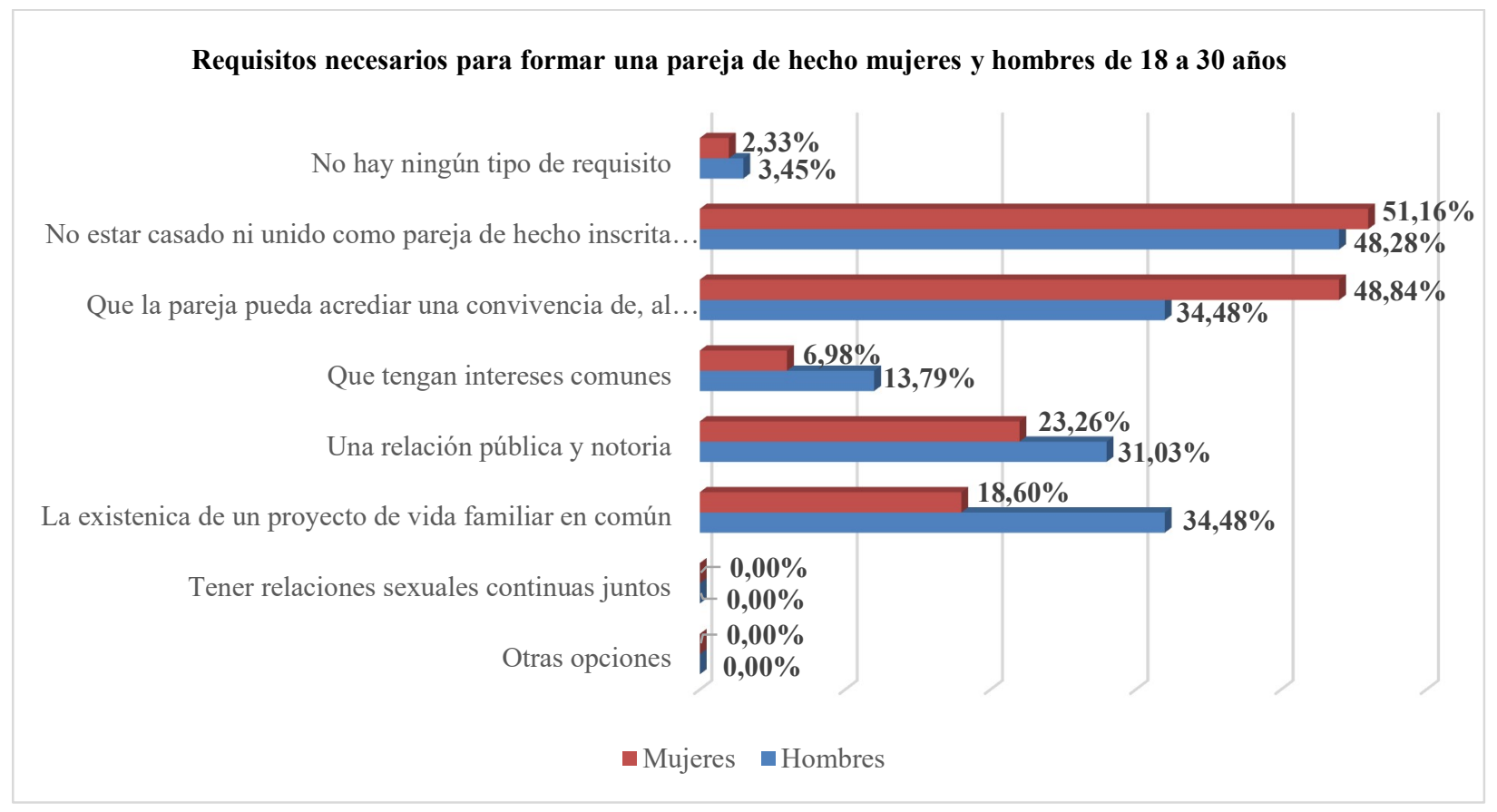

Estas diferencias se atenúan mucho con la edad ya que, al analizar el tramo de 31 a 50 años, se comprueba cómo las diferencias entre ambos sexos se difuminan de manera importante, y que, si bien se mantiene el requisito de no estar unido legalmente como exigencia fundamental en ambos sexos, y con porcentajes no muy diferentes, al ser señalado por un $55 \%$ de las mujeres de esa edad y un 50,85 \% de los hombres de la misma edad; sin embargo, parecería que la edad conduce a una solución más pragmática, pues se mantienen en porcentajes igualmente altos y similares la exigencia de acreditar la convivencia durante el período previo señalado por el $45,76 \%$ de los hombres y el 47,50 \% de las mujeres de esa edad, reduciendo el requisito de la relación pública y notoria a un $18,64 \%$ entre los hombres y solo un $10 \%$ entre las mujeres.

La existencia de un proyecto de vida en común es señalado por un $23,73 \%$ de los hombres y un $20 \%$ de las mujeres, pasando la necesidad de intereses comunes a unos porcentajes insignificantes en ambos sexos. 


\section{Gráfico 8. Requisitos necesarios para formar una pareja de hecho, respuesta por sexo en la cohorte de 31 a 50 años}

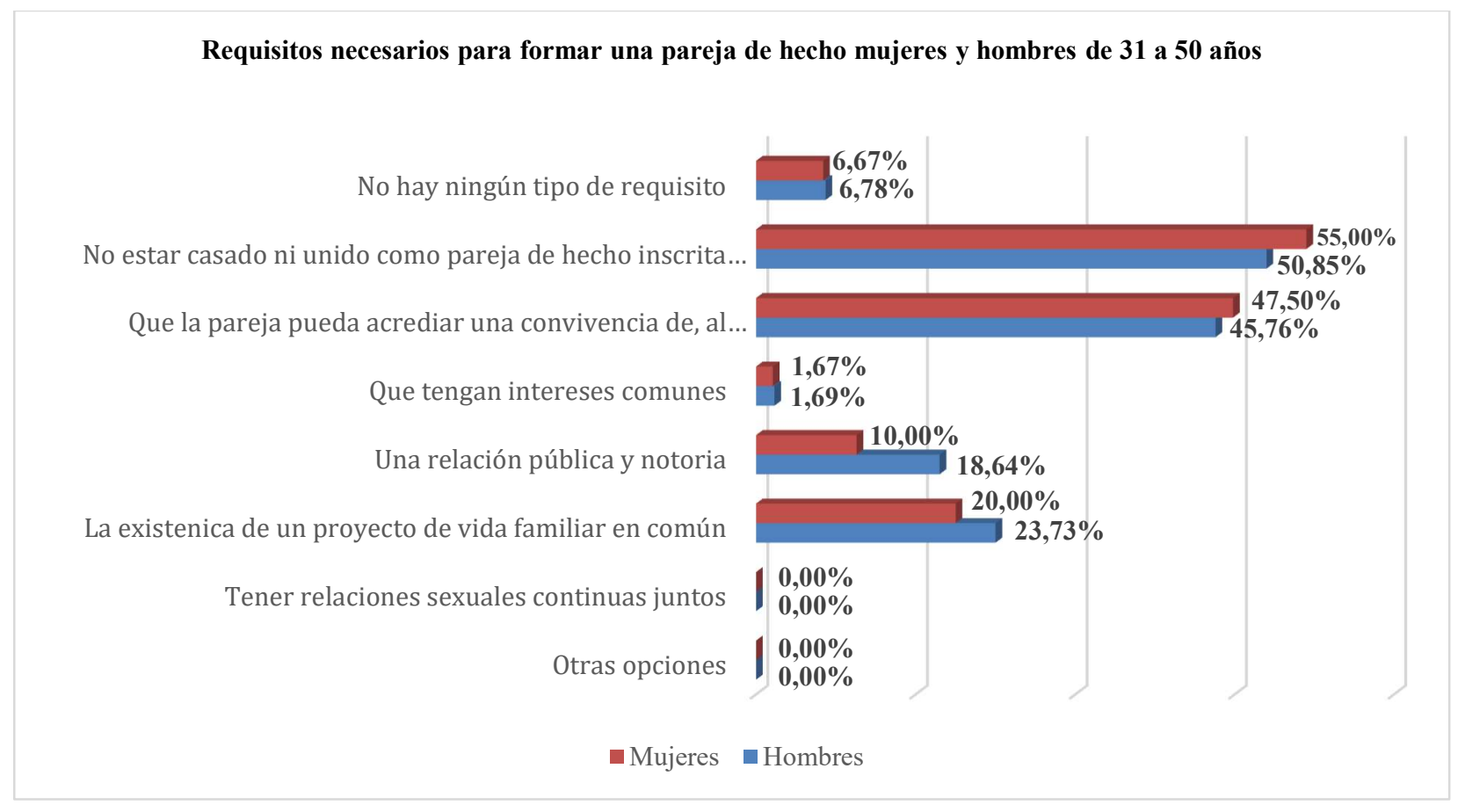

Sin embargo, entre los mayores de 51 años las respuestas resultan de mucha mayor diversidad según los sexos de los encuestados. Así, mientras entre las mujeres de esta edad se mantiene el requisito de libertad legal para constituir pareja de hecho, en porcentajes similares a las de menor edad, con un $54,43 \%$, entre los varones ese requisito solamente es señalado por el $25 \%$ de los encuestados; por el contrario, en cuanto a la exigencia de acreditar una convivencia entre los miembros de la pareja se establece como requisito por el 47,50 \% de los hombres, en línea con los de una edad inmediatamente inferior, mientras que, entre las mujeres, ese porcentaje baja hasta el 30,38\%, muy inferior al señalado entre las mujeres del tramo anterior. La exigencia de una relación pública y notoria es señalada, en cambio, por un 13,92 \% de las mujeres y un $10 \%$ de los hombres.

Otros requisitos, carentes de connotaciones legales, como la existencia de un proyecto de vida familiar en común es señalado por un destacado 32,5\% de los hombres mayores de 51 años y un $21,52 \%$ de las mujeres de esa misma edad. Mientras que la existencia de intereses comunes lo señalan un $7 \%$ de los hombres y un $3,8 \%$ de las mujeres. 


\section{Gráfico 9. Requisitos necesarios para formar una pareja de hecho, respuesta por sexo en la cohorte de 51 a 65 años}

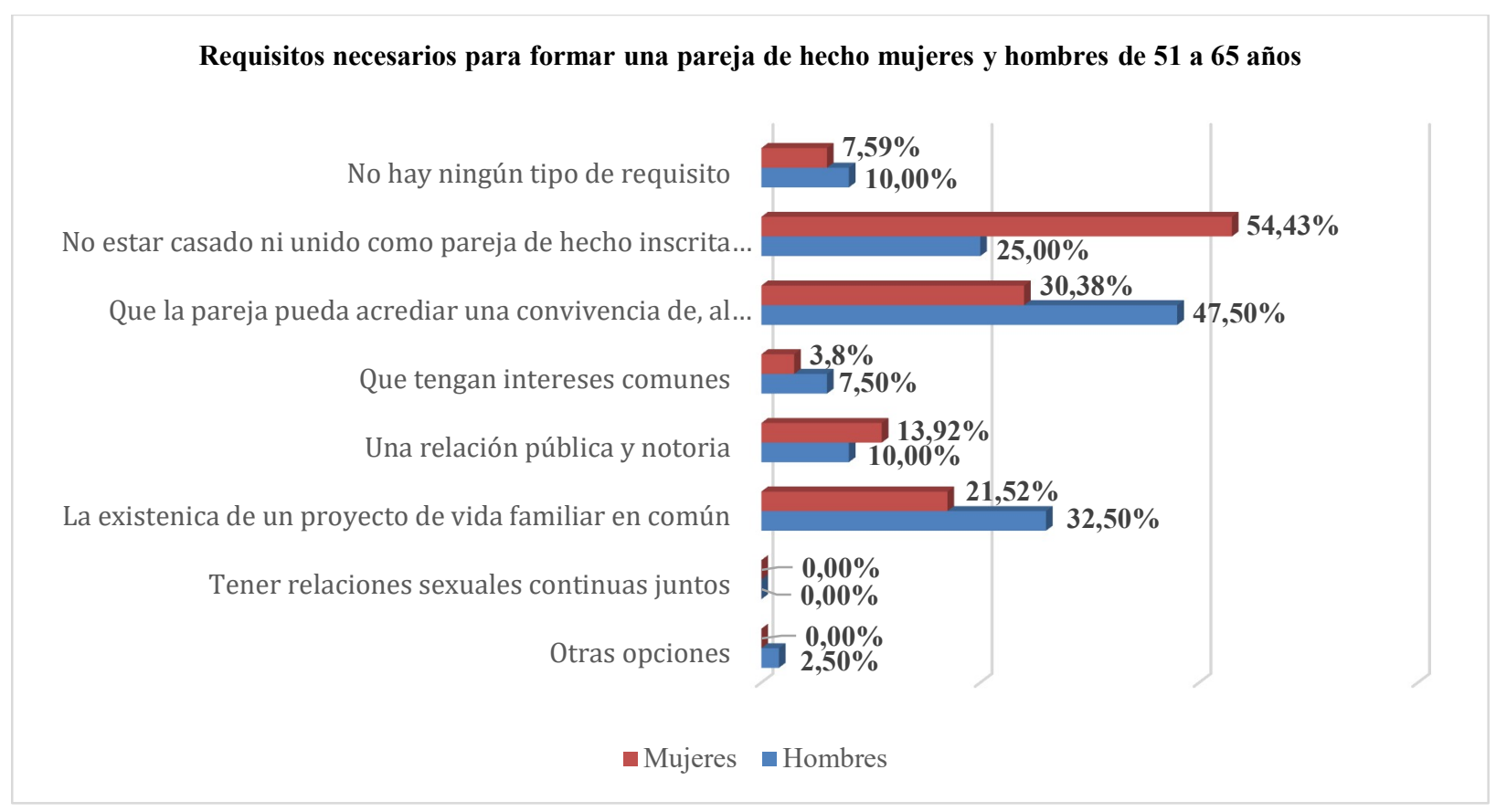

Si segregamos por el sexo y la relación de afectividad que mantienen los encuestados, obtenemos unos resultados similares, si bien con características propias en cada caso. Así entre los casados se mantiene la constante de los requisitos esenciales, de manera que el 49, $11 \%$ de las mujeres y el 36,67 \% de los hombres mantienen como requisito para constituir la pareja de hecho la necesidad de tener libertad legal para la inscripción, mientras que el requisito de acreditar la convivencia previa se señala por el 44,64 \% de las mujeres y el $40 \%$ de los hombres, mientras que la existencia de una relación pública y notoria la señalan el 15,18 \% de las mujeres y el 13,33 \% de los hombres. Manteniendo entre los casados la diferencia entre los sexos en cuanto a la exigencia de otros requisitos como la existencia de un proyecto de vida familiar en común que es señalada por el 33,33 \% de los hombres y el 20,54 \% de las mujeres y la existencia de intereses comunes es señalado por el $10 \%$ de los hombres y el $4,45 \%$ de las mujeres. 


\section{Gráfico 10. Requisitos necesarios para formar una pareja de hecho, respuesta por sexo y estado civil casado}

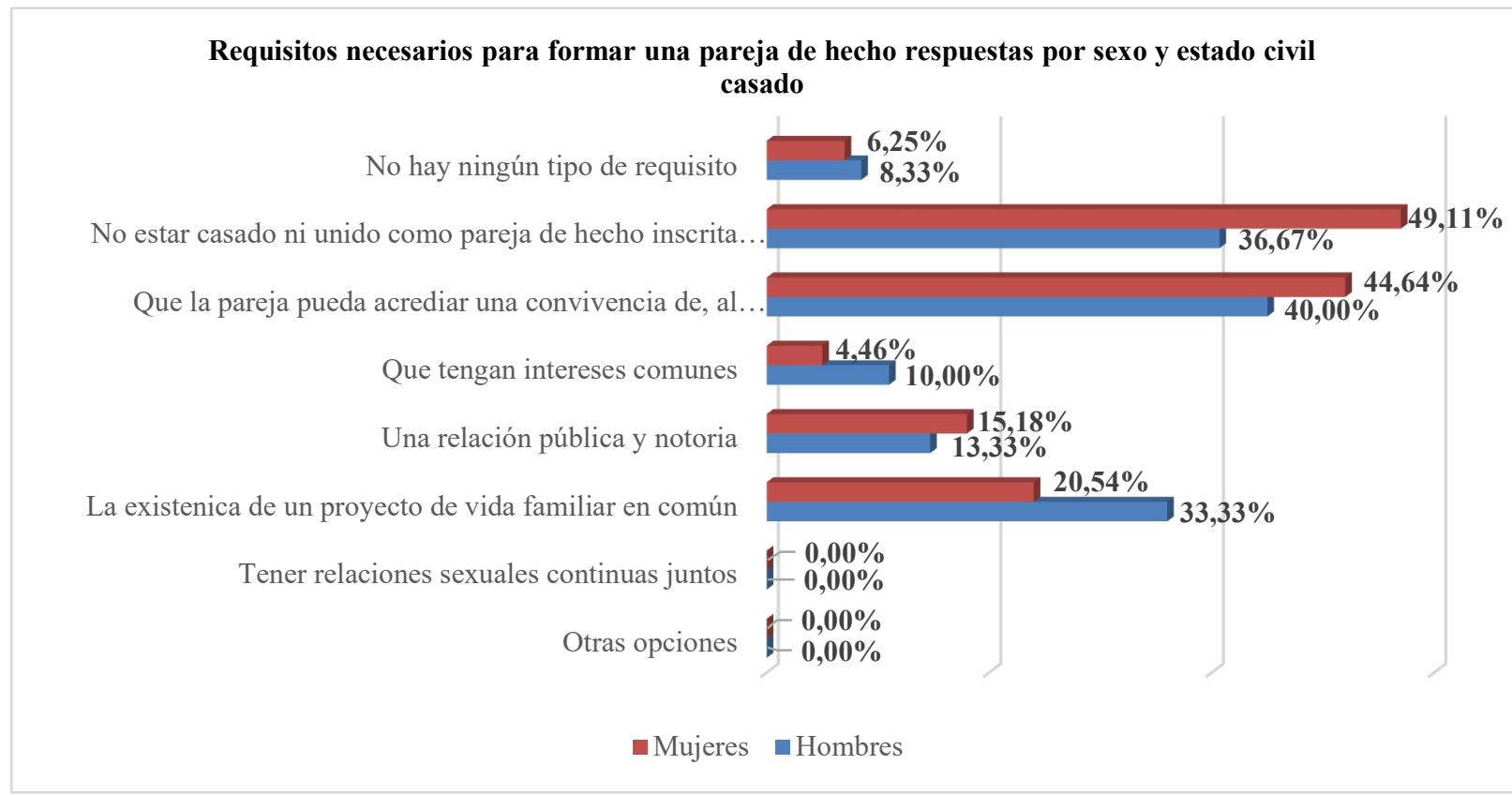

En cuanto a las personas unidas en relación de convivencia de parejas de hecho no registrada vemos como se mantienen los requisitos señalados de manera constante por los encuestados, y con las matizaciones existentes en otros grupos segregados. Así, la exigencia de no estar casados ni unidos como pareja de hecho inscrita es señalado como requisito por el $60 \%$ de las mujeres y el 41,67 \% de los hombres con este tipo de relación convivencial. Mientras que la acreditación de la convivencia durante un período previo es señalada por el $40 \%$ de las mujeres y el 41,67\% de los hombres, quienes también señalan en un alto porcentaje el requisito de una relación pública y notoria con un $41,67 \%$, mientras las mujeres lo señalan solamente en un $10 \%$.

Otros requisitos como la existencia de un proyecto de vida familiar en común, es señalado por un $25 \%$ de los hombres y un $15 \%$ de las mujeres, y la existencia de intereses comunes solamente es señalado por los hombres en un porcentaje del $8,33 \%$. 


\section{Gráfico 11. Requisitos necesarios para formar una pareja de hecho, respuesta por sexo y estado civil de pareja de hecho no registrada}

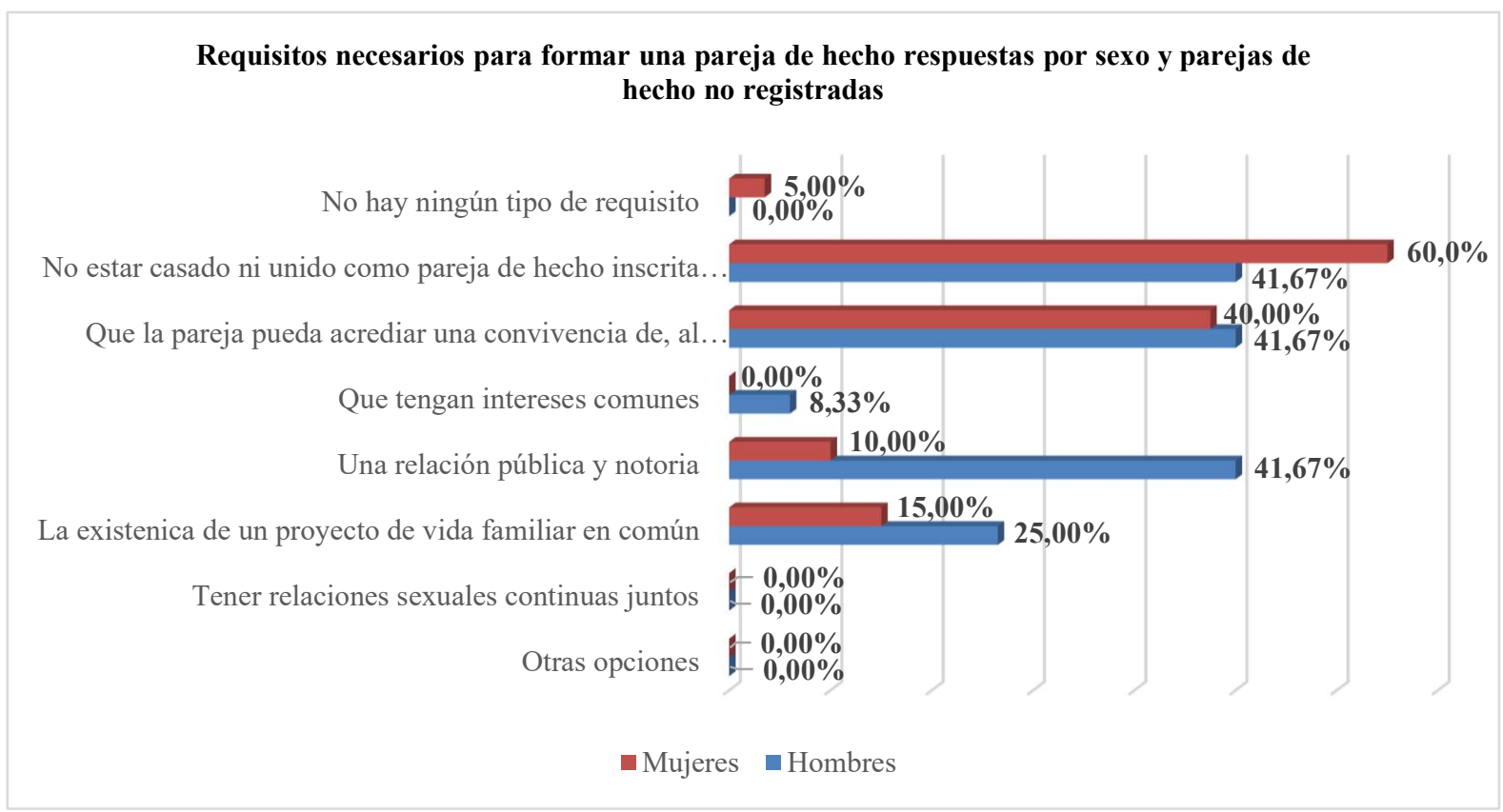

Por su parte, entre los solteros, la existencia o no de una relación estable de pareja, manteniendo las tendencias generales apuntadas, parece determinar visiones distintas de los requisitos para constituir una pareja de hecho. Así, la exigencia de no estar casado ni inscrito como pareja de hecho es señalado como requisito por el $63,83 \%$ de las mujeres solteras sin relación estable de pareja frente al $46,68 \%$ de las solteras que tienen una relación de pareja estable; mientras, entre los hombres solteros, ese requisito es señalado por el $44,12 \%$ de los solteros sin relación estable de pareja y por el 53,57 \% cuando tienen esa relación estable. La acreditación de la convivencia previa es señalada por el 44,68 \% de las solteras sin relación estable de pareja y el 40,43 cuando tienen relación estable, es decir, en porcentajes similares; algo parecido ocurre entre los hombres solteros, entre los que se señala el $41,18 \%$ entre los solteros sin relación estable de pareja y el 32,14 entre los varones solteros con relación estable de pareja. Sin embargo, estos porcentajes se invierten cuando se trata de la necesidad de una relación pública y notoria, que es señalada por el $25 \%$ de los varones solteros con relación estable de pareja y el 17,65\% de los solteros sin esa relación estable; en cambio, las mujeres señalan ese requisito en un 19,15\% de las solteras con relación estable de pareja, y solamente en un 6,38 \% de los casos de mujeres solteras sin relación estable de pareja. 
En cuanto a otros requisitos, sin las connotaciones jurídicas de los anteriores, como la existencia de un proyecto de vida familiar en común es señalado por el $42,86 \%$ de los solteros varones con relación estable de pareja y solamente por el $20,59 \%$ de los hombres solteros $\sin$ relación estable de pareja, mientras que esos porcentajes se invierten en el caso de las mujeres solteras, ya que las que no tienen pareja estable señalan el requisito de existencia de un proyecto de vida familiar en común en un 31,91\%, mientras que entre las que tienen una relación de pareja estable lo señalan en un $25,53 \%$. Siendo mucho menos significativos los porcentajes con los que señalan la necesidad de tener intereses comunes en ambos supuestos.

\section{Valoración social sobre los derechos y obligaciones, de carácter general, entre los miembros de una pareja de hecho}

Con el objeto de conocer una opinión general sobre la consideración de en qué consiste la pareja de hecho, se preguntaba a los encuestados por los derechos y obligaciones entre los miembros de una pareja de hecho en relación con los existentes en la pareja unida por matrimonio. Al efecto, se planteaban tres posibles respuestas: que los derechos y obligaciones entre los miembros de la pareja fuesen los mismos que los existentes entre los miembros de una pareja matrimonial, que existen derechos y obligaciones entre los miembros de la pareja, pero que son menos que los existentes en el matrimonio y una tercera respuesta en la que se señalaba que entre los miembros de una pareja de hecho no existen derechos y obligaciones.

\section{Gráfico 12. Derechos y obligaciones legales entre los miembros de una pareja de hecho, respuesta general}

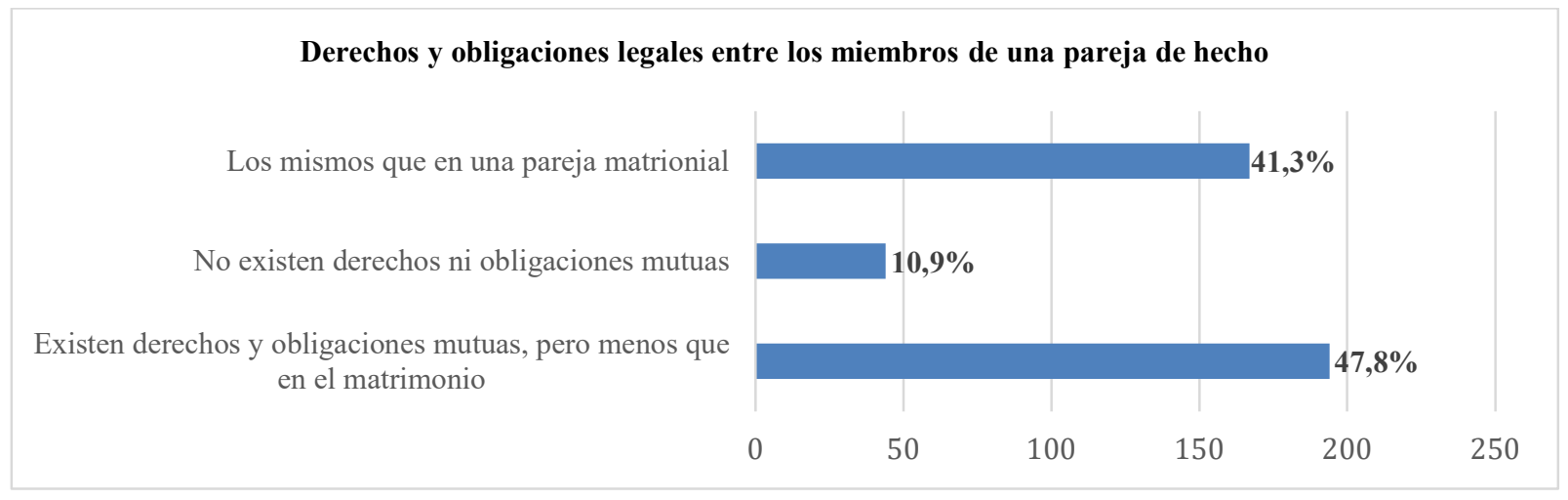

Como se observa en el gráfico general de respuestas recibidas, un 47,8 \% piensa que, si bien existen derechos y obligaciones entre los miembros de una pareja de hecho, tales derechos y 
obligaciones son menores que los existentes en una pareja casada. Mientras, un muy significativo $41,3 \%$ de los encuestados piensa que los derechos y obligaciones entre los miembros de una pareja de hecho son los mismos que los existentes en una pareja casada, y solamente en un 10,9\% de las respuestas recibidas se piensa que no existen derechos ni obligaciones entre los miembros de una pareja de hecho.

Así, pues, en una primera aproximación podría concluirse que, mayoritariamente, los españoles ven la unión more uxorio como una unión con similares características a las del matrimonio, pero con menos derechos y obligaciones que en este. Y ello, porque una inmensa mayoría del 89,1 \% entiende que la constitución de una pareja de hecho conlleva el nacimiento de una suerte de derechos y obligaciones entre los miembros de la misma; en qué consista, exactamente, tal entramado de derechos y obligaciones se verá en las respuestas a otras de las preguntas de la encuesta, pero ya en esta primera aproximación a la visión de los españoles sobre qué cosa es una pareja de hecho, resulta evidente esta conclusión: entre los miembros de una pareja de hecho, por la simple razón de constituirse como tal, surge un entramado de derechos y obligaciones.

Analizaremos de manera segregada las respuestas a fin de determinar la implantación de cada una de las respuestas propuestas entre los diferentes grupos de encuestados. En primer, lugar, veremos las diferentes respuestas dadas a la cuestión planteada por los hombres y por las mujeres, en una primera aproximación segregando por sexos a los participantes en la encuesta. Así, comprobamos que, pese a no ser muy grande la diferencia, entre los hombres se percibe como una unión generadora de derechos y obligaciones, pero menos que en el matrimonio de un modo más acusado que entre las mujeres, lo que podría ser interpretado como que los varones podrían estar más dispuestos a una relación de pareja de hecho que al matrimonio, precisamente, por ese menor haz de derechos y obligaciones que considera existen en este tipo de unión. Del mismo modo, podría concluirse que la mujer tiende a creer que el conjunto de derechos y obligaciones en una pareja de hecho es el mismo que en el matrimonio, ya que la diferencia existente entre ambas respuestas queda dentro del margen de error aceptado en la encuesta. 


\section{Gráfico 13. Derechos y obligaciones legales entre los miembros de una pareja de hecho, respuesta por sexo}
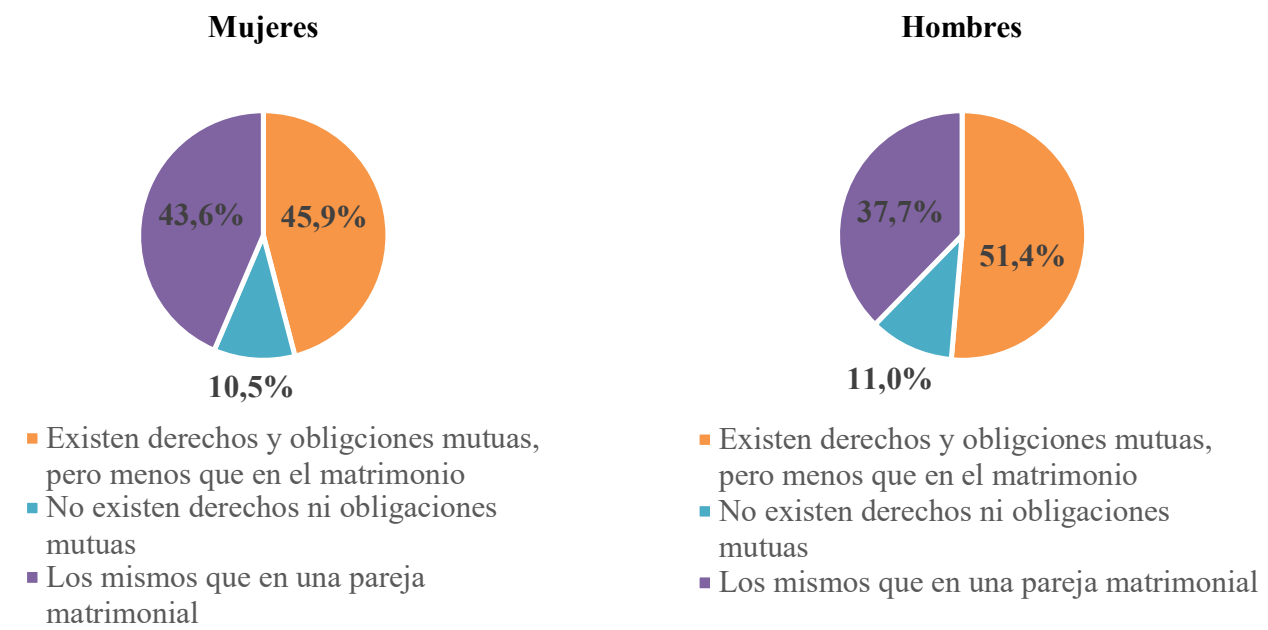

En efecto, mientras que, entre los hombres, el porcentaje de encuestados que cree que los derechos y obligaciones derivados de la unión de hecho es el mismo que en el matrimonio es de un $37,7 \%$, entre las mujeres ese porcentaje sube hasta un $43,6 \%$, es decir, seis puntos más; y, del mismo modo, en cuanto a que sí que existen derechos y obligaciones entre los miembros de una pareja de hecho, pero que son menos que en un matrimonio también se manifiesta una diferencia similar, mientras que entre las mujeres piensa de ese modo un 45,9\%, entre los hombres ese porcentaje crece hasta el 51,4\%, es decir, más de la mitad de los hombres encuestados piensan de ese modo.

Si añadimos el componente de la edad de los encuestados vemos cómo evoluciona con la edad, de manera muy diferente entre hombres y mujeres, así iremos haciendo la comparativa entre ambos sexos en los diferentes tramos de edad:

En el tramo de edad de entre 18 y 30 años la diferencia en la opinión entre hombres y mujeres resulta muy significativa, pues mientras que, entre los hombres un abrumador $72,4 \%$ piensa que existen derechos y obligaciones, pero menos que en el matrimonio, entre las mujeres ese porcentaje baja hasta un 51,2\% entre las mujeres; en sentido contrario, mientras que entre los hombres un 20,7 \% piensa que existen los mismos derechos y obligaciones que en el matrimonio, entre las mujeres ese porcentaje sube hasta el $34,9 \%$, considerando entre estas que no existen derechos y obligaciones entre los miembros de la pareja en un $14 \%$ de las encuestadas, mientras 
que entre los hombres solamente un 6,9\% piensa que no existen derechos y obligaciones como consecuencia de la constitución de una pareja de hecho.

\section{Gráfico 14. Derechos y obligaciones legales entre los miembros de una pareja de hecho, respuesta por sexo en la cohorte de 18 a 30 años}
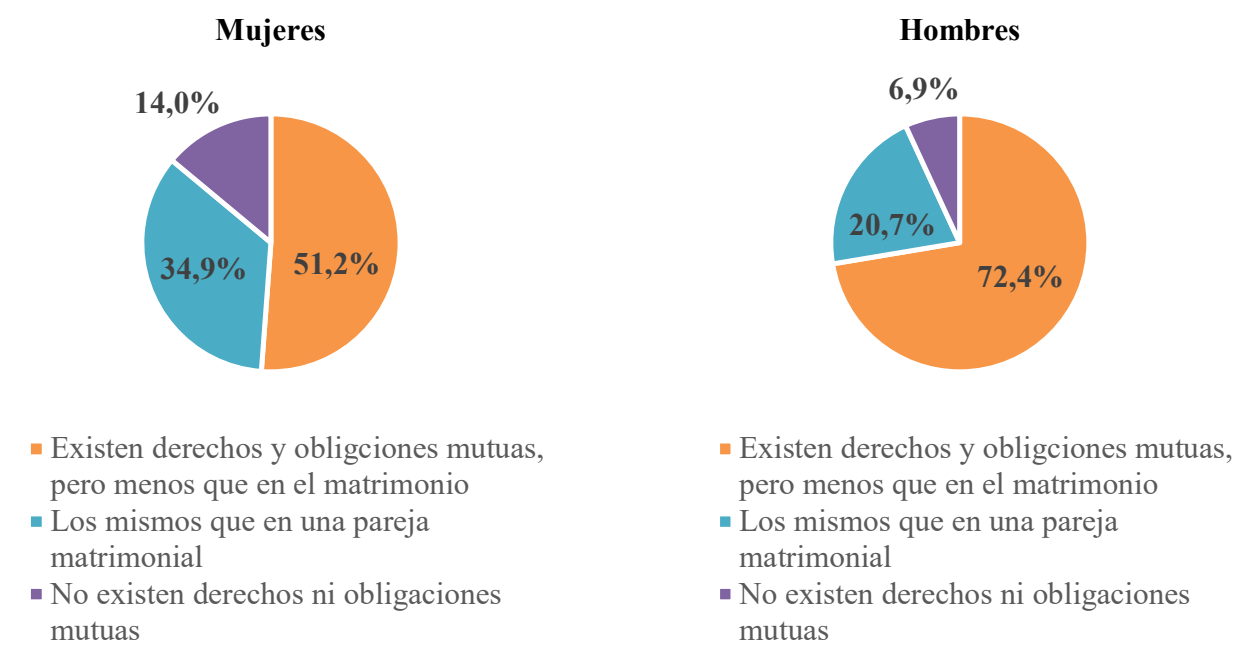

Estos porcentajes varían con la edad, de manera especialmente notoria en el caso de los hombres como iremos viendo en los distintos tramos de edad:

Gráfico 15. Derechos y obligaciones legales entre los miembros de una pareja de hecho, respuesta por sexo en la cohorte de 31 a 50 años

Mujeres

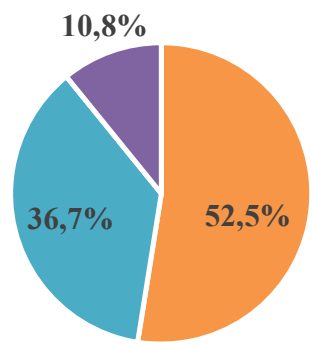

- Existen derechos y obligciones mutuas, pero menos que en el matrimonio

- Los mismos que en una pareja matrimonial

- No existen derechos ni obligaciones mutuas
Hombres

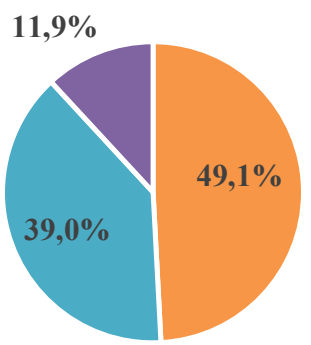

\footnotetext{
- Existen derechos y obligciones mutuas, pero menos que en el matrimonio

- Los mismos que en una pareja matrimonial

- No existen derechos ni obligaciones mutuas
} 
Y ello, porque como comprobamos en el siguiente tramo de edad, entre las personas que tienen entre 31 y 50 años, las diferencias por sexo son mínimas; así, opinan que existen derechos y obligaciones, pero menos que en el matrimonio un $49,1 \%$ de los hombres de este tramo de edad, significativamente igual que el 52,5\% de las mujeres del mismo tramo de edad. Igual sucede en el caso de los que piensan que los derechos y obligaciones son los mismos que en el matrimonio, que son un $39 \%$ entre los hombres y un $36,7 \%$ entre las mujeres.

En el siguiente tramo de edad, entre 51 y 65 años, las opiniones divergen menos por sexo, pero el cambio viene dado porque son mayoritarios en pensar que el entramado de derechos y obligaciones entre los miembros de la pareja de hecho y el matrimonio son los mismos:

\section{Gráfico 16. Derechos y obligaciones legales entre los miembros de una pareja de hecho, respuesta por sexo en la cohorte de 51 a 65 años}

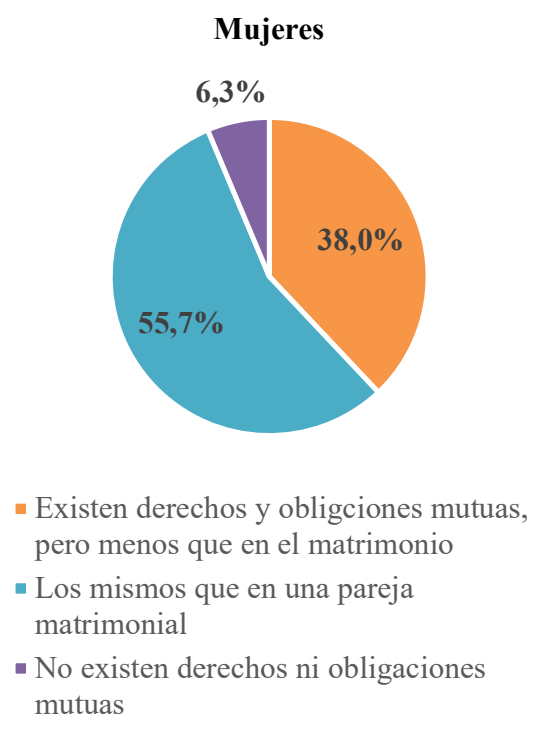

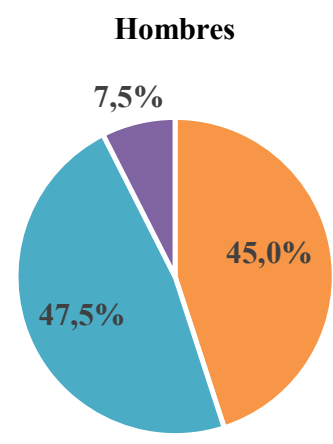

\footnotetext{
- Existen derechos y obligciones mutuas, pero menos que en el matrimonio

- Los mismos que en una pareja matrimonial

- No existen derechos ni obligaciones mutuas
}

Como se puede comprobar, los encuestados de este tramo de edad piensan que los derechos $\mathrm{y}$ obligaciones son los mismos en un matrimonio que en una pareja de hecho, aunque ese pensamiento es más acentuado entre las mujeres que entre los hombres, así piensan de este modo un $55,7 \%$ de las mujeres, frente a un $47,5 \%$ de los hombres, siendo mínimo en ambos casos los que piensan que no existen derechos ni obligaciones como consecuencia de la constitución de una unión de hecho, al limitarse a un 7,5\% de los hombres y un 6,3\% de las mujeres los que piensan de tal modo. Siendo, en cambio, un importante $45 \%$ de los hombres y un $38 \%$ de las mujeres 
quienes piensan que si bien existen derechos y obligaciones estos son menores que en el caso del matrimonio.

Si la segmentación de las respuestas de los encuestados se realiza por sexo y situación afectiva del encuestado se observa que, entre las personas casadas, se siguen los patrones más o menos generales que veíamos en la segmentación por edades de los distintos sexos, tanto entre los hombres como en las mujeres casadas se entiende que existen derechos y obligaciones derivados de la unión de hecho, ya que la respuesta de que no existen los mismos es un exiguo 7,6 \% entre las mujeres y poco más, un $10 \%$ entre los hombres.

\section{Gráfico 17. Derechos y obligaciones legales entre los miembros de una pareja de hecho, respuesta por sexo y estado civil de casado}

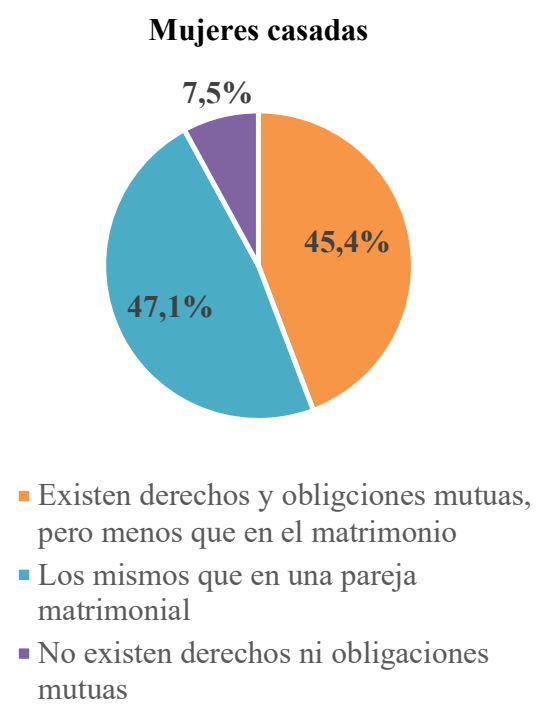

Hombres casados

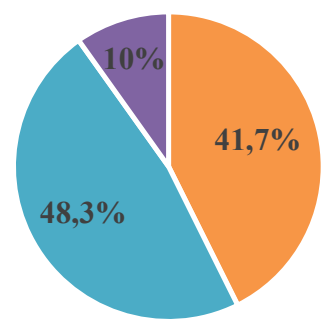

- Existen derechos y obligciones mutuas, pero menos que en el matrimonio

- Los mismos que en una pareja matrimonial

- No existen derechos ni obligaciones mutuas

En ambos casos, tanto los hombres como las mujeres unidos por matrimonio piensan que los derechos y obligaciones son los mismos en las parejas de hecho que en el matrimonio en un significativo 48,3\% de los hombres casados y en porcentaje parecido, un 47,1\% entre las mujeres. Que existen derecho y obligaciones ente los miembros de la pareja, pero menos que en el caso del matrimonio, lo piensa un porcentaje muy similar de personas casadas, un $41,7 \%$ entre los hombres y un $45,4 \%$ entre las mujeres casadas.

Llama más la atención las diferencias por sexo entre las personas que forman parte de una pareja de hecho: 


\section{Gráfico 18. Derechos y obligaciones legales entre los miembros de una pareja de hecho, respuesta por sexo y estado civil de pareja de hecho}

Mujeres pareja de hecho

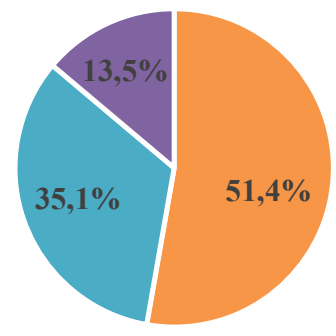

- Existen derechos y obligciones mutuas, pero menos que en el matrimonio

- Los mismos que en una pareja matrimonial

- No existen derechos ni obligaciones mutuas
Hombres pareja de hecho

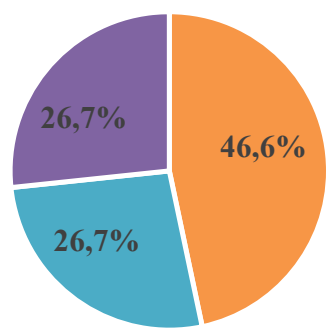

- Existen derechos y obligciones mutuas, pero menos que en el matrimonio

- Los mismos que en una pareja matrimonial

- No existen derechos ni obligaciones mutuas

Como puede apreciarse las diferencias son significativas entre ambos sexos; así, mientras que entre los hombres unidos en pareja de hecho registrada o no, un importante $26,7 \%$ de ellos piensan que no existen derecho ni obligaciones, entre las mujeres unidas en pareja de hecho ese porcentaje se reduce hasta el 13,5\%. En cualquier caso, es muy mayoritaria la creencia de que con la constitución de una pareja de hecho nacen una serie de derechos y obligaciones entre los convivientes, ya que un importante $51,4 \%$ de las mujeres en esta situación y un 46,6 \% de los hombres con este tipo de unión, piensan que existen derechos y obligaciones mutuos, pero menos que en el matrimonio. Mientras que, opinan que se trata de una unión con el mismo entramado de derechos y obligaciones que en el matrimonio, un $35,1 \%$ de las mujeres y un $26,7 \%$ de los hombres encuestados unidos en pareja de hecho.

Otra segmentación interesante entendemos que es la de las personas que permanecen solteras, independientemente de que mantengan una relación estable o no. En estos casos, los datos de que no existen derechos ni obligaciones en la constitución de una pareja de hecho son menos diferenciados por sexo de lo que eran en el caso de personas unidas en pareja de hecho, de manera que piensan que no existen relaciones obligacionales entre los miembros de la pareja en porcentajes ciertamente bajos, un $12,7 \%$ de las mujeres solteras y un $9,7 \%$ de los hombres solteros piensan 
de este modo, con lo que resulta extremadamente mayoritario el pensamiento de que existe un entramado de derechos y obligaciones mutuos al unirse en pareja de hecho.

\section{Gráfico 19. Derechos y obligaciones legales entre los miembros de una pareja de hecho, respuesta por sexo y estado civil de soltería}
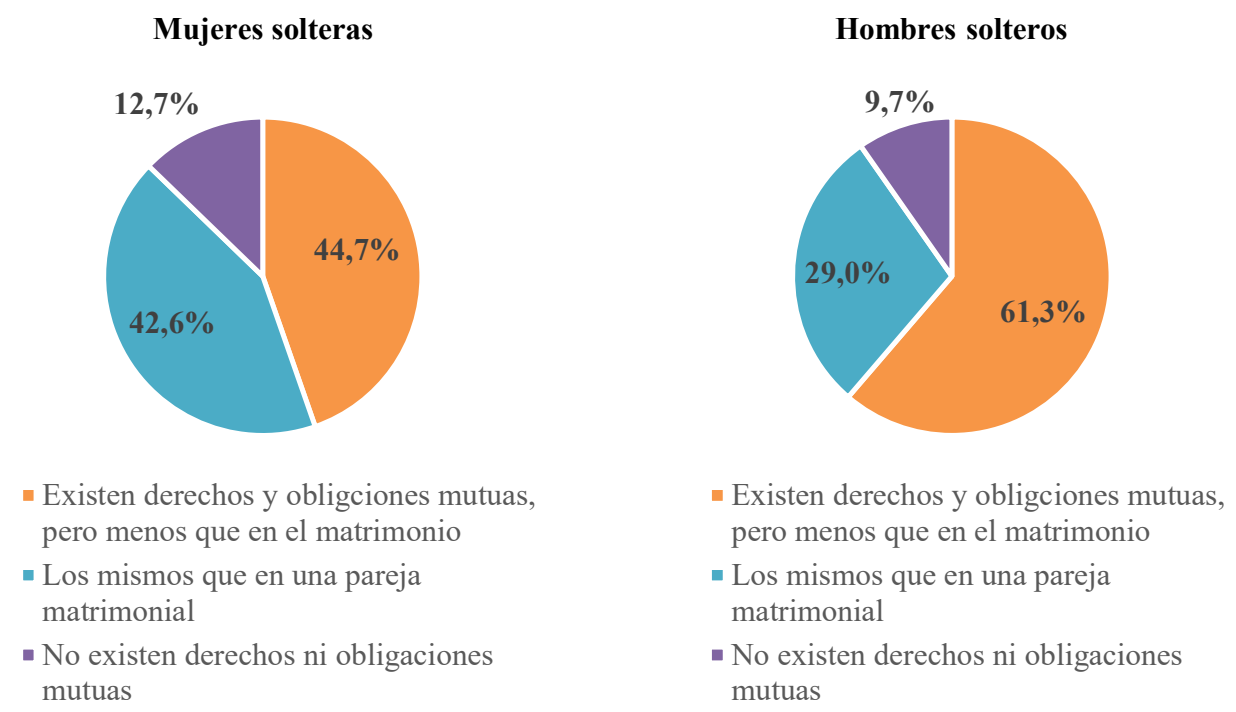

Piensan que los derechos y obligaciones derivados de la unión de hecho son los mismos que en el matrimonio un significativo $42,6 \%$ de las mujeres, porcentaje que baja hasta el $29 \%$ de los hombres solteros. En cambio, piensan que existen derechos y obligaciones mutuos un destacado $61,3 \%$ de los hombres solteros y un importante, pero claramente inferior, $44,7 \%$ de las mujeres solteras.

En suma, en esta primera pregunta sobre la opinión de los encuestados relativa a los efectos de constituir una pareja de hecho, se comprueba que es muy mayoritaria la opinión de que implica obligaciones y derechos mutuos entre los convivientes; si bien parece existir una importante confusión social sobre si al constituirse una unión de hecho se están adquiriendo los mismos derechos y obligaciones entre los miembros de la pareja que si hubiesen contraído matrimonio; o si, en cambio, la unión de hecho constituye algo así como un matrimonio más relajado, menos exigente, en el que existirían derechos y obligaciones, pero con una capacidad de obligatoriedad menor que la existente entre los cónyuges. Entre los hombres, con diferencias según la edad y el estado civil, la respuesta mayoritaria parece indicar que entienden la pareja de hecho como una relación con derechos y obligaciones mutuos, pero en una situación de menor compromiso que el 
matrimonio. Por su parte, entre las mujeres, igualmente con diferencias según la edad y el estado civil, siendo la respuesta mayoritaria la misma que entre los hombres, existe una mayor tendencia a ver la relación de convivencia more uxorio como una relación de derechos y obligaciones igual que el matrimonio. Naturalmente, el tamaño de la encuesta no permite conclusiones absolutamente definitivas, sino simplemente obtener tendencias. No obstante, esta primera impresión deberá corroborarse o matizarse en las siguientes respuestas en las que los encuestados deberán precisar más concretamente los derechos y obligaciones que consideran que existen o que deberían existir en las uniones de hecho convivenciales.

\section{B) VALORACIÓN SOBRE DERECHOS CONCRETOS ENTRE LOS MIEMBROS DE UNA PAREJA DE}

\section{HECHO}

En esta pregunta se pedía a los encuestados que indicasen los derechos existentes entre los miembros de una pareja de hecho, ya sean por Normas de derecho público o lo sean por Normas de Derecho privado. Con la pregunta se busca determinar el nivel de conocimiento social sobre los derechos que genera la relación convivencial en pareja de hecho registrada, por ello se proponían respuestas tanto de derechos reconocidos a las uniones convivenciales, como derechos de carácter privado no establecidos por norma alguna.

Una de las respuestas propuestas señalaba que "no existen derechos entre los miembros de la pareja”. Pese a que los encuestados podían señalar todas las respuestas que considerasen, solamente un $11,6 \%$ de los mismos optaron por esta contestación, pudiendo concluirse que son excepción quienes consideran que no existen derechos entre los miembros de la pareja, por lo que parece evidente que la generalidad de la población considera este modo de relación como una fuente generadora de derechos entre los convivientes. Por otra parte, este porcentaje es similar al de los que, en una respuesta anterior, ya nos decían que no existen derechos ni obligaciones entre los miembros de una pareja de hecho (entonces era el 10,9\%).

Como hemos dicho, en la encuesta se daba la oportunidad de señalar todas las respuestas que considerasen válidas, de manera que la suma de respuestas no será igual al número de encuestados, ni nos encontraremos ante unos porcentajes de suma cien, sino que los porcentajes de cada una de las respuestas será en relación con el número de encuestados.

Precisado lo anterior, comprobamos como los encuestados señalan, como derechos correspondientes a las personas unidas en pareja de hecho, los de tener derecho a días de permiso 
en el trabajo a causa de enfermedad del otro miembro de la pareja, lo cual es señalado por un representativo $60 \%$ de las respuestas, el derecho a realizar una adopción conjunta de un hijo por ambos miembros de la pareja lo señaló un 56,8 \% de los encuestados, y el derecho a pensión de viudedad en caso de fallecimiento de uno de los miembros de la pareja, con cargo al sistema nacional de la Seguridad Social, fue señalado en el 54,1 \% de las respuestas recibidas. Entre los derechos sujetos exclusivamente al ámbito del Derecho privado propuestos como posibles respuestas sorprende que el $41,7 \%$ de las respuestas recibidas señala la existencia de derechos hereditarios en caso de fallecimiento de la pareja, en proporciones claramente menores se señalaron otras situaciones como el derecho a una pensión compensatoria en caso de ruptura de la pareja, que fue señalado por un 20,5\% de los encuestados, o el derecho a la mitad de los bienes adquiridos por el otro miembro de la pareja durante el tiempo de convivencia, que fue señalado por un $2,2 \%$ de los encuestados.

\section{Gráfico 20. Conocimiento de los derechos legales entre los miembros de una pareja de hecho, respuesta general}

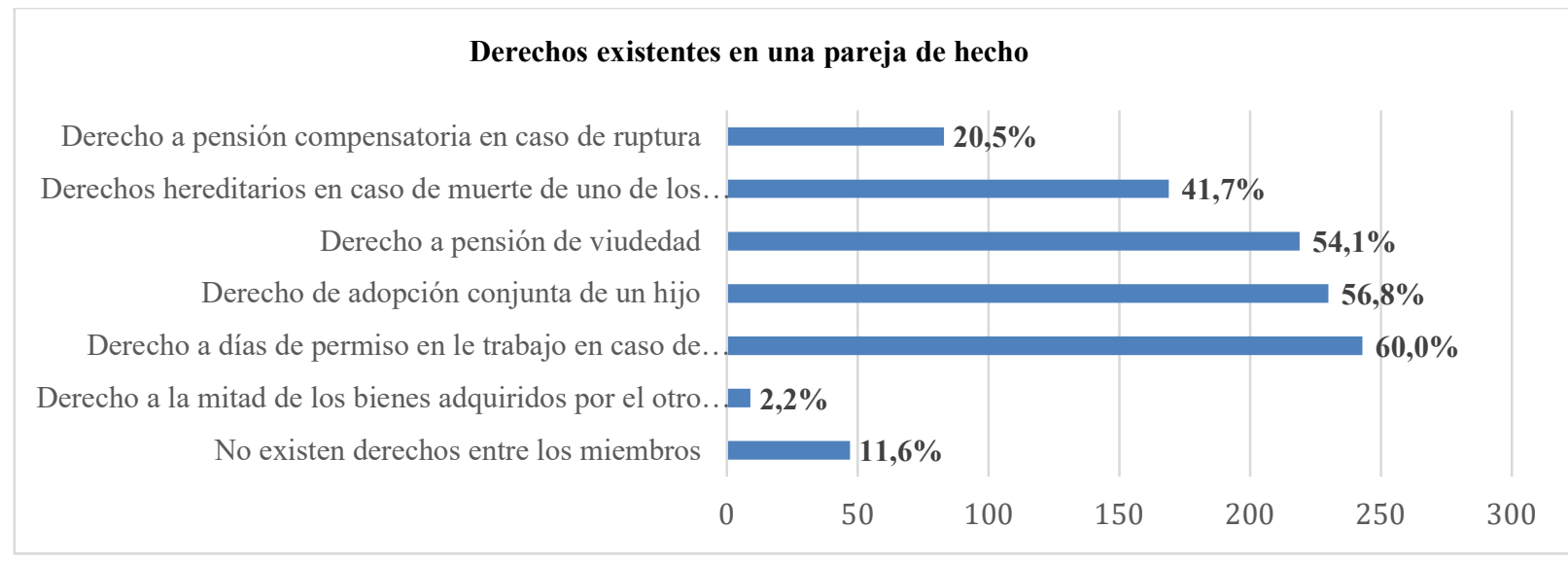

En la segregación por sexos se comprueba unas respuestas similares entre ambos sexos, es decir, no existen diferencias significativas entre hombres y mujeres a la hora de señalar cuáles son los derechos que consideran existen para los miembros de la pareja de hecho. Las respuestas son coincidentes con el análisis realizado con carácter general y los porcentajes, como se observa en el Gráfico adjunto son sensiblemente iguales en ambos sexos en todas y cada una de las respuestas, pudiendo concluirse que no existe diferencia por sexos en la población a la hora de determinar qué derechos consideran que existen entre los miembros de una pareja de hecho. 


\section{Gráfico 21. Conocimiento de los derechos legales entre los miembros de una pareja de hecho, respuesta por sexo}

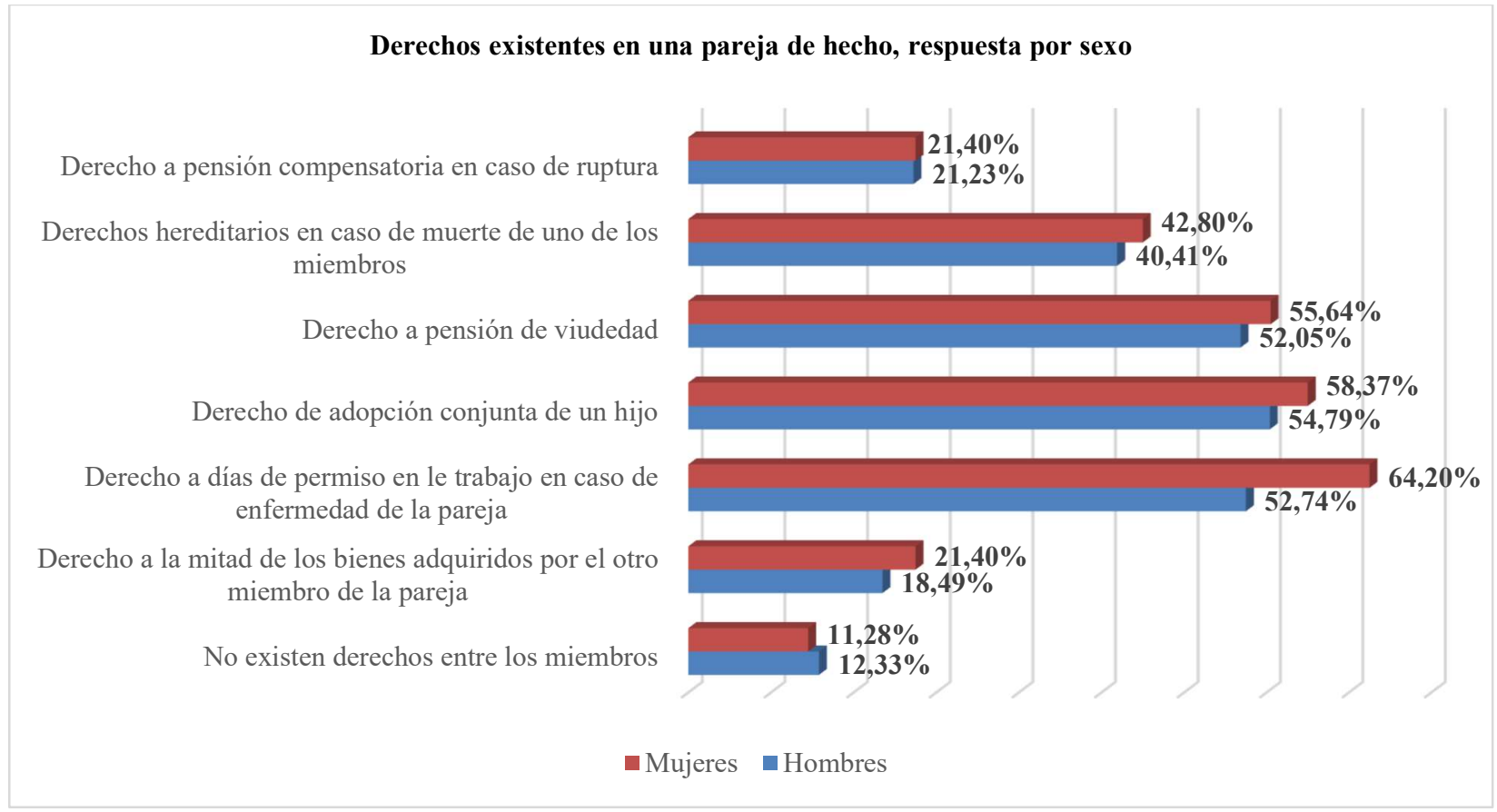

Prácticamente en todos los segmentos que se pueden realizar es la muestra se obtiene un resultado similar. La única solución diferente nos la encontramos en el caso de las parejas de hecho no registradas; en este segmento de los encuestados nos encontramos con un índice mayor de personas que entienden que no existen derechos entre los miembros de la pareja, así el $20 \%$ de las mujeres y el 33,33 \% de los hombres piensan que no existen tales derechos. En cuanto a los que piensan que sí existen derechos entre los miembros de la pareja de hecho, dentro de este segmento, nos encontramos que un $50 \%$ de los hombres unidos en pareja de hecho no registrada piensa que existe derecho a días de permiso en el trabajo en caso de enfermedad el otro miembro de la pareja porcentaje que se reduce al $30 \%$ en el caso de las mujeres con la misma relación. Para el supuesto de adopción conjunta de un hijo, el porcentaje de hombres que piensan que es un derecho de los miembros de la pareja de hecho es del 41,67\% mientras que dicho porcentaje de nuevo se reduce entre las mujeres con este tipo de relación a un $25 \%$. En relación con el derecho a pensión de viudedad en supuesto de fallecimiento de uno de los miembros de la pareja, entre los hombres, de nuevo, es más elevado que entre las mujeres; igual ocurre en relación con los derechos hereditarios para supuesto de fallecimiento de uno de los miembros de la pareja. Otros presuntos derechos obtienen resultados escasamente representativos, como pudiera ser el caso del derecho a la mitad 
de los bienes adquiridos por otro miembro de la pareja durante la convivencia, con porcentajes ciertamente muy bajos como se observa en el cuadro adjunto, del mismo modo que son porcentajes igualmente bajos los que entienden que pudiera haber un derecho a pensión compensatoria en caso de ruptura de la pareja. Lo sorprendente es que estos resultados, anormalmente diferentes de los obtenidos en la muestra universal, se produzcan precisamente entre las personas unidas como pareja de hecho no registrada.

\section{C) VALORACIÓN SOBRE OBLIGACIONES CONCRETAS ENTRE LOS MIEMBROS DE UNA PAREJA}

\section{DE HECHO}

En esta pregunta se pedía a los encuestados que indicasen las obligaciones legales existentes entre los miembros de una pareja de hecho, ya sean por Normas de Derecho público o lo sean por Normas de Derecho privado. Con la pregunta se busca determinar el nivel de conocimiento social sobre las obligaciones legales entre los miembros de la unión de hecho que genera la relación convivencial en pareja de hecho registrada, por ello se proponían respuestas que recogen presunciones legales derivadas de la propia declaración de la pareja, otras que no tienen contenido jurídicamente exigible y un tercer grupo con contenido de carácter ético.

Una de las respuestas propuestas señalaba que "no existen obligaciones" entre los miembros de la pareja. Pese a que los encuestados podían señalar todas las respuestas que considerasen, un $19,3 \%$ de los mismos optaron por esta contestación, es decir, que una quinta parte de los encuestados entienden que no existe ningún tipo de relación obligatoria entre los miembros de la pareja de hecho, ni siquiera la de convivir, que era una de las respuestas ofrecidas.

Al igual que en la pregunta anterior, en la encuesta se daba la oportunidad de señalar todas las respuestas que considerasen válidas, de manera que la suma de respuestas no será igual al número de encuestados, ni nos encontraremos ante unos porcentajes de suma cien, sino que los porcentajes de cada una de las respuestas será en relación con el número de encuestados, siendo la suma de porcentajes de las respuestas, por tanto, superior a cien.

Precisado lo anterior, comprobamos como los encuestados señalan, como obligaciones correspondientes a las personas unidas en pareja de hecho, en porcentajes similares, las de convivir juntos que es señalada por un $41,7 \%$ de los encuestados que respondieron esta pregunta; la obligación de ayuda mutua entre los miembros de la pareja es considerada por un $40 \%$ de los encuestados; en porcentaje similar se pronuncian los encuestados sobre la obligación de compartir 
las responsabilidades en la casa y en el cuidado y atención a las personas dependientes de los miembros de la pareja, que es tenida como tal obligación por el 42,20 \% de los encuestados. Baja sensiblemente el porcentaje de los que entienden que existe una obligación de respeto a las decisiones personales del otro miembro de la pareja, entendida como tal obligación por un 34,80 \% de los encuestados, mientras que un 40,50 \% de los encuestados entiende que existe la obligación de actuar siempre en interés de la familia que forma con su pareja. Y un 14,80 \% de los encuestados considera que existe obligación de guardarse fidelidad entre los miembros de la pareja de hecho.

\section{Gráfico 22. Conocimiento de las obligaciones legales entre los miembros de una pareja de hecho, respuesta general}

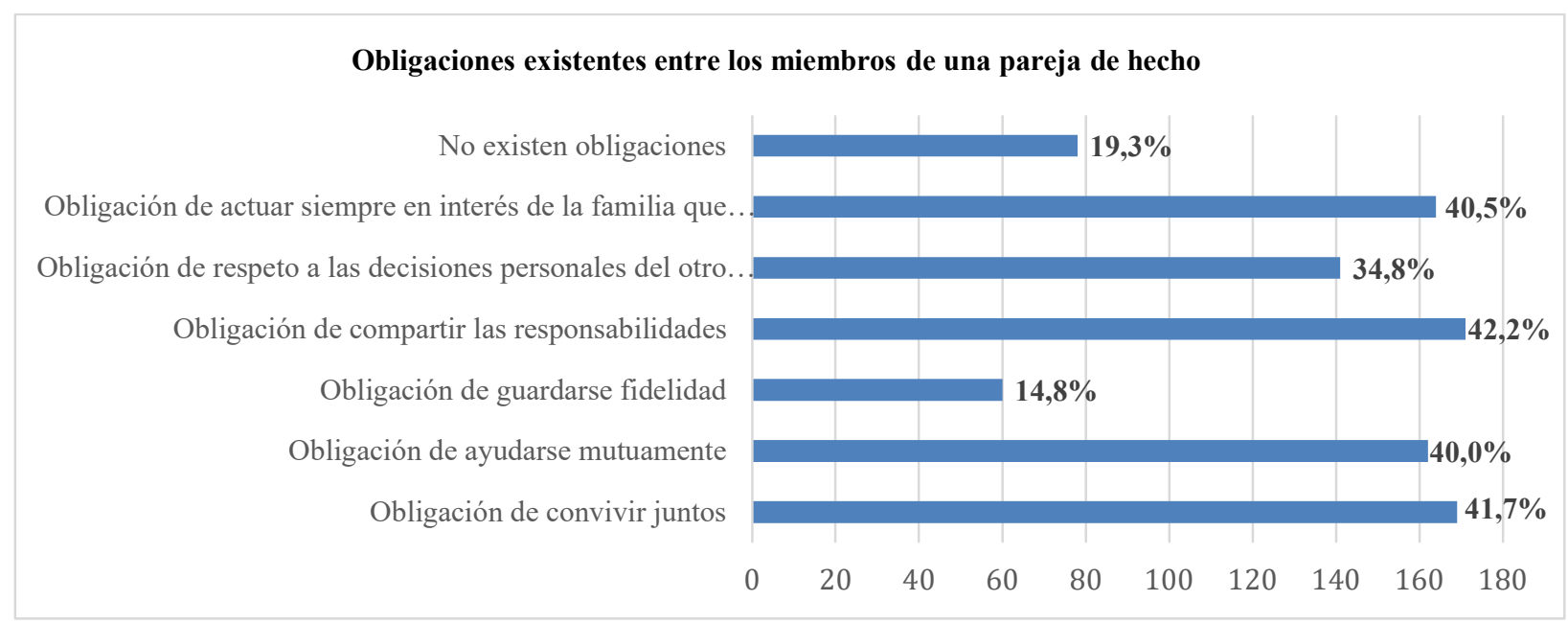

Pese a que las diferencias por sexo no parecen excesivas, sí que se producen algunas variaciones dignas de ser señaladas. Así, mientras que entre los hombres el porcentaje de los que piensan que "no existen obligaciones entre los miembros de la pareja" es de un 14,38 \%, entre las mujeres ese porcentaje asciende hasta el $21,79 \%$, lo cual marcando una misma tendencia general podría representar alguna diferencia en la percepción por sexos. En general la tendencia es similar en ambos sexos en cada una de las respuestas, por lo que se puede concluir que el sexo no determina la posición respecto a las obligaciones que pudieran existir entre los miembros de la pareja de hecho. 


\section{Gráfico 23. Conocimiento de las obligaciones legales entre los miembros de una pareja de hecho, respuesta por sexo}

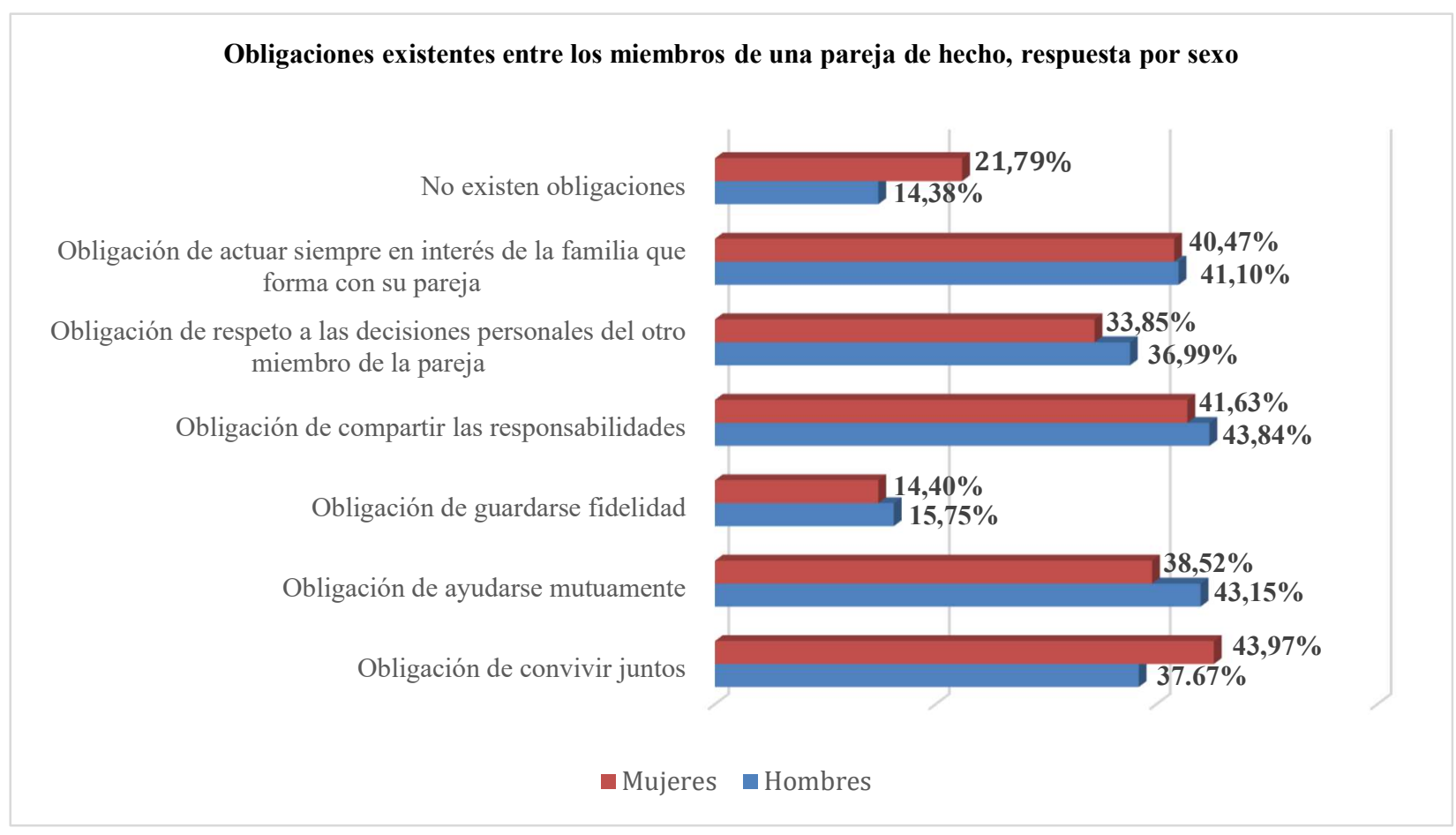

Dada la existencia de tendencias claramente comunes en función del sexo de los encuestados, analizaremos las opiniones de los mismos segregando por la relación de afectividad de los encuestados. Así, vemos que, manteniendo las tendencias generales, entre las personas que permanecen solteras se producen algunas pequeñas diferencias según que mantengan o no una relación estable de pareja. 


\section{Gráfico 24. Conocimiento de las obligaciones legales entre los miembros de una pareja de hecho, respuesta de personas solteros según mantengan o no una relación estable}

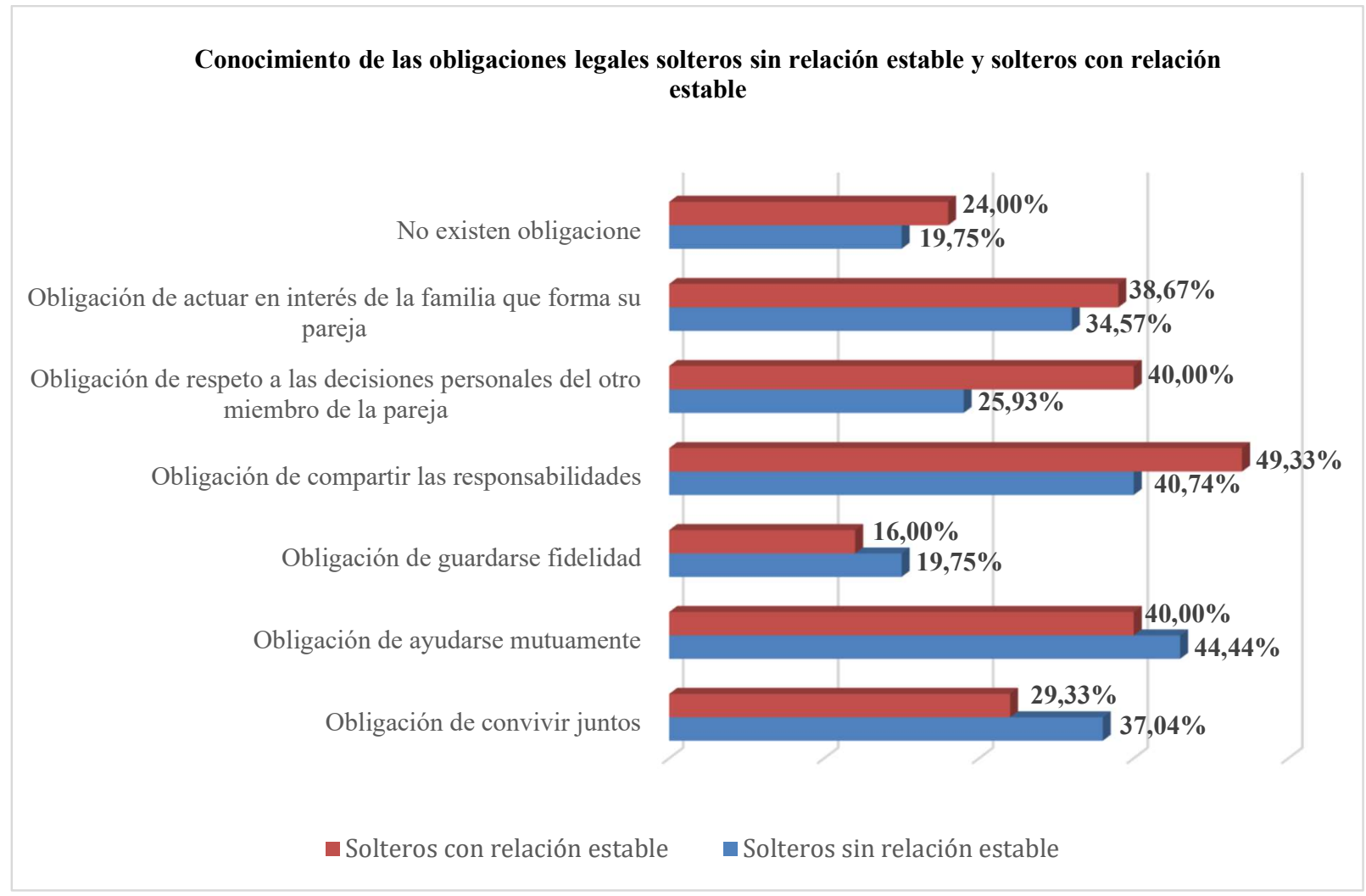

En los cuadros adjunto se comprueba la existencia de una sensible diferencia en cuanto a la obligación de respeto a las decisiones personales del otro miembro de la pareja, que entre los solteros con relación estable es señalada como una obligación por el $40 \%$, mientras que, entre los solteros sin relación estable de pareja se entiende como una obligación solamente por el 25,93\% de los encuestados que no tienen relaciones estables. Si bien, en general, se mantiene las tendencias generales señaladas.

Dentro de esas tendencias generales que se mantienen en todo tipo de relación de afectividad, tanto casados, como solteros con o sin relación estable de pareja, llama la atención los datos obtenidos entre las personas que mantienen una relación de pareja de hecho, sea registrada o no, si bien también existen diferencias entre ambos. Como decimos, las tendencias generales se mantienen, también, entre las personas que conviven como pareja de hecho, aunque existen 
porcentajes menores en todo tipo de obligaciones y destacan los porcentajes de los que piensan que no existen obligaciones entre los miembros de la pareja.

\section{Gráfico 25. Conocimiento de las obligaciones legales entre los miembros de una pareja de hecho, respuesta de personas en pareja de hecho según esté o no registrada la relación}

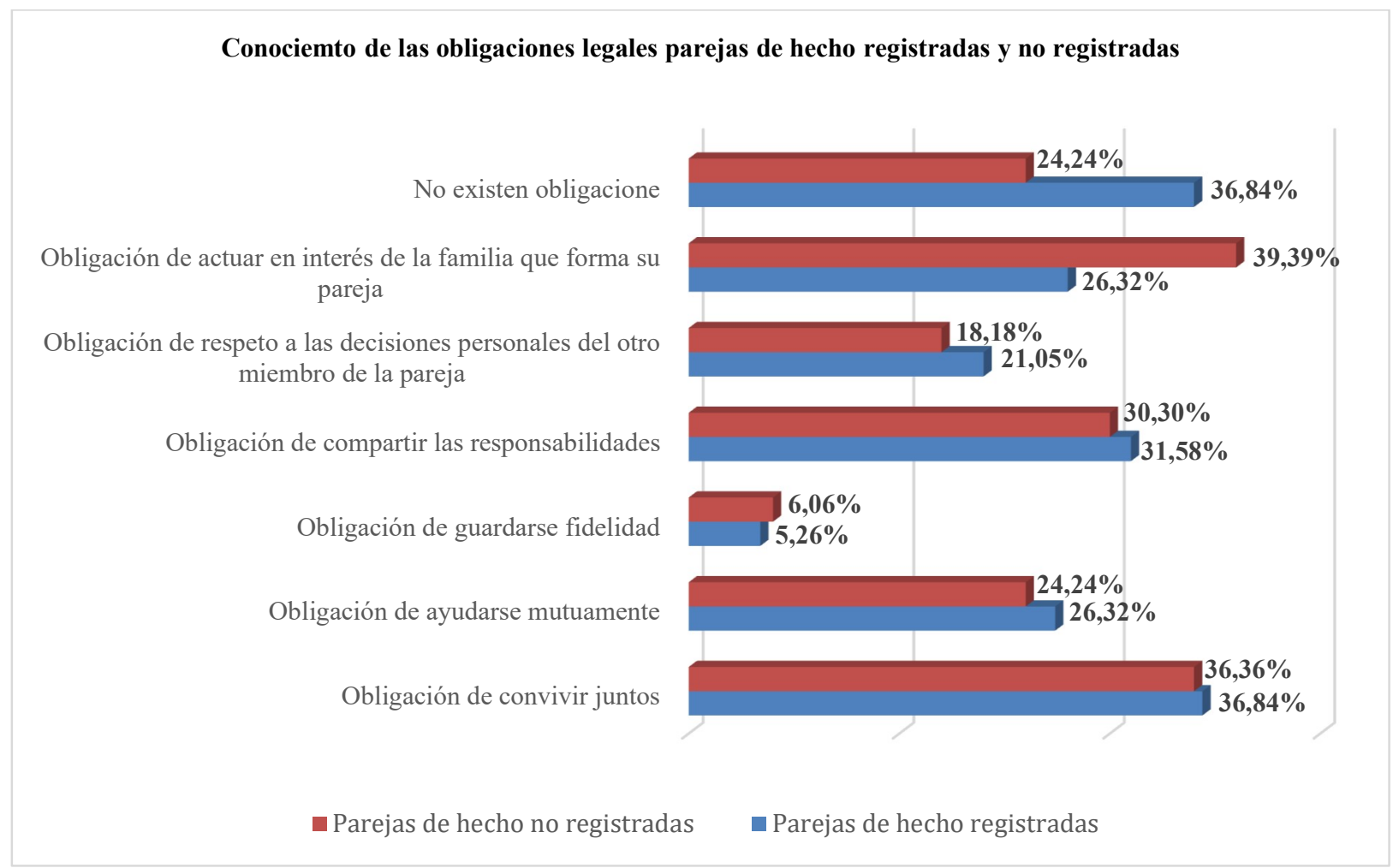

Así, se observa como en las parejas de hecho los porcentajes en todo tipo de obligaciones son más bajos que los señalados con carácter general, aunque las tendencias son comunes con las generales, tenemos que la respuesta de que no existen obligaciones entre los miembros de una pareja de hecho es mayor en el caso de personas unidas en ese modo de convivencia, tanto si la pareja está registrada como si no lo está, siendo significativo el porcentaje de los que piensan que no existen obligaciones entre los miembros de la pareja entre aquellas personas que conviven como pareja de hecho registrada, donde los que piensan de este modo llega a un estimable 36,84 \%.

Más influencia parece tener el factor de edad, siempre dentro de las mismas tendencias generales. En efecto, en los cuadros adjuntos se pueden apreciar diferencias en las tendencias en función de los tramos de edad, en los que se podría entender que, en los tramos de edad más elevada, dados los porcentajes más elevados entre los que piensan que existen determinadas 
obligaciones entre los convivientes, con gran similitud a las obligaciones del estatuto matrimonial, mientras que los porcentajes son menores entre las franjas de edad más jóvenes.

\section{Gráfico 26. Conocimiento de las obligaciones legales entre los miembros de una pareja de hecho, respuesta por edad}

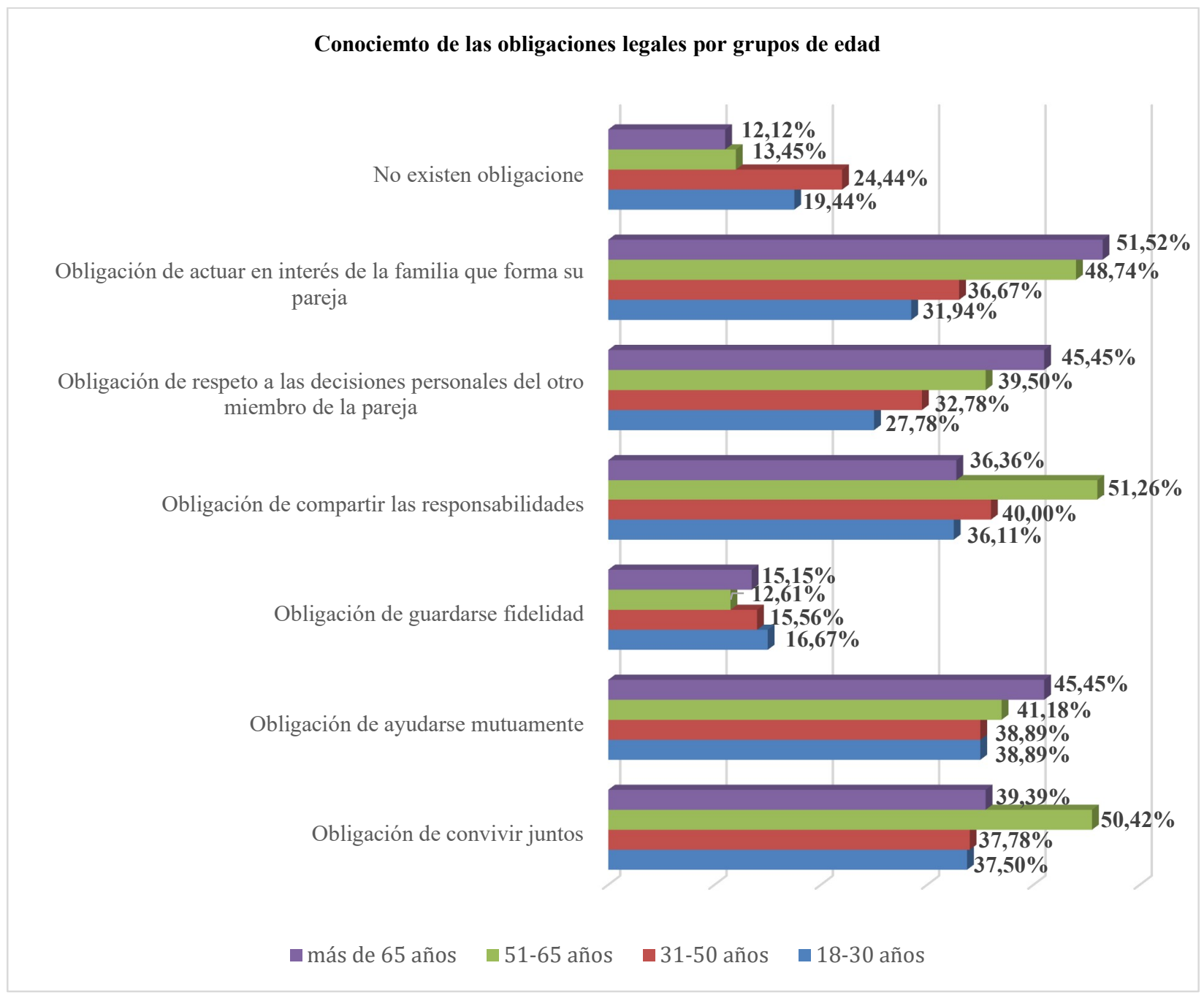

$\mathrm{Si}$, a modo de ejemplo, se compara la posición que opina que no existen obligaciones entre los miembros de la pareja de hecho, el porcentaje de los que piensan de este modo entre los que tienen una edad comprendida entre 31 y 50 años es del 24,44\%, mientras que los mayores de 65 años piensan que no existen solamente la mitad que los del tramo de edad citado. Igual sucede entre los encuestados que piensan que sí existen obligaciones entre los miembros de la pareja de hecho, en que se encuentran también diferencias importantes entre los mismos tramos de edad, como sucede en relación con si existe "obligación de actuar siempre en interés d la familia que forma con 
su pareja" que, entre los mayores de 65 años es del 51,52\%, mientras que entre los que tienen una edad entre 31 y 50 años ese porcentaje se reduce hasta un $36,67 \%$.

\section{D) VALORACIÓN SOCIAL SOBRE LAS OBLIGACIONES PATRIMONIALES, DE CARÁCTER LEGAL,}

\section{ENTRE LOS MIEMBROS DE LA PAREJA}

En esta pregunta se pedía a los encuestados su visión sobre la organización económica interna de la pareja de hecho. En concreto, cuál debe ser la aportación económica al sostenimiento de los gastos de la pareja, a la que se ofrecían las siguientes posibilidades: que lo obtenido por su trabajo o industria por cada uno de los miembros de la pareja debe ser puesto en común considerando que pertenece a ambos miembros de la pareja por igual (en una suerte de modelo ganancial); que cada uno de los miembros de la pareja debe aportar la mitad de los gastos comunes, independientemente de lo que cada uno de ellos perciba por su trabajo (en una suerte de convivencia al modo de compañeros de piso); que cada uno de los miembros de la pareja debe aportar a los gastos comunes de manera proporcional a sus ingresos (en un a modo de régimen económico de separación de bienes); por último, se planteaba que la respuesta correcta no sea ningún de las anteriores, si bien no se daba la posibilidad de indicar cuál sería el modo de afrontar esos gastos comunes. Sorprendentemente, la respuesta muy mayoritaria ha sido esta última.

\section{Gráfico 27. Régimen económico en las parejas de hecho, respuesta general}

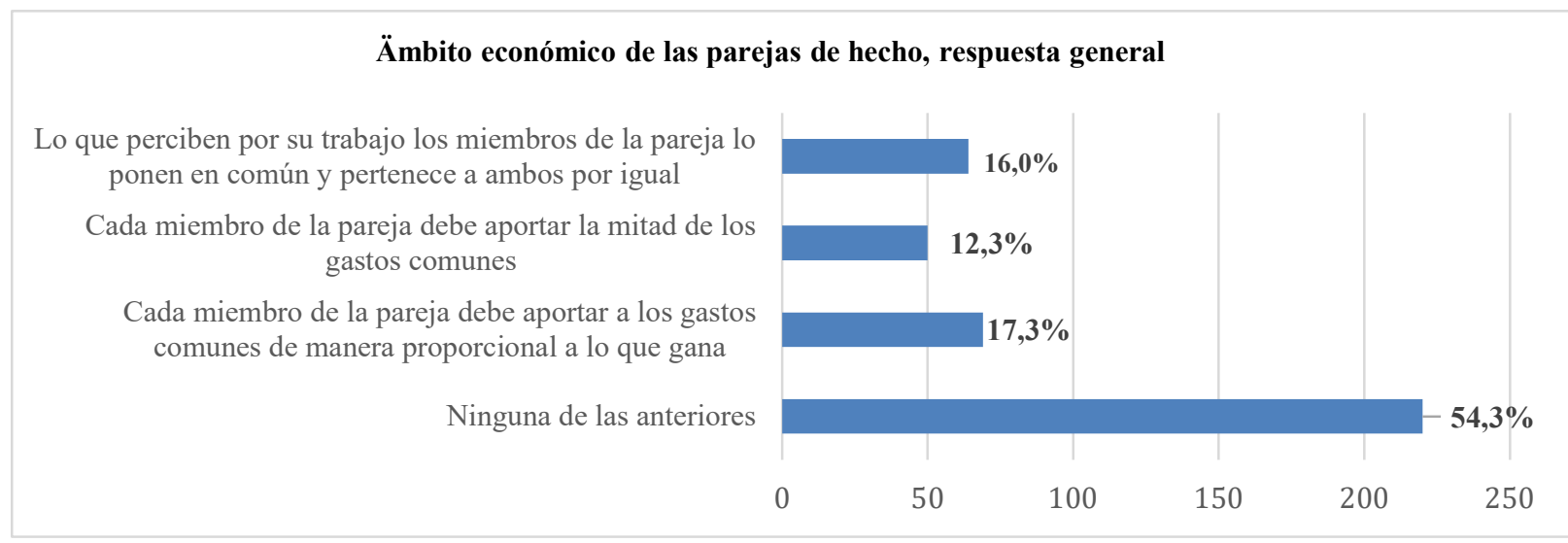

Tenemos, pues, que un 54,3\% de los encuestados opina que ninguno de los modos de organización económica de la pareja propuestos era el adecuado, ignoramos en consecuencia, cuál sea el sentir mayoritario sobre el modo en que debe organizarse económicamente una pareja de hecho. 
Entre las formas propuestas no existe una clara opción entre los encuestados que eligieron alguna de ellas. De manera que un 17,3\% optaba por una aportación a los gastos de manera proporcional a los ingresos de cada uno de los miembros de la misma; mientras un porcentaje similar, un $16 \%$, piensa que los miembros de la pareja hacen comunes los ingresos obtenidos por el trabajo o industria de cada uno de ellos, y un ligeramente menor $12,3 \%$ piensa que las aportaciones a los gastos comunes deben ser igualitarias, independientemente del caudal de cada uno de los miembros de la unión de hecho.

Resulta obvio que la pregunta no fue entendida por los encuestados o, más probablemente, no fue efectuada con la suficiente claridad, ya que lo pretendido era conocer cuál creían los encuestados que era el modo en que debían los convivientes de organizar la economía familiar; de las respuestas recibidas lo que resulta es que, una gran mayoría de los encuestados, entendía que se refería a cuál es la exigencia legal en orden a la organización económica interna, contestando, en consecuencia, que no existe una regulación, por lo que ninguna de las respuestas se corresponde con lo entendido por el encuestado.

No obstante, entendemos que del número de respuestas que se obtienen, cabe obtener algunas conclusiones. Para ello, nos centraremos solamente en la segregación por sexos, en la que observamos que las respuestas fueron las siguientes:

\section{Gráfico 28. Régimen económico en las parejas de hecho, respuesta por sexo}
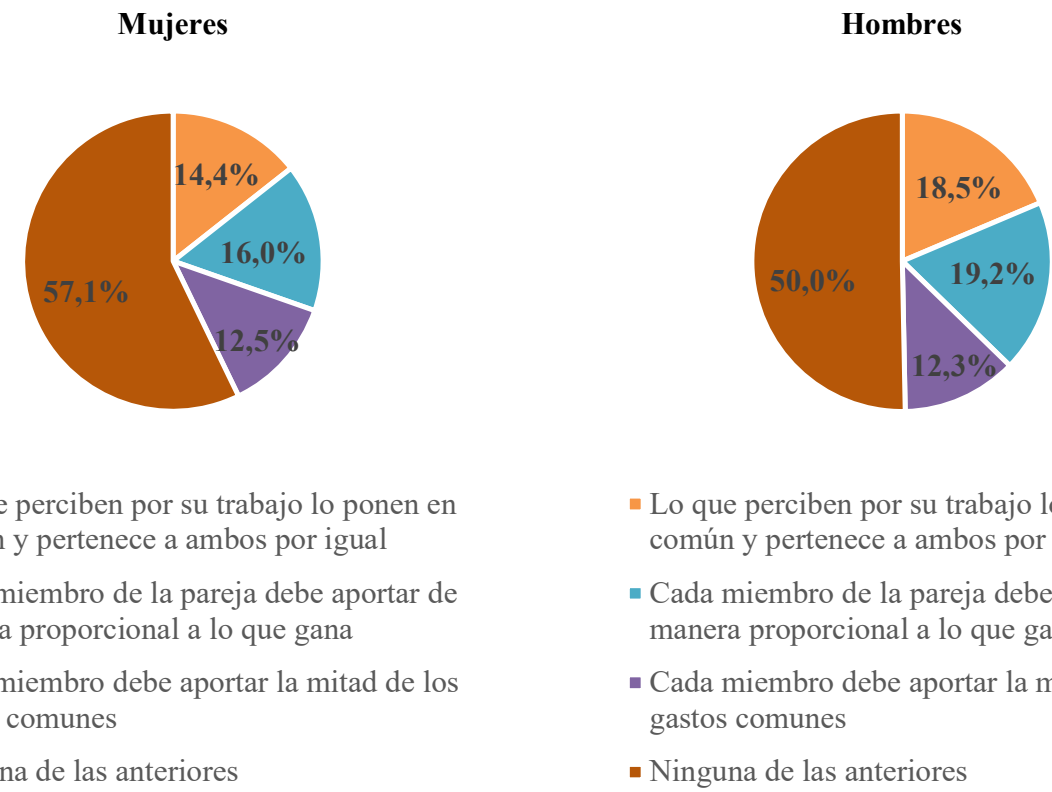

\footnotetext{
- Lo que perciben por su trabajo lo ponen en común y pertenece a ambos por igual

- Cada miembro de la pareja debe aportar de manera proporcional a lo que gana

- Cada miembro debe aportar la mitad de los gastos comunes

- Ninguna de las anteriores
}
- Lo que perciben por su trabajo lo ponen en común y pertenece a ambos por igual
- Cada miembro de la pareja debe aportar de manera proporcional a lo que gana
- Cada miembro debe aportar la mitad de los gastos comunes
- Ninguna de las anteriores


De las respuestas sobre alguna de las fórmulas propuestas que hemos recibido se obtiene una primera conclusión coincidente con la anterior. En efecto, unas personas contestan que ninguna respuesta es válida, ya que entienden que cada pareja podrá organizarse a nivel económico interno como tenga por conveniente, sin estar sometidos a ningún tipo de régimen de organización económica interna de la pareja, lo que viene a coincidir con el hecho de que las respuestas válidas no se decantan por ningún modelo concreto, dando unas respuestas que llevan a concluir que cualquiera de los modos de organización propuestos son igualmente aceptables; por lo que cabe concluir que la respuesta concorde es que cada pareja debe tener derecho a organizar sus relaciones económicas como tenga por conveniente, sin ningún tipo de interferencias externas.

A tal conclusión se llega tanto en el caso de los hombres como en el de las mujeres que contestaron optando por alguno de los modelos propuestos. Los encuestados de ambos sexos son mayoritarios en negar la existencia de un régimen legal de organización económica interna de la pareja, a la vez que, cuando optan por algún modo de organización, se divide la respuesta en porcentajes similares, perfectamente asumibles dentro del margen de error de la encuesta.

Todo ello parece congruente con el carácter dispositivo de la pareja de hecho, concediendo a los miembros de la misma la facultad, en exclusiva, de organizar la economía interna del grupo familiar como tenga por conveniente. En este aspecto, pese a lo que pudiera pensarse, existe una coincidencia básica con el régimen económico matrimonial primario, las capitulaciones matrimoniales; pero, a diferencia del mismo, en el caso de las uniones de hecho, parecería que no debe existir régimen económico subsidiario, por cuanto debería limitarse a la exigencia de definir un régimen económico interno de la pareja respetuoso con nuestro sistema constitucional y, en especial, con el derecho de igualdad. Tal parece concluirse de las respuestas obtenidas sobre el régimen económico que debe regir la vida de los convivientes.

\section{E) VALORACIÓN SOCIAL DE LOS REQUISITOS PARA EL RECONOCIMIENTO LEGAL DE LA PAREJA DE HECHO}

Ante la pregunta sobre los requisitos para que una pareja de hecho sea reconocida como tal, la coincidencia es absoluta entre los encuestados. De manera que resulta evidente que es perfectamente conocido por el conjunto de la sociedad que una pareja de hecho, a fin de ser reconocida como tal por el conjunto social, ha de constar inscrita en un registro público. 
Parece evidente que existe un amplio conocimiento de que, una pareja de hecho, solamente a partir de la inscripción en un registro público podrá ser reconocida como tal. Los encuestados parecen tener claro que solo con la inscripción en un registro público surgirán derechos y obligaciones entre los convivientes, pues ya hemos visto que la generalidad de los encuestados piensa, mayoritariamente, que entre los miembros de una unión de hecho existen derechos y obligaciones, con independencia de cuáles sean estos.

\section{Gráfico 29. Requisitos para el reconocimiento de una pareja de hecho, respuesta general}

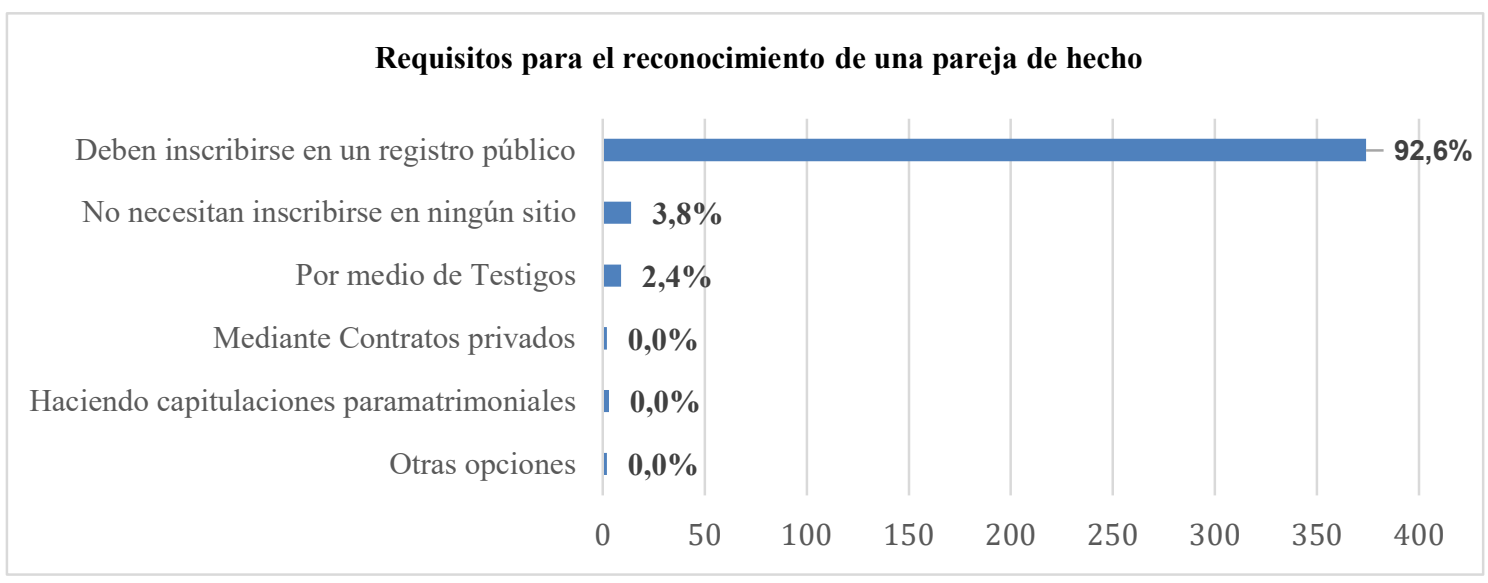

Con un resultado tan abrumador como el 92,6\% de los encuestados coincidiendo en que, para el reconocimiento social de la pareja de hecho, tal respuesta es incuestionablemente mayoritaria con cualquier sesgo que se incluya entre los encuestados. De manera que resulta irrelevante la segregación por sexos, ya que la diferencia entre los sexos o edades no es significativa. A modo de ejemplo veamos la segregación por sexos. 


\section{Gráfico 30. Requisitos para el reconocimiento de una pareja de hecho, respuesta por sexo}

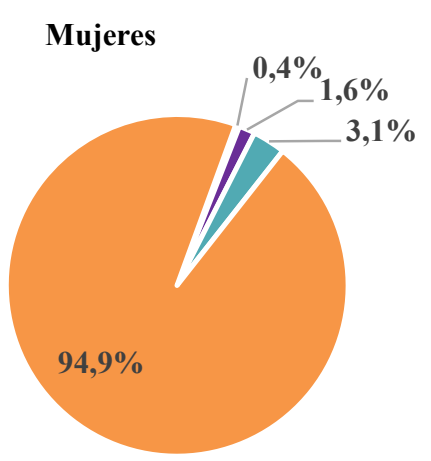

- Haciendo capitulaciones paramatrimoniales

- Por medio de Testigos

- No necesitan inscribirse en ningún sitio

- Deben inscribirse en un registro público

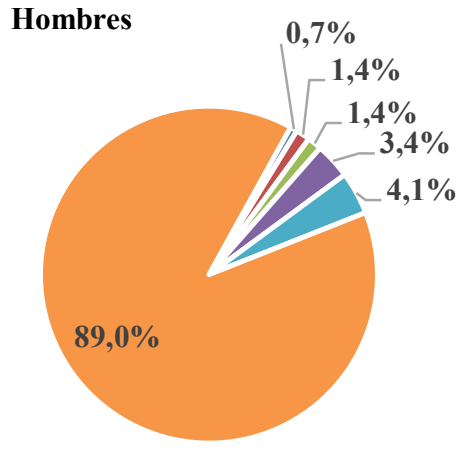

- Otras opciones

- Haciendo capitulaciones paramatrimoniales

- Mediante contratos privados

- Por medio de Testigos

- No necesitan inscribirse en ningún sitio

- Deben inscribirse en un registro público

Con el margen de error de la encuesta la diferencia entre hombres y mujeres se puede tomar por inexistente, entendiendo ambos sexos del mismo modo los requisitos de reconocimiento de la pareja de hecho. Similar situación encontraremos con cualquier segregación que realicemos, en todos los casos se comprueba que la generalidad de los encuestados entiende que existe una profunda diferencia entre las parejas de hecho registradas y las no registradas, en el sentido de que solamente las registradas tendrán un reconocimiento social y derechos y obligaciones mutuos, mientras que las no registradas serían las auténticas parejas de hecho, al entenderlas como uniones al margen del Derecho y, por tanto, son estas las relaciones que no generarán derechos y obligaciones entre los convivientes.

\section{F) ANÁlisis de los ReSUltados obtenidos}

En un análisis de conjunto, se puede observar cómo el requisito de libertad matrimonial o, más bien, el de libertad para unirse convivencialmente con otra persona, por la inexistencia de otra unión simultánea con terceros, es entendido por los encuestados como imprescindible para constituir una pareja de hecho, a lo que se une, en la percepción social de los requisitos para constituir una unión more uxorio, la nota de estabilidad con una menor importancia al 
reconocimiento social de la misma, notas que resultan más acusadas entre los más jóvenes, si bien con diferencias entre los sexos.

Llama la atención que, entre las obligaciones existentes entre los miembros de la pareja, la de guardarse fidelidad tenga muy escaso predicamento que, aunque con pequeñas diferencias, se mantiene para los distintos sexos y tramos de edad. Puesto en relación con la definición de la vida marital dada por nuestro TS, por ejemplo en su Sentencia 179/2012, de 28 de marzo, en la que definía dicho concepto de la siguiente forma: "la calificación de la expresión "vida marital con otra persona" puede hacerse desde dos punto de vista distintos: uno, desde el subjetivo, que se materializa en el hecho de que los miembros de la nueva pareja asumen un compromiso serio y duradero, basado en la fidelidad, con ausencia de forma; otro, el elemento objetivo, basado en la convivencia estable". Parecería que la percepción social se acomoda mal con dicha definición de nuestro Alto Tribunal, al entender los encuestados que el compromiso, desde luego, serio y duradero, sí que debe estar basado en una convivencia estable, pero no se considera que la nota de fidelidad sea básica en una unión de hecho. Podría ocurrir que tal conclusión sea un sesgo erróneo en la encuesta, pero dado el conjunto de respuestas a las diferentes preguntas, parecerá más bien que, efectivamente, la sociedad no considera esencial, en estos tiempos, el requisito de guardarse fidelidad los miembros de la pareja de hecho.

Otro aspecto destacable es el alto porcentaje de encuestados (41,3\%), que entienden que las uniones de hecho registradas tienen los mismos derechos y obligaciones que las uniones matrimoniales, mientras que un mínimo porcentaje entiende que no existen obligaciones ni derechos entre los convivientes. En este sentido, resulta llamativo que entre los hombres es mayoritario el pensamiento de que, si bien existen derechos y obligaciones entre los miembros de la pareja, son menos que los existentes en el matrimonio; en cambio, entre las mujeres el porcentaje de las piensan que los derechos y deberes son menores a los del matrimonio es similar al de las que piensan que son los mismos que en el matrimonio. También la variable edad influye en este aspecto, en la misma línea señalada anteriormente.

Al concretar estos derechos y obligaciones, vemos que, en cuanto a los derechos, los encuestados no encuentran grandes diferencias entre aquellos derechos pertenecientes al ámbito del Derecho público de aquellos que pertenecen al ámbito del Derecho privado; de manera que resultan reconocidos como derechos dentro de la pareja el de adopción conjunta, los permisos en el trabajo en supuestos de enfermedad del conviviente u otras circunstancias, el derecho a pensión 
de viudedad, así como un alto porcentaje, superior al $40 \%$, se pronuncia por la existencia de derechos hereditarios derivados de la situación de convivencia, y un porcentaje menor por el derecho a pensión compensatoria en caso de ruptura. No existen diferencias importantes en función del sexo, manteniendo las señaladas desde el principio en función de la edad.

En la concreción de las obligaciones se comprueba cómo las que despiertan mayor coincidencia entre la población encuestada son la de convivir juntos, la de ayuda mutua, lo que incluye la obligación de compartir las responsabilidades domésticas y en el cuidado de las personas dependientes de cualquiera de los miembros de la pareja, así como la obligación de actuar siempre en interés de la familia que forma con la persona con la que convive. En definitiva, obligaciones muy similares a las que se entenderían comprendidas en el estatuto matrimonial.

En el ámbito económico resulta palmario que los encuestados entienden que no existen obligaciones, de carácter legal, entre los miembros de la pareja, sino que serán los propios convivientes quienes fijarán, en uso de su libertad de autorregulación, las relaciones económicas que tengan por conveniente, sin que se entienda que deba existir intervención alguna de los poderes públicos.

Del conjunto de respuestas, así como de los datos de matrimonios existentes y de uniones de hecho que hay en el conjunto del Estado, podría obtenerse la conclusión de que existe algún margen de desconocimiento total de la figura, pero que el sentir social es el de que las uniones de hecho son un modo de unión marital generador de derechos y obligaciones mutuos, siendo estos menores que los del matrimonio y fijados libremente por los convivientes. 


\section{CONCLUSIONES}

\section{I}

En nuestro Derecho histórico constan múltiples referencias a la convivencia more uxorio, y tanto en diversos fueros medievales como, de manera especial, en la citada "carta de Ávila", observándose que este modo de convivencia se ha regido por la autonomía de la voluntad de los miembros de la unión. Obviamente, esta libertad de convención ha estado condicionada por las circunstancias de los diferentes momentos históricos. Pero de cualquier manera, podemos concluir que forma parte de nuestro acervo cultural la capacidad de autorregulación de las relaciones de las parejas no casadas, que mantienen una relación de afectividad análoga a la conyugal.

II

En la actualidad coexisten tres tipos de uniones de convivencia: matrimonio, uniones de hecho registradas y uniones de hecho no registradas. Estas últimas no están reconocidas por el ordenamiento jurídico, por lo que la denominación de unión de hecho le resulta absolutamente adecuado. Pese a su falta de reconocimiento, el Derecho no puede ignorar que de tal tipo de unión de convivencia se pueden derivar determinados derechos patrimoniales para los convivientes al tiempo de la ruptura de la pareja. Si bien, es cierto que ante la falta de acatamiento por los convivientes de las normas de ius cogens propias del matrimonio, estas no resultarán de aplicación. Por ello será preciso acudir a otras figuras jurídicas, tales como la doctrina del enriquecimiento/empobrecimiento injusto derivado de la relación de convivencia, o bien a lo dispuesto para las situaciones de separación del socio de la sociedad civil constituida por tiempo indefinido.

\section{III}

Las uniones de hecho registradas deberían tener otro nombre que resultase claramente diferenciador las no registradas, como podría ser el de "unión civil”, "unión estable de pareja", "unión libre", "cohabitación legal", etc. Entendemos que la denominación de este tipo de uniones registradas debería evitar cualquier tipo de confusión con las uniones que, libre y voluntariamente, renuncian a cualquier reconocimiento social. Y ello porque son, evidentemente, uniones amparadas por el Derecho, pues se acogen a las normas que el ordenamiento jurídico establece para quienes, deseando compartir la vida y sus avatares con otra persona, no aceptan en su integridad el denominado estatuto matrimonial. 
Tradicionalmente se ha sostenido que la diferencia entre el matrimonio y la unión libre o unión de hecho registrada radicaba en la falta de solemnidad en la constitución de esta última. Tal posición resultaba difícilmente sostenible desde que las CCAA empezaron a legislar sobre la materia, exigiendo el cumplimiento de requisitos formales para el reconocimiento de la unión libre o unión de hecho registrada, entre otros, la declaración de la voluntad de constituir la unión convivencial mediante escritura pública. Además, deviene absolutamente insostenible plantear tal ausencia de solemnidad, a partir de la aprobación de la modificación del CC del año 2015, que se reconoce la posibilidad de celebración del matrimonio ante notario, precisamente el mismo empleado público ante el que es posible la constitución de la unión libre o unión de hecho registrada. En consecuencia, no existe ningún requisito para la celebración del matrimonio que no se exija, también, para la existencia de la unión libre o unión de hecho registrada.

\section{$\mathbf{V}$}

Entendemos que la verdadera diferencia entre el matrimonio y estas uniones de hecho registradas o uniones libres radica en la naturaleza jurídica de ambas figuras. Pues no existe discusión acerca de que el matrimonio es una unión libremente aceptada por los cónyuges, pero sometida a un conjunto de normas de derecho necesario, conjunto de normas a las que no quiere someterse la unión libre o unión de hecho registrada, de la que no cabe duda de su naturaleza convencional.

\section{VI}

Como consecuencia de su diferente naturaleza jurídica resulta plenamente acertada la reiterada doctrina del TC y del TS acerca de la improcedente aplicación analógica de las reglas del matrimonio a estas uniones libres o uniones de hecho registradas. Ahora bien, estando comúnmente aceptada la validez y eficacia de los pactos entre los convivientes, nada impide la aplicación de las referidas reglas a estas uniones, cuando tal aplicación conste libre, consciente y voluntariamente aceptada en los citados pactos. En estos acuerdos los miembros de la pareja podrán establecer las convenciones que tengan por conveniente para regir sus relaciones económicas durante la convivencia y para liquidarla tras su extinción, siempre que no vayan contra las leyes, la moral o el orden público, y no sean limitativos de la igualdad de derechos que corresponden a cada 
conviviente, o gravemente perjudiciales para alguno de ellos. Serán tales pactos los que puedan conllevar la aplicación de cualquiera de los regímenes económicomatrimoniales previstos en el CC, pero no la mera analogía.

\section{VII}

Si el Derecho tiene como función regular la vida social, el ordenamiento jurídico no puede dar la espalda a una realidad social tan pujante como la que indican los datos. Y, curiosamente, podría afirmarse que nuestro ordenamiento en materia de Derecho público dispensa, en general, un tratamiento similar a las uniones libres o uniones de hecho registradas y al matrimonio. Si bien, en lo que se refiere a la obtención de beneficios derivados de la convivencia se acostumbran a establecer requisitos mucho más exigentes para estas uniones libres que para el matrimonio.

Sin embargo, mantiene unas limitaciones absolutas en lo relacionado con la transmisión de derechos en el ámbito privado, vetando a los convivientes en unión libre o unión de hecho registrada la transmisión de derechos, otorgándoles el mismo tratamiento que a las uniones no registradas.

Tal planteamiento no resulta coherente con las propias decisiones legislativas que permiten la obtención de prestaciones públicas por el hecho de la convivencia libre o registrada, como ocurre con la pensión de viudedad. Sin embargo, se impide al conviviente ceder a su pareja libremente elegida la transmisión de derechos privados, como podrían ser ciertos derechos hereditarios.

\section{VIII}

Por lo demás, el libre desarrollo de la personalidad fundamento de nuestro orden político amparado por el artículo 10 de la $\mathrm{CE}$, puesto en relación con el derecho a contraer matrimonio reconocido en su artículo 32.1 conducen al correlativo derecho a no contraer matrimonio.

Y, por ello, entendiendo el ejercicio de un derecho constitucionalmente garantizado, como es el de no contraer matrimonio si no se desea hacerlo, como una manifestación de la libertad del individuo, debe llevar al legislador a reconocer a los convivientes la libertad para establecer entre sí los derechos y deberes mutuos que tengan por conveniente, en ejercicio de esa libertad individual, sin otros límites que los establecidos por el ordenamiento jurídico. Añadiendo como límite específico para estas uniones libres o uniones de hecho registrada el límite de transmisión de derechos interconyugales establecidos en el ordenamiento jurídico. 


\section{IX}

En la encuesta realizada comprobamos que el conjunto social considera que de las uniones libres o uniones de hecho registradas nacen una serie de derechos y deberes entre los convivientes, que no son idénticos a los originados con el matrimonio, pero con una tendencia hacia la igualdad y, sobre todo, que estos derechos y deberes afectan tanto a aspectos del ámbito público como del privado. Todo lo cual resulta coherente con la necesidad de que sean los convivientes quienes determinen las reglas que han de regir tanto su convivencia como su final mediante el pertinente pacto de convivencia, cuya conclusión debe configurarse como obligatoria, aunque con absoluta libertad en su contenido, a fin de acomodar la configuración legal al entendimiento social de la figura. En el bien entendido de que los convivientes son libres de pactar desde la absoluta paridad con el matrimonio en la transmisión de derechos entre los miembros de la pareja, hasta la negativa de transmisión de derecho alguno. No obstante, siempre ha de regularse de algún modo las relaciones económicas durante la convivencia, y estableciendo la responsabilidad frente a terceros por las cargas de la pareja, cuando menos, respondiendo al modo del régimen económico matrimonial de separación de bienes.

\section{$\mathbf{X}$}

En las diferentes normas autonómicas se establecen distintos períodos para acreditar la convivencia como pareja de hecho. De manera que en las diferentes leyes autonómicas que se refieren a las uniones registradas las exigencias del período de convivencia, previo al nacimiento del derecho concreto de que se trate, difieren mucho. Entendemos que es preciso fijar un único período previo de convivencia para el reconocimiento de derechos al conviviente, sean éstos de Derecho público o de Derecho privado. Y, dado que se reconocen plenos derechos en el matrimonio desde el mismo momento de su celebración, e incluso es perfectamente válida la disolución del matrimonio tras tres meses de convivencia, sin que por ello se niegue la nota de estabilidad del matrimonio disuelto, entendemos que un plazo equivalente al doble, es decir seis meses, resulta suficiente para acreditar la estabilidad de la unión libre de pareja o unión de hecho registrada, lo que debe reflejarse en las normas estatales. 


\section{XI}

Actualmente todas las CCAA se han dotado de un Registro de Uniones de Hecho, independientemente de los nombres o características atribuidas en cada caso. También, en todas las legislaciones autonómicas se establece la denegación de inscripción de las parejas de hecho si alguno de los miembros de la misma está casado o consta inscrito en otra relación de pareja. Tal situación hace aconsejable que, en la tramitación del expediente de uniones de hecho en las distintas CCAA, se incluya la necesidad de requerir tanto al Registro Civil como al resto de Registros de Uniones de Hecho del Estado información sobre tal impedimento. Se trata de un medio de coordinación mínimo e inexcusable para acreditar la monogamia de los miembros de la pareja inscrita.

\section{XII}

La existencia de CCAA con Derecho Civil propio, determina que se produzcan importantes diferencias a la hora de constituir una unión libre o unión de hecho registrada, de modo que podría considerarse que se produce una discriminación por razón de la vecindad civil de los españoles, lo cual conculca lo dispuesto por el artículo 14 de la CE. Por ello, estimamos imprescindible la modificación de diversos artículos del CC, a fin de establecer una serie de reglas armonizadoras de las uniones libres o uniones de hecho registradas en todo el Estado. Tales modificaciones deberían ser, a nuestro parecer, al menos las siguientes:

En el artículo 44 CC debería añadirse un tercer párrafo con el siguiente, o similar, texto: "Las uniones no matrimoniales de similar afectividad a la conyugal tendrán los requisitos determinados en la correspondiente legislación autonómica y los efectos libremente pactados por los convivientes para la transmisión de derechos entre sí, con el límite máximo de los que pueden transmitirse por matrimonio".

$\mathrm{Al}$ artículo $61 \mathrm{CC}$ se añadiría un párrafo del siguiente tenor: "Las uniones no matrimoniales de similar afectividad a la conyugal se inscribirán en los registros correspondientes con los requisitos y efectos determinados por la correspondiente legislación”.

También al artículo 96 CC se añadiría un párrafo con el siguiente contenido: "Los mismos criterios de atribución de la vivienda conyugal se aplicarán en los casos de uniones no matrimoniales que hayan sido debidamente registradas con arreglo a la legislación que le resulte aplicable". 
En el artículo $807.3^{\circ} \mathrm{CC}$ debería añadirse el siguiente inciso: “el viudo o viuda, o el conviviente sobreviviente con análoga relación de afectividad a la conyugal, si así lo hubieran convenido por pacto, en la forma y medida que establece este Código”.

En el artículo $834 \mathrm{CC}$, se añadirá un inciso final: "El cónyuge que al morir su consorte no se hallase separado de este legalmente o de hecho, si concurre a la herencia con hijos o descendientes, tendrá derecho al usufructo del tercio destinado a mejora. El mismo derecho tendrá el conviviente de hecho supérstite, si así lo hubiese dispuesto el causante por pacto o en testamento".

El mismo inciso debería ser añadido al artículo $837 \mathrm{CC}$, el cual quedaría del siguiente modo: "No existiendo descendientes, pero sí ascendientes, el cónyuge sobreviviente tendrá derecho al usufructo de la mitad de la herencia. El mismo derecho tendrá el conviviente de hecho supérstite, si así lo hubiese señalado el causante por pacto o en testamento".

Y, lo mismo cabe decir del artículo $838 \mathrm{CC}$, el cual quedaría del siguiente modo: "No existiendo descendientes ni ascendientes el cónyuge sobreviviente tendrá derecho al usufructo de los dos tercios de la herencia. El mismo derecho tendrá el conviviente de hecho supérstite, si así lo hubiese señalado el causante por pacto o en testamento".

En lo que afecta a los artículos 839 y 840 CC procedería añadir un nuevo párrafo con el siguiente contenido: “(...) La misma regla se aplicará al conviviente de hecho en análoga relación de afectividad a la conyugal si así lo hubiese dejado dispuesto por pacto o en testamento el causante".

En la misma línea que venimos siguiendo, debería modificarse el artículo $943 \mathrm{CC}$, en el siguiente sentido: "A falta de las personas comprendidas en las dos Secciones que preceden, heredarán el cónyuge o persona sobreviviente con similar relación de afectividad a la conyugal, si así lo estableciesen por pacto los convivientes y los parientes colaterales por el orden que se establece en los artículos siguientes".

El artículo 944 CC debería ser modificado añadiendo un inciso final: En defecto de ascendientes y descendientes, y antes que los colaterales, sucederá en todos los bienes del difunto el cónyuge o persona con similar relación de afectividad a la conyugal sobreviviente, si así lo estableciesen por pacto los convivientes".

También procede la modificación del artículo 1315 CC añadiendo dos nuevos párrafos, de modo que quedaría redactado del siguiente modo: 
“1. El régimen económico del matrimonio será el que los cónyuges estipulen en capitulaciones matrimoniales, sin otras limitaciones que las establecidas en este código

2. Los convivientes en una unión no matrimonial de similar afectividad a la conyugal podrán acordar el régimen económico de la relación que tengan por conveniente, incluyendo la remisión a cualquiera de los establecidos en este código.

3. Los convivientes en una unión no matrimonial podrán establecer los pactos patrimoniales que tengan por conveniente teniendo como límite máximo de transmisión de derechos entre sí los establecidos en este código para los cónyuges".

Y, por último, proceder, igualmente, a la modificación del artículo 1316 CC añadiendo un nuevo párrafo, de modo que la redacción del artículo sería:

1. A falta de capitulaciones o cuando estas sean ineficaces, el régimen será el de la sociedad de gananciales.

2. A falta de pacto al respecto entre los convivientes de una unión no matrimonial de similar afectividad a la conyugal, o de regulación autonómica al respecto, se aplicarán a ésta las reglas del régimen económico matrimonial de separación de bienes establecido en el presente código".

Con las modificaciones señaladas entendemos que se establece un conjunto de reglas de mínimos armonizadoras de la regulación de las distintas CCAA, dejando en el ámbito competencial de las comunidades con Derecho Civil propio el establecimiento de normas imperativas, si ello resultase resulta más acorde en ese territorio. 



\section{BIBLIOGRAFÍA}

- ABAD ARENAS, E.: "La regulación de los esponsales en el Derecho romano", en e-legal history review, n. 22 (2016).

- $\quad$ ALBA FERRÉ, E.; y MORENO BLESA, L.: “E1 Reglamento (UE) 2016/1104 en materia de efectos patrimoniales de las uniones registradas y su contribución a la armonización del Derecho de familia europeo", en La Ley: Revista jurídica española de doctrina, jurisprudencia y bibliografia. Derecho de Familia n. $^{\circ}$ 19, (tercer trimestre de 2018), ed. Wolters Kluwer.

- AlBadalejO GarcíA, M.: Compendio de Derecho Civil, 10 ed. Bosch, Barcelona (1997).

- $\quad$ AlVARADO PlanAS, J.; MONTES SAlGUERO, J.J.; PEREZ MARCOS, R.M. ; y SÁNCHEZ GONZÁLEZ, M. ${ }^{a}$ D.: Textos comentados de historia del Derecho y de las instituciones, ed. Centro de Estudios Ramón Areces, Madrid (2002), pág. 23.

- AlVARADO PlanAS, J.; MONTES SALGUERO, J.J.; PÉREZ MARCOS R. M.; SÁNCHEZ GONZÁLEZ M. ${ }^{a}$ D.:Historia del Derecho español, ed. Sanz y Torres s.1., Madrid (2010).

- ANDREU MARTÍNEZ, B.: "Unión de hecho y vivienda: soluciones en la jurisprudencia”, en Revista jurídica de la Región de Murcia, n. ${ }^{\circ} 123$ (1997).

- ARCEO BARANDA, E.: Uniones de Hecho familiares (tesis doctoral). Universidad de Córdoba (2016).

- $\quad$ ARREGUI GIL, J.:"Sobre la Ley Foral 6/2000, de 3 de julio, para la igualdad de las parejas estables”, en Comentarios al Código Civil y Compilaciones Forales, addendum al Tomo XXXVII, vol 2. Ederesa, Madrid (2001).

- AYLLÓN GARCÍA, J.D.: "Las parejas de hecho en el Ordenamiento jurídico español y francés”, en La Ley: Revista jurídica española de doctrina, jurisprudencia y bibliografía, ed. Wolters Kluber, n. ${ }^{\circ}$ 9415, Sección doctrina (15 de mayo de 2019).

- AYLlÓN GARCÍA, J.D.: "Presente y futuro del Derecho sucesorio de las parejas de hecho", en Grandes tratados: la legítima y la capacidad de testar. Aranzadi, Pamplona (2019). 
- AZNAR GIL, F.R.: "Penas y sanciones contra los matrimonios clandestinos en la Península ibérica durante la Baja Edad Media”, en Revista de Estudios Histórico-jurídicos n. ${ }^{2} 25$, Valparaíso (2003).

- BALLESTER PASTOR, I.: "La cuantía de la prestación de viudedad tras la Ley 40/2007, de 4 de diciembre; cambios puntuales y entrada en juego de las uniones de hecho", en Tribuna Social, n. 209 (2008).

- BATLlE VÁZQUEZ, M.: "La evaluación del daño en las personas", en Centenario de la Ley del Notariado, Vol. II. Madrid (1962).

- BAYOD LÓPEZ, C.: "Parejas no casadas, capítulos matrimoniales y normas de régimen económico matrimonial", en RCDI, n. ${ }^{\circ} 626$, (1995).

- Belío PASCUAL, A.C.: La pensión compensatoria. Tirant lo Blanch, Valencia (2013).

- BERIAIN FLORES, I.: La adopción del hijo del cónyuge o pareja. Tirant lo Blanch, Valencia (2014).

- BERROCAL LANZAROT, A.I.: "Aspectos relevantes en torno a la vivienda familiar", en $R C D I, \mathrm{n}^{\circ} 762$ (2017).

- BORILLO, D.: "Uniones libres, convivenciales y conyugales en el Derecho francés", en Revista de Derecho privado y comunitario (2014).

- CARRASCO PERERA, A.: "Comentarios al artículo 16 de la LAU" en Comentarios a la Ley de Arrendamientos Urbanos. Tecnos, Madrid (1995).

- CASTÁn TOBEÑAS, J.: Derecho civil español, común y foral, Tomo V: Derecho de Familia, Vol. $1^{\text {o: }}$ : Relaciones conyugales, $10^{\mathrm{a}}$ ed. Reus., Madrid (1983).

- CASTRO MEJUTO, L.F.: "A propósito de la pensión de viudedad para las parejas de hecho", en Anuario da Facultade de Dereito da Universidade da Coruña (2008).

- CERDEIRA BRAVO DE MANSILla, G.: "Atribución de la vivienda familiar en las parejas de hecho tras su ruptura: ¿siempre en precario? ¿siempre sin aplicar el art. 96 c.c.?”, en Revista de Derecho patrimonial, n. ${ }^{\circ}$ 28/2012, Aranzadi, Pamplona (2012).

- ChAPARRO MATAMOROS, P.: Derecho de uso y vivienda familiar: su atribución judicial en los supuestos de crisis familiares, Tirant lo Blanch, Valencia (2018).

- CONTRERAS, J.: El Santo Oficio de la Inquisición de Galicia. Poder, Sociedad y Cultura. Akal editor, Madrid (1982). 
- DÍAS, C.: El régimen de responsabilidad por deudas de los cónyuges: problemas, críticas y sugerencias. Coimbra editora, Coimbra (2009).

- DÍAS, C.: "Uniones de Hecho: la posición sucesoria del conviviente supérstite en Portugal”, en Anuario da Facultade de Dereito da Universidade de Coruña (2014).

- DE AMUNÁTEGUI RODRÍGUEZ, C.: Uniones de Hecho. Una nueva visión después de la publicación de las leyes sobre parejas estables. Tirant lo Blanch. Valencia. 2002.

- DE AMUNÁTEGUI RODRÍGUEZ, C.: "STS de 12 de septiembre de 2005: Uniones de Hecho y enriquecimiento injusto", en Comentarios a las Sentencias de unificación de doctrina: civil y mercantil, cord. Mariano Yzquierdo Tolsada, Vol. 1, (2008).

- DE AMUNÁTEGUI RODRÍGUEZ, C.: "La situación actual de las parejas no casadas", en Revista para el análisis del Derecho, Barcelona (julio 2015).

- DE AMUNÁTEGUI RODRÍGUEZ, C.: "Comentario a la STS de 15 de enero de 2018: Nuevo intento de orden sobre las reclamaciones económicas en el momento de la ruptura de las parejas no casadas", en Comentarios a las Sentencias de unificación de doctrina: civil y mercantil, coord. Mariano Yzquierdo Tolsada, Vol. 10, (2018).

- DE CASTRO MEJUTO, L.F.: “A propósito de la pensión de viudedad para las parejas de hecho", en Anuario da Facultade de Dereito da Universidade da Coruña, n. 12 (2008).

- DE CASTRO Y BRAVO, F.: “La indemnización por causa de muerte”, en $A D C$, Tomo IX (abril-junio de 1956).

- DE LA CÁMARA ÁlVAREZ, M.: La autonomía de la voluntad en el actual Derecho español sobre la familia. Ilustre Colegio Notarial de Granada (1986).

- DE LA ROSA YANES, P. M. '; y TRUJILLO GIL, D. A.: "Pensión compensatoria, pensión de viudedad y vivienda, en las uniones de hecho", en La Ley: Revista jurídica española de doctrina, jurisprudencia y bibliografia. Derecho de Familia n. ${ }^{\circ}$ 19, ed. Wolters Kluber, (tercer trimestre 2018).

- DE PORRES ORTIZ DE URBINA, E.: "Uniones de Hecho", en Boletín del Ministerio de Justicia n. ${ }^{\circ} 1914$ (2002).

- $\quad$ DE SALTER CID, N.: La comunidad de vida al margen del matrimonio: entre el hecho y el Derecho, Ediçoes Almedina, Coimbra (2005). 
- DÍAZ DE LEZCANO SEVILLANO, I.: "Parejas no casadas y subrogación en los arrendamientos urbanos", en Boletín de la facultad de Derecho, UNED, Madrid, n. ${ }^{\text {o }}$ 8-9 (1995).

- DÍAZ-AMBRONA BARAJÍ, M. ${ }^{a}$ D. y HERNÁNDEZ GIL, F.: Lecciones de Derecho de familia, $2^{\mathrm{a}}$ ed. Editorial Universitaria Ramón Areces, Madrid (2007).

- $\quad$ DÍEZ-PICAZO, L.: Estudios de Derecho privado, Civitas, Madrid (1980).

- $\quad$ DÍEZ-PICAZO, L.: Fundamentos de Derecho Civil Patrimonial, Tomo I, "Introducción. Teoría del Contrato". Thomson-Civitas, Navarra (2007).

- DÍEZ-PICAZO, L. y GULLÓN BALlESTEROS, A.: Instituciones de Derecho Civil,. Tecnos, Madrid (1998).

- DÍEZ-PICAZO, L. y GULlÓN BAlleStEROS, A.: Sistema de Derecho Civil, Vol. II, Tomo 2, $12^{\mathrm{a}}$ ed., Tecnos, Madrid (2018).

- DUALDE GÓMEZ, J.: Concepto de la causa de los contratos (la causa es la causa). Bosch, Barcelona (1949).

- EGÚSQUizA BALMASEDA, M. a A.: "Cambio de rumbo legislativo de las parejas estables: SSTC 81/2003, de 11 d abril de 2013 y 93/2003, de 23 de abril de 2013”, en Aranzadi Civil-Mercantil, Revista doctrinal, Vol. 2, n. 5 (septiembre 2013).

- ELORRIAGA DE BONIS, F.: Régimen jurídico de la vivienda familiar. Aranzadi, Pamplona (1995).

- ESTRADA ALONSO, E.: Las uniones extramatrimoniales en Derecho Civil español. ed. Civitas, Madrid (1986),

- FAUS, M. y ARIÑO, B.: "Práctico de Derecho de Familia", en Vlex (noviembre 2019). [consulta online https://2019.vlex.com/\#vid/589291118].

- FERNÁNDEZ ROZAS, J. C.: “Un hito más en la construcción del Derecho internacional privado de la UE: regímenes económicos matrimoniales y efectos patrimoniales de las uniones registradas", en Revista Iberoamericana de Derecho Internacional y de la Integración, $\mathrm{n}^{0} 5$ (noviembre 2016).

- FERREIRO GALGUERA, J.: "Las uniones de hecho en el Derecho autonómico”, en Anuario da facultade de Dereito da Universidade da Coruña, n. 4 (2000). 
- FOSAR BENLLOCH, E.: "Las uniones no matrimoniales en el Derecho histórico español. La sucesión mortis causa a favor de los hijos extramatrimoniales en el Derecho civil aragonés", en $R C D I$ n. ${ }^{\circ} 557$, (1983).

- FRANÇA PITAO: Uniones de Hecho y economía común. $3^{\mathrm{a}}$ ed., Ediçoes Almedina, Coimbra (2011).

- GACTO FERNÁNDEZ, E.: "El divorcio en España. Evolución histórica" en Historia 16, Madrid (julio de 1978).

- GACTO FERNÁNDEZ, E.: "La filiación no legítima en Derecho histórico español”, en Anales de la Universidad hispalense, Universidad de Sevilla (1969).

- GALLEGO DOMÍNGUEZ, I.: Las parejas no casadas y sus efectos patrimoniales, Colegio de Registradores de la propiedad y mercantiles de España, Centro de Estudios registrales, Madrid (1995).

- GÁLVEZ CRIADO, A.: "El principio general del libre desarrollo de la personalidad y los pactos entre convivientes tras la STC 93/2013, de 23 de abril”, en $R C D I n$. $^{\circ} 750$ (julio 2015).

- GARCÍA GARRIDO, M.J.: Derecho privado romano, casos, acciones, instituciones. Ediciones Académicas, Madrid (2010).

- GARCÍA HERVÁS, D.: "Panorámica legislativa sobre uniones de hecho", en ius canonicum, n. ${ }^{\circ} 81$ (2001).

- GARCÍA PÉREZ, R.: La acción de reducción de donaciones inoficiosas. Tirant lo Blanch, Valencia (2004), pág. 232.

- GARCIA RUBIO, M. ${ }^{a}$ P.: Alimentos entre cónyuges y entre convivientes de hecho. Civitas, Madrid (1995).

- GAVIDIA SANCHEZ, J.V.: "La libertad de elección entre el matrimonio y la unión libre", en Derecho privado y Constitución, n. ${ }^{\circ} 12$ (1998).

- GIOVANI CASTEllanOS, D.: "Mut'ah: usos y adaptaciones de una práctica matrimonial islámica en el Pacífico colombiano", en Revista de Estudios Colombianos, n. ${ }^{\circ}$ 48 (2016).

- GÓMEZ TABOADA, J.: "El nuevo Reglamento europeo de uniones registradas", en Revista de La Notaría (marzo 2017). 
- GUTIÉRREZ SANTIAGO, P.: "El indeterminado concepto de 'vida marital' como causa de extinción de la pensión compensatoria y sus problemas de prueba", en Actualidad jurídica Iberoamericana, ${ }^{\circ}{ }^{\circ} 8$ bis (extraordinario) (julio 2018).

- GUTIÉRREZ SARMIENTO, C.E.: "La unión marital de hecho y sus efectos patrimoniales", en Revista de Derecho privado, n. ${ }^{\circ} 7$ (enero-junio 2001).

- GUZMÁN GARCÍA, J.J.: La naturaleza jurídica del matrimonio. Univ. Alcalá de Henares (2002).

- HeRrera de laS herAS, R., MARTÍNEZ RUANO, P., y PAÑOS PÉREZ, A., "Los derechos sucesorios en la pareja de hecho. Especial referencia a la STC 93/2013, de 23 de abril", en $R C D I, \mathrm{n}^{\circ} 749$ (2015).

- JiMENO ARANGUREN, R.: Matrimonio y otras uniones afines en el Derecho histórico navarro. Siglos VIII-XVIII. Ed. Dykinson, Madrid (2015).

- LACRUZ BERDEJO, J.L.; SANChO REBUllidA, F.; LUNA SERRANO, A.; DELGADO ECHEVARRIA, J. y RIVERO HERNÁNDEZ, F.; Elementos de Derecho Civil II, Derecho de Obligaciones, vol. $3^{\mathrm{o}}, 2^{\mathrm{a}}$ ed. Bosch, Barcelona (1986).

- LACRUZ BERDEJO, J.L.; SANChO REBUlLIDA, F.; LUNA SERRANO, A.; DELGADO ECHEVERRIA, J.; RIVERO HERNANDEZ, F. y RAMS ALBESA, J.: Elementos de Derecho Civil II, Derecho de Familia, vol. 1 1, $3^{\mathrm{a}}$ ed. José María Bosch, Barcelona (1990).

- LACRUZ BERDEJO, J. L.; SANCHO REBULLIDA, F.; DELGADO ECHEVARRÍA, J.; LUNA SERRANO, A.; RIVERO FERNÁNDEZ, F.; RAMS ALBESA, J.; Elementos de Derecho Civil II, Derecho de Familia, Tomo IV, $3^{\text {a }}$ ed. Dykinson, Madrid (2008).

- LAÍNA GALlegO, J. M.a: "La Pragmática de Carlos IV y el matrimonio de los hijos de familia”, en Revista de Derecho Privado n. ${ }^{\circ} 2003-4$ (Julio, 2003).

- Lasarte ÁlvareZ, C.: Principios de Derecho Civil III. Contratos, 21. a ed. Marcial Pons, Madrid (2019).

- Lasarte ÁlvareZ, C.: Principios de Derecho Civil VI, Derecho de familia, $18^{\mathrm{a}}$ ed. Marcial Pons, Madrid (2019).

- Lasarte Álvarez, C. y VAlpuesta Fernández, M. ${ }^{a}$ R.: "Consideraciones sobre la pensión dimanante de la separación o el divorcio en la Reforma del Derecho de 
Familia: matrimonio, separación, régimen económico matrimonial, filiación y patria potestad", en Jornadas Hispalenses sobre la reforma del Derecho de Familia. Imprenta sevillana, Sevilla (1982).

- LÁZARO GONZÁLEZ, I.: "Las Uniones de Hecho en el Derecho internacional privado español: balance de un siglo", en Icade: revista de la facultad de Derecho, n. ${ }^{\circ} 46$.

- LEgAZY LACAMBRA, L.: Filosofia del Derecho, $5^{\text {a }}$ ed. revisada y aumentada. Bosch, Barcelona, 1979.

- LEOPOLDO FERNANDES, A.C.: La disolución de la unión de hecho: efectos patrimoniales. Univ. Coimbra (2017).

- LIÑÁN GARCÍA, A.: "Diversas consideraciones sobre las uniones de hecho en los ordenamientos jurídicos español y canónico”, en Revista jurídica de Castilla y León, n. ${ }^{\circ} 35$ (enero 2015).

- LÓPEZ AZCONA, A.: La ruptura de las parejas de hecho. Aranzadi, Pamplona (2002).

- LÓPEZ JARA, M.: "Efectos patrimoniales derivados de la ruptura de la pareja de hecho", en La Ley: Revista jurídica española de doctrina, jurisprudencia y bibliografía. Derecho de Familia, ed. Wolters Kluberm n. ${ }^{\circ} 19$ tercer trimestre (2018).

- LÓPEZ TERRADA, E.: Uniones matrimoniales y uniones de hecho en el régimen general de la Seguridad Social. Tirant lo Blanch, Valencia (2008).

- LÓPEZ-MUÑIZ GOÑO, M.: "Las uniones paramatrimoniales ante los procesos de familia" en Guía práctica y jurisprudencia. Colex, Madrid (1994).

- LORENZO REGO, I.: "Hacia la codificación de la pareja estable," en La Ley: Revista jurídica española de doctrina, jurisprudencia y bibliografia. Actualidad Civil, n. ${ }^{\circ} 19$, Sección A Fondo, quincena del 1 al 15 de noviembre (2010).

- LUDEÑA BENITEZ, O. D.: "El Derecho de familia de la UE: Cuestiones de cooperación jurídica entre los Estados miembros", en Revista Jurídica de Castilla y León n. 32 (enero 2014).

- MANEIRO VELAZQUEZ, Y.: "La acreditación del vínculo y de la convivencia more uxorio en las parejas de hecho: una aproximación jurisprudencial", en Actualidad Laboral n. ${ }^{\circ} 5$ (2013).

- MARTín MOLINA, A. A.: Efectos de la ruptura de las parejas de hecho (tesis doctoral). Universidad de Granada (2017). 
- MARTÍN-CASALS, M.: “El derecho a la convivencia anómica en pareja ¿un nuevo derecho fundamental? Comentario a la STC de 23.4.2013 (RTC 2013/93)", en InDret, revista para el análisis del Derecho, Barcelona (julio 2013) [consulta online www.indret.com].

- MARTÍNEZ GALLEGO, E. M. a: "Compensación patrimonial en caso de ruptura de parejas de hecho", en Práctica de Derecho de daños: Revista de responsabilidad civil y seguros, n. ${ }^{\text {o }} 89$ (2011).

- MARTÍNEZ MARINA, F.: Ensayo crítico sobre la legislación de los reinos de León y Castilla especialmente sobre el Código de las Siete Paridas de Don Alfonso El Sabio, $2^{\mathrm{a}}$ ed., Tomo I. Imprenta de D. E. Aguado, Madrid (1834).

- MENDIETA JARAMILLO, I.: "Relaciones patrimoniales en la unión familiar de hecho" en $A C$, (1990-1991).

- MERINO GUTIÉRREZ, A.: "Las uniones libres y su perspectiva actual”, en La Ley: Revista jurídica española de doctrina, jurisprudencia y bibliografia, (1988-1991).

- MESA MARRERO, C.: Las uniones de hecho: análisis de las relaciones económicas y sus efectos. $3^{\mathrm{a}}$ ed., Aranzadi, Pamplona (2006).

- MORÁN MARTÍN R.: El derecho matrimonial en la historia del Derecho español. Ed. Universitas, Madrid (2005).

- MORENO MONCHOLI, M.: "El concubinato", en ADC, (1941).

- MORENO QUESADA, B.: "La comunidad de bienes surgida en la convivencia de parejas de hecho", en Parejas de hecho. Iltre Colegio Notarial de Granada, Granada (1996).

- MOSTAZA RODRÍGUEZ, A.: "La Iglesia española y el concubinato hasta el siglo X”, en Anthologia annua, n. ${ }^{\circ} 6$ (1958).

- NANCLARES VALLE, J.: "Las parejas estables tras la inconstitucionalidad parcial de la Ley Foral 6/2000, de 3 de julio: el retorno a la unión de hecho”, en $R C D I$ n. ${ }^{\circ} 750$, Madrid (2015).

- NAVA RODRÍGUEZ, J.: "Legislación estatal de los países miembros de la UE sobre las uniones de hecho: estudio de su dimensión de justicia”, en Cuadernos doctorales, derecho canónico, derecho eclesiástico del Estado, n. ${ }^{\circ} 22$, Universidad de Navarra (2007-2008). 
- NÚÑEZ GRAÑÓN, M.: "Régimen tributario de las uniones de hecho", en Derecho privado y Constitución, n. ${ }^{\circ} 12$ (1998).

- $\quad$ NÚÑEZ PAZ, M. ${ }^{a}$ I.: Consentimiento matrimonial y divorcio en Roma. Universidad de Salamanca (1988).

- O’CALLAGHAN MUÑOZ, X.: "Concepto y calificación jurídica de las uniones de hecho” en Consecuencias jurídicas de las uniones de hecho. Cuadernos de Derecho judicial, n. ${ }^{\circ}$ XX, Consejo General del Poder Judicial, Madrid (1997).

- PANERO GUTIÉRREZ, R.: Derecho romano. Tirant lo Blanch, Valencia (2008).

- PANTALEÓN PRIETO, A.: “¿Derechos sucesorios ab intestato del compañero o compañera en la Compilación de Derecho Civil de Cataluña?” (comunicación presentada en las II jornadas del Dret Catalá a Tossa, septiembre de 1984), en La Reforma de la Compilació. El sistema succesori. Cátedra de Derecho Civil Catalán “Duran i Bas” de la Universidad de Barcelona.

- PANTALEÓN PRIETO, F.: “La autorregulación de la unión libre”, en RPJ, n. 4 (1986).

- PASSINHAS, S.: "La unión de hecho en Portugal”, en Actualidad jurídica Iberoamericana, n. ${ }^{\text {o }} 11$ (agosto 2019).

- PAZ CASARES, C.: “Comentarios al artículo 1671 del CC”, en Comentarios al Código Civil. Ministerio de Justicia, Madrid (1991).

- PEÑA BERNALDO DE QUIRÓS, M.: Derecho de Familia. Facultad de Derecho, Universidad Complutense, Madrid (1989).

- PEREDA GAMEZ, J. y VEGA SALA, F.: Derecho de Familia. Editorial Praxis, Barcelona (1994).

- PINTO ANDRADE, C.: Efectos patrimoniales tras la ruptura de la pareja de hecho. Bosch, Barcelona (2009).

- PUIG BRUTAU, J.: Fundamentos de Derecho civil. Doctrina general del contrato, Tomo II, Vol. 1, 3 ${ }^{\mathrm{a}}$ ed. Bosch, Barcelona (1988).

- PUig BRUtaU, J.: Fundamentos de Derecho Civil, Familia, Matrimonio, Divorcio, Filiación, patria potestad, Tutela, Tomo IV, 2a ed. Bosch, Barcelona (1985).

- RAMS ALBESA, J.: Uso, habitación y vivienda familiar. Tecnos, Madrid (1987).

- REINA, V. y MARTINELL, J. M.: Las uniones matrimoniales de hecho, Marcial Pons, Madrid (1996). 
- RIVAS VAlLEJO, P. y VILlaGRASA AlCAIDE, C.: Revista del Ministerio de Trabajo $y$ asuntos sociales, $\mathrm{n} .^{\circ}$ 57, Madrid, 2005.

- ROBLEDO VILLAR, A.: "La actio communi dividendo ejercitada por el copropietario de una vivienda familiar que está privado de su uso por sentencia judicial”, en La Ley: Revista jurídica española de doctrina, jurisprudencia y bibliografía, n. 3905 (1995).

- ROCA TRÍAS, E.: “Comentarios al artículo 96 CC”, en Comentarios a la Reforma del Derecho de Familia, Vol. I. Tecnos, Madrid (1984).

- ROCA TRÍAS, E.: "Propuestas de regulación en el Derecho de familia", en El Derecho europeo ante las parejas de hecho: la experiencia sueca y las tendencias legislativas de nuestro entorno (VV.AA., coord. por VILLAGRASA ALCAIDE, C.). Ed. Cedecs, Barcelona (1996).

- RODRÍGUEZ GUITIÁN, A. M. a: "Función de la responsabilidad civil en determinadas relaciones de convivencia", en Aranzadi de Derecho patrimonial n. 10 (2003).

- ROMERO PAREJA, A.: "Los derechos sucesorios de las parejas no matrimoniales", en La Ley: Revista jurídica española de doctrina, jurisprudencia y bibliografía, n. ${ }^{\circ} 2$ (2003).

- RUÍZ DE CONDE, J.: El amor y el matrimonio secreto en los libros de caballerías. M. Aguilar Editor, Madrid (1948).

- SÁNCHEZ ROMÁN, F.: Estudios de Derecho Civil. Introducción e historia general de la legislación española. Madrid (1899).

- SANTOS BRIZ, J.: La responsabilidad civil. Montecorvo, Madrid (1991).

- SOTO MOYA, M.: "El reglamento (UE) 2016/1104 sobre el régimen patrimonial de las parejas registradas: algunas cuestiones controvertidas de su puesta en funcionamiento en el sistema español de Derecho internacional privado", en Revista electrónica de Estudios internacionales, (2018). [Consulta online www.reei.org (fecha consulta 20/07/2020)]

- TAVARES COELHO, J.P.: "La familia: perspectiva evolutiva del concepto tradicional", en Revista del Ministerio Público, n. ${ }^{\circ} 54$ (1993).

- TORRALBA SORIANO, V.: "Causa ilícita. Exposición sistemática de la jurisprudencia del TS”, en $A D C$, Tomo XIX (1966).

- TORRES ESCÁMEZ, S.: Parejas de hecho. Colegio Notarial de Granada (1996).

- UREÑA MARTINEZ, M.: "Parejas de hecho y pensión de viudedad tras las últimas sentencias del Tribunal Constitucional”, en Derecho privado y Constitución, n. 29 (2015). 
- VARGAS ARAVENA, D.: “De los daños civiles en las uniones de hecho", en Daños civiles en el matrimonio. ed. La Ley, Madrid (2009), y publicada en La Ley 7409/2011.

- VATTIER FUENZALIDA, C.: "Los daños de familiares y terceros por la muerte o lesiones de una persona", en Centenario del CC, Tomo II. Asociación de profesores de Derecho Civil, ed. Centro de Estudios Ramón Areces, Madrid (1990).

- VICENTE PALACIO, M.A.: "Pensión de viudedad y el tipo de documento válido para constituir pareja de hecho. STS-SCO n. ${ }^{\circ}$ 350/2019, de 9 de mayo", en Revista de jurisprudencia laboral, n. ${ }^{\circ} 4$ (2019).

- VIDAL MARTÍNEZ, J.: “Aplicación del régimen de sociedad de gananciales a una relación y convivencia no matrimonial. Convenio económico. Validez", en $R G D$, octubrenoviembre (1986).

- WÓJCIK, A.: "La unión de hecho y el matrimonio. Diferencia antropológico-jurídica”, en ius canonicum n. ${ }^{\circ}$ XLII (2002).

- ZARRALUQUI SÁNCHEZ-EZNARRIAGA, L.: “La unión paramatrimonial y la vida familiar", en $R G D$, n. $^{\circ} 48$ (mayo 1993).

- ZURIlla CARILlanA, M. a A.: "Las uniones de hecho. Aspectos patrimoniales", en Aranzadi Civil-Mercantil. Revista doctrinal, n. 22 (2007). 



\section{JURISPRUDENCIA}

\section{TRIBUNAL CONSTITUCIONAL}

ATC n. ${ }^{\circ}$ 156/1987, de 11 de febrero (RTC 1987/156 AUTO)

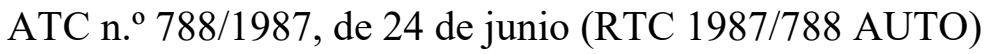

ATC n. ${ }^{\circ}$ 1022/1988, de 26 de septiembre (RTC 1988/1022 AUTO)

ATC n. ${ }^{\circ}$ 1021/1988, de 26 de septiembre (RTC 1988/1921 AUTO)

STC n. ${ }^{\circ}$ 184/1990, de 15 de noviembre (RTC1990/184)

STC n. ${ }^{\circ}$ 29/1991, de 14 de febrero; (RTC 1991/29)

STC n. ${ }^{\circ}$ 77/1991, de 11 de abril (RTC 1991/77)

STC n. ${ }^{\circ}$ 28/1992, de 9 de marzo (RTC1992/28)

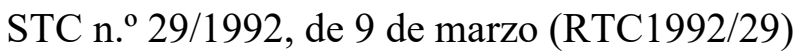

STC n. ${ }^{\circ} 222 / 1992$, de 11 de diciembre (RTC 1992/222)

STC n. ${ }^{\circ}$ 6/1993, de 18 de enero (RTC1993/6)

STC n. ${ }^{\circ}$ 47/1993, de 8 de febrero (RTC1993/47)

STC n. ${ }^{\circ}$ 66/1994, de 28 de febrero (RTC1994/66)

STC n. ${ }^{\circ}$ 155/1998, de 13 de junio (RTC 1998/155)

STC n. ${ }^{\circ}$ 116/1999, de 17 de junio. (RTC 1999/116)

STC n. ${ }^{\circ}$ 124/2003, de 17 de junio de 2003 (RTC 2003/124)

STC n. ${ }^{\circ}$ 28/2012, de 1 de marzo (RTC 2012/28)

STC n. ${ }^{\circ}$ 198/2012, de 6 de noviembre (RTC 2012/198)

STC n. ${ }^{\circ} 81 / 2013$, de 11 de abril (RTC 2013/81)

STC n. ${ }^{\circ}$ 93/2013, de 23 de abril (RTC 2013/93)

STC n. ${ }^{\circ}$ 194/2014, de 1 de diciembre de 2014 (RTC 2014/194) 
STC n. ${ }^{\circ}$ 82/2016, de 28 de abril (RTC 2016/82)

STC n. ${ }^{\circ}$ 110/2016, de 9 de junio (RTC 2016/110)

\section{TRIBUNAL SUPREMO}

STS Sala 1. ${ }^{\mathrm{a}}$, n. $^{\mathrm{o}}$ 179/2014, de 9 de mayo de 1914

STS Sala $1 .^{\text {a }}$, n. $^{\circ} 1543 / 2018$, de 8 de marzo de 1918

STS Sala 1. ${ }^{\mathrm{a}}$, n. ${ }^{\circ}$ 1921/1932, de 17 de octubre de 1932 (RJ 1932/1235)

STS Sala 1. ${ }^{\mathrm{a}}, \mathrm{n}^{\circ}$ 493/1941, de 2 de abril de 1941 (RJ 1941/493)

STS Sala 1. a, n. ${ }^{\circ}$ 177/1959, de 16 de octubre de 1959 (RJ 1959/3679)

STS Sala 1. ${ }^{\mathrm{a}}$, n. ${ }^{\mathrm{o}}$ 132/1960, de 13 de octubre de 1960 (RJ 1960/3168)

STS Sala 1. ${ }^{a}$ n. ${ }^{\circ} 2378 / 1968$, de 15 de noviembre de 1968 (RJ 1968/5816)

STS Sala 1. ${ }^{\text {a }}$, n. ${ }^{\text { }} 3527 / 1972$, de 26 de enero de 1972, (RJ 1972/120)

STS Sala 1. ${ }^{\mathrm{a}}$, n. ${ }^{\mathrm{o}}$ 2478/1972, de 10 de febrero de 1972, (RJ 1972/584)

STS Sala 1. ${ }^{\mathrm{a}}$, n. ${ }^{\mathrm{o}}$ 2922/1972, de 31 de mayo de 1972, (RJ 1972/2787)

STS Sala 1. ${ }^{\mathrm{a}}$, n. ${ }^{\circ}$ 129/1979, de 6 de abril de 1979, (RJ 1979/1274)

STS Sala 1. ${ }^{\mathrm{a}}$, n. $^{\text {o }}$ 49/1980, de 14 de febrero de 1980 (RJ 1980/516)

STS Sala 1. ${ }^{\text {a }, ~ n . ~}{ }^{\circ}$ 463/1984, de 12 de julio de 1984 (RJ 1984/3944).

STS Sala 1. ${ }^{\mathrm{a}}$, n. ${ }^{\mathrm{o}}$ 374/1986, de 13 de junio de 1986 (RJ 1986/3549)

STS Sala 1. ${ }^{\text {a }}$, n. ${ }^{\circ}$ de 29 de septiembre de 1986. (RJ 1986/4922)

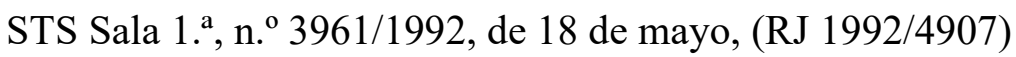

STS Sala 1. ${ }^{\mathrm{a}}$, n. ${ }^{\circ}$ 1148/1992, de 11 de diciembre de 1992, (RJ 1992/9733)

STS Sala 1. ${ }^{\text {a }}$, n. ${ }^{\circ}$ 116/1993, de 18 de febrero de 1993 (RJ 1993/1246)

STS Sala 1. ${ }^{\mathrm{a}}$, n. ${ }^{\mathrm{o}}$ 764/1993, de 22 de julio de 1993 (RJ 1993/6274)

STS Sala 1. ${ }^{\text {a }}$, n. ${ }^{\text { 894/1994, de }} 11$ de octubre de 1994, (RJ 1994/7476) 
STS, Sala 1. a, n. ${ }^{\circ}$ 948/1994, de 20 de octubre de 1994, (RJ 1994/7492)

STS Sala 1. ${ }^{\mathrm{a}}$, n. ${ }^{\circ}$ 1041/1994, de 18 de noviembre de 1994. (RJ 1994/8777)

STS Sala 1. ${ }^{\mathrm{a}}, \mathrm{n}^{\circ}{ }^{\circ} 1181 / 1994$ de 30 de diciembre de 1994. (RJ 1994\10391)

STS Sala 1. ${ }^{\text {a }}$, n. ${ }^{\circ}$ 229/1995, de 18 de marzo de 1995, (RJ 1995/1962)

STS Sala 1. a , n. ${ }^{\circ}$ 6029/1996, de 31 de octubre de 1996 (RJ 1996/7723)

STS Sala 1. ${ }^{\mathrm{a}}, \mathrm{n}^{\mathrm{o}}$ 1085/1996, de 16 de diciembre de 1996 (RJ 1996/9020)

STS Sala 1. ${ }^{\mathrm{a}}$, n. ${ }^{\circ}$ 1516/1997, de 4 de marzo de 1997 (RJ 1997/1640)

STS Sala $1 .^{\mathrm{a}}$, n. $^{\circ}$ 212/1998, de 10 de marzo de 1998 (RJ 1998/1272)

STS Sala 1. ${ }^{\mathrm{a}}$, n. ${ }^{\circ}$ 1499/1999, de 4 de marzo de 1999 (RJ 1999/1401)

STS Sala 1. a, n. ${ }^{\circ}$ 499/2000, de 13 de mayo de 2000 (RJ 2000/3410)

STS Sala $1 .{ }^{\mathrm{a}}$, n. $^{\circ}$ 327/2001, de 27 de marzo de 2001 (RJ 2001/4770)

STS Sala 1. ${ }^{\mathrm{a}}$, n. ${ }^{\circ}$ 700/2001, de 5 de julio de 2001 (RJ 2001/4993)

STS, Sala $3^{\text {a }}$, n. ${ }^{\circ} 812 / 2002$, de 8 de febrero de 2002 (RJ 2002/1928)

STS Sala $1 .^{\mathrm{a}}$, n. $^{\circ}$ 749/2002, 16 de julio de 2002 (RJ 2002/6246)

STS Sala 1. ${ }^{\mathrm{a}}$, n. ${ }^{\mathrm{o}}$ 5/2003, de 17 de enero de 2003 (RJ 2003/4)

STS Sala 1. ${ }^{\text {a }}$, n. ${ }^{\circ}$ 584/2003, de 17 de junio de 2003 (RJ 2003/4605)

STS Sala 1. a , n. ${ }^{\circ} 403 / 2004$, de 14 de mayo (RJ 2004/3477)

STS Sala 1. ${ }^{\mathrm{a}}$, n. ${ }^{\circ}$ 1107/2004, de 23 de noviembre de 2004 (RJ 2004/7385)

STS Pleno Sala 1. ${ }^{\mathrm{a}}$, n. ${ }^{\circ}$ 611/2005, de 12 de septiembre de 2005 (RJ 2005/7148)

STS Sala 1. ${ }^{a},{ }^{\circ}{ }^{\circ} 1016 / 2006$, de 6 de octubre de 2006 (RJ 2006/6650)

STS Sala 1. a , n. ${ }^{\circ}$ 1287/2006, de 5 de diciembre de 2006 (RJ 2007/231)

STS Sala $1 .{ }^{\mathrm{a}}$, n. $^{\circ}$ 240/2008, de 27 de marzo de 2008 (RJ 2008/4062)

STS Sala 1. ${ }^{\text {a }}$, n. ${ }^{\circ}$ 1040/2008, de 30 de octubre de 2008 (RJ 2009/404)

STS Sala 1. a , n. ${ }^{\circ} 431 / 2010$, de 7 de julio de 2010. (RJ 2010/3904) 
STS, Sala 1. ${ }^{\mathrm{a}}$, n. ${ }^{\circ}$ 690/2011, de 6 de octubre de 2011 (RJ 2011/6708)

STS Sala 1. ${ }^{\mathrm{a}}$, n. $^{\mathrm{o}}$ 747/2012, de 18 de diciembre de 2012 (RJ 2012/11277).

STS Sala 1. ${ }^{\mathrm{a}}$, n. ${ }^{\mathrm{o}}$ 320/2014, de 16 de junio DE 2914 (RJ 2014/3073)

STS Sala 4. ${ }^{\mathrm{a}}$, n. ${ }^{\circ}$ 1754/22016, de 30 de marzo de 2016 (RJ 2016/1606)

STS, Sala 4. ${ }^{\mathrm{a}}$, n. ${ }^{\circ}$ 932/2016, de 8 de noviembre de 2016 (RJ 2016/5881)

STS, Pleno Sala 1. ${ }^{\mathrm{a}}$, n. ${ }^{\mathrm{o}}$ 31/2017, de 19 de enero de 2017 (RJ 2017/924)

STS Sala 1. ${ }^{\mathrm{a}}$, n. ${ }^{\circ}$ 17/2018, de 15 de enero de 2018 (RJ 2018/76)

STS Sala $4^{\mathrm{a}}$, n. ${ }^{\circ}$ 350/2019, de 9 de mayo de 2019 (RJ 2019/2311)

\section{TRIBUNALES SUPERIORES DE JUSTICIA}

STSJC, Sala Civil y Penal, n. ${ }^{\circ}$ 26/2004, de 4 de octubre de 2004 (RJ 2005/288)

STSJM Sala de lo Contencioso-Administrativo, n. ${ }^{\circ}$ 359/2013, de 16 de mayo de 2013 (RJCA 2013/923)

STSJC Sala Civil y Penal, n. ${ }^{\circ}$ 24/2016, de 11 de abril de 2016 (RJ 2016/3646)

STSJM Sala de lo Contencioso-Administrativo, n. ${ }^{\circ}$ 523/2016, de 12 de mayo de 2016 (JT 2016/1006)

STSJC Sala Civil y Penal, n. ${ }^{\circ}$ 3/2017, de 23 de enero de 2017 (RJ 2017/2079)

\section{AUDIENCIAS PROVINCIALES}

SAP de Oviedo de 10 de abril de 1992 (AC 1992/265)

SAP de Palma de Mallorca de 4 de febrero de 1993, (AC 1993/599)

SAP de Zaragoza de 14 de junio de 1994 (AC 1994/9229)

SAP de Navarra de 15 de septiembre de 1994 (AC 1994/1430)

SAP de Salamanca de 29 de junio de 1995 (AC 1995/1200) 
SAP de Alicante n. ${ }^{\circ}$ 511/1995, de 18 de septiembre 1995 (AC 1995/2141)

SAP de Madrid n. ${ }^{\circ}$ 427/1995, de 20 de septiembre de 1995 (AC 1995/2518)

SAP de Ciudad Real, n. ${ }^{\circ}$ 363/1995, de 30 de diciembre de 1995 (AC 1995/2306)

SAP de Pontevedra n. ${ }^{\circ}$ 201/1998, de 6 de abril de 1998 (AC 1998/4691)

SAP de La Rioja n. ${ }^{\circ}$ 72/2005, de 9 de marzo de 2005 (AC 2005/463)

SAP de Illes Baleares n. ${ }^{\circ}$ 255/2007, de 1 de junio de 2007, (JUR 2007/17661)

SAP de Alicante n. ${ }^{\circ}$ 242/2007, de 12 de julio, (JUR 2007/336701).

SAP de Las Palmas, n. $^{\circ}$ 371/2007, de 28 de septiembre de 2007 (JUR 2007/353384)

SAP de A Coruña 370/2008, de 26 de septiembre de 2008 (JUR 2009/40170)

SAP de Tarragona, n. $^{\circ}$ 37/2009, de 23 de enero de 2009 (JUR 2009/174028)

SAP de Barcelona n. ${ }^{\circ}$ 50/2009, de 6 de febrero de 2009 (AC 2009/1192) 



\section{ANEXO. FICHA TÉCNICA DE LA ENCUESTA}

El margen de error para la muestra es del 4,75 \% para una población treinta y ocho millones de personas (población española en los rangos de edad de la encuesta) y con un nivel de confianza (grado de probabilidad de que la muestra refleje resultados precisos) del $95 \%$, se utiliza este grado de certeza por ser el más utilizado en este tipo de encuestas absolutamente aleatorias.

La muestra encuestada es de 425 personas, de las cuales 20 confesaron no saber nada de las parejas de hecho:

La distribución por sexos de los encuestados es la siguiente:

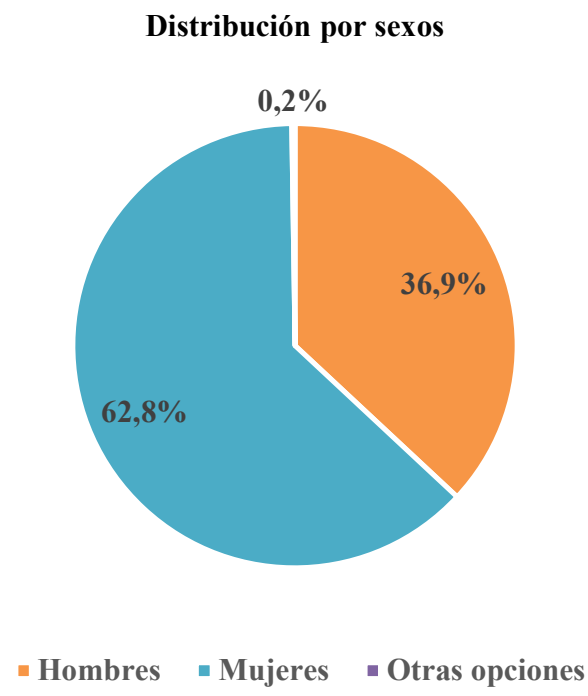

Esta distribución no se corresponde exactamente con la de la población española, la cual mantiene porcentajes similares de hombres y mujeres. Como señalamos la población española, se distribuye en un 50,97 \% de mujeres y un 49,03 \% de hombres, según estudio del Instituto Nacional de Estadística, a fecha 1 de julio de 2019, siendo en números absolutos la siguiente distribución por sexos a nivel nacional: 


\begin{tabular}{|c|c|c|c|c|c|}
\hline \multicolumn{6}{|c|}{ Población por sexo a 1 julio de 2019} \\
\hline & $\begin{array}{c}1 \text { de julio de } \\
2019\end{array}$ & & $\begin{array}{c}1 \text { de julio de } \\
2019\end{array}$ & & $\begin{array}{c}1 \text { de julio de } \\
2019\end{array}$ \\
\hline \multicolumn{2}{|c|}{ Ambos sexos } & \multicolumn{2}{|c|}{ HOMBRES } & \multicolumn{2}{|l|}{ MUJERES } \\
\hline $\begin{array}{c}\text { Total } \\
\text { nacional }\end{array}$ & 47.100 .396 & $\begin{array}{c}\text { Total } \\
\text { nacional }\end{array}$ & 23.089 .389 & $\begin{array}{c}\text { Total } \\
\text { nacional }\end{array}$ & 24.011 .006 \\
\hline Fuente: & Instituto Nacio & tadística & & & \\
\hline
\end{tabular}

En cuanto a la distribución por tramos de edad de los encuestados, pese a existir una evidente infrarrepresentación del tramo de edad de los mayores de 65 años en la muestra, en relación con la distribución de la población española por tramos de edad, entendemos que los porcentajes son suficientemente aproximados a la distribución nacional. En efecto la distribución porcentual de los encuestados es la siguiente:

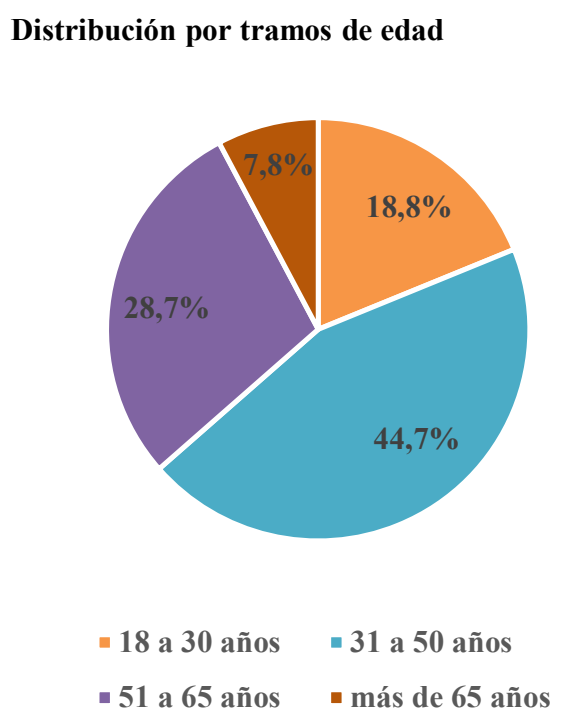

Mientras que la población española, mantiene una distribución de edad ligeramente diferente a los porcentajes señalados con una evidente infrarrepresentación de lo mayores de 65 años, posiblemente derivada de que la encuesta se realizó con la utilización de técnicas de comunicación novedosas para ese tramo de edad. 


\begin{tabular}{|c|c|c|c|c|c|c|c|}
\hline \multicolumn{8}{|c|}{ Población por franjas de edad } \\
\hline & $\begin{array}{c}1 \text { de julio } \\
\text { de } 2019\end{array}$ & & $\begin{array}{c}1 \text { de julio } \\
\text { de } 2019\end{array}$ & & $\begin{array}{c}1 \text { de julio } \\
\text { de } 2019\end{array}$ & & $\begin{array}{c}1 \text { de julio } \\
\text { de } 2019\end{array}$ \\
\hline \multicolumn{2}{|l|}{ Ambos sexos } & \multicolumn{2}{|l|}{ Ambos sexos } & \multicolumn{2}{|l|}{ Ambos sexos } & \multicolumn{2}{|l|}{ Ambos sexos } \\
\hline $\begin{array}{l}\text { TOTAL } 18 \text { A } \\
30 \text { AÑOS }\end{array}$ & 6.317 .863 & $\begin{array}{l}\text { TOTAL 31 A } \\
50 \text { AÑOS }\end{array}$ & 14.190 .121 & $\begin{array}{l}\text { TOTAL 51 A } \\
65 \text { AÑOS }\end{array}$ & 9.602 .723 & $\begin{array}{l}\text { TOTAL MÁS } \\
\text { DE } 65 \text { AÑOS }\end{array}$ & 8.672 .971 \\
\hline Fuente: & Instituto N & nal de Estadís & ica & & & & \\
\hline
\end{tabular}

Por lo tanto, efectivamente, existe una menor representación del tramo de edad de mayores de 65 años, a la vez que existe una sobrerrepresentación de los otros tramos, en especial del comprendido entre 31 y 50 años. Pese a ello, consideramos que los datos de la muestra son suficientemente significativos, una vez incluidos los elementos correctores correspondientes, y que han sido tenidos en cuenta a efectos de calcular el error de la muestra. 
